O RELACIONAMENTO BRASIL - EUA E A ARQUITETURA MODERNA:

EXPERIÊNCIAS COMPARTILHADAS, 1939-1959

DÉBORA DA ROSA RODRIGUES LIMA HORMAIN

São Paulo

2012 


\section{O RELACIONAMENTO BRASIL - EUA E A ARQUITETURA MODERNA: \\ EXPERIÊNCIAS COMPARTILHADAS, 1939-1959}

Tese apresentada à

Faculdade de Arquitetura e Urbanismo da Universidade de São Paulo para a obtenção do Título de Doutor

\section{DÉBORA DA ROSA RODRIGUES LIMA HORMAIN}

Orientador: Profa. Dra. Fernanda Fernandes da Silva

São Paulo

2012

FAUUSP 
AUTORIZO A REPRODUÇÃO E DIVULGAÇÃO TOTAL OU PARCIAL DESTE TRABALHO POR QUALQUER MEIO CONVENCIONAL OU ELETRÔNICO, PARA FINS DE ESTUDO E PESQUISA, DESDE QUE CITADA A FONTE.

E-MAIL AUTORA: deborarrl@usp.br / debora@deboralima.com

Hormain, Débora da Rosa Rodrigues Lima.

O relacionamento Brasil - EUA e a arquitetura moderna:

Experiências compartilhadas, 1939 - 1959 / Débora da Rosa

Rodrigues Lima, São Paulo, 2012. DVD

271p.: il.

Tese (Doutorado - Área de Concentração: História da Arquitetura e do Urbanismo) - FAUUSP.

Orientadora: Fernanda Fernandes da Silva.

1. Movimento Moderno. 2. Arquitetura Moderna. 3. Brasil

4. Estados Unidos da América I. Título. 
"Em 1943, com a publicação do livro Brazil Builds, conclúa-se o ciclo de construção do caso brasileiro como topos fundamental do imaginário da arquitetura do século 20. Ainda que seu processo de formação possa ser datado no começo da segunda metade da década de 1930, o ciclo se desenvolveu entre dois episódios nova-iorquinos, respectivamente em 1939 e 1943: refiro-me à construção do Pavilhão do Brasil na Feira The World of Tomorrow e à exposição Brazil Builds no Museu de Arte Modema (MoMA)".

(LERNNUR: 1999)

"Com isso foi possível se constatar as múltiplas influências sofridas por nossa arquitetura ao longo das décadas, matizando de forma significativa o monocromatismo inicial que enxergava de forma míope (talvez seja mais apropriado dizer "daltônica") apenas o fião corbusiano original, que seria a mola propulsora de um desenvolvimento particular, que muitas vezes ganhou os contornos de um processamento endógeno, sem vasos comunicantes com a produção extema". (GUERRA: 2008) 
HENRIQUE ESPADA RODRIGUES LIMA

(1942-1996) 
HORMAIN, D.R.R.L. O Relacionamento Brasil - EUA e a Arquitetura Moderna: Experiências compartilhadas, 1939 - 1959. 2012. 271 f. Tese (Doutorado) - Faculdade de Arquitetura e Urbanismo. Universidade de São Paulo, São Paulo, 2012.

\section{RESUMO}

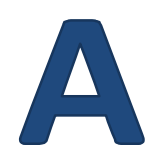

tese de Doutorado em questão analisa o relacionamento, as experiências e os intercâmbios ocorridos entre profissionais da arquitetura brasileiros e americanos (ou imigrantes na América do Norte) em um período que se estende desde o reconhecimento da arquitetura moderna brasileira no âmbito internacional, entre o final dos anos 1930 e início dos quarenta, atravessando o segundo pós-guerra até o início dos anos 1960.

Inúmeras foram as trocas entre os dois países, muitas vezes desmerecidas em detrimento daquelas ocorridas com o continente europeu, e que neste trabalho procuramos dar espaço e buscar seu entendimento.

De modo que o foco da pesquisa foi demonstrar que outras frentes de diálogo se consolidaram, justamente quando a arquitetura moderna que se fazia no Brasil passava, também, a dialogar internacionalmente, e, dentro deste panorama, os Estados Unidos da América, novo centro cultural do mundo, teve um papel essencial.

Partindo do pressuposto que o relacionamento entre o Brasil e os Estados Unidos foi decisivo no processo, na divulgação e no fortalecimento do modernismo brasileiro em âmbito internacional, o objetivo do trabalho foi compreender, através da identificação dos personagens e da análise das experiências e trocas entre os dois países, como estes fatos incidiram no campo arquitetônico brasileiro.

O tema se desenvolveu a partir de uma visão síntese da interação entre a historiografia do movimento moderno e o contexto histórico e cultural em que os profissionais arquitetos se inseriam naquele preciso momento histórico.

Palavras-chave: Movimento Moderno, Arquitetura Moderna, Brasil, Estados Unidos da América 
HORMAIN, D.R.R.L. The Relationship Brazil - USA and the Modern Architecture: Shared Experiences, 1939 - 1959. 2012. $271 \mathrm{f}$. Tese (Doutorado) - Faculdade de Arquitetura e Urbanismo. Universidade de São Paulo, São Paulo, 2012.

\section{ABSTRACT}

T he doctoral thesis examines the relationship in question, the experiences and professional exchanges occurred between the Brazilian and American architects (or immigrants in North America) in a period that extends from the recognition of Brazilian modern architecture at the international level, between late 1930s and early forties, through the second post-war until the early 1960s.

Many were the exchanges between the two countries, often undeserved in detriment of those that occurred with the European continent, and in this paper we give space and seek their understanding.

So the focus of the research was to demonstrate that other fronts of dialogue have been consolidated, just as the modern architecture that was done in Brazil was also beginning to dialogue internationally, and within this framework, the United States of America, new cultural center of the world, played a key role.

Assuming that the relationship between Brazil and the United States was instrumental in the process, dissemination and strengthening of Brazilian modernism at the international level, the objective of the work was to understand, through the identification of the characters and analysis of the experiences and exchanges between the two countries, how these events have focused on the Brazilian architectural field.

The theme was developed from a synthetic view of the interaction between the historiography of the modern movement and the historical and cultural context in which professional architects were inserted at that precise moment in history.

Keywords: Modern Movement, Modern Architecture, Brazil, United States of America 


\section{AGRADECIMENTOS}

gradeço inicialmente às seguintes instituições, cuja existência permitiu a
realização deste trabalho: a Fapesp (Fundação de Amparo à Pesquisa do Estado de São Paulo), que financiou a pesquisa entre 2009 e 2012; ao Programa de Doutorado do Curso de Pós-Graduação em História e Fundamentos da Arquitetura e Urbanismo da Faculdade de Arquitetura e Urbanismo da Universidade de São Paulo (USP).

Gostaria de agradecer aos funcionários e diretores das seguintes bibliotecas em que realizei minhas pesquisas, nas quais fui muito bem acolhida. No Brasil: Biblioteca Mário de Andrade, Bibliotecas da Graduação e Pós-Graduação da FAU-USP, arquivos do Museu de Arte Moderna de São Paulo (MAM) e MASP, além dos da Bienal de Arte de São Paulo; nos Estados Unidos: New York Public Library e arquivos do Museum of Modern Art - MoMA (New York, NY), The Library of Congress, U. S. National Archives e American Institute of Architects - AIA (Washington D.C.) e The Getty Institute (Los Angeles, California).

Especialmente a Michelle Elligot, Museum Archivist, do Museum of Modern Art, em New York.

Todos da Library of Congress em Washington D.C: à querida Karen J. Fishman, Reference Librarian (Motion Picture, Broadcasting and Recorded Sound Division), que tanto me auxiliou com a "descoberta" das entrevistas de Jonh Peter. Também a Jerry Hatfield e Ryan Chroninger, Public Services Assistants (Motion Picture, Broadcasting, and Recorded Sound Division), que me auxiliaram para a digitalização e aquisição dos áudios.

À Molly Peter, filha de John Peter, que me permitiu o copyright para digitalização dos áudios das entrevistas de seu pai com os arquitetos brasileiros.

No American Institute of Architects, também em Washington D.C., agradeço à Nancy Hadley, Assoc. AIA, CA, Manager, Archives and Records.

À minha querida orientadora, a professora Fernanda Fernandes da Silva por ter aceitado orientar este trabalho, e tê-lo feito com enorme generosidade intelectual, devo meus mais sinceros agradecimentos. 
À prof. ${ }^{a}$ Drª . Mônica Junqueira de Camargo e ao prof. Dr. Fernando Atique por terem participado de meu exame de qualificação e me proporcionarem sugestões pertinentes e construtivas para a continuidade do meu trabalho.

A convivência durante as disciplinas cursadas foi fundamental para a sedimentação de muitas das discussões colocadas aqui, servindo, inclusive, de apoio e consolo à esta travessia tão solitária. Graças, também, aos professores e colegas do programa de pós-graduação que, de formas distintas e em diferentes tempos, ajudaram para que essa sedimentação acontecesse, consigo, agora, concluir este trabalho.

Nas minhas frequentes idas a Florianópolis, minha terra natal, a acolhida dos amigos de sempre foi muito importante. Espero contar-lhes algo novo sobre a arquitetura moderna.

A meu pai, Henrique, que tanto alimentou minha curiosidade, "sempre", e a quem já dediquei minha dissertação de mestrado, dedico também este trabalho. Sua lembrança estará sempre em minha memória.

À minha família, que significa tudo para mim; minha mãe, Juraci, sempre presente, minha irmã Fabiana e meus sobrinhos queridos, Carolina, Juliana e "baby" Sam/Trey. Ao meu irmão Henrique Espada, que sempre será meu mentor intelectual, seja pelo incentivo, seja por sua própria história de vida.

Enfim, ao Fernando, que esteve ao meu lado em todos os momentos, e que já é, quase, um arquiteto, sempre disposto a me acompanhar em peregrinações em busca de "arquiteturas" pelo mundo afora. A ele agradeço, com amor, sua compreensão paciente.

E, claro, e principalmente, às minhas duas filhas amadas, para quem tudo faço e tudo farei, Natalia e Olivia, com amor.

A todos devo o suporte necessário que me estimulou a continuar e concluir esse trabalho. 


\section{RELAÇÃO DAS IMAGENS}

IMAGEM 1: View of Ministry of Justice and Government Building from Senate Building. 1964 Braslia, Brasil. Foto: Julius Shulman. Julius Shulman Photography Archive, Research Library at the Getty Research Institute. (c) J. Paul Getty Trust.

IMAGEM 2: Bauhaus Dessau Buillding. 1925-26. Dessau, Germany. Arquitetura: Walter Gropius. Foto: Débora Lima.

IMAGEM 3: Bauhaus Dessau Buillding. 1925-26. Dessau, Germany. Arquitetura: Walter Gropius. Foto: Débora Lima.

IMAGEM 4: Casa da Rua Santa Cruz. 1928. São Paulo, São Paulo, Brasil. Arquitetura: Gregori Warchavchik. Foto: Débora Lima.

IMAGEM 5: Casa Modernista da Rua Itápolis, ou simplesmente "Casa Modernista". São Paulo, São Paulo, Brasil. Arquitetura: Gregori Warchavchik. Foto: Débora Lima.

IMAGEM 6: Master's Houses, 1925-26. Dessau, Germany. Arquitetura: Walter Gropius Foto: Débora Lima.

IMAGEM 7: Ministério de Educação e Saúde no Rio de Janeiro. Arquitetura; Lucio Costa, Affonso Eduardo Reidy, Carlos Leão, Jorge Moreira, Emani Vasconcellos e Oscar Niemeyer 1936-1945. Foto: Débora Lima.

IMAGEM 8: Sede da ABI. 1936-1938. Rio de Janeiro, Rio de Janeiro, Brasil. Arquitetura Marcelo Roberto e Milton Roberto (MMRoberto). Foto: Débora Lima.

IMAGEM 9: Pavilhão do Brasil na New York World's Fair. 1939-1940. New York, New York, USA. Arquitetura: Oscar Niemeyer, Lucio Costa, Paul Lester Wiener e Thomas Price. Foto: GOODWIN, Philip L. Brazil Builds: Architecture new and Old 1652 - 1942. Photographs by G. E. Kidder Smith. New York: The Museum of Modern Art (MoMA), 1943.

IMAGEM 10: WURTS, Richard (and others). The New York World's Fair, 1939/1940: in 155 Photographs. New York: Dover Publications; 1st. edition, 1977.

IMAGEM 11: Johnson Wax Headquarters, 1936. Racine, Wisconsin, USA. Arquitetura: Frank Lloyd Wright. Foto (c) Jeff Dean.

IMAGEM 12: Pavilhão da Finlândia na New York World's Fair. 1939-1940. New York, New York, USA. Arquitetura: Alvar Aalto. Foto: Museum of Finnish Architecture, Helsinki. 
IMAGEM 13: Interior do Pavilhão do Brasil na New York World's Fair. 1939-1940. New York, New York, USA.

IMAGEM 14: Capa do livro Bazil Buils In G00DWN, Philip L. Brazil Builds: Architecture new and Old 1652-1942. Photographs by G. E. Kidder Smith. New York: The Museum of Modern Art (MoMA), 1943.

IMAGEM 15: Museum of Modern Art. 1939. New York, New York, USA. Arquitetura: Philip Goodwin e Edward Durell Stone. Foto: Débora Lima.

IMAGEM 16: Documento encontrado pela autora durante pesquisa nos arquivos do American Institute of Architects (AIA) em Washington D. C., USA. Assinado por Philip Goodwin, idealizador da mostra Brazil Builds no MoMA em New York.

IMAGEM 17: Documentos encontrados pegugela autora durante pesquisa nos arquivos do Museum of Modern Art (MoMA) em New York, New York, USA.

IMAGEM 18: Capa do livro Built in USA In MOCK, Elizabeth (editor). Prefácio de Philip L. Goodwin. Buit in USA: 1932-1944. New York: Museum of Modern Art, 1944.

IMAGEM 19: United Nations Headquarters, 1947. New York, New York, USA. Arquitetura: Oscar Niemeyer, Le Corbusier, Wallace Harrison. Foto: Débora Lima.

IMAGEM 20: Pavilhão Ciccilo Matarazzo, 1954. São Paulo, São Paulo, Brasil. Arquitetura: Oscar Niemeyer. Foto: Débora Lima.

IMAGEM 21: MASP. 1957-1968. São Paulo, São Paulo, Brasil. Arquitetura: Lna Bo Bardi. IMAGEM 22: Hollyhock House, 1921. Los Angeles, Califórnia, USA. Arquitetura: Frank Lloyd Wright. Foto: Débora Lima.

IMAGEM 23: Arthur Heurtley House, 1902. Oak Park, Ilinois, Estados Unidos, Foto: Débora Lima.

IMAGEM 24: Concurso para o Farol do Colombo, 1929. São Paulo, São Paulo, Brasil. Arquitetura: Flavio de Carvalho In NEDELYKOV, Nina; MORERA, Pedro. Caminhos da Arquitetura Moderna no Brasil: A presença de Frank Lloyd Wright. Arquitextos018 (Romano Guerra Ed. Ltda.). São Paulo, Portal Vitruvius, agosto 2001.

IMAGEM 25: Freeman House, 1923. Los Angeles, Califómia, USA. Arquitetura: Frank Lloyd Wright. Foto: Débora Lima.

IMAGEM 26: Famosa fotografia de Lucio Costa, Frank Lloyd Wright e Gregori Warchavchik na Casa Nordshild no Rio de Janeiro. 1931 
IMAGEM 27: Hanna Residence/Honeycomb House, 1936. Palo Alto, Califórnia, USA. Arquitetura: Frank Lloyd Wright.

IMAGEM 28: Residência Érico Siriuba Stickel. 1952-1954. São Paulo, São Paulo, Brasil. Arquitetura: Miguel Forte, Galiano Ciampaglia e Carlos Millan.

IMAGEM 29: Pavilhão Lowndes. 1953-1954, Samambaia, Petrópolis, RJ, Arquitetura: M.M.M. Roberto.

IMAGEM 30: Taliesin West. 1937. Scottsdale, Arizona, USA. Arquitetura: Frank Lloyd Wright. IMAGEM 31: Robie House. 1908-1910. Hyde Park, Chicago, Illinois, USA. Arquitetura: Frank Lloyd Wright. Foto: Débora Lima.

IMAGEM 32: Residência Rio Branco Paranhos. 1943. São Paulo, São Paulo, Brasil. Arquitetura: Vilanova Artigas.

IMAGEM 33: Fallingwater/Kaufmann's House. 1936. Pittsburgh, Pennsylvania, USA. Arquitetura: Frank Lloyd Wright.

IMAGEM 34: Carpenter Center for the Visual Arts - Harvard University. 1960-1963. Cambridge, Massachusetts, USA. Arquitetura: Le Corbusier.

IMAGEM 35: Case Study House \#8, Eames House. 1949. Pacific Palisades, Califórnia, USA. Arquitetura: Charles e Ray Eames. Foto: Débora Lima.

IMAGEM 36: Case Study House \#21, Bailey House. 1958. West Hollywood, Califórnia, USA. Arquitetura: Pierre Koenig. Foto: Débora Lima.

IMAGEM 37: Residência Maria Luisa e Oscar Americano. 1950. São Paulo, São Paulo, Brasil. Arquitetura: Oswaldo Arthur Bratke. Foto: Débora Lima.

IMAGEM 38: Casa Baeta. 1956. São Paulo, São Paulo, Brasil. Arquitetura: João Batista Vilanova Artigas. Foto @ Nelson Kon.

IMAGEM 39: Case Study House \#9, The Entenza House, 1949. Pacific Palisades, Califómia, USA. Arquitetura: Charles Eames e Eero Saarinen.

IMAGEM 40: Casa e estúdio do arquiteto na rua Avanhandava. 1945. São Paulo, São Paulo, Brasil. Arquitetura: Oswaldo Arthur Bratke.

IMAGEM 41: Case Study House \#16. 1951-1952. Bel Air, Califómia, USA. Arquitetura: Craig Ellwood. Foto: Débora Lima.

IMAGEM 42: Lovell Health House. 1927-1929. Los Angeles, Califórnia, USA. Arquitetura: Richard Neutra. Foto: Débora Lima. 
IMAGEM 43: Tremaine House.1947-1948. Santa Barbara, Califórnia, USA. Arquitetura: Richard Neutra.

IMAGEM 44: Residência Andrade. 1952-1953. São Paulo, São Paulo, Brasil. Arquitetura: Carlos Millan

IMAGEM 45: The Kaufmann House, 1946. Palm Springs, Califórnia, USA. Arquitetura: Richard Neutra. Foto: Débora Lima.

IMAGEM 46: Residência Castor Delgado Perez, 1958. São Paulo, São Paulo, Brasill Arquitetura:Rino Levi, Roberto Cerqueira César e Luís Roberto Carvalho Franco.

IMAGEM 47: Breuer House. 1938-1939. Lincoln, Massachusetts, USA. Arquitetura: Marcel Breuer e Walter Gropius.

IMAGEM 48: Coachella Valley Savings and Loan, 1961. Palm Springs, Califomia, USA Arquitetura: E. Stewart Williams. Foto: Débora Lima.

IMAGEM 49: Villa Alejo Condominiums, 1966. Palm Springs, California, USA. Arquitetura: Meyers \& Koozin. Foto: Débora Lma

IMAGEM 50: Edifício do Hospital da Lagoa, 1952-1958. Rio de Janeiro, Rio de Janeiro, Brasil. Arquitetura: Oscar Niemeyer. Foto: Débora Lima.

IMAGEM 51: Oasis Office Building. Palm Springs, California, USA. Arquitetura: E. Stewart Williams. Foto: Débora Lima.

IMAGEM 52: Frank Sinatra's House, 1947. Palm Springs, California, USA. Arquitetura: E Stewart Williams. Foto: Débora Lima.

IMAGEM 53: Casa Rivadávia de Mendonça. 1944. São Paulo, São, Brasil. Arquitetura: Vilanova Artigas.

IMAGEM 54: Sturges House. 1939. Brentwood Heighs, California, USA. Arquitetura: Frank Lloyd Wright. Foto: Débora Lima.

IMAGEM 55: Gropius House. 1938. Lincoln, Massachusetts, USA. Arquitetura: Walter Gropius.

IMAGEM 56: Conger Goodyear House, 1938. Old Westbury, Long Island, USA. Arquitetura: Edward Durell Stone.

IMAGEM 57: Chicago solar Home. 1955. Chicago, llinois, USA. Arquitetura: Geoge Frederick Keck

IMAGEM 58: Carter, Walloridge, Hawkins Seminar Building - Florida Southem College. 1938-1941. Lakeland, Florida, USA. Arquitetura: Frank Lloyd Wright. Foto: Débora Lima. 
IMAGEM 59: Ginásio de Itanhaém. 1959, Itanhaém, São Paulo, Brasil. Arquitetura: Vilanova Artigas e Carlos Cascaldi.

IMAGEM 60: The Farnsworth House. 1951. Plano, llinois, USA. Arquitetura: Ludvig Mies van der Rohe

IMAGEM 61: FAU-USP. 1962-69. São Paulo, São Paulo, Brasil. Arquitetura: João Batista Vilanova Artigas. Foto: Cristiano Mascaro.

IMAGEM 62: The Burton Tremaine House. 1947. Santa Barbara, Callírnia, USA. Arquitetura: Oscar Niemeyer e Burle Marx.

IMAGEM 63: Casa de Baile. 1943. Belo Horizonte, Minas Gerais, Brasil. Arquitetura: Oscar Niemeyer. Foto: Débora Lima.

IMAGEM 64: Casa das Canoas. 1951. Rio de Janeiro, Rio de Janeiro, Brasil. Arquitetura: Oscar Niemeyer. Foto: Débora Lima.

IMAGEM 65: Projeto para o Consulado dos Estados Unidos, 1957-1962. São Paulo, São Paulo, Brasil. Arquitetura: Mies van der Rohe. Maquete - Projeto não construído.

IMAGEM 66: Lake Shore Drive. 1949-1951. Chicago, llinois, USA. Arquitetura: Ludwig Mies van der Rohe. Foto: Débora Lima.

IMAGEM 67: Conjunto Metropolitano. 1960. São Paulo, São Paulo, Brasil. Arquitetura Salvador Candia e Giancarlo Gasperini.

IMAGEM 68: Edifício-sede do Bank of London \& South América Ltda - Barão de Iguape. 1959. São Paulo, São Paulo, Brasil. Arquitetura:Henrique Mindlin e Giancarlo Palanti.

IMAGEM 69: Seagram Building. 1954-1958. New York, New York, USA. Arquitetura: Ludwig Mies van der Rohe. Foto: Débora Lima.

IMAGEM 70: Edifício Wilton Paes de Almeida. 1961. São Paulo, São Paulo, Brasil. Arquitetura: Roger Zmekohl. Foto: Débora Lima.

IMAGEM 71: Fábrica Duchen. 1950-1953. Guarulhos, São Paulo, Brasil. Arquitetura: Oscar Niemeyer. DEMOLIDA

IMAGEM 72: Museu de Arte Moderna. 1953. Rio de Janeiro, Rio de Janeiro, Brasil. Arquitetura: Affonso Eduardo Reidy. Foto: Débora Lima,

IMAGEM 73: Crown Hall. 1950-1956. Chicago, llinois, USA. Arquitetura: Ludwig Mies van der Rohe.

IMAGEM 74: Painel de Burle Marx para o projeto de Richard Neutra "Amalgamated Clothing Workers of America". 1956. Los Angeles, Califórnia, USA. 
IMAGEM 75: Strick House. 1964. Santa Monica, Califórnia, USA. Arquitetura: Oscar Niemeyer. Foto: Débora Lima.

IMAGEM 77: Placa - Strick House. 1964. Santa Monica, Califórnia, USA. Arquitetura: Oscar Niemeyer. Foto: Débora Lima. 
A MODERNIDADE BRASILEIRA: HISTORIOGRAFIA, GÊNESE, INTERLOCUÇÕES E EVENTOSCHAVE BRASIL X USA

A historiografia da arquitetura moderna brasileira. .44

O papel na historiografia da presença norte-americana na Moderna Arquitetura Brasileira.

Parâmetros e paradigmas - gênese da arquitetura moderna brasileira. 53

Cronologia dos Eventos-chave de ligação Brasil x EUA e arquitetura moderna 1939-1940: Pavilhão do Brasil na New York World's Fair, New York, USA......63 1943: Exposição itinerante e livro "Brazil Builds", MoMA, New York, USA.......70 1944: Exposição "Built in USA since 1932", MoMA, New York, USA................82 1947: Participação de Oscar Niemeyer no projeto do Edifício-sede da Organização das Nações Unidas, New York, USA. .84

O Percurso das Artes - 1949/1951: Inaugurações do MASP e MAM. 1951/1953-54/1955/1957/1959: Bienais Internacionais de Arte. São Paulo, Brasil.....86 1959: Congresso Internacional Extraordinário de Críticos de Arte em Brasilia, São Paulo e Rio de Janeiro, Brasil. .94

TROCAS, TRANSFERÊNCIAS, DIÁLOGOS E OUTROS CAMINHOS - ANÁLISE DE ALGUMAS DAS EXPERIÊNCIAS COMPARTILHADAS ENTRE A MODERNA ARQUITETURA BRASILEIRA E OS ARQUITETOS E O CAMPO ARQUITETÔNICO NORTE-AMERICANO

Cronologia das trocas arquitetônicas ocorridas entre o Brasil e os EUA entre as décadas de 1930 e 1960:

1931: Visita de Frank Lloyd Wright ao Rio de Janeiro, Brasil........................102

1935: Le Corbusier nos EUA.........................................................111

1945: Início do projeto Case Study Houses, Califórnia, USA.........................114

1945: Visita de Richard Neutra ao Brasil. 
1945-1950: A Modernidade no Deserto - Palm Springs, California...... 138

1946-1947: Visita de Vilanova Artigas aos EUA.......................................141

1947: Projeto de Oscar Niemeyer para a residência Burton-Tremaine, Santa Bárbara, Califórnia, USA. 153

1954: Jonh Peter Interviews com Affonso Eduardo Reidy, Marcelo Roberto, Oscar Niemeyer e Oswaldo Bratke, Brasill e USA. 156 1957: Projeto de Mies van der Rohe para o Consulado dos Estados Unidos em São Paulo, Brasil. 161

1959: Nova visita de Richard Neutra ao Brasil..... 171

1964: Oscar Niemeyer e a Casa Strick em Santa Mônica, Califórnia, EUA.....174 
INTRODUÇÃO 
O momento atual não poderia ser mais oportuno para se discutir as questões que envolvem a História da nossa arquitetura diante dos desafios do início desta segunda década do século XXI, e dos problemas urbanos decorrentes do encontro entre realidades diferentes em nossas cidades.

O caso do Brasil, sempre hesitante entre uma identidade própria e padrões de consumo estrangeiros é, e sempre foi, uma fronteira entre realidades diferentes que se enfrentam e se contaminam, e deste modo estabelecem interlocuções, promovendo mudanças no campo arquitetônico.

Num país no qual a cultura, de modo geral, tem funcionado a partir de referências originadas no hemisfério norte, o reconhecimento de uma Arquitetura Moderna Brasileira representou uma mudança transformadora significativa, mudança esta que se caracterizou, portanto, pelo diálogo com o campo arquitetônico internacional.

Esse processo gerou trocas com via de mão dupla, oficialmente de forma quase que hegemônica com a arquitetura produzida na Europa mas, e como nos propomos aqui expor, também amplamente com o campo cultural e arquitetônico norte-americano da época.

Sendo assim, a História de nossa arquitetura modernista deve ser referida ao plano internacional, e aqui incluímos os Estados Unidos da América desempenhando um papel importante para a origem e o desenrolar desta trama.

Entretanto somente pode-se entender esse processo de trocas observando as condições de chegada, os modos de inserção na vida social local, as redes de relações estabelecidas e a ligação com a formação de campos de conhecimento e de prática profissional.

O que é importante analisar é a presença e o papel que tiveram nas universidades, em instituições culturais, na formação de associações profissionais e pela transformação de cidades como São Paulo, nitidamente impactada pela cultura americana.

Procura-se examinar na rede de relações que estabelecem, as circunstâncias diversas destas experiências, não como adaptação ou assimilação mas pelas possibilidades de confrontos, conflitos, parcerias, interações, socializações e rupturas 


\section{INTRODUÇÃO}

concretas. Ainda que tratem de viagens, de estrangeiros e de ideias em movimento, a análise da circulação de ideias e de modelos não se descola do exame de práticas e de experiências concretas. ${ }^{1}$

Estes trocas contribuem para entender o campo da arquitetura e do urbanismo no difícil processo de modernização do Brasil. Examinando no detalhe as trajetórias profissionais e geográficas, com diferentes inserções profissionais e permanências revela-se tanto da formação do campo de conhecimento e da prática profissional como do próprio processo de modernização brasileiro.

Os intercâmbios foram muitos. E tiveram sua origem, mesmo que lentamente, muito antes da consagração da arquitetura moderna brasileira.

Importante é se tomar cuidado com marcos tão intensos que indicam estas trocas ocorrendo somente a partir da final da década de 1930. Afinal, os próprios modernistas dessa época já estavam fazendo estas relações desde os primeiros anos do século XX, muitos deles ainda em fase de formação profissional.

Dentro desse panorama, a década de 1920 é crucial para entender a década seguinte porque esse projeto moderno chega e é recebido e os arquitetos que ainda estão estudando, mesmo submetidos a um dogma de formação, experimentam uma infiltração externa que vai se reproduzir na arquitetura da sua vida profissional madura, e com um lastro americano muito vivo.

Desde as primeiras décadas do século XX, por exemplo, sabe-se que muitas revistas americanas de arquitetura já circulavam por aqui, em especial nas escolas.

Durante muito tempo tivemos somente três faculdades formando engenheirosarquitetos no Brasil: a ENBA (Escola Nacional de Belas Artes) no Rio de Janeiro, e em São Paulo a Politécnica e a Escola de Engenharia Mackenzie, fundada em 1917, de origem americana, que contava com alguns professores formados nos Estados Unidos e alunos que dominavam, ainda que parcialmente, a língua inglesa, e que podiam, inclusive, obter seus diplomas nos Estados Unidos, contanto que defendessem sua tese na Universidade de Nova York. 
O próprio reitor da futura Faculdade de Arquitetura Mackenzie (fundada somente em 1947), Christiano Stockler das Neves², por muitos anos professor da Escola de Engenharia, e crítico ferrenho do advento da arquitetura moderna entre os estudantes, havia se formado nos Estados Unidos. ${ }^{3}$

É certo que ao menos as revistas norte-americanas Architectural Record, Architectural Forum e Pencil Point eram recebidas regularmente por estas escolas. ${ }^{4}$

A revista Arts and Architecture, publicação simplesmente fundamental para a arquitetura moderna da costa oeste dos Estados Unidos nasce em 1929 com o nome California: Arts and Architecure, a partir da fusão de duas outras publicações, a Pacific Coast Architect, estabelecida em 1911, e a California Southland, estabelecida em 1918, e que nos anos trinta passará a se intitular somente Arts and Architecture.

Analisando suas publicações ${ }^{5}$ verifica-se que o projeto gráfico permanece igual porém os assuntos vão mudando conforme as "modas arquitetônicas" até se transformar de fato num projeto editorial de cunho essencialmente moderno, e futuro idealizador dos Case Study Houses.

Para demonstrar que esse relacionamento americano com o Brasil é mais antigo podemos citar que a Politécnica de São Paulo assinou essa revista no seu primeiro número, e que os engenheiros-arquitetos dentro da escola a liam, bem como os alunos do Mackenzie, portanto esses estavam sendo submetidos a um tipo de arquitetura que supostamente não poderia ser aceitável, mas que já era quase impossível de ser negada.

Ou seja, em um primeiro momento esta era uma questão de princípios de arquitetura não tanto envolvendo política e relações diplomáticas entre dois países, o que iria caracterizar fortemente essas trocas a partir da segunda metade dos anos trinta.

\footnotetext{
${ }^{2}$ Cristiano Stockler das Neves (1889-1982) formou-se em arquitetura nos Estados Unidos, em 1911. Começou a lecionar na Escola de Engenharia do Mackenzie em 1917, no novo curso para engenheiros arquitetos. Em 1947, fundou a Faculdade de Arquitetura, da qual foi diretor até 1956.

Ver mais em STOCKLER e BREIA, Maria Teresa. A Transição do Ensino da arquitetura Beaus-arts para o ensino da arquitetura moderna na Faculdade de Arquitetura Mackenzie: 1947-1965. São Paulo, 2005. Tese (Doutorado). Curso de Pós-Graduação em Arquitetura e Urbanismo. Faculdade de Arquitetura e Urbanismo USP

${ }^{4}$ NEDELYKOV, Nina; MOREIRA, Pedro. Caminhos da Arquitetura Moderna no Brasil: A presença de Frank Lloyd Wright. Arquitextos018 (Romano Guerra Ed. Ltda.). São Paulo, Portal Vitruvius, agosto 2001.

${ }^{5}$ Para acessar na integra os arquivos com as edições da revista Arts \& Architecture de 1945 a 1967 ver http://www. artsandarchitecture.com.
} 


\section{INTRODUÇÃO}

Mas antes das trocas arquitetônicas, que são o centro de nosso trabalho, nas origens das transferências ocorridas, houveram as formas pelas quais se deram os contatos entre os urbanistas brasileiros e os urbanistas franceses, ingleses, americanos, e que foram diferenciadas, de acordo com Leme ${ }^{6}$, tanto para os urbanistas brasileiros enquanto recepção e assimilação de conhecimento, como para os urbanistas estrangeiros enquanto reconhecimento internacional e abertura de um campo de atuação profissional.

Segundo Leme, foram três as formas de circulação destas ideias, e originalmente a recepção e assimilação dos brasileiros à modelos estrangeiros se deu pessoalmente nos congressos e exposições internacionais, embora a presença brasileira para apresentação de trabalho ou representação oficial nestes encontros tenha sido rara, até a década de 1920.

A segunda forma de circulação de ideias se fez através da leitura de textos apresentados em congressos internacionais e dos tratados urbanísticos, e também pelo contato pela leitura de livros $^{7}$ bem como artigos publicados nas revistas especializadas da época, como já mencionamos.

A terceira forma também importante em termos de transmissão foi a realização por parte dos profissionais brasileiros de cursos de urbanismo no exterior.

Por outro lado, verificamos que a vinda de urbanistas estrangeiros ao Brasil se dá inicialmente para a realização de conferências.

Dos primeiros contatos, as relações evoluíram para a contratação dos serviços profissionais como consultor ou como responsável por projeto urbanístico ou planos urbanos quando foi proposta uma nova noção - a de ressonância - significando tratarse de um terreno de trocas de experiências em que todos os profissionais envolvidos modificaram-se através destes contatos.

\footnotetext{
ELEME, Maria Cristina da Silva. Estrangeiros: a circulação de idéias e modelos na arquitetura e no urbanismo In Anais do X Seminário Historia da Cidade e do Urbanismo - Mesa Redonda Histórias das intervenções urbanísticas públicas. Recife: outubro 2008.

${ }^{7}$ As bibliotecas pessoais desses urbanistas mostram como eram eruditos e liam diversos idiomas. Na biblioteca de Anhaia Mello doada a FAUUSPP e na de Prestes Maia formando o acervo da Biblioteca Municipal Kennedy, existem as principais obras de urbanistas alemães, franceses, americanos, ingleses adquiridas logo em seguida a data de publicação.
} 
Salienta-se muito em nosso historiografia o impacto da experiência em um outro continente na produção de Le Corbusier (1887-1965) após a sua primeira viagem à América do Sul, em 1929.

Mas o objetivo da sua viagem ao Brasil, como se evidencia em sua correspondência, era desenvolver projetos urbanos, e sua ambição não se limitava a proposta de transformação da cidade existente. Desde que havia sido informado por Blaise Cendrars (1887-1961) da aprovação pelo Congresso de verbas para uma nova capital do Brasil, Planaltina, seu interesse em realizar esta obra é evidente na correspondência que envia a seus interlocutores brasileiros. ${ }^{8}$

Ele declara, mais tarde, que não se deslocaria toda a distância que separa os dois continentes para apenas proferir conferências, e o seu interesse era desenvolver projetos. De modo geral essa opinião ele divide com a maioria dos arquitetos e urbanistas que vieram ao Brasil na época, visto como um país aonde podia-se ainda "experimentar".

Em 1936, Corbusier retorna e permanece um mês entre julho e agosto no Rio de Janeiro. Profere seis conferências na Escola Nacional de Música e, mais importante, dirige dois ateliers, um para o projeto do edifício do Ministério da Educação e Cultura, e outro para o projeto da Cidade Universitária, quando trabalha com os jovens arquitetos Lucio Costa (1902-1998), Oscar Niemeyer (1907-), Affonso Eduardo Reidy (1909-1964), entre outros.

A experiência de trabalho em equipe com Le Corbusier para o desenvolvimento do projeto do edifício do Ministério da Educação e Cultura no Rio de Janeiro foi um ponto de inflexão na trajetória profissional dos arquitetos Lucio Costa e Oscar Niemeyer e deu inicio a outros trabalhos em colaboração, bem como a suposta afiliação do movimento moderno brasileiro ao grande mestre francês. ${ }^{9}$

\footnotetext{
${ }^{8}$ LE CORBUSIER (1887-1965). Precisões sobre um estado presente da arquitetura e do urbanismo. São Paulo: Cosac \& Naify, 2004 (trad. Carlos Eugênio Marcondes de Moura, Précisions sur un état présent de l'architecture et l'urbanisme. Edição original: 1930).

'LEME, op, cit. Para Le Corbusier a natureza exuberante do continente sul americano introduz novas questões a serem enfrentadas no projeto urbano. O sitio, a topografia são elementos presentes na solução de estrutura aérea de circulação e habitação que propõe nos croquis para o Rio de Janeiro e depois desenvolve no plano Obus.
} 


\section{INTRODUÇÃO}

É o inicio de uma colaboração que se por um lado foi importante, por outro se fez com alguns conflitos e mal entendidos, e irá marcar para sempre a história a ser contada sobre o inicio do movimento moderno no Brasil.

Entretanto, outras frentes de diálogo já vinham acontecendo, independentes dessas trocadas com Le Corbusier a partir de suas tão marcantes visitas ao país, quando a arquitetura moderna que aqui se fazia passava também a dialogar internacionalmente.

Ainda em 1934, Lucio Costa, que de certa forma acaba por ser o mentor do movimento, resvala o modelo americano para o lado negativo.

Em Razões da Nova arquitetura ${ }^{10}$, compara os Estados Unidos ao Império Romano, salientando curiosas afinidades entre dois povos tão afastados no tempo: "a coragem de empreender, a arte de organizar, a ciência de administrar; a variedade das raças; a opulência dos centros cívicos; os estádios e certa foracidade esportiva; o pragmatismo; o mecenismo; o gosto da popularidade, a mania das recepções triunfais e, até mesmo, o próprio jeitão dos senadores - tudo os aproxima. Tudo o que o romano tocava, logo tomava ares romanos; quase todos que atravessam o continente saem carimbados: 'USA"'11

Salientando a característica imperialista dos Estados Unidos e concluindo a quase imposição cultural que a América imprime ele desqualifica, de certa forma, o que a arquitetura americana poderia nos fornecer, e amplia o que a Europa pode nos dar.

Enquanto os engenheiros americanos elevam a uma altura nunca dantes atingida as impressionantes afirmações metálicas da nova técnica, os arquitetos americanos - vestindo as mesmas roupas, usando os mesmos cabelos, sorrisos e chapéus, porém desgostosos com o passado pouco monumental que os antepassados legaram, e sem nada compreender do instante excepcional que estamos vivendo - embarcam para a Europa, onde tranquilamente se abastecem das mais falsas e incríveis estilizações modernas, dos mais variados e estranhos

${ }^{10}$ COSTA, Lucio. Razões da Nova Arquitetura In Lucio Costa: Registro de uma Vivência. São Paulo: Empresa das Artes, 1995, pp. 108-116. 
documentos arqueológicos, para grudá-los - com o melhor cimento - aos arcabouços impassíveis, conferindo-lhes a desejada dose de "dignidade". ${ }^{12}$ "

Talvez ele esteja se referindo ao historicismo dos arranhã céus de Chicago, que não tem uma nova linguagem para uma nova técnica. Também Le Corbusier em "Por uma Arquitetura" (1923) ${ }^{13}$ já apontava a defasagem entre as obras de engenheiros e arquitetos. De modo que o texto de Lúcio Costa já apresenta afinidades com o pensamento de Le Corbusier.

A essa época, entretanto, Frank Lloyd Wright (1867-1959) já produzira uma grande revolução na arquitetura americana, seguindo os passos de Louis Sullivan (1856-1924) e tantos outros. ${ }^{14}$ A partir de 1937 a maioria dos grandes mestres da arquitetura moderna europeia imigrariam para os Estados Unidos, iniciando uma nova trajetória.

Quanto aos europeus, Costa continua: "No entanto, os 'velhos' europeus, fartos de uma herança que os oprime, caminham para a frente, fazendo vida nova à própria custa, aproveitando as possibilidades do material e da prodigiosa técnica que os ‘jovens' americanos não souberam utilizar”.

E compara, então, os romanos e os americanos:

Assim, com vinte séculos de intervalo, a história se repete. Os romanos admiráveis engenheiros - servindo-se de alvenaria e concreto, ergueram, graças aos arcos e abóbadas, estruturas surpreendentes: não perceberam que a dois passos estava a arquitetura; apelaram para a Grécia decadente, revestindo a nudez sadia dos seus monumentos com uma crosta de colunas e platibandas de mármore e travertino, - vestígios de um sistema construtivo oposto. ${ }^{15}$

Costa continua a estabelecer relações entre técnica e uma nova linguagem, tema importante no debate moderno.

\footnotetext{
${ }^{12}$ bidem.

13LE CORBUSIER (1887-1965). Por uma arquitetura (1923). São Paulo: Perspectiva, 1981

${ }^{14}$ Documentários muito interessantes mostraram recentemente a trajetória desses dois arquitetos americanos 2004: Frank Lloyd Wright. USA; doc, cor/P\&B, um filme de Ken Burns e Lynn Novick e 2004: Tall, The American Skyscraper and Louis Sullivan. USA; doc, cor/P\&B, um filme de Manfred Kirchheimer. 


\section{INTRODUÇÃO}

As palavras de Lucio Costa repercutem dentro dos círculos acadêmicos e profissionais da arquitetura. Ao fazer uma afirmação como essa em relação aos Estados Unidos ele coloca a Europa em primeiro plano. E, mais tarde, a partir dos anos da Guerra Fria, esse parece ser um "gancho" importante para desqualificar os EUA dentro do processo de desenvolvimento da nossa arquitetura moderna, e colocar Le Corbusier à frente desse processo.

Portanto, neste trabalho, iremos considerar as intensas trocas que se processam entre Europa e Estados Unidos e posteriormente entre Europa, Estados Unidos e América Latina, em particular com o Brasil, tornando o quadro de interlocuções muito mais complexo.

Neste quadro podemos lembrar que Adolf Loos (1870-1933), autor do importante ensaio Ornamento e Delito (1908), ampliou consideravelmente seu repertório em arquitetura moderna durante uma estadia de três anos nos Estados Unidos, que começou ainda em 1893. O arquiteto de 23 anos teria ficado particularmente impressionado com a eficiência inovadora dos edifícios industriais americanos, vestuário e mobiliário doméstico.

A história brasileira, em particular, mesmo antes do início da Politica da Boa Vizinhança e do Estado Novo de Getúlio Vargas, mostra elementos que inequivocamente demonstram que o país estava construindo um relacionamento, uma troca efetiva com os Estados Unidos, que também se reflete na arquitetura.

A Câmara Americana de Comércio, AMCHAM (American Chamber of Commerce), inicialmente uma entidade de São Paulo, organizada por nove instituições visionárias - Brazaço-Mapre, Citibank, Esso, General Electric, Goodyear, Indústrias Matarazzo, Lion, Singer e Universidade Presbiteriana Mackenzie -, cujo estatuto inicial data de 1919, sempre contribuiu em áreas decisivas na aproximação entre o Brasil e os EUA, inclusive recepcionando arquitetos americanos em visita ao Brasil, influenciando políticas públicas e promovendo o comércio e os investimentos no país.

Dentro deste panorama de trocas com via de mão dupla não podemos esquecer das construtoras americanas que se empenharam em empreender abroad, edificando projetos de arquitetos americanos em várias partes do mundo, e também na América Latina e Brasil. 
Cody em seu livro Exporting American Architecture: 1870-2000 ${ }^{16}$, investiga como a arquitetura norte-americana foi "transplantada" para todos estes lugares ao longo do século $X X$, e explica como, porquê e aonde os arquitetos americanos, construtores, empreendedores, planejadores ou exportadores de material de construção levaram essa arquitetura.

O autor também descobre que existiu um Comitê de Relações Estrangeiras no AIA (American Institute of Architects), entre 1920 e 1930.

Entre a Primeira Guerra Mundial e a Depressão, muitos arquitetos americanos pareciam geralmente menos preparados para a prática no exterior do que muitos de seus colegas da engenharia civil, construção ou da área de materiais de exportação.

Houve certamente algumas exceções notáveis (como Frank Lloyd Wright no Japão), mas arquitetos americanos, muitas vezes, foram enviados para o exterior com cautela e no rastro dos outros da indústria, fazendo do design e da construção atividades dinamicamente inter-relacionadas.

O Instituto Americano de Arquitetos, organização profissional dos arquitetos norte-americanos, criado em 1867, foi de certa forma sensível aos contextos estrangeiros. Richard Morris Hunt (1827-1895), o primeiro arquiteto americano na École des Beaux-Arts, em Paris, foi um dos seus membros fundadores.

No entanto, não foi até 1920 que se formou dentro da Instituição um 'Foreign Building Cooperation Standing Committee', que durou até o começo da Grande Depressão.

Segundo Cody ${ }^{17}$, a julgar pela lista de membros do AIA no início da Primeira Guerra Mundial, parecia haver poucos arquitetos americanos praticando fora das fronteiras norte-americanas, mas que, no entanto, os endereços destes podiam ser enganosos. Muitos arquitetos trabalhavam abroad, porém tinham seus endereços de correspondência americanos no cadastro do AIA, o que os mantinham listados na associação como arquitetos baseados no país.

Houve, sem dúvida, aqueles que começaram a trabalhar no estrangeiro de forma mais ativa após a Primeira Guerra Mundial, mas que não queriam causar 


\section{INTRODUÇÃO}

problemas com o estatuto de membro alterando seus endereços para as mais exóticas cidades estrangeiras.

Até o final da guerra, o Instituto começou a voltar sua atenção de forma mais proativa para as questões miríades associados à prática de arquitetura no exterior. E Cody indica que, a partir de 1923, surge um foco claro de interesse na evolução arquitetônica que vinha ocorrendo na América Latina, uma tendência que se mantém estável até cerca de 1930, levantando questões sobre quais seriam as oportunidades na América do Sul para os arquitetos americanos.

O autor transcreve relatórios dos membros do Comitê que estiveram no Segundo Congresso Panamericano de Arquitetos em Santiago, no Chile, em 1923, aonde relatam acerca das diferenças de método entre os profissionais norteamericanos e sul-americanos, e que os códigos de ética e prática da arquitetura seriam totalmente diferentes, mas concluem que:

There is no doubt that there is a rapidly increasing open-mindedness towards North American ideas in architecture as well as other things, which is creating a demand and adding to this we have the ever-growing North American population living in South America... We believe that in time many agreeable and profitable associations may be affected by North American architects in South America, and by South American architects in North America. We consider this a matter of great interest to our young men. ${ }^{18}$

De modo que ao longo da década de 1920 as atividades do Comitê de Relações Estrangeiras do AIA proliferam. A partir de 1927-28, segundo o mesmo autor, mais arquitetos americanos decidiram praticar no exterior, especialmente na América do Sul e Leste da Ásia. Dois dos americanos mais notáveis que se instalaram na América Latina foram os graduados pela Universidade da Pensilvânia, William P. Preston (classe de 1900) e John P. Curtis (classe de 1909), que se mudou para o Rio de Janeiro em 1927 para estabelecer um escritório depois de receber uma comissão do governo dos EUA para projetar na cidade o seu Consulado. 
A Escola de Belas Artes da Universidade da Pensilvânia tinha grande orgulho no aumento do número de estudantes estrangeiros, especialmente da América do Sul, que depois de se formarem na Penn voltaram para seus países de origem: Francisco Squirru (turma de 1915) e Renato Thierry (classe de 1919), da Argentina. E Christiano Stockler das Neves (classe de 1911) e Edgar Vianna (classe de 1919) do Brasil, por exemplo.

Edgar Vianna (cuja esposa era americana) seria, inclusive, um dos tradutores de Frank Lloyd Wright no Brasil, antes de falecer precocemente com 40 anos, em 1936. Mas, retrocedendo a década de 20, quando volta da Pensilvânia e começa a trabalhar no Rio de Janeiro, Vianna era um dos principais expoentes a ser consultado pela imprensa cotidiana, sendo muito próximo da Escola Nacional de Belas Artes.

Cody nos conta que, chineses, sul-americanos e outros estudantes estrangeiros frequentaram outras escolas americanas de arquitetura - MIT, Cornell, Universidade de Illinois, Armour Institute of Technology (Chicago), Universidade de Minnesota - e foram instrumentais em trazer práticas americanas, normas e outras influências de volta à sua terra natal, após sua experiência nos programas dos EUA. ${ }^{19}$

Nas três primeiras décadas do século $X X$ descobrimos, em viagem de pesquisa a Washington, e pesquisando nos arquivos do Instituto de Arquitetos Americanos, que haviam vários Honorary Corresponding Members of the American Institute of Architects de outros países das Américas, entre eles um brasileiro, do Rio de Janeiro, agraciado com o título em 1930, Nestor Egydio de Figueiredo. ${ }^{20}$

De modo que trocas houveram, e em várias áreas, e vinham acontecendo muito antes da nossa arquitetura moderna despontar.

A partir desse panorama introdutório, podemos adentrar a década de 1930, quando os paradigmas historiográficos da nossa arquitetura moderna passam a reinar.

A partir daí, outra questão a ser levantada quando se pretende tratar da História dessa nossa arquitetura diz respeito a sua dita identidade nacional.

\footnotetext{
${ }^{19} \mathrm{CODY}$, op. cit, p. 62.

${ }^{20}$ Outros Honorary Corresponding Members do Instituo de Arquitetos Americanos até 1930: 1900 E. Bènard (Mexico City, Mexico); 1925 Horacio Acosta y Lara (Montevideo, Uruguay); 1928 Raul J.Alvarez (Buenos Aires, Argentina), 1928 Alberto Coni Molina (Buenos Aires, Argentina), 1928 Raul J. Fitte (Buenos Aires, Argentina), 1928 Bernardo Morales (Santiago, Chile), 1928 Francisco Squirru (Buenos Aires, Argentina), 1929 Alejandro Christophersen (Buenos Aires, Argentina).
} 


\section{INTRODUÇÃO}

A proposta de Lúcio Costa em relação à identidade da arquitetura moderna não era mais que uma resposta elegante a duas questões que obcecavam as elites brasileiras dos anos 20: de um lado a afirmação da identidade da cultura nacional, de outro a integração dessa cultura à modernidade internacional. ${ }^{21}$

Comas resume muito bem esta questão, salientando, entretanto, que suas observações não esgotam a compreensão da identidade da arquitetura moderna brasileira de 1936 a 1957 - como a nossa também não - mas que ainda assim, pelo menos três lições se poderiam deduzir delas:

Primeira, que se essa arquitetura pôde resolver de maneira muito sofisticada o problema da representação de uma identidade nacional foi porque não a definiu como problema único e isolado... Na realidade, essa arquitetura pôde concretizar-se porque a animava um espírito ao mesmo tempo nacionalista e modernizador, universalista e respeitador de tradições, que coincidia com as aspirações de cultos funcionários da revolução de 1930 e da ditadura de Getúlio Vargas. Foi um momento raro de convergência entre um grupo de arquitetos talentosos e um grupo de comitentes poderosos, em circunstâncias especiais e provavelmente irrepetíveis... Segunda, que essa definição e resolução sofisticadas foram facilitadas pela influência de uma tradição disciplinar acadêmica que havia desenvolvido categorias teóricas de valor genérico, não sujeitas estritamente a uma formação estilística determinada. Não importa que essa influência fosse subliminar, encoberta... Terceira e última, que se essa arquitetura é indubitavelmente moderna em sua linguagem, sua concretização não dependeu em nada da concretização da cidade da Carta de Atenas, a cidade ideal da arquitetura moderna. Ao contrário, suas realizações extraíam força representativa de sua confrontação com um contexto que obedecia a um paradigma urbanístico mais antigo, cujas regras formais permitiam que distintas manifestações estilísticas coexistissem e dialogassem civilizadamente em seu interior. ${ }^{22}$

Hoje devemos ser cada vez mais críticos quanto às interpretações feitas em relação à essa dita "identidade nacional", relativizando e muito a sua importância,

\footnotetext{
${ }^{21}$ COMAS, Carlos Eduardo Dias. Uma certa arquitetura moderna brasileira: experiência a reconhecer (1987) In: GUERRA, Abilio (org.). Textos Fundamentais sobre História da Arquitetura Moderna Brasileira. Parte 1. São Paulo Romano Guerra, 2010, pp. 66-67. 
sendo que o entendimento desse foco é imprescindível para o que nos propomos nesse trabalho.

Como nossa arquitetura moderna foi um fenômeno arquitetônico importante para o Brasil, e também, principalmente a partir da década de 1950, extremamente popular, chegando a representar um papel fundamental na cultura brasileira a partir daí ${ }^{23}$, é fundamental estudar as obras paradigmáticas como também é importante abrir o leque de investigação para a totalidade de nosso ambiente construído moderno, que está em toda parte, apesar de muitas vezes camuflado ou não reconhecido, simplesmente visto como ultrapassado e "velho".

Podemos considerar que tudo o que foi construído no Brasil depois dos anos 1940 foi fortemente influenciado pelo Movimento Moderno, de modo que uma parcela bem significativa do nosso espaço urbano é moderno, pois a maioria das grandes cidades brasileiras praticamente nasceu ou se reconstruiu a partir desse momento.

Em maior ou menor grau, com menos ou mais qualidade, mas eminentemente Moderno. ${ }^{24}$

Mas não nos interessa, de um certo ponto de vista, discutir se as distintas manifestações artísticas que coexistiram e dialogaram no interior do nosso movimento moderno, que obedecia a um paradigma urbanístico mais antigo, eram verdadeiras ou falsas. De modo que o ponto a destacar é a abertura desse paradigma a uma pluralidade de vozes, sem que isso necessariamente provocasse a cacofonia que se instalou nas cidades brasileiras com o triunfo da cidade da arquitetura moderna.

Mas, para o bem e para o mal, citando novamente COMAS (1987, pp. 76-77): “... a pluralidade de vozes é condição iniludível de uma sociedade que se pretenda democrática. Contudo, se as limitações da cidade ideal da arquitetura moderna nos levam a rechaçá-la hoje e a revalorizar outro paradigma urbanístico, isso não nos obriga a rechaçar em bloco a arquitetura moderna - ou mais precisamente as arquiteturas modernas. Há que reconhecê-las, e reconhecendo-as, reconhecer em

\footnotetext{
${ }^{23}$ SEGAWA, Hugo. The essentials of Brazilian Modernism, Design Book Review 32/33, 1994, p. 64-68; LARA, Fernando. One step back for two steps forward: the maneuverings of the Brazillian avant-garde. In Journal of Architectural Education, vol 55/4, may 2002.

${ }^{24}$ LARA, Fernando. A insustentável leveza da modernidade. Arquitextos057 (Romano Guerra Ed. Ltda.). São Paulo, Portal Vitruvius, fevereiro, 2005.
} 


\section{INTRODUÇÃO}

algumas delas um passado que pode bem iluminar o presente e ajudar a construir o futuro."

A primeira década do século XXI mostrou este modernismo voltando com força. Um resgate que não vem acontecendo somente aqui, no Brasil, mas com uma força pouco esperada, revigorada, também no continente americano do Norte, nos Estados Unidos, berço dos pós-modernismos e portanto avesso à valorização da sua arquitetura moderna por tantas décadas. ${ }^{25}$

Mas para compreender isto talvez devêssemos voltar mesmo a década de 1920, quando o desenvolvimento do modernismo em todas as artes estava conectado com a busca de um "projeto nacional".

A base desse processo ocorre num momento em que o Brasil experimenta uma relativa expansão econômica ${ }^{26}$, e o impulso empreendido pela nascente arquitetura moderna brasileira foi fator sem igual para o desenvolvimento da autoimagem da nação, alcançando uma penetração e uma divulgação internacional impressionantes, adentrando os anos cinquenta do século XX como um dos alvos principais do olhar estrangeiro. $^{27}$

Era exatamente essa a imagem que a Nação brasileira gostaria de contemplar. Gesto político e intenção do projeto, a decisão de desenvolver o país reduz a modernidade a apenas um de seus termos: o mundo novo.

Moderno é o país novo, moderna é a condensação social no ato da razão. "Somos um pais condenado ao moderno" (Mário Pedrosa), onde o progresso e a técnica mantém-se ainda, enquanto gesto inicial, intencionalmente primeira e vontade expressiva. ${ }^{28}$

De modo que o estímulo progressista da "Era Vargas" aliado muito e principalmente ao estímulo antiacadêmico de Gustavo Capanema ("verdadeiro"

\footnotetext{
25 ide SERRAINO, Pierluigi. Julius Shuman, Modernism Rediscovered. Hong Kong/Köln/London/Los Angeles/Madrid/Paris/Tokyo: Taschen, 2009 e PRUDON, Theodore H. M., FAIA. Preservation of Modern Architecture. Hoboken, New Jersey: John Wiley \& Sons, 2008

26ZWEIG, Stefan. Brazil: Land of the Future. London: Cassell, 1942

${ }^{27}$ Ver mais em TINEM, Nelci. $\bigcirc$ Alvo do olhar estrangeiro - $\bigcirc$ Brasil na Historiografia da Arquitetura Moderna João Pessoa: Manufatura, 2002 e Arquitetura Moderna Brasileira: A imagem como texto. Arquitextos072 (Romano Guerra Ed. Ltda.). São Paulo, Portal Vitruvius, maio 2006, e também em LARA, Fernando. Espelho de fora: arquitetura brasileira vista do exterior. Arquitextos004 (Romano Guerra Ed. Ltda.). São Paulo, Portal Vitruvius, setembro, 2000

28TELLES, Sophia. A Arquitetura modernista - Um espaço sem lugar (1983) In: GUERRA, Abilio (org.). Textos Fundamentais sobre História da Arquitetura Moderna Brasileira. Parte 1. São Paulo: Romano Guerra, 2010, p. 32
} 
idealizador do "projeto símbolo" do Ministério da Educação e Cultura) gerou um esforço orquestrado por parte do Estado para se "modernizar". ${ }^{29}$

Também é importante dizer que não havia um único processo de modernização em curso mas muitos, sobrepondo-se ou distanciando-se de acordo com o contexto.

$\mathrm{Na}$ Europa, a arquitetura se impõe como um dos polos do próprio olhar moderno. Ordem, clareza, evidência de técnica e de novos procedimentos, formas puras. Pura exterioridade de um interior já dissolvido pela ação do capital e reassumido pelo controle da forma, manobra que procura dirigir os afetos para a lógica estruturante da percepção, para a redução da dimensão sensível da existência a um sistema objetivo de relações universais. Afinal, é a positividade da vida moderna que a arquitetura vem mostrar e demonstrar... O modernismo aqui acolhe imediatamente esse sinal de progresso e racionalidade com o qual o Brasil precisa aprender a conviver. ${ }^{30}$

O papel fundamental que tiveram os intercâmbios entre o Brasil e a arquitetura europeia e, dentro do que nos propomos neste trabalho, também entre o Brasil e a produção e o meio arquitetônico norte-americano podem ajudar a entender essa especificidade da história da arquitetura aqui implantada e desenvolvida.

Martins $^{31}$ nos lembra do assombro de Sigfried Giedion (1888-1968) no prefácio do livro de Mindlin de 1956 "Arquitetura Moderna no Brasil"32, quando diz que "There is something irrational in the rise of brazilian architecture", afinal o desordenado crescimento urbano e a desenfreada especulação com a terra urbana que caracterizavam o desenvolvimento das principais cidades brasileiras na primeira metade do século XX constituiriam em princípio um entrave ao desenvolvimento de uma arquitetura saudável, e que a essa dificuldade vinha a se somar à precariedade das condições técnico-construtivas de um sistema produtivo ainda caracterizado por

\footnotetext{
29LEVNE, Robert M. The Vargas Regime The Critical Years 1934-1938. New York: Columbia University Press, 1973.

30TELLES, op. cit,, p. 26

${ }^{31}$ MARTINS, Carlos Alberto Ferreira. "Há algo de irracional..." (1999)" In: GUERRA, Abilio (org.). Textos Fundamentais sobre História da Arquitetura Moderna Brasileira. Parte 2. São Paulo: Romano Guerra, 2010, p. 32.

${ }^{32}$ MINDLIN, Henrique E. Arquitetura Moderna no Brasil. $2^{a}$ ed (1a ed. bras. 1999). Rio de Janeiro: Aeroplano Editora/PHAN, 2000 (tradução do original em inglês Modern Architecture in Brazil. New York: Reinhold Publishing Corporation, 1956).
} 


\section{INTRODUÇÃO}

uma industrialização incipiente e pela sobrevivência do modelo básico agroexportador. No entanto, a arquitetura moderna brasileira "cresce como uma planta tropical". ${ }^{33}$

E o incentivo à influência cultural norte-americana no Brasil principalmente a partir dos últimos anos da década de 1930 foi importantíssimo nesse processo.

Esse foi o momento em que aconteceu a substituição de referências, a transposição do centro cultural e artístico do mundo da Europa para os EUA, novo modelo de modernidade para as nações em desenvolvimento, principalmente as latino-americanas, pois com a guerra mundial em curso tornava-se difícil um contato mais estreito com a Europa, que fora até então sua principal fonte de inspiração.

Entretanto, apesar do aparente distanciamento cultural da Europa, havia o estreitamento das relações comerciais da América Latina com a Alemanha e Itália, processo que havia se fortalecido com a ascensão do Partido Nazista, em 1933. ${ }^{34}$

Tais acontecimentos acabaram por se enquadrar na gênese da política do governo norte-americano, à época preocupado com essa aproximação cheia de interesses entre a América Latina e os Países do Eixo, e que criaria a chamada "Política da Boa Vizinhança", que teve por objetivo expandir a influência americana, política, econômica e cultural pela região. ${ }^{35}$

A América Latina já representava uma importante fonte de matéria-prima e um vasto mercado consumidor para a produção industrial dos Estados Unidos. Com o início da Segunda Grande Guerra, o país buscava se afirmar como uma grande potência e, para isso, era fundamental assegurar sua hegemonia no continente. Além disso, era preciso assegurar que, no caso de um eventual conflito bélico, as nações americanas se manteriam unidas. ${ }^{36}$

\footnotetext{
${ }^{33}$ MARTINS, op. cit, p. 132

${ }^{34}$ SANTOS, Luís Cláudio Villafañe Gomes dos. $\bigcirc$ Brasil entre a América e a Europa. O Império e o Interamericanismo (do Congresso do Panamá à Conferência de Washington). São Paulo: Editora da UNESP, 2004.

${ }^{35}$ MAUAD, Ana Maria. A América é aquil: um estudo sobre a influência cultural norte-americana no cotidiano brasileiro (1930-1960). In: TORRES, Sonia (Org.) Raízes e rumos: perspectivas interdisciplinares em estudos americanos. Rio de Janeiro: 7Letras, 2001, pp.134-46.

${ }^{36}$ MOURA, Gerson. Tio Sam chega ao Brasil. A penetração cultural Americana. São Paulo: Editora Brasiliense S. A., 1985, p. 20
} 
Curioso é que existem poucos trabalhos de autores brasileiros sobre o assunto - a começar pelo já clássico livro de Gerson Moura "Tio Sam chega ao Brasil”, de 1984.

Este fato torna-se ainda mais evidente quando comparamos a produção nacional com o grande número de trabalhos americanos sobre o tema: basta conferirmos a própria bibliografia utilizada por outro autor que se empenhou no assunto, Antônio Tota. ${ }^{37}$

Richard M. Morse (1922-2001), o "Americano intranquilo", como o chama Antonio Candido ${ }^{38}$, foi um dos primeiros acadêmicos nos Estados Unidos a oferecer uma análise não tradicional dos assuntos latino-americanos, sugerindo, muitas vezes para o desespero de seus contemporâneos, que os americanos da América do Norte tinham muito a aprender com as culturas dos países da América do Sul que falavam espanhol, português e francês. Professor das prestigiadas Universidades americanas de Columbia, Yale e Stanford, estudou a fundo a metrópole de São Paulo e podemos conferir isto em suas publicações. ${ }^{39}$

Seu trabalho mais influente talvez tenha sido Prospero's Mirror ${ }^{40}$, publicado em espanhol em 1982 e em português em 1988, mas nunca inteiramente em inglês. Neste livro, Morse apaixonadamente defende que a originalidade cultural e social da América Latina, particularmente a do Brasil e a do México, pode ser a fonte de novas ideias, pensamentos e soluções para o mundo. Em 1993, Morse foi condecorado com a Ordem do Cruzeiro do Sul, maior honra que a Nação pode conferir a não-brasileiros, por suas contribuições para a cultura brasileira.

Atualmente este autor vem levantando muito interesse entre os pesquisadores pois sua temática aparece cada vez mais pertinente e também para o campo do entendimento da história da nossa arquitetura e urbanismo modernos. ${ }^{41}$

\footnotetext{
${ }^{37}$ TOTA, Antonio, O Imperialismo Sedutor: A americanização do Brasil na Segunda Guerra Mundial. São Paulo: Companhia das Letras, 2000.

${ }^{38} \mathrm{CANDDO}$, Antonio et alii. Um Americano Intraqüilo. Homenagem a Richard Morse. Rio de Janeiro: FGV, 1992. 39MORSE, Richard. De comunidade a metrópole: biografia de São Paulo. Tradução de Maria Aparecida Madeira Kerberg. São Paulo: Comissão do N Centenário, 1954.

${ }^{49 M O R S E}$, Richard. O espelho do próspero - Cultura e ideias nas Américas. São Paulo: Companhia das Letras, 1988.

${ }^{4}$ Ver mais em DOMINGUES, Beatriz H. O Código Morse - Ensaios sobre Richard Morse. Belo Horizonte: Editora da UFMG, 2010 e CASTRO, Ana Claudia Scaglione Veiga de. A formação da metrópole pelo olhar de Richard Morse: uma história cultural de São Paulo. São Paulo, 2009. Tese (Doutorado). Curso de Pós-Graduação em Arquitetura e Urbanismo. Faculdade de Arquitetura e Urbanismo - USP.
} 


\section{INTRODUÇÃO}

Tota (2000) aborda o tema fascinante e, ao mesmo tempo pouco estudado pelos historiadores nacionais, justamente sobre a ofensiva cultural realizada pelo governo americano no Brasil, dentro do espírito da 'política da boa vizinhança'.

O autor, além de trabalhar com uma vasta bibliografia norte-americana, utilizou fontes textuais, sonoras e iconográficas, tiradas de arquivos norte-americanos e brasileiros. Suas fontes são, principalmente, governamentais, o que naturalmente reflete o recorte de seu objeto: a ação do Office of Coordinatior of Inter-American Affairs (OC\|A $)^{42}$ no Brasil, com o objetivo de "seduzir" os brasileiros para uma aliança com os Estados Unidos durante a Segunda Guerra Mundial.

Sua conclusão é que a "americanização" do Brasil não foi simples cópia da cultura americana e, para analisar este processo, mesmo o conceito de "resistência cultural" é insuficiente. Assim, o autor utiliza o conceito de forma mais ampla, aproximando-o da ideia da "antropofagia cultural" de Oswald de Andrade. Para Tota, "um povo só incorpora um determinado valor cultural de outro povo se este fizer sentido no conjunto geral de sua cultura". (TOTA, 2000, p. 22)

O amplo ambiente do modernismo literário e artístico no Brasil já havia proposto uma nova estética através de um processo "canibalesco" de "devorar" elementos da cultura europeia localmente, transformando seu passado pré-civilzado num modelo avançado de tradição cultural.

Se o livro de Tota aborda um tema pouco explorado na historiografia brasileira, Roney Cytrynowicz ${ }^{43}$ teve a feliz inspiração de construir um tema absolutamente ausente, até agora, das análises históricas: o cotidiano dos paulistanos durante a Segunda Guerra Mundial e a memória deixada por este conflito nos habitantes e na geografia da cidade.

Depois de constatar que a história da Segunda Guerra Mundial no Brasil resume-se à análise das relações internacionais e ao "jogo duplo" de Vargas, às breves referências da participação da Força Expedicionária Brasileira (FEB) na Itália e aos efeitos da guerra na industrialização do país, Cytrynowicz verifica que a memória da guerra é praticamente ausente no imaginário do paulistano e se pergunta o porquê desta ausência.

\footnotetext{
${ }^{42}$ ROWLAND, D. W. A History of the Office of the Coordinator of Inter-American Affairs. Washington, D.C., 1946. ${ }^{43}$ CYTRYNOWICZ, Roney. Guerra sem Guerra: A Mobilização e o Cotidiano em São Pauli durante a Segunda Guerra Mundial. São Paulo: Geração Editorial/Edusp, 2000.
} 
A resposta para tal questão está em olhar a mobilização do front interno no Brasil durante a Segunda Guerra Mundial como mais uma estratégia política do Estado Novo visando mobilizar a população para seus ideais.

Segundo o autor:

A escassez que atingiu as classes médias e as elites de São Paulo foi mais um álibi para instituir um clima de privação coletiva de forma a tornar a guerra uma experiência coletiva, que deveria unir todos os brasileiros, independentemente de distinções sociais, para organizar a sociedade em moldes estado novistas. E, igualmente, instituir uma ordem em uma cidade que já se consolidava como metrópole, mas cuja organização e infraestrutura haviam sido projetadas, a partir da década de 1920, para uma população muito inferior à possuída nos anos $40 .{ }^{44}$

O autor faz uma distinção entre as estratégias do Estado Novo voltadas para as classes médias e aquelas dirigidas aos operários, onde medidas de intervenção direta, militarizadas, atingiram as fábricas em nome da "batalha da produção".

Este fato esclarece de uma certa forma que a modernidade almejada não era para todos.

Diante desse quadro, seria de admirar que a memória da Segunda Guerra Mundial em São Paulo fosse cultuada pela população e marcasse a paisagem urbana com monumentos, nomes de ruas e logradouros. Roney compara a memória da revolução de 1932 com a da Segunda Guerra, para concluir que aquela marcou muito mais a memória coletiva e a paisagem urbana de São Paulo do que esta última.

Mas, acima de tudo, está claro que esta conjuntura histórica se sustentou pela ampla convergência ideológica entre o objetivo dos modernistas de uma utopia social e a expansão capitalista na busca do aumento da produção em massa e da crescente integração dos mercados mundiais.

Sendo assim, a ampliação do relacionamento com os Estados Unidos da América que foi gerada de certo modo também por este discurso, principalmente entre as décadas de 1930 e 1950, terá consequências muito amplas, e que irão afetar o nosso ambiente urbano (cada vez mais "metropolizado" - ao menos nas capitais São

${ }^{44}$ CYTRYNOWICZ, op. cit, p. 24. 


\section{INTRODUÇÃO}

Paulo e Rio de Janeiro) e consequentemente o desenvolvimento de nossa arquitetura local.

Liernur inclusive afirma, em outro texto sobre o assunto, que "em 1943, com a publicação do livro Brazil Builds, concluía-se o ciclo de construção do caso brasileiro como topos fundamental do imaginário da arquitetura do século 20. Ainda que seu processo de formação possa ser datado no começo da segunda metade da década de 1930, o ciclo se desenvolveu entre dois episódios nova-iorquinos, respectivamente em 1939 e 1943: refiro-me à construção do Pavilhão do Brasil na Feira The World of Tomorrow e à exposição Brazil Builds no Museu de Arte Moderna (MoMA)". ${ }^{5}$

E tenta demonstrar que, além dos valores arquitetônicos dessas obras, suas condições de sucesso se encontram fora delas: no âmbito da política na virada para a good neighborhood policy impulsionada pelo governo de Franklin D. Roosevelt (18821945) nas vésperas da Segunda Guerra Mundial e no âmbito da história da arquitetura moderna na crise da hegemonia das ideologias funcionalistas.

Consequentemente, trocas culturais e profissionais se tornaram possíveis, direcionadas às "Nações amigas" e condições a programas de incentivo foram gerados a partir deste quadro. ${ }^{46}$

Em agosto de 1940, o presidente Roosevelt criou o Birô Interamericano ${ }^{47}$, um novo órgão estatal subordinado ao Conselho de Defesa Nacional para tratar de assuntos econômicos e culturais relativos à América Latina. Chefiado pelo até então presidente do MoMA (Museum of Modern Art), Nelson Aldrich Rockefeller (1908-1979), investiu grandes esforços de propaganda política na ideologia do pan-americanismo, "divulgando a ideia de que havia um conjunto de valores culturais e de interesses comuns aos países americanos". ${ }^{48}$

\footnotetext{
${ }^{45}$ LERNNUR, Jorge Francisco. O milagre brasileiro, os Estados Unidos e a Segunda Guerra Mundial - 1939 1943 (1999) In: GUERRA, Abilio (org.). Textos Fundamentais sobre História da Arquitetura Moderna Brasileira Parte 2. São Paulo: Romano Guerra, 2010, p. 169.

46McCANN, Frank. The Brazillian-American Alliance 1936-1945. Princeton: Princeton University Press, 1973

${ }^{47}$ Em 1940, oficialmente, o órgão se chamou Office of the Coordinator of Commercial and Cultural Relations between the American Republics e, no ano seguinte, passou a ser denominado Office of the Coordinator of Inter-American Affairs (OCIAA)

${ }^{48}$ MOURA, Gerson. Tio Sam chega ao Brasil. A penetração cultural Americana. São Paulo: Editora Brasiliense S. A., 1985, p. 24
} 
O discurso oficial era de que o Birô havia sido criado para promover "a cooperação hemisférica" e, para isso, realizou uma série de eventos promovendo a troca cultural entre os países. ${ }^{49}$

No entanto, na prática, suas ações visavam divulgar a superioridade militar norte-americana frente ao Eixo e a ideia de que os Estados Unidos era um modelo de civilização para a América Latina.

No marco de uma estratégia de defesa continental era prioritário conseguir que o Brasil voltasse sua política de maneira favorável para os Estados Unidos - não só para proteger suas fontes de matérias-primas, decisivas para a indústria de guerra, mas porque o pais possuía a mais extensa linha costeira vizinha à África, e, do seu extenso território desabitado, podia constituir-se uma base ideal de ataque aéreo ao hemisfério norte da América. ${ }^{50}$

Essas políticas oficiais estimularam simultaneamente outros signos de aproximação no âmbito privado. Os relatos de viajantes e as descrições se multiplicaram, e os meios de informação foram dando cada vez mais espaço aos assuntos das Américas.

No Brasil, a partir de 1941, aportaram diversas missões de "boa vontade": comitivas compostas de intelectuais, artistas, empresários, cientistas, militares, diplomatas, etc., empenhados em estabelecer vínculos de cooperação e negócios com brasileiros. O inverso também ocorreu. Muitos viagens de intelectuais e formadores de opinião dos países sul-americanos aos EUA foram financiadas pelo Órgão, com a certeza de que, de volta aos locais de origem, divulgariam a cultura norte-americana. ${ }^{51}$

\footnotetext{
49"É criado, no interior do Departamento de Relações Interamericanas, um departamento cultural cuja chefia é confiada ao arquiteto Wallace Harrison. Profissional ligado a Nelson Rockefeller, havia projetado a 'Cidade X', um conjunto de prédios de aparência moderna e dispostos em renque destinado à área na beira do East River, na qual acabou sendo construída a sede das Nações Unidas. Harrison havia sido o arquiteto-chefe da Feira de Nova York. Era, também, um velho conhecido dos brasileiros Costa e Niemeyer, que trabalharam em seu escritório durante a permanência em Manhattan, no ano de 1938." (CAVALCANTI, Lauro. Moderno e Brasileiro: A História de uma Nova Linguagem na Arquitetura (1930-1960). Rio de Janeiro: Jorge Zahar Editor, 2006, p. 157).

50LIERNUR, op. cit., p. 170.

${ }^{51}$ Sérgio Buarque de Hollanda, Érico Veríssimo, Heitor Villa-Lobos e Cândido Portinari foram alguns dos beneficiados por esta política, somente citando alguns exemplos em áreas distintas.
} 


\section{INTRODUÇÃO}

No campo das artes visuais o Birô aliou-se ao $\mathrm{MoMA}^{52}$ e à Galeria Nacional de Arte de Washington. Ainda que houvesse abandonado temporariamente o cargo de presidente daquele Museu, Rockefeller manteve-se ligado à Instituição, chegando a utilizar sua estrutura para realizar projetos do governo.

A abertura do MoMA para a arte dos países ao sul das Américas começou coincidentemente na mesma época da passagem da presidência americana do republicano Edgar Hoover à do democrata Franklin D. Roosevelt, que se manteria no mesmo cargo de 1933 a 1945, e visitaria o Brasil em 1936 e 1943.

Que essas iniciativas não eram produto de uma coincidência e sim parte de um plano de construção de uma aliança política ficaria claro no número especial do Boletim (do MoMA) de outubro/novembro de 1942, chamado The Museum and the War, em que se podia ler um trabalho - "A United Hemisphere" - no qual se reconhecia a necessidade de representar a imagem dos latino-americanos na opinião pública dos Estados Unidos, descobrindo novas qualidades e valores em algumas culturas que até então - e especialmente durante o anterior período republicano - só haviam sido julgadas generalizadamente pela ignorância, pelos preconceitos e pelo desprezo. No sentido inverso, tratava-se também de substituir - pelo menos transitoriamente - a imagem do gringo prepotente pela de um vizinho solidário e compreensivo. ${ }^{53}$

A partir daí, e culminando com a exposição e livro Brazil Builds em 1943, o Departamento de Arquitetura do Museu de Arte Moderna de NY ganharia prestígio internacional como o principal local para debates sobre arquitetura e passaria a exercer o papel de divulgador das novas tendências e inovações arquitetônicas, bem como havia se tornado o mais influente centro mundial para a difusão do modernismo.

De modo que, e com as inaugurações em São Paulo do MASP em $1947^{54}$ e do Museu de Arte Moderna em $1949^{55}$ e da realização da I Bienal Internacional de Artes,

\footnotetext{
${ }^{52} \mathrm{BEE}$, Harriet S.; ELLIGOTT, Michelle (edited by). Art in our time - A chronicle of The Museum of Modern Art. New York: MoMA, 2004

${ }^{53}$ LERNUUR, Jorge Francisco. O milagre brasileiro, os Estados Unidos e a Segunda Guerra Mundial - 1939 1943 (1999) In: GUERRA, Abilio (org.). Textos Fundamentais sobre História da Arquitetura Moderna Brasileira. Parte 2. São Paulo: Romano Guerra, 2010, p. 172.

${ }^{54}$ Ver mais em BARDI, Pietro Maria. História do MASP: A aventura da criação do Museu de Arte de São Paulo contada por um de seus criadores. São Paulo: Instituto Lina Bo e P. M. Bardi. 1992 e The arts in Brasil, a new museum at São Paulo. Milano: Edizione Del Milione, 1956
} 
dois anos depois, houve, no Brasil, uma vigorosa ampliação das referências artísticas internacionais, com intercâmbios constantes entre estas instituições locais e as americanas, bem como entre artistas e arquitetos dos dois países. Em 1948 seria também fundado o Museu de Arte Moderna do Rio de Janeiro, projeto de Affonso Eduardo Reidy (1909-1964).

Apesar da enorme influência entre nós, com o fim da Segunda Grande Guerra e a polarização do novo cenário geopolítico, o governo norte-americano voltou-se para o projeto de reconstrução da Europa e, consequentemente, o interesse pelas repúblicas latino-americanas se diluiu. ${ }^{56}$

Mas o investimento e esforço norte-americano no Brasil não foram em vão. A partir da década de 1940, a Europa não era mais o principal parâmetro de civilização para nós. O "país do futuro" passou a se espelhar nos Estados Unidos, uma nação vista como jovem, avançada e "livre".

Seus desdobramentos sinalizam a proeminência de um acento americano na linguagem internacional do modernismo, e também o reflexo da modernidade norteamericana se faz sentir na paisagem brasileira.

A influência americana na verticalização e metropolização do Brasil está também fortemente presente na efervescente São Paulo das décadas de 1940/50, bem como na capital do país, o Rio de Janeiro. ${ }^{57}$

Também a importância que assume o modelo adotado no Brasil, priorizando o transporte sobre pneus em relação ao transporte sobre trilhos, a ascensão no país dos arranha-céus, fenômeno tipicamente americano e o advento dos subúrbios, quase todos os sinais deixam clara o impacto da cultura norte-americana entre nós.

Enfim, inúmeras outras foram as trocas entre os dois países, trocas estas muitas vezes desmerecidas em detrimento daquelas ocorridas com o continente europeu, e que neste trabalho procuramos dar espaço e buscar seu entendimento.

\footnotetext{
5Ver mais em DE BARROS, Regina Teixeira. Revisão de uma História: a Criação do Museu de Arte Moderna de São Paulo (1946-1949). São Paulo, 2002. Dissertação (Mestrado em Artes) - Universidade de São Paulo. ${ }^{56}$ GREEN, David. The Containment of Latin America A History of the Myths and Realities of the Good Neighbor Policy. Chicago: Quadrangle, 1971. No Brasil, o Birô encerrou suas atividades em 1946, mas, segundo Gerson Moura (1985: 73-74), alguns projetos foram mantidos até cerca de 1949 pela Embaixada Americana, e através dos vínculos estabelecidos anteriormente com meios de comunicação, universidades e institutos culturais.

${ }^{57}$ Entender melhor em ARRUDA, Maria Aminda do Nascimento. Metrópole e Cultura: São Paulo no meio do século XX. Bauru: Edusc, 2001 e PINHEIRO, Maria Lúcia Bressan. Modernizada ou Moderna? A arquitetura em São Paulo, 1938-1945. São Paulo, 1997. Dissertação (Mestrado). Curso de Pós-Graduação em Estruturas Ambientais Urbanas. Faculdade de Arquitetura e Urbanismo - USP.
} 


\section{INTRODUÇÃO}

Sendo assim, esse trabalho procura demonstrar que tais trocas culturais, desenvolvidas com o meio cultural e arquitetônico americano, foram significativas para o estabelecimento de novas diretrizes nas formulações da Arquitetura Moderna Brasileira, abordagem ainda pouco valorizada pela historiografia.

Tanto as vistas de Frank Lloyd Wright (1931), Richard Neutra (1945 e 1959) e Mies van der Rohe (1957) ao Brasil, quanto as de Vilanova Artigas e Miguel Forte aos EUA, entre 1946-47.

Outros pontos de ligação essenciais e determinantes para o percurso que teve esta História se detém em eventos-chave que foram, por exemplo, o projeto do Pavilhão do Brasil na New York World's Fair, em 1939, a Exposição itinerante e o livro Brazil Builds lançado no MoMA de New York, em 1943, bem como a participação de Oscar Niemeyer no projeto do Edifício-sede da ONU na mesma cidade, em 1947.

Outros acontecimentos, menos disseminados, mas de grande importância: o Projeto para a "Cidade dos Motores" com o envolvimento de Paul Lester Wiener (1895-1967) - que trabalhara com Costa e Niemeyer no projeto do Pavilhão Brasileiro de Nova York - e Josep LLuis Sert (1902-1983), no Rio de Janeiro, entre 1945 e 1946, por exemplo.

Também os dois projetos residenciais de Oscar Niemeyer nos EUA, muito pouco explorados: a residência Burton-Tremaine em Santa Bárbara, Califórnia, em 1947, e a Casa Strick em Santa Mônica, no mesmo estado californiano, em 1964.

Fato este que nos leva à importância enorme que teve a arquitetura moderna desenvolvida na costa oeste dos EUA, principalmente através da disseminação e abrangência dos Case Study Houses ${ }^{58}$ e do boom do modernismo em Hollywood e nas casas modernas de veraneio dos americanos abastados de Palm Springs ${ }^{59}$, bem como o forte apelo ao "modern american way of life"60 que esta arquitetura apregoava, tão claramente ligado ao nosso desejo local de também alcançarmos nossa modernidade através da arquitetura.

Julius Shulman, o mais importante fotógrafo americano da arquitetura moderna declara sua admiração pela arquitetura moderna brasileira e o Brasil, aonde fotografou

\footnotetext{
${ }^{58}$ SMTHH, Elizabeth A. T. Case Study Houses, 1945-1966 - The California Impetus. Köln: Taschen, 2007. ${ }^{59}$ STERN, Michael. Julius Shulman: Palm Springs. New York: Rizzoli, 2008. 
extensamente Brasília, em seu documentário autobiográfico "Visual Acoustics"61. Quando da ascensão do pós-modernismo nos Estados Unidos e o decreto da morte do moderno americano, este fotógrafo, após décadas de carreira, declara sua aposentadoria, totalmente descrente no futuro da arquitetura. ${ }^{62}$

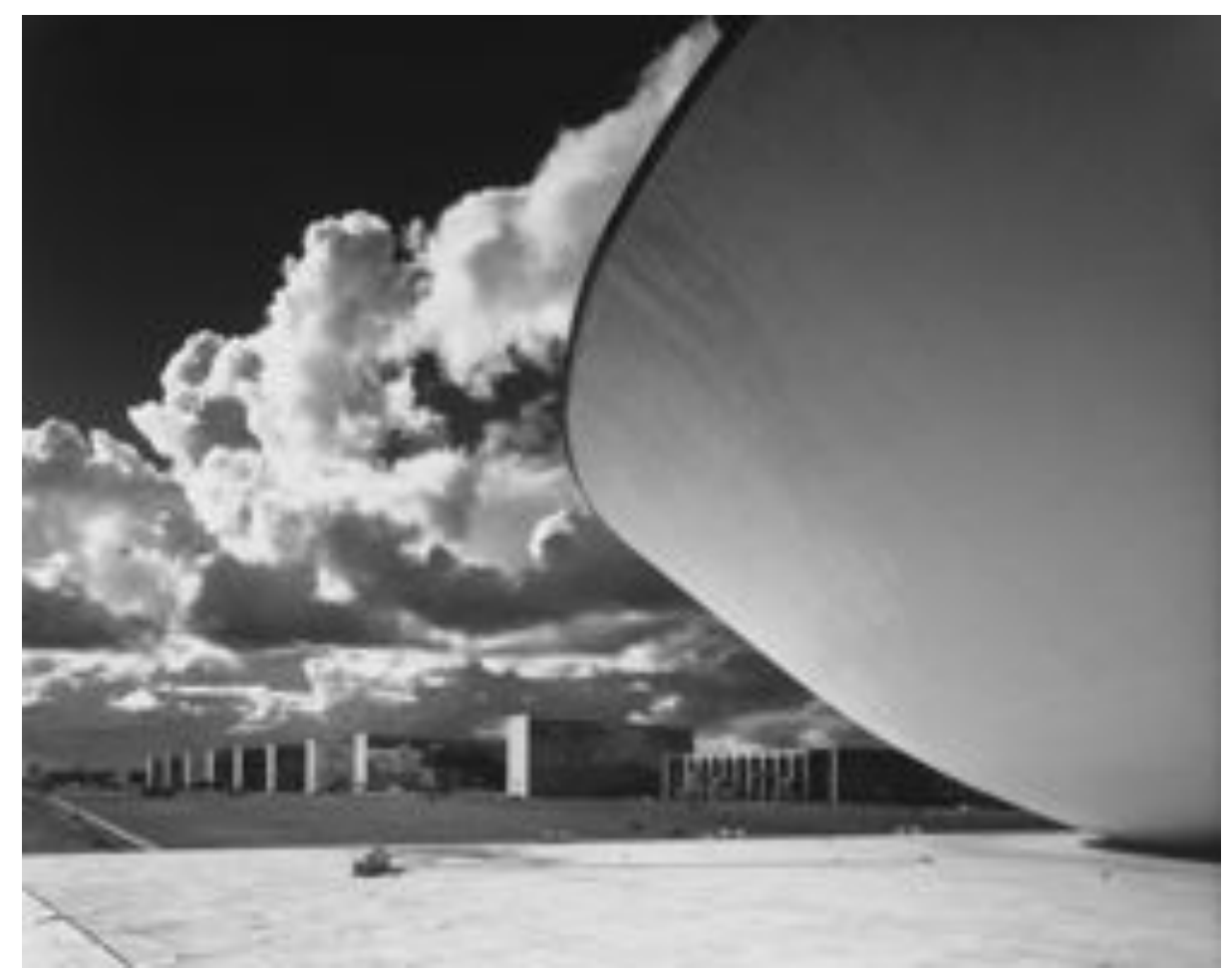

IMAGEM 1: "View of Ministry of Justice and Government Building from Senate Building". 1964. Brasilia, Brasil. Foto: Julius Shulman. Julius Shulman Photography Archive, Research Library at the Getty Research Institute. (c) J Paul Getty Trust.

Outra interação essencial para o aprimoramento da validação da arquitetura moderna brasileira em âmbito internacional através dos Estados Unidos, e muito pouco conhecida, foi a inserção de quatro arquitetos brasileiros na lista de entrevistados por John Peter (editor das revistas Look e Life e repórter de rádio e televisão da CBS americana), em 1954, para a pesquisa de seus livros "Masters of Modern Architecture"63, de 1958, e posteriormente "The Oral History of Modern Architecture" ${ }^{64}$, publicado em 1994: Affonso Eduardo Reidy, Marcelo Roberto, Oscar Niemeyer e Oswaldo Bratke. Estas entrevistas foram encontradas pela pesquisadora em viagem de estudos patrocinada pela Fapesp na Library of Congress, em

\footnotetext{
612008: Visual Acoustics, The modernism of Julius Shulman. USA; doc, cor/P\&B, um filme de Eric Bricker.

${ }^{62}$ Pesquisando nos arquivos do Getty Research Insitute, em Los Angeles, California, aonde encontra-se todo o acervo fotográfico de Julius Shulman, encontramos as raras fotografias que este grande fotógrafo fez no Brasil. ${ }^{63}$ PETER, John. Masters of modern architeture. New York: G. Braziller, 1958.

${ }^{64}$ PETER, John. The oral History of Modern Architecture - Interviews with the Greatest Architects of the Twentieth Century. New York: Harry N. Abrams, 1994.
} 


\section{INTRODUÇÃO}

Washington D.C., e estão inseridas nesse trabalho, incorporando um acervo importante para a história da nossa arquitetura moderna.

Durante a pesquisa para o trabalho descobrimos, no Instituto Americano de Arquitetos (American Institute of Architects), também sediado em Washington D.C., que alguns brasileiros foram agraciados "Honorary Fellows" pelo conceituado Instituto - além de Nestor Egydio de Figueiredo em 1930 (já mencionado) e Adolfo Morales de los Rios em 1936 - que foram: Christiano Stockler das Neves em 1957, Icaro de Castro Mello em 1958, Oscar Niemeyer em 1963 e Rino Levi e Eduardo Kneese de Mello em 1965; demonstrando que a interação e mútuo interesse existiu entre a produção arquitetônica dos dois países, durante um período relativamente longo. ${ }^{65}$

O final da década de 1950, em particular, se caracterizou pela forte presença no Brasil de arquitetos representativos do movimento moderno, como Walter Gropius (1883-1969), Mies van der Rhoe (1886-1969), Philip Johnson (1906-2005), Richard Neutra (1892-1970) e muitos outros, e também de brasileiros nos Estados Unidos, ou participando na elaboração de projetos ou assimilando conhecimento profissional.

Partindo desse panorama introdutório tentaremos contar, nos capítulos dessa tese, um pouco destes intercâmbios e pontos de ligação que incidiram no estabelecimento de novas diretrizes nas formulações da arquitetura moderna brasileira, abordagem ainda pouco estudada. Momentos de troca que aqui relatamos, a partir de uma organização cronológica que sistematizou os resultados da nossa pesquisa.

Também introduzimos um pouco da Historiografia oficial da Arquitetura Moderna Brasileira que tem especificidades que são extremamente importantes a serem analisadas, pois "atrasaram", e muito, o entendimento do que foi a trama real dessa História, seus precursores e protagonistas.

Em contraponto, ao contarmos como se deu a abertura da Historiografia da Arquitetura Moderna para outras frentes de "influência" e, também, mais recentemente, em direção ao papel importante que teve a relação Brasil-EUA no período, estamos nos propondo a abrir um leque de informações justamente para compreender as trocas e intercâmbios ocorridos de uma maneira mais clara e sem preconceitos.

${ }^{65}$ Em 1973, Fabio Penteado, em 1977, João Batista Vilanova Artigas, em 1979, Wladimir Alves De Souza, em 1993, Jaime Lerner,e em 2011 Angelo Bucci e Marcio Kogan. 
PRIMEIRO CAPÍTULO

A MODERNIDADE BRASILEIRA:

HISTORIOGRAFIA, GÊNESE, INTERLOCUÇÕES E EVENTOS-CHAVE BRASIL X EUA 


\section{A historiografia da arquitetura moderna brasileira}

A importância das experiências e contatos trocados entre os arquitetos da Moderna Arquitetura Brasileira e os arquitetos e o campo arquitetônico norteamericano e como isto se refletiu no desenvolvimento de nossa produção local nos parece cada vez mais um fato, e não uma suposição.

Comprovadamente, inclusive, e como já vimos, o relacionamento entre o Brasil e os Estados Unidos desde as primeiras décadas do século XX foi decisivo neste processo e também na divulgação e fortalecimento do modernismo brasileiro em âmbito internacional.

No entanto, esta linha de pensamento é relativamente recente, na medida em que a historiografia arquitetônica canônica se funda essencialmente na contribuição de Le Corbusier e de outras vertentes europeias de vanguarda, negligenciando outras fontes.

A historiografia da arquitetura moderna introduzida no Brasil a partir do final da década de 1920 é um fenômeno recente. Durante décadas imperou a visão presente nos mitológicos Brazil Builds e Modern Architecture in Brasil, que foi repetida de forma tão sistemática que se transformou em quase axioma ${ }^{1}$

Nossa mais difundida produção arquitetônica mereceu alguma atenção por parte de críticos e historiadores brasileiros e estrangeiros.

Entretanto, e como salienta CAMARGO (2006:66):

Com raríssimas exceções, a arquitetura brasileira é considerada, historiograficamente, como uma produção periférica e por ser geograficamente muito distante dos centros irradiadores da cultura arquitetônica moderna, as análises baseiam-se na sua maioria, em fontes referenciais recorrentes, tendo muitos críticos nunca visitado o pais. As diferentes interpretações são reveladoras das variações do próprio conceito de arquitetura para os historiadores e também do seu significado ao longo do tempo. ${ }^{2}$

\footnotetext{
${ }^{1}$ GUERRA, Abilio. A Construção de um Campo Historiográfico In: GUERRA, Abilio (org.). Textos Fundamentais sobre História da Arquitetura Moderna Brasileira. Parte 1. São Paulo: Romano Guerra, 2010, p. 11 ${ }^{2}$ CAMARGO, Mônica Junqueira de. Brazilian presence in the historiography of Twentieth Century architecture Docomomo, Paris, nº. 34, mar. 2006, pp. 66-71.
} 
A mesma autora enumera cronologicamente as várias publicações, em sua maioria as canônicas, em que nossa arquitetura moderna esteve presente; Sartoris, Goodwin, Zevi, Giedion, Dorfles, Mindlin, Pevsner, Hitchcock, Peter, Joedicke, Benevolo, Kultermann, Tafuri e Dal Co, Frampton, Curtis, Montaner e Colquhoun³, salientando que as primeiras narrativas, que com o decorrer do tempo se tornariam mestras, estavam mais preocupadas com a consolidação do movimento moderno do que com a sua investigação, e que a partir de uma visão unitária do mundo, que dominava o pensamento da época, a crítica se preocupava em tentar identificar mais as semelhanças do que as diferenças, obscurecendo as manifestações locais, regionais e étnicas.

Um olhar mais recente sobre essa mesma produção, já contemporâneo as revisões criticas da arquitetura moderna, visa identificar, não mais a hegemonia, mas justamente a diversidade, trazendo para o primeiro plano o que fora marginalizado pelas culturas dominantes. ${ }^{4}$

Em certa medida, nossa produção histórica escassa sobre a arquitetura moderna no Brasil até o início dos anos 1980 é resultante, dentre outros fatores, da

\footnotetext{
${ }^{3}$ SARTORIS, Alberto. Gil elementi dell'architettura funzionale: sintesi panoramica dell'architettura moderna. Prefazione de Le Corbusier; introduzione di Carlo Ciucci. Milano: Hoepli, 1932; GOODWIN, Philip L. Brazil Builds: Architecture new and Old 1652 - 1942. Photographs by G. E. Kidder Smith. New York: The Museum of Modern Art (MoMA), 1943; ZEVI, Bruno. Storia dell'architettura moderna. Torino: Einaudi, 1950; GIEDION, Sigfried. A Decade of Contemporary Architecture. Zurich: Girsberger, 1954; DORFLES, Gillo. L'Architettura Moderna. Milan: A. Garzanti, 1956; MINDLIN, Henrique E. Arquitetura Moderna no Brasil. $2^{a}$ ed (1ª ed. bras. 1999). Rio de Janeiro: Aeroplano Editora/PHAN, 2000 (tradução do original em inglês Modern Architecture in Brazil. New York: Reinhold Publishing Corporation, 1956); PEVSNER, Nikolau. Os Pioneiros de Desenho Moderno - de William Morris a Walter Gropius. $1^{\text {a }}$ ed. brasileira. São Paulo: Martins Fontes, 1980 (trad. it. de João Paulo Monteiro, Pioneers of Modern Design - From William Morris to Walter Gropius (1936). London: Penguin Books, 1974); HITCHCOCK, Henry-Russell, Latin American Architecture since 1945, New York: The Museum of Modern Art (MoMA), 1955; PETER, John. Masters of modern architeture. New York: G. Braziller, 1958; JOEDICKE, Jurgen. A history of modern architecture. New York: Praeger, 1959; BENEVOLO, Leonardo. História da Arquitetura Moderna. São Paulo: Perspectiva, 1989 (trad. it. de Ana M. Goldberger, Storia dell'Architettura Moderna); KULTERMANN, Udo. La arquitectura contemporanea. Barcelona: Editora Labor, 1969; TAFURI, Manfredo; Dal Co, Francesco. Architettura Contemporanea. Venecia: Electa Editrice, 1976; FRAMPTON, Kenneth. História Crítica da Arquitetura Moderna. São Paulo: Martins Fontes, 1997 (trad. it. de Jefferson Luiz Camargo, Modern architecture: A critical view. London: Thames and Hudson, 1980); CURTIS, William J. R. Arquitetura Moderna desde 1900. 3a. ed. São Paulo: Editora Bookman, 2008; MONTANER, Josep Maria. La modernidad superada: Arquitectura, arte y pensamiento del siglo XX. Barcelona: Editorial Gustavo Gili, 1997; COLQUHOUN, Alan. La Arquitectura Moderna: Una Historia Desapasionada. Barcelona: GG, 2002. ${ }^{4}$ CAMARGO, Mônica Junqueira de. Brazilian presence in the historiography of Twentieth Century architecture. Docomomo, Paris, n’. 34, mar. 2006, pp. 66-71
} 
falta de consistência teórica e metodológica da pesquisa histórica realizada nas nossas universidades.

Não é de se estranhar, portanto, que em um ambiente intelectual engessado tenha sido de um estrangeiro, o francês Yves Bruand, o primeiro estudo abrangente sobre a carreira da arquitetura moderna em nosso pais. Mas, mesmo neste livro fundamental - Arquitetura contemporânea no Brasil, publicado em $1981^{5}$ - a pauta que estrutura os argumentos e a própria lógica da evolução ainda está embebida do DNA das ideias de Costa. ${ }^{6}$

Em um sentido mais geral, a partir do amadurecimento de dois elementos pesquisa e revista -, entre as décadas de 1980 e 1990, e principalmente da consolidação das pós-graduações na área, pode-se dizer que, nesse momento, surge uma consciência da historicidade do moderno e as implicações correspondentes, em especial a possibilidade de se fazer balanços, comparações, ajuizamentos críticos etc.

São os artigos escritos e publicados nesse ambiente intelectual, entrelaçando jornalismo especializado e pesquisa acadêmica, revistas comerciais e periódicos universitários, que dão a base inicial para a formação do espaço de pesquisa sobre arquitetura moderna brasileira.

Abilio Guerra nos explica melhor esse panorama:

Durante muito tempo, dois livros mitológicos reinaram quase solitários como explicadores da arquitetura moderna brasileira: Brazil Builds, de Philip Goodwin, publicado em 1943 (GOODWIN, 1943); e Arquitetura moderna no Brasil, de Henrique Mindlin, publicado em 1956 (MINDLIN, 1956). Na década seguinte, o volume não autorizado Lucio Costa: sobre arquitetura, organizado e publicado por Alberto Xavier em 1962 (XAVIER, 1962), trará a um público maior os textos e as ideias do grande mestre da arquitetura moderna brasileira, que orientaram as duas primeiras publicações. Somente muito tempo depois é que surgiram outras colaborações significativas: em 1979, com a publicação de Arquitetura brasileira, de Carlos Lemos 
(LEMOS, 1979); em 1981, com o livro Quatro séculos de arquitetura no Brasil, de Paulo F. Santos (SANTOS, 1981). A proximidade temporal entre estas duas publicações cuja relevância está muito mais em incorporarem novo olhar sobre um tema circunscrito por uma visão quase axiomática - prenuncia a chegada do livro que revolucionará a situação modorrenta. ${ }^{7}$

No início dos anos 80, precisamente no ano de 1981, o primeiro grande manual, de autoria de Yves Bruand, dá início de fato à estruturação da história da arquitetura moderna em nosso país. Com uma bibliografia constituída hegemonicamente de periódicos e consultas às fontes primárias, o geógrafo francês construirá um notável painel do desenvolvimento de nossa arquitetura ao longo do século passado.

Das doze páginas dedicadas à bibliografia, Bruand ocupa apenas uma com os livros sobre o Brasil, sendo que estão abordadas as áreas de arquitetura (da colonial até a contemporânea), urbanismo e geografia. Específicos sobre arquitetura moderna no Brasil são muito poucos os títulos, de autoria de Atílio Correa Lima, Geraldo Ferraz, Oscar Niemeyer e Stamo Papadaki, além dos já mencionados Lúcio Costa, Philip Goodwin e Henrique Mindlin. ${ }^{8}$

Coube a Hugo Segawa enfrentar o desafio de publicar o primeiro manual pósBruand. Seu livro Arquiteturas no Brasil - 1900-1990', de 1998, vai abrir um leque grande de encaminhamentos paralelos da nossa arquitetura, se beneficiando de um conjunto já expressivo de pesquisas acadêmicas com recortes mais específicos, diversas delas monográficas.

$E$, dentro deste novo olhar, somente a partir do final do século $X X$ e estes primeiros anos do século XXI, é que a relação entre a arquitetura moderna brasileira e a dos EUA vem sendo, também, revista, principalmente através de monografias nacionais, ainda esparsas e sob criticas digamos que "desconfiadas".

\footnotetext{
${ }^{7}$ GUERRA, Abilio. História da arquitetura brasileira: pesquisas monográficas e trabalhos panorâmicos In I Encontro Nacional da Associação Nacional de Pesquisa e Pós-graduação em Arquitetura e Urbanismo, 2008. ${ }^{8}$ GUERRA, op. cit, , p. 13. 


\section{O papel na historiografia da presença norte-americana na Moderna}

\section{Arquitetura Brasileira}

Pelo panorama exposto na introdução pudemos perceber a participação atuante das questões relacionados aos "encontros" entre o Brasil e os Estados Unidos na consolidação de nossa arquitetura moderna.

O processo de revisão crítica nos anos 1990 permitiu o surgimento de novas pesquisas menos comprometidas com um pretenso caráter nacional de nossa arquitetura, o que viabilizou não só a presença dos arquitetos estrangeiros nas monografias acadêmicas - corrigindo uma distorção constrangedora, pois a presença deles é um dos dados mais flagrantes na paisagem urbana de São Paulo -, mas também um novo olhar sobre os arquitetos brasileiros.

Com isso foi possível se constatar as múltiplas influências sofridas por nossa arquitetura ao longo das décadas, matizando de forma significativa o monocromatismo inicial que enxergava de forma míope (talvez seja mais apropriado dizer "daltônica") apenas o filão corbusiano original, que seria a mola propulsora de um desenvolvimento particular, que muitas vezes ganhou os contornos de um processamento endógeno, sem vasos comunicantes com a produção externa. O afrouxamento inicial desses grilhões e seu posterior rompimento permitiram a comprovação de arquiteturas brasileiras ancoradas em outras produções do universo moderno, trazendo para a cena nacional figuras como Frank Lloyd Wright, Richard Neutra, Walter Gropius, Alvar Aalto etc. ${ }^{10}$

Hoje já é corriqueiro se ouvir referências aos "wrightianos" ou "miesianos" paulistas, o que é a face mais visível deste fenômeno ocorrido dentro das hostes acadêmicas.

Sobre o impacto da obra de Frank Lloyd Wright e alguns de seus seguidores, em especial Richard Neutra, sobre a arquitetura brasileira já temos, inclusive, um número expressivo de trabalhos. Sobre a influência de Mies van der Rohe em São

\footnotetext{
${ }^{10}$ GUERRA, Abilio. História da arquitetura brasileira: pesquisas monográficas e trabalhos panorâmicos In Encontro Nacional da Associação Nacional de Pesquisa e Pós-graduação em Arquitetura e Urbanismo, 2008.
} 
Paulo, em especial sobre a obra de Salvador Candia, já temos também ao menos uma pesquisa interessante. ${ }^{11}$

Usamos aqui o termo "influência", em geral empobrecido por sua unilateralidade, apenas para ilustrar conexões que condicionaram de alguma forma o desenvolvimento de nossa arquitetura. É evidente que estes contatos tinham mão dupla, como o comprova a obra tardia de Le Corbusier.

É nesse pano de fundo que o episódio das Bienais de São Paulo ganha vulto e expressão, pois foram momentos onde a interlocução com as ideias estrangeiras se potencializou, graças à presença ao vivo de importantes artistas e arquitetos da Europa e Estados Unidos.

Não é possível ficarmos impassíveis diante das presenças de Le Corbusier, Walter Gropius, Mies van der Rohe, Marcel Breuer, Siegfrid Giedion, Kenzo Tange, Ernesto Rogers etc. A extrema importância das diversas edições da Bienal tem ganho cada vez mais presença nos trabalhos acadêmicos recentes e se apresentam como importantes assertivas nas argumentações centrais das hipóteses do nosso desenvolvimento cultural. ${ }^{12}$

Trabalhos bem recentes inserem fatos e questões novas ao contexto da historiografia desta arquitetura, tanto nas academias nacionais, quanto através do trabalho de pesquisadores que tem desenvolvido pesquisas no exterior.

Alguns deles: Fernando Lara na Universidade de Michigan ${ }^{13}$, Isabel Maria Vilac ${ }^{14}$ e Nelci Tinem ${ }^{15}$ na Universidad Politecnica de Cataluna, Zilah Quezado Deckker na

\footnotetext{
${ }^{11}$ GUERRA, Abilio. Monografia sobre Salvador Candia e a necessidade de um diálogo acadêmico. Resenhas Online 078.03 (Romano Guerra Ed. Ltda.). São Paulo, Portal Vitruvius, junho de 2008.

${ }^{12}$ HERBST, Hélio. Pelas Bienais à Arquitetura Chora nos Manuais. São Paulo, 2007. Tese (Doutorado). Curso de Pós-Graduação em Estruturas Ambientais Urbanas. Faculdade de Arquitetura e Urbanismo - USP e Promessas e conquistas: arquitetura e modernidade nas Bienais, São Paulo, 2002. Dissertação (Mestrado). Curso de PósGraduação em Estruturas Ambientais Urbanas. Faculdade de Arquitetura e Urbanismo - USP.

${ }^{13}$ LARA, Fernando. A insustentável leveza da modernidade. Arquitextos057 (Romano Guerra Ed. Ltda.). São Paulo, Portal Vitruvius, fevereiro, 2005; Designed Memories, the roots of Brazilian modernism in BASTEA, Eleni (editor). Memory and Architecture. Albuquerque: University of New Mexico Press, 2004; Espelho de fora: arquitetura brasileira vista do exterior. Arquitextos004 (Romano Guerra Ed. Ltda.). São Paulo, Portal Vitruvius, setembro, 2000; One step back for two steps forward: the maneuverings of the Brazilian avant-garde. In Journal of Architectural Education, vol 55/4, may 2002; Popular Modernism: the unique dissemination of modern architecture in Brazil. manuscript approved by the board of the University Press of Florida on 8/31/2007, publication scheduled for Fall 2008

${ }^{14}$ MONTANER, Ma. Josep; VLAC, Isabel Maria. Paulo Mendes da Rocha. Barcelona, Editorial Gustavo Gili, 1996.
} 
University of East Anglia $^{16}$, que têm se mostrado reveladores de aspectos até então desconsiderados pela historiografia local e internacional.

Gorelik $^{17}$ e Liernur ${ }^{18}$ na Argentina inserem questões importantíssimas sobre o nosso foco de estudo.

Podemos enumerar rapidamente trabalhos recentes que indicam ou se aprofundam na questão BRASIL-EUA e a arquitetura moderna brasileira.

Como vimos, CAVALCANTI (2006:194) é um autor que salienta esta questão em "Moderno e Brasileiro: A Historia de uma nova linguagem na arquitetura (19301960)", bem como o faz em outros de seus escritos.

Alguns trabalhos recentes se aprofundam na "influência" americana no Brasil nas questões e decisões urbanísticas, principalmente em São Paulo. As monografias de Costa $^{19}$ e Salvi ${ }^{20}$, ambas desenvolvidos na FAU-USP, são exemplares. Também Fausto $^{21}$ já havia tratado do tema.

Muitos são os pequenos artigos que começam a aparecer sobre temas relacionados; os de Nedelykov e Moreira ${ }^{22}$, Loureiro e Amorim²3, Galeazzi ${ }^{24}$, SERAPIÃO ${ }^{25}$, Mahfuz $^{26}$, Foresti $^{27}$ e Cunha ${ }^{28}$.

\footnotetext{
${ }^{15}$ TINEM, Nelci. Arquitetura Moderna Brasileira: A imagem como texto. Arquitextos072 (Romano Guerra Ed. Ltda.). São Paulo, Portal Vitruvius, maio 2006; $\bigcirc$ Alvo do olhar estrangeiro - $\bigcirc$ Brasil na Historiografia da Arquitetura Moderna. João Pessoa: Manufatura, 2002.

${ }^{16}$ DECKKER, Zilah Quezado. Brazil Built: The Architecture of the Modern Movement. London, New York: Spon Press - Taylor \& Francis Group, 2001

${ }^{17}$ GORELIK, Adrián: Das vanguardas a Brasilia. Cultura urbana e arquitetura na América Latina. Trad. Maria Antonieta Pereira. Belo Horizonte, Editora UFMG, 2005. e A produção da "cidade latino-americana". Tempo Social - Revista de sociologia da USP, 2005b, vol. 17, no 1, p. 111-133.

${ }^{18}$ LEERNUR, Jorge Francisco. O milagre brasileiro, os Estados Unidos e a Segunda Guerra Mundial - 1939 1943 (1999) In: GUERRA, Abilio (org.). Textos Fundamentais sobre História da Arquitetura Moderna Brasileira. Parte 1. São Paulo: Romano Guerra, 2010.

${ }^{19}$ COSTA, Luiz Augusto Maia. O moderno planejamento territorial e urbano em São Paulo: a presença norteamericana no debate da formação do pensamento urbanístico paulista 1886-1919. São Paulo, 2005. Tese (Doutorado). Curso de Pós-Graduação em Estruturas Ambientais Urbanas. Faculdade de Arquitetura e Urbanismo - USP.

${ }^{20}$ SALVI, Ana Elena. Cidadelas da civilização; políticas norte-americanas no processo de urbanização brasileira com ênfase na metropolização paulistana dos anos 1950 a 1969. São Paulo, 2005. Tese (Doutorado). Curso de Pós-Graduação em Estruturas Ambientais Urbanas. Faculdade de Arquitetura e Urbanismo - USP.

${ }^{21}$ FAUSTO, Boris (org.). Os anos 30 e a Difusão do Urbanismo Americano no Brasil. In Anais do 60 Seminário de História da Cidade e do Urbanismo. Natal: UFRN, 2000.

${ }^{22}$ NEDEL YKKOV, Nina; MOREIRA, Pedro. Caminhos da Arquitetura Moderna no Brasil: A presença de Frank Lloyd Wright. Arquitextos018 (Romano Guerra Ed. Ltda.). São Paulo, Portal Vitruvius, agosto 2001.

23LOUREIRO, Claudia; AMORIM, Luiz. Por uma arquitetura social: a influência de Richard Neutra em prédios escolares no Brasil. Arquitextos020 (Romano Guerra Ed. Ltda.). São Paulo, Portal Vitruvius, janeiro 2002

${ }^{24}$ GALEAZZ, Ítalo. Mies van der Rohe no Brasil. Projeto para o Consulado dos Estados Unidos em São Paulo, 1957-1962. Arquitextos056 (Romano Guerra Ed. Ltda.). São Paulo, Portal Vitruvius, janeiro 2005
} 
E por fim, Fujioka ${ }^{29}$ também trata das influências de Frank Lloyd Wright na arquitetura moderna paulistana.

Também os "livros de viagens" começam a aparecer, viagens estas, muitas vezes de estudos, empreendidas por arquitetos brasileiros entre o Brasil e os EUA na época da gênese do movimento.

A publicação bastante precursora de Irigoyen, "Wright e Artigas - Duas Viagens"30, abriu infinitas novas frentes de pesquisa envolvendo o assunto, inclusive sua tese de doutoramento "Da Califórnia a São Paulo" ${ }^{31}$, que é justamente um estudo da casa paulista moderna situando-a em relação à arquitetura norte-americana, especialmente a que teve origem na costa oeste.

Outra publicação recente é o diário de viagens do próprio Miguel Forte aos EUA em $1947^{32}$, mesmo ano em que Artigas fazia sua viagem pelo mesmo pais. Também do trabalho de Forte e de sua corrente wrightiana fala Camargo. ${ }^{33}$

Outros dos poucos trabalhos recentes sobre estas questões, mas que nos ajudam a "tentar" elucidar muitas delas, são os de Herbst ${ }^{34}$, sobre a arquitetura e as primeiras Bienais de São Paulo.

\footnotetext{
${ }^{25}$ SERAPIÃO, Fernando. Johnson e Niemeyer. Os pupilos americanos in PROJETODESIGN, edição 301, março de 2005.

${ }^{26}$ MAHFUZ, Edson da Cunha. Ordem, estrutura e perfeição no trópico - Mies van der Rohe e a arquitetura paulistana na segunda metade do século XX. Arquitextos057.02 (Romano Guerra Ed. Ltda.). São Paulo, Portal Vitruvius, ano 05, fevereiro 2005.

${ }^{27}$ FORESTI, Debora Fabbri. Aspectos da arquitetura orgânica de Frank Lloyd Wright na arquitetura paulista : a obra de José Leite de Carvalho e Silva. Dissertação de mestrado. Orientador Renato Anelli. São Carlos, EESC USP, 2008

${ }^{28}$ CUNHA, Marcio Cotrim. Mies e Artigas: a delimitação do espaço através de uma única cobertura. Arquitextos108.01 (Romano Guerra Ed. Ltda.). São Paulo, Portal Vitruvius, ano 09, maio 2009.

${ }^{29}$ FUJIOKA, Paulo Y. Princípios da arquitetura de Frank Lloyd Wright e suas influências na arquitetura moderna paulistana. São Paulo, 2003. Tese (Doutorado). Curso de Pós-Graduação em Estruturas Ambientais Urbanas. Faculdade de Arquitetura e Urbanismo - USP.

30/RIGOYEN, Adriana. Wright e Artigas - Duas Viagens. São Paulo: Ateliê Cultural, 2002.

${ }^{31}$ IRIGOYEN, Adriana. Da Califórnia a São Paulo: referências norte-americanas na casa moderna paulista 1945 1960. São Paulo, 2005. Tese (Doutorado). Curso de Pós-Graduação em Estruturas Ambientais Urbanas. Faculdade de Arquitetura e Urbanismo - USP.

${ }^{32}$ FORTE, Miguel. Diário de um jovem arquiteto: minha viagem aos Estados Unidos em 1947. São Paulo: Editora Mackenzie, 2001.

${ }^{33}$ CAMARGO, Mônica Junqueira de. Arquiteto Miguel Forte, 1915-2002. Arquitextos030.05 (Romano Guerra Ed. Ltda.). São Paulo, Portal Vitruvius, ano 03, novembro 2002.

${ }^{34}$ HERBST, Hélio. Pelas Bienais à Arquitetura Chora nos Manuais. São Paulo, 2007. Tese (Doutorado). Curso de Pós-Graduação em Estruturas Ambientais Urbanas. Faculdade de Arquitetura e Urbanismo - USP e Promessas e conquistas: arquitetura e modernidade nas Bienais. São Paulo, 2002. Dissertação (Mestrado). Curso de PósGraduação em Estruturas Ambientais Urbanas. Faculdade de Arquitetura e Urbanismo - USP.
} 
Portanto, e concluindo dentro do panorama exposto, o que impressiona dentro de todo este processo é a pouca importância que a maioria da historiografia arquitetônica nacional atribui à relação Brasil-EUA, que resultou em realizações desmerecidas pela crítica em geral.

É compreensível tal fato na geração dos pioneiros do movimento, formados sob forte influência europeia, particularmente da cultura francesa. Menos compreensível é a ausência desse aspecto na análise feita por historiadores contemporâneos.

O desinteresse da maioria dos pesquisadores por nossa realidade cultural, a rudeza pragmática da política norte-americana em relação ao Brasil e o papel menor que ocupamos nas suas relações internacionais desde os anos 1970 talvez expliquem essa má vontade no presente.

Fato é, contudo, que a história da arquitetura modernista brasileira não pode mais ser escrita somente em termos da influência europeia nas Américas. Uma abordagem considerando um diálogo triangular pode expandir e lançar nova luz na compreensão do fluxo de formas e ideias nas arquiteturas modernas do Brasil, Estados Unidos e Europa. ${ }^{35}$

Analisar o relacionamento, as experiências e os intercâmbios ocorridos entre profissionais da arquitetura moderna brasileiros e americanos ou imigrantes na América do Norte entre o período de 1939 a 1959 significa também procurar mostrar essas transferências ocorridas de uma maneira mais aberta a diálogos.

E, dentro desta linha de pensamento, desmistificar a História de uma certa forma "oficial" como nos foi contada e recontada acerca dos primeiros passos da arquitetura moderna brasileira é um processo que se faz necessário, procurando conhecer suas entrelinhas, antes de certa forma escondidas, ou até apagadas.

Nos propomos a inserir um breve panorama dessa História oficial, introduzindo a gênese da clássica era modernista, entre as décadas de 1920 e 1930, e a seguir expomos, para um entendimento mais amplo das questões envolvendo o Brasil e os Estados Unidos, uma cronologia dos Eventos-chave que marcaram esta História.

\footnotetext{
${ }^{35}$ CAVALCANTI, Lauro. Moderno e Brasileiro: A História de uma Nova Linguagem na Arquitetura (1930-1960) Rio de Janeiro: Jorge Zahar Editor, 2006, p. 194.
} 


\section{Parâmetros e paradigmas - gênese da arquitetura moderna brasileira}

A Arquitetura Moderna realizada no Brasil sempre se caracterizou pelo diálogo com o campo arquitetônico internacional que resultou nas diretrizes seguidas em sua produção local e, portanto, a sua história só é compreensível quando referida ao plano internacional.

A própria história da gênese e do desenvolvimento dessa arquitetura local "...é uma história de trocas e transferências". ${ }^{36}$ Teve início na década de 1920 a partir dos preceitos do movimento criado na Europa, trazido para o Brasil da mesma forma que para outros países do Novo Mundo, através de visitantes e imigrantes europeus e norte-americanos e de brasileiros que retornavam após lá estudarem.

Mas para uma apreciação da bagagem que esses vários arquitetos trouxeram para o Brasil faz-se aqui necessária uma breve intersecção entre o momento vivido por eles quando da sua permanência ou estabelecimento.

O momento representa crise profunda e início da decadência do movimento moderno na Europa, e "um começo" para os americanos, coincidindo com a introdução do "International Style".

A "interpretação brasileira" dos princípios modernistas, que se desenvolveu principalmente pelo entusiasmo ao novo estilo por parte das gerações mais jovens de arquitetos, redirecionou o fluxo de volta ao hemisfério norte, influenciando o discurso internacional no segundo pós-guerra.

Apesar disto, convenciona-se creditar, hoje, ao que se tornou reconhecido como Brazilian Style, que este era somente uma adaptação local do Internacional Style, disseminado principalmente por Philip Johnson através dos EUA, uma mera derivação aparentemente miraculosa e espontânea da norma funcionalista. ${ }^{37}$

Esta é uma noção bastante generalizada, na visão americana, do que realmente foi o processo de estabelecimento da Arquitetura Moderna realizada no Brasil.

\footnotetext{
${ }^{36}$ ANDREOLI, Elisabetta; FORTY, Adrian. Brazil's Modern Architecture. London, New York: Phaidon Press, 2004, p. 14. 
O que há de concreto nisto é que a desestabilização social e econômica do período entre Guerras fez com que alguns profissionais se limitassem a atuar como difusores e escritores de vanguarda, ou procurassem trabalho emigrando para países como o Brasil e os Estados Unidos. ${ }^{38}$

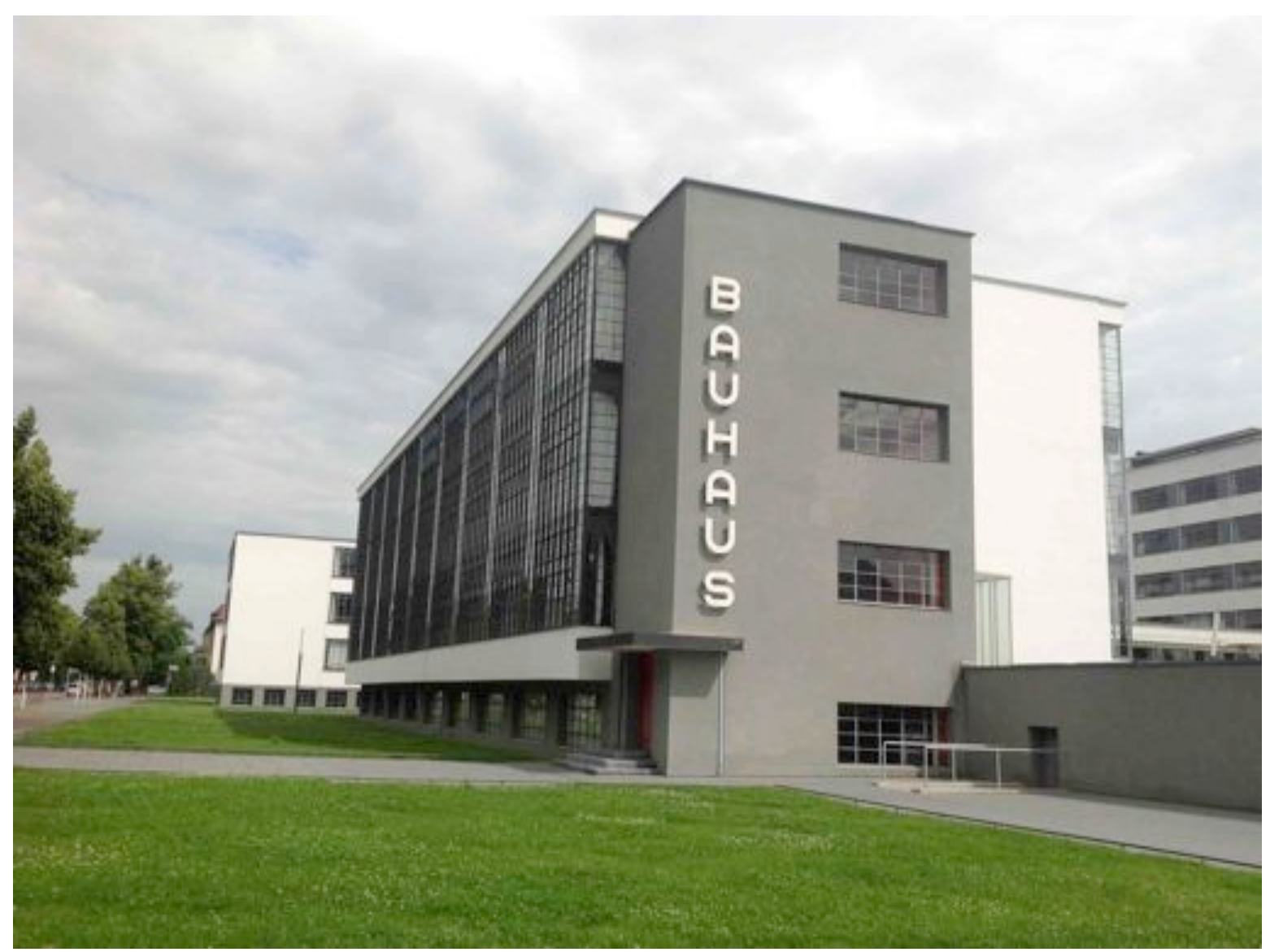

IMAGEM 2: Bauhaus Dessau Buillding. 1925-26. Dessau, Germany. Arquitetura: Walter Gropius. Foto: Débora Lima.

Para os EUA ocorre a famosa "Diáspora da Bauhaus". Em 1937 emigram Mies van der Rohe (1886-1969), Walter Gropius (1883-1969) e Marcel Breuer (1902-1981), "o trio da Bauhaus". Outros emigrantes famosos haviam se transferido anteriormente: Richard Neutra (1892-1970) em 1923 e Rudolf Schindler (1887-1953) em 1914, ambos influenciados por Wright, e ainda Josep Lluis Sert (1902-1983) em 1939, dentre tantos outros, a maioria deles entre o final da década de 1920 e principalmente ao longo dos anos trinta. ${ }^{39}$

\footnotetext{
${ }^{38}$ FAUSTO, Boris (org.). Fazer a América: A imigração em massa para a América Latina. São Paulo: EDUSP, 1999.

${ }^{39}$ Entender mais como se deu esta diáspora em: KENTGENS-CRAlG, Margret. The Bauhaus and America: First Contacts, 1919-1936. Cambridge: The MIT Press, 1999
} 


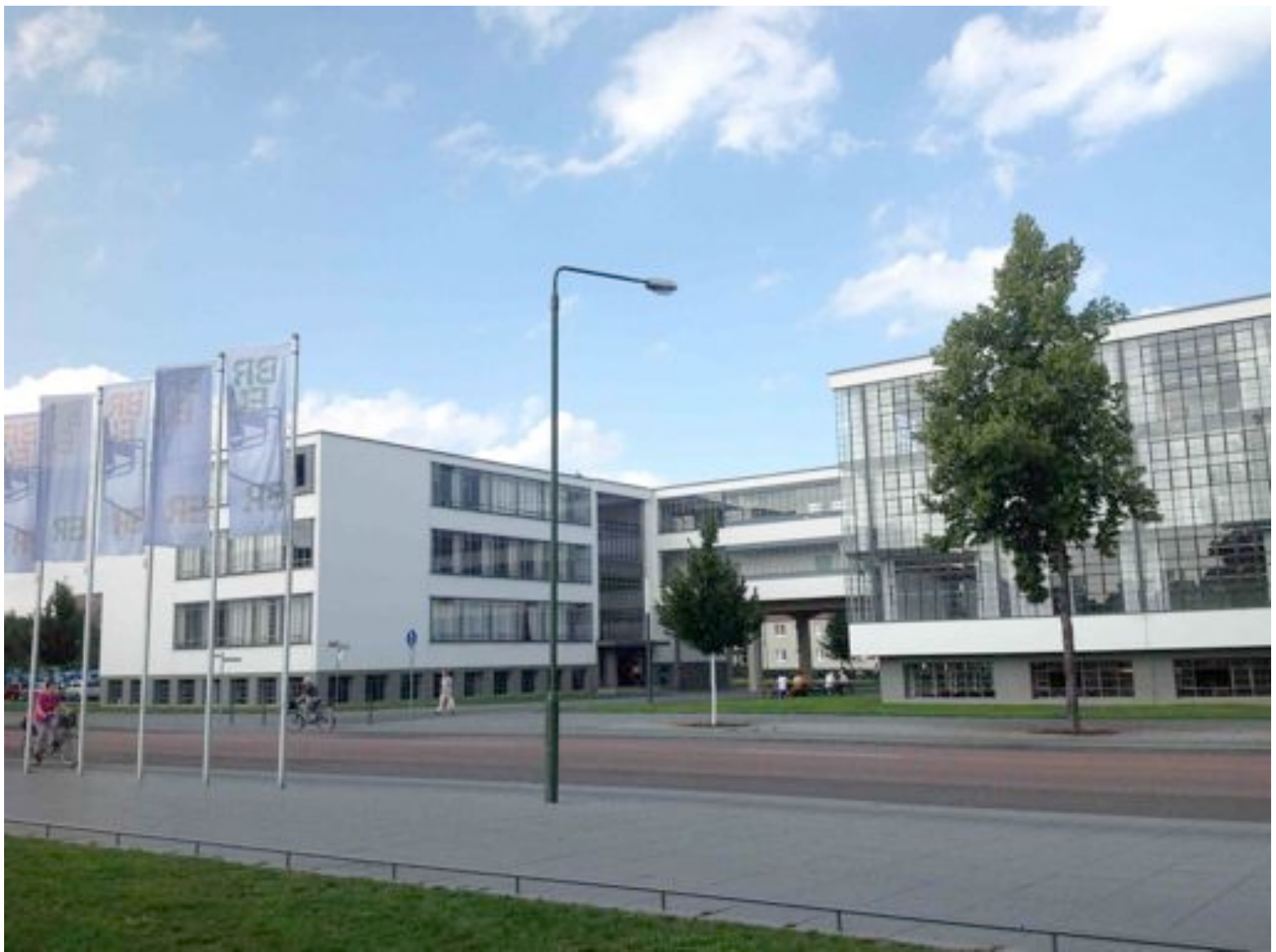

IMAGEM 3: Bauhaus Dessau Buillding. 1925-26. Dessau, Germany. Arquitetura: Walter Gropius. Foto: Débora Lima.

Nenhum modernista europeu de reputação já estabelecida emigra para o Brasil, porém os intercâmbios começam a acontecer.

Os anos que se seguiram à grande depressão econômica - estagnação econômica na Europa e inércia da burguesia norte-americana - deram aos países do Terceiro Mundo uma "autoridade" temporária, e ao Brasil um papel determinante neste processo (Le Corbusier apud ANDREOLI, 2004: 36).

No Brasil, no entanto, viriam a se fixar ou retornar de estudos no exterior, imigrantes e brasileiros que, influenciados pelas correntes modernas de vanguarda europeias, aqui iriam contribuir para o desenvolvimento de nossa moderna arquitetura como Gregori Warchavchik (1896-1972) em 1923 e Rino Levi (1901-1965) ${ }^{40}$ e Flavio de Carvalho (1899-1973), dentre tantos outros.

\footnotetext{
${ }^{40}$ ANELLL, Renato; GUERRA, Abilio; KON, Nelson. Rino Levi - Arquitetura e Cidade. São Paulo: Romano Guerra Editora, 2001
} 
Arquitetos renomados já haviam visitado o Brasil, como August Perret (18741954) na década de 1930, mas não haviam se entusiasmado em desenvolver uma 'aventura' nos trópicos.

Le Corbusier (1887-1965) visitara o Brasil em 1929, quando suas conferências e propostas haviam causado grande impacto, como se sabe, e havia estado em São Paulo e Rio de Janeiro, aproveitando para conhecer também Buenos Aires e Montevidéu. Viria novamente em 1936.

A partir dos encontros desse arquiteto com o Brasil e os arquitetos brasileiros, a história mais difundida de como se deu o início da nossa Arquitetura Moderna começa a ser contada, e inicia-se a identificação de seus projetos pioneiros.

Porém, como atualmente o enfoque da leitura da gênese do movimento moderno brasileiro vem sendo revisto continuamente, podemos dizer que foram os arquitetos participantes do grupo paulista liderados principalmente por Gregori Warchavchik ${ }^{41}$ no período precursor de 1927 a 1933, os grandes responsáveis por encarar a nova arquitetura como manifestação liberta dos moldes estilísticos e históricos.

Apesar disso, a critica da obra de Warchavchik foi "marcada pela dificuldade de estabelecer-lhe um lugar na trama narrativa que prioriza o caráter brasileiro da arquitetura moderna desenvolvida a partir dos episódios-chave do Ministério e da Pampulha". 42

De 1927 até o começo da década de 1930, Warchavchik projeta uma série de casas modernas, "racionais, confortáveis, de pura utilidade, repletas de cor, luz e de alegria", como ele costumava definir.

\footnotetext{
${ }^{41}$ Ver mais acerca da arquitetura moderna de Warchavchik em FARIAS, Agnaldo Aricê Caldas. Arquitetura Eclipsada - Notas sobre Arquitetura e História, a Propósito da Obra de Gregori Warchavchik, Introdutor da Arquitetura Moderna no Brasil. Campinas, 1990. Dissertação (Mestrado em História). Universidade Estadual de Campinas - UNICAMP; LIRA, José Tavares Correia de. Warchavchik: fraturas da vanguarda. São Paulo: Cosac \& Naify, 2011. Também, obviamente, o manifesto de Geraldo Ferraz. Warchavchilk e a Introdução da Nova Arquitetura no Brasil: 1925 a 1940. São Paulo: Museu de Arte de São Paulo, 1965.

${ }^{42}$ MARTINS, Carlos A. Ferreira. Gregori Warchavchik: combates pelo futuro (introdução) In WARCHAVCHIK, Gregori. Arquitetura do século XX e outros escritos. Organização: Carlos A. Ferreira Martins. São Paulo: Cosac Naify, 2006, p. 15.
} 


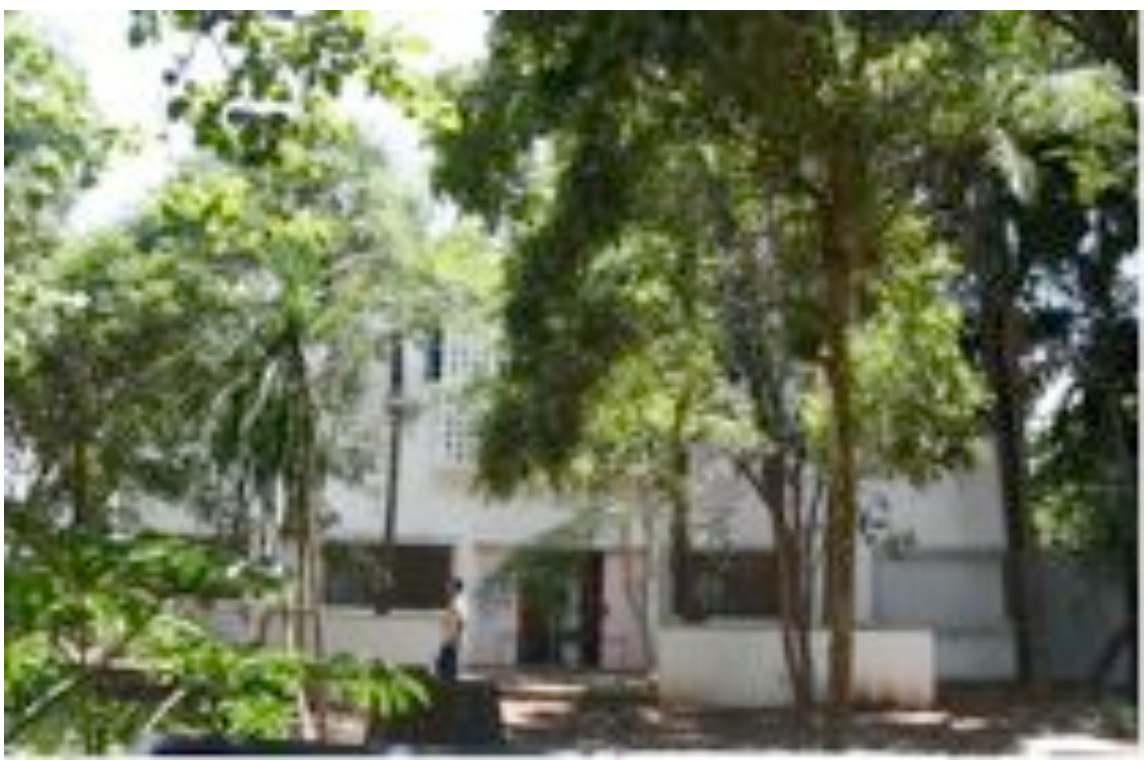

IMAGEM 4: Casa da Rua Santa Cruz, em São Paulo. Projeto de Gregori Warchavchik, de 1928. Reformada em 1935. Integra o breve período precursor, compreendido entre 1927 e 1933. Neste seu projeto quase que inaugural no Brasil, o arquiteto usa as soluções originais do projeto se relacionando ao modo como combina a doutrina funcionalista de Gropius e Le Corbusier com o ambiente local e com a escassez de produtos industrializados no país. Foto: Débora Lima.

A década de 1930 constitui um momento de maturidade e consagração na carreira do arquiteto. O reconhecimento de seu trabalho pelo próprio Le Corbusier quando de sua passagem pelo Brasil, em 1929, representa os primeiros passos na direção da repercussão internacional de sua obra.

IMAGEM 5: 'Casa Modernista' da Rua Itápolis, inaugurada em São Paulo em 1930. Projeto de Gregori Warchavchik. Foto: Débora Lima

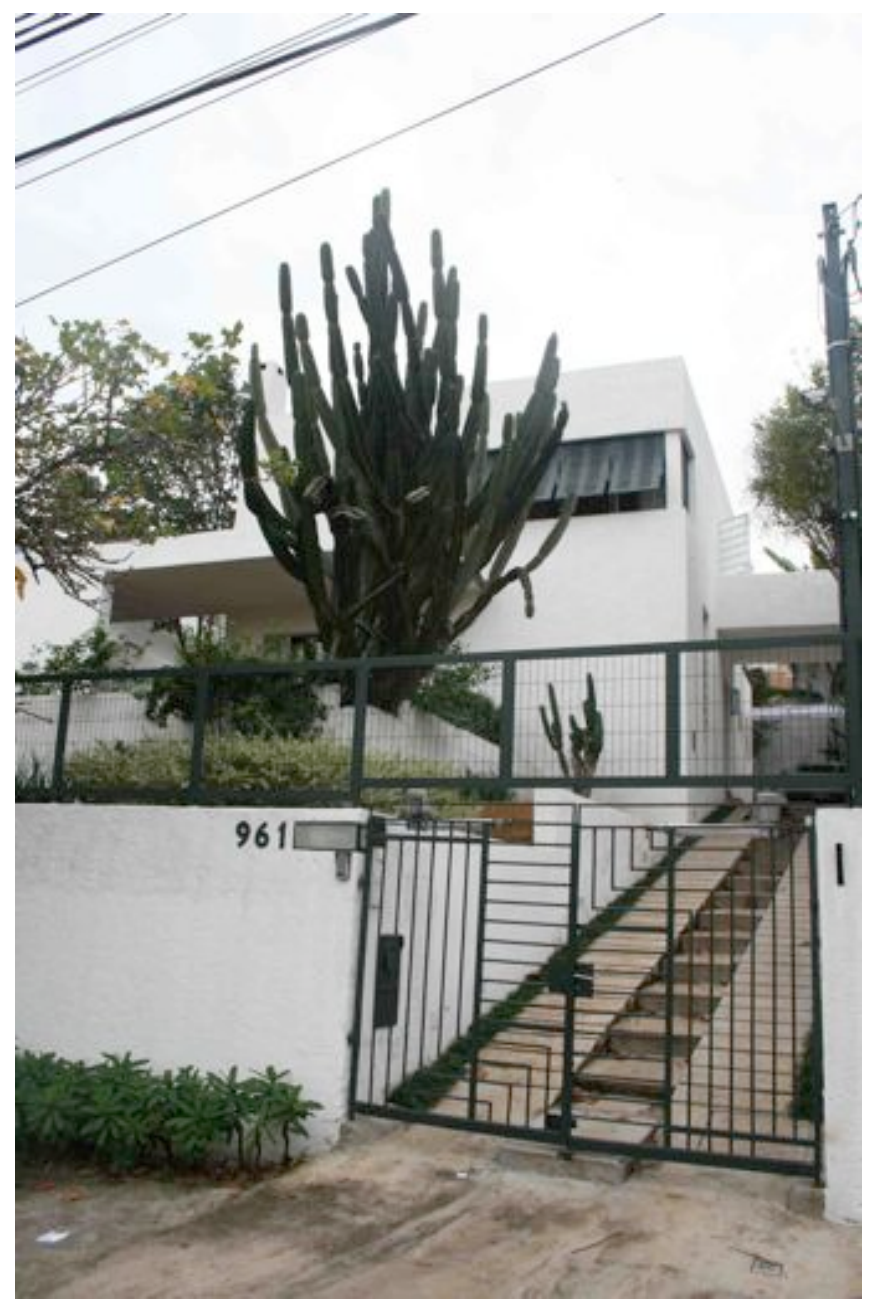


É designado por Siegfried Giedeon, por sugestão de Le Corbusier, representante da América Latina no $2^{\circ}$ CIAM a ser realizado em Bruxelas em 1930.

De modo que o pioneirismo de Warchavchik na constituição da arquitetura moderna no Brasil é ponto consensual dos estudiosos, unânimes em associar seu nome às origens do racionalismo arquitetônico no país. Se verificarmos a semelhança de sua arquitetura com aquela realizada por Walter Gropius, por exemplo, na mesma época, ainda residente na Alemanha, essa afirmação toma ainda mais significado.

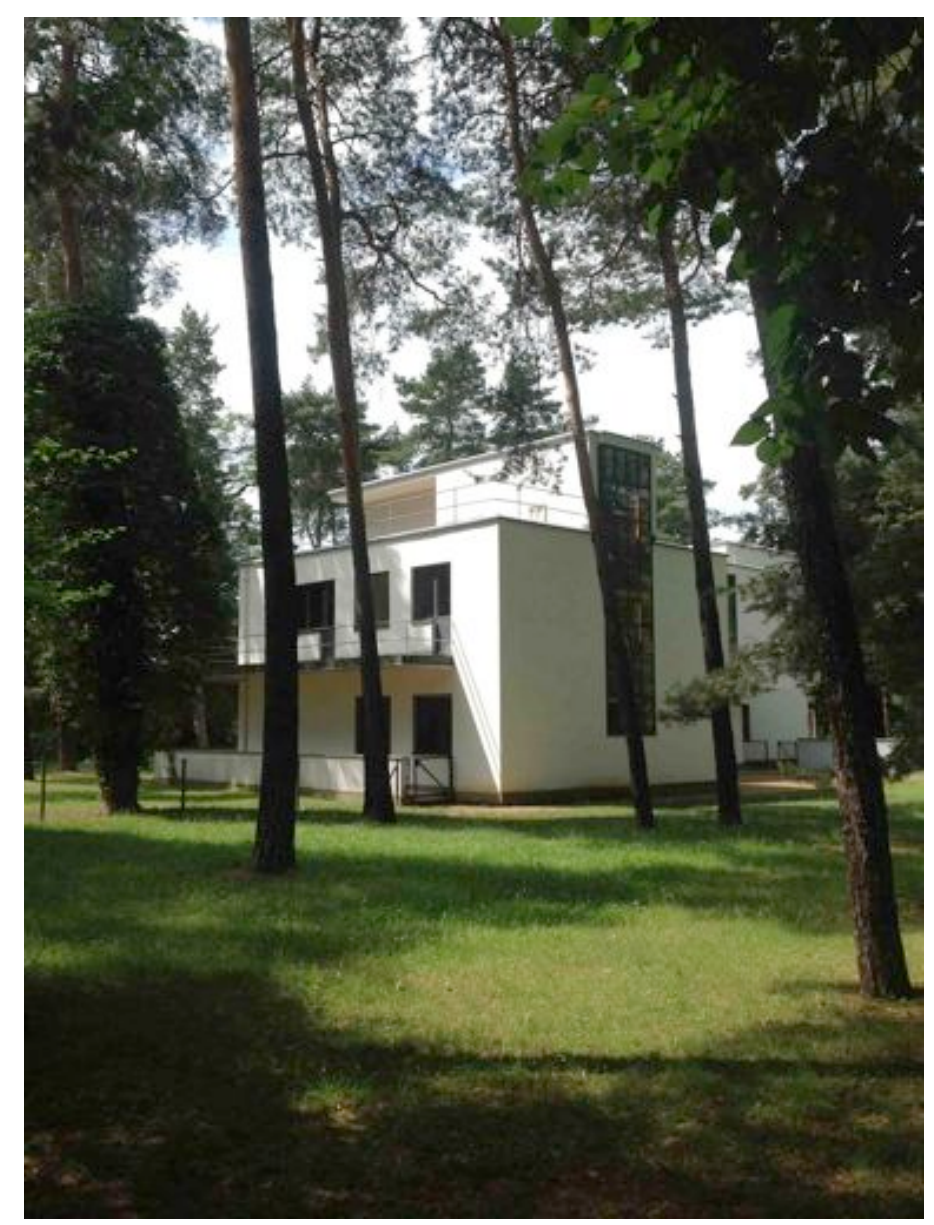

IMAGEM 6: Master's Houses. 1925-26 Dessau, Germany. Arquitetura: Walter Gropius. Foto: Débora Lima.

Mas, enfim, oficialmente, o Modernismo Brasileiro na Arquitetura, cultivado a princípio por Lucio Costa e associados no Rio de Janeiro, e então "descoberto" e levado para os Estados Unidos por dois americanos, Philip Goodwin (1885-1958) e George E. Kidder Smith (1913-1997), através da exibição e livro Brazil Builds ${ }^{43}$ de 1943, foi celebrado precisamente porque era visto como alternativa ao funcionalismo do entre - guerras e, ainda, porque ficaria evidente sua habilidade em se desenvolver e rejuvenescer a si próprio.

\footnotetext{
${ }^{43}$ GOODWIN, Philip L. Brazil Builds: Architecture new and Old 1652 - 1942 Photographs by G. E. Kidder Smith. New York: The Museum of Modern Art (MoMA), 1943.
} 
Essa afirmação aqui feita, bastante direta e forte, na verdade nos remete a um termo, Escola Carioca, que é o nome pelo qual parte da produção moderna da arquitetura brasileira é comumente identificada pela historiografia.

Trata-se originalmente da obra produzida por um grupo radicado no Rio de Janeiro, que, com a liderança intelectual de Lucio Costa e formal de Oscar Niemeyer cria um estilo nacional de arquitetura moderna: uma espécie de brazilian style, que se dissemina pelo país entre os anos 1940 e 1950, contrapondo ao international style, hegemônico até os anos $1930 .^{44}$

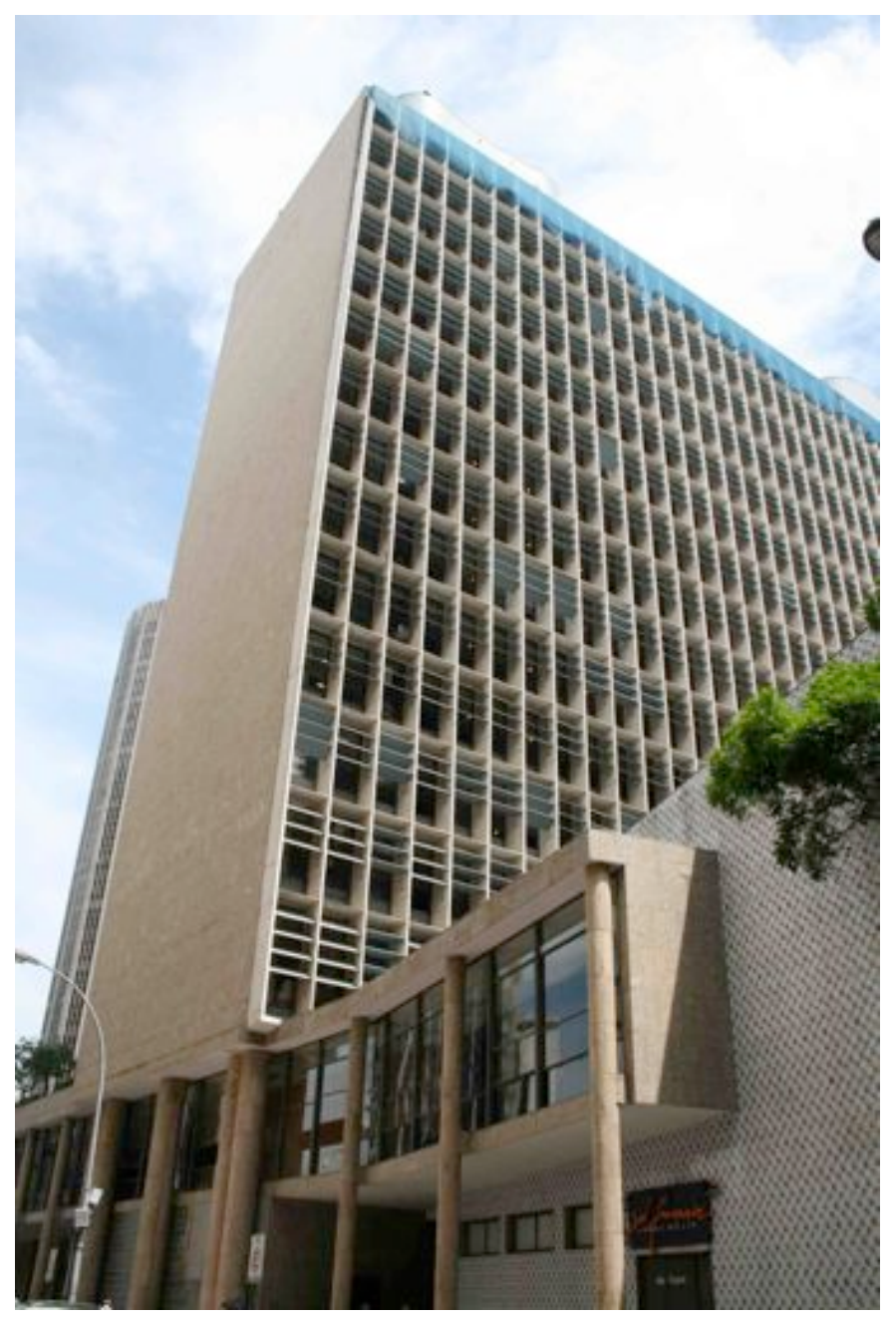

IMAGEM 7: Ministério de Educação e Saúde no Rio de Janeiro. Projeto de Lucio Costa, Affonso Eduardo Reidy, Carlos Leão, Jorge Moreira, Ernani Vasconcellos e Oscar Niemeyer. 1936-1945. Foto: Débora Lima.

Para entender o termo há que se recorrer a um dos episódios "fundadores" da moderna arquitetura brasileira: o projeto do Ministério da Educação e Saúde (MES), atual Palácio Gustavo Capanema, no Rio de Janeiro, de 1936-1943, elaborado no governo Getúlio Vargas. O edifício é desenhado por uma equipe liderada por Lucio Costa com a orientação direta de Le Corbusier, que vem ao Brasil auxiliar os jovens arquitetos na tarefa de projetar um prédio moderno como sede do ministério.

A equipe, formada por Carlos Leão (1906-1983), Affonso Eduardo Reidy (19091964), Jorge Moreira (1904-1992), Ernani Vasconcelos (1912-1989) e Oscar Niemeyer

\footnotetext{
${ }^{44}$ Segundo Hugo Segawa, "Brazilian School, Cariocan School, First National Style in Mordern Architecture, Neobarroco foram alguns dos rótulos atribuídos pela história e critica de arquitetura pensada e escrita pelos estudiosos europeus e norte-americanos, para a arquitetura feita no Brasil mais ou menos entre a década de 1930 até Braslia", fruto da revisão historiográfica do pós-guerra. Cf. SEGAWA, Hugo. Arquiteturas no Brasill: 1900-1990, São Paulo: Edusp, 1998, p.103.
} 
(1907), realiza o primeiro edifício que incorpora em grande escala os cinco pontos da arquitetura corbusiana - brise soleil [quebrassol], pan de verre [pano de vidro ou courtain wall, teto-jardim, térreo com pilotis e planta livre - ao mesmo tempo que lança mão de uma plasticidade que não se vê comumente na arquitetura moderna de outros países e recupera elementos "nacionais", como os painéis de azulejo.

Além do MES, são considerados exemplares da Escola Carioca obras como o edifício sede da Associação Brasileira de Imprensa (ABI) (1936), dos irmãos Roberto: Marcelo (1908-1964), Milton (1914-1953) e Maurício (1921-1996); a Estação de Passageiros de Hidroaviões (1937), de Attílio Corrêa Lima (1901-1943); o Grande Hotel de Ouro Preto (1938), de Niemeyer; o Pavilhão do Brasil na Feira Internacional de Nova York (1938-1939), de Costa e Niemeyer; o Conjunto Arquitetônico de Pampulha, projetado por Niemeyer em Belo Horizonte; o Park Hotel São Clemente(1944), em Friburgo, Rio de Janeiro, de Lucio Costa; o Conjunto Habitacional Pedregulho (1950- ) 1952), de Reidy, entre outros.

IMAGEM 8: Sede da ABl. 1936-1938. Rio de Janeiro, Rio de Janeiro, Brasil. Arquitetura: Marcelo Roberto e Milton Roberto (MMRoberto). Foto: Débora Lima.

A ideia do termo Escola Carioca de arquitetura é esboçada pela primeira vez por ocasião da publicação do catálogo da exposição Brazil Builds, no Museum of Modern Art (MoMA), de Nova York, em 1943, ocasião em que também surge o termo brazilian style, em texto escrito em 1944 pelo crítico Mário de Andrade (1893-1945) sobre a importância dessa realização. ${ }^{45}$

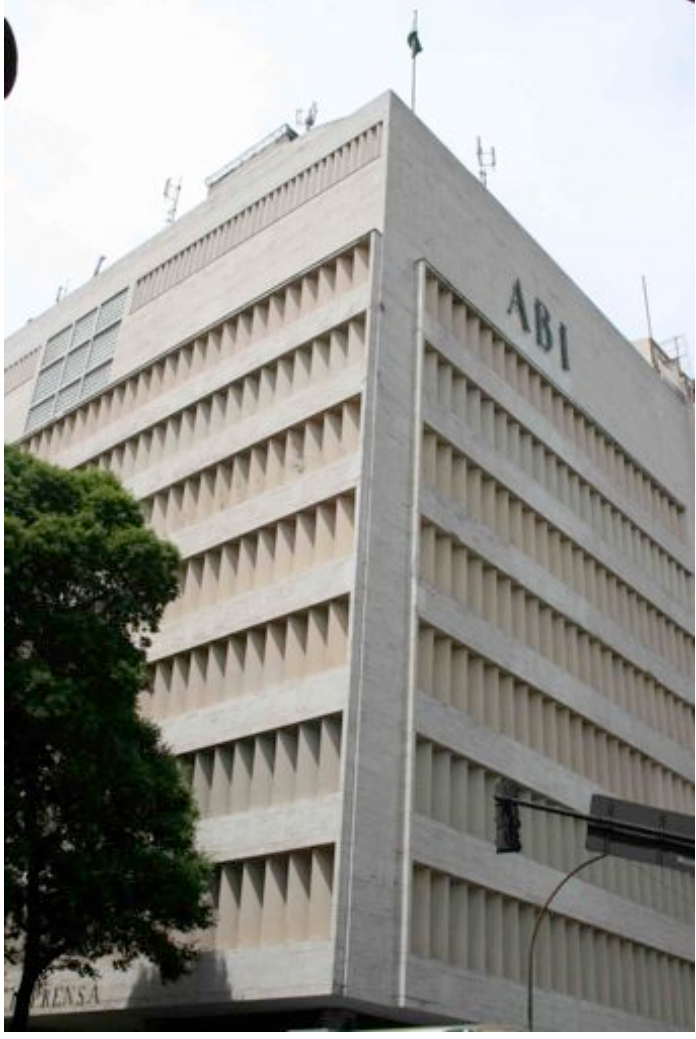

Andrade diz - não sem antes afirmar que a primeira manifestação da arquitetura moderna no Brasil, como a das outras artes, tenha se dado em São Paulo, com uma casa do arquiteto Warchavchik muito comentada pelas nossas revistas de então - que "a primeira escola, o que se pode chamar legitimamente de 'escola' de 
arquitetura moderna no Brasil, foi a do Rio, com Lucio Costa à frente, e ainda inigualada até hoje". ${ }^{46}$ No mesmo ano, essa produção nomeada internamente de Escola Carioca começa a ser conhecida como brazilian style. A simultaneidade dos termos faz com que durante muito tempo se tome a produção arquitetônica "carioca" pela totalidade da produção nacional, algo que vem sendo revisto pela historiografia da arquitetura desde os anos 1980. ${ }^{47}$

De fato, a partir da década de 1940 é possível verificar em várias cidades do Brasil uma produção que pode ser identificada com a rubrica Escola Carioca. Encabeçada por arquitetos cariocas ou formados no Rio de Janeiro - como Hélio Duarte (1906-1989), que dirige a experiência do Convênio Escolar em São Paulo, 1948 -1952 e Oscar Niemeyer, que projeta os principais edifícios do Parque do lbirapuera, responsáveis pela introdução da arquitetura moderna nos edifícios públicos em São Paulo -, não se pode afirmar que ela represente a totalidade da produção arquitetônica brasileira. Pois mesmo entre os arquitetos cariocas há aqueles que em sua obra ou em alguns projetos buscam se manter fiéis aos preceitos racionalistas mais estritos, como Jorge Moreira e Vital Brazil (1909-1997), ou construir outros vocabulários arquitetônicos, como Sérgio Bernardes (1919-2002).

Também não se pode generalizar de forma alguma esta questão pois, por exemplo, as "Escola parque" capitaneadas por Hélio Duarte tiveram sua gênese ainda no final dos anos vinte e bem no início dos anos trinta e através da participação de Anísio Teixeira, que realizaria uma grande reforma na rede de ensino brasileira, baseada no método americano, e que, inclusive, havia estudado na Columbia University de Nova York e conhecido o educador americano John Dewey. ${ }^{48}$

Ou seja, iniciativas que também ajudaram a moldar a arquitetura moderna brasileira, e que foram acontecimentos anteriores ao Brazil Builds, à "Escola Carioca" e a visita de Le Corbusier e que também tinham uma relação com os Estados Unidos.

\footnotetext{
${ }^{46}$ ANDRADE, op. cit., p. 179,

${ }^{47}$ TINEM, Nelci. O Alvo do Olhar Estrangeiro: o Brasil na historiografia da arquitetura moderna. João Pessoa: Ed Manufatura, 2002, il p\&b, p. 237.

"QVer mais em FERRAZ, Artemis Rodrigues Fontana. Arquitetura moderna das escolas "S" paulistas, 1952-1968: projetar para a formação do trabalhador. São Paulo, 2008. Tese (Doutorado). Curso de Pós-Graduação em Arquitetura e Urbanismo. Faculdade de Arquitetura e Urbanismo - USP e WISNIIK, Guilherme. O programa escolar e a formação da 'escola paulista'. In: Arquitetura escolar paulista: anos 1950 e 1960. Organização Avany de Francisco Ferreira e Mirela Geiger Mello. São Paulo: FDE, 2006, p.59.
} 
O termo, portanto, está longe de ser consensual, pois identifica superficialmente uma série de obras como uma produção hegemônica, em detrimento da variedade de propostas em curso no país entre as décadas de 1930 e 1950, mesmo entre aqueles que se tornam seus símbolos, como Costa, Niemeyer, Reidy, Moreira e os Roberto. ${ }^{49}$

Mas, enfim, a exposição Brazil Builds se consolidaria como o primeiro levantamento sistemático da produção moderna no Brasil. Com vasto espaço dedicado à produção colonial, teria definido a primazia da arquitetura carioca e de Le Corbusier.

Desmerecendo ou simplesmente desconhecendo obras e ideias importantes e fundamentais como as de Warchavchik, esse "livro de imagens" conta uma história engendrada para alcançar fins bem definidos.

De modo que o contexto de intercâmbios internacionais constantes em que se desenvolveu não prejudicou a fabricação de seu "caráter local", o que permitiu Banham distingui-la como "o primeiro estilo nacional da arquitetura moderna" "estilo" que se criou praticamente do nada e refinou-se, em meros vinte e cinco anos, do Ministério da Educação e Saúde Pública, em 1936, para a inauguração de Brasília, em 1960.

Enquanto isso, na América do Norte, forçadamente ou não, este novo conceito de "estilo", o "International Style"51, passa a ser utilizado de uma maneira não depreciativa, por Henry-Russell Hitchcock (1903-1987) e Philip Johnson (1906-2005), coincidentemente à diáspora da Bauhaus. ${ }^{52}$

\footnotetext{
49WISNIK, Guilherme. Modernidade congênita. In: Elizabetta Andreolli e Adrian Forty. Londres: Phaidon, 2004, p. 30. 50BANHAM, Reyner. Guide to Modern Architecture, London: Architectural Press, 1962, p. 36. ${ }^{51} \mathrm{KHAN}$, Hasan-Uddin. International Style - Modernist Architecture from 1925 to 1965. Kong/Köln/London/Los Angeles/Madrid/Paris/Tokyo: Taschen, 2009 


\section{Cronologia dos Eventos-chave de ligação Brasil x EUA e a arquitetura moderna}

\section{9-1940: Pavilhão do Brasil na New York World's Fair, New York, USA}

Um acontecimento determinante para o florescimento da arquitetura moderna brasileira foi a concepção do projeto do Pavilhão do Brasil na New York World's Fair de 1939-40 ${ }^{53}$, na qual as Nações latino-americanas acorreram em massa, antecipando os ares da Política da Boa Vizinhança, acontecimento este enormemente divulgado e alardeado por nossa historiografia, antes e ainda hoje. É quando nossa arquitetura mostra-se "internacionalmente" pela primeira vez.

Além do aspecto de inovação tecnológica, expresso pelo tema "Construindo o Mundo de Amanhã", a implantação da Feira no Queens trouxe também inovações nas concepções arquitetônicas, impondo regras aos projetos a serem concebidos, que restringiam o uso de velhos estilos históricos no desenho dos pavilhões norte americanos e decretavam que os pavilhões estrangeiros se conformassem com o estilo moderno em concordância com o tema abrangente da Feira.

Entre os norte-americanos ou imigrantes residentes nos EUA que participaram dos projetos da Feira Mundial figuram Robert Moses (1888-1981), Norman Bel Geddes (1893-1958), Joseph Urban (1872-1933), William Lescaze (1896-1969), Walter Dorwin Teague (1883-1960), Henry Dreyfuss (1904-1972), Donald Deskey (1894-1989), Raymond Loewy (1893-1986), com a colaboração do russo Vyacheslav K. Oltarzewski (1883-1966), que trabalhava no escritório de Wallace K. Harrison (1895-1981), Harrison \& Abramovitz, esse próprio responsável pelo desenho da Feira e do Trylon e Perisphere, ícones esculturais do evento, com formas geométricas puras.

No Brasil, foi realizado um concurso entre os modernistas, saindo vitorioso Lucio Costa. Este, "reconhecendo as virtudes" do arrojado projeto de seu jovem colaborador, Oscar Niemeyer, classificado em segundo lugar, convida-o para trabalharem juntos. ${ }^{54}$

\footnotetext{
${ }^{53}$ Conhecer mais sobre a Feira em COTTER, Bill. The 1939-1940 New York World's Fair (Images of America). New York: Arcadia Publishing, 2009 e WURTS, Richard (and others). The New York World's Fair, 1939/1940: in 155 Photographs. New York: Dover Publications; 1st, edition, 1977.

${ }^{54}$ Ler depoimento de Lucio Costa sobre a experiência em COSTA, Lucio. Lucio Costa: Registro de uma Vivência. São Paulo: Empresa das Artes, 1995, pp. 190-193.
} 


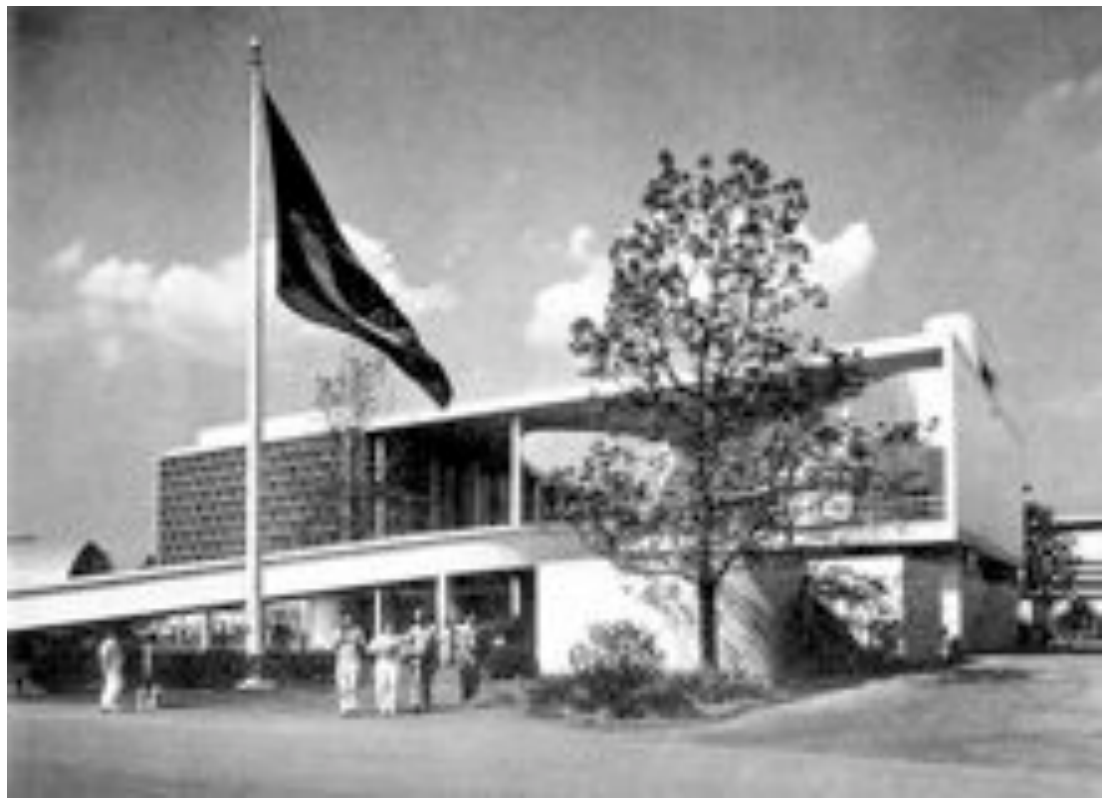

IMAGEM 9: Pavilhão do Brasil na New York World's Fair. 1939 1940. New York, New York, USA. Arquitetura: Oscar Niemeyer, Lucio Costa, Paul Lester Wiener e Thomas Price. Foto: GOODWN, Philip L. Brazil Builds: Architecture new and Old 1652 - 1942. Photographs by G. E. Kidder Smith. New York: The Museum of Modern Art (MOMA), 1943.

Concebido ao longo de um ano e construído em apenas cinco meses, o Pavilhão do Brasil, que teve papel de destaque na Feira, apesar de usar o vocabulário básico de Le Corbusier, afirma-se: "antecipou futuras tendências, com a liberdade de sua rampa, flexibilidade de volumes, proteção da insolação com elementos fixos, uso da curva como elemento expressivo e indistinção de espaço externo e interno".

O apoio incondicional que Lucio Costa e Oscar Niemeyer obtiveram em sua estadia em Nova York teve uma fundamentação política. O governo de Roosevelt desejava mudar o bom relacionamento de Getúlio Vargas com os regimes nazista e fascista de Hitler e Mussolini. Daí o interesse em valorizar a presença do Brasil na Feira.

O convite aos dois arquitetos brasileiros para trabalharem no escritório de Harrison \& Abramovitz, profissionais bastante ligados à Nelson Rockefeller e que seriam também parceiros de Niemeyer no projeto do Edifício-sede da ONU em 1947, foi um exemplo importante deste apoio.

Observando o mapa da Feira, na Imagem 10 abaixo, constatamos que a localização do Pavilhão do Brasil (B2), ao lado do "American Art Today" e do "Town of Tomorrow" e tendo o prestigiado Pavilhão da França ao seu lado, foi estrategicamente bem posicionada, mostrando-se em evidência dentro do evento. 


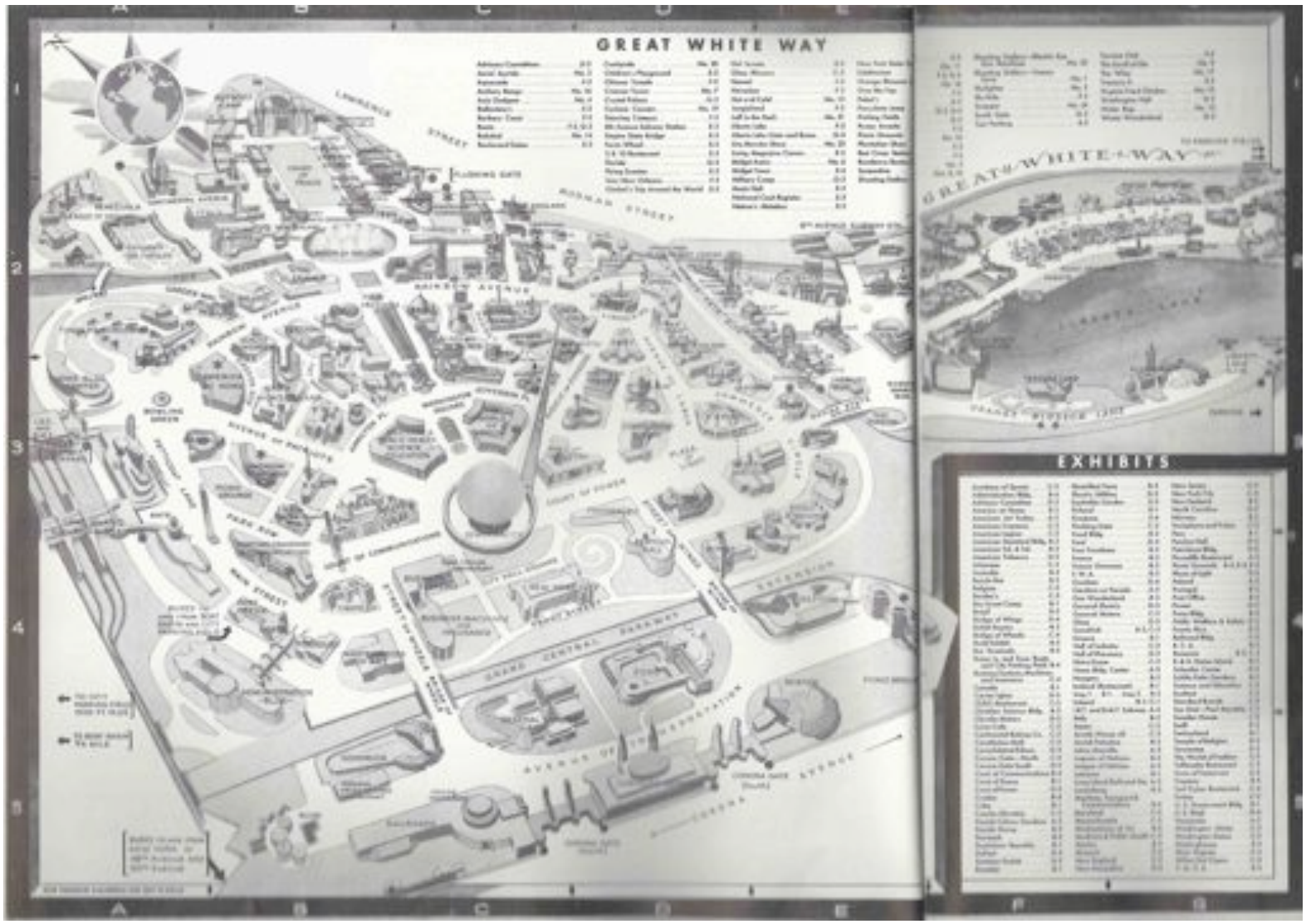

IMAGEM 10: WURTS, Richard (and others). The New York World's Fair, 1939/1940: in 155 Photographs New York: Dover Publications; 1st. edition, 1977.

O caráter inovador do pavilhão brasileiro, como livre interpretação "regionalista" do Movimento Moderno, indicava uma tendência que tinha certo apoio no recente debate arquitetônico norte-americano.

De modo que:

Ao mesmo tempo, existia nos Estados Unidos uma posição estética, defendida por Frank Lloyd Wright e o historiador Lewis Mumford, que rejeitava o racionalismo "duro" de origem europeia e defendia a liberdade de um vocabulário associado ao relacionamento com a natureza e o uso dos materiais naturais, mais próximos às tradições culturais locais. Por outra parte, os códigos "maquinistas" eram associados ao styling e à diversidade das formas curvas aplicadas aos objetos industriais, também assimilada por Wright na sede da Johnson Wax (1936). Entre o regionalismo e o Depression Style existia um embasamento de invenções plásticas que não era alheio ao pavilhão brasileiro. ${ }^{55}$

\footnotetext{
55SEGRE, Roberto. O sonho americano de Oscar Niemeyer, Le Corbusier e as Américas In Revista al, edição 165, dezembro de 2007.
} 


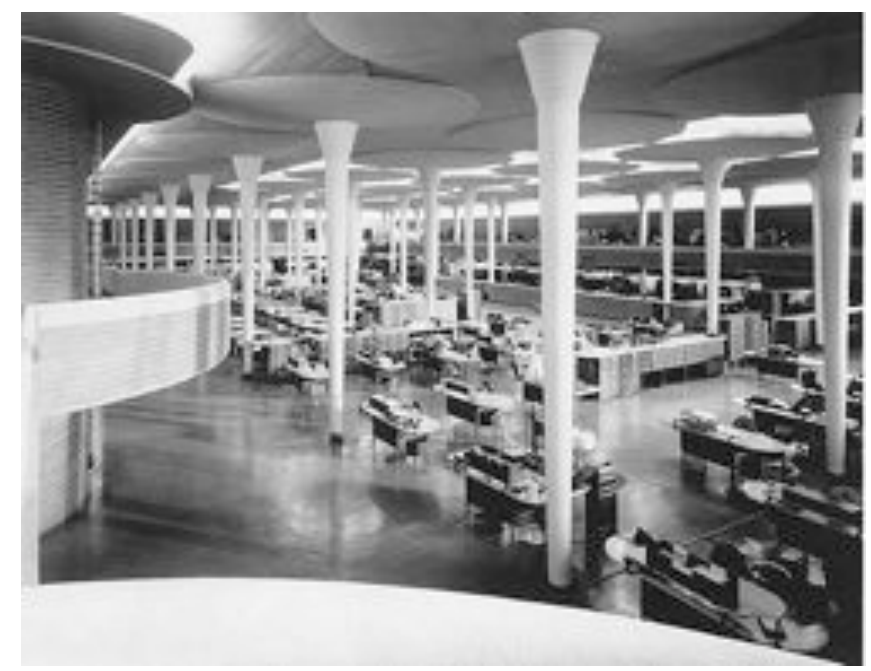

IMAGEM 11: Johnson Wax Headquarters, 1936

Racine, Wisconsin, USA. Arquitetura: Frank Lloyd Wright. Foto (CJeff Dean.

Sua originalidade e a intensidade expressiva de uma nova linguagem que identificaria Niemeyer com a estética da Escola Carioca não foi um fenômeno isolado no contexto da exposição.

A Finlândia, com Alvar Aalto, e a Suécia, com Sven Markelius, orientados na mesma procura de uma identidade arquitetônica nacional, apresentavam questionamento semelhante.

IMAGEM 12: Pavilhão da Finlândia na New York World's Fair, 1939-1940. New York, New York, USA.

Arquitetura: Alvar Aalto. Foto: Museum of Finnish Architecture, Helsinki.

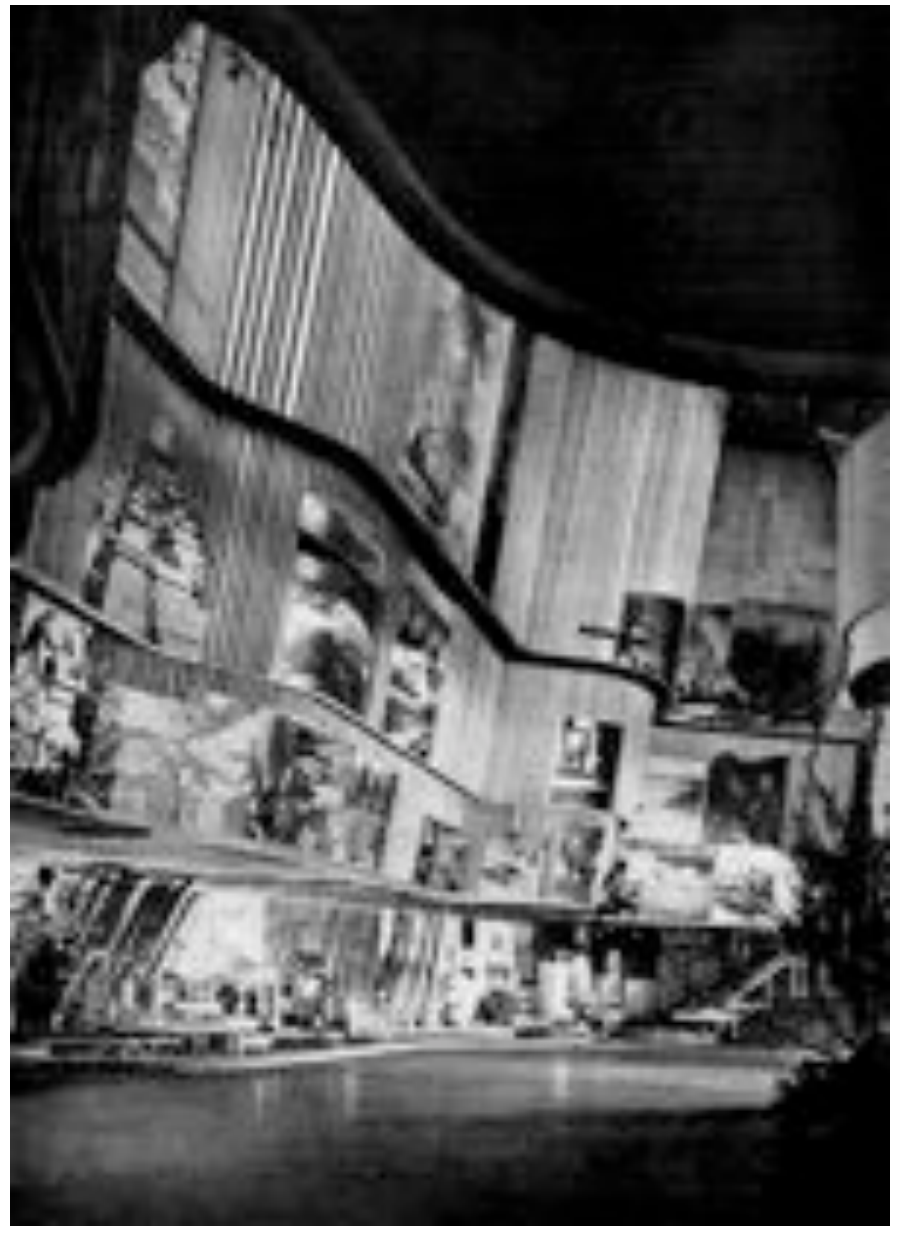

Como o projeto definitivo do pavilhão foi elaborado em Nova York (foi necessário refazer os dois desenhos diferentes e antagônicos apresentados por Costa e Niemeyer no concurso) sem dúvida esse clima artístico deve ter influenciado a elaboração da nova proposta. 
Tampouco foi difícil a colaboração entre os projetistas brasileiros e os profissionais norte-americanos que participaram da criação dos desenhos. Um deles foi o paisagista Thomas Price, autor dos jardins (erroneamente creditados a Burle Marx por alguns autores). Havia ainda o arquiteto de origem alemã emigrado para os EUA em 1913 Paul Lester Wiener, responsável pelo mobiliário e pelo sistema expositivo, que ecoava as estruturas publicitárias e decorativas predominantes em Nova York no final daquela década. Sem dúvida, essas experiências facilitaram a consolidação da linguagem de Niemeyer.

De modo que, da mesma forma que os pavilhões da Finlândia e da Suécia, o Pavilhão brasileiro entusiasmou os críticos.

Segundo Giedion: "É de importância extrema que a nossa civilização não mais se desenvolva a partir de um único centro e que obras criativas emanem de países até então provincianos, como a Finlândia e o Brasil". ${ }^{56}$

O sucesso do pavilhão brasileiro e os elogios dos críticos - além de Giedion, também Frederick A. Gutheim e Henry-Russel Hitchcock, ente outros - determinaram, segundo Lucio Costa, o lançamento mundial de Oscar Niemeyer, ratificado pela difusão das novas obras realizadas no Brasil, contidas no livro e exposição Brazil Builds do MoMA, daí a quatro anos, fazendo com que este arquiteto, logo após a Segunda Guerra, se transformasse em uma figura relevante no contexto latino-americano, muito impulsionado por estes acontecimentos em solo norte-americano.

Vários autores (Yves Bruand, Carlos Eduardo Comas, Lauro Cavalcanti, David Underwood, Hugo Segawa, entre outros) ${ }^{57}$ analisaram em detalhe o pavilhão do Brasil e a sua contribuição para o desenvolvimento da arquitetura brasileira.

Oficialmente, diz-se que começou nesse projeto o estabelecimento de uma linguagem brasileira própria, independente e autônoma da sua matriz europeia. ${ }^{58}$

\footnotetext{
${ }^{56}$ Giedion no prefácio de MINDLIN, Henrique E. Arquitetura Moderna no Brasil. $2^{2}$ ed. Rio de Janeiro: Aeroplano Editora/PHAN, 2000.

${ }^{57}$ BRUAND, Yves. Arquitetura Contemporânea no Brasil. São Paulo: Perspectiva, 1981; COMAS, Eduardo Dias. Arquitetura moderna, estilo Corbu, pavilhão brasileiro In GUERRA, Abilio (org.). Textos Fundamentais sobre História da Arquitetura Moderna Brasileira. Parte 1. São Paulo: Romano Guerra, 2010, pp. 207-225; UNDERWOOD, David. Oscar Niemeyer e o Modernismo de formas livres no Brasil. São Paulo: Cosac \& Naify, 2002; SEGAWA, Hugo. Arquiteturas no Brasil 1900-1990. São Paulo: Edusp, 1998.

${ }^{58}$ CAVALCANTI, Lauro, Moderno e Brasileiro: A História de uma Nova Linguagem na Arquitetura (1930-1960). Rio de Janeiro: Jorge Zahar Editor, 2006, p. 184.
} 


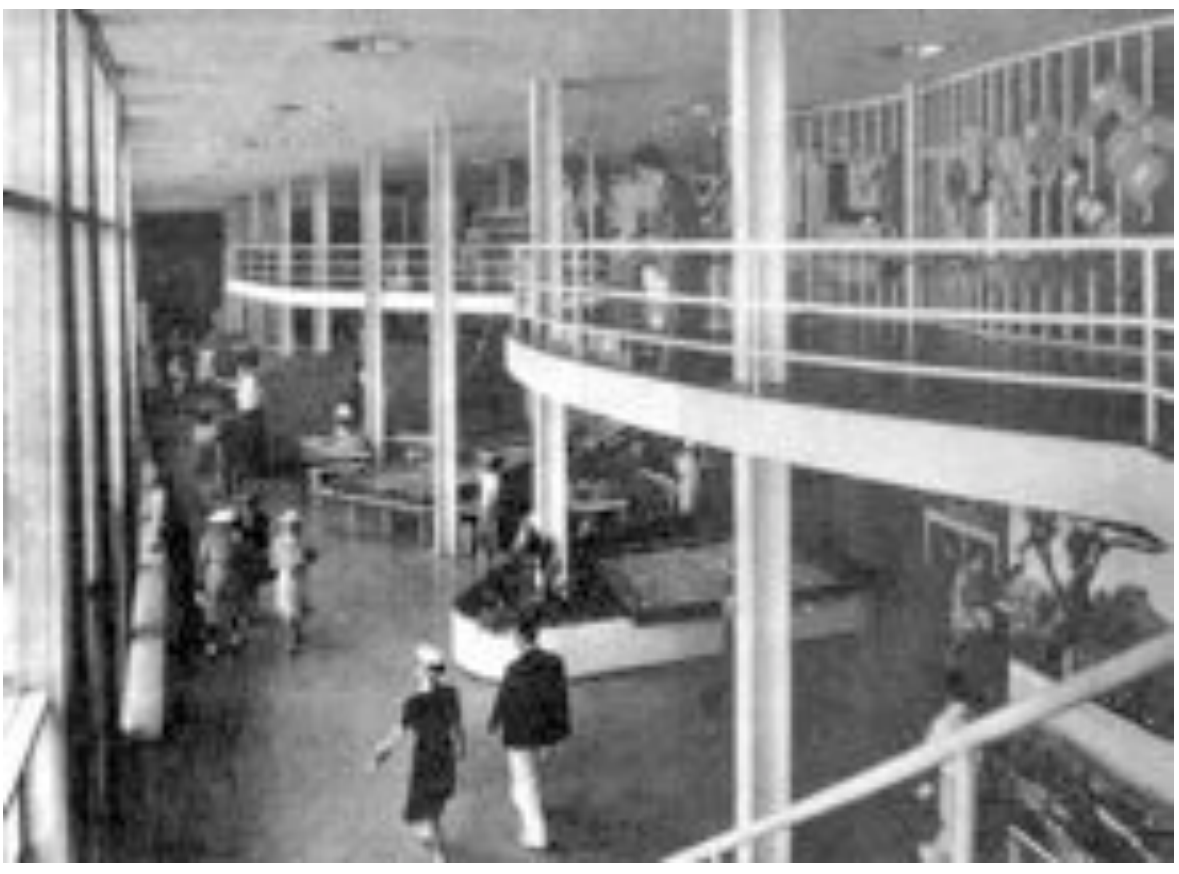

IMAGEM 13: Interior do Pavilhão do Brasil na New York World's Fair. 1939 1940. New York, New York, USA.

Em 1939, ano de inauguração do Pavilhão em NY, a construção no Rio de Janeiro do prédio do Ministério da Educação e Saúde (1937-43) mal estava começando, e o único exemplar concluído, em termos de grande escala, do nosso modernismo era a sede da ABI (1936-38).

Podemos auferir deste acontecimento específico, apesar de sua valorização sabemos exacerbada, a demonstração da possibilidade de passos diferentes daqueles do funcionalismo europeu no projeto desenvolvido por Lucio Costa e Oscar Niemeyer em Nova York que, definitivamente, teve uma importância crucial no desenvolvimento do modernismo brasileiro.

Se a consultoria de Le Corbusier no projeto do Ministério da Educação e Saúde, somente dois anos antes, foi uma espécie de graduação moderna informal para Niemeyer e Costa, a permanência de um ano em Manhattan desempenhou o papel de uma pós-graduação.

Esse fato permitiu também aos dois arquitetos, nos oito meses que passaram na cidade, o encontro com a elite cultural norte-americana e europeia, incrementada pela presença dos artistas e arquitetos que emigravam da Europa. ${ }^{59}$

\footnotetext{
${ }^{59}$ Entre eles citemos Frederick Kiesler, José Luis Sert, Max Ernst, Fernand Léger, Hans Arp, Marcel Duschamp, Constantin Brancusi. Também faziam parte do grupo Salvador Dali, Marc Chagall e Alexander Calder
} 
Entrando em contato com várias tendências, linguagens e tecnologias do modernismo internacional, com certeza desenvolveram uma visão muito mais ampla e inclusiva do campo internacional da arquitetura, estabelecendo inúmeras trocas.

Pode-se afirmar que as experiências trocadas entre estes profissionais arquitetos começariam a surtir efeito, e seus desdobramentos iriam se incorporar à sua produção.

De volta ao Brasil, Niemeyer passa a desempenhar papel proeminente na equipe que termina o Ministério e, sobretudo, está pronto para desenvolver uma linguagem própria no conjunto da Pampulha (1942-43).

Pavilhão e Ministério são as âncoras da mostra de arquitetura brasileira planejada pelo Museu de Arte Moderna de Nova York a partir de 1942. Além de servir à Política da Boa Vizinhança de Roosevelt, a mostra se recomenda pela própria carência de material para exposições de arquitetura moderna, dada sua proscrição na Rússia de Stalin e na Alemanha de Hitler tanto quanto a redução da atividade de construção no hemisfério norte, abalado pela depressão e logo pela guerra.

Mais decisivo ainda é o interesse do MoMA na superação da estética que promovera via "The International Style: Architecture since 1922". Interesse que vinha aumentando quase que desde a inauguração da própria Exposição. ${ }^{60}$

\footnotetext{
60"Os ttulos das exposições seguintes falam por si: A New House by Frank Lloyd Wright on Bear Run, Pennsylvania (1938), The Bauhaus: 1919-28 (1938), Architecture and Furniture by Alvar and Aino Aalto (1938), Three Centuries of American Architecture (1940), a seção de arquitetura colonial mexicana em Twenty Centuries of Mexican Art (1940), The Wooden House in America (1940), Stockholm Builds (1940), Frank Lloyd Wright, American Architect (1941), Regional Building in America (1941), Architecture of Eric Mendelsohn (1942)."
} 


\section{3: Exposição itinerante e livro "Brazil Builds", MoMA, New York, USA}

No que diz respeito diretamente ao reconhecimento da Arquitetura Moderna Brasileira no período, um dos episódios mais importantes dentro deste processo foi a inauguração, em 1943, no Museu de Arte Moderna de Nova York, da exposição itinerante e do livro Brazil Builds, um imenso panorama da Nova Arquitetura Brasileira.

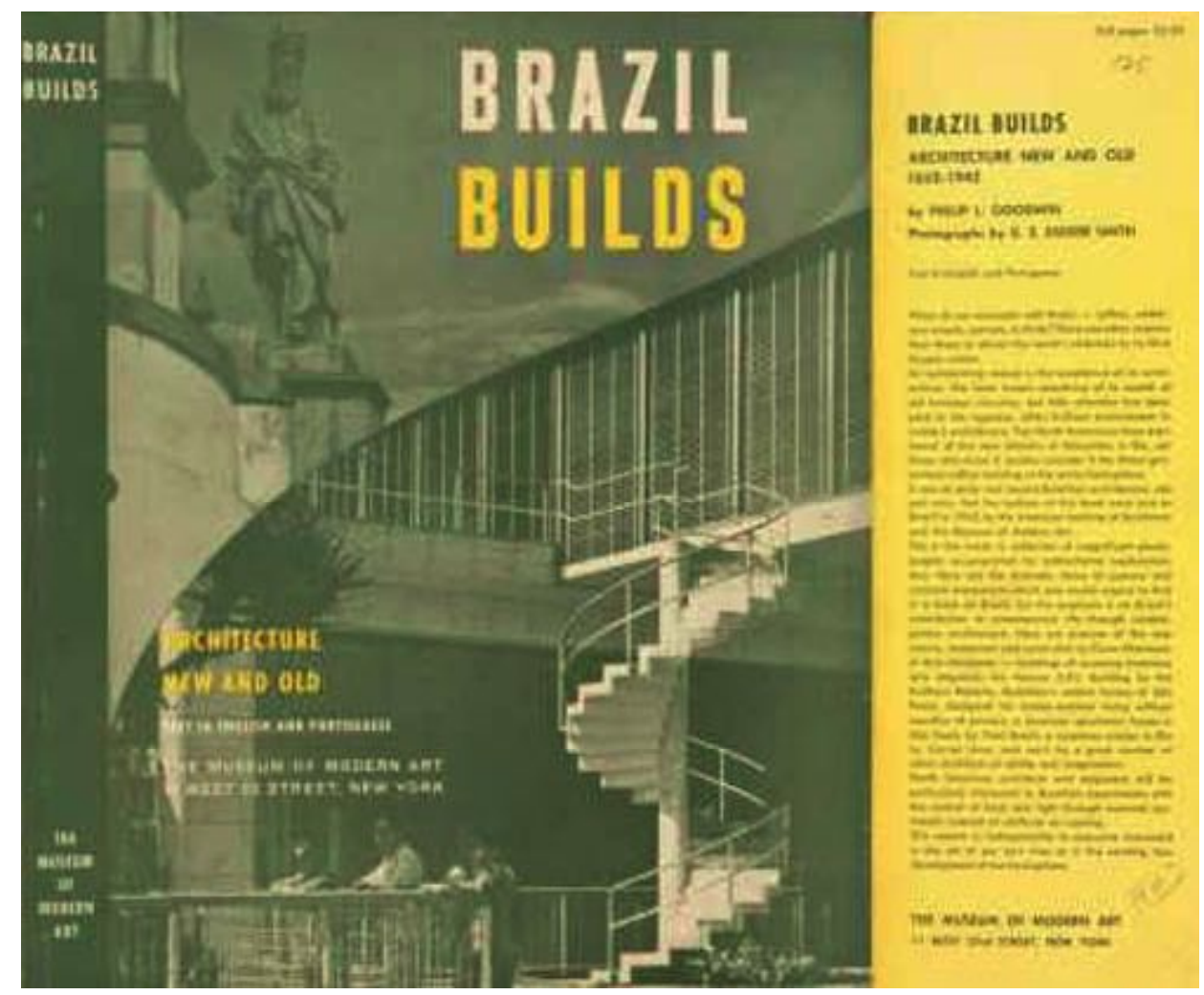

IMAGEM 14: Capa do livro Bazil Buils In GOODWIN, Philip L. Brazil Builds: Architecture new and Old 1652 1942. Photographs by G. E. Kidder Smith. New York: The Museum of Modern Art (MoMA), 1943.

O mesmo museu já havia despendido especial atenção ao "tema" Brasil três anos antes, quando estreou, com grande destaque na imprensa e na crítica, "Portinari of Brazil", a primeira mostra individual de um artista latino-americano nas novas instalações do museu. ${ }^{61}$

Em 1943, ainda, a mostra "The Latin American Collection of the Museum of Modern Art" havia sido organizada, mas nada que se comparasse, contudo, àquela que seria a mais importante mostra sobre o Brasil organizada pela Instituição.

\footnotetext{
${ }^{61}$ Em janeiro de 1942 são inaugurados quatro grandes murais de sua autoria, alusivos à história latinoamericana, na Biblioteca do Congresso, em Washington.
} 


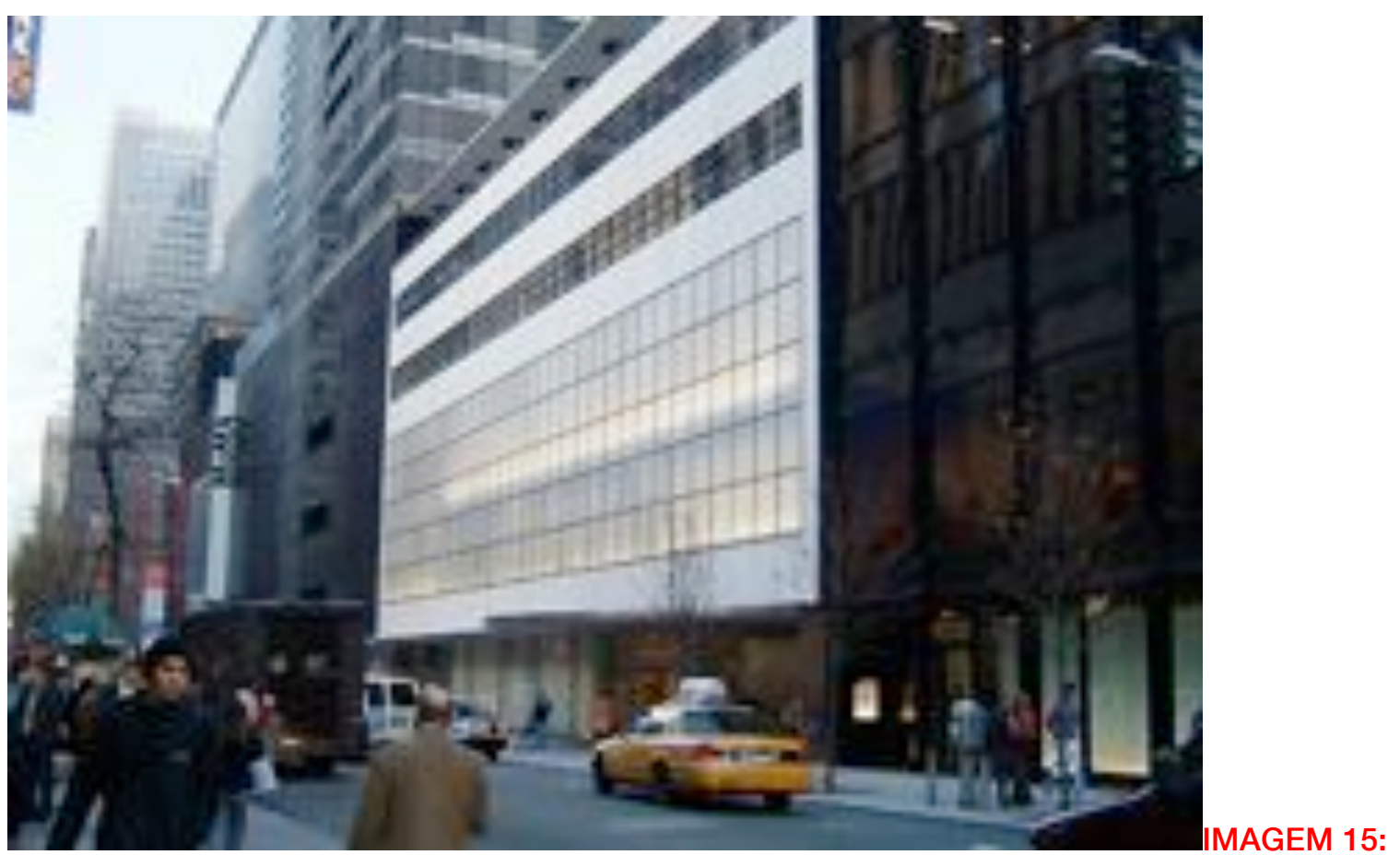

Museum of Modern Art. 1939. New York, New York, USA. Arquitetura: Philip Goodwin e Edward Durell Stone. Foto: Débora Lima.

Philip Goodwin, curador da mostra ${ }^{62}$ e autor dos textos do catálogo - e arquiteto com Edward Durell Stone do prédio do MoMA de 1939, cujo projeto seguiu rigorosamente os preceitos do International Style predominante -, e o fotógrafo George E. Kidder-Smith passaram, em 1942, seis meses no Brasil, visitando edifícios e entrevistando a nova geração de arquitetos brasileiros.

"Fascinados" com o modernismo brasileiro, eles organizaram a primeira exibição até então a capturar sua singular ligação entre as formas revolucionárias e as tradicionais, redescobertas e preservadas nos prédios históricos dos séculos XVII e $\mathrm{XVIII.}{ }^{63}$

Certo, o cartaz de Brazil Builds a descreve como uma exposição de Arquitetura Colonial e Moderna, porque a possibilidade de analogia com o contexto americano se tornava assim mais direta. Não se poderia pretender que o americano médio soubesse que o Brasil havia sido Reino Unido com Portugal antes de se tornar Império independente. O número de exemplos barrocos e neoclássicos na seleção de arquitetura antiga é proporcional ao período de florescimento da arquitetura barroca e

\footnotetext{
${ }^{62}$ GOODWN, Philip L. Brazil Builds: Architecture new and Old 1652 - 1942. Photographs by G. E. Kidder Smith New York: The Museum of Modern Art (MoMA), 1943.

63Ler um panorama completo sobre esta exposição no trabalho minucioso de DECKKER, Zilah Quezado. Brazil Built: The Architecture of the Modern Movement. London, New York: Spon Press - Taylor \& Francis Group, 2001.
} 
da arquitetura neoclássica no pais. De fato,.., os exemplos neoclássicos tem mesmo posição de destaque, no catálogo e na mostra. Não há preconceito contra o século XIX mas contra o ecletismo, cuja omissão é programática e relativa, porque é citada e tem mesmo uma obra ilustrada. É igualmente programática - mas completa - a omissão de exemplos anteriores a 1936 que se enquadrariam no estilo internacional. Entretanto, a seleção inclui sem dúvida as obras mais significativas do período 1936-42. ${ }^{64}$

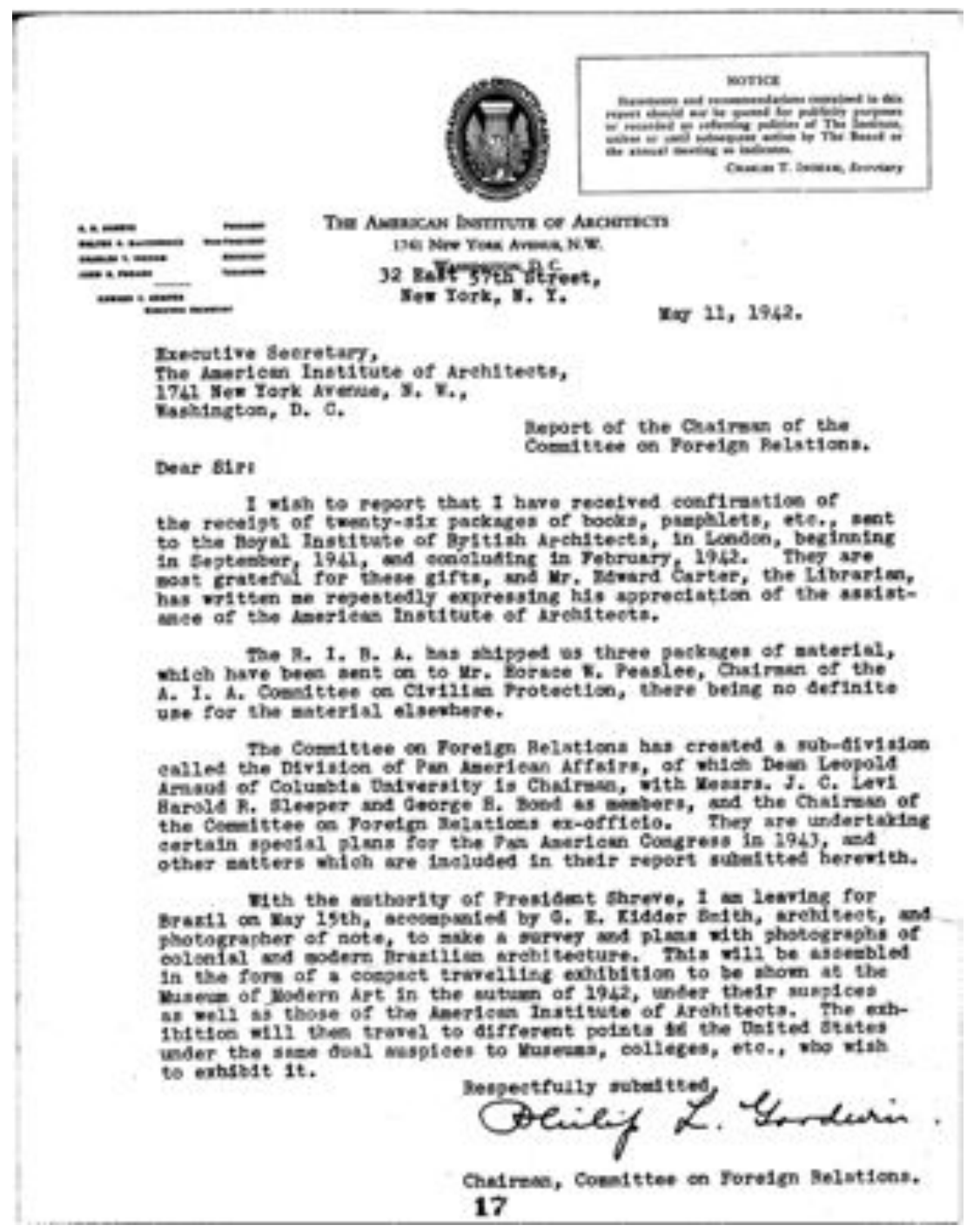

IMAGEM 16: Documento encontrado pela autora durante pesquisa nos arquivos do American Institute of Architects (AIA) em Washington D. C., USA. Assinado por Philip Goodwin, idealizador da mostra Brazil Builds no MoMA em New York.

Segundo CAVALCANTI, em 13 de janeiro de 1943, o The New York Times declarou: "New Yorkers who are proud of their skyscrapers will have the opportunity to

\footnotetext{
${ }^{64}$ COMAS, Carlos Eduardo Dias. Brazil Builds e a Bossa Barroca: notas sobre a singularização da arquitetura moderna 
know some of the admirable achievements of the other great nation of the Western Hemisphere, with the opening today of the exhibit 'Brazil Builds' in the MoMA'. ${ }^{65}$

À época, o catálogo da exposição dava atenção especial à maneira pela qual a construção no Brasil era ao mesmo tempo moderna e brasileira, também identificando seus avanços tecnológicos, dos quais os arquitetos americanos poderiam, para seu próprio benefício, apreender. ${ }^{66}$

O sucesso e a abrangência deste evento acelerou a vitória dos modernistas sobre os estilos concorrentes neocoloniais e acadêmicos que ainda tentavam se apresentar como opção possível para a arquitetura futura do país. "A opinião pública leiga, mesmo que ainda se chocasse com a fragilidade e a estética despojada do estilo moderno, começa a desconfiar que, com tamanho êxito nos EUA, talvez ele tivesse algum valor". 67

E então podemos nos remeter ao texto de Mário de Andrade, Brazil Builds, já mencionado aqui, publicado no jornal Folha da Manhã, de São Paulo, em 23 de março de 1944, aonde este versa, entre outras assuntos, justamente sobre a inauguração da mostra e do livro:

Admirável também é a coleção de fotografias Brazil Builds, que o Museu de Arte Moderna de Nova York, acaba de publicar com, em geral, excelentes comentários do arquiteto Philip L. Goodwin. Eu creio que este é um dos gestos de humanidade mais fecundos que os Estados Unidos já praticaram em relação a nós, brasileiros. Porque ele virá, já veio, regenerar a nossa confiança em nós e diminuir o desastroso complexo de inferioridade de mestiços, que nos prejudica tanto. Já escutei muito brasileiro, não apenas assombrado, mas até mesmo estomagado diante desse livro que prova possuirmos uma arquitetura moderna tão boa como os mais avançados países do mundo. Essa consciência da nossa normalidade humana só mesmo os

\footnotetext{
${ }^{65}$ "Os novaiorquinos que são orgulhosos de seus arranha-céus terão a oportunidade de conhecer algumas das admiráveis conquistas da outra grande Nação do Hemisfério Oeste, com a abertura hoje da exibição Brazil Builds no MoMA". CAVALCANTI, Lauro. When Brazil was Modern: Guide to Architecture, 1928-1960. New York: Princeton Architectural Press, 2003, p. 20.

${ }^{66}$ CAVALCANTI, Lauro. When Brazil was Modern: Guide to Architecture, 1928-1960. New York: Princeton Architectural Press, 2003, p. 20.

${ }^{67}$ CAVALCANTI, Lauro, Moderno e Brasileiro: A História de uma Nova Linguagem na Arquitetura (1930-1960). Rio de Janeiro: Jorge Zahar Editor, 2006, p. 170.
} 
estrangeiros é que podem nos dar... Ninguém está esquecido de que foi um prêmio nos Estados Unidos que deu genialidade a Portinari, apesar dos poucos brasileiros que muito antes disso já afirmavam essa genialidade...

Nós nunca seremos uns arianos, e talvez graças a Deus! Brazil Builds é um livro que nos regenera em nosso valor normal... A nossa arquitetura moderna é tão boa como a arquitetura moderna dos Estados Unidos ou da França. ${ }^{68}$

A partir daí, o Departamento de Arquitetura do Museu, que havia sido a primeira instituição destinada a abrigar a criação moderna mundial, ganharia prestígio internacional como o principal local para debates sobre arquitetura e passaria a exercer o papel de divulgador das novas tendências e inovações arquitetônicas, bem como o mais influente centro mundial para a difusão do modernismo.

Ao pesquisar nos arquivos do Museu de Arte Moderna de Nova York, descobrimos relatos muito vivos e entusiasmados desse momento de intersecção entre o Brasil e os Estados Unidos e que foi tão importante para a história e o desenrolar da nossa Arquitetura Moderna.

Visitando os arquivos das "press releases" daquele início do ano de 1943 encontramos algumas preciosidades, que relatam o entusiasmo com que a mostra foi recebida, e como a procura foi tão grande que se pensou até em adiar o seu encerramento. Relatos que somente comprovam o grande interesse que a arquitetura moderna brasileira vinha levantando, tanto nos círculos acadêmicos, profissionais e culturais locais, como entre o público em geral.

\footnotetext{
${ }^{68}$ ANDRADE, Mário de. Brazil Builds (1944) In XAVER, Alberto (org.). Depoimento de uma geração - arquitetura moderna brasileira. São Paulo: Cosac \& Naify, 2003, p. 180.
} 
$43104-1$

THE MUSEUM OF MODERN ART

11 WEST S3RD STREET, NEW YORK

TELCHONE: CIBCLE saaOo

\author{
$\ln , 11-7$ \\ POR TMTRTATE RELEhSE
}

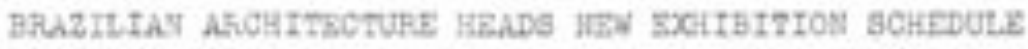

POA 2USBUU OF WODERS ART

Arsilteature of Brazt1

Jan. 13 - Karoh 7,1943

New Yorkera w111 have an opsortunity on Fiedneodny, January 13 , to beccme noquninted with wowe of the finest modern arohiteoture not only in this Bealopiore but in the world titen the Wuseus of Modern drt opene the first exlibition of 1 ts 1943 season: Brez11 Byllan. The oxh1b1tion w111 f111 almost the entire ground floor of the Huseun and $\mathbf{m} 11$ bo coaposod of nodels, onlargod photographe, eroilitootural renderingw, dravings, plans, anps, and oontimuous toreen prołeotion of forty-eletht eclos ollaes.

To obtaln antorial for the oxhlbition Ph111p L. Goodrin, Y.A.I.A., tho in oolinborstion with 24 mara D. Stone was the architoot

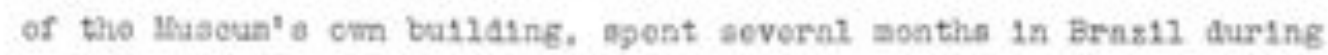
tho waner of 1942 viulting neny parte of that equntry whore ito

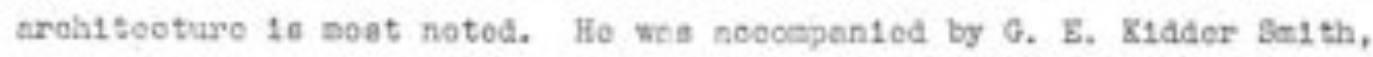
A.I.A., tho 10 woll know as an nrehltootural photographor.

Fros the antorlal gathered by Hr. Ooodwin and the thousand or noro black-and-rhit to photoeraphe nade by ftr. Sast th the exh1b1t1on has been largoly asacabled. Mot only w111 the notorn arohiteoture of the aolodaus of tho South be shows best Broz11's boautiful old bullaings, many of then fedoes for thelr olaboreto gold-oneruetod interiors, w111 comprited almost a thint of tho exh1bition. After 1t elosen on

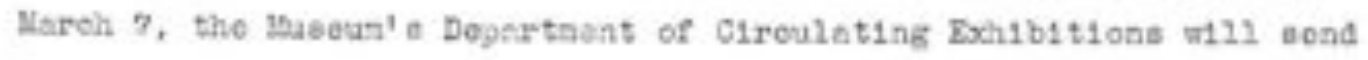

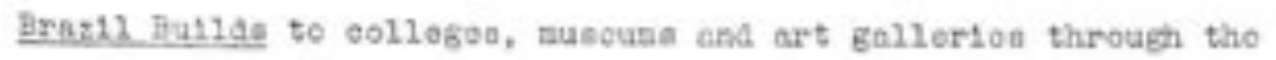
oountry. 
$43 r / 2+2$

THE MUSEUM OF MODERN ART

it WEST S3Fo STREET, NIW YORK

nesmota ciecie nosen

reh tastotats nksuas

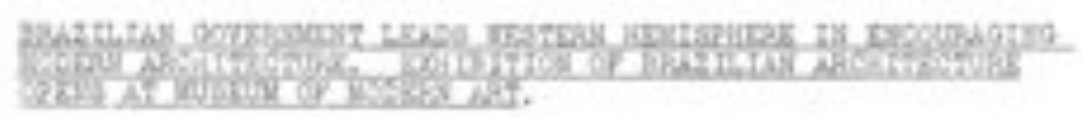

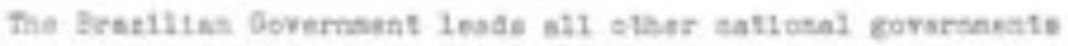

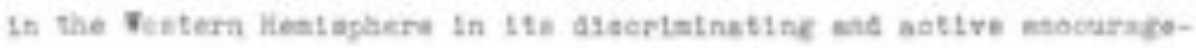

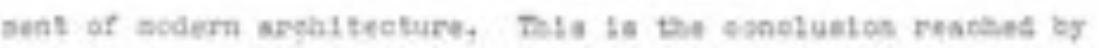

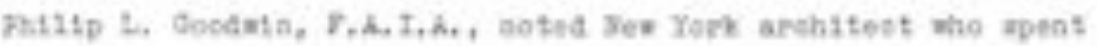

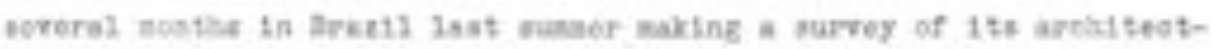

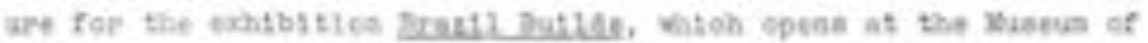

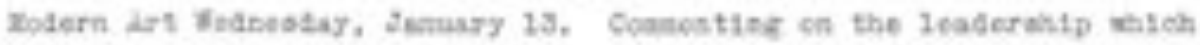

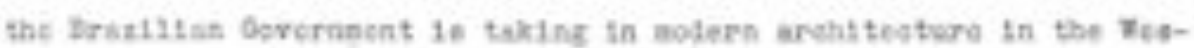

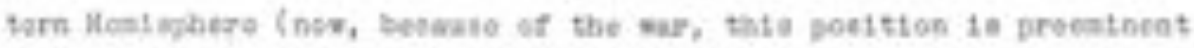
is the vorid), $\mathbf{z r}$, Goedeth letd!

"rven bofory the alvest of the Varzea covernuest is 1900

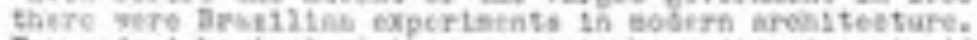

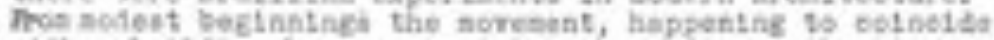

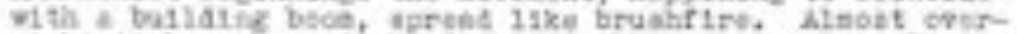

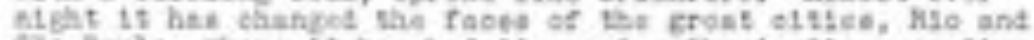

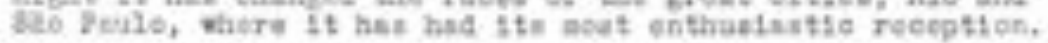

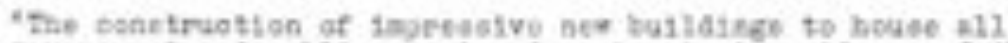
covernaest and gublis norvios teparteenta to avidesese of the

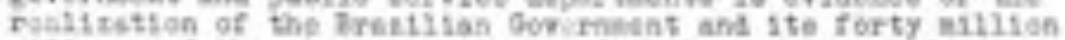

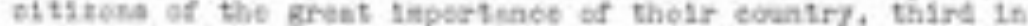

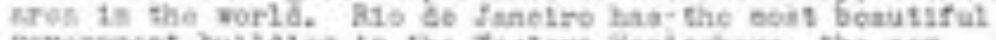

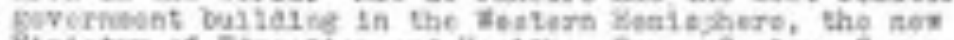

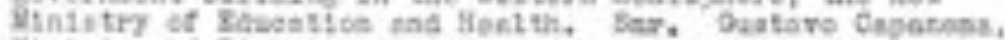

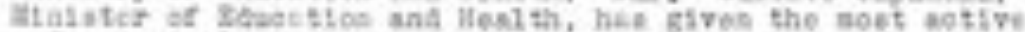

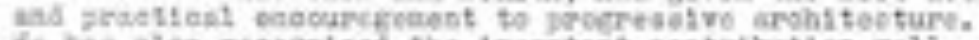
As kaz alio reesentred the tojortent oontribotiva willFelstch paistirg and seulpturs wan anke to erohitestura.

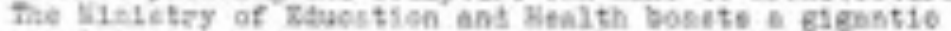

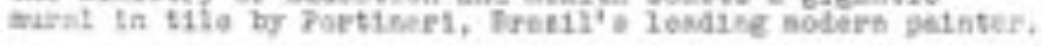

"Other ersital eitter of the vorth lag far behind Kto de fenetro in aroist teobural dasien. milo Foderal elsase in

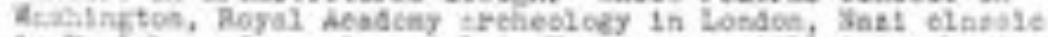

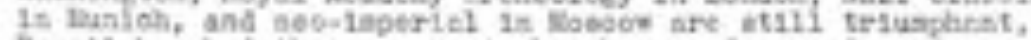

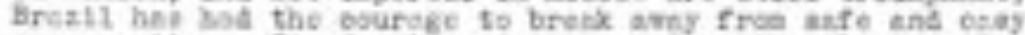

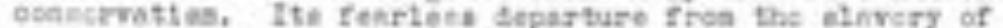

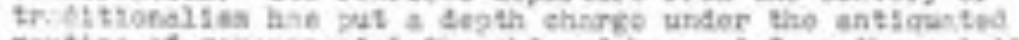

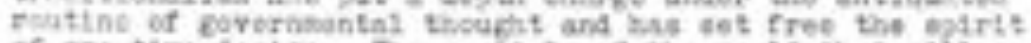

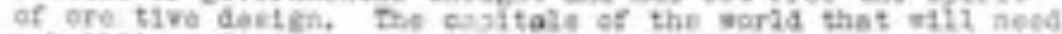

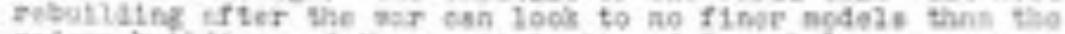

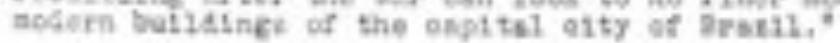

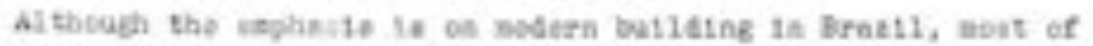
12 sroeted in the lest deeste, the older areksteeture has hot besn cefleoted, $F e p$ the exhibitios cabraben a popled ef sinoes thrse ech-

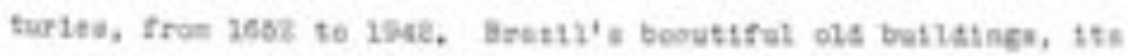

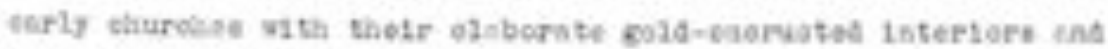

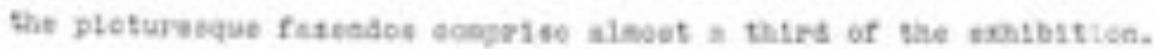

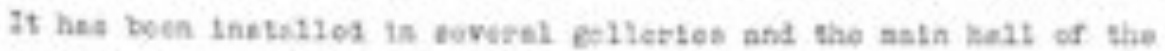

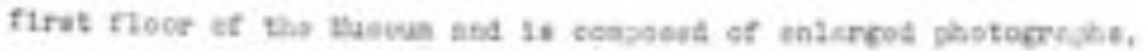

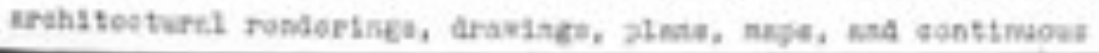




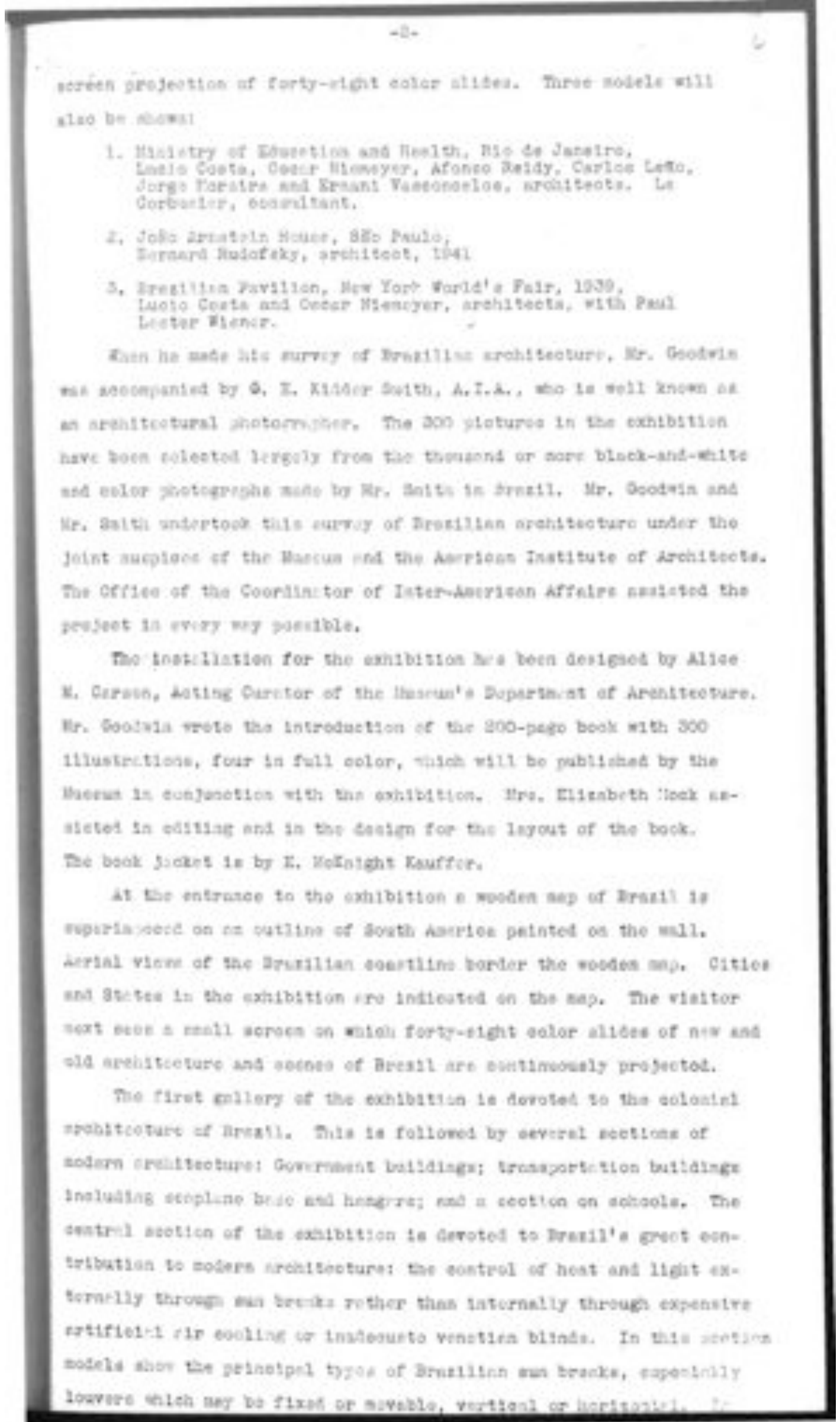




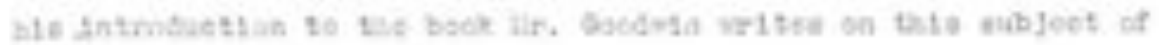

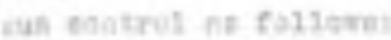

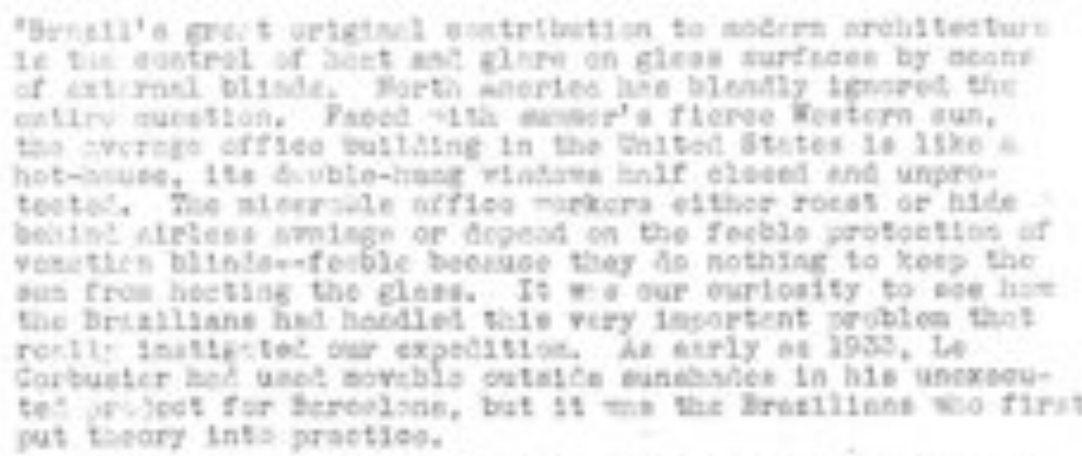

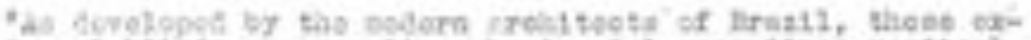

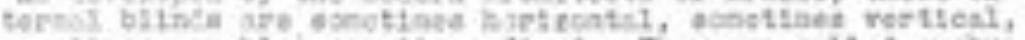

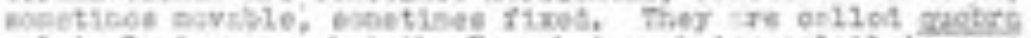

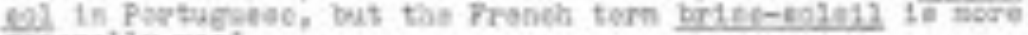
censarily weot.

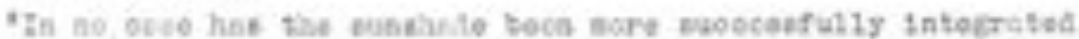

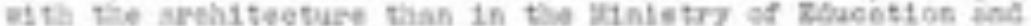

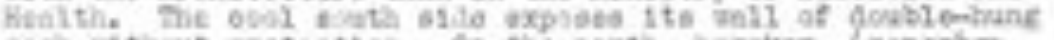

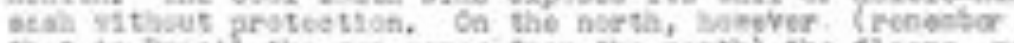

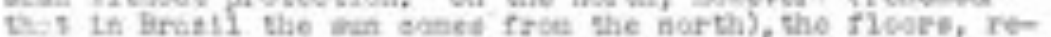

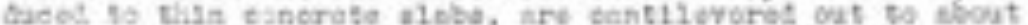

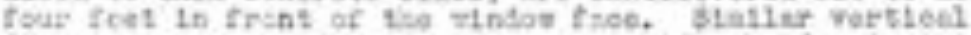

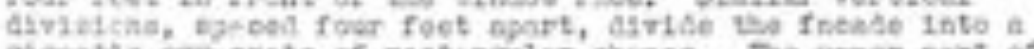

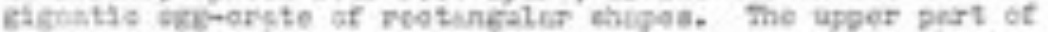

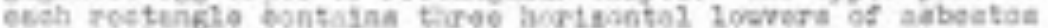

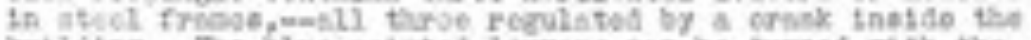

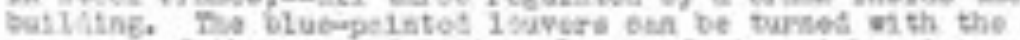

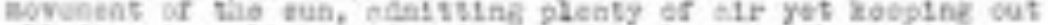

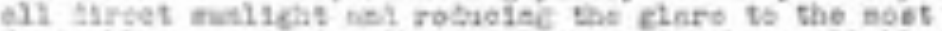

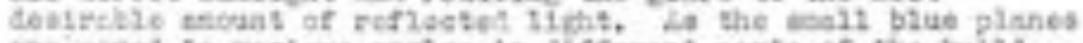

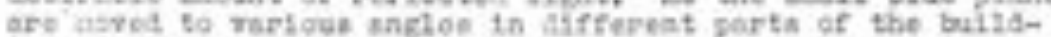

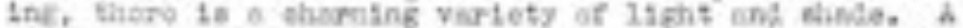

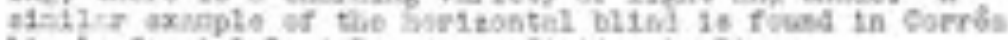

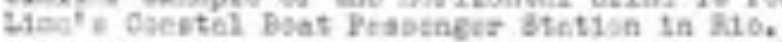

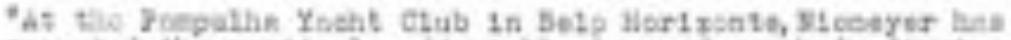

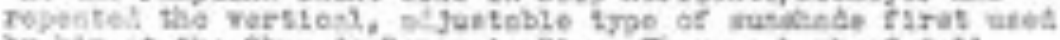
by his at the obro do serge in liso. Thare a bank of tail

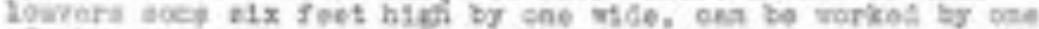
of the mins rt th no poro trouble than it taken to turn a dast thenclie.

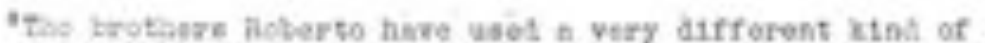

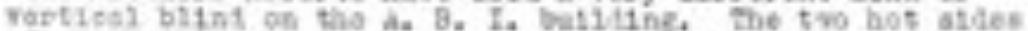

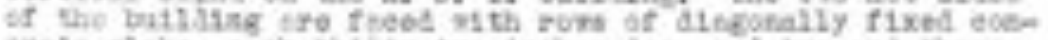

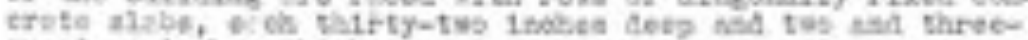

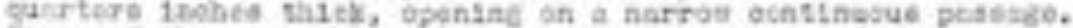

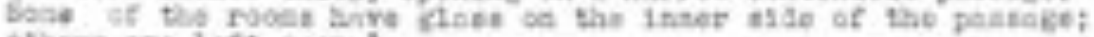
bthere are lott sean,"

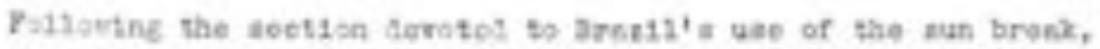

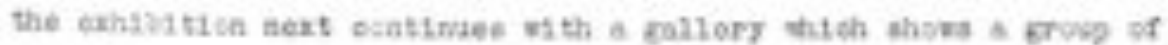

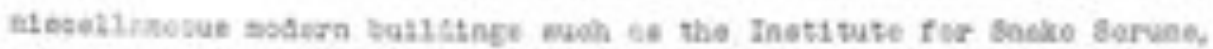

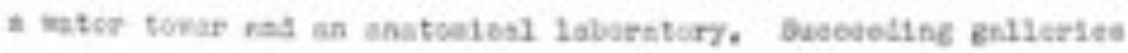

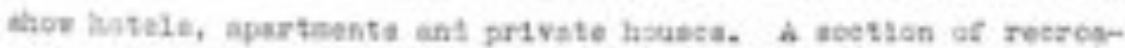

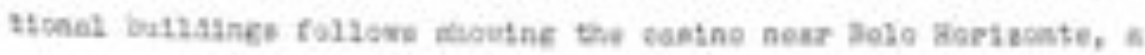

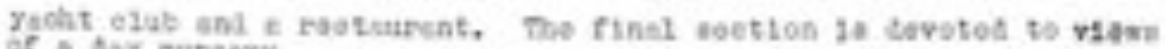
of in tay mureery

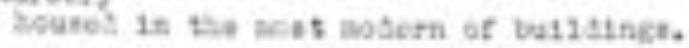




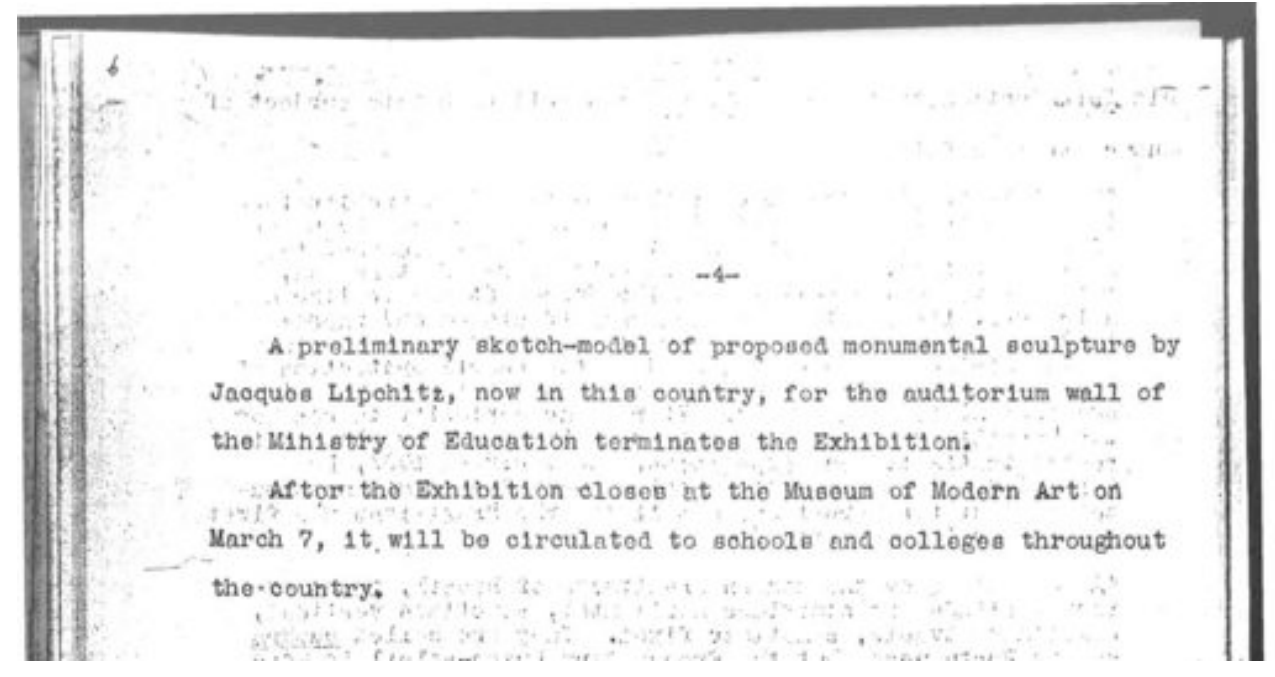

$43 n z-3$

THE MUSEUM OF MODERN ART

H WEST s3no sTRET, NEW rohk.

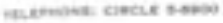

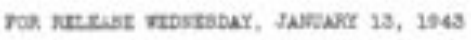

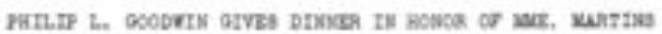

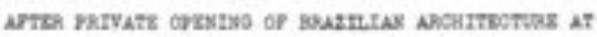

veskre of noters alt

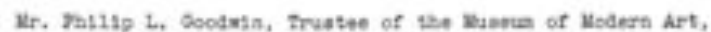

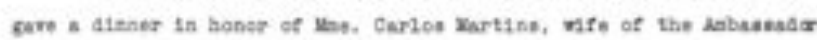
froe braxil, last night (Ruenday) lanedistely after the private

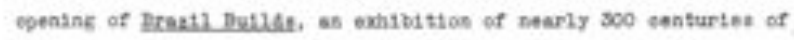

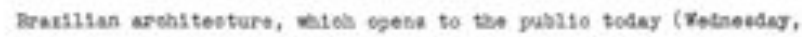
Zanuary 13) at the Haseds.

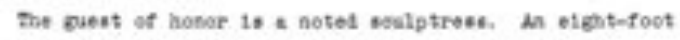

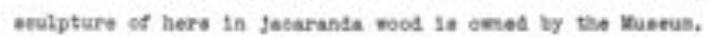

duceg the pueste at the dienez wore:

Hus Hora Hertine

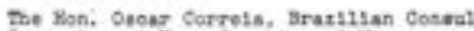

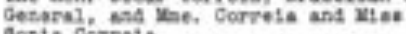

47. Vietor de Carvalno, of the Bratiatan

Connilate

VF. Rent d'Hernenbsurt

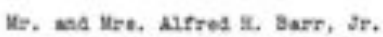

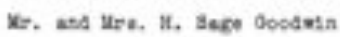

W- A, Conewe dooksen

Ir. Maisip glanosn

yra, O, r. ridaer satter

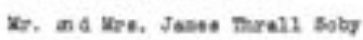

yr. Rovert G, Gatts

Xr. Weervo Thenler

Xr. ond Xes. Faul Lator Woner 
$45125-6$

THE MUSEUM OF MODERN ART

G) WEST SARO STREET. NEW YOAK

thamose eacic sosos

ros panctate incese

\section{geqascontog}

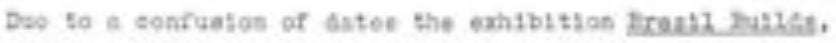

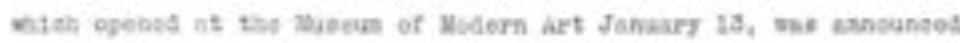

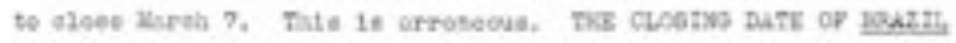

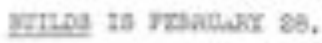

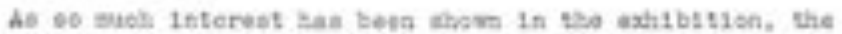

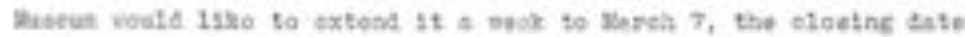

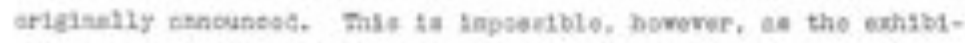

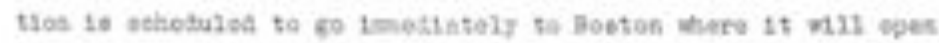
undes tag mupleee of the Pon dnortesn Boelety wa Maroh 14 at the Eusue of ran apts.

IMAGEM 17: Documentos encontrados pela autora durante pesquisa nos arquivos do Museum of Modern Art (MoMA) em New York, New York, USA, datados de 4, 12 e 25 de janeiro de 1943.

Brazil Builds tem sucesso maior que o esperado. Finda a mostra no MoMA, circula pelos Estados Unidos, México e Canadá. Exposta em Londres, subsidia 
número especial de The Architectural Review em 1944. Uma versão em português se exibe no Ministério da Educação no Rio de Janeiro ainda em 1943 e circula por todos os cantos do Brasil até 1946, ano da última das quatro edições do catálogo. ${ }^{69}$

Enfim, a abrangência e disseminação da mostra foram impressionantes, principalmente através da circulação que teve Brasil afora e, dentro daquilo que os historiadores tem chamado de circuito social de uma obra, que é a ideia da produção, da circulação, da recepção e das leituras que provoca a partir de uma determinada chegada em determinadas sociedades, Brazil Builds abriu para o país uma outra possibilidade de narrativa historiográfica, que é muito rica.

Afinal essa exposição passaria por locais os mais remotos do Brasil, com divulgação nos jornais e revistas locais, alcançando assim profissionais que estavam atuando e construindo naquela específica localidade e que foram afetados por esta nova arquitetura moderna brasileira que fazia tanto sucesso nos Estados Unidos. Ou seja, com certeza, isso repercute no seu trabalho, e assim vemos construções com inspiração moderna em locais os mais diversos e longínquos, se tornando uma voz ativa para esses atores sociais que estão nessas cidades, de leitura e filtro de recepção daquela ideia.

A exibição é seguida por uma enxurrada de entusiásticas publicações versando sobre o tema na língua inglesa e projetos brasileiros passam a ocupar com frequência também as páginas de periódicos europeus e norte-americanos. Além da publicação avulsa de projetos e obras nas revistas mais prestigiosas, a arquitetura moderna brasileira ganha edições especiais em L'Architecture d'Aujourd'hui (1947) e Architectural Forum (1947), e figura proeminentemente em A Decade of Contemporary Architecture $^{70}$, o balanço da década 1937-47 feito por Giedion a partir da mostra exposta no VI CIAM de Bridgewater, em 1947.

\footnotetext{
${ }^{69} \mathrm{Na}$ totalidade a exposição visitou quarenta e oito cidades das Américas até 1946. Seu catálogo foi vendido nas principais capitais da Europa e em paises tão distantes como a África do Sul. Criticos e arquitetos começaram a dar atenção à sofisticada arquitetura de um pais até então associado somente a um típico folclore. No entanto, e de acordo com CAVALCANTI (2006:166), não existe registro nos arquivos do MoMA do paradeiro da mostra completa que, simplesmente, desapareceu no tempo. A versão itinerante foi vendida, em 1958, para a Universidade de Manitoba, no Canadá. Nos anos 70, por desinteresse e falta de espaço para armazená-la, a mostra foi destruída 


\section{4: Exposição "Built in USA since 1932", MoMA, New York, USA}

"Built in USA-since 32"71 é a mostra que o MoMA faz em 1944 e enseja um paralelo interessante com a exposição dedicada à arquitetura brasileira realizada no ano anterior. Balanço duma década de arquitetura moderna americana, inclui quarenta e sete obras. $^{72}$

A comparação com Brazil Builds fica mais pertinente ainda porque só três bairros-jardim e a fábrica de asfalto de Kahn e Jacobs são posteriores a 1942.

No ensaio que introduz Built in USA, Elizabeth Mock diz que a confluência dos idiomas aparentemente irreconciliáveis é uma das surpresas da década 1932-42. O Pavilhão de Barcelona de Mies compatibiliza a planta livre de Le Corbusier com a afirmação enfática do teto característica de Wright. Os planos rebocados da Casa da Cascata aproximam Wright dos europeus. As experiências de Le Corbusier com materiais naturais o aproximam do americano. Mock faz autocrítica. Na sua definição da arquitetura moderna como estilo internacional, o MoMA havia colocado demasiada ênfase em volume obtido por planos desmaterializados. Estes caracterizavam uma fase purista e eram mais válidos como símbolos da idealização da máquina e da arte abstrata pelos arquitetos que uma afirmação de materiais e construção real. Os americanos já sofriam com a hiper-mecanização de suas vidas e não encontravam nada de romântico na tecnologia. ${ }^{73}$

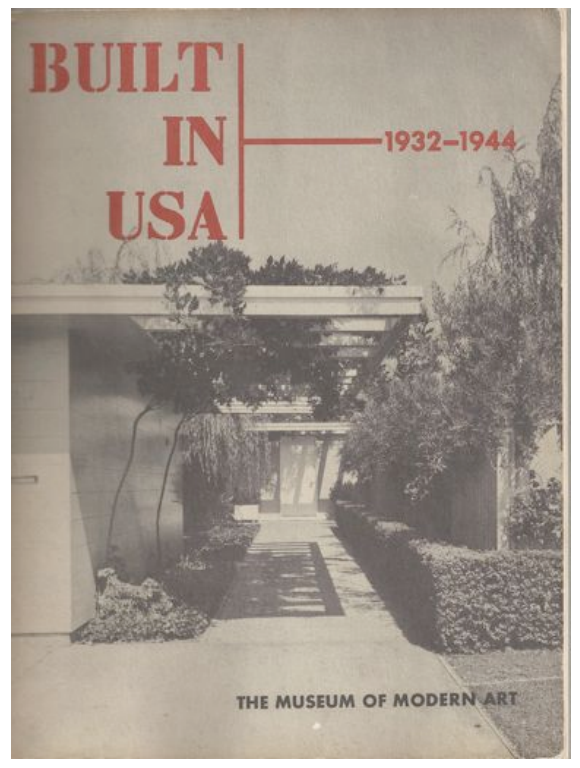

IMAGEM 18: Capa do livro Built in USA In MOCK, Elizabeth (editor) Prefácio de Philip L. Goodwin. Buit in USA: 1932-1944. New York: Museum of Modern Art, 1944.

\footnotetext{
${ }^{71}$ MOCK, Elizabeth (editor). Buit in USA: A Survey of Contemporary american architecture since 1932. New York: Simon \& Schuster, Museum of Modern Art, 1944.

${ }^{72}$ Alguns exemplos: casas uni familliares isoladas, destacando-se Wright (com a Fallingwater House, Taliesin West e a Winkler-Goetsch House, da série usonian), os emigrados Gropius e Breuer (com as casas Chamberlain e Ford) além de Philip Johnson (com sua casa pátio em Cambridge).Alguns edifícios de escritórios como o PSFS de Howe e Lescaze já exposto em 1932, e o Rockefeller Center, que entra pela sua popularidade e urbanidade. ${ }^{73}$ COMAS, Carlos Eduardo Dias. Brazil Builds e a Bossa Barroca: notas sobre a singularização da arquitetura moderna 
Segundo Mock, os americanos, estimulados talvez por Wright e Le Corbusier, tinham olhado de novo para as granjas de pedra da Pennsylvania, as casas de madeira da Nova Inglaterra, as fazendas do Oeste - não pelo detalhe pitoresco, mas pelo uso direto do material e pela adaptação sutil à topografia e ao clima. "Aqui estava o encorajamento local para o crescente movimento internacional em direção a uma arquitetura contemporânea mais amistosa e diferenciada."

A paleta de materiais se ampliara para além da abstração do reboco branco liso, voltando o gosto pelos materiais naturais e pela diferenciação de texturas. A préfabricação não se julgava mais uma panaceia. A passagem da alvenaria portante à ossatura independente não se associava mais à evolução de crustáceo para vertebrado. O concreto armado e a madeira compensada tinham validado formas estruturais de superfície ativa, em que a rigidez máxima se obtém ao moldar painéis em formas curvas.

Na década de 1930, o interesse pelas curvas em geral e pelas curvas livres em particular viera de todos os lados. Mas o ensaio de Mock para Built in USA desautoriza qualquer pretensão de singularizar a arquitetura moderna brasileira pela curva livre.

Mock cita Le Corbusier, Lubetkin e Aalto, assinalando que a tendência para formas orgânicas tinha afetado as artes plásticas muito antes da arquitetura, no abstracionismo e no cubismo. Além da obra de Aalto, o Pavilhão Sueco e o Pavilhão Brasileiro na Feira de Nova York se consideram exemplares.

Mock diz que a "luta contra a simetria e a compartimentação tinha sido ganha, mas reconhece que a mais nova convenção da planta aberta implica às vezes considerável sacrifício de silêncio e privacidade". Valoriza a casa uni familiar pela flexibilidade, a casa com pátio pela maior privacidade que propicia. Enfatiza a importância do clima como condicionante da arquitetura e critica a falta de integração da arquitetura moderna com o entorno natural ou construído preexistente, afirmando que o exemplo brilhante do Brasil no trato com o quebra-sol deve ser seguido.

Está numa posição de autoridade e o ensaio para "Built in USA" contém observações que direta ou indiretamente dizem respeito à arquitetura moderna brasileira.

$\mathrm{Na}$ verdade, Mock amplifica proposições enunciadas nos artigos que tinha escrito para divulgar "Brazil Builds" - deixando claro no processo o programa do 
MoMA quanto à superação do estilo internacional e o papel exemplar da arquitetura moderna brasileira nesse sentido. "Legitimação do vernacular e do popular como fonte da arquitetura moderna, valorização das afinidades entre arquitetura moderna e tradição nacional, realce da importância do clima e da geografia, qualificação da exaltação da máquina promovida pela vanguarda moderna europeia na década de 1920, celebração duma síntese entre Wright e Le Corbusier passando por Mies, interesse no biomorfismo e preocupação com a caracterização ou expressão duma monumentalidade democrática, tudo isso faz parte do programa". ${ }^{74}$

\section{7: Participação de Oscar Niemeyer no projeto do Edifício-sede} da Organização das Nações Unidas, New York, USA

É justamente a participação proeminente de Oscar Niemeyer no grupo de trabalho internacional para a construção do edifício-sede das Organizações das Nações Unidas também em Manhattan ${ }^{75}$, Nova York, em 1947, outro ponto de ligação entre o Brasil e os Estados Unidos no campo da arquitetura no período, sendo que tal fato firmou, definitivamente, "o arquiteto brasileiro no que se convencionou chamar de star-system da arquitetura mundial"”76, e até hoje um dos únicos nomes, quando não o único, a ser identificado no "estrangeiro" como "representante" da nossa abrangente arquitetura brasileira.

Quando foi decidida a instalação da sede da ONU em Nova York, em um terreno adquirido e doado por Nelson Rockefeller (decisão na qual teve grande peso Le Corbusier, que tinha uma relação de amor e ódio com a cidade), formou-se, em 1947, um comitê internacional de arquitetos de diferentes países, presidido por Wallace Harrison, que se interessou em convidar Niemeyer.

Faziam parte da equipe Le Corbusier (França), Gaston Brunfaut (Bélgica), Ernest Cormier (Canadá), Ssu-Ch'eng Liang (China), Sven Markelius (Suécia), Nikolai D. Bassov (União Soviética), Howard Robertson (Inglaterra) e Julio Vilamajó (Uruguai). E os consultores foram Wladimir Bodiansky (França), Matthew Nowicki (Polônia) e Erns Weissmann (lugoslávia).

\footnotetext{
${ }^{4}$ |bidem.

${ }^{75}$ REED, Peter. The United Nations in Perspective. New York: Museum of Modern Art (MoMA), 1995.

${ }^{76}$ CAVALCANTI, Lauro. Moderno e Brasileiro: A História de uma Nova Linguagem na Arquitetura (1930-1960) Rio de Janeiro: Jorge Zahar Editor, 2006, p. 187.
} 
Niemeyer, filiado ao Partido Comunista Brasileiro em 1945, teve o visto de entrada nos Estados Unidos negado em 1946, quando foi convidado a palestrar na Universidade de Yale. Mas obteve autorização para morar sete meses em Nova York como membro da equipe internacional da ONU. Não escapou, contudo, de ter sua militância política criticada. Com o objetivo de diminuir o seu prestígio profissional, a revista Time publicou foto do arquiteto vendendo o jornal Imprensa Popular do Partido nas ruas do Rio de Janeiro.

Foi complexo o relacionamento com Le Corbusier. Agora, Niemeyer já não era o jovem discípulo que desenhava sob a orientação do mestre francês, como fora no projeto para o Ministério da Educação e Saúde, no Rio, mas um arquiteto experiente e famoso.

Por um lado, Corbusier desejava obter a autoria da sede da ONU, uma lâmina de 40 andares, cuja forma pura seria a sua vingança contra os arranha-céus novaiorquinos, introduzindo no skyline da cidade o símbolo de sua Ville Radieuse.

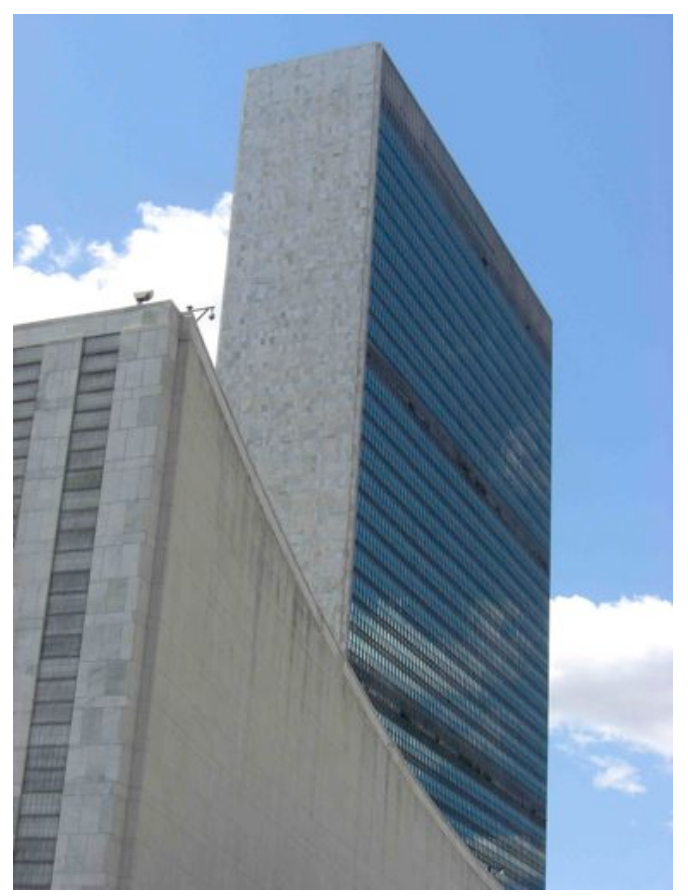

Mas a proposta em planta dos elementos funcionais básicos não satisfez e a equipe de Harrison solicitou a Niemeyer que apresentasse a sua alternativa. Ele, que no Ministério da Educação e Saúde no Rio de Janeiro, em 1936, tinha melhorado os desenhos de Le Corbusier e criado a brilhante solução definitiva da sede, ficou desconfortável de corrigir novamente o mestre.

IMAGEM 19: United Nations Headquarters, 1947. New York, New York, USA. Arquitetura: Oscar Niemeyer, Le Corbusier, Wallace Harrison. Foto: Débora Lima.

É conhecida a história das duas propostas, a 23, do francês, e a 32, de Niemeyer, diferenciadas pela localização do volume da Assembleia Geral. O primeiro a colocava no centro do terreno. O segundo, no extremo, para liberar a praça para os atos públicos e o relacionamento com a cidade. Finalmente se chegou a uma solução intermediária, que juntava as duas alternativas na colocação do volume baixo, que foi 
aprovada por Harrison, que escreveu, "the only scheme that gets complete satisfaction in an early idea of Le Corbusier's as carried out, was drawn up by Oscar Niemeyer".

Essa nova experiência norte-americana, com um conjunto urbanístico de grande escala e a necessidade de compreensão do funcionamento complexo de um arranha-céu de 40 andares que continha 3.400 funcionários, foi extremamente desafiadora para Niemeyer.

Além da experiência direta nos arranha-céus de Nova York, em particular do Rockefeller Center, o seu conhecimento dos problemas existentes nos prédios de escritórios, já decantado no MES, adquiriu uma nova dimensão, que abriu a perspectiva dos grandes projetos que surgiriam no Brasil no início dos anos 50: a lâmina curvilínea do Copan em São Paulo, o conjunto JK em Belo Horizonte e as obras monumentais em Brasília.

\section{O Percurso das artes - 1949/1951: Inaugurações do MASP e MAM. 1951/1953-54/1955/1957/1959: Primeiras Bienais Internacionais de Arte. São Paulo, Brasil}

A década de 1950 marca, definitivamente, a entrada do Brasil e da Arquitetura Moderna Brasileira para o circuito cultural internacional. São Paulo, principalmente, integra-se aos circuitos da contemporaneidade artística internacional e a instituição das Bienais Internacionais de arte e arquitetura com a presença maciça de arquitetos representantes do movimento moderno que viviam na América do Norte à época somente ajudaram neste processo.

Em 1949 e 1951, as inaugurações do MASP (ligado à Nelson Rockefeller) e do Museu de Arte Moderna (ligado ao MoMA de New York), respectivamente, haviam também ajudado o amadurecimento deste processo.

Até a década de 40, o investimento do Governo na produção cultural e artística se restringia ao Rio de Janeiro. No restante do Brasil, não havia programas culturais de maior amplitude que levassem a marca do Estado.

À época, São Paulo alcançava a posição inédita de maior centro econômico e populacional do país, suplantando a capital federal, e sua elite financeira e intelectual procurava delinear os marcos simbólicos de sua hegemonia material. 
Surgia, assim, um clima propício à implantação de entidades museológicas que rompessem a atmosfera dos salões e os limites da Pinacoteca do Estado, reduto do academicismo e contrária às novas tendências, alterando as bases da vida cultural paulistana.

Num contexto de expansão industrial que incide sobre a fisionomia da cidade, em franco processo de metropolização, os novos empreendimentos culturais foram sustentados por um novo mecenato, proveniente dos setores emergentes da sociedade: a indústria e também as organizações da imprensa, que passaram a financiar a cultura em empreendimentos conectados a um movimento de ascensão e de busca de legitimidade, desejando se colocar como representantes de um projeto modernizador compatível com a construção de seus parques industriais.

De modo que estas novas instituições culturais nascem por iniciativa privada sem qualquer dependência em relação ao poder público, e de uma forma bem peculiar, já que não havia grandes investimentos com bases empresariais, mas sim investimentos particulares de homens ricos.

Sendo assim, desde os anos 1930, o grupo remanescente do movimento pioneiro da Semana de 1922, ampliado por representantes desta elite paulistana, e também por novos artistas ${ }^{77}$ e intelectuais de São Paulo, procuram divulgar a arte moderna brasileira e internacional.

Intelectuais como Mário de Andrade (1893-1945) e Sérgio Milliet (1898-19660) então diretor da Biblioteca Municipal de São Paulo - defendiam a criação de um museu voltado para as manifestações artísticas modernas. Seus textos reivindicam esta necessidade, e tais ideias dominam o meio cultural da ascendente metrópole. ${ }^{78}$

\footnotetext{
${ }^{77}$ Artistas estes ligados às classes urbanas, que em São Paulo ganhavam força tematizando a cidade com seus contrastes característicos.

${ }^{78}$ Entre o final dos anos 30 e o início dos 40, Sérgio Milliet, como professor da Escola de Sociologia e Política, esteve em contato com representantes americanos interessados na politica de aproximação com os países latino-americanos. Em 1942, o Dr. David Stevens, diretor da Divisão de Humanidades da Fundação Rockefeller, visitou a Escola e doou cinco contos de réis destinados à constituição de um acervo bibliográfico e à pesquisa social, repetindo a atitude em 1944 e 1946. O adido cultural do Consulado Americano em São Paulo, Carlton Sprague Smith, era também professor na Escola de Sociologia e Política e empolgava-se, àquela altura, com a idéia da criação de um museu de arte moderna, acabando por tornar-se um intermediário desse processo com a Fundação Rockefeller (Gonçalves, 1992:80)
} 
Namorávamos Tio Sam, afastávamos da Europa agônica e destruída, dávamos as costas para o nacional e queríamos alçar o modelo capitalista exportado pelos Estados Unidos, tido como progresso e arrojo. ${ }^{79}$

Neste contexto, a discussão concreta sobre a implementação de uma instituição voltada para a preservação e divulgação da arte moderna começou a tomar corpo, inspirada em instituições norte-americanas, sendo que a grande singularidade do período foi a inclusão do abstracionismo, até então inexistente entre nós, sob influência direta do modelo americano, personificado pelo Museum of Modern Art de Nova York, o MoMA, este bastante interessado em criar "filiais" na América Latina.

Nos países sob domínio dos Estados Unidos, a tendência a interpretar a abstração como continuidade do modernismo anterior à Segunda Guerra Mundial, se firma. Assim, o novo discurso alinhava-se aos interesses estéticos norte-americanos, ao promover o debate entre a nascente abstração nacional e a figuração modernista já enraizada no país.

De modo que o interesse do MoMA na criação de museus de arte moderna no Brasil se insere num contexto muito mais amplo. O objetivo de estabelecer zonas de influência se estendeu ao campo das artes, daí o envolvimento da instituição americana nesse processo. ${ }^{80}$

Havia a preocupação de disseminar a arte moderna, em particular o abstracionismo, como já foi mencionado, para combater o realismo socialista propagado pelos artistas que atuavam atrás da Cortina de Ferro. ${ }^{81}$

O Brasil agora dispunha de divisas acumuladas para investimentos nos diversos setores da economia e da cultura. O intercâmbio internacional também era favorável, já que os países europeus, em reconstrução, colocavam sua produção artística no mercado a preços baixos. Com esse ambiente propício, só faltava quem investisse recursos para dar continuidade ao processo de institucionalização da cultura.

Dentre os novos personagens do fomento cultural localizava-se um pequeno grupo de burgueses, fruto de uma mistura da antiga elite da terra e de uma elite mais

\footnotetext{
79LOURENÇO, Maria Cecilia França. Museus acolhem moderno. São Paulo: EDUSP, 2000, p. 106. ${ }^{80}$ Mas a relação do MoMA não se limitou ao campo da mera intenção ideológica. Com o tempo, o museu distanciou-se dos objetivos geopolíticos e se consolidou como uma fonte de referência para ações culturais do mundo todo, seguindo sua vocação natural.

${ }^{81}$ Ver mais em LOURENÇO, Maria Cecilia França. Museus acolhem moderno. São Paulo: EDUSP, 2000, pp. $103-131$
} 
recente de origem italiana, sendo que o mecenas representante do setor industrial seria Francisco Matarazzo Sobrinho (1892-1977) $)^{82}$, o Ciccillo, que, juntamente com sua esposa, Yolanda Penteado (1903-1983), inicia uma coleção de arte e será o futuro fundador do Museu de Arte Moderna de São Paulo.

Seguindo exemplo de Solomon R. Guggenheim (1861-1949), cuja crescente coleção iniciada em 1929-30 foi instalada em seu apartamento privado no Plaza Hotel de Nova York, o casal apresenta, em 1947, parte de suas obras em sua própria casa.

De modo que, e também a partir desta experiência, o industrial paulistano motiva-se a incrementar sua coleção, tomando, assim, a decisão definitiva de formar uma coleção de arte contemporânea de dimensões internacionais, "comprando primeiro os quadros e pensando depois no prédio para guardá-los. Teve ainda a seu favor o câmbio, nessa ocasião muito baixo na Europa, pois era logo depois da última guerra." 83

Espelhando-se, então, no modelo de ricos industriais americanos como Solomon R. Guggenheim, da Fundação Guggenheim ${ }^{84}$ e John D. Rockefeller (18391937), do Museum of Modern Art de Nova York ${ }^{85}$, que haviam iniciado, já no final da década de vinte, uma grande e importante coleção de arte moderna, Ciccillo pretende criar, em São Paulo, um museu de arte moderna.

Com a mesma prerrogativa do museu americano, a sucursal local do MoMA tinha por objetivo "perceived a need to challenge the conservative policies of traditional museums and to establish an institution devoted exclusively to modern art". Ou seja, buscar a necessidade de desafiar as políticas conservadoras dos museus tradicionais e estabelecer uma instituição devotada exclusivamente à arte moderna.

Sérgio Milliet, um dos maiores entusiastas da ideia, coordena vários encontros do grupo interessado em formar o museu, e troca cartas com Nelson Rockefeller, relatando as iniciativas e também as dificuldades para concretizar o projeto, sendo que este promete a doação de obras para integrar o acervo do novo museu.

\footnotetext{
82Ler mais sobre essa personalidade em ALMEIDA, Fernando Azevedo de. O Franciscano Ciccillo. São Paulo: Pioneira, 1976. 
De acordo com Amaral, "a pequena doação a ser feita estabeleceria uma vinculação (à época tão combatida pelos intelectuais e artistas de esquerda brasileiros) com o Museu de Arte Moderna de Nova York, através de Nelson Rockefeller". ${ }^{66}$ Este deixa a distribuição dos objetos a Carlton Sprague Smith, conselheiro do MoMA.

Em uma carta enviada em novembro de 1946, Rockefeller registra: "Também tivemos dificuldades que, felizmente, se resolveram com o tempo", referindo-se à criação do museu nova-iorquino, e completa, entusiasmado, que a instituição, criada em 1929, poderia servir de modelo a "todas as entidades que se abririam com esse nome no mundo ocidental". ${ }^{87}$

A 15 de julho 1948, os estatutos para a criação foram legalizados e Ciccillo Matarazzo Sobrinho cria o Museu de Arte Moderna de São Paulo. Enfim:

Os contatos, os recursos financeiros e a firme decisão de Ciccillo, junto a Penteado, resultaram na abertura do museu, estimulado também pelo prestígio incontestável dado pelo MoMA, ao efetuar doações, que têm mais caráter simbólico do que valor excepcional. ${ }^{88}$

Museu privado sem fins lucrativos, antes mesmo de ter uma sede própria, o MAM distribuía seu acervo ainda incipiente entre a residência do casal, Ciccillo e Yolanda, e sua sede provisória, na rua Caetano Pinto, endereço da Metalúrgica Matarazzo. O acervo ainda é pequeno, mas composto de obras-primas da arte moderna.

Firmados esses contatos ${ }^{89}$, Ciccillo passou a assumir a liderança do projeto.

A René Drouin e Leon Degand (primeiro diretor do MAM) entregou a organização da exposição de arte não-figurativa para a inauguração do Museu. Instaurou-se o MAM no dia 8 de março de 1949, às nove horas da noite de uma terçafeira, em pavimento do Edifício Guilherme Guinle, sede dos Diários Associados, cedido pelo jornalista Assis Chateaubriand. Museu que levaria avante um amplo programa cultural de difusão, estudo e pesquisa de arte da nossa era, promovendo bienais

\footnotetext{
${ }^{86}$ AMARAL, Aracy (org.). Museu de Arte Contemporânea da Universidade de São Paulo: Perfil de um acervo. São Paulo: TECHINT ENGENHARIA S/A, 1988, p. 14.

${ }^{87}$ As correspondências entre as partes constam dos arquivos do MACSP. Ver mais em unw. mac. usp. br 88LOURENÇO, Maria Ceclilia França. Museus acolhem moderno. São Paulo: EDUSP, 2000, p. 108. ${ }^{89}$ Entre esses contatos, destaca-se o convite de David Rockefeller para que Matarazzo Sobrinho integrasse a Comissão do Conselho Internacional do MoMA.
} 
internacionais de Artes Plásticas e Arquitetura e uma Bienal de Teatro, consideradas, pela critica mundial, como das maiores manifestações artísticas do mundo. ${ }^{90}$

O edifício da rua sete de abril dividiria espaço com o MASP (Museu de Arte de São Paulo), já lá instalado desde 2 de outubro de 1947, pelo outro mecenas da ocasião, este o maior e mais influente representante da imprensa local da época, o também Francisco, Assis Chateaubriand (1892-1968) que, juntamente com Pietro Maria Bardi, apesar de também bastante conectado com Rockefeller, irá se concentrar na montagem de um acervo mais histórico. ${ }^{91}$

Para além das divergências, Ciccillo e Chateaubriand tinham muito em comum. O caminho dos dois empresários se cruzou numa mesma empreitada: a consolidação de São Paulo como polo artístico e cultural do país.

Hoje, se o Museu de Arte de São Paulo é nosso Metropolitan, e possui a maior coleção de arte ocidental da América Latina, o Museu de Arte Contemporânea da Universidade de São Paulo (cuja grande parcela das obras é proveniente do MAM de Ciccillo e Yolanda) é nosso Museum of Modern Art, conservando a maior coleção de arte contemporânea. Além do acervo, há os fatos históricos, que comprovam tal afirmação.

Entretanto, apesar de toda a efervescência em torno da arte e da arquitetura brasileiras e sua divulgação, ainda os anos 1940/50 darão alguns sinais do "resfriamento" que irá se abater sobre o interesse internacional também na Arquitetura Moderna Brasileira.

Novas visões, mais críticas, ao nosso estilo local, irão aparecer, culminando nos debates ocorridos a partir da realização da I Bienal Internacional de Arte de São Paulo em 1951 que, mesmo contando com a forte presença de arquitetos representantes do Movimento Moderno, será o palco de muitas divergências. ${ }^{92}$

Porém o prestígio da arquitetura brasileira na época ainda justificava o interesse dos participantes, de dentro e de fora do país, a maioria residentes nos EUA.

\footnotetext{
90ALMEIDA, Fernando Azevedo de. O Franciscano Ciccillo. São Paulo: Pioneira, 1976, p. 33. ${ }^{91}$ Ler mais sobre a saga da criação do MASP em MORAIS, Fernando. Chatô: O Rei do Brasil. São Paulo: Companhia das Letras, 1994 e BARDI, Pietro Maria. História do MASP: A aventura da criação do Museu de Arte de São Paulo contada por um de seus criadores. São Paulo: Instituto Lina Bo e P. M. Bardi. 1992. ${ }^{92} \mathrm{CRUZ}$, José Armênio Brito. Os concretos e o concreto. A vinda de Max Bill ao Brasil. Coluna Hoje ontem, n 3 (editoria Documento). São Paulo, Portal Vitruvius, maio 2006.
} 
A realização da I Bienal e da I Exposição Internacional de Arquitetura, em São Paulo, contaria com a forte presença de arquitetos representantes do Movimento Moderno, a maioria residentes nos EUA. ${ }^{93}$

Entre os premiados estrangeiros estão Le Corbusier e Pier Luigi Nervi. Entre os brasileiros estão Lúcio Costa, Henrique Mindlin, Rino Levi, Vital Brazil, Oscar Niemeyer, Affonso Reidy, Joaquim Cardoso. O Júri compõe-se de Siegfried Giedion, Eduardo Knesse de Melo, Junzo Sakakura, Mario Pani e Francisco Beck.

A II Exposição Internacional de Arquitetura, inaugurada em dezembro de 1953 dentro da II Bienal - pela primeira vez realizada nos novos pavilhões do Parque do Ibirapuera, recentemente concluídos para os festejos do IV Centenário - aperfeiçoa-se com a experiência adquirida em 1951, e se consolida com a participação espontânea de 170 arquitetos estrangeiros.

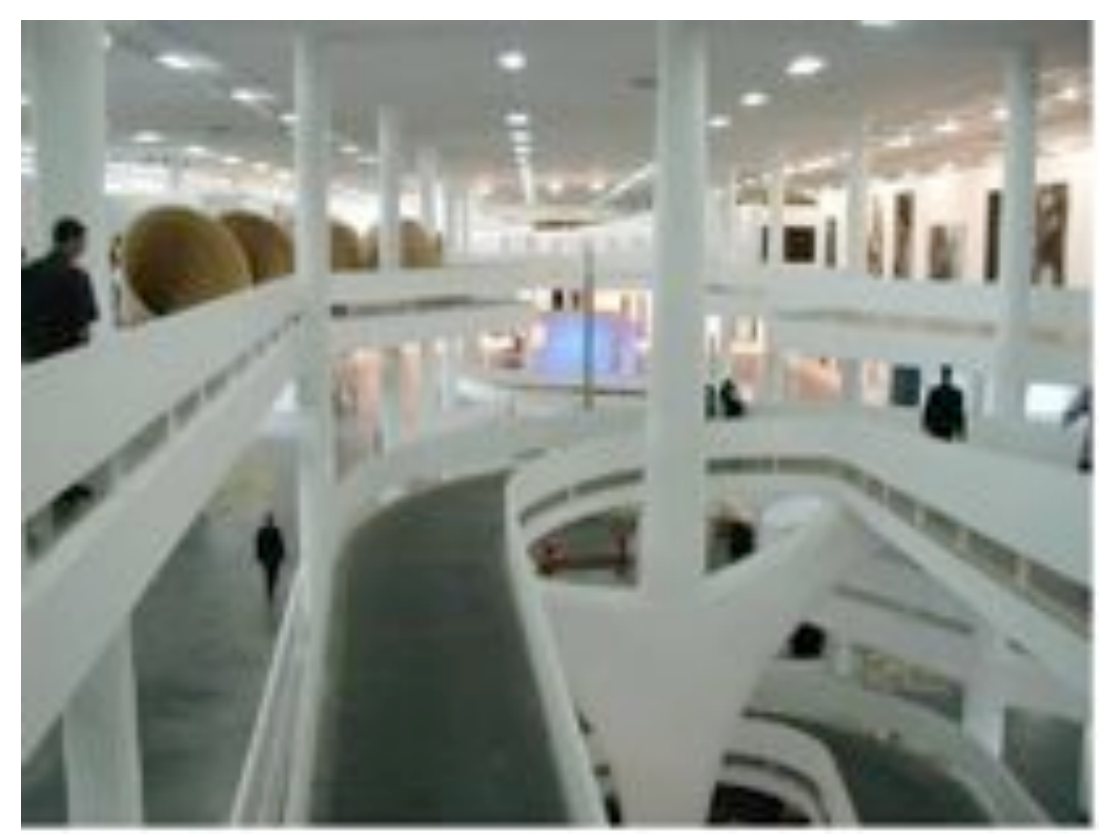

IMAGEM 20: Pavilhão Ciccilo Matarazzo. 1954. São Paulo, São Paulo, Brasil. Arquitetura: Oscar Nliemeyer. Foto: Débora Lima.

\section{O grande}

homenageado seria Walter Gropius, que seria agraciado com 0 Prêmio São Paulo. Dentre os premiados estrangeiros: Philip Jonhson, Arne Jacobsen, Paul Rudolph, Renzo Ravanella, Universidade de Waseda/Japão, Escola Politécnica de Milão. Entre os brasileiros: Jorge Moreira, Burle Marx, Sérgio Bernardes, FAU-USP.

O Júri é composto por nomes de "peso": Alvar Aalto, Ernesto Rogers, Oswaldo Affonso Reidy, Lourival Gomes Machado, Walter Gropius. Salas especiais: Walter Gropius.

\footnotetext{
9Yer mais em FARIAS, AGNALDO (org.). Bienal 50 anos 1951-2001. São Paulo: Fundação Bienal de São Paulo, 2002 e HERBST, Helio. Pelas Bienais à Arquitetura Chora nos Manuais. São Paulo, 2007. Tese (Doutorado em Arquitetura). Curso de Pós-Graduação em Estruturas Ambientais Urbanas. Faculdade de Arquitetura e Urbanismo - USP.
} 
A partir da III Bienal, em 1955, a Exposição Internacional de Arquitetura tem uma presença inconstante dependendo da ocorrência de novidades substanciais nos dois anos de intervalo.

Premiados estrangeiros: Universidade de Waseda/Japão, Universidade de Havana; júri: Oscar Niemeyer, Jorge Moreira, Sérgio Bernardes, Oswaldo Bratke, Eduardo Knesse de Melo, Salvador Candia, Lourival Gomes Machado, Francisco Beck.

A IV Bienal em 1957, voltaria a contar com a presença de alguns notáveis de arquitetura mundial como Mies Van der Rohe, Kenzo Tange, Marcel Breuer e Philip Johnson.

Premiados estrangeiros: Gian Antonio Bernasconi, A. Fiacchi e M. Nozzoli, Ecole Speciale D'architecture/Paris, Universidade Central da Venezuela, Universidade de Waseda; premiados brasileiros: Salvador Candia, Plinio Croce e Roberto Aflalo, Jorge Moreira, Fau-Usp; júri: Mies van der Rohe, Kenzo Tange, Marcel Breuer, Philip Johnson, Mario Henrique Glicério Torres, Eduardo Kneese de Melo, Plinio Croce, Francisco Beck; salas especiais: Brasília, arquitetos canadenses, arquitetura holandesa.

A V Bienal Internacional de São Paulo, de 1959, está vinculada às atividades do Congresso Internacional Extraordinário de Críticos de Arte - que aconteceu entre as cidades de Brasília (em obras), São Paulo e Rio de Janeiro - consolidando-se como um evento autônomo na promoção e divulgação da arte, além de formar público, estimular um mercado de artes e ampliar a inclusão do país num circuito cultural.

A Bienal integra o debate dos especialistas e participantes do Congresso que se deslocaram do sol primaveril do cerrado, Brasília, para o planalto paulista, ampliando o time de críticos envolvidos no certame.

Esta Bienal trazia destaques e salas especiais para Vincent van Gogh, Victor Horta, Mies van der Rohe, Gaudí, arte japonesa e chinesa, além da obra de Burle Marx. Paralelamente, sob a marquise do parque havia a exposição Bahia no Ibirapuera, organizada e montada por Lina Bo Bardi. Trata-se de uma exposição que destacava objetos das manifestações da arte popular coletados por Lina e consagra suas estratégias de museografia e museologia.

À época Lina já estava desenvolvendo o projeto do Museu de Arte de São Paulo. 


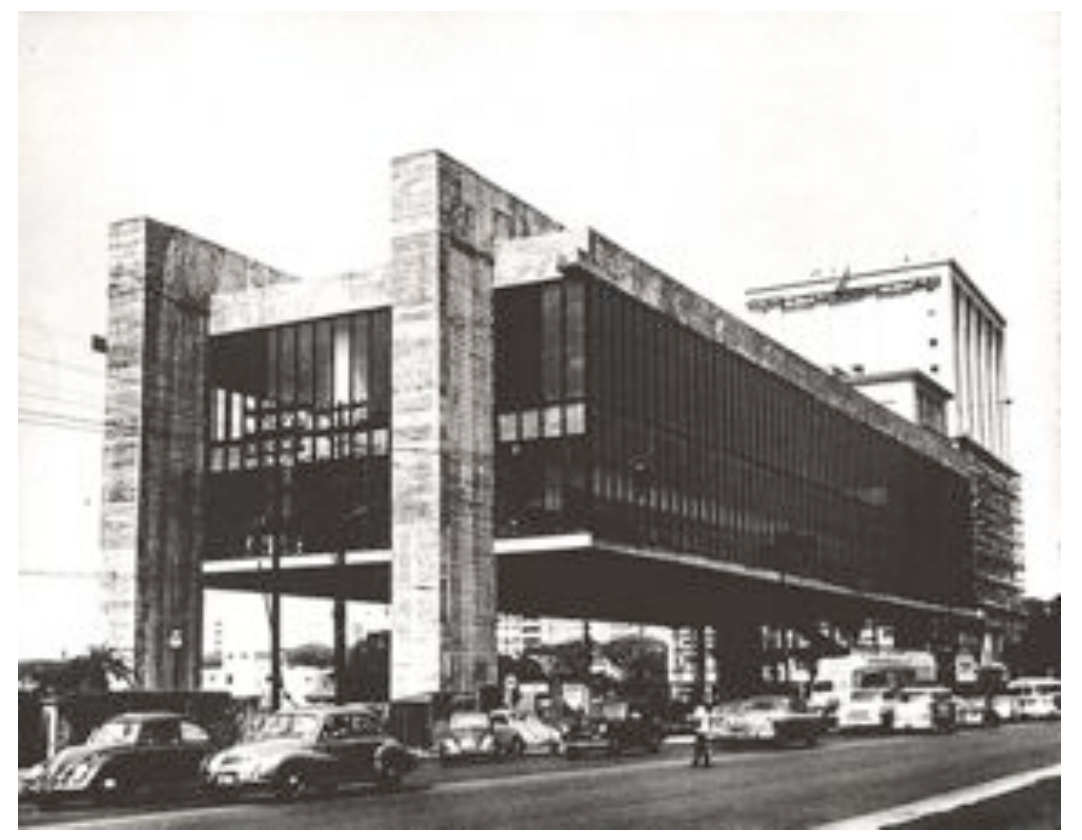

IMAGEM 21: MASP. 1957-1968. São Paulo, São Paulo, Brasil. Arquitetura: Lina Bo Bardi.

Nesse pano de fundo as bienais de São Paulo se transformaram em episódios que ganharam vulto e expressão, pois se mostraram momentos onde a interlocução com as ideias estrangeiras se potencializou, graças à presença ao vivo de importantes artistas e arquitetos, na época principalmente atuantes nos Estados Unidos, como o eram Walter Gropius, Mies van der Rohe, Marcel Breuer, dentre tantos mencionados.

\section{9 - Congresso Internacional Extraordinário de Críticos de Arte em Brasília, São Paulo e Rio de Janeiro, Brasil}

Em 1959, ano anterior a inauguração de Brasília, é realizado o CIAM XI que dissolveu a própria instituição do Congresso Internacional de Arquitetura Moderna.

Foi também em 1959 que Frank Lloyd Wright falece e que o Museu Guggenheim de New York é inaugurado.

Nesse mesmo ano, Juscelino Kubitschek quis que os principais críticos de arte e arquitetura, arquitetos, historiadores e designers, debatessem sobre o futuro das cidades no século vinte, e a significação de Brasília, como expressão do urbanismo moderno. $^{94}$

O Congresso Internacional Extraordinário dos Críticos de Arte -doravante também apenas Congresso - foi organizado pela Associação Internacional do Críticos

\footnotetext{
94 Ler mais em SEGRE, Roberto; LOBO, Maria da Silveira. Congresso Internacional Extraordinário de Críticos de Arte: Cidade Nova - Sintese das Artes. Rio de Janeiro: UFRJ, 2009.
} 
de Arte -I.A.C.A. - para ocorrer em outras duas cidades além de Brasília: Rio de Janeiro e São Paulo. Em São Paulo, seu cronograma se vincula às atividades da $V$ Bienal Internacional de São Paulo, articulando as agendas para tornar o campo cultural brasileiro um ambiente menos periférico ao debate internacional das artes.

O crítico de arte Mário Pedrosa assumiu a responsabilidade do evento que foi presidido pelo crítico italiano Giulio Carlo Argan, e nos debates participaram representantes da cultura, arquitetura e arte da América Latina, Europa e Estados Unidos.

Em contrapartida ao ocaso do baluarte do Movimento Moderno, agentes das mais variadas expressões do campo arquitetônico, tais como Richard Neutra, Frederick J. Kiesler, Eero e Aline Saarinen, John Entenza, Stamos Papadaki, Will Grohman, Andre Bloc, Charlotte Perriand, Jean Prouvé, André Wogenscky, William Holford, Bruno Alfieri, Giulio Carlo Argan, Gillo Dorfles, Alberto Sartoris e Bruno Zevi, entre outros, estiveram ao Brasil para conhecer e/ou reconhecer a sua vanguarda arquitetônica e, de certo modo, dar o seu "Ok" à grande empreitada.

Em que pese o difícil acesso aos seus Anais, é sintomático que, ainda hoje, este Congresso seja mais lembrado pela grande quantidade de ilustres visitantes, do que pelo conteúdo crítico e pela contribuição deles sobre Brasília ou sobre arquitetura.

Com a construção da nova Capital, e a permanente transformação do campo arquitetônico brasileiro numa nova circunstância diante da utopia em processo de materialização, vai se instaurando o que se denominou chamar a "condição pósBrasilia".

Esta condição pós-Brasília se caracteriza pela manutenção de questões e posturas modernas em diálogo com novas questões e outras posturas, que já não correspondem dogmaticamente às premissas modernistas, mas nem tampouco são, automaticamente, pós-modernas. Trata-se de uma dilatação do sentido da modernidade inerente à produção da arquitetura brasileira que, para além de uma linguagem já consolidada, mantém o debate refratário às críticas ao Movimento Moderno, que são contemporâneas à Brasília -o ponto máximo de nossa modernidade. A condição pós-Brasília se encerra dentro da construção da cidade, entre 1957 e 1960. Esta condição pós-Brasília representa menos do que a mera ruptura, sinaliza mais do que a mera continuidade e significa tanto quanto uma 
complexa transformação do campo arquitetônico que está distante de uma coesão lastreada e decantada sobre a produção arquitetônica brasileira pós-1960. ${ }^{95}$

Neste sentido, Segawa afirma que "Brasília está no bojo desse projeto desenvolvimentista e constituiu o marco final dessa vanguarda arquitetônica alimentada por uma política de 'conciliações' ideológicas. O marco cronológico final desta etapa está em 1964, com a implantação da ditadura militar, encerrando a utopia [arquitetônica] do segundo pós-guerra."96

O cerne do debate do campo no mundo -o CIAM - ruíra e o Congresso Internacional Extraordinário dos Críticos de Arte torna-se uma instância reflexiva e legitimadora da relativa autonomia do campo arquitetônico brasileiro sendo que o Congresso é parte da construção simbólica de Brasília, sendo o gesto mais internacionalizante de exposição da cidade.

Ao trazer especialistas do mundo todo para ver a nova Capital em obras, comprova-se a factualidade de sua existência e globaliza-se o mito ora em processo de construção.

Simultaneamente, o Congresso tornou-se o palco do anúncio de uma "crise" do Movimento Moderno e da produção arquitetônica. Bruno Zevi assinala que "...a arquitetura moderna (...) está em profunda crise, crise esta que se sente com muita força na Itália, que é muito evidente nos Estados Unidos e muito menos evidente em Brasilia, mas que existe em todo o mundo."97

Ou seja, Brasília em obras assiste o prenúncio da crise que se efetivaria posteriormente e se firma como um ponto de inflexão de um momento outro, ratificando a condição pós-Brasília no campo da arquitetura brasileira.

Embora possa ser considerado como um evento de caráter acadêmico, o Congresso configurou-se desde o início como um evento político legitimador de estratégias diplomáticas singulares, para a divulgação de Brasília e do Brasil mundo à fora, tanto que foi organizado pelo Itamaraty e não pelas universidades.

\footnotetext{
${ }^{95}$ ROSSETTI, Eduardo Pierrotti. Braslia, 1959: a cidade em obras e o Congresso Intemacional Extraordinário dos Criticos de Arte. Arquitextos11.03 (Romano Guerra Ed. Ltda.). São Paulo, Portal Vitruvius, agosto 2009. ${ }^{96}$ SEGAWA, Hugo. Arquiteturas no Brasil 1900-1990. São Paulo: Edusp, 1998, p. 114.

${ }^{97}$ ANAIS do Congresso Internacional Extraordinário de Criticos de Arte. Brasilia - São Paulo - Rio de Janeiro, 17 a 25 de setembro de 1959. Mimeo - transcrição por Mary Pedrosa, p. 21 In ROSSETTI, Eduardo Pierrotti. Brasilia, 1959: a cidade em obras e o Congresso Internacional Extraordinário dos Críticos de Arte. Arquitextos11.03 (Romano Guerra Ed. Ltda.). São Paulo, Portal Vitruvius, agosto 2009.
} 
A correspondência diplomática revela ainda que houve um interesse específico para trazer Mies van der Rohe, Walter Gropius e Phillip Johnson (que participaram da V Bienal de São Paulo), o que ampliaria o rol de ilustres visitantes do campo arquitetônico que conheceram Brasília ainda em construção.

Outro grande arquiteto atuante nos Estados Unidos e que fez parte do Congresso foi Richard Neutra, agora em sua segunda visita ao Brasil.

O Congresso foi dividido em oito sessões, a saber: 1) A cidade Nova 2) Urbanística 3) Técnica e Expressividade 4) Da Arquitetura 5) Das Artes Plásticas 6) Das Artes Industriais 7) A Educação Artística e 8) Situação das Artes na Idade Moderna.

No frenético cronograma da construção de Brasília, 1959 é um ano crucial e determinante do sucesso da empreitada capitaneada pelo então Presidente Juscelino Kubitschek. Neste ano, a construção da futura Capital do Brasil atinge um estágio definitivo, impulsionando a economia e canalizando ações governamentais para consagrar sua meta-síntese.

Na paisagem do cerrado do Planalto Central Brasília se torna, irrevogavelmente, um projeto nacional autônomo, atingindo a opinião pública e todos os setores sociais. representando um gesto de afirmação nacional sem precedentes, consubstanciandose num projeto urbano e arquitetônico que se insere num projeto de nação, uma epopeia de modernização imposta ao próprio país, como um novo parâmetro de desafios e perspectivas simbólicas, suplantando toda ordem de valores e práticas que apontassem em sentido contrário.

Contrapor a rarefeita ocupação dos vastos territórios do Planalto Central com a nova Capital, significava tomar posse do país.

Será no processo desta tomada de posse, num cerrado revolvido, ocupado por máquinas, tratores, caminhões, estruturas metálicas dos edifícios e milhares de candangos, que os participantes do Congresso Internacional Extraordinário dos Críticos de Arte instauram um debate sobre a própria cidade-capital em construção como síntese das artes.

Ao longo dos três dias de permanência em Brasília, os congressistas participaram de sessões temáticas, mas para eles, tanto quanto essas atividades da praxe acadêmica, valeria visitar, conhecer e experimentar, quase que em primeira mão, 
os edifícios oficiais, as quadras residenciais e as obras complementares da futura cidade, quanto efetivar o debate eminente.

Para balizar e pautar as questões decorrentes em função das visitas, o arquiteto Oscar Niemeyer se precavê ministrando antes uma palestra sobre a sua arquitetura em Brasília. Embora esta palestra não esteja registrada no Anais do Congresso, é mais que razoável pressupor que o arquiteto já tenha apresentado uma argumentação com a convicção que ainda hoje the é peculiar, sobre as qualidades espaciais, simbólicas, plásticas e estruturais das obras que seriam visitadas, acentuando o caráter condensador destas obras e a coerência de seu discurso. Tal fato se deve não somente à repercussão desta palestra ao longo das demais discussões registradas nos Anais, mas também pela recorrente manifestação de limitação crítica e dos impasses que toda a experiência de estar em Brasília durante as obras ensejava. $^{98}$

Enquanto Lucio Costa se mantém distante do embate direto que um evento deste porte proporciona, Oscar Niemeyer atua de modo distinto, participando francamente das atividades do Congresso em Brasília. Naquele momento, Oscar Niemeyer já era um arquiteto reconhecido internacionalmente que não apenas já possuía uma produção excepcional, mas também estava projetando coisas extraordinárias numa circunstância excepcional.

Menos do que uma mera estratégia persuasiva para garantir mais legitimidade à estratégia do Itamaraty, a presença de Oscar Niemeyer durante as visitas é uma oportunidade singular: conhecer a obra com seu próprio autor. Foram realizadas visitas aos edifícios representativos, tais como o Palácio do Planalto, o Palácio do Supremo Tribunal Federal, o Palácio do Congresso Nacional e o Palácio da Alvorada. Os congressistas também visitaram junto com Niemeyer a Igreja de N.S. Fátima e os apartamentos das superquadras.

Ao afirmar na sessão de abertura que "...nós vos chamamos para criticar, para colaborar, e não para [fazer] a apologia." Mario Pedrosa propõe um desafio ao próprio 
aparato crítico dos participantes. Afinal, como poderiam os críticos se posicionarem perante uma cidade em obras? ...uma obra em processo? Como poderiam os críticos formularem abordagens precisas sobre as questões urbanas e sobre arquiteturas que estavam em pleno processo de construção, ainda gestando nas pranchetas? Como os congressistas poderiam solucionar tudo isso a partir daqueles três preciosos dias que vivenciaram o movimentado canteiro das obras de Brasília? A experiência de conhecer Brasília em obras se mostra excepcional, mas tal colaboração se torna algo efetivamente improvável, inclusive porque o grande projeto em curso não seria alterado. Isso indica que todas as opiniões, formulações e observações críticas deveriam alimentar não somente aquele debate, mas repercutir no campo externo o grau e o nível então atingido pelo campo da arquitetura brasileira. ${ }^{99}$

Como referência ao grau do desafio em que Pedrosa enredou os participantes, considere-se o projeto mais significativo de Brasília que é o Congresso Nacional. Naquele momento, seu edifício ainda não estava terminado, apresentando a estrutura de concreto armado das 2 torres com 28 andares e a plataforma de embasamento com suas cúpulas.

No entanto, devido ao escoramento das formas da concretagem da cúpula da Câmara dos Deputados, torna-se impossível a leitura plena de suas formas e de sua presença icônica na paisagem, ainda que fosse no canteiro monumental. Deste modo, a percepção parcial desta e de outras tantas obras tem sua legibilidade integral comprometida, pois todas estavam em diferentes fases do processo construtivo.

Todos haviam chego cedo demais.

Assim, é possível assinalar que em 1959, em meio às tensões entre a cidade projetada, o canteiro de obras da cidade e a futura cidade-Capital, Brasília de fato não existia como uma cidade pronta. De modo geral, os congressistas consideram Brasília em ao menos três diferentes instâncias: a cidade projetada pelos arquitetos e urbanistas, a cidade como canteiro de obras e a futura cidade-Capital. É comum detectar que é assim - cidade, canteiro e Capital- que ela é tratada em muitas abordagens, embora para consubstanciação factual de Brasília, essas e outras visões concorrem, se amalgamam e se influenciam. Embora houvesse uma vida urbana 
transcorrendo, independentemente dos hábitos e valores que também poderiam contribuir para a futura cidade, naquele momento em 1959, havia uma utopia em processo de construção que materializaria uma cidade a ser povoada e consolidada por um outro processo, de algum modo distinto de sua própria construção. ${ }^{100}$

Assim, testemunhar tal fato já transforma este Congresso excepcional por si mesmo, o que mostraria ser ainda mais atraente para todos aqueles que vieram pra cá interessados em poder participar deste momento histórico. Enquanto que por um lado os congressistas não conseguiram ver uma cidade, porque ela ainda estava em pleno processo de construção, por outro, ao conhecerem os canteiros de Brasília, eles puderam vislumbrar a emergência do mito de um Brasil em franco processo de modernização.

Deste modo, o Congresso legitimou autonomia ao campo arquitetônico brasileiro frente à opinião mundial, legitimando-o in totum através de uma obra singular. Ao mesmo tempo em que Brasília servia para dinamizar e transformar a imagem do país, ela servia também para questionar os parâmetros internos do campo arquitetônico, encerrando outra crise, instaurando a condição pós-Brasília. Ou seja, Brasília em obras assiste ao prenúncio de uma crise e anuncia outra crise.

Naquele momento, Brasília em obras se inscreve numa circunstância mais que ideal "entre": entre a cidade projetada e a futura cidade. Em setembro de 1959, Brasília em obras se mostra mesmo como a própria utopia em construção.

\footnotetext{
100ROSSETTI, Eduardo Pierrotti. Brasilia, 1959: a cidade em obras e o Congresso Internacional Extraordinário dos Críticos de Arte. Arquitextos11.03 (Romano Guerra Ed. Ltda.). São Paulo, Portal Vitruvius, agosto 2009.
} 
SEGUNDO CAPÍTULO

TROCAS, TRANSFERÊNCIAS E OUTROS CAMINHOS - ANÁLISE DE

ALGUMAS DAS EXPERIÊNCIAS COMPARTILHADAS ENTRE A MODERNA ARQUITETURA BRASILEIRA E OS ARQUITETOS E $O$ CAMPO ARQUITETÔNICO NORTE-AMERICANO 


\section{Cronologia das trocas arquitetônicas ocorridas entre o Brasil e os EUA entre as décadas de 1930 e 1960}

\section{1: Visita de Frank Lloyd Wright ao Brasil}

Não há até o momento indícios concretos de como e quando a obra wrightiana tenha chegado ao Brasil, no entanto a possibilidade de seu conhecimento pelos brasileiros nos anos 20 deve ser considerada. O que sabe-se é que diversas publicações europeias já disseminavam a obra de Frank Lloyd Wright (1867-1959) posterior a 1910.

Já anteriormente à visita de Wright é possível detectar nos anos 20 sinais do conhecimento ou interesse de alguns profissionais por sua obra no Brasil, ou seja, no período embrionário deste Modernismo. ${ }^{1}$

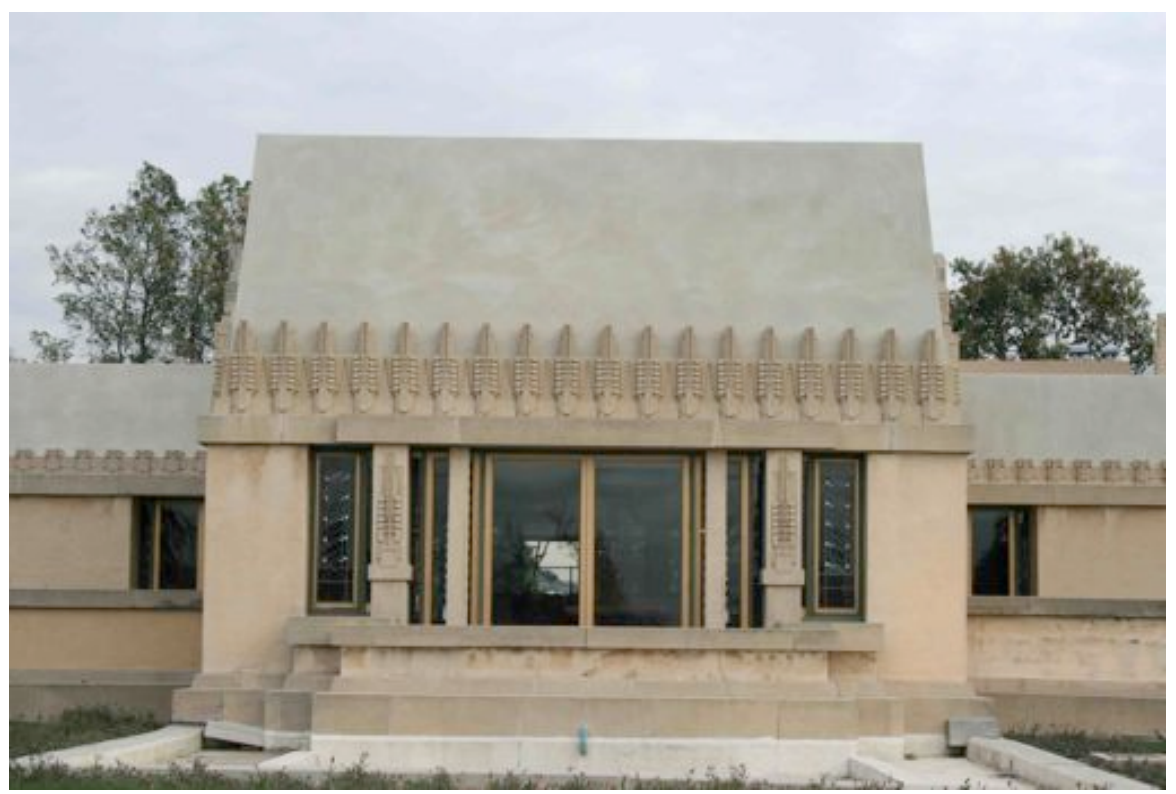

IMAGEM 22: Hollyhock House. 1921. Los Angeles, Califórnia, USA. Arquitetura: Frank Lloyd Wright. Foto: Débora Lima.

Quando esteve no Brasil, à época já aos 64 anos de idade, e considerando-se sua ambição intelectual e profissional, Wright

passava por uma fase de isolamento. Também a realização de obras ao longo dos anos 20 ficara muito aquém de suas expectativas.

Se por um lado seu trabalho, em particular suas Prairie Houses, era venerada pelos colegas mais jovens como precursora fundamental da nova arquitetura, estes o colocavam como representante de uma geração anterior, de uma fase já ultrapassada. 
IMAGEM 23: Arthur Heurtley House. 1902. Oak Park, llinois, Estados Unidos. Exemplar das Prairie Houses de Frank Lloyd Wright. Foto: Débora Lima.

Wright, inclusive, via com olhos críticos certos encaminhamentos

Movimento Moderno, em especial a glorificação da Estética da Máquina, no

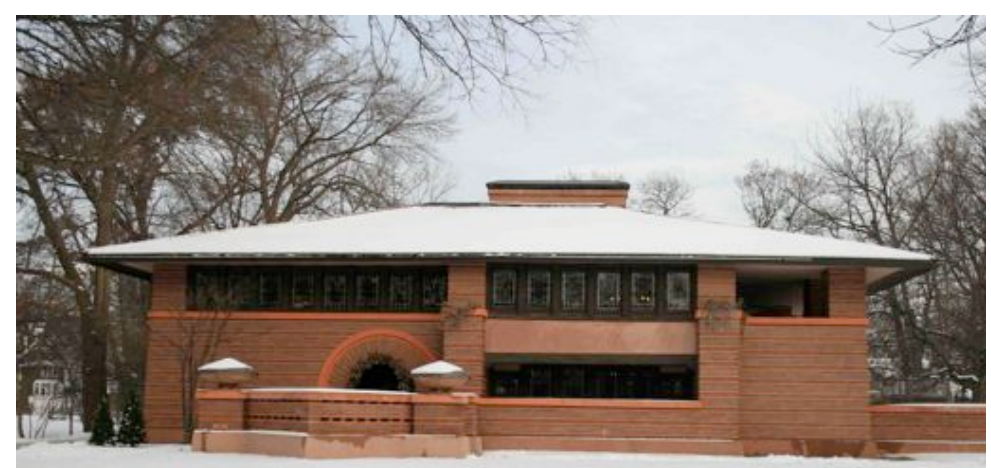
ambiente arquitetônico europeu, a qual ele veemente condenou nas chamadas Kahn Lectures on Modern Architecture na Princeton University em 1930.

Com a contribuição da exposição de 1932, The International Style: Architecture since $1922^{2}$, a produção europeia moderna das primeiras décadas do século XX passa a ser difundida nos EUA como estilo.

Para os inventores do International Style, Wright não é mais que um dos últimos representantes do Romantismo e os princípios que ele defende devem ser erradicados da face da terra em nome da "verdadeira" arquitetura moderna, cujos líderes são Walter Gropius, J. J. P. Oud, Le Corbusier e Mies van der Rohe... Wright era contrário do novo estilo, que considerava tão nocivo quanto o Ecletismo. ${ }^{3}$

Após seu retorno do Brasil, Wright estabelece formalmente a Taliesin Fellowship em 1932, e no mesmo ano publica The Disappearing City, e a primeira versão de An Autobiography, na qual não menciona sua visita aos "trópicos".

Tal visita se fez por razão de uma iniciativa da Union of American Republics, que organiza em 1929 a primeira etapa de um dos grandes concursos internacionais de Arquitetura daqueles anos ${ }^{4}$, cujo objetivo era a construção de um Monumento ao Descobrimento da América em Santo Domingo, República Dominicana.

\footnotetext{
2HITCHCOCK, Henry-Russel; JOHNSON, Philip. The International Style: architecture since 1922. 3a ed. New York/London: W.W. Norton \& Company, 1995. 
Participaram desta fase arquitetos de 48 países, inclusive Flavio de Carvalho representando o Brasil.

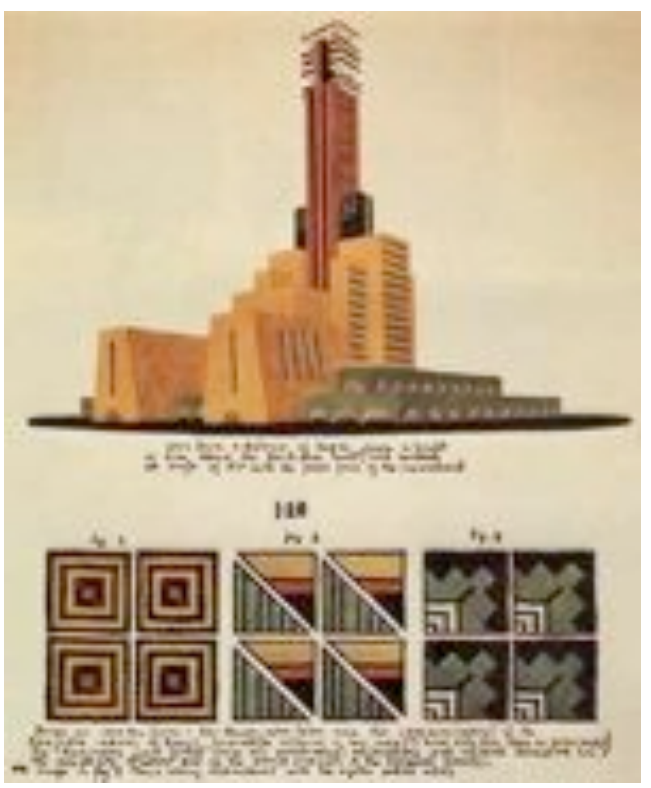

IMAGEM 24: Concurso para o Farol do Colombo, 1929. São Paulo, São Paulo, Brasill. Arquitetura: Flavio de Carvalho.

Insatisfeitos com os resultados iniciais, os organizadores decidem pela realização de um segundo concurso, cujo julgamento acontece em 1931 no Rio de Janeiro. Frank Lloyd Wright é convidado a participar do júri, como representante das Américas, e parte para o Brasil em setembro permanecendo na cidade por três semanas.

A bordo no navio encontra-se um segundo jurado, Eliel Saarinen (1873-1950) que, embora vivendo nos EUA era o jurado representante da Europa.

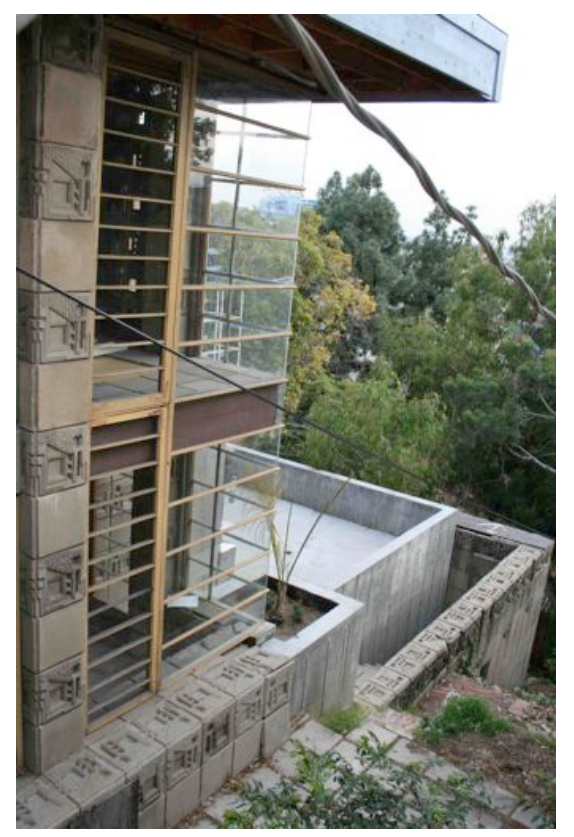

IMAGEM 25: Freeman House. 1923. Los Angeles, Califómia, USA. Arquitetura: Frank Lloyd Wright. Foto: Débora Lima.

Exemplo de uma Textle Block House, Comparar com os estudos de Flavio de Carvalho acima.

Já no porto do Rio, Wright é imediatamente procurado pelos estudantes grevistas da Escola Nacional de Belas Artes (Enba), que buscavam apoio ao movimento em favor de Lucio Costa, que havia sido demitido pela radicalidade da mudança no ensino da escola, ao tentar introduzir conceitos da Arquitetura Moderna.

Na edição revisada de An Autobiography, de 1943, Wright descreve, de forma certamente folclórica, a recepção que teve, dando grande ênfase a certos fatos periféricos de sua estadia, como a vida social carioca. Sobre os colegas brasileiros, 
limita-se a comentar: "I met the modern professors the boys wanted. They were good architects and excellent men". ${ }^{.}$

Warchavchik acabara de inaugurar a Casa Nordschild da rua Toneleros (1930), na qual por várias vezes reúnem-se os professores e estudantes da ENBA para escutar o mestre norte-americano.

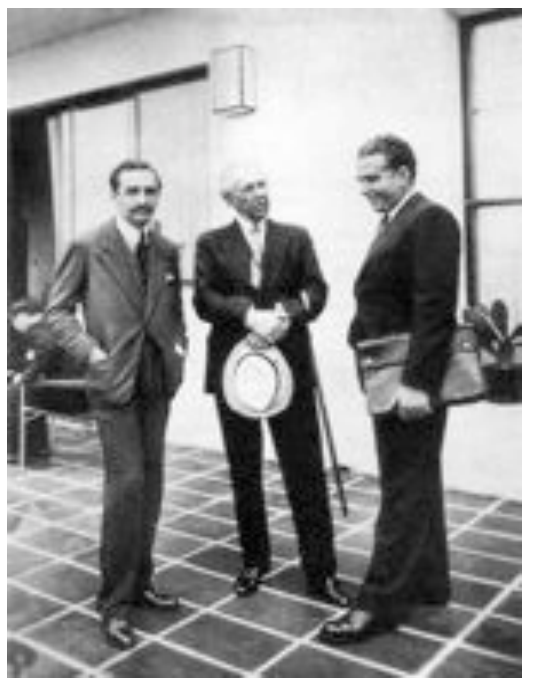

IMAGEM 26: Famosa fotografia de Lucio Costa, Frank Lloyd Wright e Gregori Warchavchik na Casa Nordshild no Rio de Janeiro, em 1931

Encontra-se, portanto, com Lucio Costa e Gregori Warchavchik, como nos conta IRIGOYEN ${ }^{6}$, que afirma ter sido esta visita o único aspecto de sua presença abordado pela historiografia da arquitetura moderna brasileira.

No entanto, tal passagem permanece até nossos dias um episódio pouco investigado, e o mesmo se pode dizer dos aspectos ligados à apreciação da obra do Mestre norte-americano por parte dos brasileiros, e de suas consequências na formulação de certas propostas estéticas até os anos $60{ }^{7}$

Wright deixa clara a problemática da comunicação, já que a língua estrangeira mais difundida nesse período no Brasil era o francês.

Segundo ele "only one (and a halph, say) spoke english", referindo-se aos cerca de 700 estudantes da EnBA. Seus tradutores são o jornalista Herbert Moses (coproprietário do jornal $O$ Globo) e o então estudante Alcides Rocha Miranda ${ }^{8}$. Wright enfatiza que, pelo tom exacerbado de suas traduções, Moses, que ele apelida de $E /$

\footnotetext{
${ }^{5}$ NEDELYKOV, Nina; MOREIRA, Pedro. Caminhos da Arquitetura Moderna no Brasil: A presença de Frank Lloyd Wright. Arquitextos018 (Romano Guerra Ed. Ltda.). São Paulo, Portal Vitruvius, agosto 2001.

${ }^{6}$ RIGOYEN, op. cit, , p. 46.

${ }^{7}$ FUJIOKA, Paulo Y. Princípios da arquitetura de Frank Lloyd Wright e suas influências na arquitetura moderna paulistana. São Paulo, 2003. Tese (Doutorado). Curso de Pós-Graduação em Estruturas Ambientais Urbanas. Faculdade de Arquitetura e Urbanismo - USP.

${ }^{8}$ Alcides da Rocha Miranda, que veio a ter significativo papel no desenvolvimento da Arquitetura Brasileira nos anos 30 a 50, organiza com três colegas em 1933 no Rio o $1^{\circ}$ Salão de Arquitetura Tropical, no qual Frank Lloyd Wright (e não Le Corbusier) é homenageado como Presidente de Honra.
} 


\section{TROCAS, TRANSFERÊNCIAS, DIÁLOGOS E OUTROS CAMINHOS}

Globo, provavelmente transmitiu aos ouvintes uma versão pessoal e deturpada de suas palavras. $^{9}$

Wright publica em sua breve estadia no Rio uma série de artigos em jornais cariocas em prol da Nova Arquitetura e em apoio aos estudantes, e menciona um certo "risco" na empreitada, já que alguns dos grevistas haviam sido presos pela polícia. $^{10}$

Mesmo como opositor ao academicismo, Wright chega a ser homenageado, recebendo entre outros o título de Membro Honorário da Academia Brasileira.

Nos anos seguintes à sua visita, são poucos os indícios de qualquer impacto direto dessa sua curta estadia no Brasil, mas sua obra de modo geral não passa despercebida pelos arquitetos locais, apesar de pouco se falar sobre o assunto, esta continua sendo disseminada através dos periódicos e de visitas de arquitetos brasileiros aos Estados Unidos. ${ }^{11}$

Entretanto, ao longo dos anos 1930 os jovens arquitetos buscaram referência nas obras dos já chamados "mestres" internacionais. Consolida-se a liderança da figura de Lucio Costa entre os Modernistas, e sua escolhida veneração extrema por Le Corbusier generaliza-se entre os colegas.

Sabemos, hoje, que esta oposição não foi, então, entre racionalismo e organicismo, mas entre Europa e América. A obra e o discurso de Wright, muito menos acessíveis (e talvez mais complexos) que os de Corbusier naquele momento, caem em certo ostracismo no Brasil.

A obra de Wright, como sabemos, terá resposta em projetos de Miguel Forte, José Leite de Carvalho e Silva ${ }^{12}$ e também Carlos Millan, bem como entre os Irmãos

\footnotetext{
${ }^{9} \mathrm{NEDELYKOV}$, op. cit.

${ }^{10}$ Ler mais em IRIGOYEN, Adriana. Wright e Artigas - Duas Viagens. São Paulo: Ateliê Cultural, 2002.

${ }^{11}$ "Depois de sua passagem pelo Rio de Janeiro, algumas das pessoas que conhece na cidade continuam em contato com Wright. Com a criação da escola de Taliesin em 1932, José Cortez, Lucio Costa, Nestor de Figueiredo, Edwin Morgan e Maria da Silva passaram a integrar a lista de Friends of the fellowship, que contava entre seus membros com os historiadores C. R. Ashbee, Walter Curt Behrendt e Lewis Munford; os arquitetos Ludwig Mies van der Rohe, Wlater Gropius, Buckminster Füller, Eric Mendelsohn e J. J. P. Oud; e os pintores Diego rivera, José Clemente Orozcoe Georgia O'Keeffe, entre aoutros". (IRIGOYEN, Adriana. Wright e Artigas Duas Viagens. São Paulo: Ateliê Cultural, 2002, pp. 57-58)

${ }^{12}$ Ver mais em FORESTI, Debora Fabbri. Aspectos da arquitetura orgânica de Frank Lloyd Wright na arquitetura paulista: a obra de José Leite de Carvalho e Silva. Dissertação de mestrado. Orientador Renato Anelli. São Carlos, EESC USP, 2008.
} 
Roberto, entre muitos outros, mas principalmente entre os arquitetos atuantes em São Paulo.

Sobre o grupo do Mackenzie (São Paulo), Júlio Katinsky escreveu que tinham "a firme convicção (acredito que a todos os integrantes do grupo) de que o futuro da humanidade era o presente dos Estados Unidos da América. Penso que o entusiasmo comum por Frank Lloyd Wright adivinha não só daquela mesma visão protoluterana do trabalho (tão impregnada na cultura saxônica), como da pregação democrática que o arquiteto americano exprimia em seus escritos". ${ }^{13}$

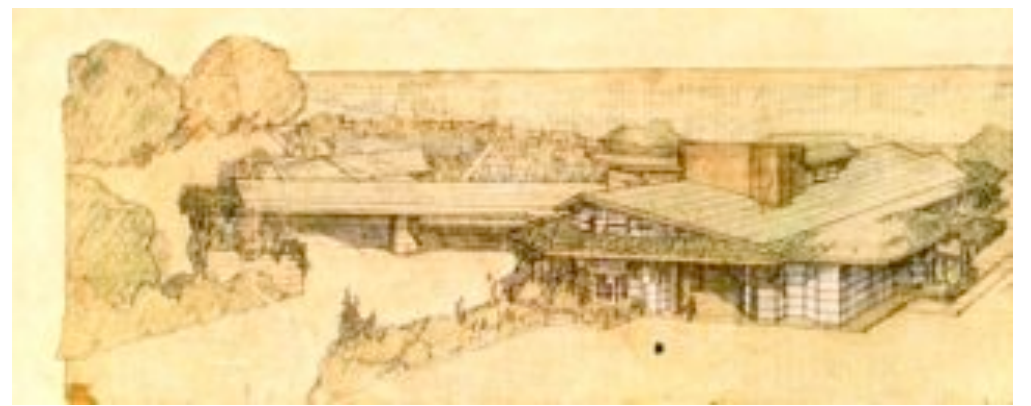

IMAGEM 27: Hanna

Residence/Honeycomb House. 1936. Palo Alto, Califórnia, USA Arquitetura: Frank Lloyd Wright limitado pelas áreas de estar, refeições e biblioteca, cujos materiais utilizados foram a pedra, a madeira, o vidro e o revestimento cerâmico nas paredes externas

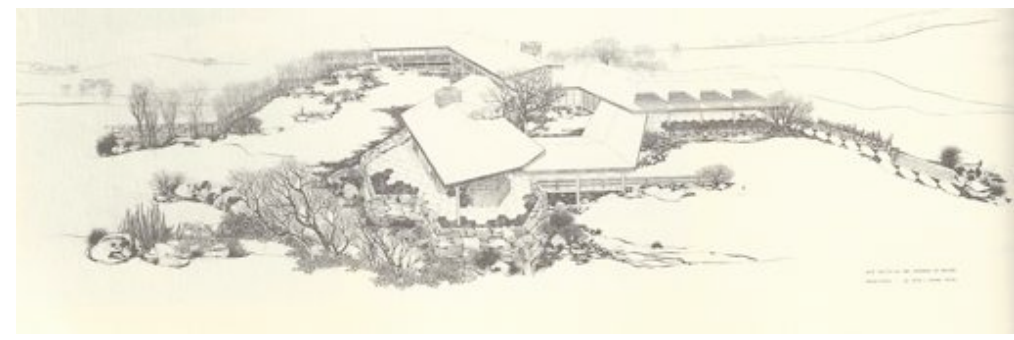

IMAGEM 28: Residência Érico

Siriuba Stickel. 1952-1954. São Paulo, São Paulo, Brasil. Arquitetura: Miguel Forte, Galiano Ciampaglia e Carlos Millan.

A produção de Carlos Millan, no período a partir do inicio da década de 1950 está ligada às influências deste grupo, com características como "extensos detalhamentos, estruturas de concreto não aparentes, largos beirais de cobertura e grande variedade de materiais de acabamentos especificados". ${ }^{14}$

Vale também ressaltar aqui o Pavilhão Lowndes, concebido pelos irmãos M.M.M. Roberto ${ }^{15}$ em Petrópolis, Rio de Janeiro, entre 1953-54, como escritório de vendas para um loteamento comercial.

\footnotetext{
${ }^{13}$ KATINSKY, Julio In ACAYABA, Marlene M. Branco e Preto: Uma História de Design Brasileiro nos Anos 50 São Paulo: Instituto Lino Bo e P. M. Bardi, 1994, p. 1 (prefácio).

${ }^{14}$ MATERA, Sérgio. Carlos Millan: Um estudo sobre a produção em arquitetura. São Paulo, 2005. Dissertação (Mestrado). Curso de Pós-Graduação em Estruturas Ambientais Urbanas. Faculdade de Arquitetura e Urbanismo - USP, P. 44

${ }^{15}$ PEREIRA, Cláudio Calovi. Os irmãos Roberto e a arquitetura moderna no Rio de Janeiro (1936-1954). Dissertação de mestrado. Orientador Carlos Eduardo Dias Comas. Porto Alegre, FAU-UFRGS, 1993
} 
Como bem coloca Yves Bruand, a obra é "a antítese da maneira de Le Corbusier, e aproxima-se mais do estilo de Wright". O Pavilhão Lowndes, tão peculiar dentro da obra dos Roberto, estabelece um diálogo orgânico entre a presença humana e a paisagem pitoresca e então quase intocada de Petrópolis, de maneira correlata a Taliesin West em Scottsdale, Arizona, realizado por Wright entre 1937-38 e em seguida amplamente publicado.

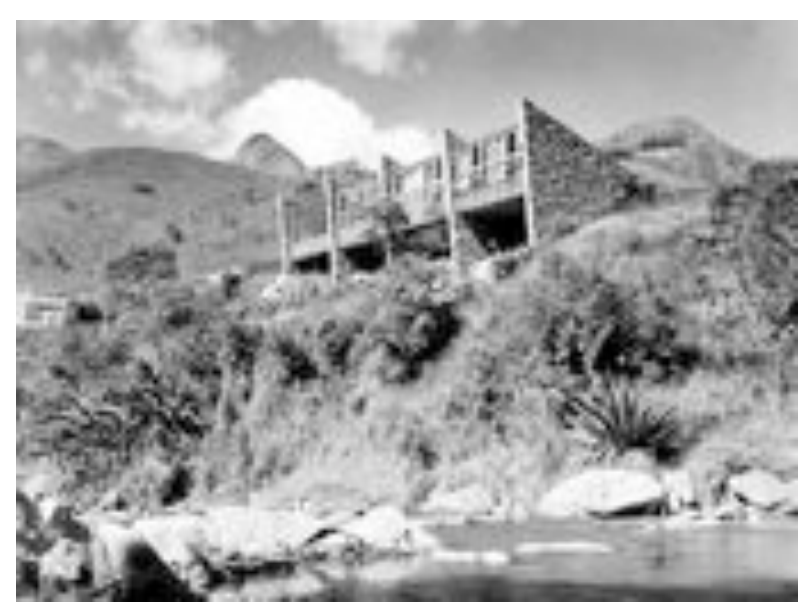

A obra é definida por uma sequência modular de cinco paredes de cantaria, cuja expressão plástica é acentuada pelo uso de diagonais em relação ao terreno, e pela clareza de sua relação com a estrutura de madeira que define a cobertura e o piso da parte posterior, elevada do terreno.

IMAGEM 29: Pavilhão Lowndes, 1953-1954, Samambaia, Petrópolis, RJ, Arquitetura: M.M.M. Roberto

IMAGEM 30: Taliesin West. 1937. Scottsdale, Arizona, USA. Arquitetura: Frank Lloyd Wright.

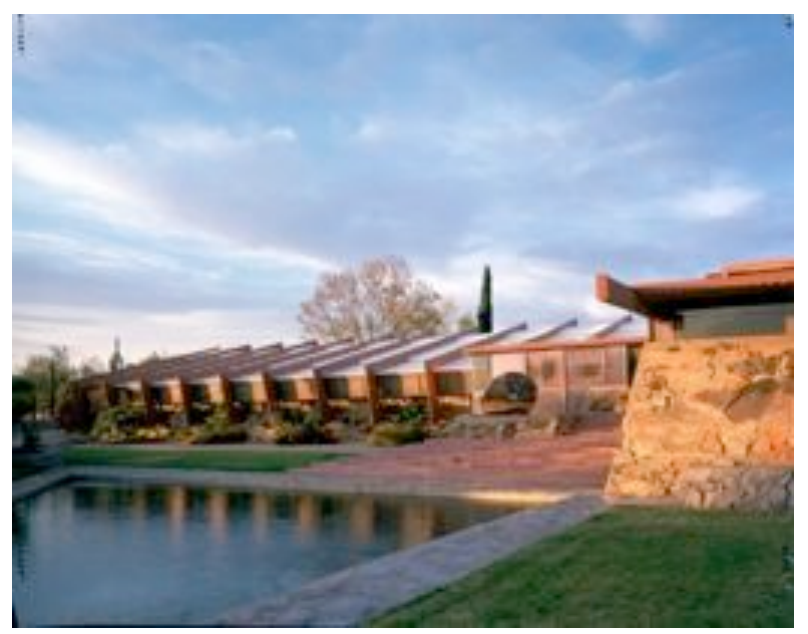

Mas o reflexo decisivo da obra de Wright no Brasil dá-se porém através de João Batista Vilanova Artigas (1915-1984), e sintomaticamente em São Paulo, já que o Rio de Janeiro se consolidara como "território dos corbusianos".

A pesquisa formal de Artigas, em torno do ano de 1940, começou a mostrar preocupações com tentativas de racionalizações e explorações com outras linguagens que não fossem variações ecléticas. O primeiro referencial identificável em sua 
produção veio da arquitetura norte americana, na produção de Frank Lloyd Wright nas Prairie Houses. ${ }^{16}$

Muitas são as referências que ajudam a compreender melhor os aspectos da obra de Wright que podem ter sido assimilados por Artigas, como nos mostra muito bem IRIGOYEN ${ }^{17}$, e é possível detectar diferentes vertentes na sua obra, mas é a residência Rio Branco Paranhos de 1943, segundo a mesma autora, a única nitidamente inspirada nas Prairie Houses, e talvez por esse motivo tenha se convertido na obra emblemática deste período wrightiano da obra de Artigas.

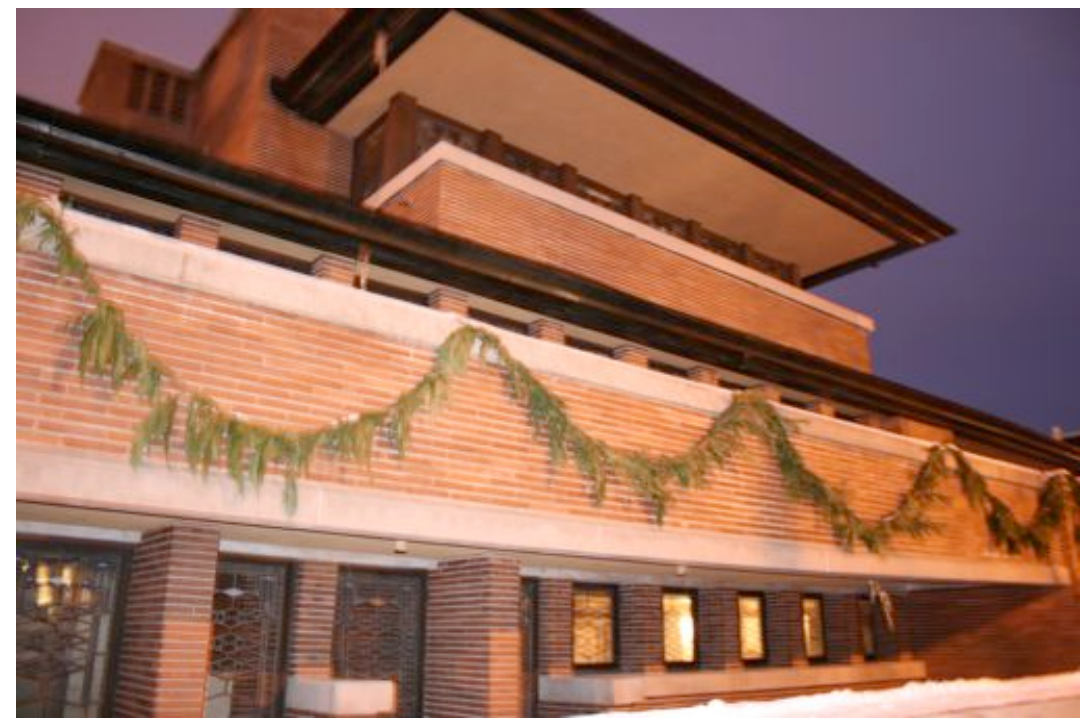

IMAGEM 31: Robie House 1908-1910. Hyde Park, Chicago, Illinois, USA. Arquitetura: Frank Lloyd Wright. Foto: Débora Lima.

As Prairie Houses, constituídas de longas linhas horizontais baixas que se desenvolviam paralelamente ao lado plano do terreno, com seus vastos telhados que se esparramavam em direção ao entorno e amarravam as varandas e os principais volumes em uma unidade assimétrica e dinâmica inspiraram Artigas nesta casa em São Paulo. As janelas eram reduzidas a meros filtros de luz - havia poucas paredes sólidas - e os espaços internos estavam interligados.

Enfim, como sabemos, ao longo dos anos, Frank Lloyd Wright reassume seu papel de inovador da Arquitetura Moderna com a realização da Edgar J. Kaufmann House (Fallingwater) entre 1934-37. Nesta casa ele explicita como em nenhuma outra sua teoria orgânica, desenvolvimento lógico de uma extensa e complexa obra que a antecede.

\footnotetext{
${ }^{16}$ MATERA, Sérgio, Carlos Millan: Um estudo sobre a produção em arquitetura. São Paulo, 2005. Dissertação (Mestrado). Curso de Pós-Graduação em Estruturas Ambientais Urbanas. Faculdade de Arquitetura e Urbanismo - USP, p. 54

17"Wright e Vilanova Artigas" In RIGOYEN, Adriana. Wright e Artigas - Duas Viagens. São Paulo: Ateliê Cultural, 2002, pp. 128-146.
} 


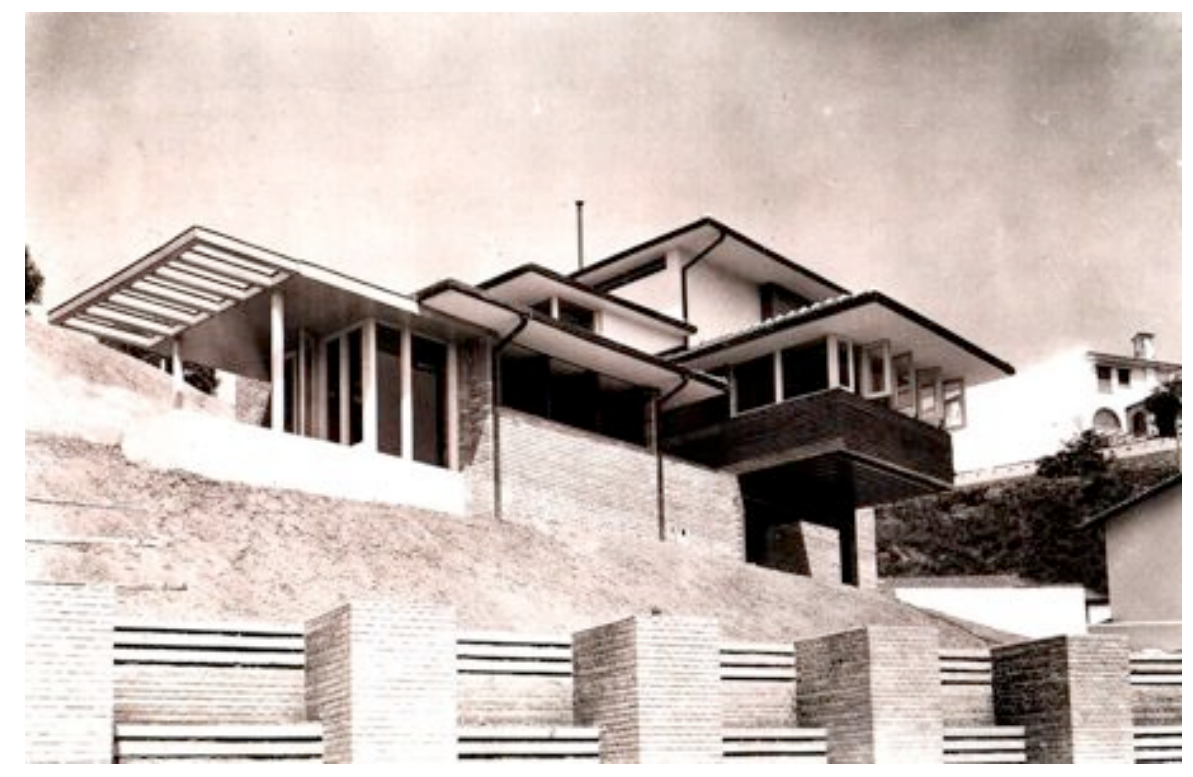

IMAGEM 32: Residência Rio Branco Paranhos. 1943. São Paulo, São Paulo, Brasil. Arquitetura: Vilanova Artigas.

A razão de sua menção é a dissolução de um pequeno "mito" presente na historiografia da Arquitetura Brasileira, segundo o qual Wright

teria se inspirado no terraço da Casa da Rua Toneleros de Warchavchik ao concebê-la. Fica clara a necessidade de autoafirmação dos brasileiros ao longo dos anos 30 e 40, até que a nova Arquitetura se consolidasse. ${ }^{18}$

É interessante constatar como Frank Lloyd Wright é, entre todos os Grandes Mestres do Movimento Moderno (Mies, Le Corbusier, Aalto, Gropius), o menos conhecido dos brasileiros.

Segundo Fujioka $^{19}$ a historiografia wrightiana permaneceu relativamente escassa, em comparação com a dos outros arquitetos, até a década de 80. "E no Brasil, estuda-se muito mais a obra de Le Corbusier do que a de Wright (pela influência que o primeiro teve na formação da Arquitetura Moderna Brasileira). Isto confirma-se pelas dúvidas e discussões que sempre ocorrem durante a apresentação de qualquer aula, palestra ou debate sobre Wright."

O trabalho deste pesquisador coloca uma questão muito interessante sobre a obra do grande arquiteto, dentro do seu conceito de arquitetura orgânica, e opta pelo aprofundamento num tema ainda pouco explorado: a influência do Romantismo do século XIX, entendendo-se o organicismo como invenção ou reinvenção romântica que leva a uma arquitetura totalmente original.

\footnotetext{
${ }^{18}$ NEDEL YKOV, Nina; MORERA, Pedro. Caminhos da Arquitetura Moderna no Brasil: A presença de Frank Lloyd Wright. Arquitextos018 (Romano Guerra Ed. Ltda.). São Paulo, Portal Vitruvius, agosto 2001.

${ }^{19}$ FUJIOKA, Paulo Y. Princípios da arquitetura de Frank Lloyd Wright e suas influências na arquitetura moderna paulistana. São Paulo, 2003. Tese (Doutorado). Curso de Pós-Graduação em Estruturas Ambientais Urbanas. Faculdade de Arquitetura e Urbanismo - USP.
} 


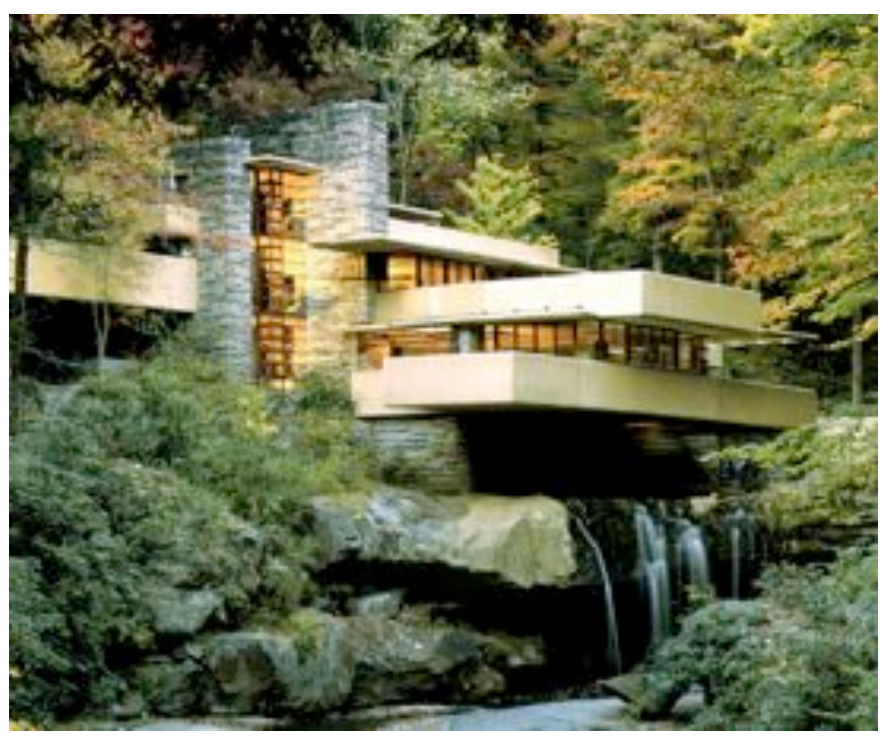

IMAGEM 33: Fallingwater/Kaufmann's House 1936. Pittsburgh, Pennsylvania, USA Arquitetura: Frank Lloyd Wright.

Segundo o mesmo autor, na obra de FLW, a influência romântica manifesta-se através de fenômenos pouco avaliados na historiografia wrightiana, como o culto à natureza, a invocação do ideal medieval (a partir do Arts \& Crafts) e o orientalismo, ou seja, inspiração na arte e literatura das civilizações não classicistas (maia, indígena, japonesa, chinesa, celta-gaélica), que terão, sim, alguns seguidores entre os arquitetos brasileiros.

$E$ isso nos leva a outra vertente de pesquisa, que é o estudo sobre profissionais japoneses que tomaram contato com a obra do mestre e emigraram para o Brasil a partir dos anos 20.

\section{5: Visita de Le Corbusier aos EUA}

Cabe aqui inserir esta interação importante que Le Corbusier teve com os Estados Unidos, fato não muito lembrado, mas que devido ao papel que este arquiteto teve no desenvolvimento de nossa arquitetura moderna, principalmente a partir de 1936, ganha relevância.

E também porque este fato demonstra a triangulação das trocas que foram feitas entre Europa, Brasil e Estados Unidos no período.

Esta primeira viagem de Le Corbusier para os Estados Unidos é geralmente considerada um fracasso porque não produziu comissões. A experiência, no entanto, teve um efeito profundo sobre ele, tanto pessoalmente como profissionalmente.

Patrocinada pelo MoMA de Nova York, Le Corbusier promoveu suas ideias através de uma turnê de palestras, exposições e conferências de imprensa, bem como em reuniões com empresários, reformadores habitacionais, tecnocratas do New Deal, e editores. Contudo, o objetivo do arquiteto era conhecer os arranha-céus de 


\section{TROCAS, TRANSFERÊNCIAS, DIÁLOGOS E OUTROS CAMINHOS}

Manhattan - modelo contraposto à sua visão da Ville Radieuse - e obter alguma encomenda importante, é claro, na escala urbana. Daí a sua insistência em estabelecer contatos com empresários.

Sua ilusão era convencer Nelson Rockefeller a promover um investimento imobiliário em Nova York, ou colaborar com suas iniciativas culturais e a publicação dos seus livros em inglês. Corbusier queria persuadir o magnata a participar da Exposição Internacional de 1937, em Paris, ou a solicitar-lhe o projeto de um pavilhão para a Feira Mundial de Nova York, em 1939, que já começava a ser organizada. ${ }^{20}$

Nada disso foi concretizado. Em primeiro lugar, porque os Estados Unidos saíam lentamente da crise de 1929. Em segundo, porque suas teses radicais e sua personalidade difícil não obtiveram o apoio esperado da classe profissional e das instituições universitárias.

Como mencionam FRAMPTON e MUNFORD ${ }^{21}$, e como já bem sabemos, no inicio dos anos 1930, Le Corbusier "saw no conflct in attempting to work for a variety of 'authorities' ranging from wealthy private patrons to governments of both the right and left, including the Soviet Union, the Second Spanish Republic, Fascist Italy, the Brazilian dictatorship of Getúlio Vargas, the French Popular Front government of Leon Blum, and eventually the Vichy regime. He was prescient at this time in realizing that in the future the operations of large corporations would have many similarities to bureaucratic regimes of both the left and the right. As Le Corbusier saw it, for an urban designer what mattered most in a client was simply the power to override opposition to reconfiguring the metropolitan environment according to his directives."

Assim, seu grupo de interlocutores nos Estados Unidos foi limitado a Wallace K. Harrison, William Lescaze, Paul Nelson, Albert Fry e Richard Neutra, entre outros. Nunca obteve a entrevista solicitada a Wright, que se negou a recebê-lo em Taliesin.

O início do interesse do MoMA na superação das limitações de vocabulário e sintaxe do estilo internacional e da estética que a própria Instituição promovera, em 1932, via Modern Architecture: International Exhibition e seu catálogo, The International

\footnotetext{
${ }^{20}$ SEGRE, Roberto, O sonho americano de Oscar Niemeyer, Le Corbusier e as Américas In Revista aU, edição 165, dezembro de 2007. 
Style: Architecture since $1922^{22}$ se evidencia na mostra "Recent works by Le Corbusier", no mesmo ano da visita do arquiteto ao país, em 1935.

No entanto, ele voltou para a França de mãos vazias e publicou um relato amargo, Quand les cathédrales étaient blanches: voyage au pays des timides (Quando as Catedrais eram brancas: Viagem ao País dos tímidos), em que diz que falta a América a coragem de adotar suas ideias.

No primeiro grande estudo sobre a visita de Le Corbusier aos EUA, Mardges Bacon reconstrói seu encontro com a América em todos os seus detalhes fascinantes. Através de extensa pesquisa a arquivos e entrevistas, ela apresenta uma história crítica do passeio, bem como um retrato sutil e íntimo do arquiteto. ${ }^{23}$

Bacon observa que o diálogo de Le Corbusier com a América foi elaborado dentro de um discurso europeu animado pelo "americanismo". Ela afirma que a viagem teria validado seu conceito de uma "second machine age" que uniria padronizados métodos industriais com um novo humanismo. O trabalho posterior de Le Corbusier, ela sugere, reflete uma "americanização", evidenciada pela introdução de estruturas de tensão e os arranha-céus texturizados concebidos com um sistema integrado com funções articuladas. Ela também define o papel de Le Corbusier no debate acerca do "New York City high-rise public housing".

Essa viagem foi também, de certa forma, a germinação de um encontro que mudaria para sempre a história da nossa arquitetura moderna, o seu com Oscar Niemeyer, arquiteto que teria com este um diálogo assimétrico nas mútuas interações na América Latina, Estados Unidos e Europa. ${ }^{24}$

Interação esta que teve dois momentos diferenciados, primeiro com a estreita afinidade vivida durante o mês de trabalho conjunto para o desenvolvimento do projeto do Ministério de Educação e Saúde, no Rio de Janeiro (1936) e, mais tarde, a forma como pavimentou o caminho e garantiu a Lucio Costa e Oscar Niemeyer uma boa

\footnotetext{
22Philip Johnson e Henry-Russell Hitchcock selecionam então setenta e duas obras construídas entre 1926 e 1931. A representação latina se limita à França, a americana aos Estados Unidos, a asiática a um exemplo no Japão. A representação alemã impressiona pelo número, Le Corbusier e Mies atraem pela qualidade. O Pavilhão de Barcelona e a casa de Mandrot são exceções no universo de caixas brancas e ar fabril, típicas duma década preocupada com a expressão do espirito da época. Frank Lloyd Wright não é representado na mostra. ${ }^{23} \mathrm{BACON}$, Mardges. Le Corbusier in America: Travels in the Land of the Timid. Cambridge: The MIT Press, 2003. 
acolhida nos Estados Unidos, em 1938, quando estes permaneceram nos Estados Unidos por alguns meses para desenvolver o projeto do Pavilhão do Brasil na New York World's Fair de 1939-40.

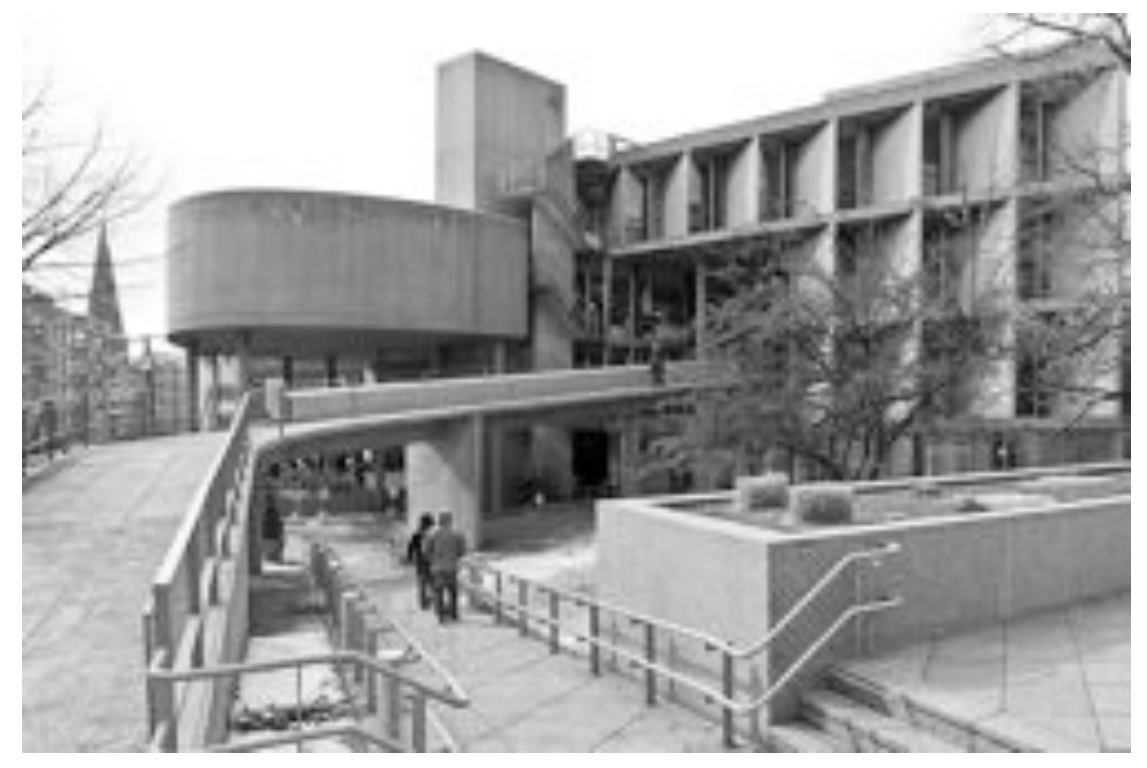

IMAGEM 34: Carpenter Center for the Visual Arts - Harvard University. 1960-1963. Cambridge, Massachusetts, USA. Arquitetura: Le Corbusier.

Nos Estados Unidos, além da sede da ONU, em cujo projeto participaria junto com Niemeyer e a equipe internacional liderada por Wallace K. Harrison, Corbusier construiu somente o Carpenter Center, em Harvard, Massachusetts.

\section{5: Início do projeto Case Study Houses, Califórnia, USA}

Além das trocas ocorridas entre os arquitetos brasileiros com aqueles atuantes na costa leste dos EUA, importantes foram também os contatos feitos com os arquitetos que vinham simultaneamente desenvolvendo uma arquitetura própria na costa oeste. É comprovado o interesse dos arquitetos, principalmente os paulistas, pela arquitetura moderna californiana, a qual transplantaram para o Brasil com um caráter local.

A coincidência temporal entre o projeto californiano "Case Study Houses", dirigido por John Entenza da Arts \& Architecture Magazine a partir de $1945 \mathrm{com}$ o boom da arquitetura moderna brasileira não pode ser desmerecida. 
O Programa Case Study Houses (P.C.S.H.) $)^{25}$ se baseou em "experimentos" na arquitetura residencial americana, patrocinados pela revista, que comissionou alguns dos arquitetos mais importantes da época, incluindo Richard Neutra, Raphael Soriano, Craig Ellwood, Charles \& Ray Eames, Pierre Koenig, Eero Saarinen, entre outros, para projetar e construir baratas e eficientes casas modelo para o boom imobiliário americano causado pelo fim da II Guerra Mundial e o retorno de milhões de soldados.

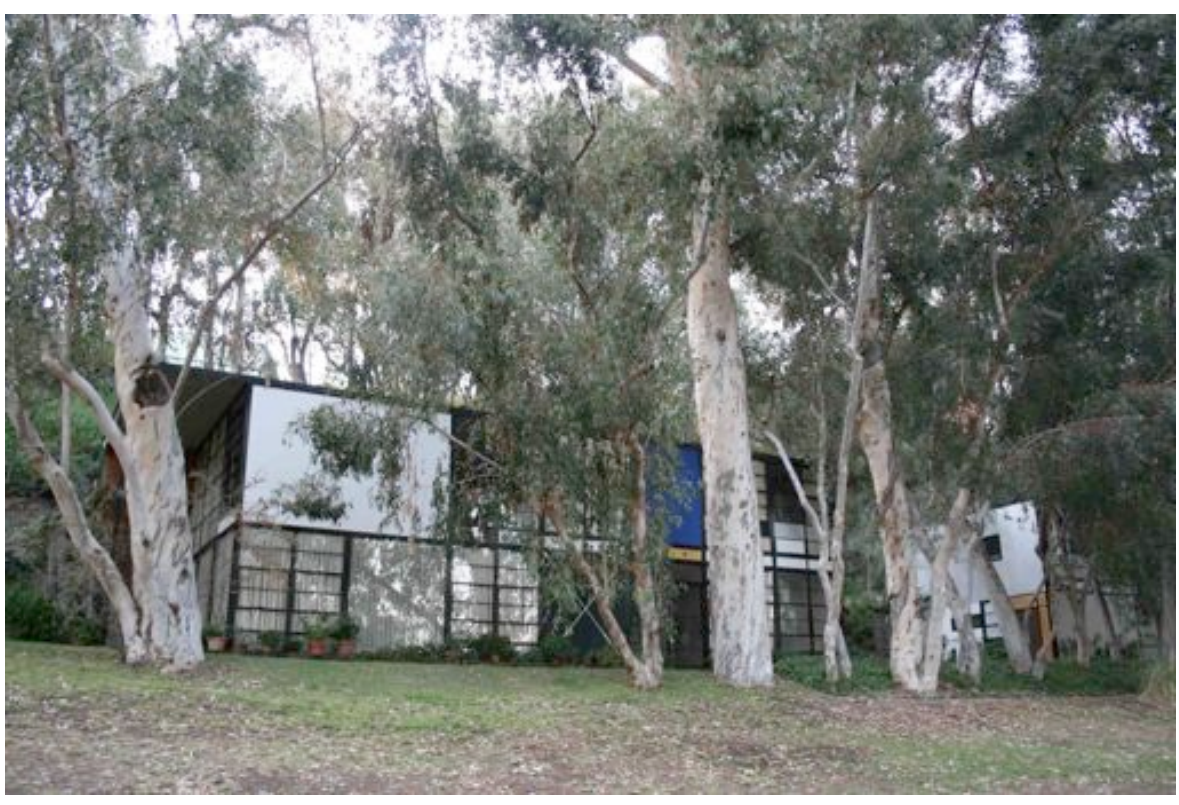

IMAGEM 35: Case Study House \#8, Eames House. 1949. Pacific Palisades, Califórnia, USA. Arquitetura: Charles e Ray Eames. Foto: Débora Lima

O programa funcionou de forma intermitente de 1945 a 1966, sendo que os projetos foram amplamente divulgados e obtiveram uma aceitação local muito grande, virando inclusive atração turística, na época e ainda hoje.

O principio dos projetos era bastante simples e incrivelmente interessante e eficiente, reproduzindo um jeito moderno de viver que poderia ser seguido, em termos, em qualquer parte do mundo, mas principalmente em locais de clima quente, como o

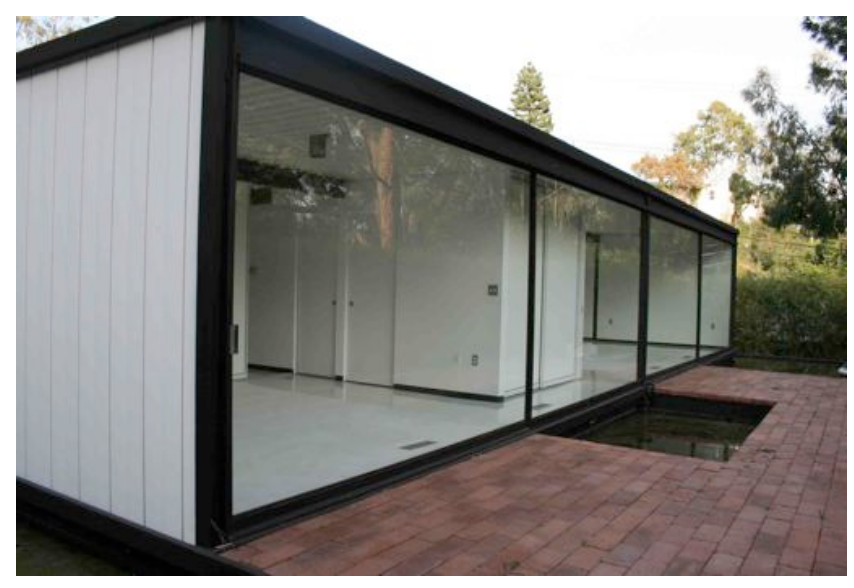
Brasil e Los Angeles, cidade sede da maioria das casas. Sem contar na facilidade e baixo custo das construções.

IMAGEM 36: Case Study House \#21, Bailey House, 1958. West Hollywood, Califórnia, USA Arquitetura: Pierre Koenig. Foto: Débora Lima.

\footnotetext{
${ }^{25}$ Conhecer mais sobre este Programa em SMITH, Elizabeth A. T. Case Study Houses, 1945-1966 - The California Impetus. Köln: Taschen, 2007.
} 
No entanto, no Brasil, este intuito foi de certa forma desvirtuado, e as elegantes e espaçosas residências construídas muitas delas no rico bairro paulistano do Morumbi e que tiveram influências do Programa foram destinadas às classe altas.

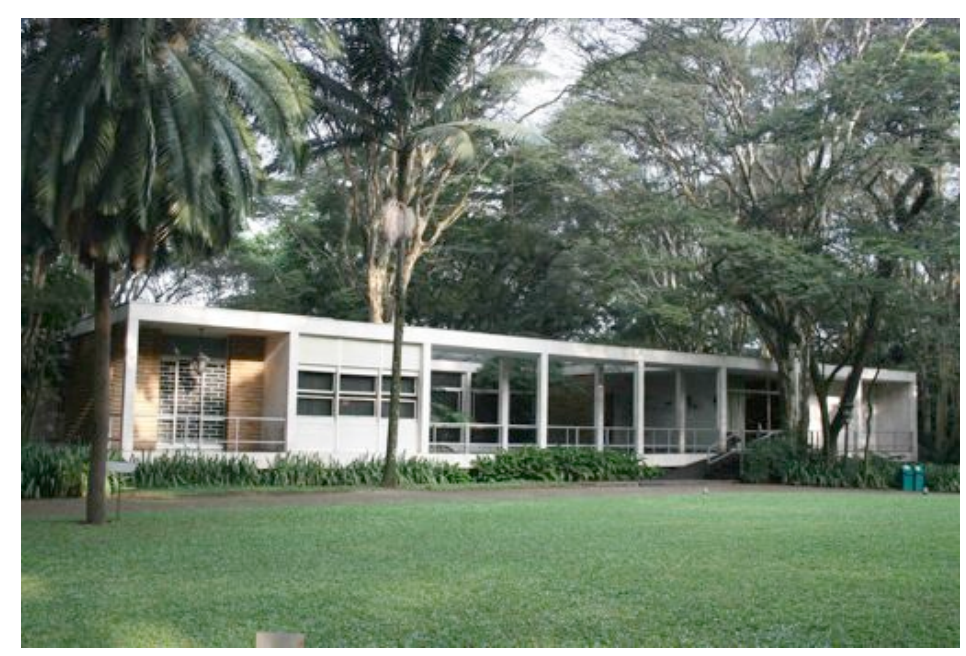

IMAGEM 37: Residência Maria Luísa e Oscar Americano. 1950. São Paulo, São Paulo, Brasil. Arquitetura: Oswaldo Arthur Bratke. Foto: Débora Lima.

Porém não em todos os casos, como nos mostrou IRIGOYEN ${ }^{26}$, de forma muito interessante, em sua abordagem sobre esta ligação, que faz em seu trabalho "Da Califórnia a São Paulo: referências norte-americanas na casa moderna paulista 19451960", aonde relaciona projetos de vários arquitetos - Oswaldo Arthur Bratke, Rino Levi, entre vários outros - e busca semelhanças e precedentes nesta arquitetura californiana.

O que nos parece também interessante destacar aqui é um novo ponto colocado por CUNHA ${ }^{27}$, sobre a influência deste programa na obra de Vilanova Atrigas do período.

Artigas realizou uma viagem de estudos aos Estados Unidos entre 1946 e 1947 e visitou projetos e arquitetos tanto na costa leste quando na costa oeste, o que marcaria muito a sua carreira.

Neste artigo o autor trata do que esse chama de delimitação do espaço através de uma única cobertura ${ }^{28}$, e da projeção da sombra resultante, que esteve presente ao

\footnotetext{
${ }^{26}$ RIGOYEN, Adriana. Da Califórnia a São Paulo: referências norte-americanas na casa moderna paulista 19451960. São Paulo, 2005. Tese (Doutorado). Curso de Pós-Graduação em Estruturas Ambientais Urbanas Faculdade de Arquitetura e Urbanismo - USP.

${ }^{27}$ CUNHA, Marcio Cotrim. Mies e Artigas: a delimitação do espaço através de uma única cobertura Arquitextos108.01 (Romano Guerra Ed. Ltda.). São Paulo, Portal Vitruvius, ano 09, maio 2009.

${ }^{28} \mathrm{~A}$ imagem da cobertura única ao longo da cultura arquitetônica do século XX foi significativa, manifestando-se em diferentes contextos, programas e escalas através de distintas soluções e materiais; foi marcada, de um lado, por um forte caráter simbólico impregnado no conceito de abrigo, e de outro, pelo necessário avanço
} 
longo de praticamente toda a obra desse arquiteto a partir de meados dos anos 1950, e que terá tido uma ligação com essa arquitetura da costa oeste americana.

E, dessa maneira, passaria por alguns projetos norte-americanos do final dos anos 1940 e início dos anos 1950, nos quais os arquitetos se debruçaram na tentativa de redefinição da casa para uma classe média emergente do pós-guerra, e dentro deste contexto se inserem as Case Study Houses, que iriam ter seguidores, obviamente, no Brasil, e na arquitetura aqui desenvolvida.

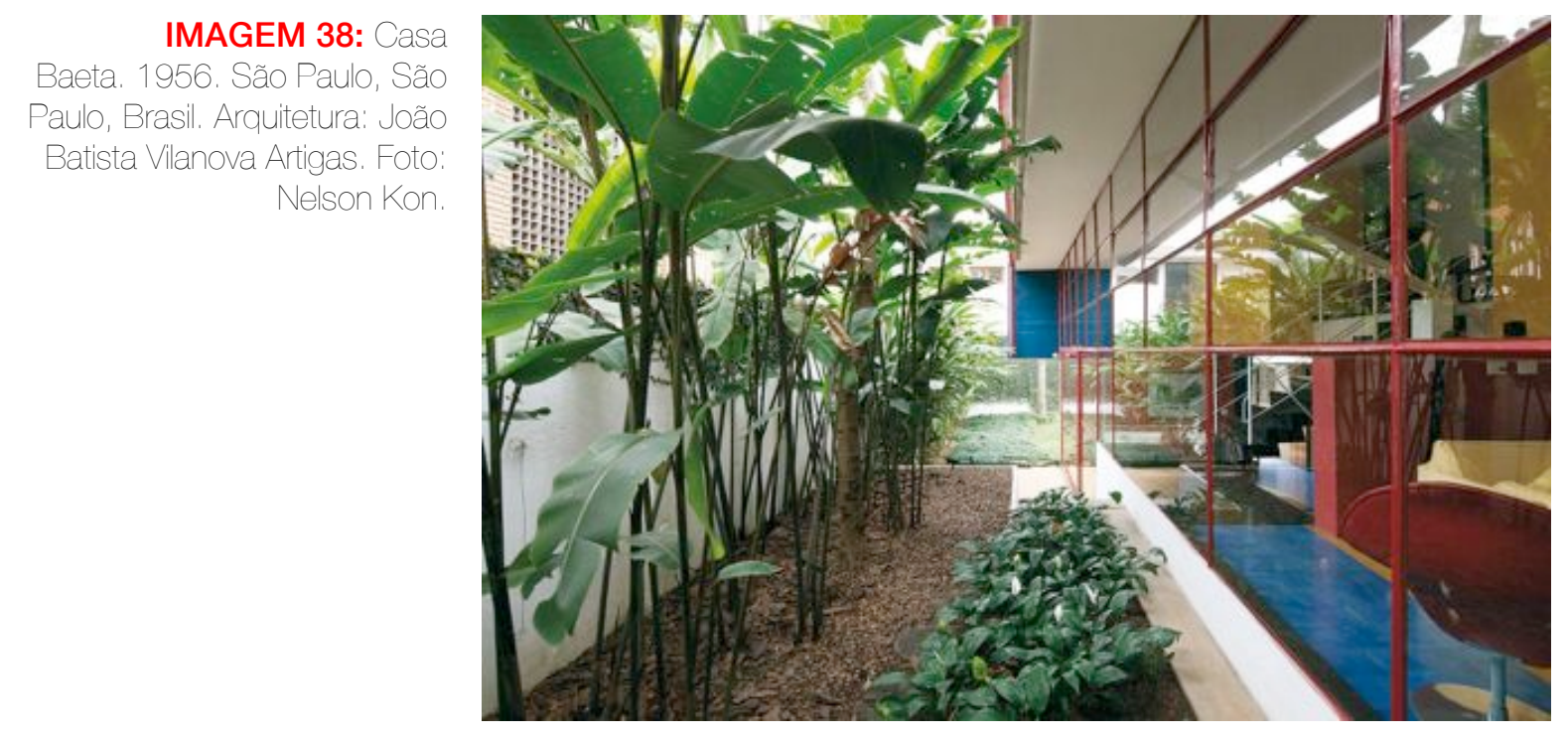

Segundo Artigas, em uma entrevista nos anos 1980, a partir da segunda metade da década de 1940: "[foi] necessário mudar a tipologia da casa paulistana. Tratava-se de modificar a divisão interna da casa da classe média paulista, que necessitava se atualizar em relação às modificações sociais que se processavam neste país"29

Dando continuidade a estes argumentos, podemos considerar o projeto elaborado pelo casal Eames e E. Saarinen para a casa de número nove do programa Case Study House, publicado na revista A\&A em dezembro de 1945. Hugo Segawa, em seu livro Arquiteturas no Brasil: 1900-1990 chamou a atenção para a possível influência deste programa na obra de Artigas. Segundo Segawa: "Não se deve 
descartar, também, uma influência da visão 'industrializável' da arquitetura norteamericana"30

À parte das possíveis questões vinculadas ao processo de industrialização dos componentes arquitetônicos, todo o programa da Case Study House n9, incluindo a garagem - assim como no sistema prevalecente na obra de Artigas a partir da segunda metade dos anos 1950 - foi contido sob uma única cobertura, neste caso retangular, formada por quatro módulos com quatro pilares em cada uma de suas extremidades. $^{31}$

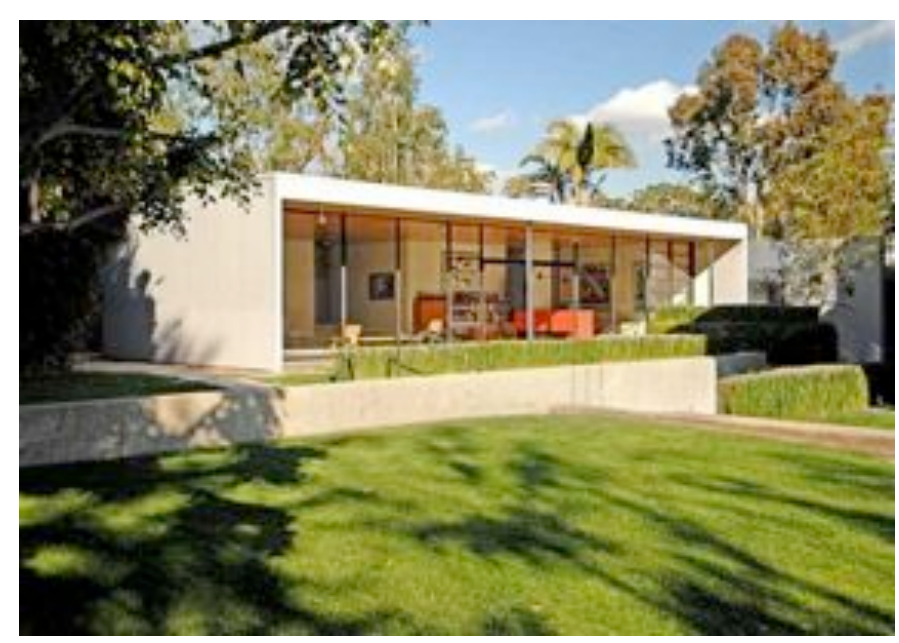

IMAGEM 39: The Entenza House/Case Study House \#9. 1949. Pacific Palisades, Califórnia, USA. Arquitetura: Charles Eames e Eero Saarinen.

Todas estas proximidades que estamos tentando fazer entre a arquitetura moderna brasileira desenvolvida no período com aquela produzida também na costa oeste dos EUA, e que efetivamente ocorreram, se encaixam plenamente no quadro em que estavam as cidades brasileiras naquela época, principalmente São Paulo, em função de seu perfil industrial, e que não poderiam desejar um modelo mais apropriado que os Estados Unidos, cuja presença ganha enorme visibilidades nestes anos, e sua penetração não se limita à área econômica, sendo que este processo de americanização atingiu, pouco a pouco, todas as esferas, e o american way of life irrompe nos novos bairros ajardinados da cidade.

Impulsionados pela crescente relação da cidade com os Estados Unidos, alguns arquitetos de São Paulo sentem-se atraídos pelas novidades que chegam do

\footnotetext{
${ }^{30}$ CUNHA, op. cit,

${ }^{31}$ Para a relação entre a obra de Vilanova Artigas e o P.C.S.H. ver: COTRIM, Marcio. João Batista Vilanova Artigas: Doze casas paulistas, 1942 a 1969. Dissertação de Mestrado, Barcelona, ETSAB, 2002.
} 
Norte. Revistas especializadas circulam entre os profissionais locais. Architectural Forum, Architectural Record, Pencil Points, Progressive Architecture e Arts \& Architecture se convertem em fonte de inspiração e aprendizagem. Livros como Built in USA 1932-1944 ou Modern House constituem referências para uma geração que tenta abrir caminho em um meio dominado por arquitetos formados na tradição acadêmica. Também as revistas locais abrem espaço para a nova arquitetura americana. ${ }^{32}$

Deste mesmo modo, alguns outros pontos importantes e relevantes a que também estiveram ao entorno do programa P.C.S.H. dentro da cultura arquitetônica brasileira podem ser aqui destacados:

Em 1937, a revista da Escola de Engenharia do Mackenzie (São Paulo), publica um resumo de "New Building Art in California", de Richard Neutra. ${ }^{33}$

A exposição sobre arquitetura contemporânea na Califórnia, no San Francisco Museum of Art, que gera a publicação, na revista Time em 20 de abril de 1942, do texto intitulado "New California Architecture", a qual os arquitetos brasileiros com certeza tiveram acesso.

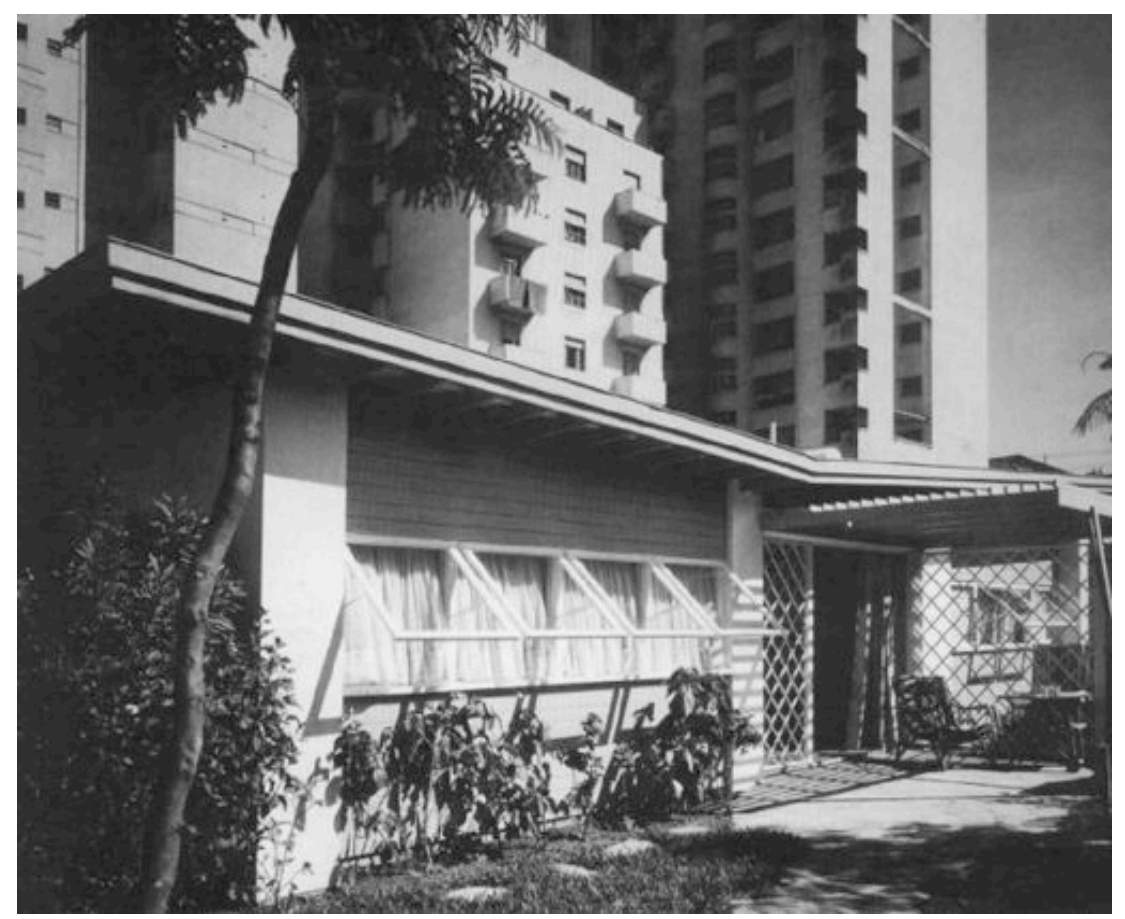

A publicação da casa da Rua Avanhandava, em São Paulo, de Oswaldo Arthur Bratke, de 1948, na revista Arts \& Architecture, a mesma que havia criado 0 Programa Case Study Houses 3 anos antes.

IMAGEM 40: Casa e estúdio do arquiteto na rua Avanhandava, 1945. São Paulo, São Paulo, Brasil. Arquitetura: Oswaldo Arthur Bratk

\footnotetext{
${ }^{32}$ IRIGOYEN, Adriana. Wright e Artigas - Duas Viagens. São Paulo: Ateliê Cultural, 2002, p. 116.

${ }^{33} \mathrm{O}$ mesmo arquiteto publicaria, em 1948, no Brasil, o livro "Arquitetura social em países de clima quente", e, segundo Hugo Segawa, foi o "único arquiteto estrangeiro nesses anos com uma publicação bilíngüe editada no Brasil".
} 
A também publicação do livro sobre as obras de Richard Neutra por Pietro Maria Bardi, em 1951, e a "intenção" de se fazer uma exposição sobre suas residências no MASP de São Paulo.

A partir de 1950, um grupo de estudantes do Mackenzie (Carlos Millan, Jorge Wilheim, Luiz Roberto Carvalho Franco, Paola Tagliacozzo e Sidney Fonseca) inicia a publicação da revista Pilotis, que se tornará o principal instrumento de resistência dos alunos na defesa dos postulados da arquitetura moderna contra a atitude conservadora e intransigente do diretor da escola, Christiano Stockler das Neves. Um projeto de Richard Neutra é publicado nessa revista e ela é enviada para Neutra que inclusive parabeniza a publicação.

A premiação de Craig Ellwood, autor da Case Study House n¹6, na Bienal de Arquitetura de São Paulo de 1953.

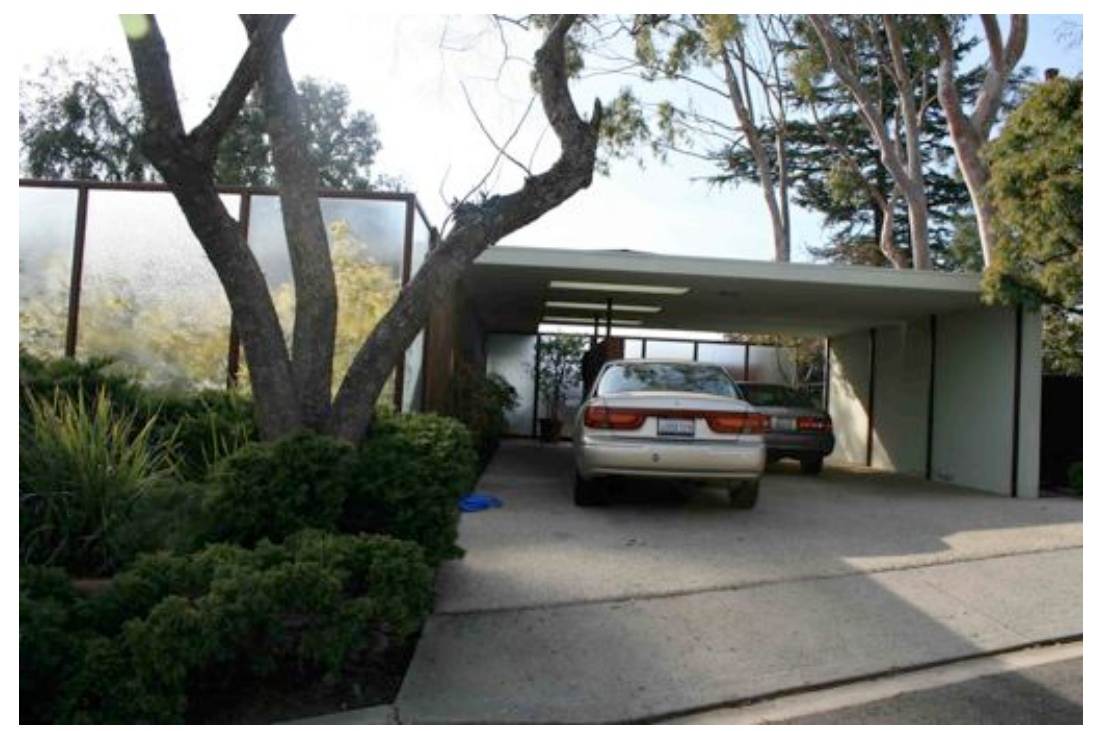

IMAGEM 41: Case Study House \#16. 1951-1952. Bel Air, Califórnia, USA. Arquitetura Craig Ellwood. Foto: Débora Lima.

Todos estes pontos de ligação e trocas ocorridas foram importantes e tiveram, sim, desdobramentos em nossa arquitetura local. E, como resultado disso, é possível estabelecer certos paralelos entre a arquitetura residencial estadunidense e sua equivalente em São Paulo. E, "poder-se-ia dizer que essa relação é determinada por três elementos. Existe uma população de imigrantes enriquecidos, ávidos por um modelo próprio. A industrialização favorece a importação de novas tecnologias. E, por último, é evidente um sincero pragmatismo, como aquele que caracteriza os pioneiros de Chicago". ${ }^{34}$

Hoje, as casas do P.C.S.H., e outras projetadas por arquitetos que fizeram parte do projeto, alcançam valores altíssimos no mercado imobiliário americano, principalmente se considerarmos suas metragens, relativamente pequenas.

${ }^{34}$ RIGOYEN, Adriana. Wright e Artigas - Duas Viagens. São Paulo: Ateliê Cultural, 2002, p. 116 


\section{5: Visita de Richard Neutra ao Brasil}

O impacto do abrangente trabalho de Richard Neutra na arquitetura brasileira ainda está por ser devidamente estudado. Sabe-se, entretanto, que seus projetos habitacionais na Califórnia e sua atuação no Programa Case Study Houses eram conhecidos pelos arquitetos brasileiros atuantes no período.

Richard Neutra é considerado uma das figuras centrais do movimento moderno em arquitetura. ${ }^{35} \mathrm{Em} \mathrm{1923,} \mathrm{depois} \mathrm{de} \mathrm{anos} \mathrm{de} \mathrm{tentativas,} \mathrm{finalmente} \mathrm{emigrou} \mathrm{para} \mathrm{os}$ EUA - como o fariam também vários outros arquitetos europeus - chegando inicialmente na cidade de Nova York, sendo que depois de 4 meses fixou-se em Chicago, onde se engajou em sua primeira experiência com construções de grande escala.

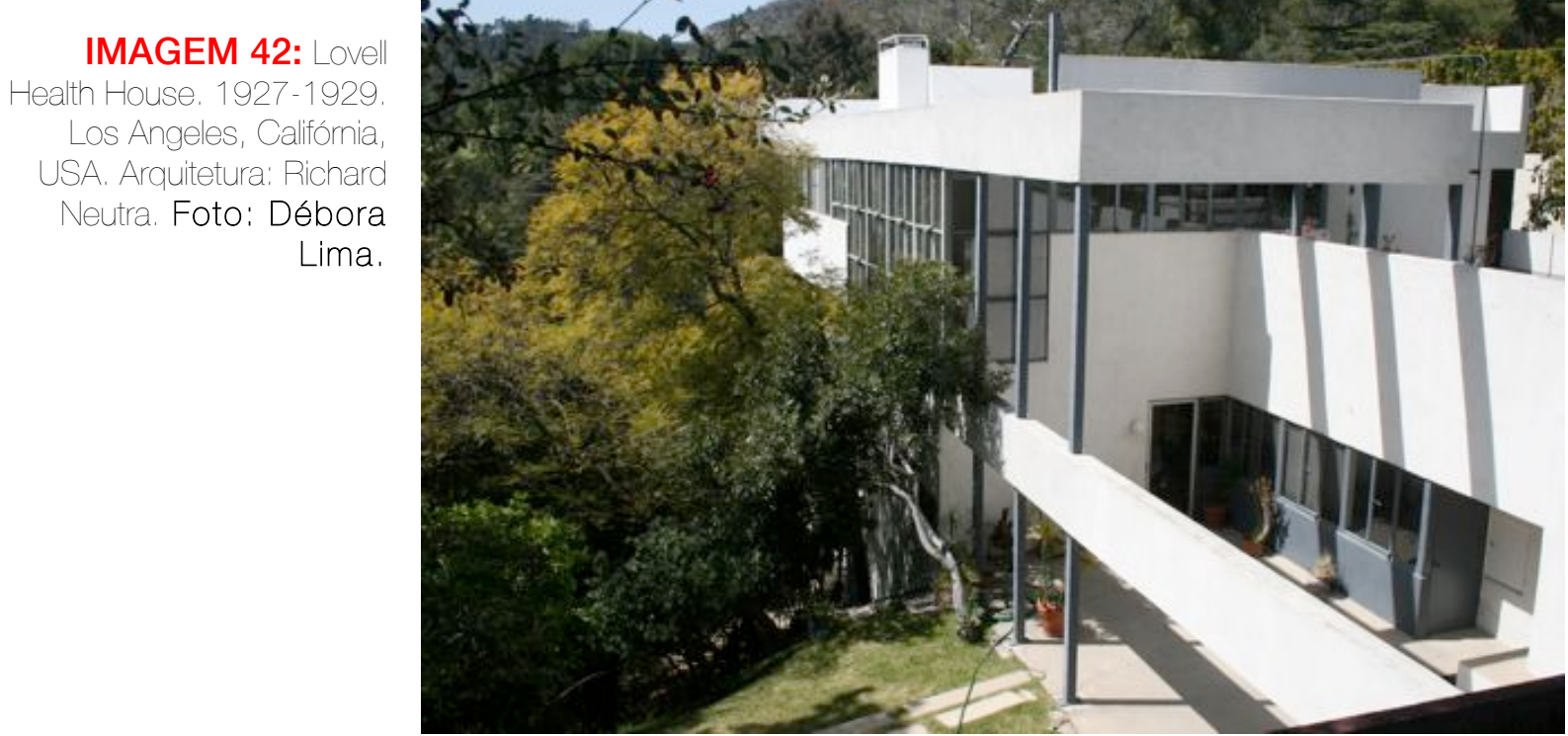

Seus esforços em encontrar o seu lugar no Novo Mundo, o fascínio pela metrópole moderna, o arranha-céu e os novos métodos de construção logo o conduziriam a um posto destacado na cena arquitetônica norte-americana. ${ }^{36}$

\footnotetext{
${ }^{35}$ Em Viena foi aluno de Adolf Loos (1870-1933). Em 1914, sua educação foi subitamente interrompida pela Guerra, quando foi enviado ao front nos Bálcãs. Em 1918, depois que concluiu o curso em Viena com o armistício, transferiu-se para a Suíça e, em 1920, para a Alemanha, onde atuou em Luckenwald e Berlim, inclusive como colaborador no escritório de Erich Mendelsohn (1887-1953). Thomas Hines. Richard Neutra and the search for Modern Architecture. New York: Rizzoli, 2005; Arthur Drexler and Thomas Hines. The Architecture of Richard Neutra: from international Style to Callfornia Modern. New York: The Museum of Modern Art, 1982; Barbara Lamprecht. Neutra, 1892-1970: survival through design. Koln: Tachen, 2006.

${ }^{36}$ LRA, José Tavares Correia de. Richard Neutra, modernismo, tropicalismo e desenvolvimentismo: Aventuras e desventuras de um arquiteto estrangeiro na América Latina. Texto elaborado para o projeto temático Fapesp "São Paulo: os estrangeiros e a construção da cidade", 2011.
} 
Em 1924, juntou-se a Frank Lloyd Wright em sua Taliesin East, em Wisconsin, e pouco depois transferiu-se para Los Angeles para trabalhar com seu compatriota e colega de faculdade Rudolph Schindler, a princípio em comissões de Wright e logo depois na sociedade independente Architecture Group for Industry and Commerce.

Com Schindler, Neutra tomou parte do polêmico concurso de 1926 para a sede da Liga das Nações e, no ano seguinte iniciou, com a obra dos Jardinette Apartments, uma longa e intensa atividade projetual e construtiva nos EUA.

Sua atividade naqueles anos estava tão sintonizada com a experimentação funcionalista europeia do período, que em 1932 ocupou um papel de destaque na famosa Exibição do MoMA, que apresentou pela primeira vez a sua obra nos EUA, ao lado das de Le Corbusier, Walter Gropius, Mies van der Rohe, entre outros, como manifestações pioneiras de um "estilo internacional" contemporâneo.

Tomando parte dos Congressos Internacionais de Arquitetura Moderna desde sua primeira edição em 1928, Richard Neutra foi eleito presidente do CIAM em 1944, quando a organização se transferiu para os EUA durante a guerra. ${ }^{37}$

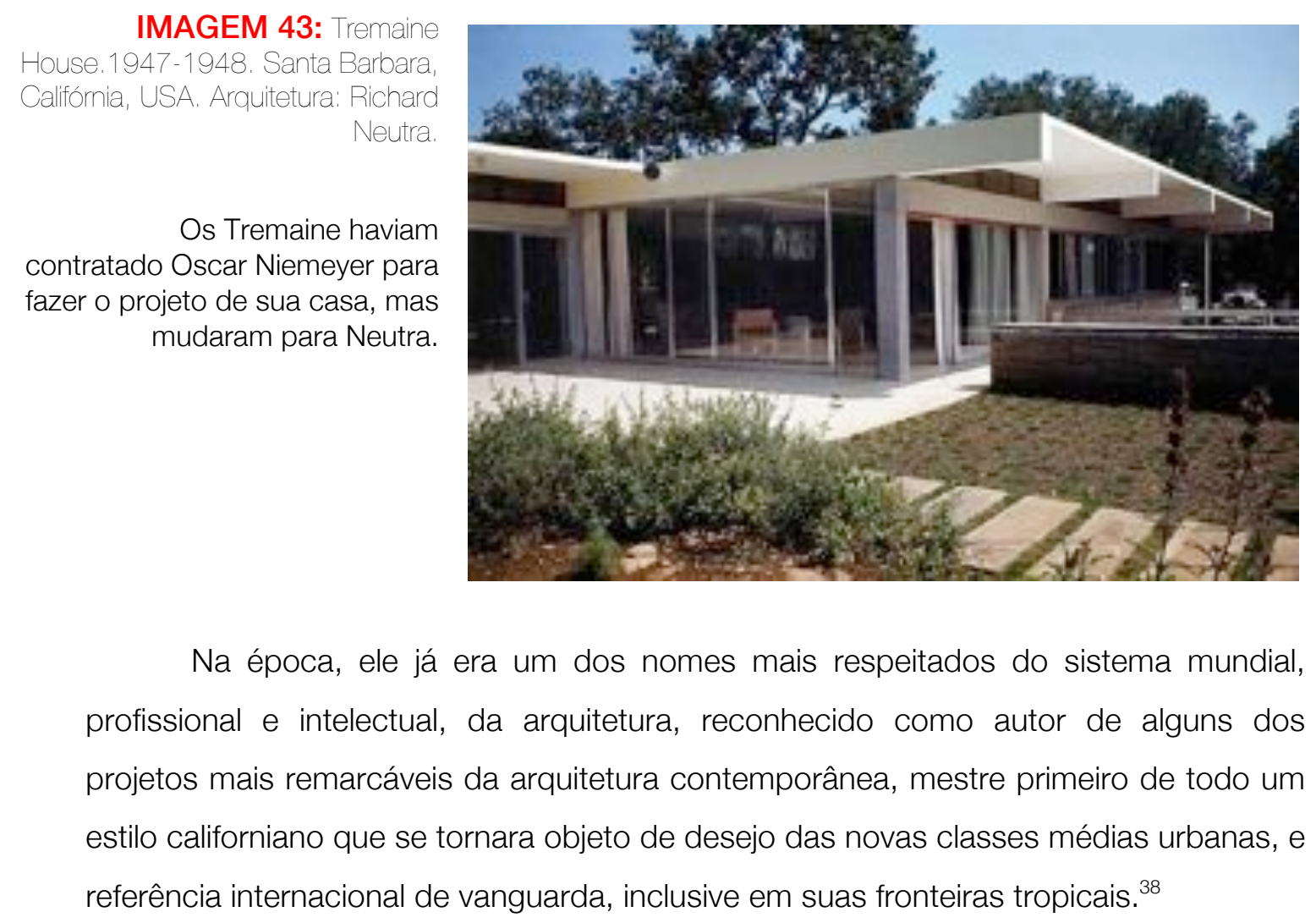

\footnotetext{
${ }^{37}$ MUNFORD, Eric; FRAMPTON, Kenneth. The CIAM discourse on urbanism, 1928-1960. Boston: Massachusetts Institute of Technology, 2000, pp. 142-149 
Para Neutra, viajante que sempre foi, o pós-guerra assinala uma mudança em seus destinos habituais, quando ele dá início a uma longa aventura profissional na América Latina e em outras regiões subdesenvolvidas do planeta.

O que talvez nos interesse diretamente seja a sua atuação como arquiteto a serviço do governo porto-riquenho em 1943-44, e a identificação da gênese de uma estratégia subsequente de afirmação do arquiteto estrangeiro no cenário internacional do pós-guerra, e no seu interior o lugar atribuído às passagens por cidades latinoamericanas, especialmente por São Paulo. ${ }^{39}$

De modo que, pouco depois de sua experiência em Porto Rico, em 1945, embarca em um tour patrocinado pelo Departamento de Estado norte-americano pelo Equador, Peru, Bolívia, Argentina, Uruguai e também Brasil.

Quando o Departamento de Estado dos EUA comissiona Richard Neutra para uma missão de cooperação cultural na América do Sul ele ainda era o presidente do seção norte-americana do CIAM.

O estreitamento das relações entre arquitetura moderna e diplomacia oficial havia concedido à organização maior prestígio técnico e político no enfrentamento das tarefas da reconstrução junto a instituições internacionais como as Nações Unidas e a UNESCO.

Não é irrelevante, aliás, que o projeto de suas sedes em Nova York e Paris, respectivamente, tenham sido entregues a importantes lideranças da agremiação como Le Corbusier, Alvar Aalto, Walter Gropius, Mies van der Rohe, Oscar Niemeyer, Jose Luis Sert, Eero Saarinem, Wallace Harrison, Lucio Costa, Pier Luigi Nervi, Marcel Breuer, Bernard Zehrfuss, Sven Markelius, Ernesto Rogers, entre outros. ${ }^{40}$

Também o Birô de Assuntos Interamericanos, e instituições influentes como o Museu de Arte Moderna de Nova York haviam claramente substituído a União PanAmericana na definição de uma agenda continental de cooperação e intercâmbios culturais, o que incluía o patrocínio da arquitetura moderna. Não apenas Neutra, mas

\footnotetext{
${ }^{39}$ LRA, op, cit.

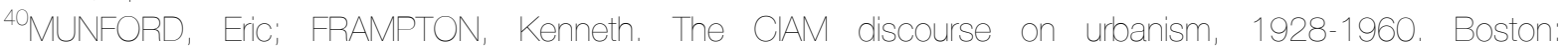
Massachusetts Institute of Technology, 2000, pp. 159-160.
} 
outros arquitetos como Jaqueline Tyrwhitt, Walter Gropius e Kenneth Conant seriam privilegiados pelo Departamento de Estado dos EUA. ${ }^{41}$

Na preparação de sua longa viagem através da região, Neutra contou com o apoio do Birô de Informações das Nações Unidas, tanto para entrar em contato com os escritórios diplomáticos latino-americanos nos EUA, como para organizar as recepções locais e coberturas de imprensa durante a viagem. ${ }^{42}$

Cartas foram pessoalmente enviadas a profissionais e uma longa lista de contatos foi elaborada nos países a serem visitados. No Brasil: no Rio de Janeiro, os arquitetos Oscar Niemeyer, os irmãos Roberto e Henrique Mindlin; em São Paulo, o escritor Sergio Milliet e o arquiteto Rino Levi.

A missão foi empreendida no início de outubro de 1945 e se estenderia até o final de novembro. No Brasil, ele visitou o Rio Janeiro, São Paulo, Belo Horizonte e Ouro Preto. ${ }^{43}$

Em um país que ingressava em intenso processo de industrialização, e cuja arquitetura começava a ser internacionalmente aclamada, a visita de Neutra aparentemente assumiria um sentido menos evangelizador. Mas é evidente o entusiasmo que a produção local lhe suscitara.

Em todo caso contou com enorme hospitalidade, particular, profissional e oficial. Em São Paulo ele foi recebido por Gregori Warchavchik, incluindo um grupo de elite da arquitetura no país, entre nacionais e estrangeiros, entre os quais Henrique Mindlin, Rino Levi, Daniele Calabi, Eduardo Kneese de Mello, Lucyan Korngold e Vilanova Artigas.

No Rio, uma agenda oficial o aproximaria de instituições e autoridades - o prefeito da capital, o Ministro de Relações Exteriores, o embaixador dos EUA, o Instituto de Arquitetos do Brasil, a Escola de Belas Artes, etc. -, mas uma boa parte de seu tempo foi tomado pelas visitas a algumas das mais destacadas obras de

\footnotetext{
${ }^{41}$ LERNUR, J.F. Vanguardistas versus expertos: reconstrución europea, expansión norte-americana y emergencia del "Tercer Mundo": para una relectura del debate arquitectonico en la segunda posguerra (una mirada desde America Latina). Block, n. 6, Buenos Aires, march 2004, p. 25.

${ }^{42}$ UCLA Y Young Research Library/ Special Collections. Richard Neutra Papers: Correspondence. Box 1429, Folder 8: United Nations Information Office: Latin America; Directory Press, Periodical, Radio, News, Photographic Representatives: Latin America, May 1, 1945.

${ }^{43}$ Outras fontes também se referem a visitas à Bahia, Pernambuco, Maranhão e a Amazônia.
} 
arquitetos brasileiros como Oscar Niemeyer, Jorge Moreira, Lucio Costa, os irmãos Roberto, Burle Marx, Affonso Reidy entre outros.

Em toda parte, nas visitas e palestras, no encontro com colegas de profissão ou em entrevistas na imprensa, o discurso de Neutra claramente se deslocara do elogio do planejamento para a ética e o compromisso social do planejador, oscilando entre "os requisitos sociais e comunitários" do projeto e "a responsabilidade social do arquiteto" ou a "arquitetura para o povo em geral." ${ }^{\text {"4 }}$

O papel estratégico atribuído a toda essa movimentação do arquiteto pelo continente pode ser verificada na extensa correspondência que trocou com políticos locais, lideranças profissionais e acadêmicas, editores, assim como com colegas arquitetos, artistas e estudantes dos mais diversos países.

Suas oportunidades profissionais nos EUA não eram à época muito promissoras. Como o próprio Neutra observaria, a América Latina, que até então vinha sendo refreada pelas condições políticas, geográficas e econômicas adversas, tornarase uma nova fronteira a ser explorada. E tomando-se o atraso como vantagem, não era só um território a ser descoberto pelo especialista estrangeiro, mas tinha agora uma chance de "adquirir o desenvolvimento". ${ }^{45}$

O envolvimento em assuntos Interamericanos é, como dissemos, parte de uma estratégia profissional. No contexto do pós-guerra tornara-se uma espécie de elo político e financeiro com as redes de planejamento e desenvolvimento em escala continental. ${ }^{46}$

Nos três dias que passou em São Paulo, Neutra visitou projetos e obras tidos por ele como "impressionantes". Na área mais central, onde destacou o arranha-céu da biblioteca municipal, o cinema Excelsior, edifícios de apartamentos e escritórios, e nos bairros e arredores da cidade, desde algumas residências particulares projetadas

\footnotetext{
44LIRA, José Tavares Correia de. Richard Neutra, modernismo, tropicalismo e desenvolvimentismo: Aventuras e desventuras de um arquiteto estrangeiro na América Latina. Texto elaborado para o projeto temático Fapesp "São Paulo: os estrangeiros e a construção da cidade", 2011. 


\section{TROCAS, TRANSFERÊNCIAS, DIÁLOGOS E OUTROS CAMINHOS}

por Artigas, Rino Levi, Warchavchik, Rudofsky, Calabi até a usina hidrelétrica de Billings, o subúrbio de Interlagos e obras em Santos e no Guarujá. ${ }^{47}$

Apesar da enorme distância que então separava os dois personagens naquele momento de sua trajetória, Warchavchik foi um dos grandes anfitriões de Neutra em São Paulo em sua viagem de 1945. Integrando a comitiva de mais de 20 autoridades públicas, arquitetos e urbanistas, registrou atentamente seu desembarque em Congonhas, e ofereceu-Ihe uma recepção de arquitetos "interessados em cooperação interamericana", diria Neutra, nos jardins de sua residência à rua Santa Cruz.

Por mais que desempenhassem papéis muito diversos naquele momento de suas carreiras, "talvez o itinerário comum os tenha aproximado: ambos descendiam de famílias judaicas burguesas, urbanas e assimiladas, que se formaram arquitetos em uma Europa sacudida pelas crises do pós-primeira guerra, e que aportaram no Novo Mundo no mesmo ano de 1923 para pouco depois, ainda que por caminhos diversos, afirmarem-se como pioneiros do movimento moderno no continente americano". ${ }^{48}$

A empatia entre os dois é evidente, tanto que pouco depois de retornar aos EUA Richard Neutra publicou dois artigos nas edições de maio e outubro de 1946 da Progressive Architecture, dando conta da obra recente de Warchavchik. Do outro lado, Warchavchik assinaria a introdução do livro Arquitetura Social em países de clima quente que Neutra publica no Brasil em 1948.

Demonstrando pleno conhecimento das questões projetuais levantadas por seu colega austríaco-norte americano quando a realidade latino-americana se impôs em sua trajetória, nele reconhecia mais que competência técnica, sensibilidade artística e propósito social: "uma compreensão instintiva e uma extraordinária sabedoria dos homens e das coisas. [...] se, de longe, já era tão grande a sua influência sobre todos nós, que dizer do que foi a sua presença aqui”? ${ }^{49}$

\footnotetext{
${ }^{47}$ UCLA Y Young Research Library/ Special Collections. Richard Neutra Papers: Correspondence. Box 1429, Folder 8: Report on Visit of South American Republics. By Richard J. Neutra, Architect and President, U.S. Chapter of CIAM. Undated.

48LIRA, José Tavares Correia de. Warchavchik: fraturas da vanguarda. São Paulo: Cosac \& Naify, 2011

${ }^{49}$ Gregori Warchavchil, "Introdução", in NEUTRA, Richrad. Arquitetura social em países de clima quente. São Paulo: Todtman, 1948. O volume bilíngue foi traduzido para o português por Mina Klabin Warchavchik e Carmem de Almeida.
} 
Curiosamente, afirma FRASER ${ }^{50}$, apesar de Warchavchik conhecer o trabalho de Neutra, este se mostra um completo ignorante acerca do Brasil e de suas prévias realizações no campo da Arquitetura, que somente vem a conhecer após essa visita.

Se assim como Warchavchik, a imigração representara para Neutra um passo decisivo na sua afirmação como liderança de vanguarda no país de adoção, diferentemente dele sua trajetória revelaria uma mobilidade excepcional, sobretudo depois da $2^{\mathrm{a}}$. Guerra Mundial. Enquanto o primeiro parecia cada vez mais enraizar-se na encomenda comercial e novas clientelas que emergiam em uma São Paulo em rápido processo de industrialização e urbanização, o segundo parecia oscilar entre a perda de espaço no mercado imobiliário norte-americano e o estabelecimento de uma escala global de intervenção, sobretudo em territórios subdesenvolvidos do commonwealth norte-americano, de colônias e ex-colônias europeias e nações independentes em franco processo de modernização. O capítulo brasileiro desta empresa parece inserir-se nessa direção, seja enquanto espaço dentre outros de possível ampliação de sua influência e clientela, seja como pólo estratégico de legitimação em toda uma franja tropical que nele reconhecia enfoques arquitetônicos afins à sua própria realidade, tanto na América Latina, como na África e mesmo na Ásia. ${ }^{51}$

No Brasil sua obra teve grande impacto, a começar pela influência que suas residências térreas com jardins internos tiveram em muitas casas na capital paulista, principalmente.

Na obra de Carlos Millan, podemos identificar isto com bastante clareza. Nos primeiros anos de atividade profissional, sem uma linha de trabalho definida e amadurecida, a obra de Millan mostra as influências dos seus estudos junto ao grupo do Mackenzie, como já comentamos. Se na Residência Érico J. Sirituba Stickel a referência direta é da Casa Hanna (1936) de Frank Lloyd Wright, na Residência Tomas

\footnotetext{
${ }^{50}$ FRASER, Valerie. Building the New World: Studies in the Modern Architecture of Latin América 1930-1960. London, New York: Verso, 2000, p. 169.

${ }^{51}$ LIRA, José Tavares Correia de. Richard Neutra, modernismo, tropicalismo e desenvolvimentismo: Aventuras e desventuras de um arquiteto estrangeiro na América Latina. Texto elaborado para o projeto temático Fapesp "São Paulo: os estrangeiros e a construção da cidade", 2011.
} 
Marinho de Andrade (1952-1953) a referência é a Casa Kaufmann (1946) de Richard Neutra.

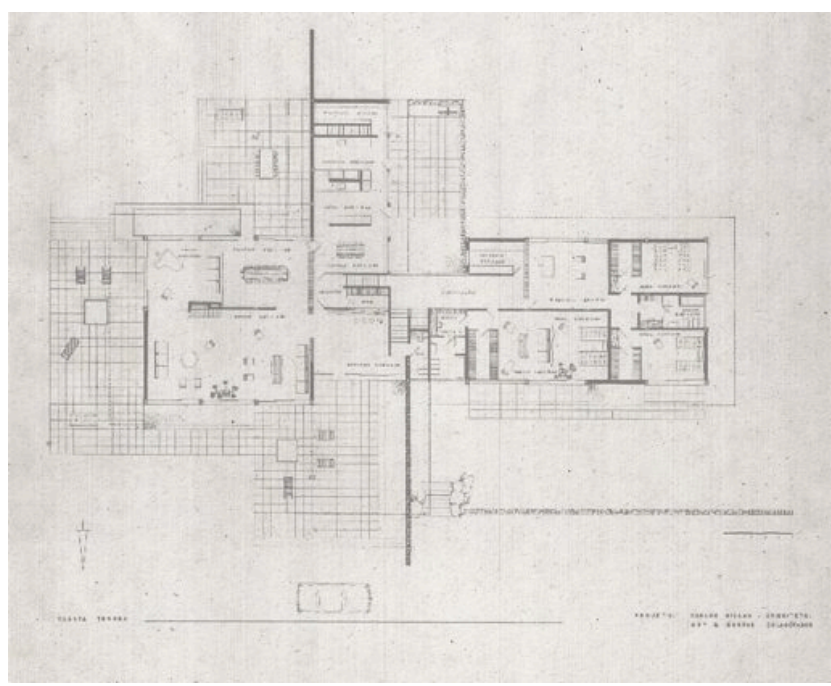

IMAGEM 44: Residência Andrade. 1952-1953

São Paulo, São Paulo, Brasil. Arquitetura: Carlos Millan

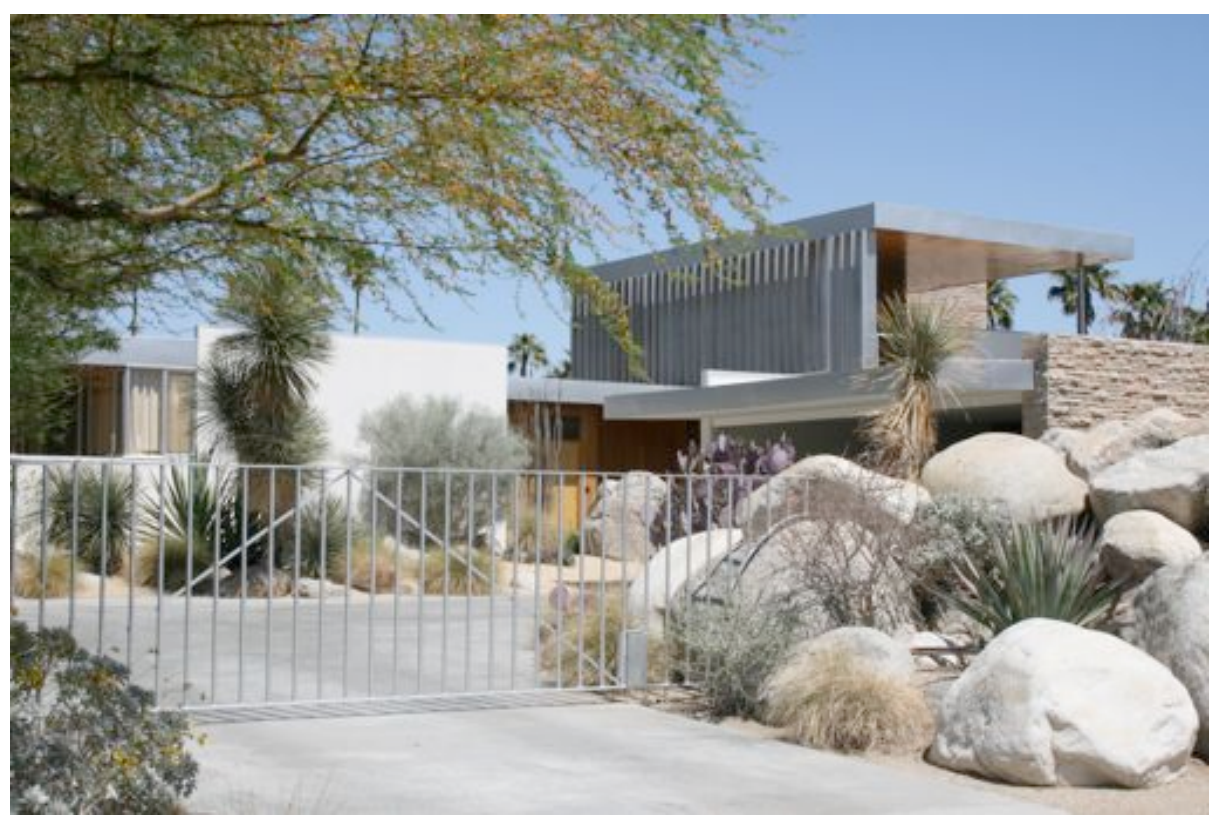

IMAGEM 45: The Kaufmann House, 1946. Palm Springs, Califórnia, USA. Arquitetura: Richard Neutra. Foto: Débora Lima.

Porém, esta relação não é explícita neste projeto como o é na Residência Stickel. Millan mostra compreender a arquitetura além das influências estéticas, compreende o método de projeto e adota determinadas soluções em função de suas intenções funcionais e plásticas.

A solução de volumetria e da planta em cruz com duas grandes paredes de pedra, que formam planos verticais de divisão das alas da casa assemelham-se com a concepção espacial do projeto de Neutra. Porém a arquitetura rigorosa e controlada de 
Neutra não faz concessões naturalistas como paredes e embasamentos de pedra, preocupa-se com a reflexão do sol do deserto da Califórnia, evita os ventos predominantes e as tempestades de areia e emprega soluções estruturais que suportem terremotos. Com solicitações mais amenas e com uma tecnologia disponível menos sofisticada, o detalhamento e a especificação de materiais de Millan afastam-se de Neutra e aproximam-se de Breuer e Wright, com o uso de pedras, cerâmica e madeira. O sistema construtivo é tradicional com estrutura de concreto armado pintada de branco, alvenaria revestida com litocerâmica do lado externo, caixilhos de madeira também pintados de branco e laje de cobertura com beirais. As condições tecnológicas da construção civil em São Paulo não permitiam que se reproduzissem os exemplares da arquitetura industrializada no pós guerra, talvez não fosse a intenção do arquiteto, que mesclava nas obras diferentes influências procurando produzir uma arquitetura contemporânea dentro das condições brasileiras. ${ }^{52}$

Esta é uma análise bastante interessante feita por Matera sobre como o arquiteto brasileiro "interpretou" as características de um projeto de um arquiteto estrangeiro para uma residência muito longe daqui e as implantou tentando se adaptar às especificidades locais.

Na obra de Millan também podemos identificar nas soluções de implantação, ventilações cruzadas e proteção solar, relações com os cuidados de adequação às condições climáticas da arquitetura norte americana de Neutra, também propostas em seu livro "Arquitetura social em países de clima quente".

Um exemplo disso está na "Escola para Olivo Gomes" de 1952, cuja "implantação em blocos com jardim interno, salas de aula que se abrem para pequenos pátios que possibilitam aulas ao ar livre, detalhes de cobertura para ventilação cruzada sobre o forro de madeira, detalhes de proteções solares, inclinações de telhados em direção à calha central para melhor ventilação e aproveitamento da luz natural, e circulações em passagens abertas sob os beirais, são todas soluções presentes neste projeto e propostas por Neutra no livro." 53

\footnotetext{
52MATERA, Sérgio. Carlos Millan O Um estudo sobre a produção em arquitetura. São Paulo, 2005. Dissertação (Mestrado). Curso de Pós-Graduação em Estruturas Ambientais Urbanas. Faculdade de Arquitetura e Urbanismo - USP, pp. 147-148, 
Também, e como já dissemos, as casas-pátios projetadas em São Paulo por Rino Levi e Oswaldo Bratke apresentam nítida semelhança com os projetos de Richard Neutra. As residências Castor Delgado Perez e Paulo Nogueira Neto, projetadas por Levi e Bratke, respectivamente, são exemplos do nível de desenvolvimento arquitetônico residencial na cidade de São Paulo na década de 50.

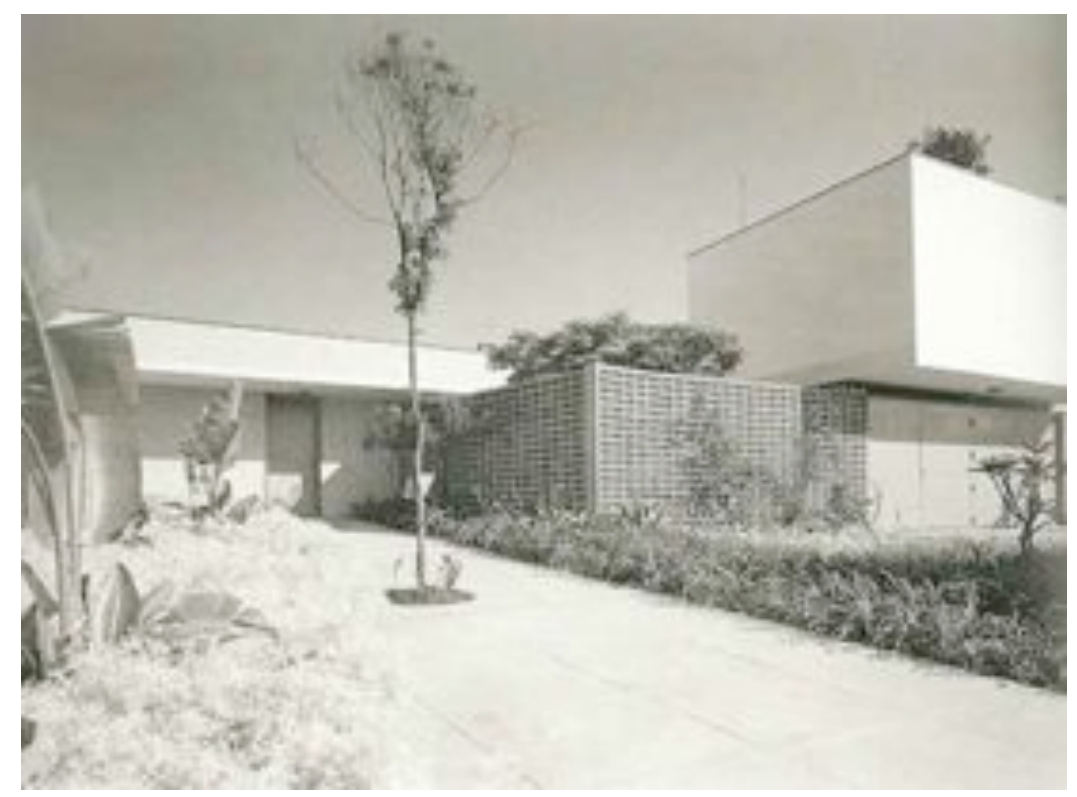

IMAGEM 46: Residência Castor Delgado Perez. 1958. São Paulo, São Paulo, Brasill. Arquitetura: Rino Levi, Roberto Cerqueira César e Luís Roberto Carvalho Franco.

Os dois arquitetos, conscientes de que a casa urbana necessitava de privacidade e intimidade, passaram a projetar casas recuadas em relação à rua, fazendo fechamentos frontais e voltando o prédio para o interior do lote. Nesse momento, o pátio passa a ser um grande gerador das relações do interno com o meio externo da casa e seu entorno imediato. As paredes fechadas são substituídas por grandes vãos envidraçados e móveis, possibilitando a participação do pátio no cenário residencial. O partido composto por diversos volumes ou elementos de composição permite a adequação à topografia, estabelecendo relação visual com a paisagem. Os pátios intercalados aos volumes são ajardinados, trazendo a natureza para o interior da casa.

Deste modo é possível fazer uma aproximação entre estas casas com as residências californianas de Richard Neutra, bem como com as residências binucleares de Marcel Breuer, outro arquiteto residente nos Estados Unidos na época e que irá influenciar a arquitetura residencial brasileira no período, e também o desenho 
do mobiliário, através da primeira loja de móveis modernos de São Paulo, a Branco \& Preto, que era uma sociedade dos arquitetos Miguel Forte, Jacob Ruchti, Plínio Croce, Roberto Aflalo, Carlos Millan e Chen Y Hwa, todos formados no Mackenzie entre o final da década de 40 e o início da década de 50, exceto o chinês Chen que era formado na Pennsylvania State University nos Estados Unidos.

IMAGEM 47: Breuer House. 1938 1939. Lincoln, Massachusetts, USA. Arquitetura: Marcel Breuer e Walter Gropius

Grupo este que iria, por muito tempo, se guiar justamente pelo trabalho de Levi e Bratke ${ }^{54}$, seus "mentores", e, porque não dizer, pela trabalho dos arquitetos atuantes nos EUA no período.

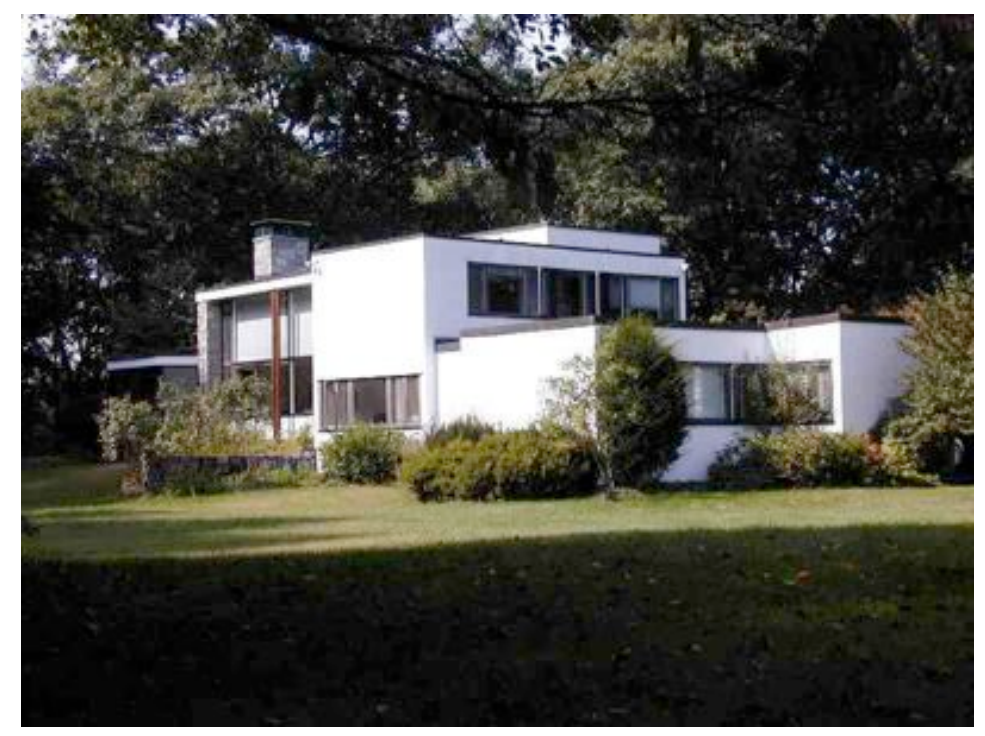

A visita de Richard Neutra ao Brasil em 1945 também resultaria na publicação, em 1948, do livro bilíngue fartamente ilustrado, reunindo os projetos do arquiteto para o programa de educação e saúde do governo de Porto Rico, além de alguns projetos habitacionais na Califórnia. ${ }^{55}$

Um claro movimento de capitalização dessa experiência na América Latina e Caribe é flagrante em seus esforços de publicação livro em inglês e português.

Para mim era um mistério a razão que o levara a publicar este livro sobre o trabalho em Porto Rico no Brasil e não ali onde atuara ou nos EUA. Contudo, sua correspondência com o editor alemão residente em São Paulo, Gerth Todtmann, é bem reveladora a esse respeito. O contrato entre Neutra e Todtmann foi estabelecido em janeiro de 1947, mas já no começo de 1946 ele parecia ter o livro em mente. Em uma carta para o editor da revista argentina Nuestra Architectura, enviada logo depois

\footnotetext{
${ }^{54}$ Entender melhor em ARANHA, Maria Beatriz de Camargo. Rino Levi: arquitetura como ofício. Dissertação de mestrado. Orientadora Fernanda Fernandes da Silva. São Paulo, FAU-USP, 2003 e CAMARGO, Mônica Junqueira de. Princípios de arquitetura moderna na obra de Oswaldo Arthur Bratke. Tese de doutorado. Orientador Paulo Júlio Valentino Bruna. São Paulo, FAU-USP, 2000.

${ }^{55}$ NEUTRA, Richard. Arquitetura social em países de clima quente. São Paulo: Todtmann, 1948.
} 
de seu retorno a Los Angeles do tour sul-americano, Neutra anunciava a publicação "graças ao apoio de Gregori Warchavchik", que conforme ele sugeria "estaria possivelmente interessado em cooperar com ele também em uma edição espanhola" ${ }^{56}$

Em paralelo, negociações estavam sendo firmadas com Pietro Maria Bardi para a organização de uma exposição da obra arquitetônica de Neutra no Museu de Arte de São Paulo, evento por ele considerado como importante para a divulgação do livro, assim como para a afirmação de seu próprio prestígio no meio brasileiro: especialmente se "tal exposição" não fosse apenas apresentada em São Paulo mas seguisse "para outras cidades - para toda a América Latina talvez".

A exposição, planejada para 1951, jamais viria a ser realizada, tendo sido publicado, todavia, também por Todtmann, uma espécie de catálogo de sua arquitetura residencial, que seria exposta no MASP. ${ }^{57}$

No prefácio assinado por Bardi, percebe-se o papel didático e publicitário atribuído às iniciativas do museu e da arquitetura moderna como um de seus capítulos redentores:

É por esse motivo que nosso Museu promoverá, este ano, um grande número de exposições de arquitetura, em proporções talvez jamais planejadas por qualquer outro museu existente: cumpre acostumar nosso público a saber ver a arquitetura e avaliá-la em multíplices aspectos, funções e caracteres. (...) Em nosso primeira exposição didática da historia da arte, damos farta documentação dessa excelência da arquitetura. Serviu aquela de preâmbulo às exposições que agora levaremos a efeito, apresentando os mestres contemporâneos, a fim de que possa o público medir o esforço realizado por poucos nos sentido de melhorar a habitação do homem, a cidade e o campo. Após a apresentação de duas bem estudadas e planejadas instituições hospitalares, devidas a Rino Levi e Roberto Cerqueira César, e após o curso efetuado por Oscar Niemeyer, eis agora a exposição de um dos mais límpidos arquitetos do mundo: Richard Neutra. (...) Possui Neutra a virtude de não desviar-se nunca do caminho do bom senso, de participar do denominador comum que é a inteligência

\footnotetext{
56LIRA, José Tavares Correia de. Richard Neutra, modernismo, tropicalismo e desenvolvimentismo: Aventuras e desventuras de um arquiteto estrangeiro na América Latina. Texto elaborado para o projeto temático Fapesp "São Paulo: os estrangeiros e a construção da cidade", 2011. 
salvadora da humanidade, a inteligência comum, que se retira quando os homens fazem tudo o que podem para estragá-la. (...) Há nesse criador de habitações um entusiasmo ativo, que não é vago nem aproximativo, indeterminado ou abstrato, mas sim dirigido para uma finalidade inventiva e a estimulação de uma força controladora: fatos esses que correspondem a exigências de ordem moral. É o arquiteto um servidor de seus semelhantes; não um servidor passivo, mas, ao contrário, que sabe tornar-se útil, assumindo a responsabilidade das boas iniciativas, mesmo quando estas parecem exageradas à maioria. ${ }^{58}$

Ainda que não tenha sido efetivamente realizada, para Neutra, a ideia da exposição parecia tanto mais favorável quanto poderia auxiliar na divulgação do livro, "não apenas em São Paulo, mas em todas as capitais da América do Sul e quem sabe até em museus de arte e universidades norte-americanas".

O impacto do livro de Neutra, apesar de pouco referido, parece ter sido significativo: veio a representar uma importante referência para a elaboração de projetos de edificações públicas, sobretudo para as redes de ensino, e essas ideias tiveram influência também no Brasil.

A pesquisa de LOUREIRO e AMORIM ${ }^{59}$ confirma pelo menos um exemplo desta influência: o Instituto de Educação de Pernambuco, projeto dos arquitetos Marcos Domingues da Silva e Carlos Falcão Correia Lima, ganhadores de concurso público nacional, realizado em 1956.

Os autores confirmam a importância do livro na fundamentação do esquema vencedor, da interpretação do problema à solução do conjunto. É no bloco destinado ao jardim de infância, no entanto, onde residem mais claramente as referências aos preceitos expressos no livro, inclusive com a introdução pioneira de salas de aula que se prolongam para um pátio exterior, através de portas pivotantes que se abrem horizontalmente, como recomendado por Neutra.

Descobrimos na Library of Congress, durante pesquisa de campo em Washington D.C., um exemplar do livro, bem difícil de ser encontrado no Brasil.

\footnotetext{
58BARDI, op. cit., pp. 10-14

59LOUREIRO, Claudia; AMORMM, Luiz. Por uma arquitetura social: a influência de Richard Neutra em prédios escolares no Brasil. ArquitextosO20 (Romano Guerra Ed. Ltda.). São Paulo, Portal Vitruvius, janeiro 2002.
} 


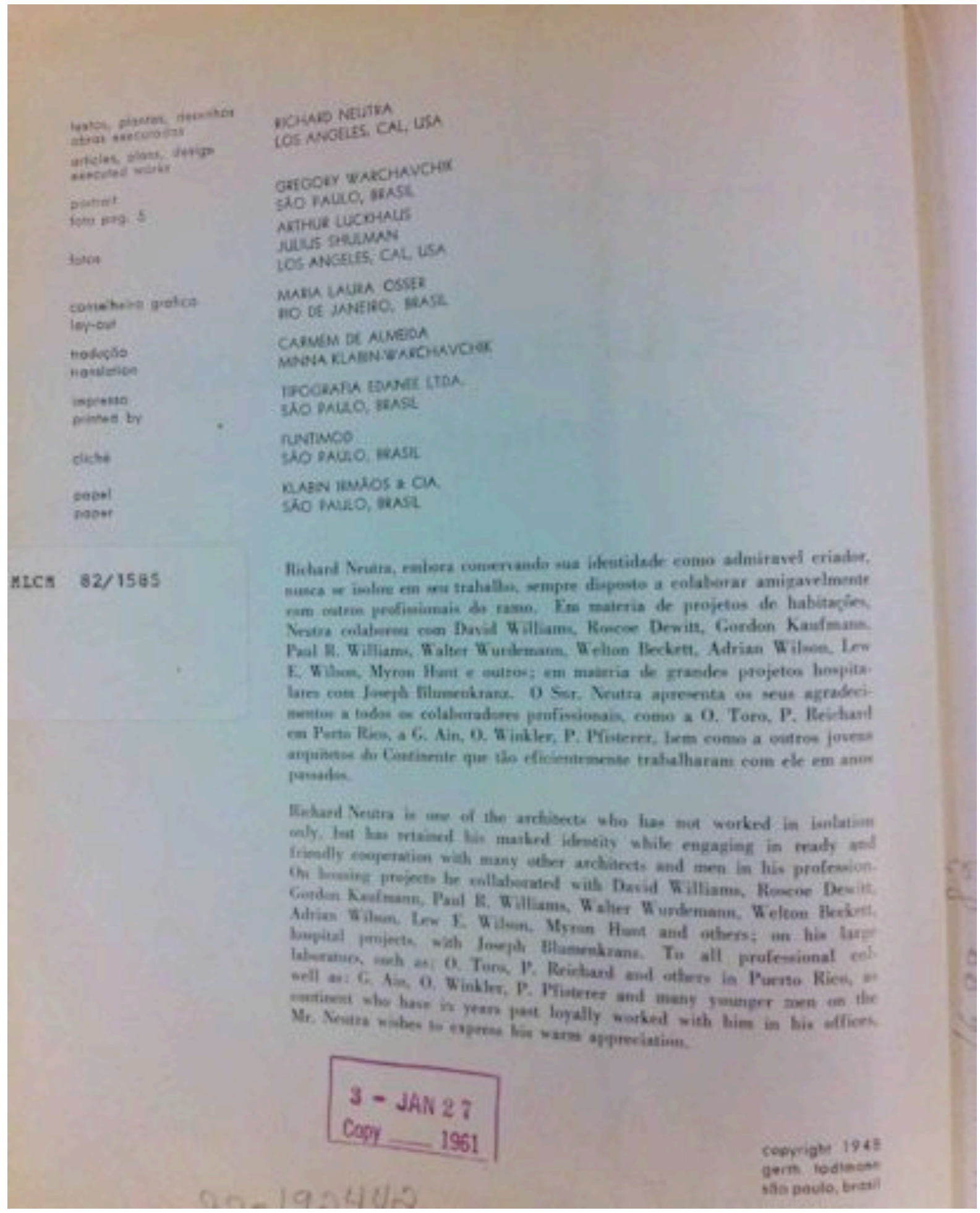

$\mathrm{Na}$ contracapa podemos verificar todos os nomes das pessoas envolvidas, inclusive Warchavchik e sua esposa Minna Klabin. As fotografias dos projetos de Los Angeles constantes no livro foram feitas por Julius Shulman, grande fotógrafo americano que em alguns anos registraria também a arquitetura moderna brasileira, e figura essencial na divulgação mundial do modernismo americano. 
A introdução do livro, escrita por Warchavchik é reveladora da admiração que este nutria por Richard Neutra.

Não seria muito fácil separar a biografia de Richard Neutra da história da arquitetura moderna; e, estudada de perto, como contribuição a êsse (sic) grande movimento inovador de uma técnica a serviço do homem contemporâneo, ela adquire uma fisionomia tôda (sic) própria, viva e palpitante...

... Bem preparado pelos estudos politécnicos, consegue Neutra chegar a soluções inteiramente novas para os mais importantes problemas da nova arte de construir. O seu interêsse (sic) se prende a novos materiais, a sua utilização mais racional, a novos elementos técnicos, novos processos e novos métodos, e à sua aplicação às realidades sociais e economias, assim com ao clima e às necessidades diversas, tanto na cidade quanto nas regiões rurais em que seu trabalho se fixa.

... Ante êsses (sic) problemas, Richard Neutra nos apresenta a sua concepção da arquitetura em harmonia com a época - uma arquitetura funcional, que se destina às necessidades humanas, libertada de formalismos excessivos.

No início de sua carrêira (sic), era muito reduzido o numero dos que, como êle (sic), procuravam soluções novas; além disso, estavam isolados uns dos outros por grandes distâncias, inclusive os do Brasil...

O talento de Richard Neutra revela logo, em alto grau, a sua capacidade, a importância de sua contribuição para a arquitetura nova. Suas concepções são equilibradas, harmoniosas; sua compreensão humana se revela cada vez mais profunda. Essas qualidades tornam sempre mais fértil e original a sua obra.

Em 1923, Richard Neutra fixou residência nos Estados Unidos. Tornou-se cidadão norte-americano, mas conservou suas qualidades de cidadão do mundo.

Corrêra o globo, visitando a Ásia, a África, a Europa e as Américas, até conhecer bem êsses (sic) continentes e aprender a amá-los. Trabalhando, estudando e viajando em tantos lugares, acumulara vasta experiência, alargando o seu horizonte e a sua compreensão, como raras vezes acontece. Era ainda muito jovem quando foi admitido na intimidade de Louis Sullivan, de quem eram grande admirador. Depois, durante algum tempo fora assistente de Frank Lloyd Wright. A seguir, trabalhando em grandes escritórios norte-americanos, como os de Holabird e Roche, Neutra tem conhecido os mais variados aspectos da vida norte-americana.

Dêsde (sic) 1925, quando passou a residir em Los Angeles, Califórnia, é fácil acompanhar a sua carreira ascensional, e sua crescente influência sôbre (sic) a nova 
arquitetura. De Los Angeles, irradia-se por todo o país e pelo mundo a ação de Richard Neutra como urbanista, aquitéto (sic), criador de novos conceitos estruturais e teóricos e novos métodos de trabalho para as novas formas de arquitetura. Já em 1925, Gropius citava Neutra entre os pioneiros mundiais da arquitetura nova.

Em 1929, Alfred Barr, diretor do Museu de arte Moderna de Nova York, então em organização, e que escreveu a apresentação da primeira grande exposição de arquitetura contemporânea, declarou: "Entre os arquitetos americanos, Richard Neutra é superado apenas por Frank Lloyd Wright em sua reputação internacional”. Quinze anos mais tarde, um júri nacional, nomeado pelo mesmo Museu, já uma instituição de grande importância cultural, selecionou dois trabalhos de Neutra, classificando-os como os melhores projetos arquitetônicos idealizados nos Estados Unidos. 'Fortune”, provavelmente a mais importante e mais bem feita revista do hemisférios, dá a sua opinião: "Em 1934, Neutra aparece como a mais poderosa influência da nova arquitetura na América", e continua: "êle (sic) nos falava de pre-fabricação, quando os outros ainda se ocupavam de vigas góticas!.

... a atividade literária de Neutra, alcançando tôdos (sic) os continentes e traduzida em tôdas (sic) as línguas cultas do mundo, estimulando a opinião pública de muitos países, assim como a sua constante colaboração em numerosas revistas, tem esclarecido, guiado e interessado a milhares de pessoas, particularmente das novas gerações, muitas das quais nunca o viram pessoalmente mas são por êle (sic) influenciadas através da publicação e reprodução de seus estudos e projetos.

Neutra ainda mais alargou sua influência, realizando conferências perante diversos e numerosos públicos, inclusive em centros culturais como Princeton, Columbia, Harvard, Yale e praticamente em tôdas (sic) as Universidades importantes, desde a Argentina até o Canadá, em países Europeus e no Japão.

... Além disso, êle (sic) tem participado de comissões para concursos nacionais e atuado como conselheiro do Departamento do Tesouro Norte-americano para a construção dos Correios dos Estados Unidos. Também foi nomeado conselheiro da "U.S. Housing" e da "Federal Public Housing Authorities". Consultaram-no a "National Youth Administration" e vários govêrnos (sic) estrangeiros. Finalmente, dirige êle (sic) os estudos da "California State Planning Board" e participa como mêmbro (sic) da "Professional Standards Comission".

E assim, através desta descrição biográfica pela obra e vida de outra, Warchavchik continua a introdução do livro explicando sobre as técnicas construtivas e 
experiência as quais Neutra vai incorporar, com majestade, ao tema a que se refere o livro.

E conclui:

Agora, tendo descrito ligeiramente o alcance e a expressão da personalidade de Neutra, não poderei deixar de acrescentar que êle (sic) não se limita ao plêno (sic) domínio de tôdos (sic) os recursos técnicos e nem aos seus tão proveitosos estudos a respeito das necessidades sociais; acima de tudo isso e através de uma sensibilidade artística incomum, paira uma compreensão instintiva e uma extraordinária sabedoria dos homens e das coisas.

Em fins de 1945, tivemos o prazer de conhecer Neutra, quando da sua viagem às Américas do Centro e do Sul, organizada pelo Departamento de Estado dos Estados Unidos.

Se, de longe, já era tão grande a sua influência sôbre (sic) tôdos (sic) nós, que dizer o que foi a sua presença aqui? Tivemos o enséjo (sic) de conhecer o homem simples e afetivo que êle (sic) é, irradiando aquela simpatia própria só dos sêres (sic) humanos cuja bondade profunda se manifesta em tôdas (sic) as ocasiões, ajudando, encorajando e admirando o trabalho criador de outros homens, sem, no entanto, jamais trair a si mesmo, e seguindo o seu próprio caminho. Nessa viagem, o arquiteto (sic) se transformou, diante de nossos olhos, num artista de fino senso plástico. Seu lápis criou pequenas maravilhas em seu album de desenhos.

E com essa relevante figura da vida contemporânea, com algumas de suas idéias (sic) e alguns de seus trabalhos, que o leitor irá tomar conhecimento nas páginas que seguem. ${ }^{60}$

Através dessas palavras pudemos entender vivamente como as trocas entre arquitetos de diferentes países, e nesse caso em particular entre um brasileiro e um arquiteto austríaco atuante nos Estados Unidos, podem ser compensadoras e importantes para o prosseguimento e encaminhamento de novas linguagens, o uso de novas técnicas, termos, conhecimento, enfim. Experiência que são capazes de provocar um impacto enorme em todos os envolvidos.

Em 1959 Richard Neutra retornaria ao Brasil, convidado pelos organizadores do Congresso Internacional Extraordinário de Críticos de Arte, realizado no canteiro de

60NEUTRA, Richard. Arquitetura social em países de clima quente. São Paulo: Todtmann, 1948, pp. 10-20. 
obras de Brasília, assim como no Rio de Janeiro e em São Paulo, de onde Neutra estendeu a viagem para Buenos Aires, La Plata, Córdoba e Rosário na Argentina.

É verdade que suas encomendas na América Latina ao longo dos anos ainda surgem em grande medida ligadas à reputação do arquiteto de residências privadas bem projetadas e de acordo com os requisitos de isolamento térmico.

\section{5-1950: A Modernidade no Deserto - Arquitetura Moderna em} Palm Springs, Califórnia, USA

Palm Springs, uma pequena cidade inserida no Vale de Coachella, na California, possui a maior concentração de Arquitetura Moderna americana de meados do século vinte.

Desde a década de 1920, arquitetos modernistas visionários criaram elegantes casas modernas que abraçaram o ambiente do deserto. Os dramáticas arredores geográficas do Coachella Valley inspiraram uma estética de design no meio do século vinte hoje denominado "Desert Modernism".

Não pudemos passar incólumes a essa pequena cidade que tanto em comum tem com a nossa arquitetura moderna e que, invariavelmente foi tocada por nossa produção.

IMAGEM 48: Coa

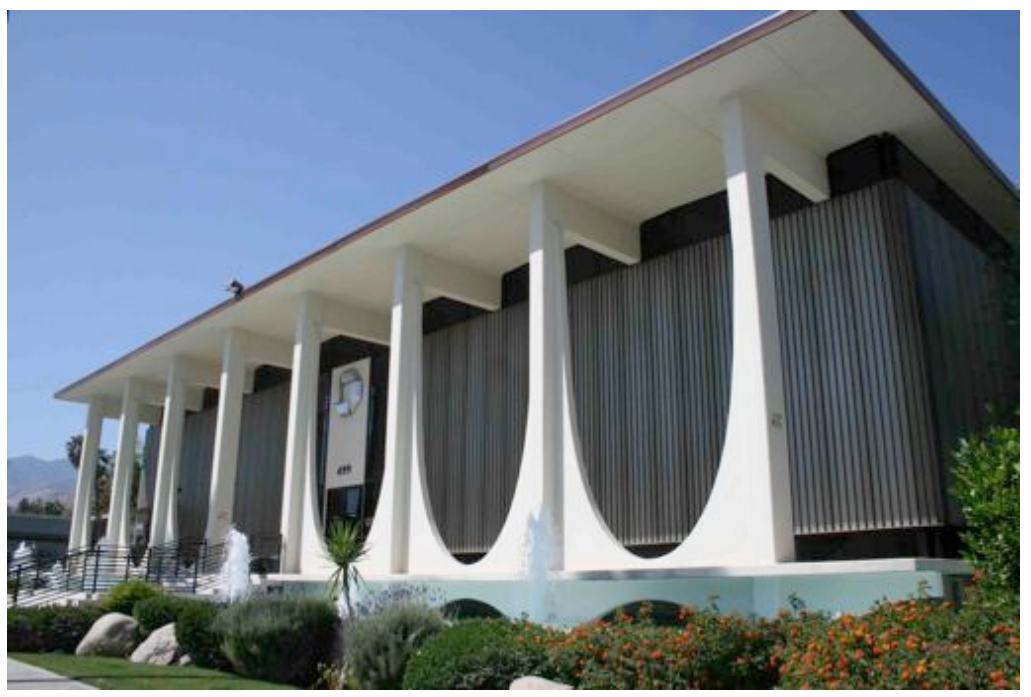
Williams. Foto: Débora Lima.

Notável por sua utilização do vidro, linhas limpas, os recursos naturais e manufaturados e espaços indoor / outdoor, o Modernismo do deserto evoca um estilo de vida de uma elegância simples e a informalidade. Influenciado pelos ditames da vida 
no deserto e o clima intenso, o estilo cresceu do uso adaptativo dos arquitetos de materiais criativos, técnicas de construção modernas, novos tecnologias do pósguerra, e serviu uma entusiasmada e disposta clientela. ${ }^{61}$

\section{IMAGEM 49: \\ Villa Alejo \\ Condominiums. 1966, Palm Springs, California, USA. Arquitetura: Meyers \& Koozin \\ Foto: Débora Lima \\ Arquitetos \\ talentosos \\ foram \\ atraídos para o deserto \\ de por conta do acaso \\ e oportunidade. Eles \\ criaram \\ edifícios}

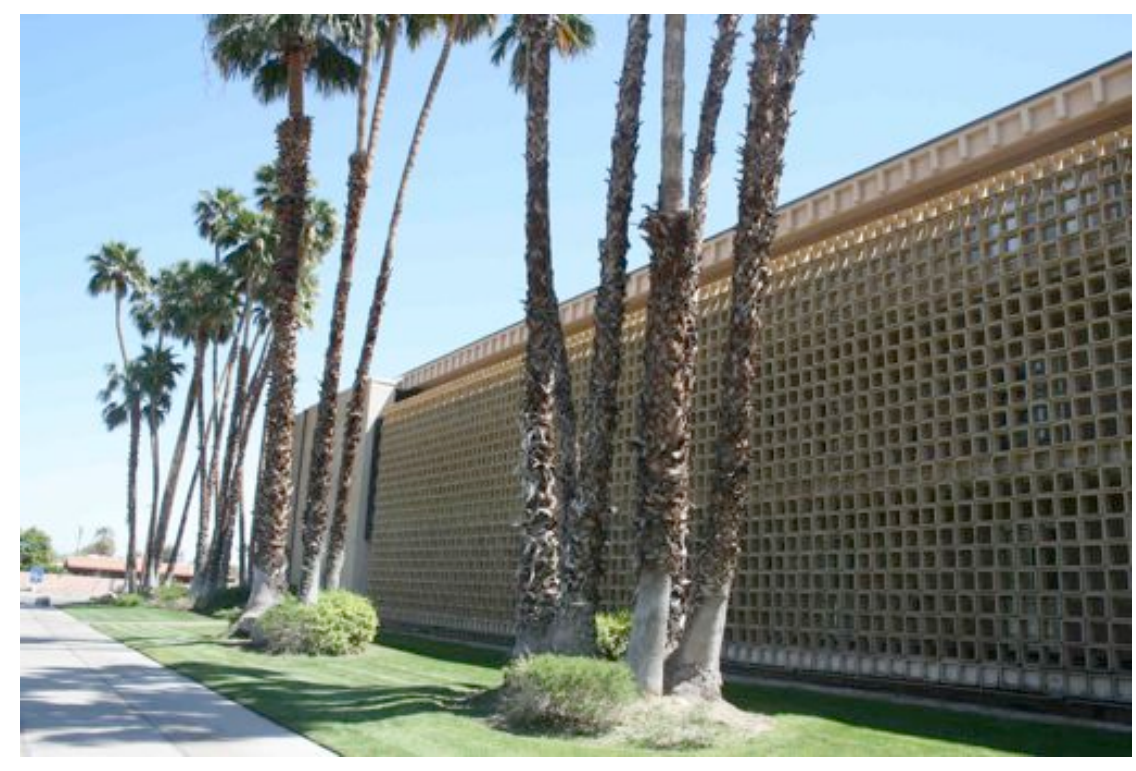

notáveis de todo o tipo: residenciais, comerciais, cívicos, religiosos, hotéis, escolas, centros culturais, etc.

Arquitetos e empreendedores de Palm Springs da época incluem: Richard Neutra, John Lautner, Donald Wexler, Albert Frey, William "Bill" Krisel, Palmer e Krisel, Inc., William F. Cody, John Porter Clark, George e Robert Alexander, e E. Stewart Williams.

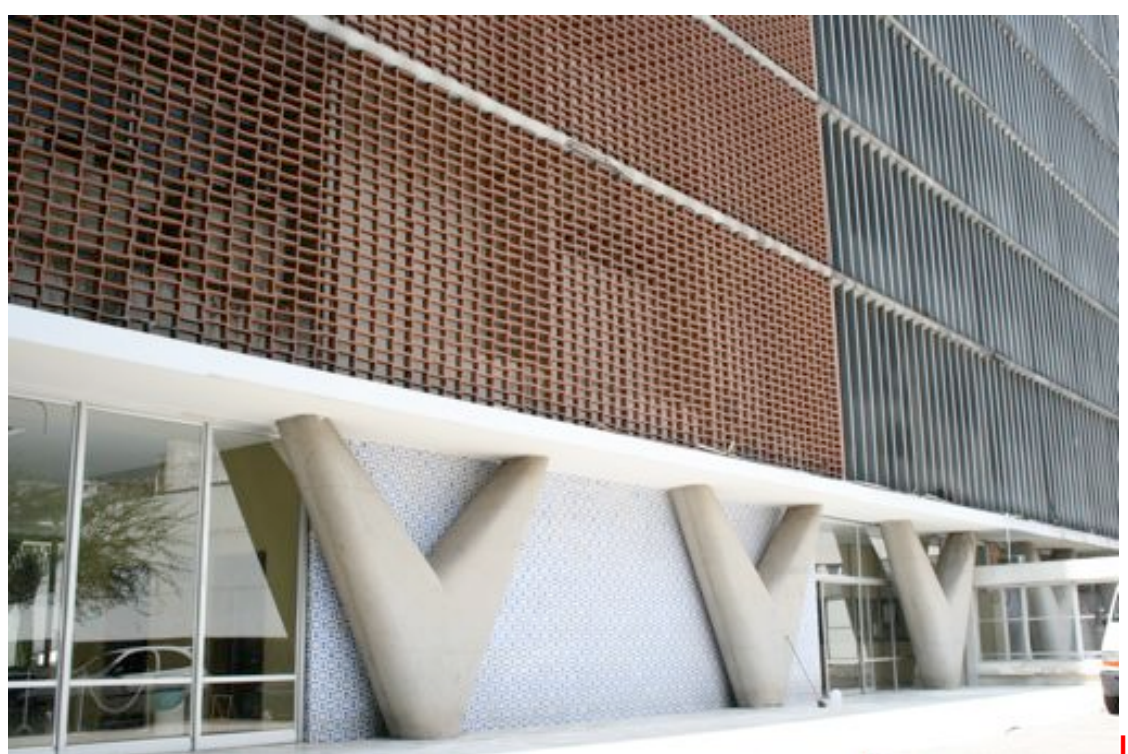

IMAGEM 50: Edifício do Hospital da Lagoa. 1952-1958. Rio de Janeiro, Rio de Janeiro, Brasil. Arquitetura: Oscar Niemeyer. Foto: Débora Lima.

${ }^{61}$ STERN, Michael. Julius Shulman: Palm Springs. New York: Rizzoli, 2008 


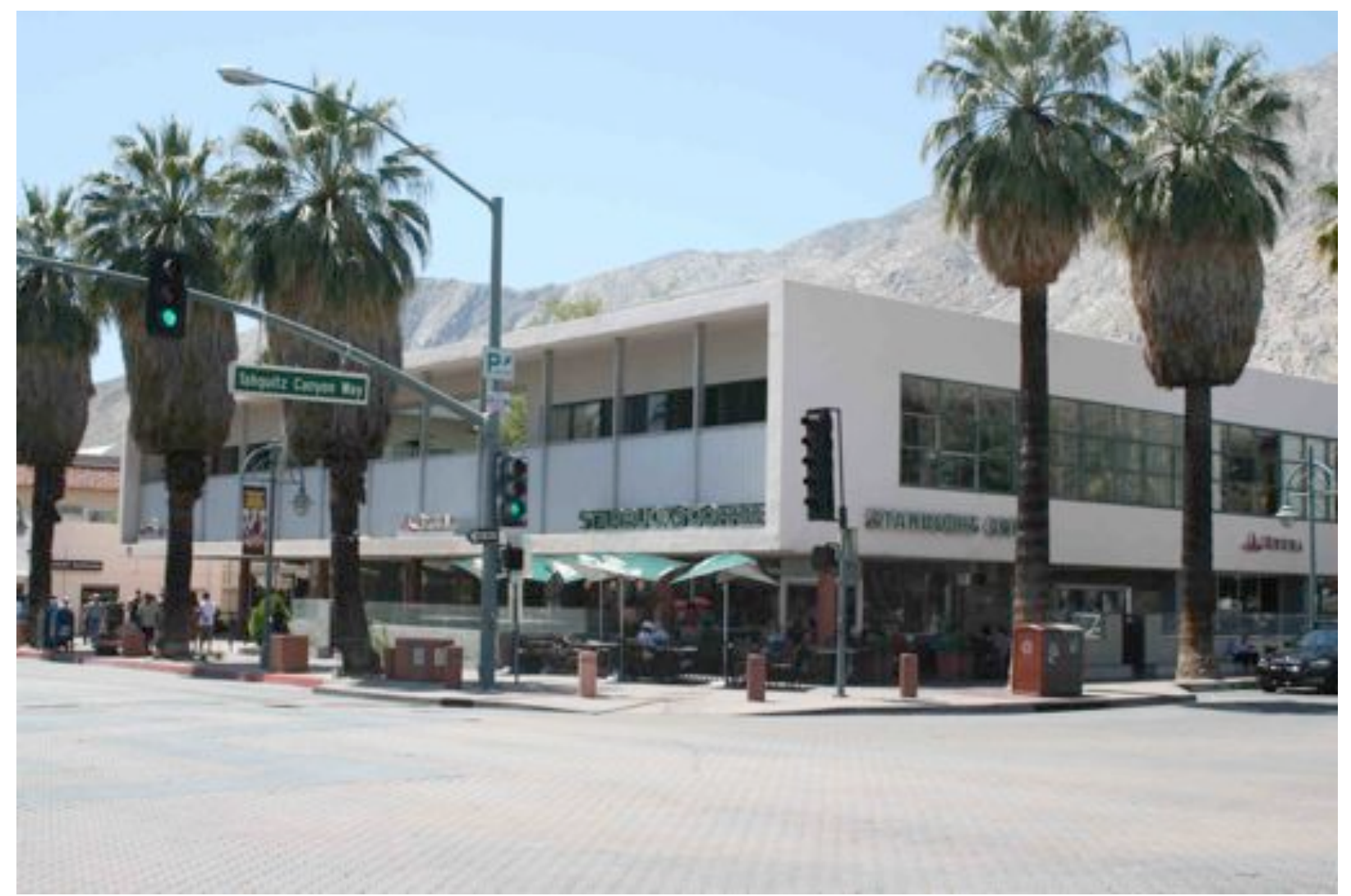

IMAGEM 51: Oasis Office Building. Palm Springs, California, USA. Arquitetura: E. Stewart Williams. Foto: Débora Lima.

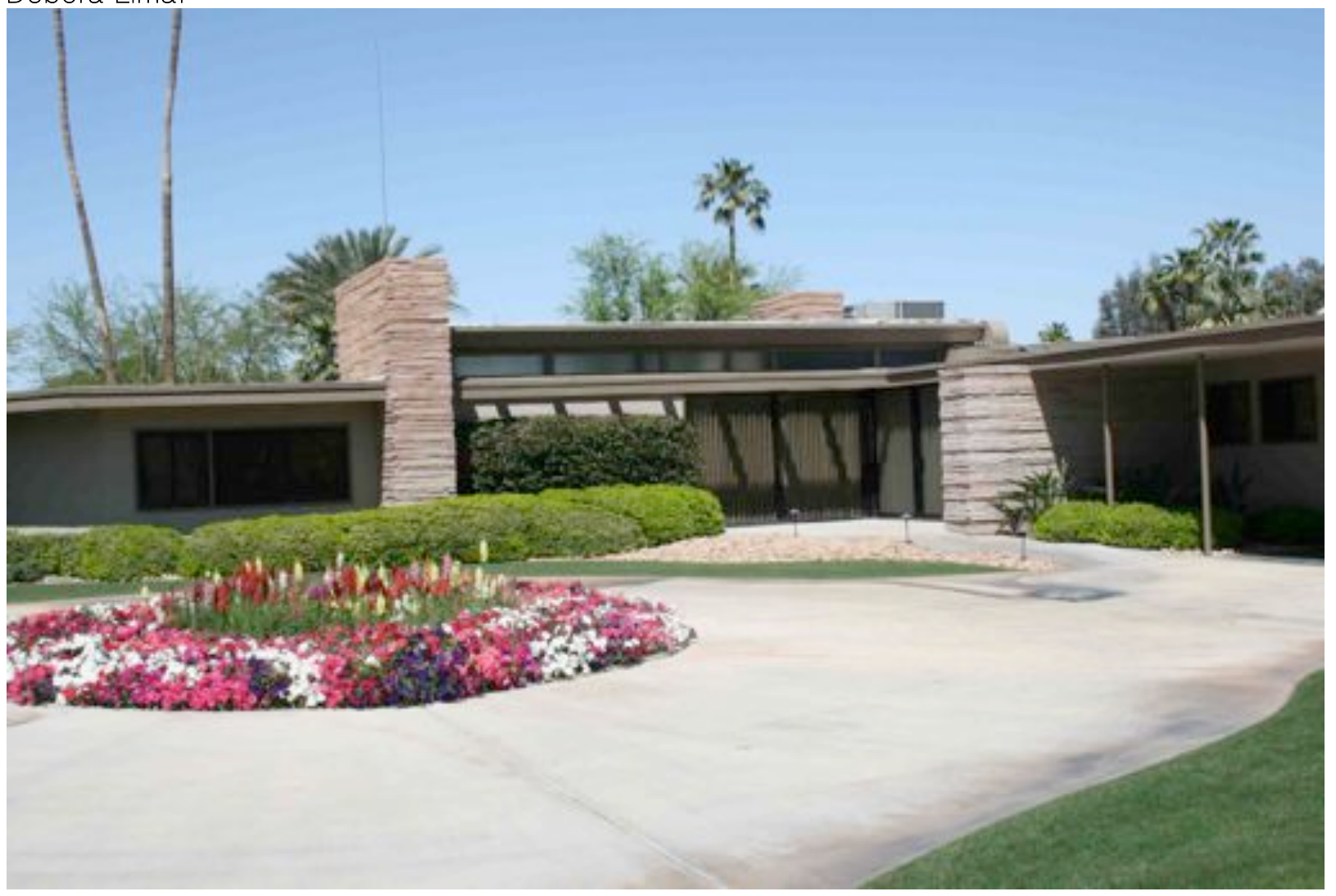

IMAGEM 52: Frank Sinatra's House, 1947. Palm Springs, California, USA. Arquitetura: E. Stewart Williams Foto: Débora Lima. 


\section{6-1947: Viagem de Vilanova Artigas aos Estados Unidos}

A viagem empreendida por João Batista Vilanova Artigas pelos Estados Unidos, bem na fase em que a cultura norte-americana ainda despertava o seu entusiasmo e decidido que estava a incorporar sua experiência à arquitetura moderna de São Paulo, é de extrema importância para o nosso entendimento das relações entre a arquitetura moderna brasileira e americana no período.

É evidente o interesse do arquiteto, na fase embrionária de sua vida profissional, pelas novas manifestações da arquitetura americana, fato que iria ter relevância em seu trabalho permanentemente. Quando sai da Escola Politécnica da USP com o título de engenheiro-arquiteto ${ }^{62}$, Artigas é seduzido pela obra de Frank Lloyd Wright, não somente, mas pela arquitetura americana, em linhas gerais, que aparecia em livros e revistas da época.

Anos mais tarde, como sabemos, já transformado em um ícone da modernidade paulistana, negaria com veemência toda relação com o "imperialismo".

A apreciação de Artigas a Wright distancia-se de formalismos e cópias: trata-se de uma interpretação seletiva e crítica dos princípios orgânicos, inteligentemente interrelacionados com valores da obra de outros mestres, como a pureza estrutural de Mies van der Rohe, e sob a égide de uma visão socialista. Sua crítica a Wright dá-se no que chama de "dionísico" na obra deste, e a nível urbanístico, opondo-se veementemente ao caráter bucólico, "medieval" da visão de Broadacre City. ${ }^{63}$

Já a partir do final dos anos 1930 realiza em São Paulo pequenas residências ${ }^{64}$, nas quais sua busca por uma compreensão e desenvolvimento do pensamento wrightiano são legíveis, sendo que uma de suas principais preocupações no momento é a honestidade dos materiais, desencadeada, por um lado, por sua própria experiência como projetista e construtor, e por outro pela leitura de textos de Wright ou sobre ele.

\footnotetext{
${ }^{62}$ Antes disso havia trabalhado também, como estagiário, no escritório Bratke e Botti, como tantos outros importantes arquitetos paulistanos o fizeram.

${ }^{63}$ NEDELYKOV, Nina; MOREIRA, Pedro. Caminhos da Arquitetura Modema no Brasil: A presença de Frank Lloyd Wright. Arquitextos018 (Romano Guerra Ed. Ltda.). São Paulo, Portal Vitruvius, agosto 2001.

${ }^{64}$ Em parceria com Dulilo Marone, com quem organiza uma empresa construtora, que funciona entre 1937 e 1944.
} 
Deste ponto de vista, é possível reconsiderar a ideia de pioneirismo de um período da carreira de Artigas que sempre foi ofuscado por sua obra madura. É a fase compreendida entre 1937 - ano de sua formatura - e de 1946, período em que viaja para os Estados Unidos sob o patrocínio da Fundação Guggenheim. ${ }^{65}$

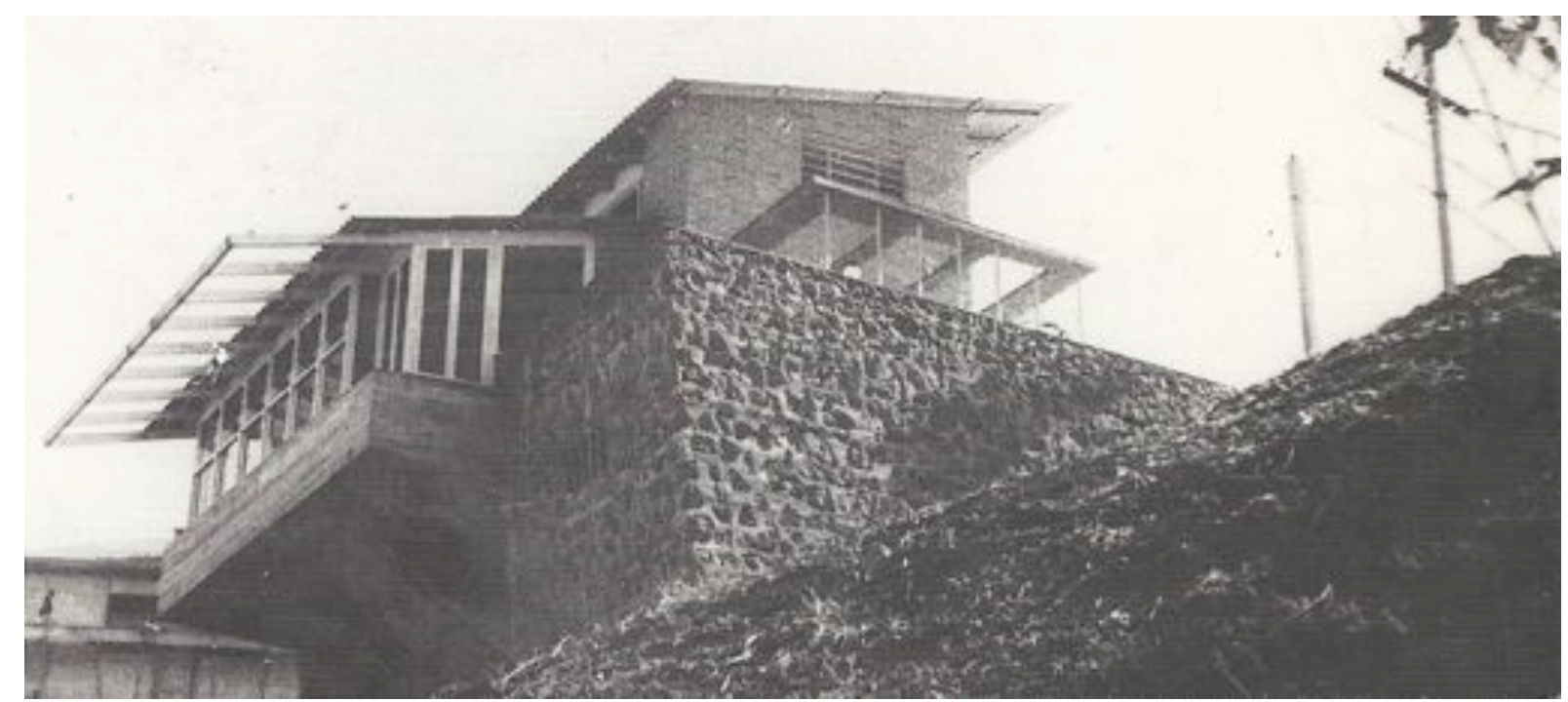

IMAGEM 53: Casa Rivadávia de Mendonça. 1944. São Paulo, São, Brasil. Arquitetura: Vilanova Artigas.

IRIGOYEN (2002) cita a morada para a familia Rivadávia de Mendonça - que inclusive foi publicada na edição dedicada ao Brasil de 1947 da Architectural Forum - apresentando uma semelhança conceitual marcante com a casa Sturges - visitada por Artigas em sua viagem - sendo que ambas foram construídas sobre uma ladeira e

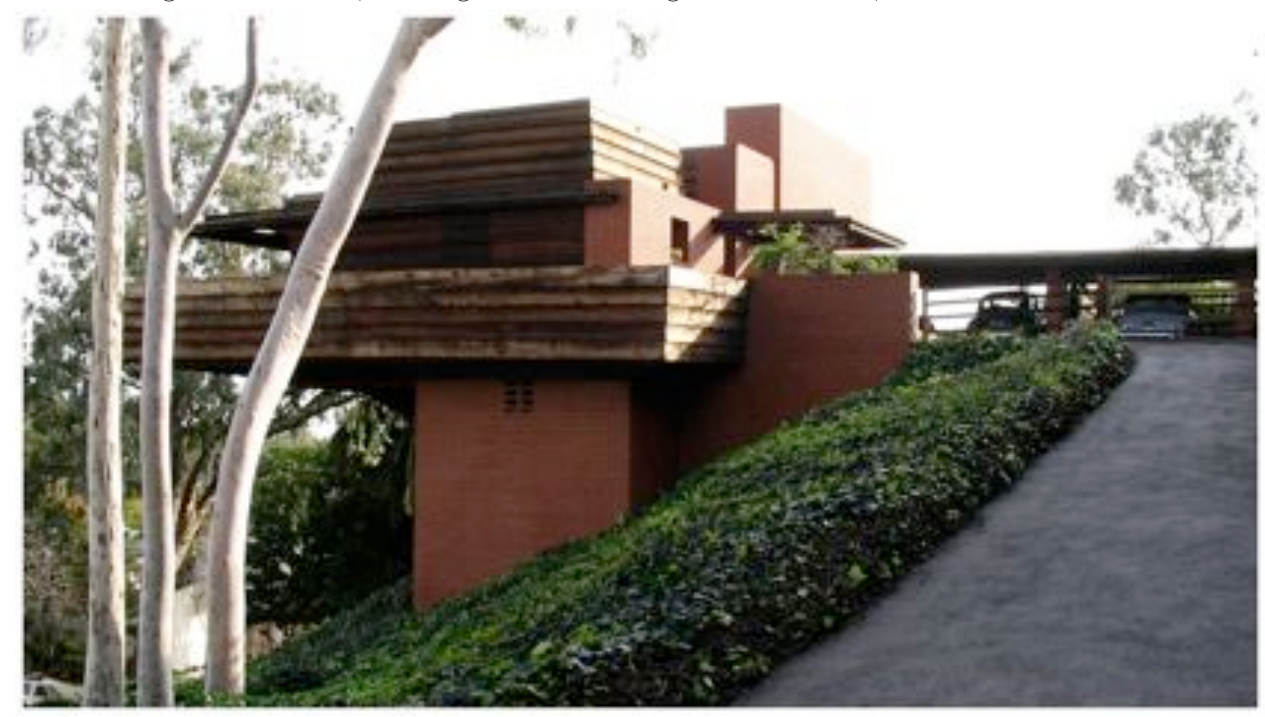
exploram a ideia de uma estrutura tipo "árvore" com generosas lajas em balanço

IMAGEM 54:

Sturges House. 1939. Brentwood Heighs, California, USA. Arquitetura: Frank Lloyd Wright. Foto: Débora Lima.

De modo que quando de sua viagem aos EUA tem a oportunidade de ver obras do grande arquiteto norte americano, além de entrar em contato com ex-membros da Bauhaus, recém-imigrados. 
É lendária a viagem aos Estados Unidos que o arquiteto paulista, então com 41 anos, realizou entre setembro de 1946 e novembro de 1947, sob os auspícios da John Simon Guggenheim Memorial Foundation, às vésperas da chamada Guerra Fria. Um episódio sobre o qual pairava uma névoa mítica apropriada para um retrato de um artista quando jovem. O álibi básico desta visita de reconhecimento era o ensino de arquitetura norte-americano. Instado a se aprofundar sobre seu objeto precípuo de interesse no MIT pelos que o acolheram, o irrequieto paulista logo se safou da modorra em Cambridge e saiu em turnê norte-americana, passando a maior parte de sua estadia percorrendo o país de costa a costa como um turista aprendiz. A convivência com o american way of life não demoveu a fé anticapitalista que povoou o discurso de maturidade de Artigas, mas renegar a influência norte-americana foi muito mais uma boutade de um ideólogo engajado que um arquiteto sensível à contribuição de um país que se tornou o exílio dourado dos luminares da arquitetura europeia do século $X X{ }^{66}$

Sua viagem só foi possível porque, como já assinalado, fazia parte da orquestrada campanha de incremento das relações culturais entre os EUA e seu principal sócio latino-americano, o Brasil, reforçado por um ativo intercâmbio cultural, que deu um destaque especial à arquitetura. Muitos brasileiros receberam bolsas de estudos na época, e Artigas incluía-se neste grupo, tendo sido beneficiado, em 1946, no auge deste idílio. ${ }^{67}$

Irigoyen (2002) nos introduz ao plano de estudos que Artigas apresentara à Fundação Guggenheim, e ressalta que, dado seu caráter inédito, é de grande interesse sua transcrição completa. Opinião que dividimos com a autora:

Os Estados Unidos representam no momento uma grande fonte para estudo e investigação em arquitetura, não só pelo que alguns de seus arquitetos já fizeram, como também porque tem atualmente quase que o monopólio dos grandes arquitetos do mundo. F. L. Wright, Walter Gropius, R. Neutra, somente para começar uma grande lista. A influência que estes mestres podem ter no desenvolvimento da arquitetura

\footnotetext{
${ }^{66}$ SEGAWA, Hugo (prefácio) In IRIGOYEN, Adriana. Wright e Artigas - Duas Viagens. São Paulo: Ateliê Cultural, 2002, p. 13.

${ }^{67}$ A vinculação de Artigas ao Partido Comunista Brasileiro (PCB) - ao qual era filiado desde 1945 - não representa um impedimento para a concessão da bolsa de estudos, afinal a guerra fria e seu combate sistemático ao comunismo somente teria início em 1947.
} 
americana, nós, brasileiros podemos julgar bem, lembrando, como frequentemente fazemos, o efeito no Rio de Janeiro da visita de Le Corbusier.

Já em São Paulo, a minha cidade, as coisas têm-se passado de maneira bem diferente. Condições locais especiais têm dificultado maiores raízes para a arquitetura moderna. O que nos tem faltado, pretendo trazer da América.

Para isso o sul dos Estados Unidos me parece a região ideal para pesquisa, dadas as condições de meio físico mais ou menos semelhantes. O controle dessas condições e as soluções particulares adotadas são generalizáveis? As solar houses de George Fred Keck, por exemplo, despertam particular interesse, especialmente quando prometidas para produção industrial.

Esse estudo, entretanto, não deveria prender-se unicamente às soluções particulares que cada arquiteto ou grupo de arquitetos tenha dado, mas às determinantes culturais das soluções. O carpenter americano levou a arquitetura a resolver certos problemas de maneira diferente do pedreiro brasileiro. Até onde aquele auxiliou e sugeriu a industrialização enquanto este conservou o artesanato, e qual o caminho para, com a identidade de problemas, generalizar as soluções com os meios de que dispomos. Como fundir um elemento típico da cultura nórdica com outro de ascendência mediterrânea? Para alguns (Lucio Costa) esse é o escopo principal da arquitetura moderna no que tem de internacional.

Espero que os estudos que eu venha a fazer tragam apreciáveis vantagens para a arquitetura brasileira. Em meu país trata-se justamente agora, da reorganização dos cursos oficiais de arquitetura. Nessa tarefa, e na de ensinar na minha universidade, poderia colaborar ajudando os arquitetos modernos de minha pátria, se pudesse juntar aos meus conhecimentos, a experiência que a América e os seus homens me pudessem proporcionar. A Universidade de São Paulo é interessada direta em meus estudos e providenciará a publicação do que eu julgar necessário. ${ }^{68}$

Essa transcrição é muito significativa ao nosso objeto de estudo pois apresenta questões que pareciam não existirem dentre os arquitetos brasileiros no período, mas que estavam, sim, latentes, como o era o interesse por parte destes pela arquitetura americana, como demonstra Vilanova em suas colocações. 
Irigoyen, mais uma vez, reflete que, da leitura do projeto podem-se extrair algumas questões. "Em primeiro lugar, é óbvio que Artigas pretende estabelecer uma relação entre São Paulo e os Estados Unidos como contraponto ao monopólio Rio de Janeiro-França. Embora contrariamente à exclusividade da ascendência de Le Corbusier no affair carioca, reconhece que São Paulo é um lugar aberto a múltiplas influências, desde que possam adequar-se às condições locais. Com isso, confirma tanto a rivalidade existente entre ambas as cidades, como a reticência paulista em filiar-se a uma única corrente do Movimento Moderno. Tal contraposição com o Rio em termos de influência cultural desembocará em uma contradição moral." ${ }^{69}$

Artigas chega a Nova York em 28 de setembro de 1946, mas faz do MIT (Massachusetts Institute of Technology) sua base de operações. Tendo sido sugerido um período inicial de participação em seminários e aulas no MIT para estudar a arquitetura moderna americana, inverte a ordem e logo começa, já em novembro, sua viagem pelo país, com a intenção de conhecer as obras mais importantes, in loco, bem como as instituições de ensino de arquitetura mais importantes do país. Retornaria ao Instituto apenas no verão de 1947.

De modo que, pouco depois de ter sido declarado "visitante do Instituto", onde conhece Alvar Aalto, Walter Gropius, Carl Koch, Ralph Rapson, Gyorgy Kepes e Joseph Hudnut, Artigas inicia a sua empreitada.

Em Nova York visita a Universidade de Columbia, sua Escola de Arquitetura e a Biblioteca Avery; na Carolina do Norte visita a Black Mountain College; na Florida conhece a Florida Southern College, em Lakeland, e em Scottsdale, Arizona, o Taliesin West - ambos projetos de Wright - aonde inclusive passa alguns dias em companhia do arquiteto. Em Los Angeles encontra-se com Richard Neutra que, sem dúvida, sugere os principais pontos de peregrinação da Costa Oeste, e cabe destacar aqui o interesse de Artigas pela arquitetura da Califórnia.

Ainda vale mencionar os contatos estabelecidos por Artigas na viagem com William Wilson Wurster (Case Study House $n^{\circ} 3$ ), Ralph Rapson (Case Study House $n^{\circ}$ 4) e o próprio Richard Neutra (Case Study House $n^{\circ} 6$ e no 13). 
Pelas imagens apresentadas no livro de Irigoyen (2002) e que são o seu álbum de viagens, o arquiteto visitou também obras de Philip Johnson, Edward Durell Stone, Carl Koch, Walter Gropius, Marcel Breuer, Bernard Maybeck, entre outros.

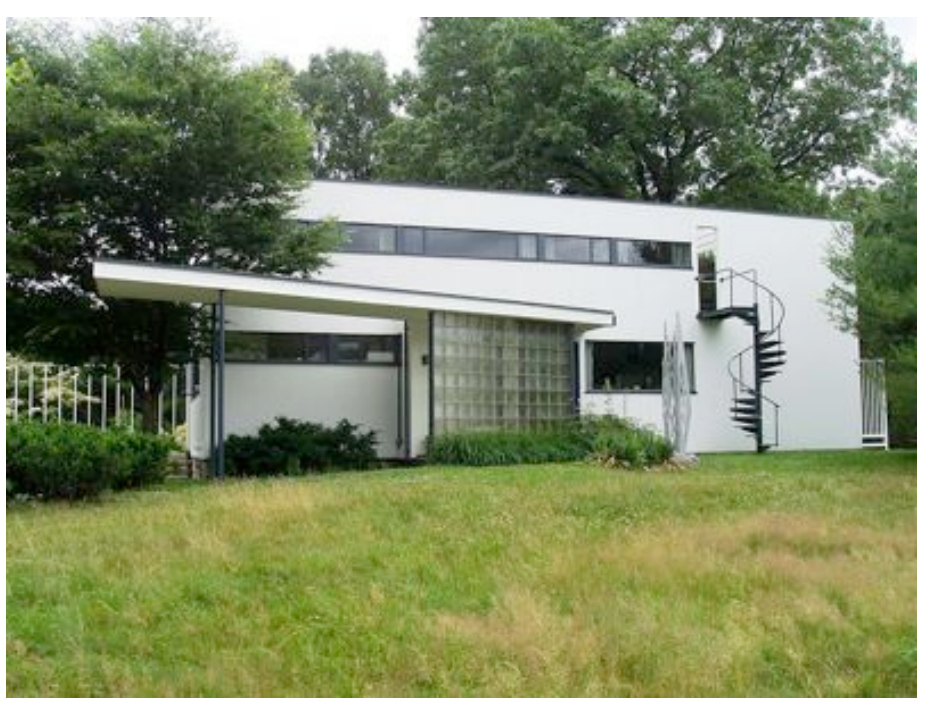

IMAGEM 55: Gropius House. 1938. Lincoln, Massachusetts, USA. Arquitetura: Walter Gropius

Passando por muitos outros destinos, após, literalmente, cruzar o país de canto a canto, o arquiteto retorna ao MIT aonde transcorrem os últimos meses de sua bolsa, retornando ao Brasil em novembro de 1947.

Muito deve ter visto, em muitas obras deve ter-se detido por uma período mais longo, ao registrar em fotografias o que conheceu, e muito apreendeu sobre a arquitetura que vinha sendo feita por lá.

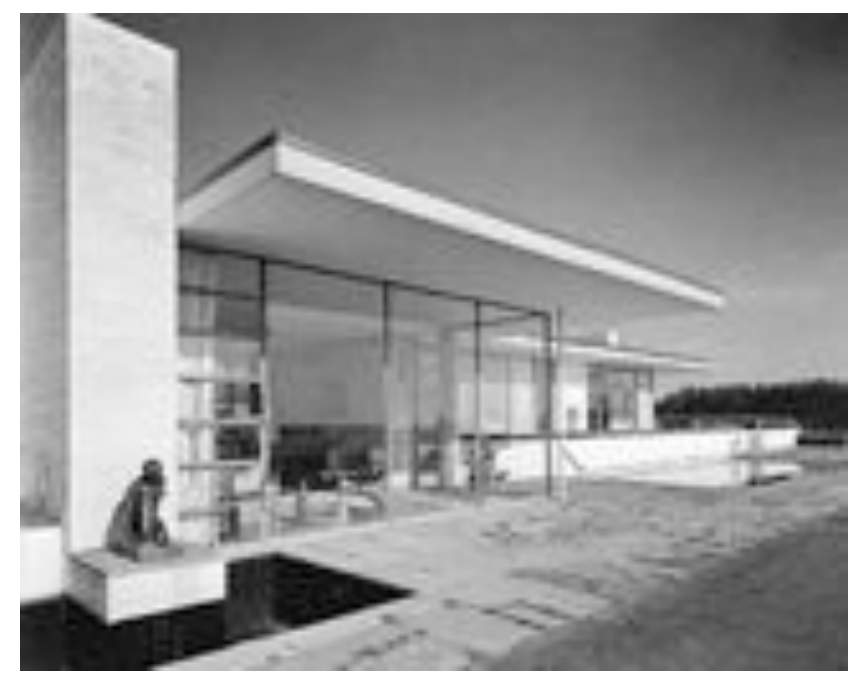

IMAGEM 56: Conger Goodyear House. 1938 Old Westbury, Long Island, USA. Arquitetura Edward Durell Stone.

Mas e o que ficou para a obra de Artigas desta viagem? As imagens feitas pelo arquiteto revivem sua visão de um país que, então, parecia admirar. No trabalho precursor de Irigoyen, no qual praticamente baseamos nosso texto, todas as obras do arquiteto analisadas pela autora foram realizadas por ele anteriormente à viagem. Nesse sentido, ela se pergunta: o tour representa a confirmação ou, talvez, o desencanto das ideias que havia abraçado no período 1937/1946? 
O impacto da estadia americana na vida profissional do arquiteto nos faz acreditar que não foi somente a influência de Wright a marcar seus trabalhos, como também os contatos com os institutos de ensino americanos e a visita à tantas obras paradigmáticas que o arquiteto empreendeu.

O plano de trabalho de sua bolsa de estudos já deixava claro que o arquiteto conhecia e também se interessava pelo trabalho de muitos outros arquitetos atuantes nos Estados Unidos, além de Wright.

George Frederick Keck, por exemplo, com a utilização de plantas em meios níveis - que pode ser verificada em projetos como a Casa Rio Branco Paranhos (1943) e sua própria casa (1942) - e suas "casas-solares" - cuja espacialidade fluida com a possibilidade de produção em escala industrial -, já interessavam Artigas antes da viagem. E todos os várias arquitetos atuando em Chicago nessa época podem tê-lo influenciado. ${ }^{70}$

Mas ainda pode-se notar a importância de Keck na obra de Artigas do final da década de 1950 quando “certas inovações incluídas nas 'casas solares' serão reelaboradas por Artigas na hora de transformar a moradia paulista. A fachada cega, as plantas em meios níveis e os tetos com lâmina de água merecem sua atenção."71

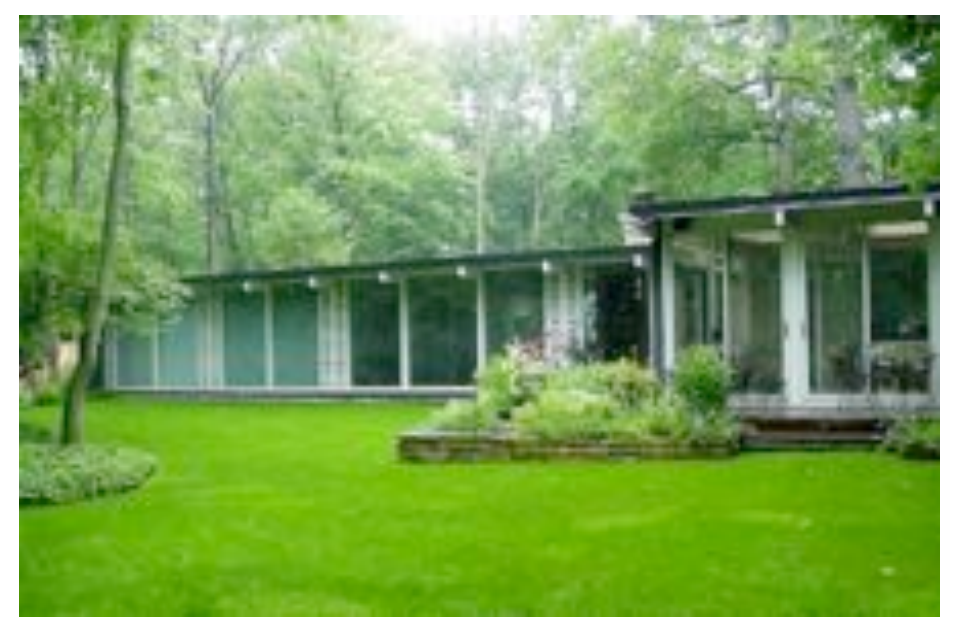

IMAGEM 57: Chicago solar Home. 1955 Chicago, llinois, USA. Arquitetura: Geoge Frederick Keck.

Uma obra de Wright de 1938 distanciada conceitualmente das Prairie Houses tão vinculas à Artigas, mas que chamou especialmente atenção quando de sua visita foi o Florida Southern College, em Lakeland. "Bibliotecas, salas de aula, capela, centro estudantil; todas as construções foram projetadas com expressivas estruturas de concreto armado, cujos pilares recebem um destaque que até então não era comum 
na obra de Wright. O motivo é retomado nas numerosas galerias e passagens cobertas que tentam amenizar o clima da região, situada a sessenta quilômetros da cidade costeira de Tampa. O clima e a latitude de Lakeland podem se assemelhar aos de São Paulo. A imagem arquitetônica surpreende por sua analogia conceitual com certas experiências estruturais de Artigas, como o Ginásio de Guarulhos, de 1960."72 Ou mesmo o Ginásio de Itanhaém, de 1959.

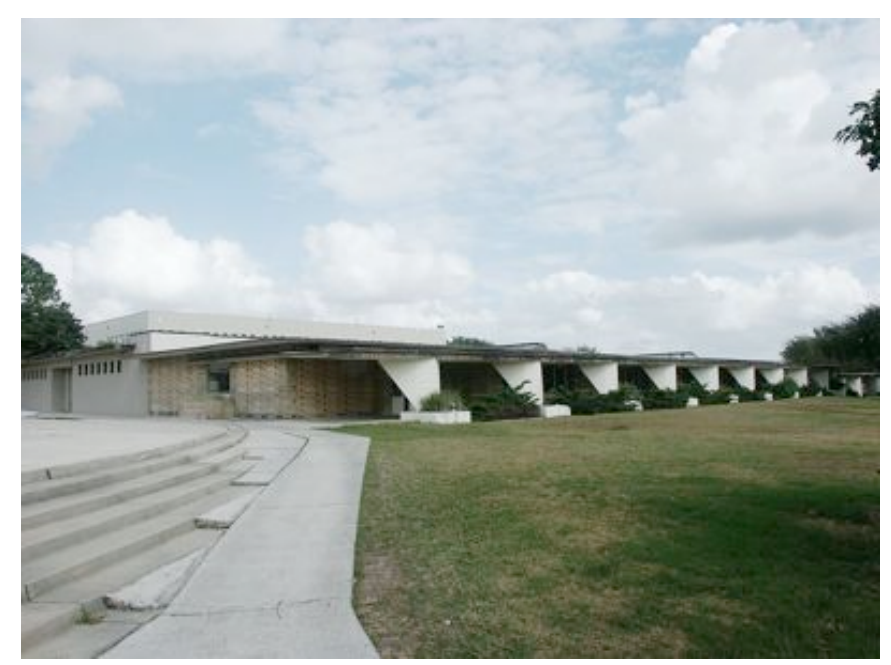

IMAGEM 58: "Carter, Walbridge, Hawkins Seminar Building - Florida Southern College", 1938-1941 Lakeland, Florida, USA. Arquitetura: Frank Lloyd Wright. Foto: Débora Lima.

IMAGEM 59: G

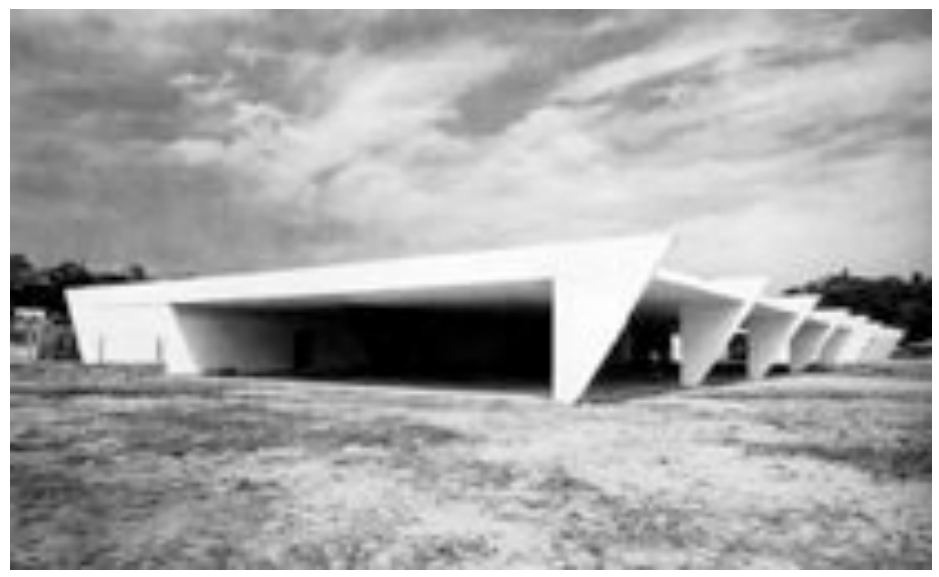

Retornando ao Brasil, projeta nos anos 50 edifícios significativos, dentro do vocabulário "corbusiano" da Nova Arquitetura Brasileira, porém com características muito distintas, enfatizando com suas lages de cobertura o caráter de "Abrigo" de seus edifícios. 
A partir de 1960 a obra de Artigas atinge maturidade e independência de linguagem, e virá a profundamente influenciar toda uma geração de Arquitetos em São Paulo.

Outra questão a ser colocada aqui é que a presença na obra de Artigas de uma contundente relação entre estrutura, delimitação espacial e expressividade põe em evidência parecenças com a produção, a partir de 1945, também de Mies van der Rohe.

Esta suposta conexão - bem menos comum dentro da historiografia brasileira do que a estabelecida com Wright e Corbusier - é também proposta por Hugo Segawa, dando continuidade a seu argumento de uma possível influência da visão industrializável contida na arquitetura norte-americana do pós-guerra. Segundo ele, referindo-se à obra de Artigas: "Não se deve descartar, também, uma influência da visão industrializável da arquitetura norte-americana [...] em particular a obra de Mies van der Rohe - sintetizador da máxima da arquitetura como estrutura". ${ }^{73}$

Edson Mafhuz, sem a intenção de criar "uma teia de relações nacionais e internacionais que comprove afiliações e influências" em seu artigo "Transparência e sombra: o plano horizontal na arquitetura paulista" ${ }^{\text {"4 }}$, corrobora essa provável relação acrescentando também a arquitetura de Paulo Mendes da Rocha -, e ainda matiza a independência da produção brasileira na forma como isso ocorre:

O que fica claro desde o primeiro exame dos projetos de Vilanova Artigas e Paulo Mendes da Rocha, talvez um dos seus aspectos mais interessantes, é que não estamos diante de transposições diretas de um procedimento projetual. [...], o que encontramos na obra de ambos são edifícios com personalidade própria, fruto de transformações e adaptações relacionadas a uma cultura muito diferente da norteamericana. O que se vislumbra na obra dos dois arquitetos paulistanos é o desenvolvimento de uma série de temas essenciais que podem ser extraídos dos precedentes. $^{75}$

\footnotetext{
${ }^{73}$ SEGAWA, Hugo. Arquiteturas no Brasil 1900 - 1990. São Paulo: Editora da Universidade de São Paulo, 2002, p. 148

${ }^{74}$ MAFHUZ, Edson. Transparência e sombra: o plano horizontal na arquitetura paulista. Arquitextos, n. 79.01. São Paulo, Portal Vitruvius, dez. 2006

${ }^{75}$ MAFHUZ, op. cit.
} 
De fato, na segunda metade da década de 1940 Mies Van der Rohe já gozava de um grande prestígio como arquiteto, sobretudo nos Estados Unidos, para onde tinha se mudado em setembro de 1938.

Artigas passara também por Chicago durante sua viagem, em meados de 1947, período em que já se tinham iniciado as obras do novo campus do Institute of Technology de Chicago; o certo é que em 1946 já estavam construídos o Alumni Memorial Hall e o edifício da Faculdade de Química.

Nesse momento acontecia também a exposição no MoMA de New York organizada por Philip Johnson sobre o trabalho de Mies, na qual se deu a conhecer por primeira vez - através de uma maquete - a Casa Farnsworth.

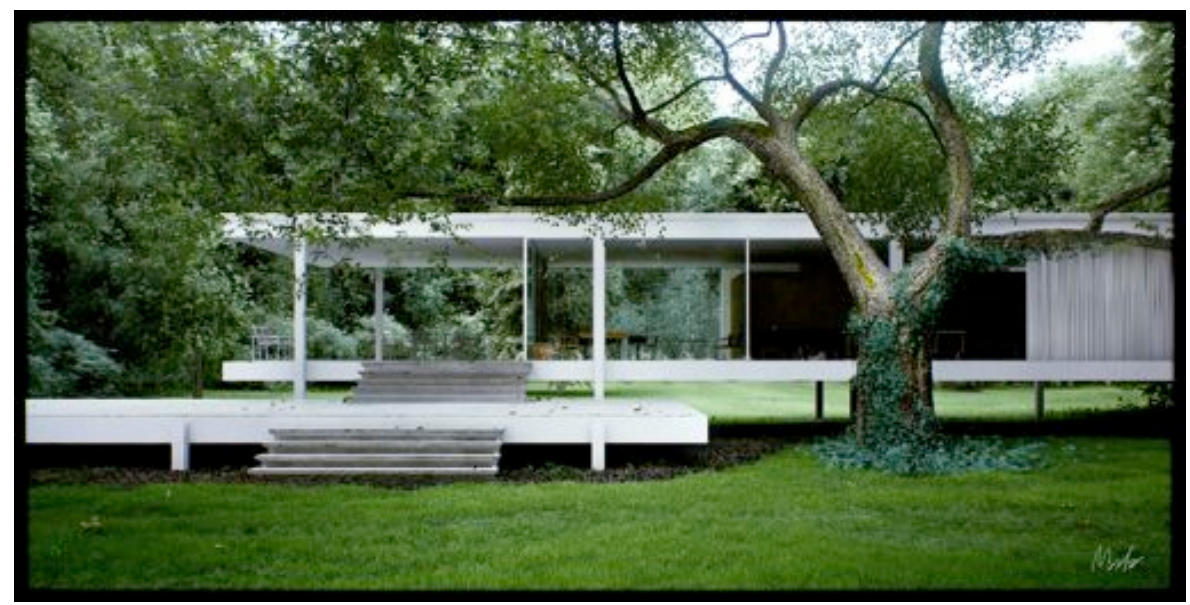

IMAGEM 60: The Farnsworth House. 1951. Plano, linois, USA. Arquitetura: Ludwig Mies van der Rohe

Não se pode dizer se Artigas teve a oportunidade de voltar a New York (havia sido a quarta parada de sua trajetória pelo país) para ver a exposição, mas ao menos o trabalho de Philip Johnson - organizador da exposição e naquele momento o discípulo mais importante de Mies - já lhe parecia interessar, pois fotografou sua casa em Cambridge.

Cunha $^{76}$ propõe uma argumentação muito pertinente quando analisa o trabalhos dos dois arquitetos: Mies e Artigas. E levanta que, à parte da possibilidade de que Artigas conhecesse e ainda se interessasse pelo trabalho de Mies realizado a

\footnotetext{
${ }^{76} \mathrm{CUNHHA}$, Marcio Cotrim. Mies e Artigas: a delimitação do espaço através de uma única cobertura. Arquitextos108.01 (Romano Guerra Ed. Ltda.). São Paulo, Portal Vitruvius, ano 09, maio 2009.
} 
partir de 1937 nos Estados Unidos, Ihe chama especial atenção alguns dos projetos de Mies entre 1945 e 1969. ${ }^{77}$

Edifícios que revelam a intenção de Mies por construir uma espacialidade diáfana e contínua, determinada por uma única cobertura sustentada através de uma estrutura vertical perimetral, posicionada fora dos fechamentos do edifício que, em seu conjunto de vigas e pilares, determina a imagem final destes projetos. A exposição da estrutura e da lógica com a qual foi concebida desvelou, por trás da clareza e simplicidade alcançada, um rigoroso conhecimento técnico, evoluído e experimentado ao longo da obra anterior do arquiteto.

Essa descrição ampla e generalizável de parte da obra de Mies aproxima-se, ao menos de modo superficial, da estratégia inicial utilizada em grande parte dos projetos de Artigas a partir da segunda metade dos anos 1950: a definição de um contingente de área por uma cobertura sob a qual todo programa é livremente articulado em níveis intermediários e onde a estrutura, sem a interferência de outros elementos, assume o caráter expressivo do projeto. Portanto, mesmo conscientes de que no caso de Artigas por trás desta descrição simplificada ao máximo se escondam diferenças importantes em cada um dos projetos, serve para descrever casas, escolas, clubes e estações rodoviárias, abrangendo, assim como no caso de Mies, uma gama de programas díspares e de dimensões aparentemente incompatíveis. ${ }^{78}$

E o autor continua sua análise, e por não querer permanecer no âmbito da superficialidade, vê a necessidade de assinalar ao menos duas questões que delimitam semelhanças e diferenças, e que matizam aspectos importantes entre ambas as obras.

Nos projetos de Artigas depois de 1956 prevaleceu a utilização do concreto armado in loco; nos de Mies, com uma evidente anterioridade, prevaleceu a partir da década de 1930 a utilização de estruturas metálicas industrializadas. Por trás desta evidente e importante diferença esconde-se uma atitude que em essência os

\footnotetext{
${ }^{77}$ A Casa Farnsworth (1951), o Teatro Nacional de Mannheim (1952-53), o S.R Crown Hall (1950-69), a Casa 50x50 (1950-51), o Centro de Convenções de Chicago (1953), o edifício administrativo do Run Bacardi em Cuba (1957), o Museu Georg Schäefer, em Schweinfurt (1960-1961) Galeria Nacional de Berlim (1 962-68). 
aproximam: a eleição de materiais condizentes com a realidade técnica local, tanto no que diz respeito a questões orçamentárias como tecnológicas e construtivas. Se considerarmos a prevalência da obra de Mies - depois de 1937 - nos Estados Unidos, a escolha dos materiais, nos dois casos, se insere numa possível tradição moderna local. Ao se aceitar esta constatação - a diferença de material como uma forma de aproximação conceitual -, as diferentes soluções formais alcançadas são legitimadas por se tratarem de respostas associadas à técnica e ao material correspondente. Portanto, ao sobressaltarem-se os aspectos formais de cada componente estrutural, revelam-se estratégias similares.

Contudo, é fundamental perceber que no interior destes edifícios essa semelhança resulta espacialmente diferente.

A relação entre as áreas externas e internas prefiguradas pelas coberturas descobrem a outra diferença importante entre os dois arquitetos. A permeabilidade entre interior/exterior nos projetos de Mies é controlada por um embasamento prévio, submetendo-a a uma limitação geométrica física, atribuindo a estes projetos - casas ou museus - o caráter de templo. Essa relação é mediada por uma plataforma, um embasamento criado onde o usuário deve, por meio de escadas ou rampas, tomar consciência de que acede antes de ultrapassar a linha imaginária da cobertura e as paredes envidraçadas.

No caso de Artigas, e tomando como exemplos os projetos da FAU-USP (1962-1969), da Escola de Utinga em Santo André (1962) e do Ginásio Itanhaém (1960-61), a consciência de aceder ao edifício se dá já no seu interior - tornando a transição mais sutil e prolongada ao máximo - onde numa situação idealizada, já sob a cobertura, o usuário percebe ter deixado o espaço publico da rua e tem a opção de subir ou descer através de rampas e/ou escadas. ${ }^{79}$ 


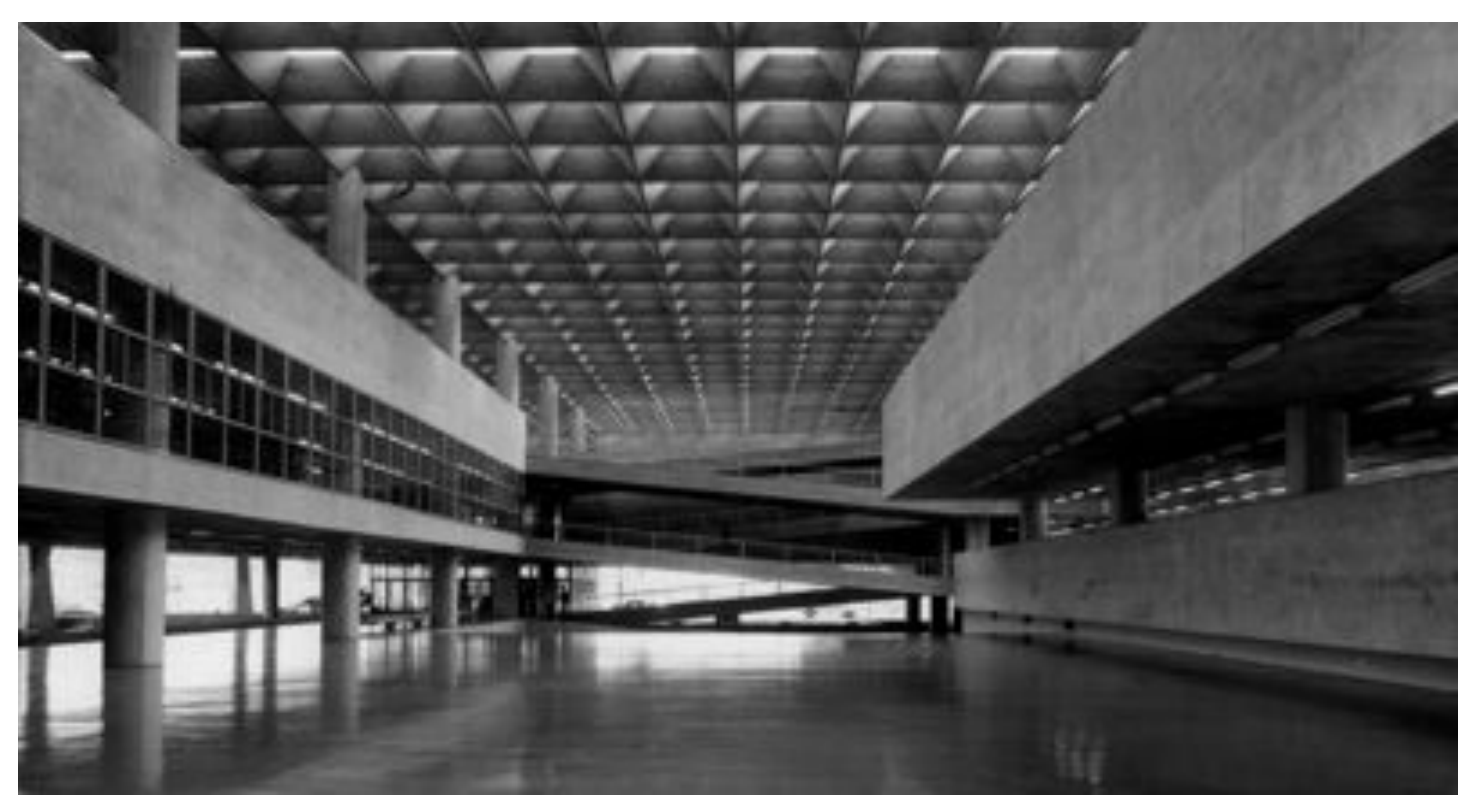

IMAGEM 61: "FAU-USP". 1962-69. São Paulo, São Paulo, Brasil. Arquitetura: João Batista Vilanova Artigas. Foto: Cristiano Mascaro.

1947: Projeto de Oscar Niemeyer para a residência Burton-Tremaine, Santa Bárbara, Califórnia, USA

Nunca foi fácil o relacionamento de Oscar Niemeyer com a América do Norte. Por outra parte, a "dinâmica" da cultura brasileira esteve sempre mais voltada para a Europa, cujos centros metropolitanos geraram os modelos válidos da modernidade assumidos pelos arquitetos ao longo do século 20.

De modo que foi sempre muita complexo o vínculo de Niemeyer com os Estados Unidos, onde - não deixa de ser curioso - participou da construção de três edifícios. O primeiro deles foi o pavilhão do Brasil para a Feira de Nova York (1939). Houve ainda a sede da ONU (1947) e também a Residência Strick em 1964.

Mais houve um outro projeto, não construído, que ligaria Niemeyer aos Estados Unidos.

Aproveitando a presença do mestre brasileiro em Nova York por vários meses, em 1947, quando da elaboração junto ao grupo de trabalho internacional para o projeto do Edifício-sede das Nações Unidas em New York, o rico financista Burton Tremaine solicitou-Ihe o projeto de uma casa em Santa Bárbara, na Califórnia. 


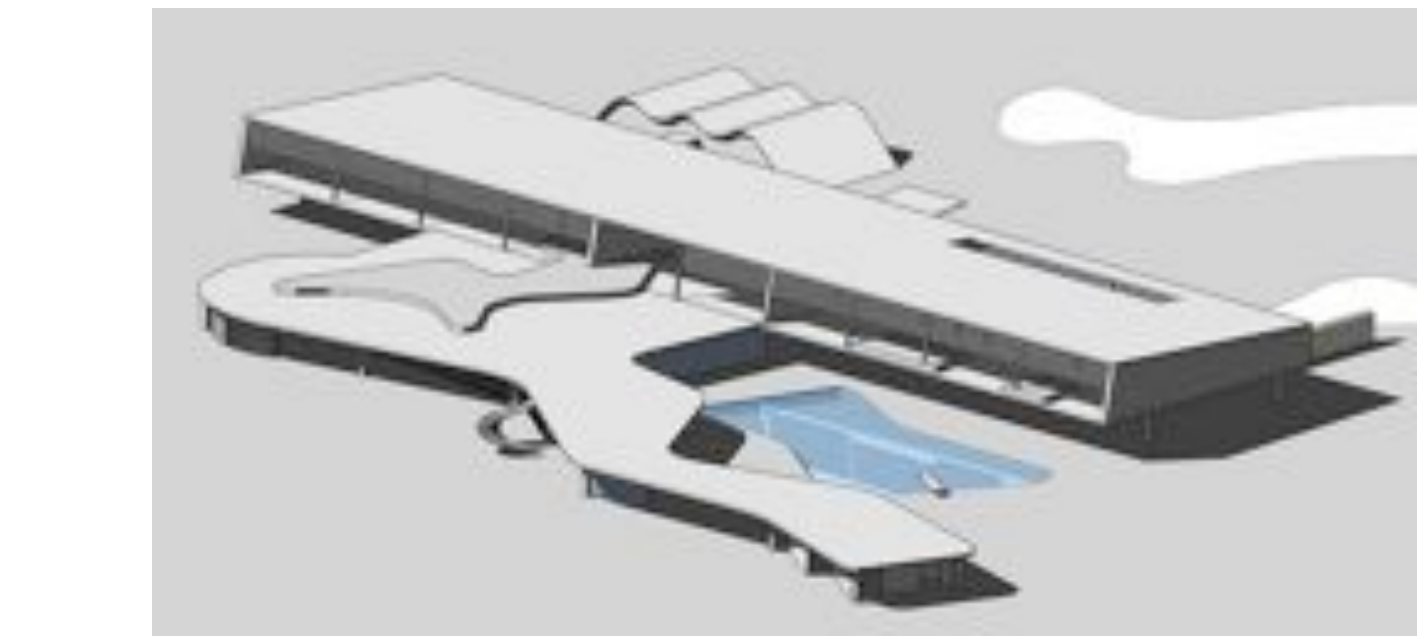

IMAGEM 62: The Burton Tremaine House. 1947. Santa Barbara, Califórnia, USA. Arquitetura: Oscar Niemeyer e Burle Marx.

O terreno situava-se em uma alta plataforma na beira do oceano Pacífico, com uma vista extraordinária para a paisagem marítima.

Aqui Niemeyer continuou as articulações linguísticas que começara na Pampulha, estabelecendo um diálogo entre a herança racionalista dos volumes puros e a liberdade plástica das formas sinuosas que iriam caracterizar a sua produção posterior. Separou radicalmente as funções públicas e privadas. Em um retângulo colocado sobre pilotis, paralelo ao oceano, situou os quartos, protegidos por uma varanda com as empenas inclinadas para permitir a entrada controlada do sol no seu espaço aberto. ${ }^{80}$

Niemeyer tinha começado a utilizar essa solução na residência Prudente de Morais Neto, no Rio de Janeiro (1944), e depois a aplicaria nos projetos em Diamantina, MG. A circulação horizontal dos quartos se desenvolve em uma galeria protegida por uma fachada de brises, com um espaço central aberto onde fica a escada principal. Com essa distribuição, como aparece nos riscos de estudo da casa, garante-se o controle solar e a ventilação cruzada nos quartos, além de direcionar as visuais para o oceano.

Entretanto, a parte mais original da residência aparece na extensa laje curvilínea que prolonga o espaço livre dos pilotis (lembrança da Casa do Baile, na Pampulha, e antecedente da cobertura da Casa das Canoas), que contém as salas de visita e de 
jantar, e a área de lazer ao redor da piscina, permitindo a percepção da paisagem marítima.

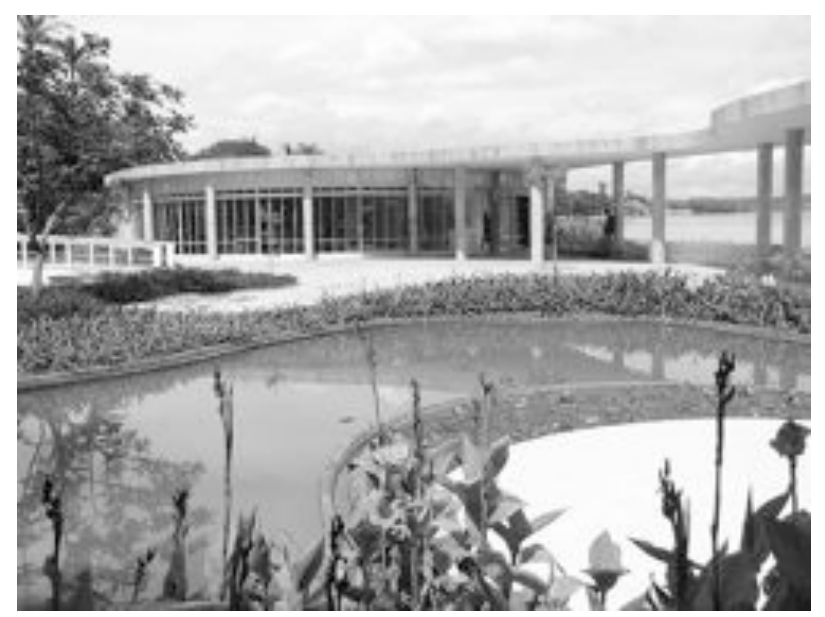

IMAGEM 63: Casa de Baile. 1943. Belo Horizonte, Minas Gerais, Brasil. Arquitetura: Oscar Niemeyer. Foto: Débora Lima.

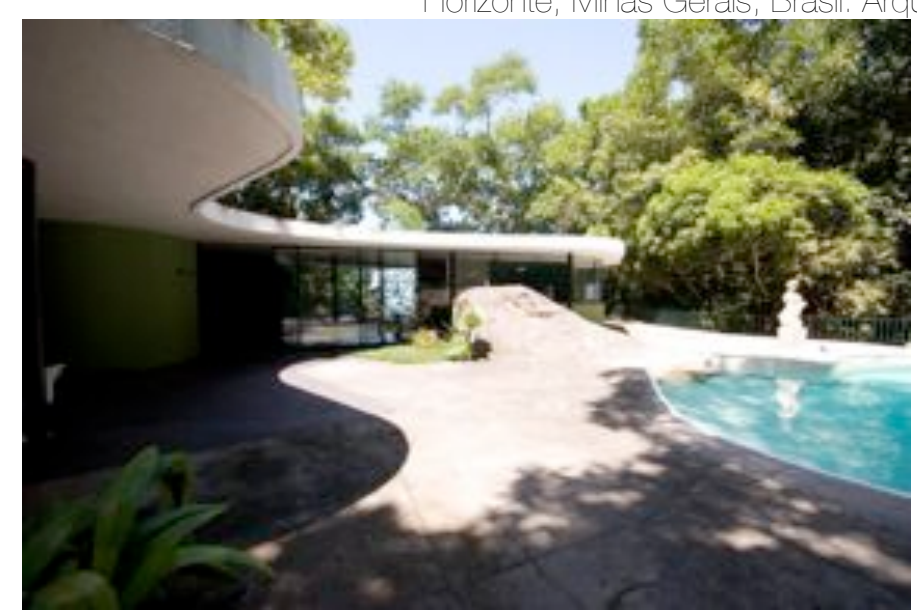

IMAGEM 64: Casa das Canoas, 1951. Rio de Janeiro, Rio de Janeiro, Brasil. Arquitetura: Oscar Niemeyer Foto: Débora Lima.

Com essa solução, a introversão da vida privada era contraposta à dinâmica hedonista do espaço público, caracterizado pela sua continuidade e ao mesmo tempo pela identificação, com painéis divisórios, das particularidades ambientais das diferentes funções. O acesso é identificado por uma laje em balanço, e três abóbadas (referência à Igreja de São Francisco do complexo da Pampulha) definem a cobertura dos carros.

As curvas livres da vila à beira-mar são comparadas com as de Hans Arp em Painting toward architecture (1948) de Hitchcock e com as da vila Savoye na mostra do MoMA "From Le Corbusier to Niemeyer: 1929/49", pouco antes de Stamo 
Papadaki se engajar na primeira monografia sobre a obra de Oscar, "The Work of Oscar Niemeyer"81, em 1950.

O projeto não foi realizado, não se sabem as razões. Mas como teria sido recebido, e quais desdobramentos esta "Pampulha californiana" teria na produção local?

\section{4: Jonh Peter Interviews, USA}

John Peter (1917-1998) foi o "modern living editor" das revistas Look e Life e repórter de rádio e televisão para a CBS e a NBC. Por muitos anos foi o chefe de sua própria empresa de consultoria em publicações em Nova York, com clientes nos Estados Unidos e Europa.

Fitas e fotografias incluídas na "John Peter Collection", que hoje faz parte dos arquivos da Library of Congress, foram utilizados no seu livro "A História Oral da Arquitetura Moderna: Entrevistas com os maiores arquitetos do século XX" (The Oral History of Modern Architecture: Interviews with the Greatest Architects of the Twentieth Century ${ }^{82}$ ), publicado em 1994.

Fotos também foram utilizados no livro "Mestres da arquitetura moderna" (Masters of Modern Architecture) $)^{83}$, de 1958.

A Coleção consiste de transcrições das entrevistas e fotografias usadas por John Peter em seus livros sobre os arquitetos do século 20.

Arquitetos que estão particularmente bem representados nesses materiais incluem Buckminster Fuller, Walter Gropius, Philip Johnson, Louis Kahn, Le Corbusier, Mies van der Rohe, Richard Neutra, IM Pei, Eero Saarinen, Minoru Yamasaki, e Frank Lloyd Wright.

Ao pesquisar nos arquivos da coleção descobrimos que John Peter não entrevistou somente Oscar Niemeyer, como pensávamos, mas também outros três arquitetos brasileiros: Affonso Eduardo Reidy, Marcelo Roberto e Oswaldo Arthur Bratke.

\footnotetext{
${ }^{81}$ PAPADAKI, Stamo. The Work of Oscar Niemeyer. New York: Reinhold, 1950.

82PETER, John. The oral History of Modern Architecture - Interviews with the Greatest Architects of the Twentieth Century. New York: Harry N. Abrams, 1994.

83PETER, John. Masters of modern architeture. New York: G. Braziller, 1958.
} 
Como sabemos, a presença de projetos brasileiros em publicações especializadas na Europa e nos EUA tornou-se comum nos anos 40 e 50.

Em Masters of Modern Architecture, livro publicado nos EUA e que seria muito popular no final da década de 1950, são apresentadas obras de 38 arquitetos de todo o mundo, dentre os quais: quatro da Itália, um da Espanha, três do Japão, dois da França e cinco do Brasil.

A metodologia que John Peter utilizou para definir quais seriam os "mestres" a serem incluídos no seu livro é um indício de como as trocas entre os arquitetos de diferentes nacionalidade foram fundamentais.

Ele faz um panorama histórico da arquitetura moderna não a partir dos fatos e dos processos, mas a partir dos arquitetos, dos profissionais, que foram a base da sua pesquisa.

Envia, então, formulários impressos para todos os escritórios e arquitetos americanos cadastrados no AIA (American Institute of Architects) e propõe a pergunta: Quem são os mestres da arquitetura moderna?

Muitos respondem: Gropius, Mies Van der Rohe, Wright, como se esperava. Dentre tantos modernistas, vários representantes da arquitetura moderna no Brasil são "votados", no total 16 são brasileiros.

A partir dai John Peter passa a entrevistar uma série deles. No documento abaixo, que faz parte do acervo "Transcripts and Photographs from the John Peter Collection", vemos a lista desses arquitetos, e os quatro brasileiros citados.

Escutar esses arquitetos respondendo perguntas como: How did you happen to became an architect? What is your architectural philosophy? What is the future of architecture? What are the most important influences in your work? é um fato revelador dos principios arquitetônicos defendidos por esses grandes mestres da nossa arquitetura brasileira, no ano de 1954, e indicam o quanto eles estavam integrados inteiramente ao discurso do movimento modern mundial.

Em anexo inserimos a trascrição destas entrevistas, bem como os arquivos com os áudios digitalizados especialmente para esse trabalho, ou seja, inéditos até aqui. 
Deallot Descripties of the Tramsripts and Fategraphs fren the Jabn Peer Collestien

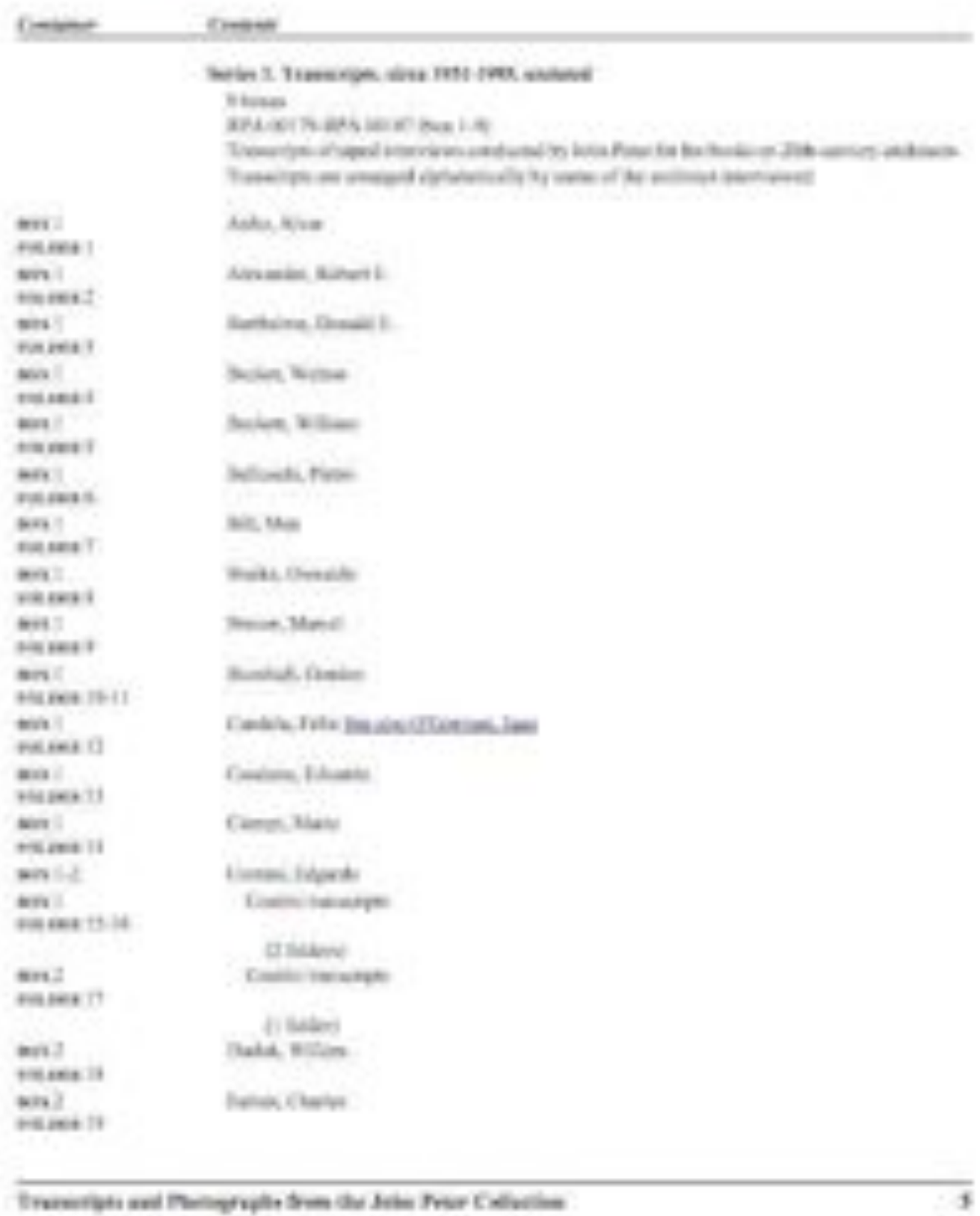




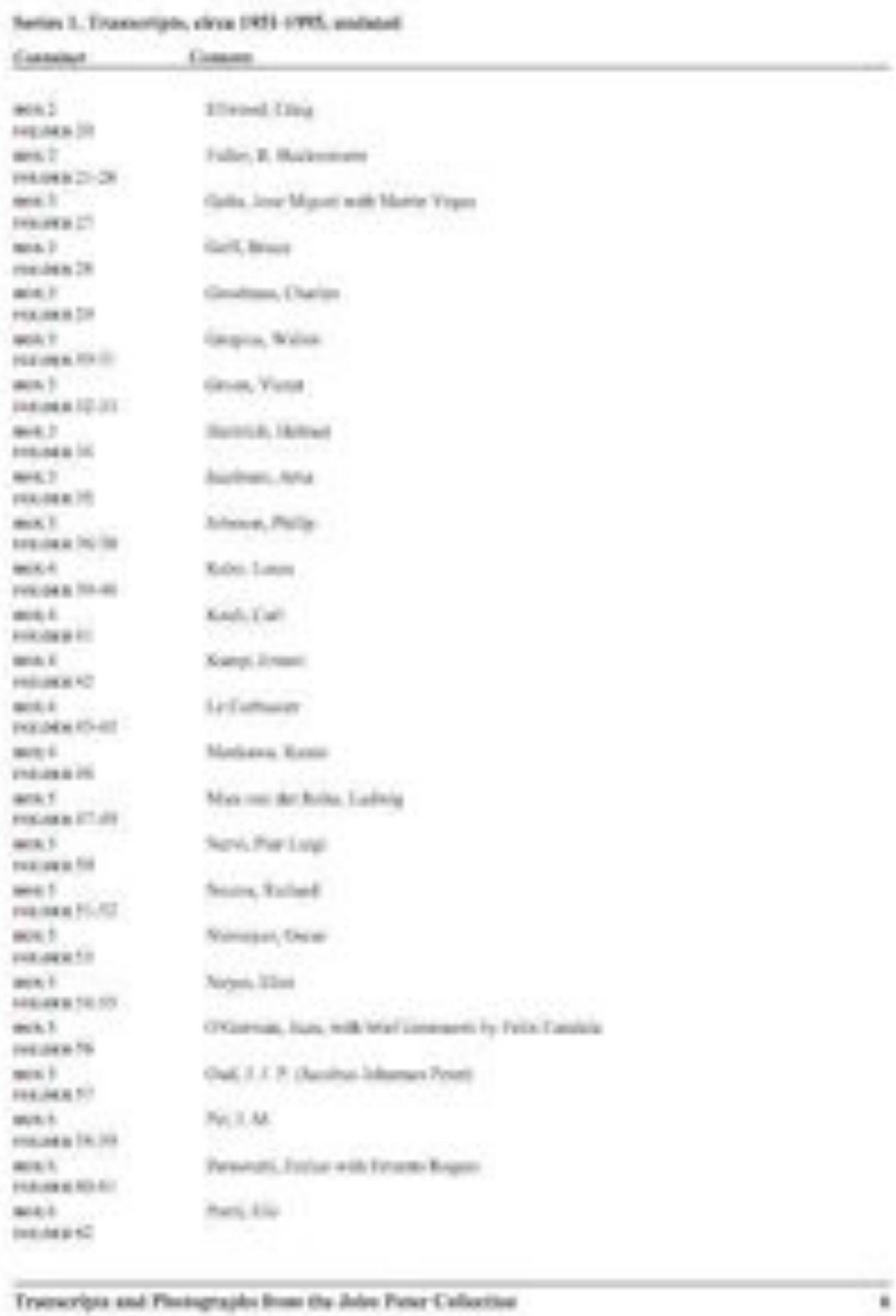




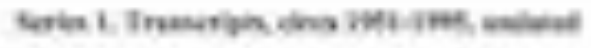

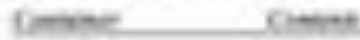

$\operatorname{man}$

ats bis

trimmintat

$\cos$

Anes kith

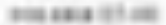

$\min$

namiantas

$m:$

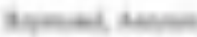

xim nasta

hกา

tient 15

$\min 7$

nata 7

$\min 7$

towes

min

wat

an?

mentet

an?

tems

$\sin 3$

neme $\mathrm{T}$

men?

timas

nent

mase thin

$m+1$

andast

min

nemsere

min:

netmat1

nin

temtw

$\sin$

newro

wos:

noseat

$+\infty)^{4}$

tivent

and

nakno in

hens

nos kes on

ena

wask $k=$

twa 7

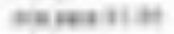

$\min =$

tositis

Ants Noluen Ribet

An 1 =

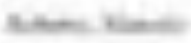

ans wert

anams had

tumotim

Kinew was

hemere Rew ine

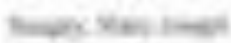

Nitriess the

Whim

then niabs

thes kiyhe

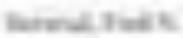

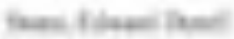

Fen lase

Yionestime

ane nete

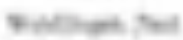

atining

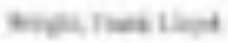

sornet. Fine

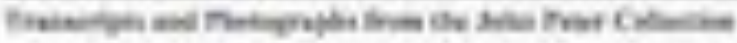

Series t. Transeripts, circa 195i-1995, unduted

Comiuiner Compuris

\begin{tabular}{|c|c|}
\hline 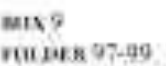 & Youna: Nimoru \\
\hline $\begin{array}{l}\text { nox } Q \\
\text { ratinit ise }\end{array}$ & Yashimun Jatizo \\
\hline $\begin{array}{l}\text { mox } 9 \\
\text { focipe } 10 \text { Jo! }\end{array}$ & 7elfin, Exy: \\
\hline
\end{tabular}




\section{7-1962: O projeto de Mies Van der Rohe para o Consulado americano em São Paulo}

Em 1957, como se sabe, realizou-se em São Paulo, a IV Bienal de Arte. Mies van der Rohe, Marcel Breuer, Kenzo Tange, Phillip Johnson, Francisco Beck, Jacob Mauricio Ruchti e Mario Glicério Torres foram os arquitetos convidados para compor o júri que selecionaria os melhores projetos apresentados na Exposição Internacional de Arquitetura.

Entretanto, como nos relata GALEAZZI ${ }^{84}$, segundo a ata publicada na revista Acrópole n 227 de 1957, aonde estão divulgados os profissionais premiados, o nome de Mies van der Rohe não está relacionado entre aqueles já referidos, responsáveis pelas menções.

Desconhecidos os motivos da provável ausência deste nas atividades que the haviam reservado na Bienal, sabe-se que o arquiteto esteve em São Paulo para visitar o terreno onde projetaria o edifício do Consulado dos Estados Unidos. Projeto este que, por razões ainda desconhecidas, não foi construído.

Como se pode comprovar na nota publicada por Philipp Lohbauer na revista Acrópole n 230 de dezembro de 1957, e também transcrita por GALEAZZI: "Esteve em nosso meio, durante poucos dias, o 'Pai da Arquitetura Moderna' - Mies van der Rohe. Veio ele para estudar o local para projetar a nova Embaixada dos Estados Unidos em São Paulo, que será localizada na av. Paulista. (...) Contou-nos que com frequência Ihe pedem que faça conferências sobre arquitetura. Sempre rejeita os convites. 'A língua do arquiteto', afirma, 'é o lápis, a obra deve falar por ele. Existe uma arquitetura só, a boa, a qual é, porém uma arte, o resultado de um processo específico de desenvolvimento lógico, processo esse que deverá evoluir do complicado e difícil para a última perfeição do simples, do sóbrio, do puro'."

Sobre o seu ensino, desde quando dirigia a Bauhaus, até o trabalho que até então desenvolvia na ITT (llinois Institute of Technology) em Chicago, Mies explica ao entrevistador: "Em nossa escola não projetamos, não fazemos projetos. Desenvolvemos nos primeiros quatro anos um 'curriculum', para, estudados todos os elementos estruturais, todas as condições específicas de uma obra, resolvidos todos 


\section{TROCAS, TRANSFERÊNCIAS, DIÁLOGOS E OUTROS CAMINHOS}

os problemas particulares e inerentes à arte de construir (não de projetar), alcançar no quinto ano a composição de todos estes elementos, da qual deverá resultar a arquitetura pura com toda a sua beleza das proporções e da expressão limpa do seu destino". 85

O terreno destinado ao Consulado correspondia a uma parcela urbana na Avenida Paulista delimitada pelas ruas Itapeva e Rio Claro. Levantamentos aerofotogramétricos de 1968 indicam que até finais dos anos sessenta, não existiam edifícios construídos na área.

GALEAZZI nos explica que, no volume 17 dos Arquivos Garland Mies van der Rohe do Museu de Arte Moderna de Nova York, estão publicados uma série de croquis, anotações e documentos técnicos, referentes ao projeto de 1957 do arquiteto para o consulado dos Estados Unidos em São Paulo. O projeto, como se sabe, não foi construído, mas na relação de documentos pesquisados estão apresentadas plantas executivas, o que indica que o projeto chegou a etapas de finalização já em 1960.

No texto de apresentação que antecede o catálogo de desenhos, escrito por Fran Schulze, editor responsável pelos Arquivos, observam-se algumas incongruências quanto às imagens selecionadas para ilustrar o que seria a versão final do projeto. As pranchas não pertencem ao mesmo jogo, isto é, as propostas se distanciam em um ano já que as informações especificadas nos selos, indicam datas de 1959 e de 1960 e, efetivamente, o material gráfico não corresponde à mesma versão se organizarmos segundo a ordem descrita no índice do catálogo. Além disso, estão relacionados

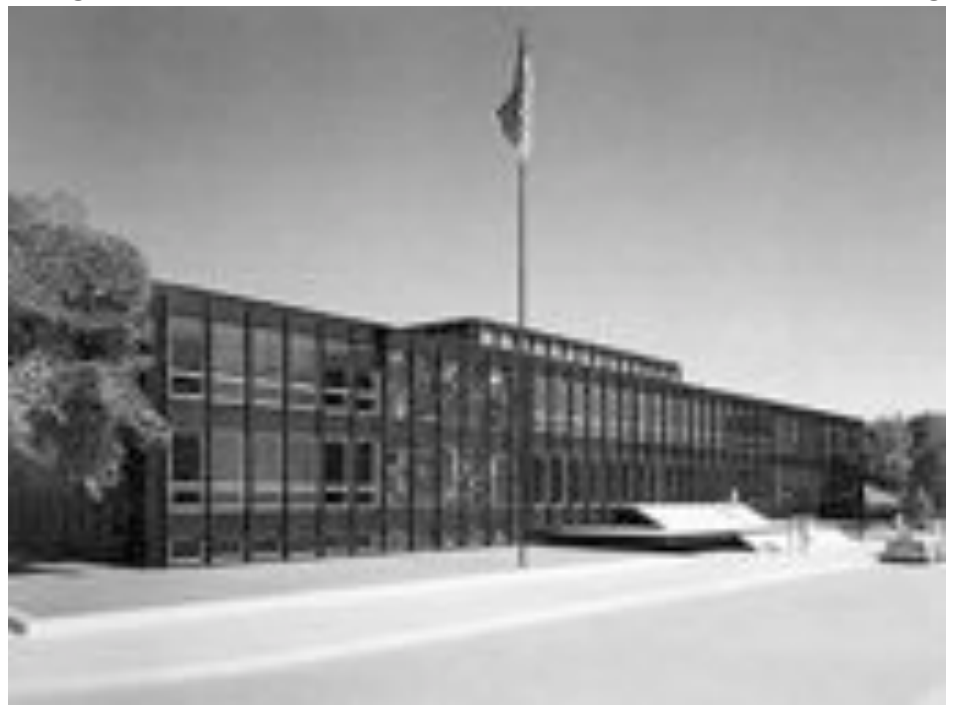
desenhos do projeto executivo da versão definitiva que não correspondem aos primeiros anotados.

IMAGEM 65: Projeto para o Consulado dos Estados Unidos. 1957-1962. São Paulo, São Paulo, Brasil. Arquitetura: Mies van der Rohe. Maquete - Projeto não construído

\footnotetext{
${ }^{85}$ GALEAZZ, Ítalo. Mies van der Rohe no Brasil. Projeto para o Consulado dos Estados Unidos em São Paulo, 1957-1962. Arquitextos056 (Romano Guerra Ed. Ltda.). São Paulo, Portal Vitruvius, janeiro 2005.
} 
No entanto, a falta de correspondência relativa à seleção de imagens, as quais foram identificadas depois de uma organização prévia de todo o catálogo, são esquecidas para que toda a atenção seja dirigida ao estudo do projeto arquitetônico, que está bem apresentado numa sequência de imagens que incitam ao entendimento das fases do projeto e à identificação das características inerentes às obras de Mies van der Rohe, que realizou uma série de croquis preliminares para o projeto do Consulado, em que trabalha e estuda diferentes sistemas estruturais. Organiza as funções conforme número de plantas e estrutura. Desenha fachadas e croquis perspectivos nos quais identificam-se diferentes tipologias. É importante observar que nestes croquis podem ser reconhecidos outros projetos que Mies desenvolvia paralelamente ou que já tinha trabalhado antes.

A questão da originalidade é, portanto, irrelevante desde o ponto de vista da concepção moderna: não se trata de obter produtos novos, senão de construir objetos genuínos, cujos atributos formais, deem conta ao mesmo tempo de sua estrutura visual e de seu programa. Artefatos que resolvam suas contradições internas por meio da síntese da forma, estabelecido em ordem que estruture o projeto, sem violentar as lógicas particulares dos elementos que o constituem. ${ }^{86}$

E para a Arquitetura Moderna Brasileira? Qual foi a contribuição deste projeto de Mies, num período em que a arquitetura brasileira - sobretudo a paulista apresentou seus melhores frutos?

O que é importante ressaltar é que o grande arquiteto representante do modernismo internacional esteve envolvido por um bom tempo em um projeto para o Brasil, pelo menos entre o período de desenvolvimento do trabalho, que foi de 1957 a 1962. O projeto executivo é de junho de 1960, permanecendo a incógnita sobre o que aconteceu nos dois últimos anos.

É importante ressaltar que muitas técnicas construtivas aplicadas aqui foram adaptadas às circunstâncias brasileiras sob vários aspectos - tecnologia, indústria, economia, cultura, etc. -, o que, de certa forma, foi importante para conferir 
particularidades a estes projetos brasileiros, prontamente reconhecidos internacionalmente.

Como sabemos é muito conhecida e analisada a presença de Le Corbusier sobre a arquitetura brasileira. A de Mies van der Rohe, outro grande mestre do século $X X$, é escassamente mencionada na historiografia da nossa arquitetura, apesar de que sua influência, principalmente em São Paulo, já estava mais do que estabelecida desde o final da década de 40, início da década de 50.

Uma possível explicação se prende ao fato de que a influência do maestro alemão é mais difícil de identificar, pois opera fundamentalmente de modo abstrato, ao nível dos princípios e das estruturas formais, enquanto a influência corbusiana, embora também contenha um componente abstrato, vai além dos esquemas distributivos e soluções estruturais e se caracteriza também pela utilização de muitos dos elementos que configuram a aparência dos projetos do arquiteto franco-suíço. ${ }^{87}$

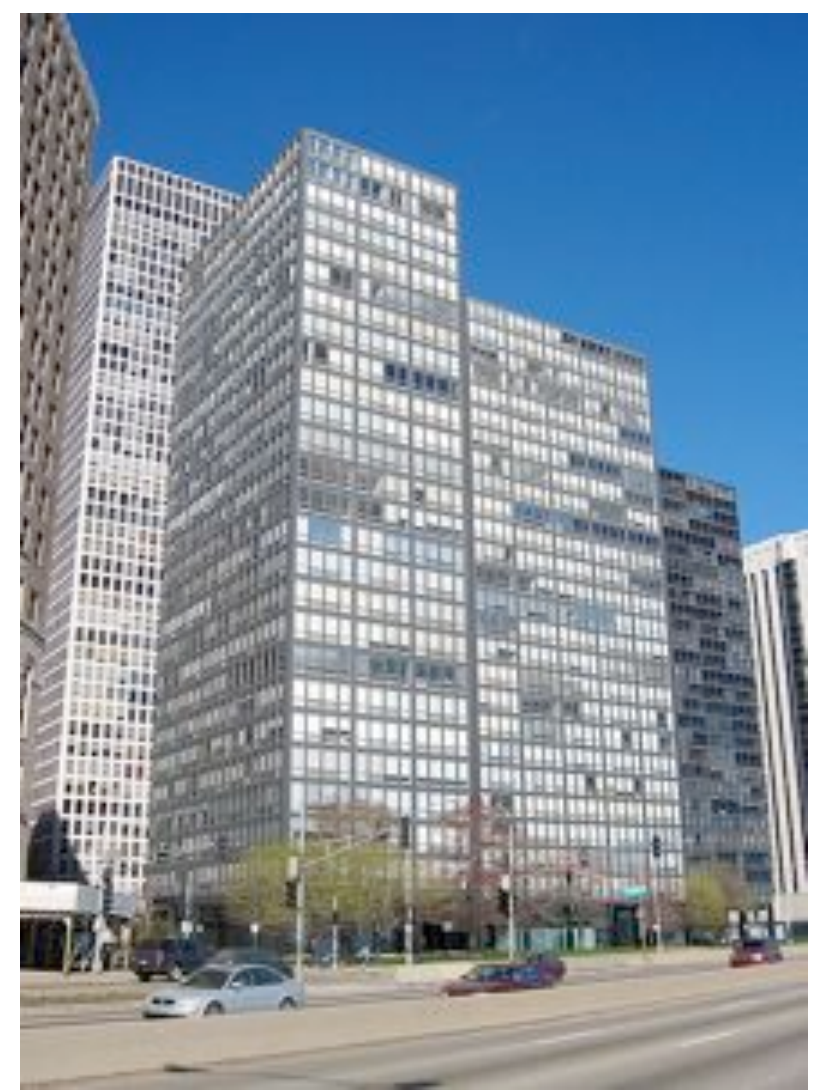

IMAGEM 66: Lake Shore Drive. 1949-1951. Chicago, llinois, USA. Arquitetura: Ludwig Mies van der Rohe. Foto: Débora Lima.

\footnotetext{
${ }^{87}$ MAHFUZ, Edson da Cunha. Ordem, estrutura e perfeição no trópico - Mies van der Rohe e a arquitetura paulistana na segunda metade do século XX. Arquitextos057.02 (Romano Guerra Ed. Ltda.). São Paulo, Portal Vitruvius, ano 05, fevereiro 2005
} 
É conhecida a quantidade de projetos realizados por arquitetos brasileiros entre as décadas de 50 e 60 em que se pode reconhecer um diálogo com certas características presentes nos projetos deste arquiteto e sua "visão industrializável"88, mesmo em um país economicamente e principalmente tecnicamente deficiente nesse sentido. De modo que hoje já é corriqueiro se ouvir referências aos miesianos, principalmente paulistas.

O interessante trabalho de Ferroni, intitulado "Aproximações sobre a obra de Salvador Candia" ${ }^{89}$, por exemplo, observa a obra desse arquiteto em função de alguns critérios específicos - relação do edifício com o contexto urbano, a coerência formal e aspectos construtivos -, justamente a partir de uma clara e assumida influência exercida pela obra de Mies van der Rohe - em especial a realizada durante seu longo exílio nos Estados Unidos - sobre a sua obra.

O autor chega a mencionar que a obra de Candia "procura ainda estabelecer uma interlocução com a arquitetura moderna produzida nos Estados Unidos no segundo pós-guerra, notadamente a realizada pelos arquitetos da Bauhaus, como Breuer, Gropius e Mies van der Rohe"90, mas acreditamos que a relação estabelecida de uma forma mais orgânica se dê apenas com o último.

No grupo dos arquitetos mackenzistas, do qual Salvador Candia fazia parte, o mesmo autor detecta uma interessante propensão ao trabalho colaborativo, com a pouca incidência de trabalhos individuais, uma vez que os projetos são quase sempre assinados por dois, três ou mais arquitetos. Tal propensão talvez explique também a maleabilidade com que se portam tais arquitetos, Candia dentre eles, na absorção das influências de arquitetos brasileiros mais velhos e dos arquitetos estrangeiros.

O autor menciona tais relações de forma enfática, afirmando que este grupo de arquitetos, buscando alternativas à forte presença carioca, tentava firmar "suas bases em um repertório distinto daquele empregado de forma hegemônica pelos cariocas, indo buscar suas referências nos Estados Unidos através de Wright, Mies, Gropius,

\footnotetext{
${ }^{88}$ SEGAWA, Hugo. Arquiteturas no Brasil 1900-1990. São Paulo: Edusp, 1998, p. 148. ${ }^{89}$ FERRONI, Eduardo Rocha. Aproximações sobre a obra de Salvador Candia. São Paulo: FAUUSP, $1^{a}$ edição, 2008. 
Breuer, Neutra, e se aproximando de Oswaldo Bratke, Franz Heep e Rino Levi no Brasil". 91

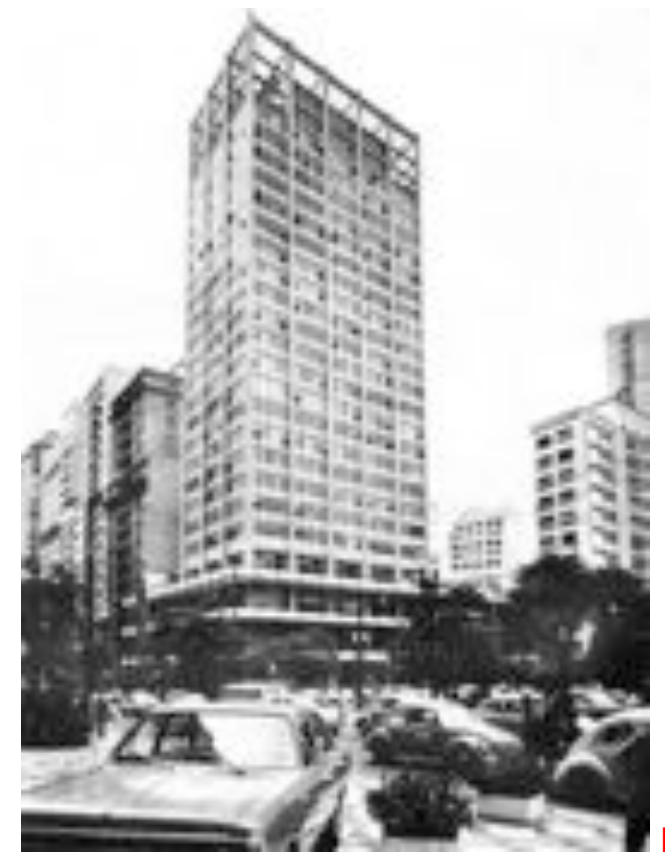

IMAGEM 67: Conjunto Metropolitano, 1960. São Paulo, São Paulo, Brasil. Arquitetura: Salvador Candia e Giancarlo Gasperini.

"O partido adotado previa nos fundos do terreno um importante conjunto comercial, organizado em torno deu um pátio central, vazado em casa um dos cinco níveis, permitindo ampla visibilidade das lojas superpostas. Um cinema de 1.200 lugares completam esse corpo. À frente e acima dele nasce a torre de escritórios, com 19 andares, visivelmente comprometida com as soluções de Mies van der Rohe"92

Salvador Candia e seus colegas se veem diante de "novos programas" engendrados pelos processos de verticalização e metropolização e que caberiam aos arquitetos resolver: o "grande prédio de escritórios", a "grande loja de departamentos" e o "grande prédio de apartamentos", programas estes que se encaixam perfeitamente nas especificidades dos projetos norte-americanos da época, muitos deles desenvolvidos por Mies van der Rohe.

Em trabalhos de muitos outros arquitetos podemos perceber esta presença. As novas relações entre arquitetura moderna e cidade tradicional a partir dos anos 1950 e que na cidade de São Paulo terá como cena a necessidade de se construir em lotes estreitos e profundos, herança da divisão territorial fragmentária de períodos anteriores, e tendo como contexto um centro tencionado entre uma breve história consolidada e

\footnotetext{
${ }^{91}$ FERRON, op. cit, p. 64

92XAVIER, Alberto; LEMOS, Carlos; CORONA, Eduardo. Arquitetura Moderna Paulistana. São Paulo: Pini, 1983, P. 53
} 
as forças de transformação constante, se mostra uma questão desafiadora para estes arquitetos.

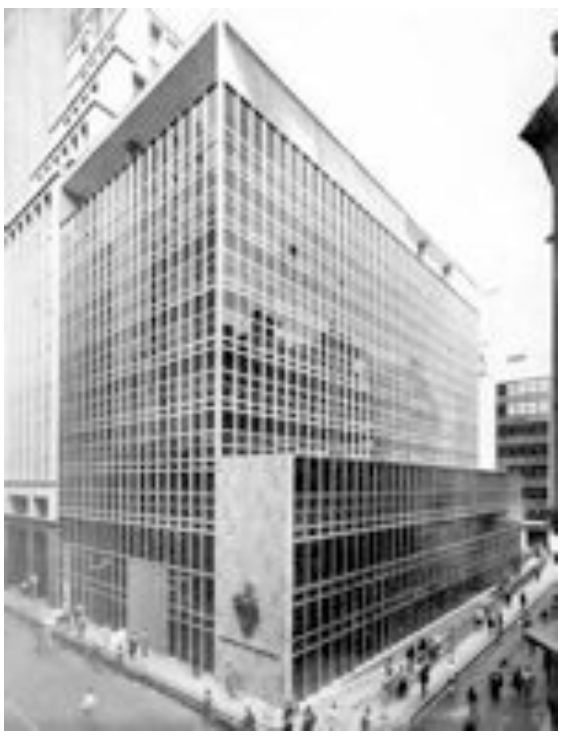

IMAGEM 68: 'Edifício-sede do Bank of London \& South América Ltda. Barão de lguape. 1959. São Paulo, São Paulo, Brasil.

Arquitetura: Henrique Mindlin e Giancarlo Palanti.

"Este edifício contrasta com os demais prédios da rua XV, tradicionalmente dedicados às atividades bancarias... Trata-se de um dos primeiros bancos construídos todo de vidro - material que nunca havia sugerido ideia de segurança -, daí o ineditismo da solução... A pequena largura da rua da Quitanda determina o recuo no bloco, que é dotado de garagem, a primeira de edífício bancário no centro da cidade"93

Nas referências às obras do arquiteto Mies van der Rohe podemos constatar não só o nível da interlocução estético-cultural em curso naquele momento, como também as predileções do arquiteto estudado. Na discussão sobre as soluções técnico-construtivas propostas pelos arquitetos e as que foram de fato assumidas pelos promotores temos um excelente desenho da cena civilizacional, onde as ideias esbarram em impossibilidades tecnológicas e financeiras.

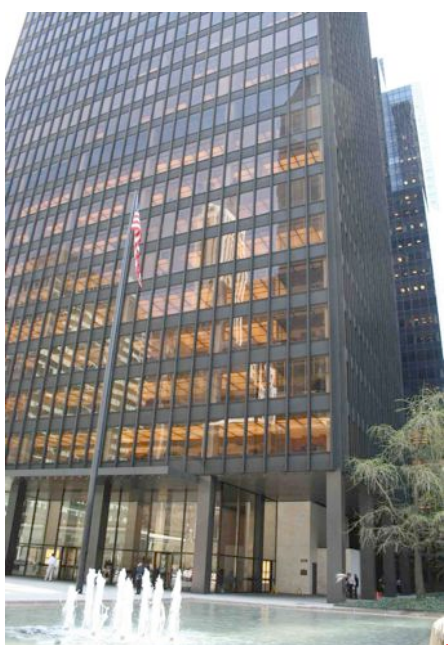

IMAGEM 69: Seagram Building. 1954-1958. New York, New York, USA Arquitetura: Ludvig Mies van der Rohe. Foto: Débora Lima.

"Destinado à sede de grande empresa industrial este edifício de 20 andares emprega com largueza a solução "curtain-wall", associando-a, nas prumadas de serviços e sanitários, a painéis pré-moldados de alumínio. Apresentando sofisticado conjunto de detalhes, especificações e equipamentos, flila-se com rigor ao desenho do arranha-céu "miesiano", o que determina a redução das bordas da laje nervurada de concreto armado a dimensões ínfimas, de modo a resultarem extremamente delgados os perfis horizontais da caixilharia de alumínio que as envolvem" 94

${ }^{93}$ XAVIER, op, cit, p. 51

${ }^{94}$ XAVIER, op. cit, , p. 59 


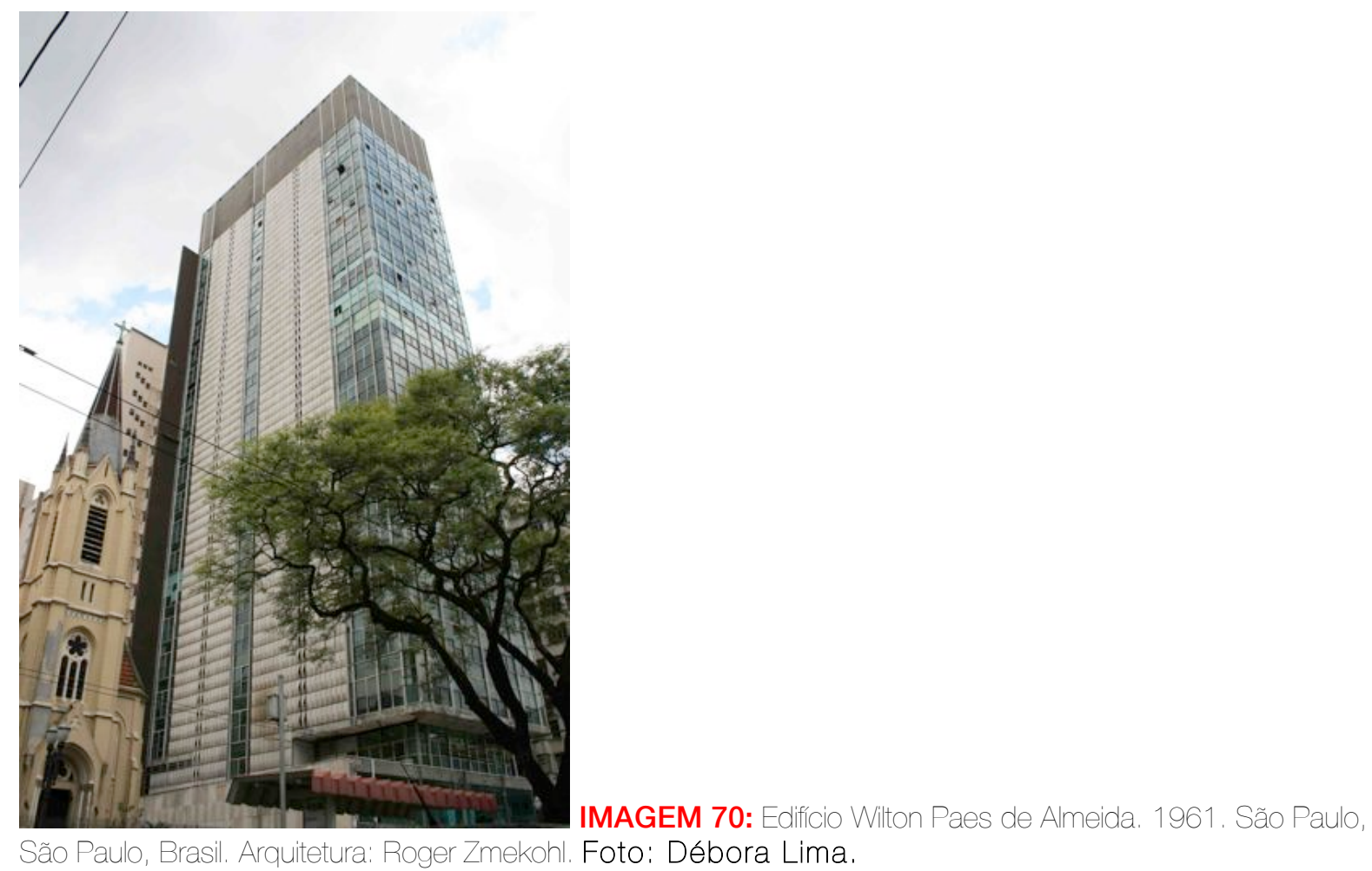

São Paulo, Brasil. Arquitetura: Roger Zmekohl. Foto: Débora Lima.

Existem ainda evidências, algumas das quais Mahfuz apresenta em seu artigo ${ }^{95}$, em favor da hipótese de que a arquitetura paulistana foi, especialmente e também nas décadas de 60 e 70, influenciada pela de Mies van der Rohe, e que essa influência, transformada e adaptada, definiu algumas das suas características mais importantes e é parcialmente responsável pela qualidade dessa arquitetura.

É no âmbito da construção formal que Mahfuz aborda esta questão, localizando-a em algumas soluções estruturais e no papel dessa estrutura na definição da forma do edifício. É o caso dos projetos que empregam o esquema estrutural comumente descrito como exoesqueleto, cuja natureza é ser externo ao volume por ele vertebrado, ficando visíveis tanto os elementos verticais como os horizontais.

Surgido em 1931, no projeto para Palácio dos Sovietes, de Le Corbusier, o exoesqueleto vai aparecer no Brasil, em toda a sua clareza, somente em 1941, pela mão de Oscar Niemeyer, no Teatro Municipal de Belo Horizonte, voltando a ser utilizado pelo mesmo arquiteto no auditório do Ministério de Educação e Saúde (1948), e na fábrica Duchen (1950).

\footnotetext{
${ }^{95}$ MAHFUZ, Edson da Cunha. Ordem, estrutura e perfeição no trópico - Mies van der Rohe e a arquitetura paulistana na segunda metade do século XX. Arquitextos057.02 (Romano Guerra Ed. Ltda.). São Paulo, Portal Vitruvius, ano 05, fevereiro 2005
} 


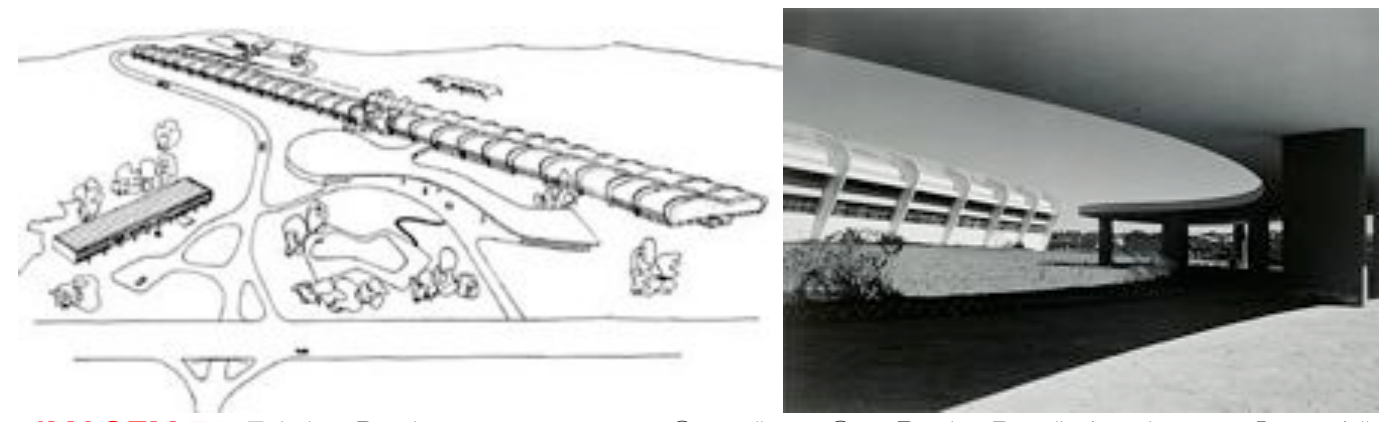

IMAGEM 71: Fábrica Duchen. 1950-1953. Guarulhos, São Paulo, Brasil. Arquitetura: Oscar Niemeyer. DEMOLIDA

Embora o exoesqueleto corbusiano possa ter influenciado diretamente os projetos citados de Niemeyer e os de Affonso Reidy para a Escola BrasilParaguai (1952) e para o MAM (1953), os precedentes para o caso paulistano parecem ser de extração miesiana, pela sua elementaridade, contenção e austeridade: uns e outros se configuram como pórticos ortogonais de seção retangular. ${ }^{96}$

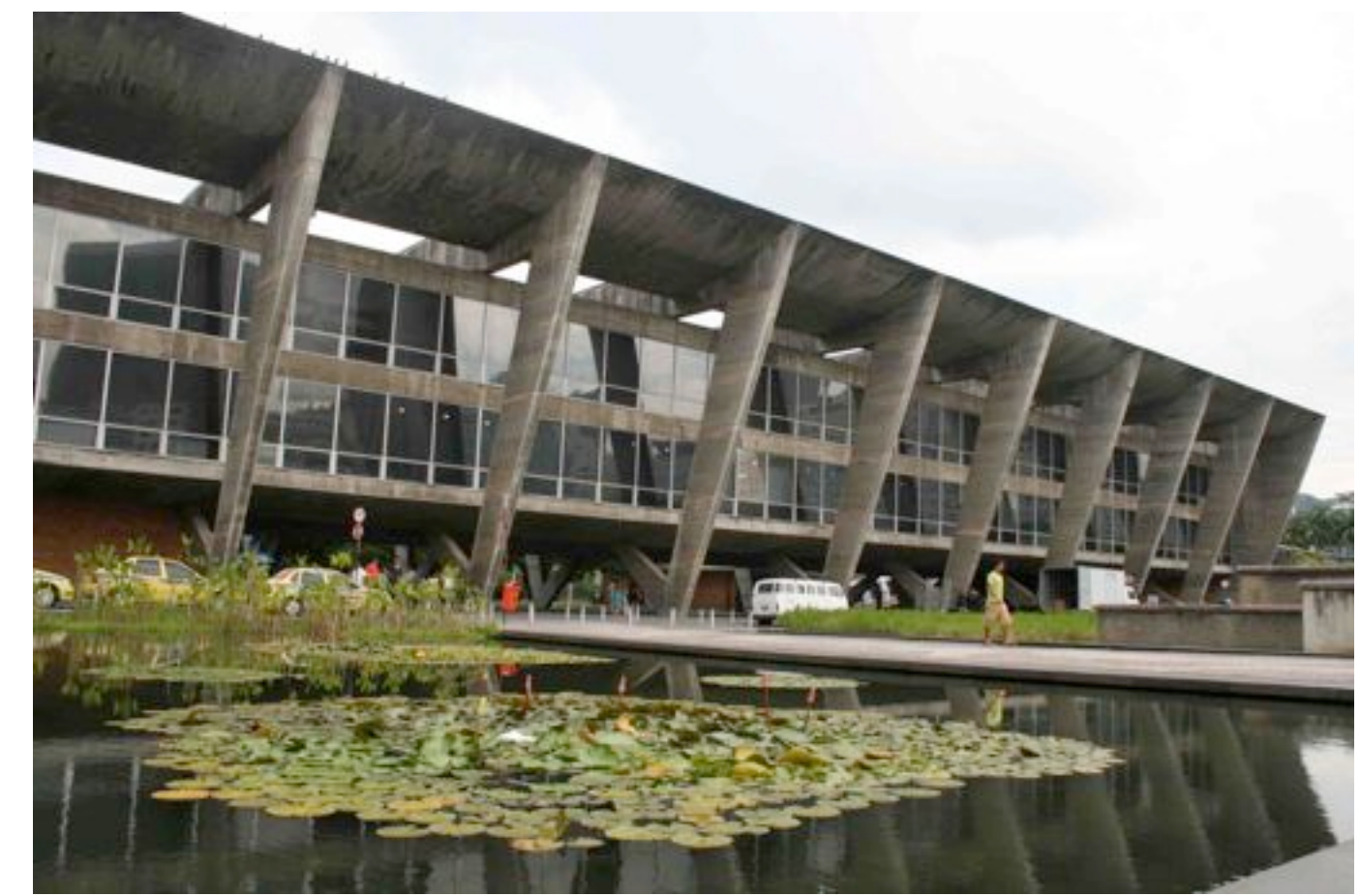

IMAGEM 72: Museu de Arte Moderna. 1953. Rio de Janeiro, Rio de Janeiro, Brasil. Arquitetura: Affonso Eduardo Reidy. Foto:Débora Lima.

A solução ensaiada por Mies acaba se concretizando no Crown Hall, em Chicago, 1945. E em todos seus precedentes vemos uma estrutura monodirecional composta por vigas externas, das quais é suspensa a laje de cobertura, apoiadas em 
pilares periféricos, o que resulta na total ausência de pilares no interior dos grandes espaços assim definidos.

Este projeto é certamente a base para o do Museu de Arte de São Paulo (195768), de Lina Bo Bardi, pois a mesma intenção de elevar o edifício e liberar o solo é evidente.

No entanto, há nele uma alteração significativa: há apenas dois pórticos, e eles estão orientados Iongitudinalmente, cobrindo o maior vão. Essa decisão, aparentemente irracional e antieconômica do ponto de vista exclusivamente técnico, se explica pelo desejo de tornar o espaço sob o edifício totalmente permeável. ${ }^{97}$

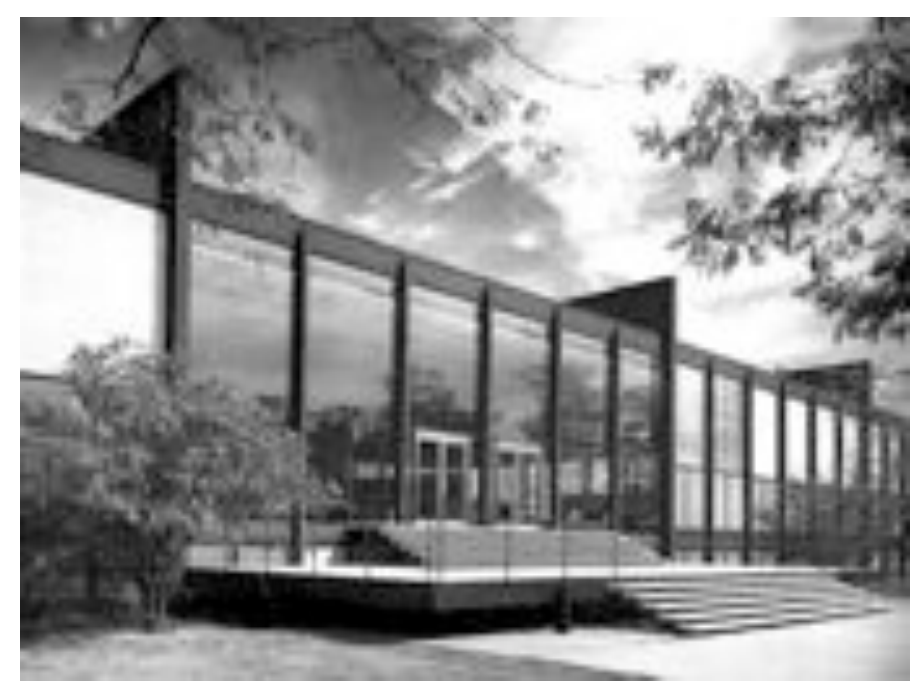

IMAGEM 73: Crown Hall. 1950-1956

Chicago, llinois, USA. Arquitetura: Ludwig Mies van der Rohe.

Em anos subsequentes 0 esquema de exoesqueletos porticados aparece com frequência na obra de João Vilanova Artigas, sempre no sentido transversal. Em projetos muito parecidos para duas escolas, em Itanhaém (1959) e

Guarulhos (1960), dois edifícios térreos, Artigas, protege espaços coletivos sob os pórticos e experimenta com a configuração dos apoios verticais.

Talvez o aspecto mais importante do intercâmbio entre a arquitetura de Mies van der Rohe e a arquitetura paulistana tenha a ver com a absorção de princípios. No caso presente, me refiro a um princípio genérico - a forma moderna é a síntese do programa, da construção e do lugar, obtida por meio da ordem visual - e a um princípio específico, o da definição simultânea da estrutura formal/espacial e da estrutura resistente de um edifício. Ao contrário do que acontece comumente na prática cotidiana - primeiro se define a "forma", depois ela é viabilizada construtivamente - a arquitetura paulistana das décadas de 1960 e 1970 é pródiga em exemplos em que a forma sintetiza todos os componentes do problema arquitetônico, 
e de tal modo que não se pode individualizar nenhum deles. O ginásio do Clube Atlético Paulistano, de Paulo Mendes da Rocha (1958), o edifício da FAUSP (1961) e a Rodoviária de Jaú, ambos de Vilanova Artigas, são apenas alguns projetos que ilustram esta afirmação. ${ }^{98}$

\section{9: Nova visita de Richard Neutra ao Brasil}

Em 1959 Richard Neutra retornaria ao Brasil, em sua segunda visita, convidado pelos organizadores do Congresso Internacional Extraordinário de Críticos de Arte, realizado no canteiro de obras de Brasília, assim como no Rio de Janeiro e em São Paulo.

RIBEIRO ${ }^{99}$ analisou justamente a participação de Richard Neutra no Congresso, que foi na segunda sessão, quando "os trabalhos foram abertos pelo historiador Giulio Carlo Argan e participaram da mesa como presidente J. Starzynski, como palestrantes William Holford, Bruno Zevi e Richard J. Neutra e como debatedores Eero Saarinem, Douglas Haskell, Fredrick J. Kiesler e André Wogenscky. Usaram a palavra Hain Gamzu e Mario Pedrosa", sendo que "as palestras proferidas versaram sobre o Plano de Brasília, foram abordadas por olhares distintos mas em síntese o que estava presente nas falas era a reflexão entre os grandes progressos tecnológicos e as necessidades dos seres humanos, tema inclusive que estava presente no debate internacional".

Segunda a mesma autora, essa foi a participação oral do arquiteto Neutra conforme transcrição da sessão, que falou após Zevi, "refletiu sobre as grandes realizações que ocorreriam no mundo naquele momento o que consequentemente incidiram em um maior consumo de óleo combustível e de eletricidade. Mostrou-se preocupado com a crescente população norte-americana que apresentava problemas emocionais e psicológicos em função de deficiências do ambiente humano no meio urbano e elogiou: 'no meio de todas essas realizações de massa, Oscar Niemeyer e Lucio Costa não se perderam, e souberam dar valor ao individuo. Talvez seja esta a impressão mais importante que se leva de Brasilia'. Disse que estava muito feliz de estar participando junto com colegas arquitetos do momento em que criam Brasília,

\footnotetext{
${ }^{8}$ |bidem.

${ }^{99} \mathrm{RIBE}$ RO, Patrícia Pimenta Azevedo. A participação do arquiteto Richard Neutra no Congresso Internacional Extraordinário de Críticos de Arte em 1959
} 


\section{TROCAS, TRANSFERÊNCIAS, DIÁLOGOS E OUTROS CAMINHOS}

conforme suas palavras: 'na hora em que o futuro começa'. Neutra acreditou na proposta do plano de Lucio Costa. Estabeleceu um contraste entre as cidades de Sodoma e Gomorra e Brasilia, sendo que as primeiras se 'tornaram célebres por terem pervertido a natureza; Brasilia se tornará célebre pela tentativa de restabelecer o que é biologicamente suportável'. Apesar de estarem em Brasília para ver Brasilia tratou dos aspectos não visuais da arquitetura e do urbanismo, pois acreditava que essa era a forma de 'ver' o futuro. Esses aspectos estão relacionados às sensações do homem, ou melhor, aos receptores sensoriais que o homem possui. Para Neutra o meio urbano nos apresenta como local onde sofremos muitos estímulos que vão muito além do meramente visual. Demonstrou sua análise acerca da visão e das sensações geradas por essa ação com o exemplo que se focarmos em um ponto de interesse na paisagem o nosso olho capta, na extremidade da retina, outros elementos que interferem na nossa leitura do todo. Várias impressões visuais. Assim, se participamos de uma cena a vemos diferente do que a olhássemos por uma fotografia. Entra aí a percepção que está vinculada às nossas outras sensações e as teorias da percepção da "Gestalt" onde o valor advém de um olho inteligente. E comentou como esse fenômeno acontece em Brasília."100

O texto dos Anais de autoria de Richard Neutra e que foi divulgado pela Revista Habitat em dezembro de 1959 foi denominado "Dos aspectos formais não visuais do plano da cidade e seu contexto urbanístico" e versa sobre a planificação da cidade por uma abordagem sinestésica e afirma a necessidade de um esforço conjunto de todas as artes e de todas as técnicas para concretização do projeto urbano. Neutra propôs que a arte e a técnica se associem com a mesma naturalidade que as encontramos na natureza.

O texto publicado em outubro de 1959 na revista Módulo "Planejamento um problema humano com base no individuo" problematiza o raciocínio do projeto só com bases estatísticas e defende o raciocínio por uma análise do homem com as características da individualidade.

\footnotetext{
${ }^{100}$ bidem. Para entendermos melhor o que Neutra disse é importante salientar que ele foi um estudioso da psicologia experimental através das investigações de Wilhelm Wundt (1832-1920) sobre as sensações físicas relacionando o fisiológico com o psicológico.
} 
Novamente fez alusão à arquitetura brasileira quanto ao sentido humano que observou ao visitar Minas Gerais e Brasília. "Para mim, os brasileiros levam a palma como os mais humanos. Sempre lutei para encontrar esse denominador comum". Ou seja, Neutra encontra aqui uma arquitetura e um urbanismo com características humanas, preocupados com o individuo, e suas emoções. E essa é uma pesquisa que ele buscava nos seus trabalhos. Neutra disse que como arquiteto e urbanista "põe em dúvida os conceitos da 'razão pura' do século XVIII e as subsequentes ideias do século XIX, de simples raciocínio utilitário e pratico". Deu a devida importância a emoção "as emoções não são uma adulteração ou um aviltamento da razão"... Recriminou a arquitetura americana que faz um 'tratamento de ausentes' com fundamento em estatísticas. "A arquitetura e o urbanismo, em nossa era cientifica, devem ser produto da observação e nunca de conjecturas estatísticas."101

Dois projetos de Richard Neutra contaram com a participação do brasileiro Roberto Burle Marx para contribuir com a síntese das artes na arquitetura.

Na casa De Schulthess, perto de Havana, Cuba, de 1956, Marx foi convidado por Neutra para fazer o paisagismo enfatizando assim uma das premissas dos projetos de Neutra que é relacionar o interior da residência com a paisagem exterior.

O outro projeto, que a nós parece interessante, pois em solo americano, foi o painel da sede "Amalgamated Clothing Workers of America", em Los Angeles em 1956, que Burle Marx desenhou, além do paisagismo, um mural abstrato nas cores preta, branca, verde e amarela, infelizmente hoje inexistente. Este painel construtivista, com base na vertente De Stijl via Mondrian, estava no saguão, um espaço de acesso público e demonstrava a participação social do artista.

Como sabemos, ele já havia trabalhado com vários arquitetos com um espírito de integração entre arquitetura e arte mural.

LAMPRECHT comenta sobre o trabalho de paisagismo de Burle Marx na arquitetura de Richard Neutra: "Não é surpreendente que Neutra frequentemente trabalhe com o pintor Roberto Burle Marx e Garret Eckbo, ambos brilhantes paisagistas do século $X X$. Seus trabalhos livres, mas mesmo assim repletos de 
segurança, quando empregam curvas e diagonais oferecem um dinamismo aprimorado às formas retilíneas de Neutra." ${ }^{102}$

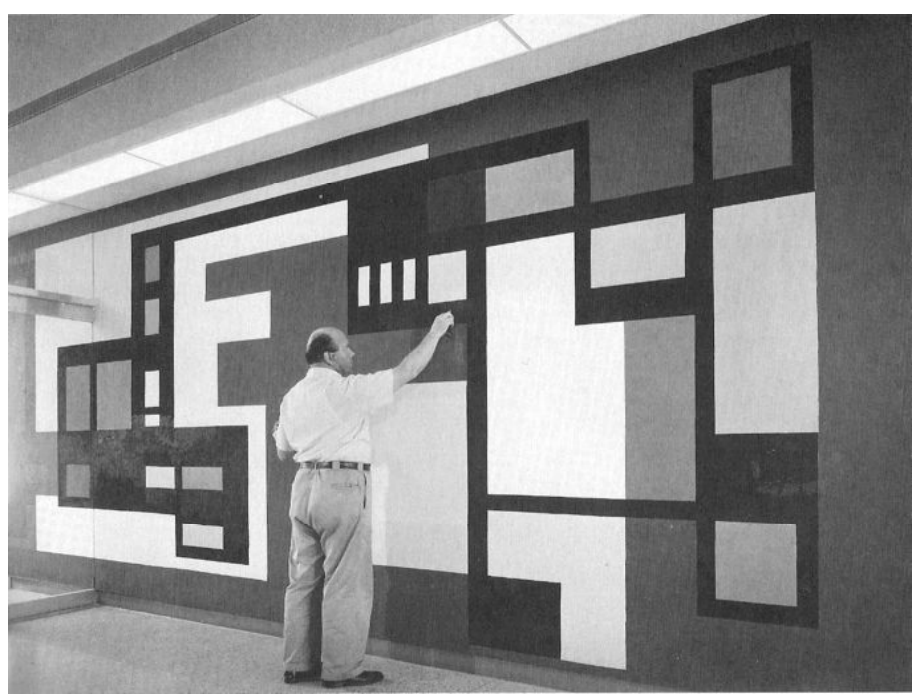

IMAGEM 75: Painel de Burle Marx para o projeto de Richard Neutra "Amalgamated Clothing Workers of America", em Los Angeles, Califórnia, USA, 1956 in HINES, Thomas. Richard Neutra and the search for Modern Architecture. New York: Rizzoli, 2005.

1963-64: Oscar Niemeyer projeta a Casa Strick em Santa Mônica, Califórnia, EUA

A vanguarda sempre se sentiu bem à vontade na Califórnia. Foi lá que, no início do século 20, surgiram as primeiras construções modernas dos Estados Unidos.

Décadas mais tarde, como vimos, entre 1945 e 1966, o programa Case Study Houses engrossou o caldo do movimento ao espalhar pelo estado 36 moradias assinadas por expoentes do modernismo, como Richard Neutra, Eero Saarinen e Charles e Ray Eames.

Nesse contexto, não é de estranhar que, em 1963, um casal contratasse o arquiteto brasileiro Oscar Niemeyer para desenhar sua residência em Santa Mônica, Califórnia. $^{103}$

Projeto posterior ao período em estudo, mas importante para entender a relação Brasil-EUA que se criou.

O arquiteto, no entanto, nunca pôde viajar aos Estados Unidos para conhecer seus clientes. Comunista em plena guerra fria, estava impedido de entrar no país. Por

\footnotetext{
102 LAMPRECHT, Barbara. Neutra, 1892-1970: survival through design. Koln: Tachen, 2006.

${ }^{103}$ Apesar de carregar o traço do mestre, a morada com 420 m2, organizada em duas alas dispostas em T, só ficou famosa em 2002, quando esteve a ponto de ser demolida. A prefeitura de Santa Mônica vetou a idéía, o caso veio à tona e logo surgiram novos interessados: Michael e Gabrielle Boyd, colecionadores de arte e experientes reformadores de construções modernas. Ver mais em WEBB, Michael. Modernist Paradise Niemeyer House/Boyd Collection. New York: Rizzoli International Publications, Inc., 2007.
} 
isso, o projeto foi desenvolvido à distância e acompanhado por um arquiteto local - o que explica por que o brasileiro nunca incluiu este trabalho em seu portfolio.

Dessa forma, é possível que detalhes originais tenham se perdido, e a casa parece ter sofrido muitas modificações durante a construção.

Esta moradia na Califórnia, no entanto, não marcou a trajetória do arquiteto brasileiro e foi realizada sem sua supervisão. Faltam as curvas e as grandes varandas, presentes nos principais trabalhos que realizou. É importante, contudo, observar que sua recente restauração - apesar de certas liberdades - procurou exaltar o fato de o projeto ser do mestre.

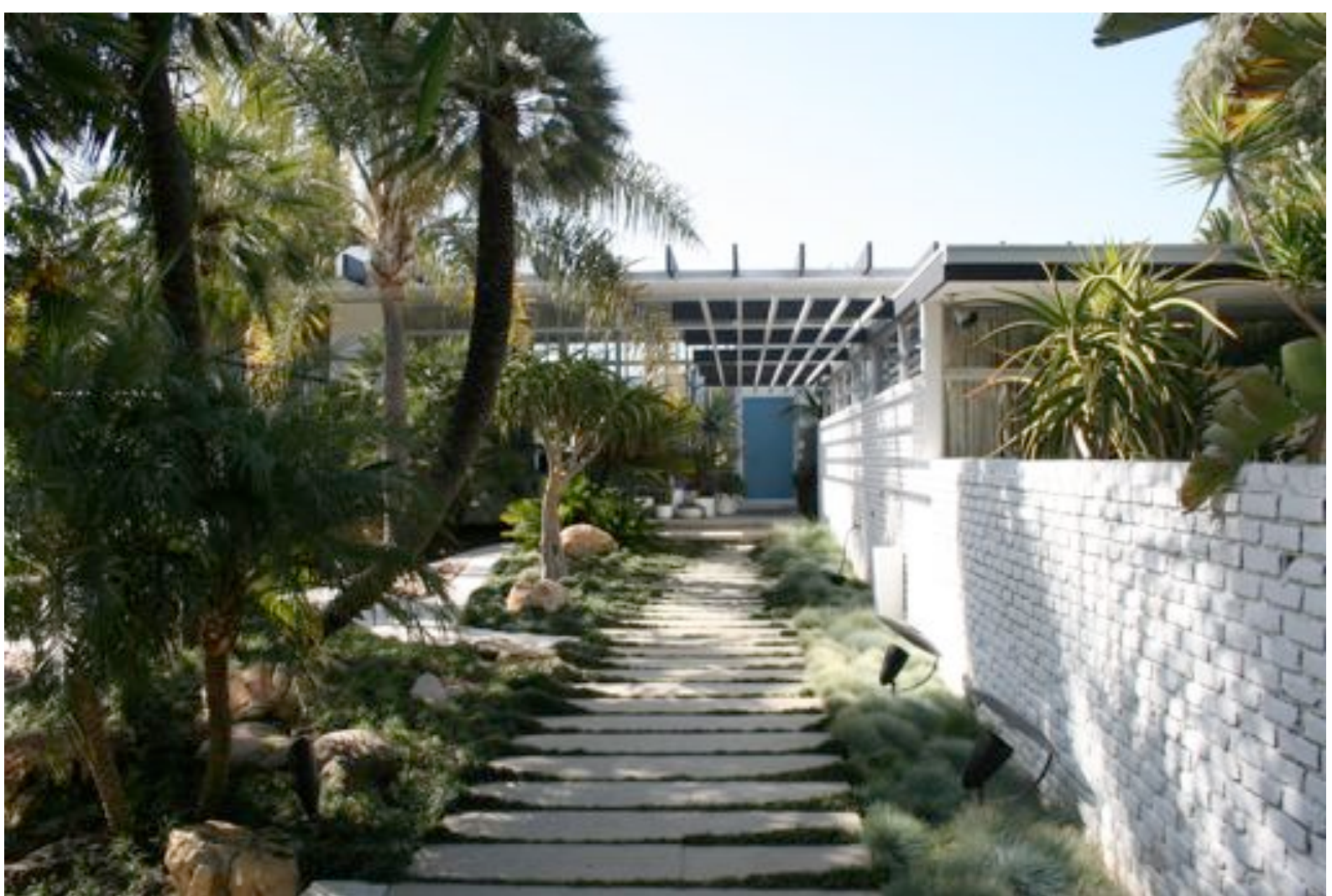

IMAGEM 76: Strick House. 1964. Santa Monica, Califórnia, USA. Arquitetura: Oscar Niemeyer. Foto: Débora Lima

Trata-se de um interessante projeto de período determinante de sua carreira (1963) - depois de Brasília e antes de seu exílio em consequência do regime militar. Mesmo que não fosse atribuída a ele, ou assumindo que o projeto sofreu deturpações, é uma bela realização arquitetônica, que reflete o que havia de melhor na arquitetura residencial da época. 
O diretor cinematográfico de Hollywood, Joseph Strick, entusiasmado com os projetos de Niemeyer para Brasília, em 1964, decidiu solicitar-Ihe uma nova casa em La Mesa Drive, situada perto de um country club e com vista para as montanhas de Santa Mônica. Diferente da proposta feita para os Tremaines, a solução nesse caso foi menos arrojada e mais identificada com a tipologia das casas californianas do que com a obra de Niemeyer. Como nunca visitou o terreno e não acompanhou a construção, Niemeyer nunca se interessou em divulgar essa casa em seus livros. ${ }^{104}$

Com planta em T, que distribui os espaços públicos e privados, a mão do mestre aparece na qualidade e particularidade dos diferentes locais e nas transparências que permitem a percepção das montanhas. A leveza da estrutura de aço e madeira utilizada na região, que caracteriza a cobertura com vigas expostas moduladas, se contrapõe com a parede de tijolos que define a linearidade da entrada principal e delimita a área de serviço, disposta em um bloco cuja outra extremidade contém os quartos que, articulados com o living, configuram o pátio interno com piscina. Ao longo da construção os proprietários introduziram várias modificações ao projeto original, mas hoje a casa conserva a imagem básica criada por Niemeyer.

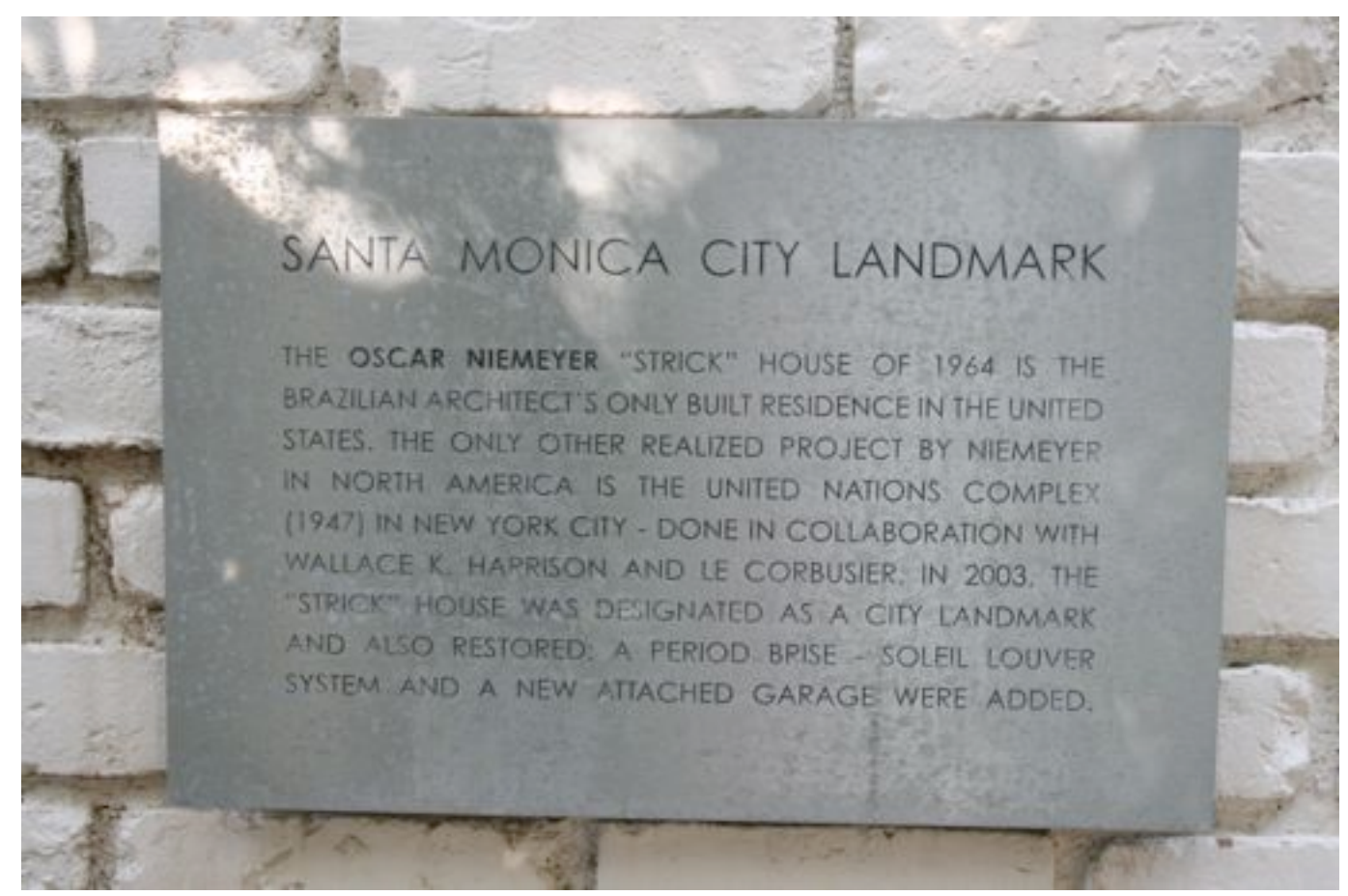

IMAGEM 77: Placa - Strick House. 1964. Santa Monica, Califórnia, USA. Arquitetura: Oscar Niemeyer. Foto: Débora Lima.

\footnotetext{
${ }^{104}$ SEGRE, Roberto. O sonho americano de Oscar Niemeyer, Le Corbusier e as Américas In Revista aU, edição 165, dezembro de 2007.
} 
Niemeyer nunca se interessou por divulgar sua obra erguida no exterior. Algumas, como essa residência, a única construída nos Estados Unidos, só foi publicada recentemente.

O entusiasmo de políticos, empresários e profissionais pela originalidade da sua obra entrou em contradição com a rejeição do governo dos Estados Unidos por sua militância política: o arquiteto declarou abertamente sua afiliação ao Partido Comunista Brasileiro.

O trabalho de Niemeyer, porém, já fora apresentado ao público norteamericano, como já relatamos, através de "Brazil Builds" (1943), "The Work of Oscar Niemeyer" (1950), "Oscar Niemeyer: Works in progress" (1956), e já havia sido publicado pelas revistas mais importantes de arquitetura (Architectural Record, Pencil Points e Architectural Forum), assim como por periódicos populares de grande circulação, como Life (1942), e Reader's digest (1946).

O diálogo das formas curvas livres do brasileiro com a linguagem de arquitetos norte-americanos como Eero Saarinen e Wallace K. Harrison também demonstram a ambiguidade da relação entre Niemeyer e os Estados Unidos, país que Ihe negou o visto de entrada em várias ocasiões.

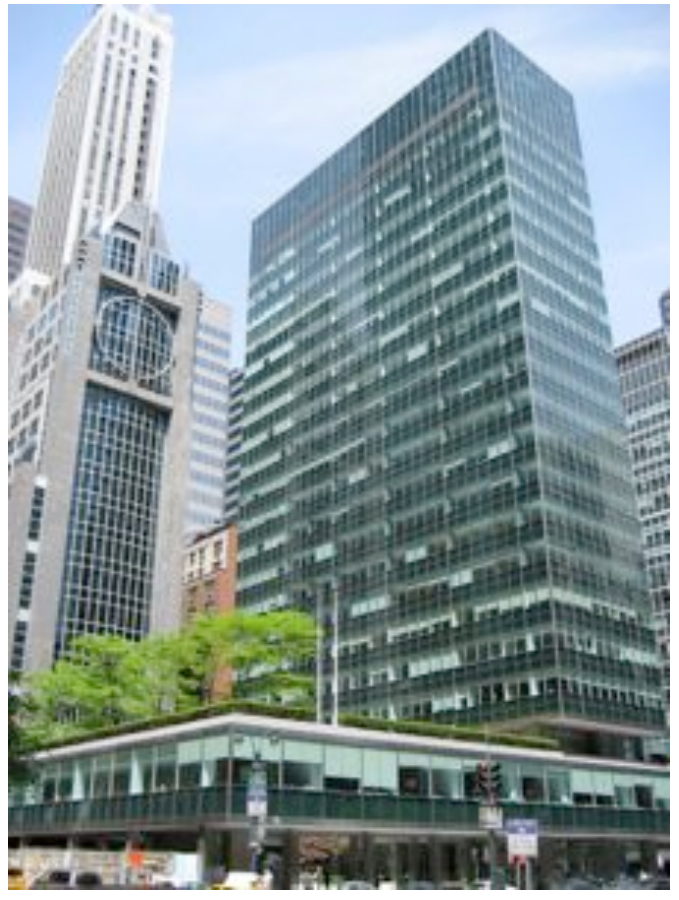

Ambiguidade que rondou também o Prêmio Pritzker, em 1988, injustamente compartilhado por Niemeyer com o arquiteto norte-americano Gordon Bunchaft, autor da cortina de vidro da Lever House, em New York, de 1952, cuja significação internacional nunca poderia ser equivalente à obtida pelo mestre brasileiro.

IMAGEM 88: Lever House. 1951-1952. New York, New York, USA. Arquitetura: Gordon Bunshaft da Skidmore, Owings and Merrill. Foto: Débora Lima. 
CONCLUSÃO 
O relacionamento entre os governos norte-americano e brasileiro, sob uma capa oficial de amizade, foi tenso desde o Brasil Império, independentemente do viés ideológico dos brasileiros no poder.

A vasta maioria dos americanos sempre soube muito pouco, talvez nada, sobre o nosso país. Desde sempre, inclusive, os formadores da política externa dos EUA não pensam o Brasil como um igual, sendo que os ocupantes da Casa Branca sempre cometeram o mesmo erro: considerar o Brasil apenas parte da América Latina, não um país com importância própria.

De modo que, politicamente e também culturalmente, os EUA têm sido uma presença contínua na mente brasileira, enquanto o Brasil tem sido uma presença um tanto vaga na mente americana, aparentemente com uma pequena brecha aberta entre o final das décadas de 1930 e 1960, época justamente em que floresce a Arquitetura Moderna Brasileira.

Entretanto, até então, culturalmente a Europa representava um modelo de prestígio. Os Estados Unidos era considerado, de certa forma, um concorrente ou, no melhor dos casos, um semelhante, apesar de bastante presente no imaginário popular. O vínculo com os países latinos - especialmente com a França - sempre predominou no Brasil frente às relações com os países de origem anglo-saxônica.

Mas o entre - Guerras mudará essa História, e o eixo cultural se desviará bruscamente da Europa para os Estados Unidos da América. E como ficaríamos imunes a este fato?

A política da boa vizinhança conduzida pelos Estados Unidos frente aos países latino americanos facilitava uma presença norte americana mais marcante no panorama cultural brasileiro, já que eram também facilitadas as importações de livros, revistas e filmes deste país. Desse modo, pode-se entender que jovens arquitetos tivessem acesso mais fácil às publicações americanas do que às europeias, cujo continente sofria com os problemas decorrentes da guerra.

A partir desse período alguns momentos de troca entre os dois países foram de importância fundamental para a consolidação de nossa arquitetura moderna, bem como para sua afirmação, independência e autonomia em relação à inicial matriz europeia, confirmando que sua história internacional não se restringiu, portanto, apenas ao contato com a vertente europeia. 


\section{CONCLUSÃO}

É interessante lembrar que as primeiras influências do modernismo brasileiro foram, sim, europeias, fossem elas teóricas ou de projetos de arquitetos imigrantes aqui estabelecidos. Mas a presença cultural americana é anterior ao primeiro momento da arquitetura Moderna tanto em São Paulo quanto no Rio de Janeiro, e trouxe uma discussão importante ao panorama.

Vale também lembrar que o Brasil estava sob a ditadura do Estado Novo de Getúlio Vargas enquanto foi deflagrada a $2^{a}$ Guerra Mundial e, nessa conjuntura, os contatos com culturas exteriores estavam comprometidos.

Em termos estritos, a identificação da arquitetura moderna patrocinada por este governo com uma arquitetura moderna nacional não passa de pensamento esperançoso, e dista muito de ser hegemônica. Para comprová-lo, basta olhar os prédios do Ministério da Fazenda e do Trabalho, projetados à volta do Ministério da Educação em data posterior. Pode-se enxergá-la, evidentemente, como caracterização da nação e afirmação de identidade nacional, mas desde o ponto de vista dum segmento da inteligentzia que é influente mas definitivamente minoritário.

A arquitetura moderna brasileira não é a arquitetura de uma democracia como no modelo americano. Na melhor das hipóteses, emerge de uma democracia autoritária. Entretanto, seu sucesso no exterior, e principalmente através dos EUA, lhe dá potencial de emblema, e contribui para uma hegemonia que se firma por volta dos anos 1950, e vai se tornar pendão de um nacionalismo que recrudesce num clima de guerra fria.

De forma que, descortinar se História se baseia, claramente, no conhecido interesse político e influência cultural norte-americana em nosso país à época, que resultou em uma série de trocas culturais e também profissionais que se tornaram possíveis direcionadas às "Nações amigas", graças às condições e aos programas de incentivo gerados deste quadro cujos desdobramentos se espelharam na proeminência de um acento americano na linguagem internacional do modernismo.

A repercussão e recepção das diversas interlocuções assim estabelecidas e de como foram "digeridas" constituíram o núcleo central dessa abordagem, demonstrando que estas trocas culturais e profissionais, para ambos os lados, foram significativas. 
Nas narrativas sobre a arquitetura moderna brasileira a participação de estrangeiros aparece de diversas maneiras. Algumas especificidades no contexto da produção de arquitetos estrangeiros no Brasil são muito importantes dentro deste quadro.

Em alguns momentos ela é singular, e uma rápida estadia no país é capaz de conformar os traços dessas histórias, como foi o caso da participação de Le Corbusier no episódio do projeto do Ministério da Educação e Saúde, no Rio de Janeiro.

Em outros ainda eles são tratados como um grupo, como aconteceu com os arquitetos imigrantes que aportaram no Brasil no pós-guerra, a maioria deles bem situados profissionalmente em seus países de origem, que vinham à procura de novos horizontes de vida e trabalho, muitos destes aqui chegando em um momento de consagração internacional de nossa arquitetura, impulsionada justamente pela apresentação do pavilhão brasileiro em New York - por Lucio Costa e Oscar Niemeyer -, em 1939, ou pela mostra de arquitetura brasileira Brazil Buids no MoMA, na mesma cidade, em 1943.

Interessante é que ambos os fatos aconteceram nos Estados Unidos, e foram, sim, a mola propulsora de vários acontecimentos que influenciariam nosso arquitetura local de maneira permanente. O que nos leva ao outro lado dessa história, a presença de arquitetos brasileiros em solo americano, a trabalho ou a passeio e o que isso resultou para a nossa arquitetura moderna.

Enfim, desde a vinda destes imigrantes, a visitas esparsas de arquitetos americanos e/ou emigrados para a América do Norte ao Brasil - para atender à eventos culturais como as primeiras Bienais de Arte e Arquitetura em São Paulo, convidados para proferir Conferências, participar em projetos locais, etc. - passando pela ida de arquitetos brasileiros a passeio, estudo ou a trabalho, aos EUA, as trocas e transferências foram acontecendo. Interlocuções que obviamente não passaram em branco, para ambos os lados.

E são esses momentos de ligação que aqui relatamos, neste Trabalho, a partir de uma organização cronológica que sistematizou os resultados da pesquisa, em que são analisadas as obras arquitetônicas relacionadas ao momento histórico e cultural de sua produção. 
Durante os anos 1940 e 1950 verificam-se, inclusive, semelhanças de partido e conceitos entre os projetos de arquitetos atuantes no Brasil e nos EUA, sugerindo que os momentos de diálogo entre os dois países resultaram em desdobramentos significativos na produção arquitetônica.

Sendo assim, nosso objetivo foi mostrar alguns destes intercâmbios, relações, vinculações que se desenvolveram entre o Brasil e os Estados Unidos e como incidiram no estabelecimento de novas diretrizes nas formulações da arquitetura moderna brasileira, abordagem ainda pouco estudada.

Analisando estas "experiências compartilhadas" acabamos por conhecer e entender com muito mais profundidade o complicado processo de modernização brasileiro e a História, tão rica, da nossa Arquitetura Moderna Brasileira, o que nos dará subsídios para continuar pesquisando e tentar aprimorar o debate em torno desse assunto que vem intrigando gerações de arquitetos, desde a inauguração de Brasília, em 1960. Pois, o que aconteceu com a nossa arquitetura de lá pra cá?

Sabemos que os anos sessenta - após a construção de Brasília e o golpe militar que será decisivo para os rumos da arquitetura - podem ser caracterizados como o período de silêncio/esquecimento, momento em que os historiadores internacionais se desinteressam pela arquitetura moderna brasileira e decretam sua morte. ${ }^{1}$

O Brasil descobria-se possuidor de um dos mais ricos patrimônios de arquitetura modernista do mundo, no entanto, tal condição pareceu curiosamente contribuir para manter o país relativamente alheio à contemporaneidade arquitetônica dos últimos quarenta anos, e praticamente some na historiografia oficial.

Não que a arquitetura local tenha parado. Grandes arquitetos brasileiros continuaram produzindo e reinventando uma Nova Arquitetura. De modo que a herança da clássica era modernista sempre foi latente.

O que é de conhecimento comum é que a Arquitetura Moderna Brasileira, de alguma maneira, alcançou uma disseminação mais ampla e mais profunda e fez ressaltar a variedade de programas enfrentados e bem resolvidos pelos arquitetos brasileiros. A demonstração da versatilidade de nossa arquitetura moderna é cabal. 
Mas também é sabido que o modernismo, especialmente nos EUA, nunca foi popular (como brandiam com razão os defensores do pós-modernismo), e esta constatação foi usada como argumento em favor da superação do Movimento Moderno, que se transformava também: ${ }^{2}$

Da metade dos anos 1950 em diante, esta apreciação das contribuições regionais dos "países distantes" foi gradualmente substituída pelas revisões do Movimento Moderno que tomaram lugar nos países centrais tais como Inglaterra e França - através do "Novo Brutalismo", produção do casal inglês Alison e Peter Smithson, e do trabalho Pós-Guerra de Le Corbusier - e nos Estados Unidos - com o trabalho de Louis Kahn. Na metade dos anos sessenta tais revisões foram articuladas em especulações megaestruturais e na publicação em 1966 dos primeiros manifestos anti-Modernos: "L'Architettura della Città", de Aldo Rossi, e Complexity and Contradiction in Architecture, de Robert Venturi. ${ }^{3}$

Os americanos, inclusive, e de um modo geral, se "traumatizaram" com a experiência moderna, muito mais com o que convencionou-se chamar "International Style", que se proliferou em "horrendos" prédios de apartamentos caixotes ao longo das avenidas em quadrilátero de New York.

A personificação do movimento moderno para o americano comum é o Edifício da MetLife que teve assessoria arquitetônica de Walter Gropius e que, para os novaiorquinos significou o bloqueio da visão em perspectiva que se tinha da Park Avenue através da Grand Central Station.

A arquitetura que deslumbrou Nova York, a ponto dos arquitetos brasileiros desempenharam um papel essencial na proeminência de um acento americano na linguagem internacional do modernismo, bem que podia influenciar ainda um pouco

\footnotetext{
${ }^{2} \mathrm{BROLIN}, \mathrm{B}$. The Cultural Roots of Modern Architecture In The failure of modern architecture. New York, Van Nostrand, 1976; NEWMAN, O. Whose failure is modern architecture? In MIKELLLDES, B. (ed). Architecture for people. New York, Holt, Rinehart and Winston, 1980, p. 45-58; VENTURI, Robert. Complexity and contradiction, New York: MoMA, 1966.

${ }^{3}$ ANDREOLI, Elisabetta; FORTY, Adrian. Brazil's Modern Architecture. London, New York: Phaidon Press, 2004, p. 36.
} 


\section{CONCLUSÃO}

mais nossa arquitetura genérica, esta senhora tão volátil, superficial e facilmente manipulável.

Mas sabemos que o Modernismo arquitetônico hoje volta com uma força incrível, e em comum acordo estão o Brasil e os Estados Unidos quando se trata desta volta.

A crise ambiental e econômica mundial que estamos atravessando faz, de novo, da arquitetura moderna, a melhor escolha, a mais eficiente, a mais sustentável, aquela que condiz com uma sociedade que busca se desfazer dos excessos, de viver e conviver de uma maneira, enfim, mais MODERNA. 
BIBLIOGRAFIA 
ACAYABA, Marlene M. Branco e Preto: Uma História de Design Brasileiro nos Anos 50. São Paulo: Instituto Lino Bo e P. M. Bardi, 1994.

ACKEL, Luiz Gonzaga Montans. Attílio Corrêa Lima. Uma trajetória para a modernidade. Tese de doutorado. Orientador Paulo Júlio Valentino Bruna. São Paulo, FAU-USP, 2007.

ALMEIDA, Fernando Azevedo de. O Franciscano Ciccillo. São Paulo: Pioneira, 1976.

AMARAL, Aracy (org.). Museu de Arte Contemporânea da Universidade de São Paulo: Perfil de um acervo. São Paulo: TECHINT ENGENHARIA S/A, 1988.

ANAIS do Congresso Internacional Extraordinário de Críticos de Arte. Brasília - São Paulo - Rio de Janeiro, 17 a 25 de setembro de 1959. Mimeo - transcrição por Mary Pedrosa.

ANDRADE, Marco A. Pasqualini de. O Congresso Internacional Extraordinário de Críticos de Arte de 1959: Contradições da Síntese das Artes. Houston: ICAA Documents Project Working Papers, n. 2, maio 2008.

ANDREOLI, Elisabetta; FORTY, Adrian. Brazil's Modern Architecture. London, New York: Phaidon Press, 2004.

ANDREWS, Wayne. Architecture, ambition and Americans. New York: The Free Press, 1964.

ANELLI, Renato. Arquitetura e cidade na obra de Rino Levi. Tese de doutorado. Orientador Bruno Roberto Padovano. São Paulo, FAU-USP, 1995.

ARANHA, Maria Beatriz de Camargo. Rino Levi: arquitetura como ofício. Dissertação de mestrado. Orientadora Fernanda Fernandes da Silva. São Paulo, FAU-USP, 2003.

ARGAN, Giulio Carlo. Arte Moderna. São Paulo: Companhia das Letras, 1992 (trad. it. de Denise Bottmann e Federico Carotti, L'arte moderna: Dall'lluminismo ai movimenti contemporanei. Firenze: Sansoni Editore, 1988).

ATIQUE, Fernando. Arquitetando a "Boa Vizinhança": Arquitetura, Cidade e Cultura nas relações Brasil - Estados Unidos 1876-1945. São Paulo: FAPESP, 2010.

BACON, Mardges. Le Corbusier in America: Travels in the Land of the Timid. Cambridge: The MIT Press, 2003.

BANHAM, Reyner. Guide to Modern Architecture. London: Architectural Press, 1962.

BARDI, Pietro Maria. História do MASP: A aventura da criação do Museu de Arte de São Paulo contada por um de seus criadores. São Paulo: Instituto Lina Bo e P. M. Bardi. 1992.

1951.

Neutra: Residências/ Residences. São Paulo: Todtmann \& Cia, . The arts in Brasil, a new museum at São Paulo. Milano: Edizione Del Milione, 1956.

BEE, Harriet S.; ELLIGOTT, Michelle (edited by). Art in our time - A chronicle of The Museum of Modern Art. New York: MoMA, 2004. 
BROLIN, B. The Cultural Roots of Modern Architecture In The failure of modern architecture. New York: Van Nostrand, 1976.

BRUAND, Yves. Arquitetura Contemporânea no Brasil (trad. Ana M. Goldberger, L'architecture contemporaine au Brésil). São Paulo: Perspectiva, 1981.

CAMARGO, Mônica Junqueira de. Arquiteto Miguel Forte, 1915-2002. Arquitextos030.05 (Romano Guerra Ed. Ltda.). São Paulo, Portal Vitruvius, ano 03, novembro 2002.

. Brazilian presence in the historiography of Twentieth Century architecture. Docomomo, Paris, n. 34, mar. 2006, pp. 66-71.

- Princípios de arquitetura moderna na obra de Oswaldo Arthur Bratke. Tese de doutorado. Orientador Paulo Júlio Valentino Bruna. São Paulo, FAU-USP, 2000.

. Uma Highway de muitas pistas: Relações arquitetônicas Brasil-EUA. In Anais do Seminário Procad. 2010/1.

CANDIDO, Antonio et alii. Um Americano Intranqüilo. Homenagem a Richard Morse. Rio de Janeiro: FGV, 1992.

CAPPELLO, Maria Beatriz Camargo. Arquitetura em revista: Arquitetura moderna no Brasil e sua recepção nas revistas francesas, inglesas e italianas (1945-1960). São Paulo, 2005. Tese (Doutorado). Curso de Pós-Graduação em Estruturas Ambientais Urbanas. Faculdade de Arquitetura e Urbanismo - USP.

CASTRO, Ana Claudia Scaglione Veiga de. A formação da metrópole pelo olhar de Richard Morse: uma história cultural de São Paulo. São Paulo, 2009. Tese (Doutorado). Curso de Pós-Graduação em Arquitetura e Urbanismo. Faculdade de Arquitetura e Urbanismo - USP.

CAVALCANTI, Lauro. Moderno e Brasileiro: A História de uma Nova Linguagem na Arquitetura (1930-1960). Rio de Janeiro: Jorge Zahar Editor, 2006.

When Brazil was Modern: Guide to Architecture, 1928-1960. New York: Princeton Architectural Press, 2003.

CIUCCI, Giorgio; DAL CO, Francesco; TAFURI, Manfredo. La ciudad americana, de la Guerra Civil al New Deal. Barcelona: Gustavo Gili, 1975.

CODY, Jeffrey W. Exporting American Architecture: 1870-2000. New York: Routledge, 2003.

COHEN, Jean - Louis. Scenes of the world to come: European architecture and the American challenge, 1893-1960. Paris: Flammarion/Canadian Centre for Architecture, 1995.

COLQUHOUN, Alan. La Arquitectura Moderna: Una Historia Desapasionada. Barcelona: GG, 2002.

COMAS, Carlos Eduardo Dias. Brazil Builds e a Bossa Barroca: notas sobre a singularização da arquitetura moderna brasileira. Disponível em http://www.docomomo.org.br/seminario\%206\%20pdfs/Carlos\%20Eduardo\%20Co mas.pdf . Acesso em 21 junho de 2011, 14:50:00. 
COSTA, Alcilia Afonso de Albuquerque. As contribuições arquitetônicas habitacionais propostas na Cidade dos Motores (1945-46). Town Plannings Associates. Xerém, RJ. Arquitextos124.01 (Romano Guerra Ed. Ltda.). São Paulo, Portal Vitruvius, setembro de 2010.

COSTA, Lucio. Lucio Costa: Registro de uma Vivência. São Paulo: Empresa das Artes, 1995.

COSTA, Xavier; HARTRAY, Guido (Editors). SERT Arquitecto en Nueva York. Barcelona: Museu d'Art Contemporani Barcelona, 1997.

COSTA, Luiz Augusto Maia. O moderno planejamento territorial e urbano em São Paulo: a presença norte-americana no debate da formação do pensamento urbanístico paulista 1886-1919. São Paulo, 2005. Tese (Doutorado). Curso de PósGraduação em Estruturas Ambientais Urbanas. Faculdade de Arquitetura e Urbanismo - USP.

COTTER, Bill. The 1939-1940 New York World's Fair (Images of America). New York: Arcadia Publishing, 2009.

COTRIM, Marcio. João Batista Vilanova Artigas: Doze casas paulistas, 1942 a 1969. Dissertação de Mestrado, Barcelona, ETSAB, 2002.

CUNHA, Marcio Cotrim. Mies e Artigas: a delimitação do espaço através de uma única cobertura. Arquitextos108.01 (Romano Guerra Ed. Ltda.). São Paulo, Portal Vitruvius, ano 09, maio 2009.

CRUZ, José Armênio Brito. Os concretos e o concreto. A vinda de Max Bill ao Brasil. Coluna Hoje ontem, $n^{\circ} 3$ (editoria Documento). São Paulo, Portal Vitruvius, maio 2006.

CURTIS, William J. R. Arquitetura Moderna desde 1900. 3a. ed. São Paulo: Editora Bookman, 2008.

CYTRYNOWICZ, Roney. Guerra sem Guerra: A Mobilização e o Cotidiano em São Paulo durante a Segunda Guerra Mundial. São Paulo: Geração Editorial/Edusp, 2000.

DAHER, Luiz Carlos. Flávio de Carvalho: arquitetura e expressionismo. São Paulo, Projeto, 1982.

DE BARROS, Regina Teixeira. Revisão de uma História: a Criação do Museu de Arte Moderna de São Paulo (1946-1949). São Paulo, 2002. Dissertação (Mestrado). Curso de Pós-Graduação da Escola de Comunicações e Artes - USP.

DECKKER, Thomas. The Modern City Revisited. London: Taylor \& Francis, 2000.

DECKKER, Zilah Quezado. Brazil Built: The Architecture of the Modern Movement. London, New York: Spon Press - Taylor \& Francis Group, 2001.

DOCOMOMO. Back from Utopia, The Challenge of the Modern Movement. Rotterdam: Hubert-Jan Henket and Hilde Heynen, 2002.

DOMINGUES, Beatriz H. O Código Morse - Ensaios sobre Richard Morse. Belo Horizonte: Editora da UFMG, 2010.

DORFLES, Gillo. L'Architettura Moderna. Milan: A. Garzanti, 1956. 
DREXLER, Arthur; HINES, Thomas. The Architecture of Richard Neutra: from international Style to California Modern. New York: The Museum of Modern Art, 1982.

FARIAS, AGNALDO (org.). Bienal 50 anos 1951-2001. São Paulo: Fundação Bienal de São Paulo, 2002.

FAUSTO, Boris (org.). Fazer a América: A imigração em massa para a América Latina. São Paulo: EDUSP, 1999.

. Os anos 30 e a Difusão do Urbanismo Americano no Brasil. In Anais do $6^{\circ}$ Seminário de História da Cidade e do Urbanismo. Natal: UFRN, 2000.

FELDMAN, Sarah. A americanização do Setor de Urbanismo da Administração Municipal de São Paulo. In: Anais do IV Seminário de História da Cidade e do Urbanismo "Herança, Identidade e Tendências da Cidade Latino-americana" vol. 1. Denise B. Pinheiro Machado (org.). Rio de Janeiro: UFRJ/PROURB, 1996.

. Os anos 30 e a Difusão do Urbanismo Americano no Brasil. In Anais do $6^{\circ}$ Seminário de História da Cidade e do Urbanismo. Natal: UFRN, 2000.

FERNANDES, Fernanda. A síntese das artes e a moderna arquitetura brasileira dos anos 1950. In www.iar.unicamp.br/dap/vanguarda/artigos acessado em abril 2009. Arquitetura no Brasil no segundo pós-guerra - a síntese das artes. In www.docomomo.org.br/seminario acessado em março de 2009.

FERRAZ, Artemis Rodrigues Fontana. Arquitetura moderna das escolas "S" paulistas, 1952-1968: projetar para a formação do trabalhador. São Paulo, 2008. Tese (Doutorado). Curso de Pós-Graduação em Arquitetura e Urbanismo. Faculdade de Arquitetura e Urbanismo - USP.

FERRAZ, Geraldo. Warchavchik e a Introdução da Nova Arquitetura no Brasil: 1925 a 1940. São Paulo: Museu de Arte de São Paulo, 1965.

FERREIRA, Carlos A. Martins. Arquitetura e Estado no Brasil - Elementos para uma Investigação sobre a Constituição do Discurso Moderno no Brasil: a Obra de Lúcio Costa (1924/1952). São Paulo, 1987. Dissertação (Mestrado). FFLCH/USP.

FERRONI, Eduardo Rocha. Aproximações sobre a obra de Salvador Candia. São Paulo: FAUUSP, $1^{\text {a }}$ edição, 2008.

FISCHER, Sylvia e ACAYABA, Marlene Milan. Arquitetura moderna brasileira. São Paulo: Projeto Editores Associados, 1982.

FORESTI, Debora Fabbri. Aspectos da arquitetura orgânica de Frank Lloyd Wright na arquitetura paulista: a obra de José Leite de Carvalho e Silva. Dissertação de mestrado. Orientador Renato Anelli. São Carlos, EESC USP, 2008.

FORTE, Miguel. Diário de um jovem arquiteto: minha viagem aos Estados Unidos em 1947. São Paulo: Editora Mackenzie, 2001.

FRAMPTON, Kenneth. História Crítica da Arquitetura Moderna. São Paulo: Martins Fontes, 1997 (trad. it. de Jefferson Luiz Camargo, Modern architecture: A critical view. London: Thames and Hudson, 1980). 


\section{York: Rizzoli, 1983.}

FUTAGAWA, Yukio. Modern Architecture 1920-1945. New

FRASER, Valerie. Building the New World: Studies in the Modern Architecture of Latin America 1930-1960. London, New York: Verso, 2000.

FREYRE, Gilberto. New World in the Tropics: The Culture of Modern Brazil. New York: Vintage Books, 1959.

FRIEDMAN, Alice T. American Glamour and the evolution of Modern Architecture. New Haven and London: Yale University Press, 2010.

FUJIOKA, Paulo Y. Princípios da arquitetura de Frank Lloyd Wright e suas influências na arquitetura moderna paulistana. São Paulo, 2003. Tese (Doutorado). Curso de Pós-Graduação em Estruturas Ambientais Urbanas. Faculdade de Arquitetura e Urbanismo - USP.

GALEAZZI, Ítalo. Mies van der Rohe no Brasil. Projeto para o Consulado dos Estados Unidos em São Paulo, 1957-1962. Arquitextos056 (Romano Guerra Ed. Ltda.). São Paulo, Portal Vitruvius, janeiro 2005.

GAND, Gary. Julius Shulman: Chicago Mid-Century Modernism. New York: Rizzoli International Publications, Inc., 2010.

GARCIA-CANCLINI, Nestor. Hybrid cultures: strategies for entering and leaving modernity. Minneapolis: University of Minnesota Press, 1995.

GIEDION, Sigfried. A Decade of Contemporary Architecture. Zurich: Girsberger, 1951.

Espaço, Tempo e Arquitetura: O desenvolvimento de uma nova tradição. São Paulo: Martins Fontes, 2004.

GOMES, Marco Aurélio A. De Filgueiras (org.). Urbanismo na América do Sul circulação de ideias e constituição do campo, 1920-1960. Salvador, EDUFBA, 2009.

GOODWIN, Philip L. Brazil Builds: Architecture new and Old 1652 - 1942. Photographs by G. E. Kidder Smith. New York: The Museum of Modern Art (MoMA), 1943.

GORELIK, Adrian. A produção da "cidade latino-americana". Tempo Social - Revista de sociologia da USP , 2005, vol. 17, n 1, p. 111-133.

- Das vanguardas a Brasília. Cultura urbana e arquitetura na América Latina. Trad. Maria Antonieta Pereira. Belo Horizonte, Editora UFMG, 2005.

GREEN, David. The Containment of Latin America A History of the Myths and Realities of the Good Neighbor Policy. Chicago: Quadrangle, 1971.

GUERRA, Abilio (org.). Textos Fundamentais sobre História da Arquitetura Moderna Brasileira. Parte 1 e 2. São Paulo: Romano Guerra, 2010.

. História da arquitetura brasileira: pesquisas monográficas e trabalhos panorâmicos In I Encontro Nacional da Associação Nacional de Pesquisa e Pósgraduação em Arquitetura e Urbanismo, 2008.

- Monografia sobre Salvador Candia e a necessidade de um diálogo acadêmico. Resenhas Online 078.03 (Romano Guerra Ed. Ltda.). São Paulo, Portal Vitruvius, junho de 2008. 
HARRIS, Elisabeth D. Le Corbusier: Riscos Brasileiros. São Paulo: Studio Nobel, 1976.

HERBST, Helio. Pelas Bienais à Arquitetura Chora nos Manuais. São Paulo, 2007. Tese (Doutorado em Arquitetura). Curso de Pós-Graduação em Estruturas Ambientais Urbanas. Faculdade de Arquitetura e Urbanismo - USP.

HINES, Thomas. Richard Neutra and the search for Modern Architecture. New York: Rizzoli, 2005.

HITCHCOCK, Henry-Russell. Latin American Architecture since 1945. New York: The Museum of Modern Art (MoMA), 1955.

; JOHNSON, Philip. The International Style: architecture since 1922. $3^{\mathrm{a}}$ ed. New York/London: W.W. Norton \& Company, 1995.

HUYSSEN, Andreas. After the great divide: modernism, mass culture, post-modernism. Bloomington, Indiana University Press, 1986.

HYMANN, Isabelle. Marcel Breuer, architect: the career and the buildings. New York: Abrams, 2001.

IRIGOYEN, Adriana. Da Califórnia a São Paulo: referências norte-americanas na casa moderna paulista 1945-1960. São Paulo, 2005. Tese (Doutorado). Curso de PósGraduação em Estruturas Ambientais Urbanas. Faculdade de Arquitetura e Urbanismo - USP.

Wright e Artigas - Duas Viagens. São Paulo: Ateliê Cultural, 2002.

JOEDICKE, Jurgen. A history of modern architecture. New York: Praeger, 1959.

JORGE, Luis Antônio. O Espaço Seco - Imaginário e Poéticas da Arquitetura Moderna na América. São Paulo, 1999. Tese (Doutorado). Curso de Pós-Graduação em Arquitetura e Urbanismo. Faculdade de Arquitetura e Urbanismo - USP.

KAMITA, João Masao. Espaço moderno e ética construtiva: a arquitetura de Affonso Eduardo Reidy. Dissertação de mestrado. Orientador Ronaldo Brito Fernandes. Rio de Janeiro, PUC-RJ, 1994 . Vilanova Artigas. São Paulo: Cosac \& Naify, 2000.

KENTGENS-CRAIG, Margret. The Bauhaus and America: First Contacts, 1919-1936. Cambridge: The MIT Press, 1999.

KHAN, Hasan-Uddin. International Style - Modernist Architecture from 1925 to 1965. Hong Kong/Köln/London/Los Angeles/Madrid/Paris/Tokyo: Taschen, 2009.

KULTERMANN, Udo. La arquitectura contemporanea. Barcelona: Editora Labor, 1969.

LAMPRECHT, Barbara. Neutra, 1892-1970: survival through design. Koln: Tachen, 2006.

LARA, Fernando. A insustentável leveza da modernidade. Arquitextos057 (Romano Guerra Ed. Ltda.). São Paulo, Portal Vitruvius, fevereiro, 2005.

Designed Memories, the roots of Brazilian modernism in BASTEA, Eleni (editor). Memory and Architecture. Albuquerque: University of New Mexico Press, 2004. 
- Espelho de fora: arquitetura brasileira vista do exterior. Arquitextos004 (Romano Guerra Ed. Ltda.). São Paulo, Portal Vitruvius, setembro, 2000.

One step back for two steps forward: the maneuverings of the Brazilian avant-garde. In Journal of Architectural Education, vol 55/4, may 2002.

. The Rise of Popular Modernist Architecture in Brazil. Miami: University Press of Florida, 2008.

LE CORBUSIER and P. Jeanneret. CEuvre Complète 8 vols. Zurich: Editions d'Architecture Artemis, 1984.

LE CORBUSIER (1887-1965). Por uma arquitetura (1923). São Paulo: Perspectiva, 1981.

Precisões sobre um estado presente da arquitetura e do urbanismo. São Paulo: Cosac \& Naify, 2004 (trad. Carlos Eugênio Marcondes de Moura, Précisions sur un état présent de l'architecture et l'urbanisme. Edição original: 1930).

LEME, Maria Cristina da Silva. Estrangeiros: a circulação de idéias e modelos na arquitetura e no urbanismo In Anais do X Seminário Historia da Cidade e do Urbanismo - Mesa Redonda Histórias das intervenções urbanísticas públicas. Recife: outubro 2008.

LEMOS, Carlos. Arquitetura brasileira. São Paulo: Melhoramentos/EDUSP, 1979.

LÉVI-STRAUSS, Claude. Tristes Tropiques. Paris: Plon, 1955; London: Picador, 1989.

LEVINE, Robert M. The Vargas Regime The Critical Years 1934-1938. New York: Columbia University Press, 1973.

LIERNUR, J.F. Vanguardistas versus expertos: reconstrución europea, expansión norte-americana y emergencia del "Tercer Mundo": para una relectura del debate arquitectonico en la segunda posguerra (una mirada desde America Latina). Block, n. 6, Buenos Aires, march 2004.

LINS, Paulo de Tarso Amendola. Arquitetura e as primeiras Bienais 1951 e 1953. São Carlos, 2000. Mestrado na Escola de Engenharia de São Carlos.

LIRA, José Tavares Correia de. Richard Neutra, modernismo, tropicalismo e desenvolvimentismo: Aventuras e desventuras de um arquiteto estrangeiro na América Latina. Texto elaborado para o projeto temático Fapesp "São Paulo: os estrangeiros e a construção da cidade", 2011.

Cosac \& Naify, 2011.

Warchavchik: fraturas da vanguarda. São Paulo:

LOBATO, Monteiro. América. São Paulo: Cia. Ed. Nacional, 1932.

LOUREIRO, Claudia; AMORIM, Luiz. Por uma arquitetura social: a influência de Richard Neutra em prédios escolares no Brasil. Arquitextos020 (Romano Guerra Ed. Ltda.). São Paulo, Portal Vitruvius, janeiro 2002.

LOURENÇO, Maria Cecília França. Operários da Modernidade. São Paulo: HUCITEC/EDUSP, 1995. 
. Museus acolhem moderno. São Paulo: EDUSP, 2000.

MACLAMPRECHT, Barbara. Richard Neutra: complete works. Kolh/London/Madrid/New York/Paris/Tókio: Taschen, 2000.

McCANN, Frank. The Brazilian-American Alliance 1936-1945. Princeton: Princeton University Press, 1973.

MACHADO, Lúcio Gomes. Rino Levi e a renovação da arquitetura brasileira. Tese de doutorado. Orientador Benedito Lima de Toledo. São Paulo, FAU-USP, 1992.

MAHFUZ, Edson da Cunha. Ordem, estrutura e perfeição no trópico - Mies van der Rohe e a arquitetura paulistana na segunda metade do século XX. Arquitextos057.02 (Romano Guerra Ed. Ltda.). São Paulo, Portal Vitruvius, ano 05, fevereiro 2005.

Transparência e sombra: o plano horizontal na arquitetura paulista. Arquitextos, n. 79.01. São Paulo, Portal Vitruvius, dez. 2006.

MARINHO, Maria Gabriela S. M. C. Norte-americanos no Brasil. Uma história da Fundação Rockefeller na Universidade de São Paulo (1934-1952). Campinas, SP: Autores Associados, São Paulo: Universidade São Francisco, 2001.

MARTINS, Carlos Alberto Ferreira. Le Corbusier en la conquista de America: ciudad y paisaje en los proyectos sudamericanos y el embate contra el SFU in Seminário Internacional As origens das Políticas modernas na América Latina 1900-1945 IPPUR, Rio de Janeiro, agosto/setembro 1994.

MATERA, Sérgio. Carlos Millan - Um estudo sobre a produção em arquitetura. São Paulo, 2005. Dissertação (Mestrado). Curso de Pós-Graduação em Estruturas Ambientais Urbanas. Faculdade de Arquitetura e Urbanismo - USP.

MAUAD, Ana Maria. A América é aqui: um estudo sobre a influência cultural norteamericana no cotidiano brasileiro (1930-1960). In: TORRES, Sonia (Org.) Raízes e rumos: perspectivas interdisciplinares em estudos americanos. Rio de Janeiro: 7Letras, 2001, pp.134-46.

MEYER, Regina Maria Prosperi. Metróple e Urbanismo: São Paulo anos 50. São Paulo, 1991. Tese (Doutorado). Curso de Pós-Graduação em Estruturas Ambientais Urbanas. Faculdade de Arquitetura e Urbanismo - USP.

MINDLIN, Henrique E. Arquitetura Moderna no Brasil. $2^{a}$ ed (1 $1^{a}$ ed. bras. 1999). Rio de Janeiro: Aeroplano Editora/IPHAN, 2000 (tradução do original em inglês Modern Architecture in Brazil. New York: Reinhold Publishing Corporation, 1956).

MIRANDA, Clara Luiza. A crítica nas revistas de arquitetura nos anos 50: a expressão plástica e a síntese das artes. São Carlos, 1998. Programa de Pós-Graduação em Arquitetura e Urbanismo. Escola de Engenharia de São Carlos - USP.

MOCK, Elizabeth (editor). Prefácio de Philip L. Goodwin. Buit in USA: 1932-1944. New York: Museum of Modern Art, 1944.

MONTANER, Josep Maria. Arquitectura e critica. Barcelona: Editorial Gustavo Gili, 1999. 
Despues del movimiento moderno: Arquictetura de la segunda mitad del siglo XX. Barcelona: Editorial Gustavo Gili, 1993.

MORSE, Richard. De comunidade a metrópole: biografia de São Paulo. Tradução de Maria Aparecida Madeira Kerberg. São Paulo: Comissão do IV Centenário, 1954.

. O espelho do próspero - Cultura e ideias nas Américas. São Paulo: Companhia das Letras, 1988.

MOSES, Robert. Program of Public Improvements for São Paulo. New York: IBEC Technical Services, 1950.

MOURA, Gérson. Tim Sam chega ao Brasil. São Paulo: Brasiliense, 1984.

MUNFORD, Eric; FRAMPTON, Kenneth The CIAM discourse on urbanism, 1928-1960. Boston: Massachusetts Institute of Technology, 2000.

NASCIMENTO, Ana Paula. MAM: Museu para a metrópole. São Paulo, 2003. Dissertação (Mestrado em Arquitetura). Curso de Pós-Graduação em Estruturas Ambientais Urbanas. Faculdade de Arquitetura e Urbanismo - USP.

NEDELYKOV, Nina; MOREIRA, Pedro. Caminhos da Arquitetura Moderna no Brasil: A presença de Frank Lloyd Wright. Arquitextos018 (Romano Guerra Ed. Ltda.). São Paulo, Portal Vitruvius, agosto 2001.

NEUTRA, Richard. Arquitetura social em países de clima quente. São Paulo: Todtmann, 1948.

NEWMAN, O. Whose failure is modern architecture? In MIKELLIDES, B. (ed). Architecture for people. New York, Holt, Rinehart and Winston, 1980.

NOBRE, Ana Luiza; KAMITA, João Masao; LEONÍDIO, Otavio; CONDURU, Roberto (org.). Lucio Costa: Um modo de ser Moderno. São Paulo: Cosac \& Naify, 2004.

OCKMAN, Joan. Architecture Culture 1943-1968: A Documentary Anthology. New York: Columbia Books of Architecture/Rizzoli International Publications, 1993.

Towards a Theory of Normative Architecture In The Architecture of Everyday. New York: Princeton Architectural Press, 1996, p. 122-152.

ORTIZ, Renato. A moderna tradição brasileira - Cultura brasileira e indústria cultural. São Paulo: Brasiliense, 1988. . Cultura brasileira e identidade nacional. São Paulo: Brasiliense, 1985.

PAPADAKI, Stamo. The Work of Oscar Niemeyer. New York: Reinhold, 1950.

PENTEADO, Yolanda. Tudo em cor-de-rosa. Rio de Janeiro: Nova Fronteira, 1976.

PEREIRA, Cláudio Calovi. Os irmãos Roberto e a arquitetura moderna no Rio de Janeiro (1936-1954). Dissertação de mestrado. Orientador Carlos Eduardo Dias Comas. Porto Alegre, FAU-UFRGS, 1993.

PETER, John. Masters of modern architeture. New York: G. Braziller, 1958.

The oral History of Modern Architecture - Interviews with the Greatest Architects of the Twentieth Century. New York: Harry N. Abrams, 1994. 
PEVSNER, Nikolau. Os Pioneiros de Desenho Moderno - de William Morris a Walter Gropius. $1^{a}$ ed. brasileira. São Paulo: Martins Fontes, 1980 (trad. it. de João Paulo Monteiro, Pioneers of Modern Design - From William Morris to Walter Gropius (1936). London: Penguin Books, 1974).

An outline of European architecture. 6a. Ed. Melbourne: Penguim Books, 1957.

PINHEIRO, Maria Lúcia Bressan. Modernizada ou Moderna? A arquitetura em São Paulo, 1938-1945. São Paulo, 1997. Dissertação (Mestrado). Curso de PósGraduação em Estruturas Ambientais Urbanas. Faculdade de Arquitetura e Urbanismo - USP.

PORTOGUESI, Paolo. Depois da Arquitetura Moderna. São Paulo: Martins Fontes, 1985.

PRUDON, Theodore H. M., FAIA. Preservation of Modern Architecture. Hoboken, New Jersey: John Wiley \& Sons, 2008.

QUEIROZ, Rodrigo Cristiano. Oscar Niemeyer e Le Corbusier: Encontros. São Paulo, 2007. Tese (Doutorado). Curso de Pós-Graduação em Estruturas Ambientais Urbanas. Faculdade de Arquitetura e Urbanismo - USP.

REED, Peter. The United Nations in Perspective. New York: Museum of Modern Art (MoMA), 1995.

RIBEIRO, Otavio Leonidio. Carradas de Razão: Lucio Costa e a Arquitetura Moderna Brasileira. Rio de Janeiro: PUC-Rio/Editora Loyola, 2007.

RIBEIRO, Patrícia Pimenta Azevedo. A participação do arquiteto Richard Neutra no Congresso Internacional Extraordinário de Críticos de Arte em 1959.

- Teoria e prática: a obra do arquiteto Richard Neutra. Tese de doutorado em arquitetura e urbanismo. Orientador Adilson Costa Macedo. São Paulo, Universidade de São Paulo, 2007.

ROSSETTI, Eduardo Pierrotti. Brasília, 1959: a cidade em obras e o Congresso Internacional Extraordinário dos Críticos de Arte. Arquitextos11.03 (Romano Guerra Ed. Ltda.). São Paulo, Portal Vitruvius, agosto 2009.

ROWLAND, D. W. A History of the Office of the Coordinator of Inter-American Affairs. Washington, D.C., 1946.

SALVI, Ana Elena. Cidadelas da civilização; políticas norte americanas no processo de urbanização brasileira com ênfase na metropolização paulistana dos anos 1950 a 1969. São Paulo, 2005. Tese (Doutorado). Curso de Pós-Graduação em Estruturas Ambientais Urbanas. Faculdade de Arquitetura e Urbanismo - USP.

SANTOS, Cecilia Rodrigues dos; PEREIRA, Margareth da Silva; CALDEIRA, Vasco; PEREIRA, Romão Veriano da Silva. Le Corbusier e o Brasil. São Paulo: Tessela/Projeto, 1987.

SANTOS, Luís Cláudio Villafañe Gomes dos. O Brasil entre a América e a Europa. O Império e o Interamericanismo (do Congresso do Panamá à Conferência de Washington). São Paulo: Editora da UNESP, 2004. 
SANTOS, Paulo. Quatro séculos de arquitetura. Rio de Janeiro: Valenca, 1977.

SARTORIS, Alberto. Gli elementi dell'architettura funzionale: sintesi panoramica dell'architettura moderna. Prefazione de Le Corbusier; introduzione di Carlo Ciucci. Milano: Hoepli, 1932.

SCOTT BROWN, D. Architectural taste in a pluralistic society In The Harvard Architectural Review, Vol. 1, Spring 1980. Cambridge, MA, MIT Press, p. 41-51.

SCULLY Jr., Vincent. Arquitetura Moderna - A Arquitetura da Democracia. São Paulo: Cosac \& Naify, 2002 (trad. it. de Ana Luiza Dantas Borges, Modern architecture: the architecture of democracy. New York: George Braziller, 1961).

SEGAWA, Hugo. Arquiteturas no Brasil 1900-1990. São Paulo: Edusp, 2ªed., 2010. . The essentials of Brazilian Modernism, Design Book Review 32/33, 1994, p. 64-68.

SEGRE, Roberto; LOBO, Maria da Silveira. Congresso Internacional Extraordinário de Críticos de Arte: Cidade Nova - Sintese das Artes. Rio de Janeiro: UFRJ, 2009.

. O sonho americano de Oscar Niemeyer, Le Corbusier e as Américas In Revista aU, edição 165, dezembro de 2007.

SERAPIÃO, Fernando. Johnson e Niemeyer. Os pupilos americanos In PROJETODESIGN, edição 301, março de 2005.

SERRAINO, Pierluigi. Julius Shulman, Modernism Rediscovered. Hong Kong/Köln/London/Los Angeles/Madrid/Paris/Tokyo: Taschen, 2009.

SKIDMORE, Thomas; SMITH, Peter. Modern Latin America. $5^{\mathrm{a}}$ ed. New York/Oxford: Oxford University Press, 2001.

SMITH, Elizabeth A. T. Case Study Houses, 1945-1966 - The California Impetus. Köln: Taschen, 2007.

SOUZA, Maria Adélia A. A identidade da metrópole: a verticalização em São Paulo. São Paulo: Hucitec/Edusp, 1994.

STEINBECK, John. A América e os Americanos: e Outros Ensaios Selecionados. Rio de Janeiro: Record, 2004 (trad. it. de Maria Beatriz de Medina. America and Americans (1966) and selected Nonfiction. New York: Penguin Classics, 2003).

STERN, Michael. Julius Shulman: Palm Springs. New York: Rizzoli, 2008.

STOCKLER e BREIA, Maria Teresa. A Transição do Ensino da arquitetura Beaus-arts para o ensino da arquitetura moderna na Faculdade de Arquitetura Mackenzie: 1947-1965. São Paulo, 2005. Tese (Doutorado). Curso de Pós-Graduação em Arquitetura e Urbanismo. Faculdade de Arquitetura e Urbanismo - USP.

TAFURI, Manfredo; Dal Co, Francesco. Modern Architecture. Milão: Electa/Rizzoli, 1986.

. Teorias e História da Arquitetura. Lisboa: Ed. Presença; São Paulo: Martins Fontes, 1979. 
THOMAZ, Dalva Elias. Um olhar sobre Vilanova Artigas e sua contribuição à arquitetura brasileira. Dissertação de mestrado. Orientadora Ana Maria de Moraes Belluzzo. São Paulo, FAU-USP, 1997.

TINEM, Nelci. Arquitetura Moderna Brasileira: A imagem como texto. Arquitextos072 (Romano Guerra Ed. Ltda.). São Paulo, Portal Vitruvius, maio 2006.

O Alvo do olhar estrangeiro - O Brasil na Historiografia da Arquitetura Moderna. João Pessoa: Manufatura, 2002.

TOTA, Antonio. O Imperialismo Sedutor: A americanização do Brasil na Segunda Guerra Mundial. São Paulo: Companhia das Letras, 2000.

UNDERWOOD, David. Oscar Niemeyer e o Modernismo de formas livres no Brasil. São Paulo: Cosac \& Naify, 2002.

VENTURI, Robert. Complexity and contradiction, New York: MoMA, 1966.

VIDLER, Anthony. Histories of the Immediate Present: inventing architectural modernism. Cambridge, Mass: MIT Press, 2008.

WARCHAVCHIK, Gregori (1896-1972). Arquitetura do século XX e outros escritos. Organização: Carlos A. Ferreira Martins. São Paulo: Cosac \& Naify, 2006.

WEBB, Michael. Modernist Paradise - Niemeyer House/Boyd Collection. New York: Rizzoli International Publications, Inc., 2007.

WISNIK, Guilherme Teixeira. Formalismo e Tradição: A arquitetura moderna brasileira e sua recepção critica. São Paulo, 2003. Dissertação (Mestrado). FFLCH/USP.

WURTS, Richard (and others). The New York World's Fair, 1939/1940: in 155 Photographs. New York: Dover Publications; 1st. edition, 1977.

XAVIER, Alberto; LEMOS, Carlos; CORONA, Eduardo. Arquitetura Moderna Paulistana. São Paulo: Pini, 1983.

XAVIER, Alberto (org.). Depoimento de uma geração - arquitetura moderna brasileira. São Paulo: Cosac \& Naify, 2003.

- Lucio Costa: sobre arquitetura. Porto Alegre: Centro de Estudos Universitários de Arquitetura da Universidade do Rio Grande do Sul, 1962.

ZWEIG, Stefan. Brazil: Land of the Future. London: Cassell, 1942.

\section{Periódicos}

BIDEN, Alf. "Report on Brazil", In: Architectural Review, n 646, vol. 108, out 1950, pp. $221 / 222$.

BILL, Max. "Lettere al direttore”, In: Casabella, n²01, maio 1954, pp. II.

BILL, Max et ali. "Reports on Brazil". Architectural Review. Nova lorque. vol. 116, no. 694.p.235-250, out.1954.

BLOC, André. “Amerique Latine”, In: L'Architecture d'Aujourd'hui, n 10, mar 1947.

BLOC, André. "Ayons Confiance dans l'architecture", In: L'Architecture d'Aujourd'hui, no 42/43, ago 1952. 


\section{BIBLIOGRAFIA}

GROPIUS, Walter y otros. "Report on Brazil", In: Architectural Review, vol 116, out 1954, pp. 234/250.

KIDDER-SMITH, G. E. "The architects and the modern scene", In: Architectural Review, vol 095, n 567, mar 1944, pp. 78-84.

MARSHALL, P. J. "South America scrapbook", In: Architectural Review, vol 107, n 638, feb 1950, pp. 123-130.

NIEMEYER, Oscar. "Ce qui manque a notre architecture", In: L'Architecture d'Aujourd'hui no 13/14, set 1947.

NIEMEYER, Oscar. Criticada a Arquitetura Brasileira. Módulo, Rio de Janeiro, no.1, p.46-47, 1955.

NIEMEYER, Oscar. Problemas Atuais da Arquitetura Brasileira. Módulo, Rio de Janeiro, no.3, p.19-20, 1955.

PERSITZ, Alexandre. "L'Architecture au Brésil", In: L'Architecture d'Aujourd'hui, nº 13/14, set 1947.

ROGERS, Ernesto. "Report on Brazil”, In: Architectural Review, vol 116, out 1954.

ROGERS, Ernesto. "Pretesti per una critica non formalista", In: Casabella, n 200, fev 1954, pp.1-3.

SITWELL, Sacheverell. "The brazilian style", In: Architectural Review, vol 095, n 567, mar 1944, pp. 65-68.

WOODWARD-SMITH. "South America: Study in Contemporary Architecture in Brazil", In: Architectural Forum, n 11. nov 1947, pp 65-117.

ZEVI, Bruno. "La moda lecorbuseriana in Brasile: Max Bill apostrofa Oscar Niemeyer (02/11/1954)", In: Cronache di Architettura I (1954/1955) - Da Wright sul Canal Grande alla Capelle de Ronchamp 1/72. Bari, Laterza, 1971 (nº 1 a 72).

\section{Filmografia/Documentários:}

2001: Vilanova Artigas. Brasil; doc, cor/P\&B, um filme de Cacá Vicalvi.

2004: Frank Lloyd Wright. USA; doc, cor/P\&B, um filme de Ken Burns e Lynn Novick.

2004: Tall, The American Skyscraper and Louis Sullivan. USA; doc, cor/P\&B, um filme de Manfred Kirchheimer.

2007: Oscar Niemeyer, a vida é um sopro. Brasil; doc, cor/P\&B, um filme de Fabiano Maciel e Sacha.

2007: Julius Shulman, Desert Modern. USA; doc, cor/P\&B, um filme de Michael Stern.

2008: Visual Acoustics, The modernism of Julius Shulman. USA; doc, cor/P\&B, um filme de Eric Bricker.

2009: Reidy, a construção da utopia. Brasil; doc, cor/P\&B, um filme de Ana Maria Magalhães.

2009: Journeyman Architect, The life and work of Donaldo Wexler. USA; doc, cor/P\&B, um filme de Jake Gorst. 
2011: William Krisel, Architect (William Krisel, Arquiteto). USA; doc, cor/P\&B, um filme de Jake Gorst.

2011: Os imãos Roberto. Brasil; doc, cor/P\&B, um filme de Ivana Mendes e Tiago Arakilian.

2011: Eames, The architect and the painter. USA; doc, cor/P\&B, um filme de Jason Cohn. 
ANEXO 


\section{OSWALDO ARTHUR BRATKE}

My name is: Oswaldo Arthur Brakte.

I was born in Butucatu, Sao Paulo, Brazil, on August 24th, 1907. I am an architect. I graduated in architecture from the School of Engineering at Mackenzie University in 1931. With my friend Carlos Bothi, who was also an architect, 1 constructed approximately 450 buildings for a great variety of uses. In 1942, Carlos Bothi died. I continued to construct for 3 more years. Thereafter, I went on just to do designing. I did designing for over 2000 buildings. Among those, two villages consisting approximately of 800 units. The other designings were usually units for different clients. The type of designing I did most was houses, which comprise approximately $80 \%$ of all my work.

Mr. PETER: How did you become an architect? How or what are your reasons for becoming an architect?

Mr. BRAKTE: I studied architecture, partly because it suited my personality and partly because I inherited it. My father was neither an architect nor an engineer. But there were some engineers in my family. Since early childhood, I had always contact with professional architects. Perhaps, I can consider this fact one of the reasons for my being an architect; the other reason might be my knack for drawing. I always had contact with people who worked in this area or used drawing as a pastime.

Mr. PETER: How did you became an archilect?

Mr. BRAKTE: Perhaps, I studied architecture because it suited my personality or because I had more contact with professionals in this area. And also, because of my knack for drawing, having contacts with people in this field, as well as, painting, sculpture, etc. Most of my primary and elementary school classmates went on to study engineering and archilecture along with me. A very interesting fact that is happening nowachas in our family is that there is a large group of people graduating in architecture. Today we total almost a dozen and a half architocts and 
engineers.

Mr. PETER: Did you ever read anything or start thinking about architecture or art when you were a child? Did you start by being an artist drawing or - ?

Mr. BRAKTE: Yes. As I said, I had a knack for drawing. This led me to the field of painting, designing, and mainly to the contacts with professionals of this area.

Mr. PETER: What is your definition of an architet? What is an architect?

Mr. BRAKTE: For me an architect is a person who defines a given useful space, with art, technique, and human sense, for a specific function and a given character. In each specific case, he has to take into account the client's personality; and in public works, he has to take into account the feeling of the majority.

Mr.PETER: Do you see an architect primarily as an artist or first as an engineering or social... . What is an architect?

Mr. BRAKTE: I see an architect as a person with technical knowledge who is also an artist striving for the purest form of art.

Mr. PETER: Who gave you the best architectural advice?

Mr. BRAKTE: Perhaps, the best teachings I received came from the contrast between my professors and that progressive architectural movement that we saw especially in Europe, during our youth; and the will to find out which one was right. Later on, knowledge comes from the experience one acquires in the exercise of the protession.

Mr. PETER: What are the most important influences in your work?

Mr. BRAKTE: In the beginning the works of architects such as Wright, Le Corbusier, Van Den Vluct and others. Later, Japanese architecture, because of its purity, art, and spontaneity, maintaining simultaneously the contact with nature and man. But, in general, the main influence in our work are the experiences during our lives, the climate of our land, the progress of our industry and the demands of our clients. 
Mr. PETER: What is the philosophy of your architecture?

Mr. BRAKTE: It is only when the architect has in mind the welfare of man and his harmony with society, the needs of hygiene, stability and economy, and the search for a spontaneous and beautiful form(which is what last in architecture), than he will have reached the goals of his profession.

Mr.PETER: What is wrong with architecture today? What is wrong with architecture throughout the worid?

Mr.BRAKTE: You ask me what is wrong with architecture today. Architecture reflects the way of life of a people. We live in a period of renovation, where society is being destroyed by a revolution based upon individualism. Only when we find a common expression will we be able to trace the path of architecture.

Mr.PETER: Do you have a favorite building material?

Mr. BRAKTE: I like materials that appear natural such as wood, iron, stone, brick, etc. I have a special pleasure in working with wood. If it was not difficult to work with concrete without the necessary cover protection, which takes away its beauty, the wood would be the most beautiful contemporary material.

Mr. PETER: Is there a techinical development that promises to make a change in the way buiklings are made?

Mr. BRAKTE: These two questions..., whether technical development leads to more changes in construction than social movement... . I prefer to reduce them to a singie question and answer in the following way: I tend to believe that technical devolopments are less responsible for the transformations of life and constructions, than social changes. After thousands of years, the dominant materials are, in most of the world, wood, brick, clay tiles. I believe that new forms appeared, which are made possible because of new materials and more sophisticated techniques. However, the important aspect is the function and this is motivated by social structure. Certainly, reinforced concrete was very responsible for 
changes in architecture in the last decades; but it was the social structure that characterized Medieval, 19th century, and contemporary architecture. The first one was identified with a lack of security; the second with frivolity; and the third one with the struggle for survival.

Mr. PETER: What about social development? is there a social development that changod the way...?

Mr. BRAKTE: It has been asked what are, in my opinion, the three best modern works and why. I do not think one can classify any three modern works as the best. Each work fulfills a determined purpose or function; and one cannot state which is the best function. For me the best works are those which could fulfill those requirements we mentioned in the question about the definition of an architect. The best works are not, necessarily, those which get attention, but, very often, those which laymen and even professionals do not notice.

Mr. PETER: What is the future of archifecture? Are you an optimist so far? Mr. BRAKTE: Architecture portrays the life of a people. One cannot, properly, talk about the future of architecture. Since architecture is the reflection of man's life and society, the changes society experiences today will be reflected by the architecture of the future.

MR. PETER: Could you do me a favor? Answer the last one in English also.

Mr. BRAKTE: You are asking me about the future of architecture. To me that makes no sense. I prefer to speak about the future of society. Architecture being the image of society, each transformations or modifications of this society will be reflected by a good architecture. 


\section{OSCAR NIEMEYER}

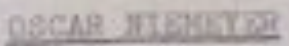

19. Pakint what is your nase, place of birts, and who are your parentu?

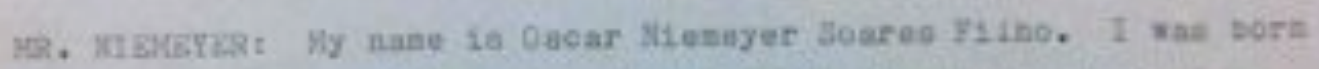
In 810 de Janelfo which todny ie the gtate of Guanabara and I a the mon of Oncar Fideneyor Boares ane Deifina sinelda de Fieseyur Seares.

199. PETE2: What in your definition of ah urchitect?

X8. Mrekrak: I think an architeet should have an underatanatng

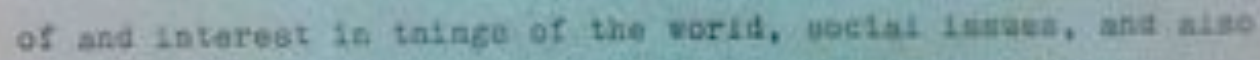
goosens the qualitien that anoule tead his to the profesalos, Is other worall, I taskik an arohitect should be born an urchitect, juat all a painter io born a painter.

YR. Fotien: why did you pecose an architect?

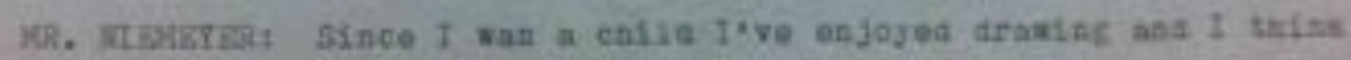
It was taik afrindey for droxing that breaght ay to the eshoot of arcnit toctare.

19. Frtug: who gave you the boet advice about arcbiteetare and wat: was the sarted yod recefrod?

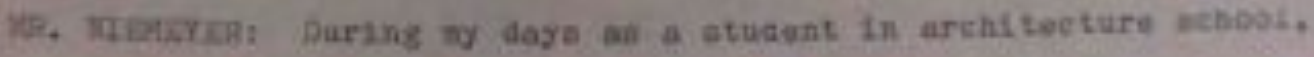


I. sorices in the offiee of focio coats and with hi= I learned about tse profeesion.

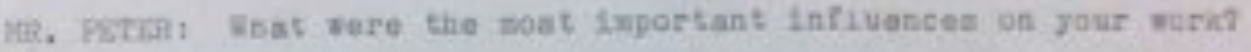

MR. Hraxyse; The profenalonel infuese of Lucto Coeta and the work of Deforbualez for whteh 1 feel the nost esthealasa.

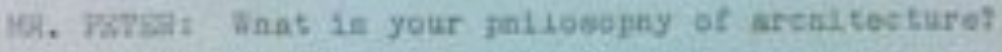

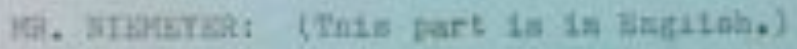

Hitr. Patzaf; Ia wat you jeat tola ab, you talked about the relationanlp between the coionfal atyle aba the butuesnga trat you created

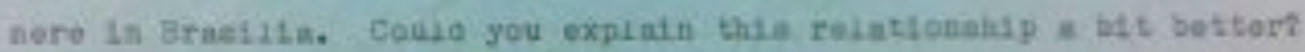

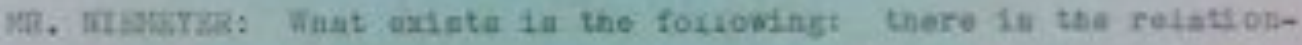
ahip batseen tan atiltuse of the arentect of tae cosontal jerfie

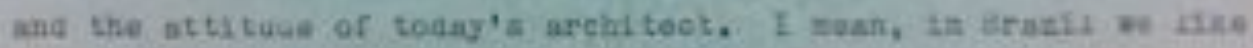
to retaln the voncern: for bhe ahaye, the furve, in othar woras, for a more oothetie arenitecture.

Hos we icnos that there cashat be coly one fezakiosahip becaude What suggepts the stylo in preciseiy the progrene of technoloig. 3ine dane th a earferunt say atac. But we keap the aate athtude.

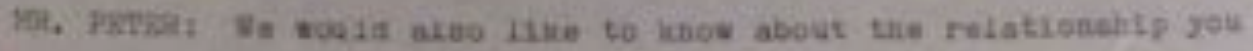
apose about between jaetry ubi tha form yeu created. 


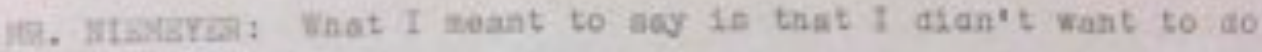
architecture baned only on technology, on tne technology of ateel reinforces concrote, or on the casvaniencen of concrete. 1 vanted to produce arcnitecture last 1 feel ig differest becaune I tninic arenttecture 1 is beyand these thisge. Architecture ahould be difocted towaros boalaty, towardin sobething differest, nuvel, and creative. Sp I wanked the Plaza of the Tnree Powere (Fraca doe Tren foderes) to not have the cola feeling a lin mosatimes the case with wodern arcmilecture. I wanted it to have more of a murrealistic espeet, wore dreas-11ice, an 10 seetr It the paintingso of Granute which I thinis are narveloub. For oxample, dobotiaed architects Baon up at the Congrabefonal Palace (Palacio do Congreseo) who want to know why the curved were wade with that ahape. fiere there wall a techntcal reason. Fae ahape of the curves altava for a view.

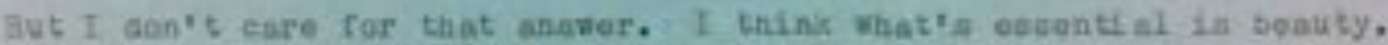
When at ara in front of II vary leportant work frob the pant, euch

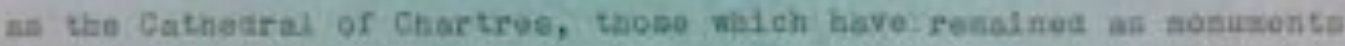

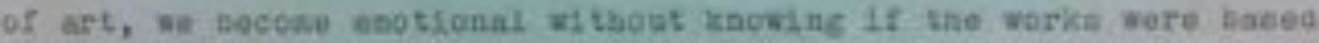
on tectrosogleat naede becauso they are vory old. It $1 \mathrm{a}$ only a bensation Lowardo beausy.

Y3. Fmrait It wousa be interantiab for you to ctru auviee to the nes arohitecta of to baee who are gotng to be archttecta. OLve wasen atrise noput whych they anould think, . .

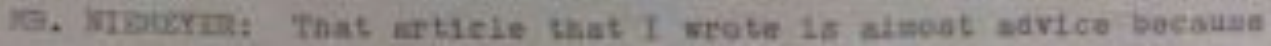

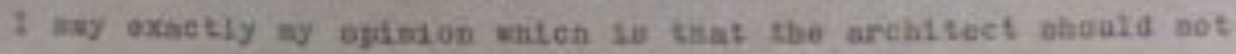

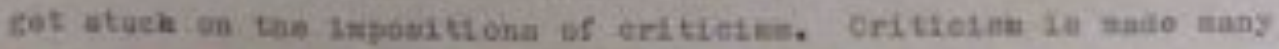


yuari later. Back moold follow hin 1ncinationg and he will only be secceseful if ho toen what he likes whtnout being vorried about was thoy'zu golab to thinic of his woric. Hile work noould be interesting to hi=nels above ith.

19h. PaFsi: What do you thisik in wrong with architecture in tno sorld today - todey' a areht tecture?

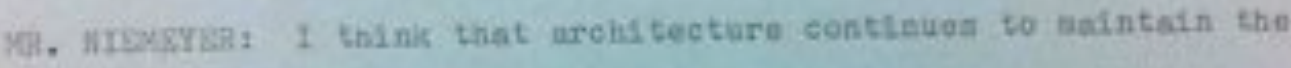

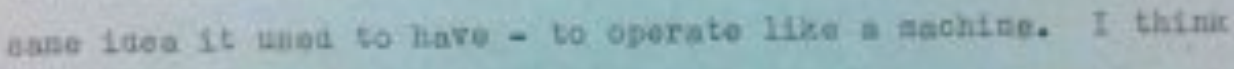

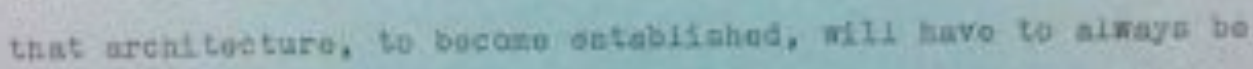
dose baed as the pant's arent tecture. The arcetseoture of the jost rosadine a greet exanjle of arekstecture, that 10 , os eceothing boatiful mien, to be beautifut, can overcoae any projedsce. $t$. salaic that wat an arcinftect cannot do 10 work ghut wishin a acnool, an orlestation or 14 as tationa that lead $n$ as to ropetition wineut งมต.

10ir. Farket: whas in the material andek you like to weo wout?

M. Magrats In lirazl1 ve work sitn stool felnforced eobcrete

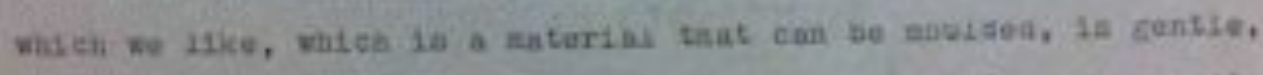
ana wieb does averythtag we want. With ateel retaforcen cancrete

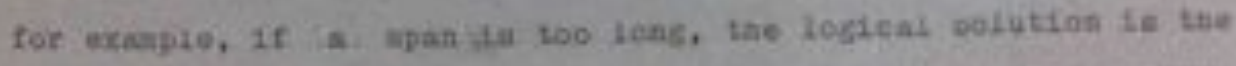
curve. In other sorde, we aph't fall into cne rlybd arent tecture toat the anthi sirueturea juatify.

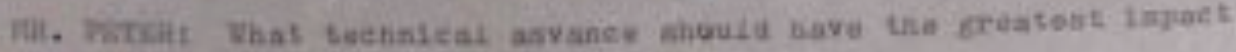




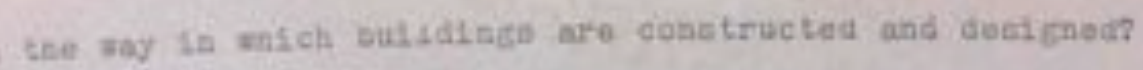

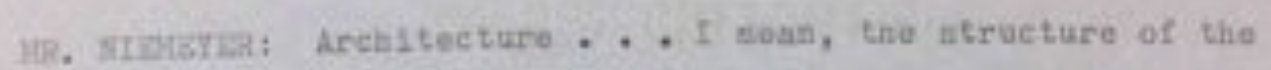
butudinge in mat gugsoste tae architecture and whes the aethod of atraeture changes, the buldaspgin change aloo. In thio way the

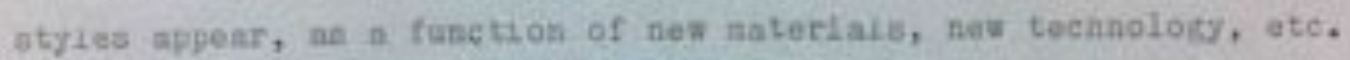

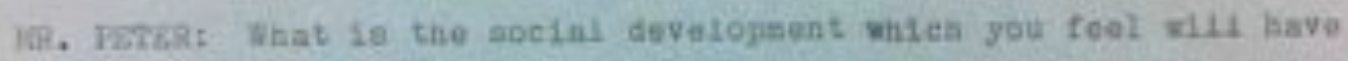
the greatest Influence on the changee in the types of buildings ande and in the way in whleh they are doelgned and eanstruetact?

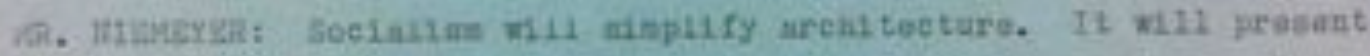

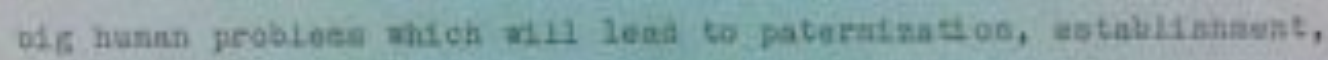
and the solettos to problean of cotiectivity.

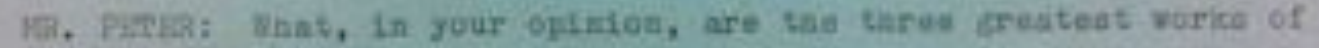
meters arehil tocture und why do you feel they are?

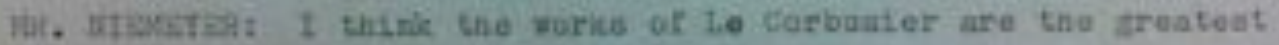
works of moders arcintecturo, as wuch for the buslalsge eabutrueted

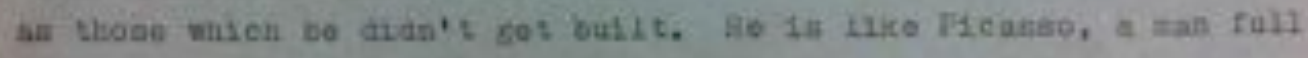
of Inagination, whe lan't atuck tin any oootrise. Ho doed axactiy an no pisoued.

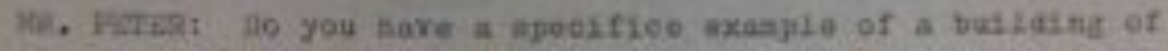

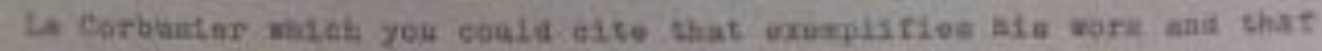
yes batnis sontafne liss best tambas 


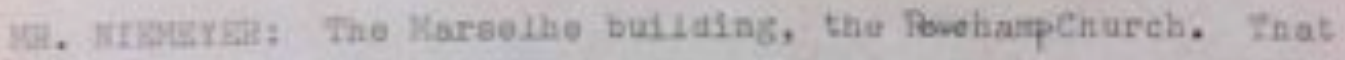
churob nas a freer Lneknatiot, when $1 \mathrm{~s}$ the Ineliantion I prefer, mackis thinge with the greatest freedon of form, without concera for whetior tho form 1 s based on profesalonal rosacning. He did $1 t$ only becaues the thought it was boatiful.

Wh. Fatak: Wast do you think is the future of architocture?

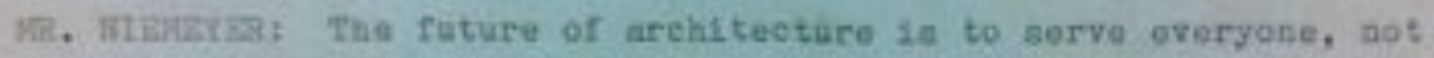
to resain, as it dae until now, ae a priviledge of the rore powerfal clsssea. It should be isrected to all the peopla and the architecte ahould work for the peoplo, not juot for those who, at tae nosent, poseess the eobey und ean pay for the arcbltecte' woris. 


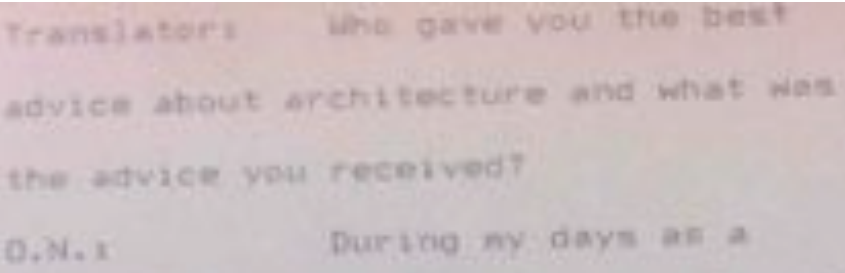


Weise anavernou not understoods leter un Inew abebiutin respect ask adeirstion. Ther ara trian. But $t$ as raging. They was the subject of soeculator upon the crotolens in fors and architencture. It: is this testakene of an architect who is the thited Theorgical, and

ret and $h a s$ perofessiomal

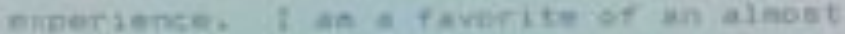

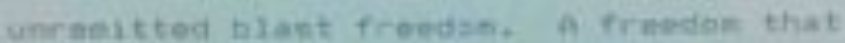
is not...te Iavishiy suberdinated te thin reatione of ary givmn testimique of functionalise, but wheh makes an wepeal te the teapinstion to thine that a reu

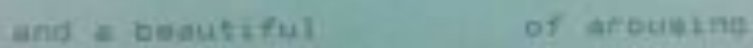




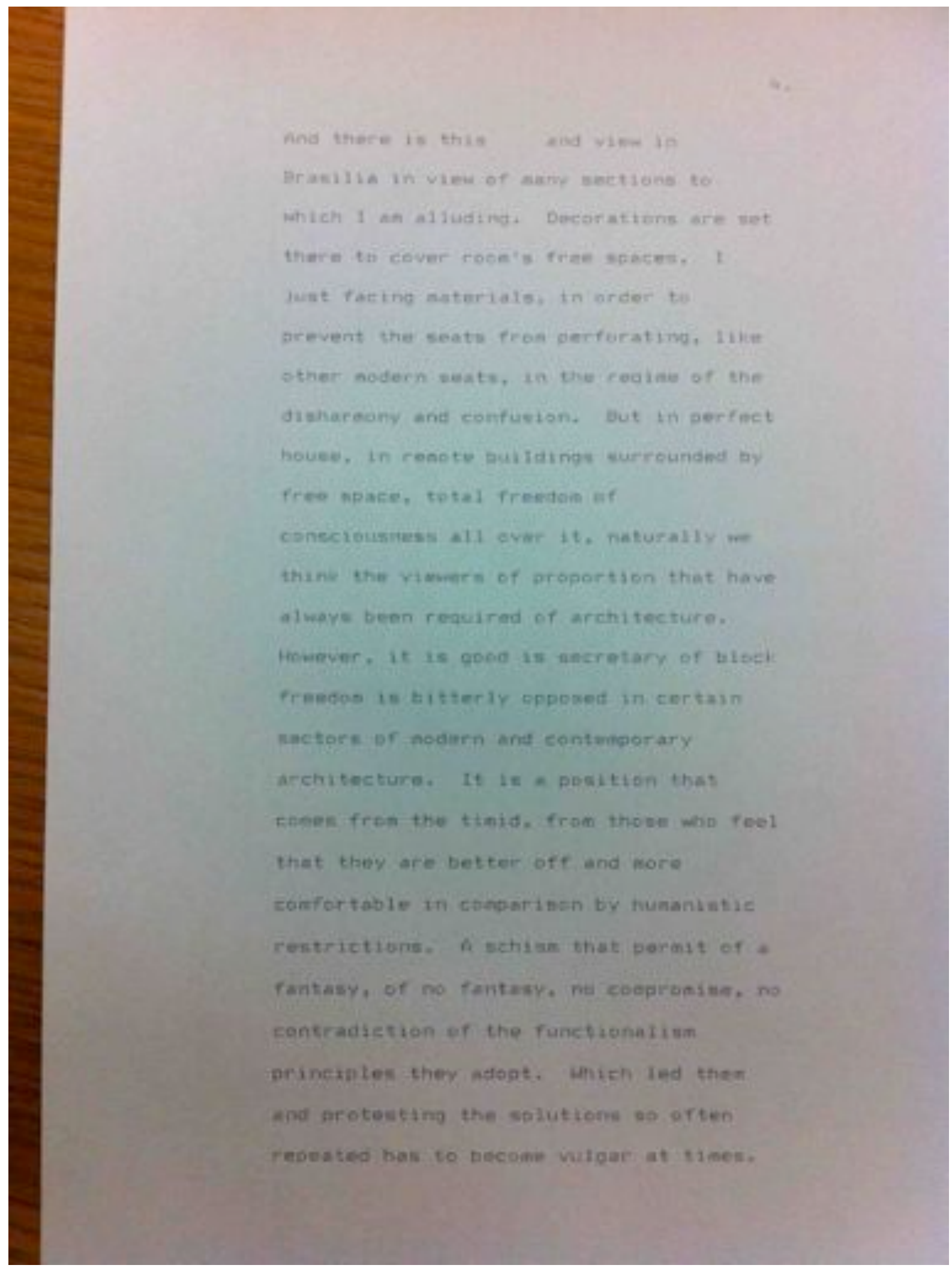


And in the field of discussierw, they are ended and are shaken theugh in thetr deferise of functionalian of stanclardizations and so on. and when it is a quention of spectal jobs where the prebtens of is aecondary. Thereupon thers

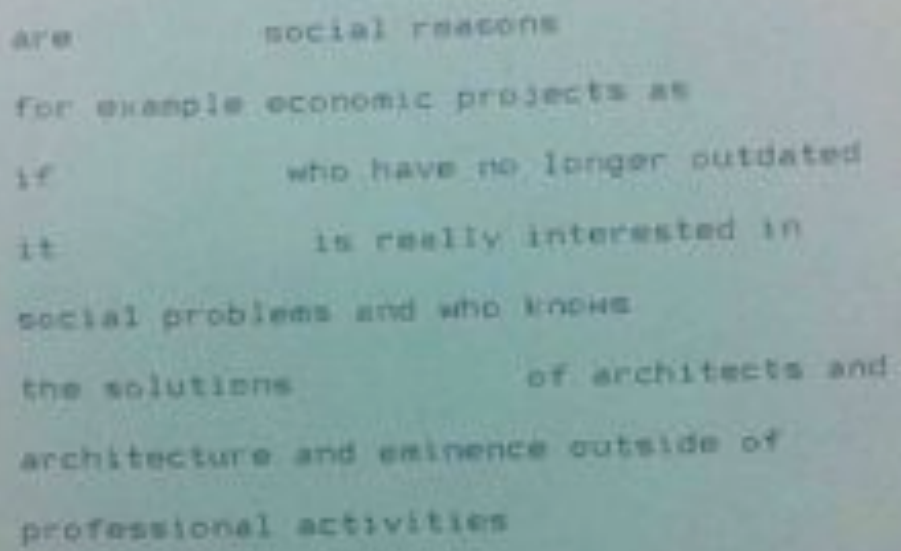




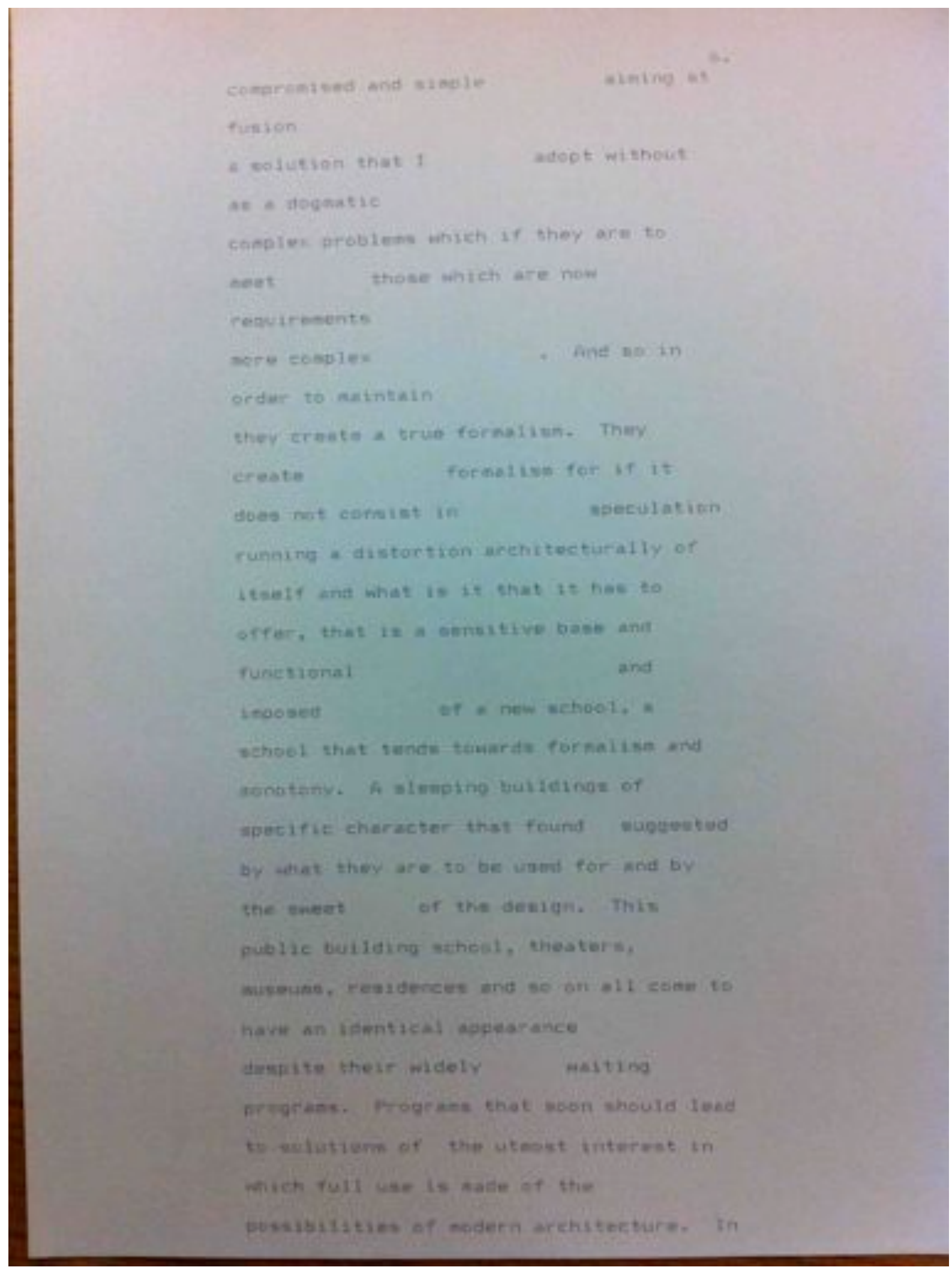




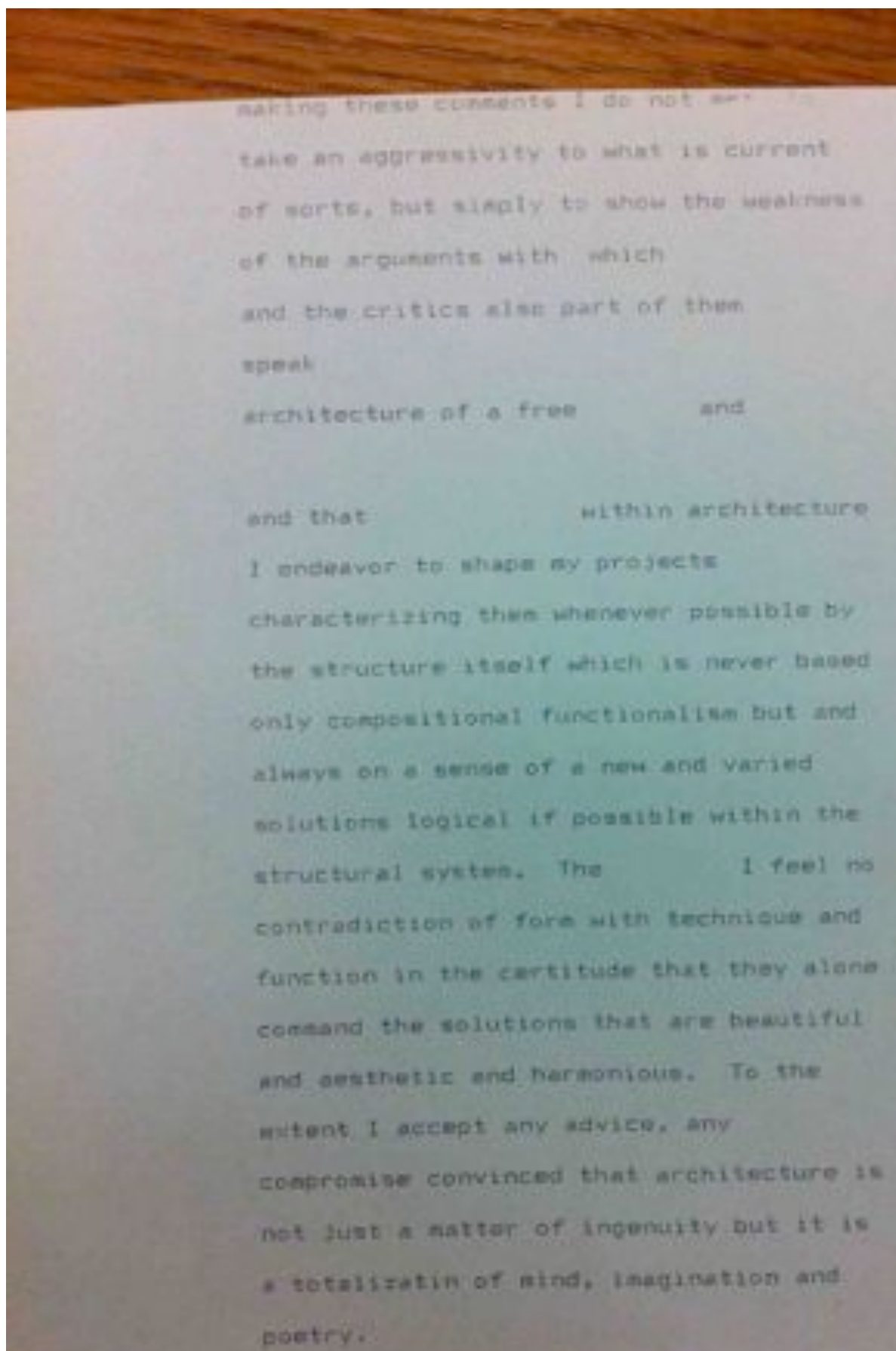




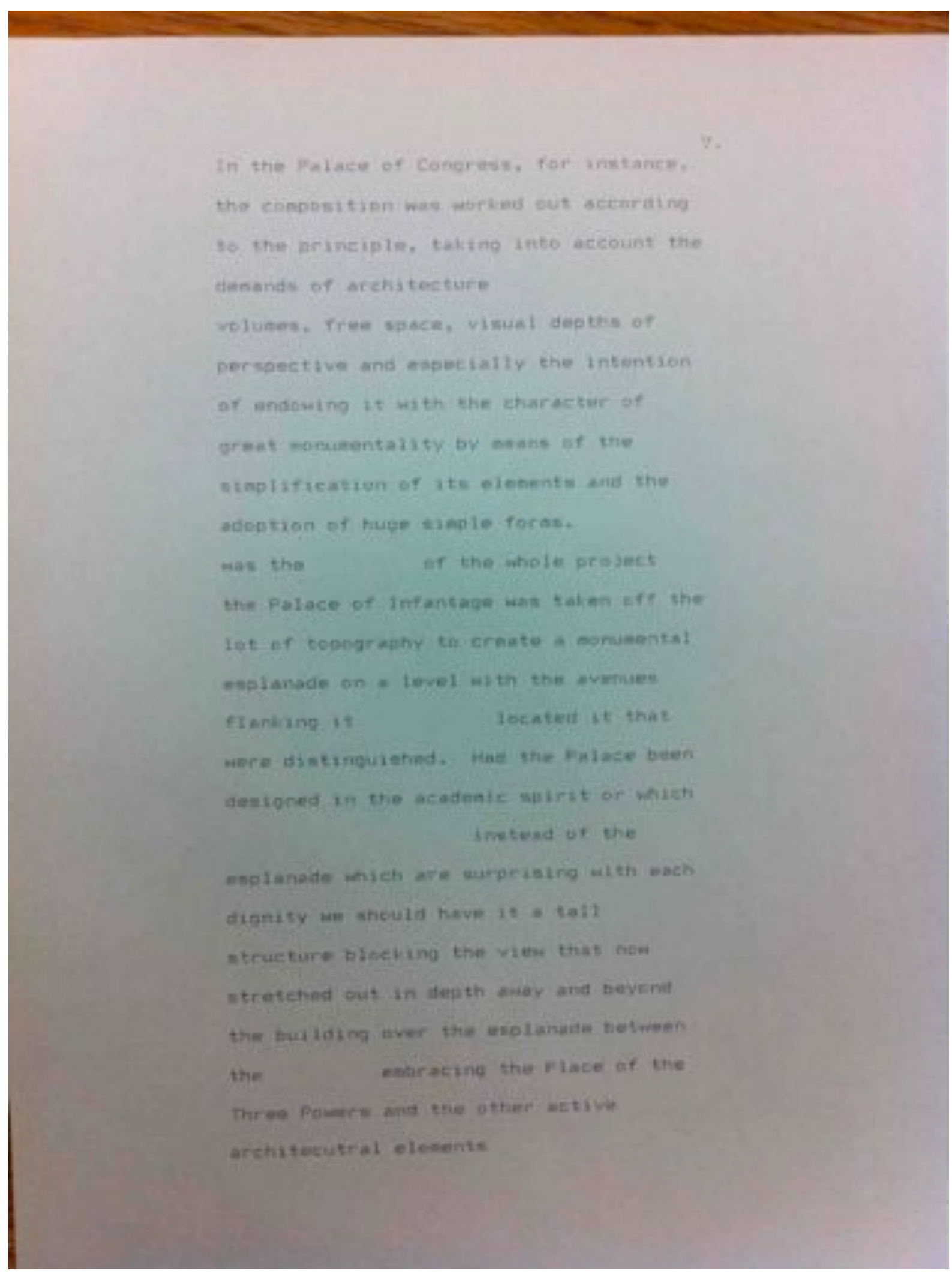


that warknd to compsein it then

oractiraliy and does making the overall

perepective nore

then in the

Threse Power s of the

Justice

and

1 have to stick to by

speculatisn to the form of the supportw

of celumns of

1 did not wunt to adoot the usual

sectrone

which

mould have theen stingle and cheaper but

wousht other forns that they might heve

run counter to raceive functibnalist

precepts would give the buildithe

character.

and creating an appmaranee of en

attochaent. I thought they were merely

resting on the ground.

With the randa tapering to a point.

Fron that greas with new

When he stands in the middis of the place

If the Three Fomers surrounding him es on

both sides but in the front as it were

br spain taking and sequirting neid and

different espects as

and it is pledsing me to fent

hemmonr modest that 


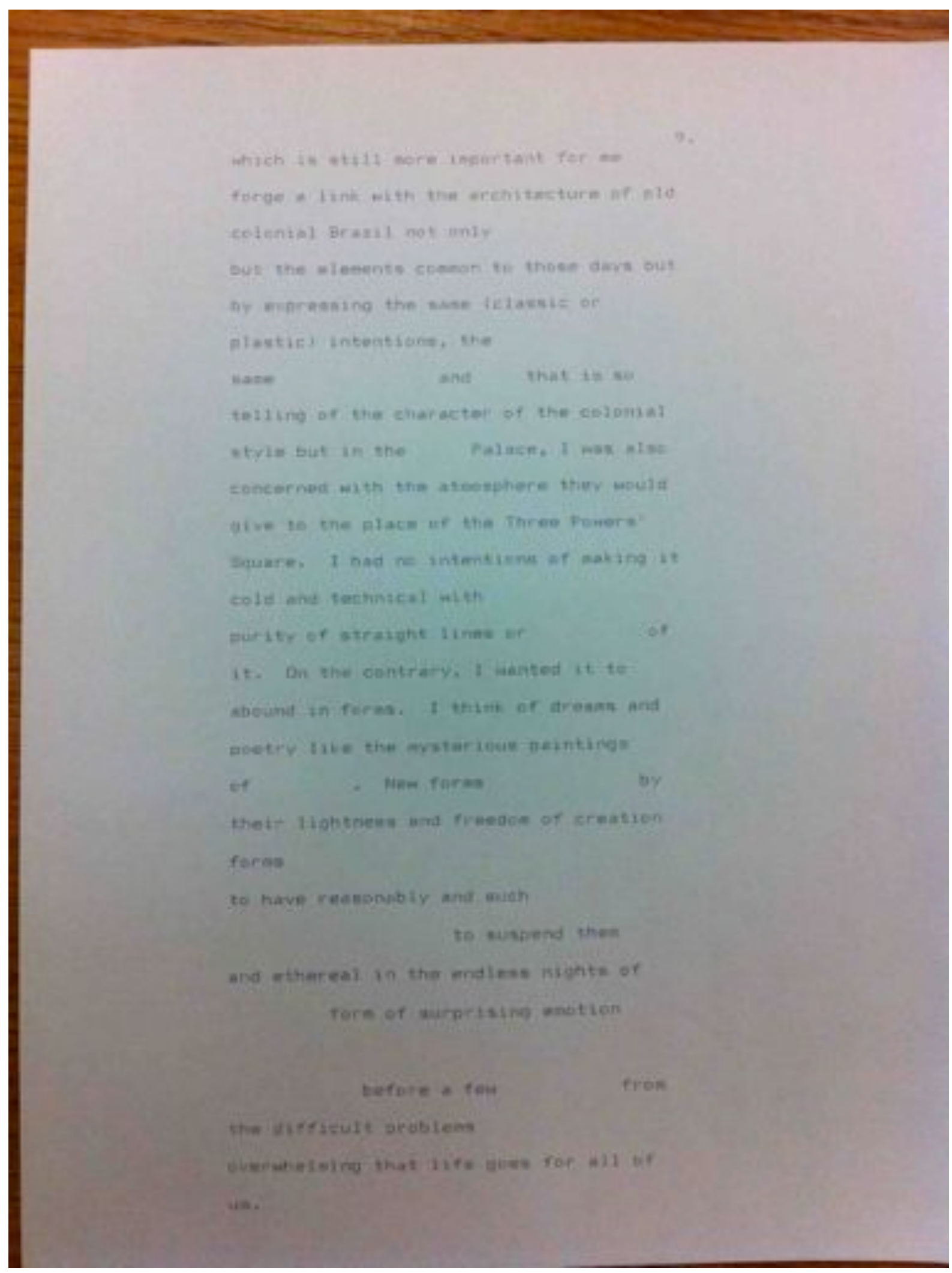




\section{AFFONSO EDUARDO REIDY}

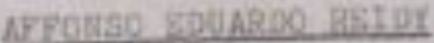

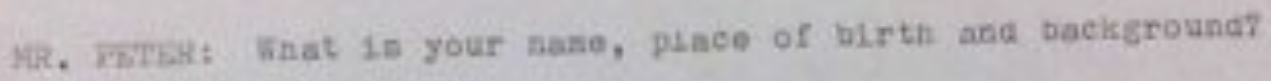

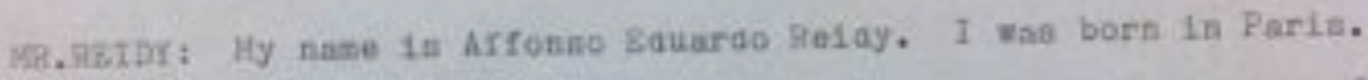
Ky fateer was Bagliden and an engtaear. Ky mother wae Braztlian of Italian porents. All of my schooling wan done in Brazil where I otuasea at the Becota llacloaal de Betan Arten from whioh I rocelved fy degrea in arohitecture.

Mr. Parzk: What in your definition of an archltect?

97. Retort hin architect 1 a a porbon who createa an appropriate conoition for life and a heofthy and plessant ntepspaere for sankint. He 10 a poraos who has to have, obviously, a great potental. for artiatic creativity and have a good underasanding of nocial lesued to be able to attend to trio soet injortant neads of 11 fe.

KR. Parkes finen du you becond an arcnitect?

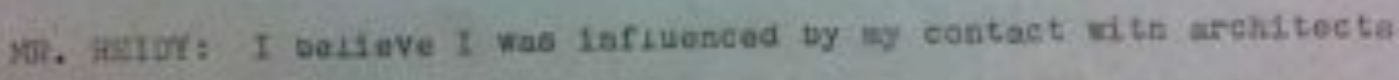
nnd aybe that care se s taste for the profecaton, an aantration for arcnitocture, al cabaip I was very youns at the time.

M. Firisf the care you the beat advice about areat tecture and what van that arvice?

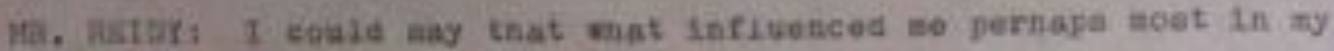


approacs as an architect van priasily the written work of

Le Corbualer. Finen I flret found ogt about the work of Le corbuner I. was atill a atudent at the Kantolpal Jenool of Belas Artea. I was atuaying in an extremely acadenle atmonphere wnted was very Influeneed by the ayaten of equcation of the sebeol of belas Artes In Porle. Ky reading of the work of Le Corbunder was a type of fovelar tion that extreasy changed and infiuenced my ray of thinking. It provoiked in me a curlomty and a great intereet in a series of things whose exkstence I cane to knos for the first time and this graatly enangea the courae that 1 took in ay wany geara in thil profendiot.

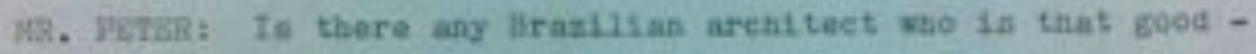
even a tragitional architects

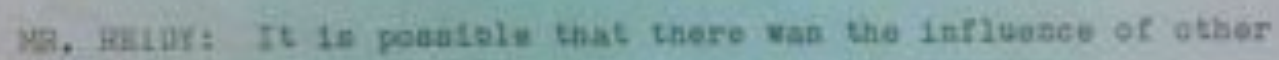
architecta becawse when the sodern urchltecture worasobt really

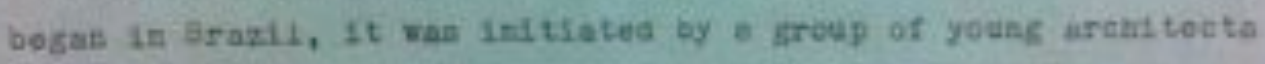
who, Hise ne, wore practicalyy just rinatig out sbout the exileteace of mels thinge. We forsed a group of alx of aeven colleagroes all.

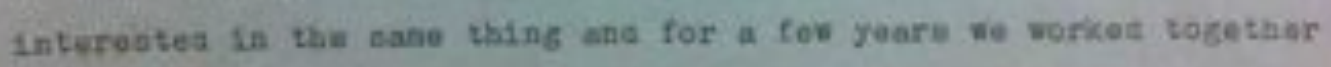
In wach a way that $I$ belleve wu infieanced secb othor in debater

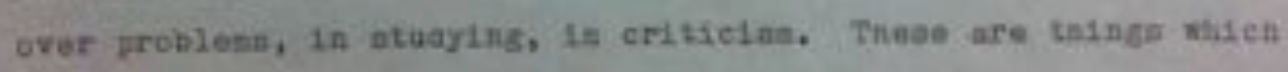

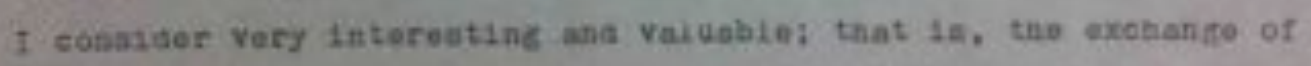
leas and the cooperatioe in the nesen of debatinc probseall. priscipolly st the age so vore at the Hwe. Ve wera basteanly atarstne, feediac oot the terrain that we would have to woric in in the futuro. Leter, sita naturity, each followed thair own yath, 
possibly asfrereat, is accordance wh their faclinatioss and personaistien.

XR. PSTBRs What are the greateet and soot inportint infleesced on your work?

KR. RaIDY: I belleve tiat, fet's say, three arenitects have gubatalitially influenced ny wark. Theee arehitecta ares Le Corbusier, Hila Van der Rohe and latter Orophus, esch esntributing an ulesent. For exnzpie, 1 conaldor Uropies to have Influenced my wark Breatiy ey way of asakening in ap an interest in attenulag to oocial problese which at that tise vare peglected. Malniy it brougat up tae frobleas of bounsag whtch, ustli the tine 1 started woriclag in the ares, was Yery aloorganlaod hare in Fragti. I bad inadeglate bacisround for this kine of xork becaude tre probles bud been reaueed te Iooking to

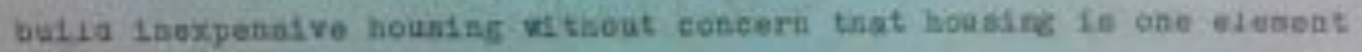
In a group nhioh ahosid be conptetud as pert of a narten of othor

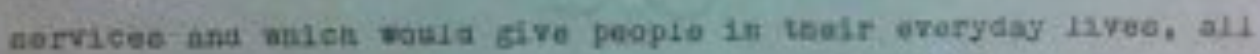

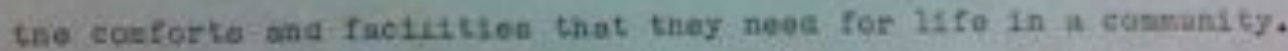
Gropiue save ae a great dead of inforation on tria topse.

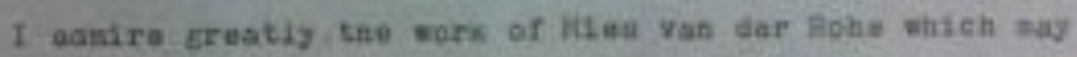
neen contradietory - So aanlre the work of Meu ran der Robe asd

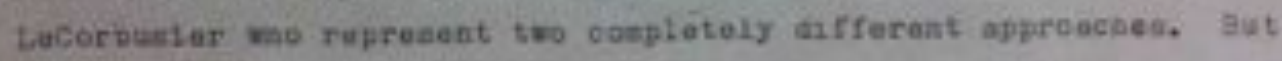

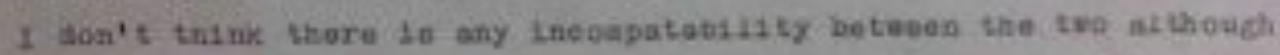

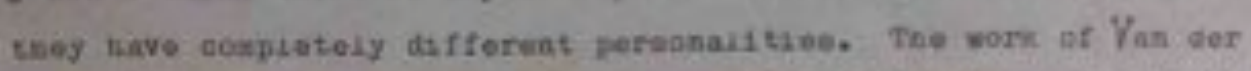

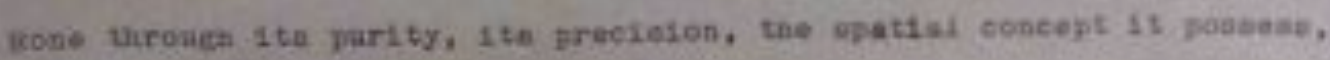
provokes aamiration in se. 
19. FaTnes is it posabbie that Le Corbunter, wio vorice in a kind of Mealterraneas otyie, ia nore aultable for Brazlis?

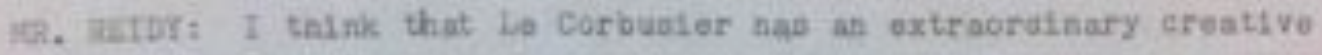
yoser. I canaleer le Corbuater to be a trae genilua, a creative apirit. I reneaber trest a guete of his that I noard which to cas abadiute truta. The quote 18 thas "1 as an Invention sackine."

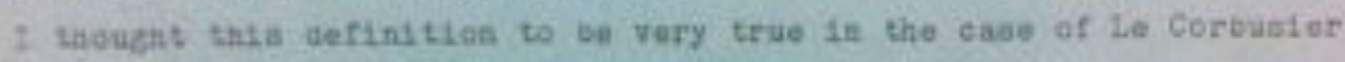

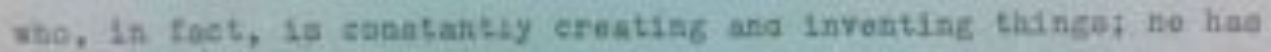
a tresendeus oreshive aphit alid an artietie senes which is traly notabie.

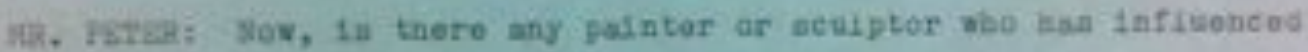
your woric or jues arehstoota? Any gaintor at erltse?

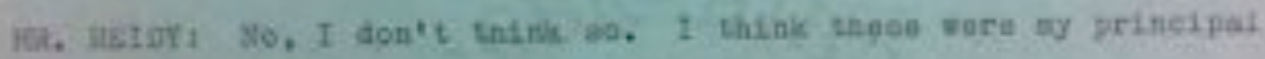
Infueascos.

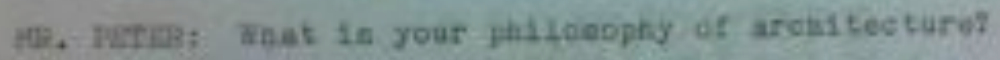

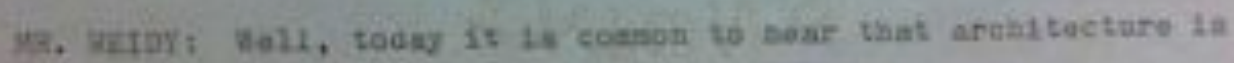

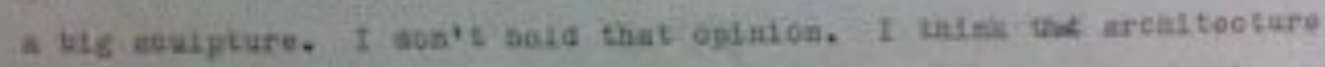

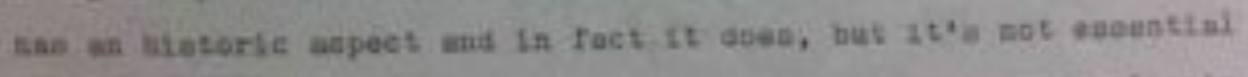
to arcastuctare. I bejteve nore that architecture in mes cloeely iluces to $=$ epactai ooncept than to the eethetc eleaest of a

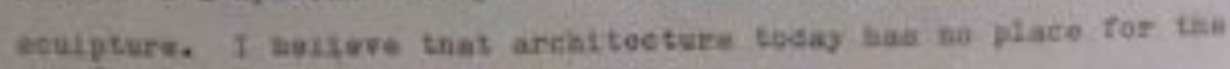

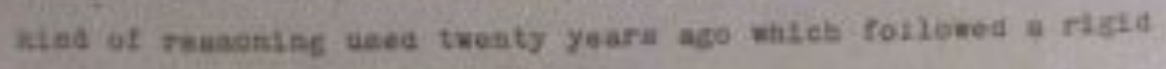
pritnespis of rationsiliz and foectsosality. But yow tan in wo vay 
forget that architecture hall 1 th utilitarlan atde, that 15, it exinta to nerve a purpose. Sov, it's not enough that it aerve this yurpose. It 18 necenasy that the function and the techabiogy, the actual way in whoh to realize tho architect's intentson, wways be concefved keopdng in mind the spacial probles because the internal and external apaces are the toole that the architect aearched for. Trey are the basic objectin that the araht teot looka for. Brideatly

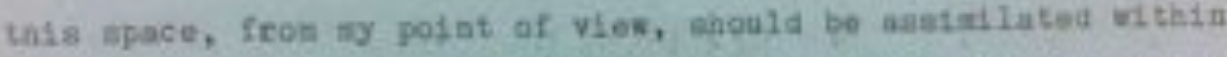
an arckitectural sumber. Tale is a maber which does not beconasily have to take the forn of eleaentary gooestry. It can be any fors that dsaciplisnel space. I don't think that arobitecture bas to be linttes to the froeack of epactul conceptlon. Le I bae 1t, the free plan, vatea to the banic elenunt of moders azchitecture, and

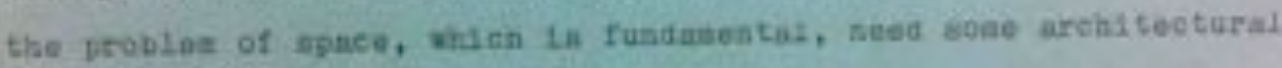
arocipline of space. Tae voluse all, let'g pay, call inte ploy the qualities of sculptwre to arenitecture. I sean, the wodptural aripoct ezoritee with the volume that ovo Ka and that contasne she strace wheh definas arehiteoture.

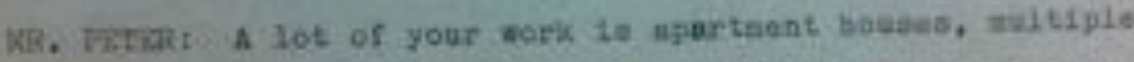

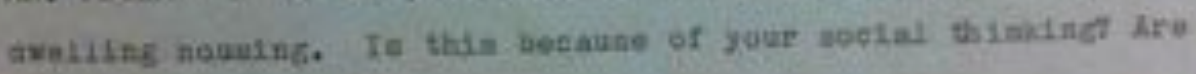
you attractea to tate?

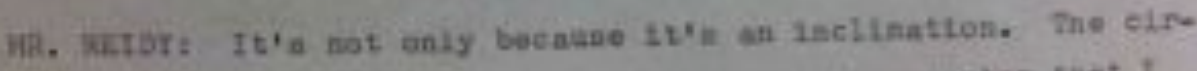
ounirtaneed broughs an to telli wector, bat $1 t$ ta a wetof that $t$ sirays loves. I truly conelaer 14 to be the most ingortant arae of archisecture. I conmider houating to bo the area that attracted

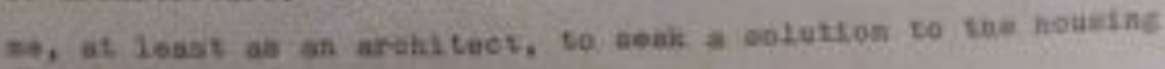


probles in the bout way posetbie. Precteely oncaude of a derted of cireasntances, I was lea to work in this sector which T've been, dolng for alsoet ten yeari now. I'd alwaya more convincad of the need for arcaltecta to becond apre involved in Ghib aros, to isprove the livise eondstsons primarliy of those of leseor finanolal means.

MR. PaTES: Mbat is wrong Fith arenitactura today?

MR. Fictor: What ia wrong with arohitecture todey Fell, a littie wh1 le ago I reforrod to sose inolinations shich I don't agree with. I woulas't ang they are wrong becalise ondy tise w111 tell wio'

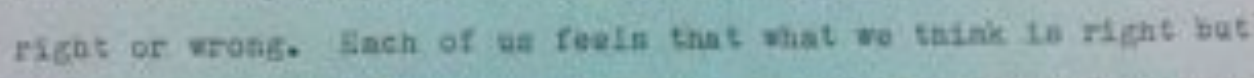
oftus thinge don't tarn out that woy. I weplds't nay taeykre wrong;

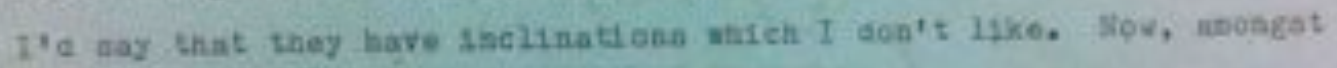

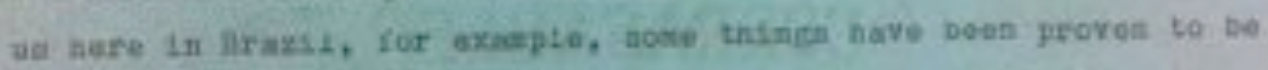

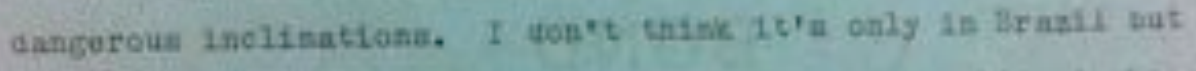
overyshere. In goherst, the atudoal, tha young arthitect nt thout expertenee, boocued enanorud of the paperflotelity of certals

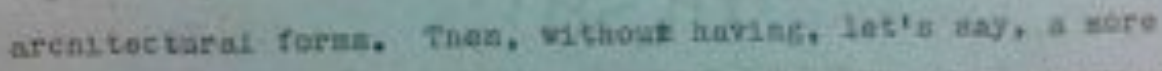
profound undoratinstne of the rogocma why theas forma arobe, they

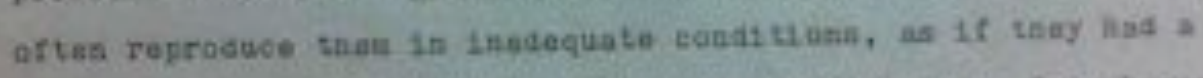
reusen for bolns an they bad when they ware sreated. Tsey becena

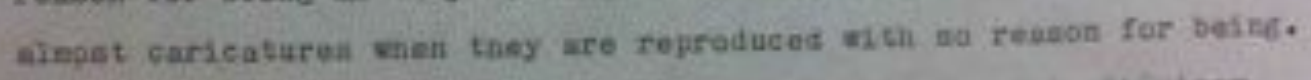

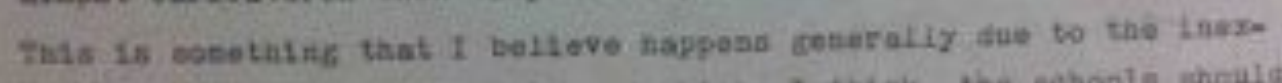

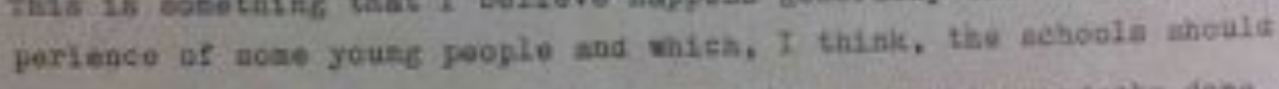
try to elorkly and cobost, Tala is primarily seen le projectin dohe for echool. The soot recent workis of fasous urheltsetu iafuenace the stuants in such a vwy that boy atart to ruproduse certasin 
forme. I an refarriag to archiftectare because $t$ would boy., for oxanple, that 540 de Janotro, all of Bruztl in fact, ubt a lot of wat ta dope under the Iabat of archstecture ta nothitis acre thas neso conserefal exploitstion. Really a Felatively amali nosber cond be polated ont ge having the true iglrit of artiatic croativity. Thore in a loag lino of aportwot bulldinge of alnat pure comercial Interebt and unfortanately thaee nake up the creatent nusber of bullelnge is agr city. The lack of an adequate master pian, pris-

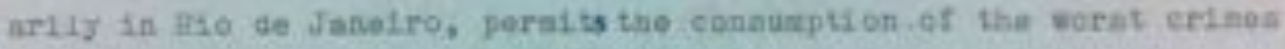
againat asthetice, ngaibet urbanization, the natural boasty, the Ianabeape of the elty malch unfortunately has been acrificed by the lack of a mater ptas.

15i. PKTs: Wast is your favprite conetractios asterialt

X2. Rerpy: Iin cas't iteay that ateel resnforced conprete, because of zts ability to be mowded, eevas to se to be the sateriul of

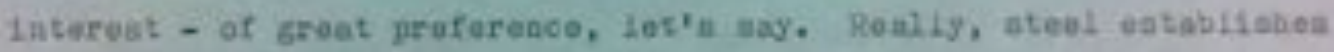
a certala rigldity in the actual creativity wheroun ateol relaforced conereto gives tae archited wuon moro froodos of croatsvity. dat anyewy, I trukik that, banicaliy, wat ope ahowld etrive to do to take advantoge of each anterlat, for 1 ta fanction, colar, texture and form. Whenover pooatbia teice adrantase of the matertal all it 10, trying to coneerve an much an posalbie ito orisinal atute.

1h. Friakt Obe of the problose that people say about arenitecture

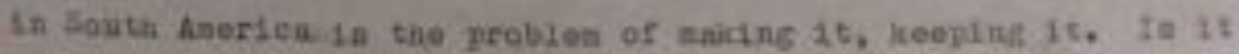
tram 


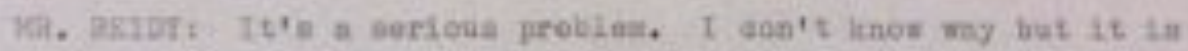

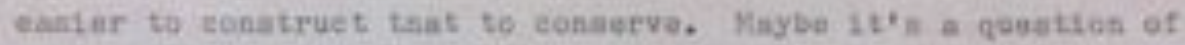

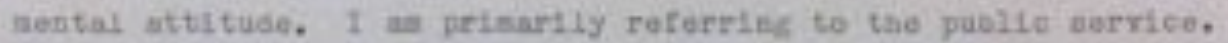
The probies In aore covere in the prublie worvice on governasht workin taan in private iniolatives. In poblic ourvice all tha jobe arn dobe throogs funda whech are ullocated on a bugget, be 15 fros the chty of wtate. And when a Job 1 ap aproved and axtended oredit for 1 to constructios, (amally parcelled out ovory gear), toe sredit if nqt very difficuit to get. But wen tee aandalatrotion In wollotit formogy for madrtenaneo of conbervation, taese funde are cut, taey are rebees in bueb a way that the fuide approved

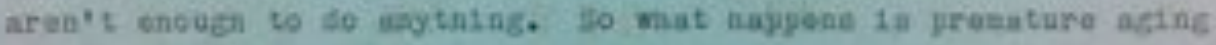

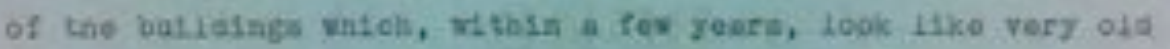
atrieturea that bedin to detariorate accape of the pashs that' a Elaaling that protoctn toe 1ren. Fox wasple, tan inos eorrodes, tpe wood zotif. In other sords, thars is a merien of dasacos that gecur uas to seb lack of wathtenanes.

VR. Fetsiti inat, in your opanson, sre the thrue greatabt roeks of nodarn archi tecture usi why?

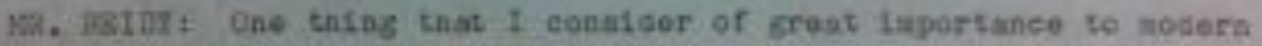
archisecture, not for ita volumb out for mat it prenests of axternal

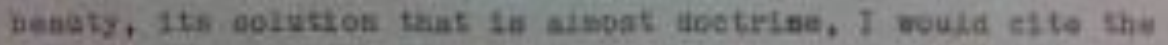
worke of Leforoiater. Hbey have purity of rors, sacpifueent ntructure ana fartsy of realisation.

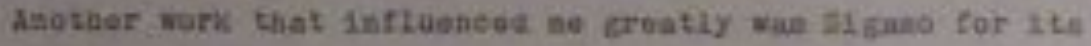

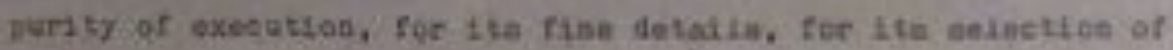


astertalin and finaliy, for extrwordinary porfection. There are ab many worke tast 1 equid ofte that I becona anoure.

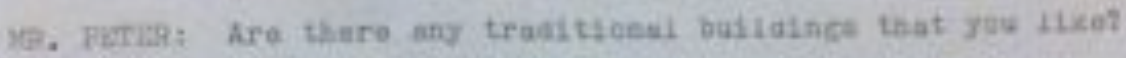

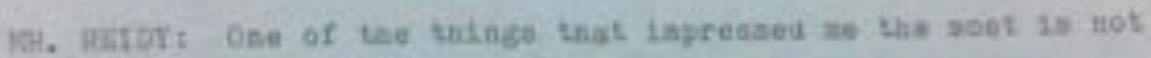
a butiales but the flana of Gad Karco. It's eoxnon to bear that the Flase of Bas Baree til deagliful. But two hilnga in Thasy extresuly Ingresed net the Ptaze of tho llareo und the Flaza da

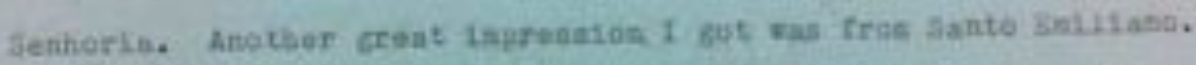

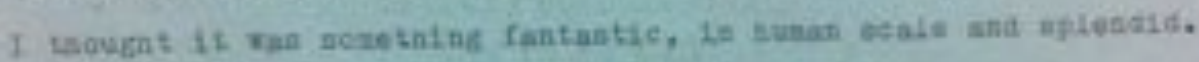

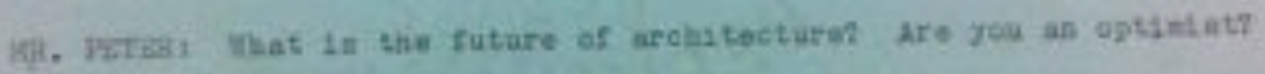

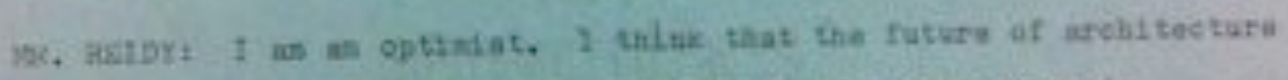

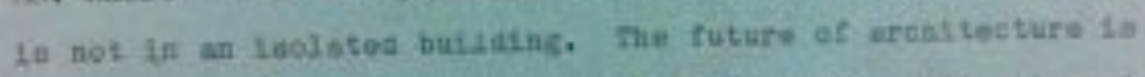

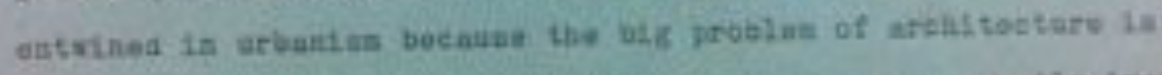

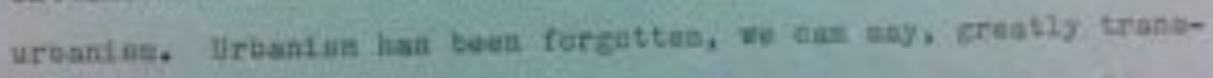
forded Into abiy a eelentifio eubject. Het 14 is naceesary to

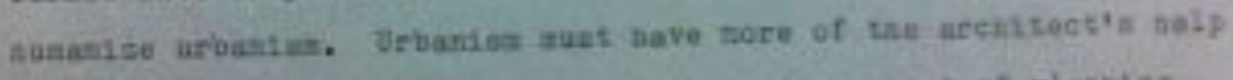

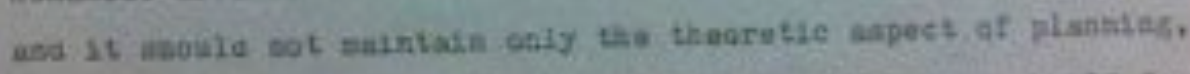

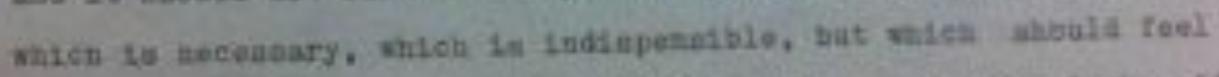

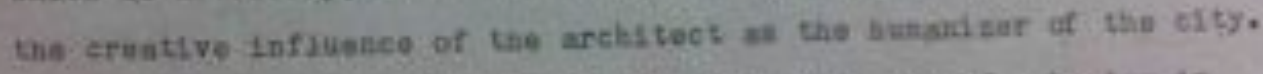

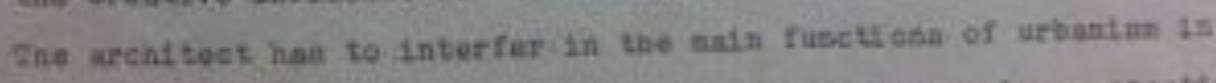

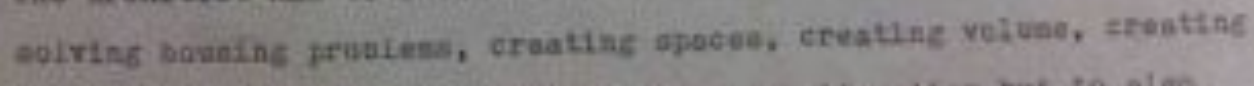

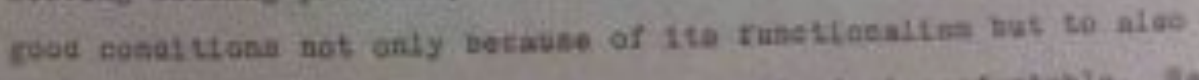

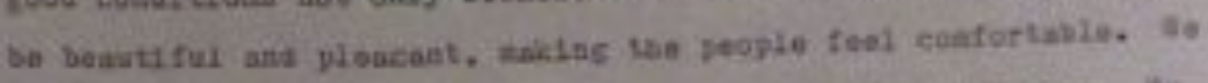

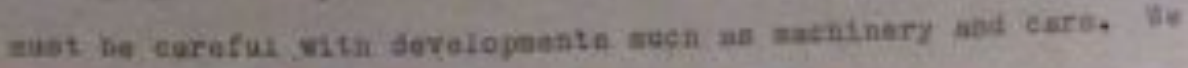


We are beconitis elavei to care. Inateas, the cltien whould be ande for the poople and the yrtbespol slearent ahould be the peopill, the podeatrien on the streeta. The sath codicera is for the cars. Fhe

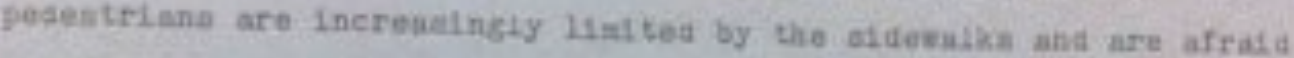
of bejing run over by the cors. It Is net icnown teat there faes youtthing aone theoe poet fow yeara to sive the podestrians, the people,

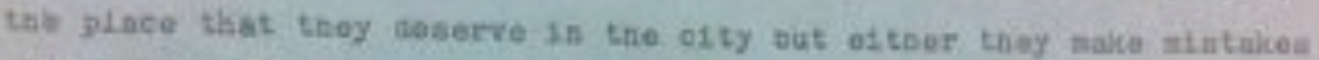
for lack of foreasist into tho peeds of the car elreulation or for excesa of 1aportance tagt they give to cara, eonfining the pedodrian.

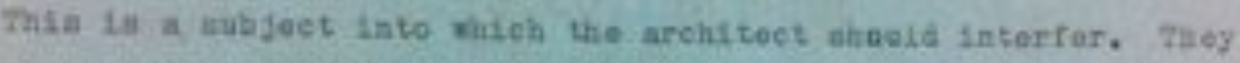
should cartall a littie bit the higkxay enginoerat tondoncy to dee Ealy blie care on the road anit niet the reat of the pletrre.

1F. PRTaR: Could you fopeat thas last yart in Girlsath

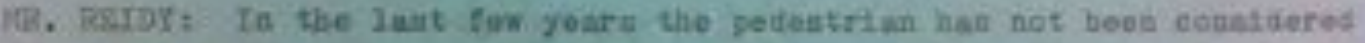
a part of the afty. Thay think ondy wbout tha autcinobize, alghwayo, expresswaye, oll of whel are very basutiful. but thoy are not the objectuves of a city. Toe exty til asce for ang to live is and an Ie tho prinotpul thing of the ettr. Cosattona sust be nade to fres ils of matosobilea and not be a elave te automobilas. 


\section{MARCELO ROBERTO}

\section{INGLÊS}

\section{TYTZSVID VITI MARCQLA POHERTO}

Qt What is your nane, birthplace and backgrausd?

At I prefer to answer in Portuguese, for I can express syself better in ay ova lahguage. My naso is Marcelo Roberto, and I an the first of a fanily of architects: in yoanger brochers are archicects, too. I was born in 1908; m brother Milton in 1914, and Maricio, the youngest, in 1921. I was born in the city of Bio de Janeiro, exactly vhere I an speoking to you but just a little farther down. As to backgroand, I come from a fanily of doctors and lavyers, I think that answers your queation.

Q: Was your grandfather, of fatber, or anybedy an architect?

A: No. My father was a doctor-an vere ay grandfacher and alpost all of ay uneles on both sides of the fand1y. They vere either doctors or lavgers. not a aingle architect. I'n the first one in the fandly.

Q1 What about school?

At My brothers and I attended the School of Architecture here in the city of Rio te Janeiro. All of our formal studies vere here in Rio. Any trips $\mathrm{I}$ sade later vere as an architect, never with the inteation of further atodies. I did, of course, want to take advantage of such travel to gather nev knowledge, seeing and studying the vork of others, but never In fornal courses.

Q: You might talk a little about vorking with your brothers and that you all designed, and so forth.

At I begah working whes I case back froe Europe in 1990 after spending twa years in France, but traveling and getting to know the country rather than foraally working with any fasous architect. Then Milton, wy second brother, ease to work with ne and innediately ve becaos a very close teas. Years later, ay lether Muricto-the last of the Roberto afchitects-foined our firm. That was when ve started to siga our voriss net Roberto." Today, unfortunately, there are no langer three of us: just two, because ay brother Miltch-the one in the afddle-died in 1953. Mauricio and $I$ enderstand each ocher perfectly, asd the way we work is for one of us to start and the other continees so that there is never a 
break in the continuity. Happily, our understanding of each other is even greater since our brother Mitco died. Our vork coatinues to progress, and ve are increasingly close.

Q: Hov...ve'll naybe get to that later... but later I vant to ask you obout how you feel about group practices for individual vork. When we talk sbeut phllosophy - you knov. 1ike Gropias feels that the architect should be a teas... Yos after all work with your brother. Do you work like a teas, do you belleve in a tean philosophy?

A: Tes and no. My case, now with ay brother and until a fev yesrs ago with both brothers, is a real exceptice. We had a very special understanding. Is general, I fon't thisk that great works can cone fros joint efforts. They can be produced by a teas, but I believe that inherent creativity depends prinarily on the individual. Today, as in the past, in our firm either $\mathrm{my}$ brother or I will start on woeshing and then the other nay take over as though it wire just on porson because of our very special understanding, the product of many years of shared existence and, most inportantly, the very close ties ve have. Usually, hovever, I \&on't think that materpieces can be a joint mbertaking.

Q: Weederful. What is your defiai- -1 can follow a litcleWhat is your definition of an arebitect?

A: 1 believe that an architect is firat of all an artiat, a great artist. Secondly, a perace wo kmows how to handle techniques and materlals; and finaliy, an individual with a great love for makidnd, for all hunan befogh in general. That's what an arehitect is, in my opteion.

Q! How did you hapien to become an architect? Why architect instead of enaineer or......

A: Mine is a rather interesting case. Even vhen I vos very asil, I $14 \mathrm{ked}$ to drax. My mother hat a collection of an Engliah masaine called The Stadio," and when I was a child I liked to leat through then. One of ay pastines was to copy thon turn-of-the-century Roglinh cottages, and so everybody saidt Tarcelo, whon you grow $=$ p you're poing to sake bounes." Later on I learned that a nan who akkes houses is called an arehitect. So at an early age I vanted to be a man who designed houses. That's the explanation.

Q1 Wha gave gos the best architectural advice? And this could be your father, of it could be another architect, or it could be a book... 
3

At I don't think anyone gave ne any specific advice of that nature. Or naybe they gave ne too moch advice. At my rate. I don"t recall any that was all that important.

Q: What are the nost isportant influences in your work? This could be sither the work of other sen, or the nature of the saterial, of the region, or any influesces that are at work. Why does your work look different froe acebody else's workm-wy is it differeat from Mieneyer's or Frank Lloyd Wright's ........

A: I belleve that the most important fnfleence on my vork vas our llazilian sun. The importance of the sun, the heat it generates, because ve have to protect ourbelves fros the sun in car country, in our city. And then when I vas younger, the books by le Corbusier-not his vorks, but the books he vrote. I think those vere the ast. inportant influences that I felt.

Q: Any other books that influenced you beaides Corbusier?

A: In ay early youth, I think Corbuaier was the oely inportant oae. The others, even Wright, evee Mies hinself, case later. And then I was cospletely carried away, as I said, not by le Corbesier's aystell, but by hila slogans, his writing, the thrust I-found in his books.

Q: What is your architectural phileaophy? What is your thinking about architecture?

A: I vouldn"t call it a philowaphy, but I believe that our alsaica-the architect's aission-is ajecifically to organdse apace for the developant of husah eventa: in other vords, any evest that is atroes. ative and ieportast. I den't. thitik that architecture is aerely a formal gase. It is primarily a preparatios, a definition and a lisitation of apace for the play of humen behavior through its nost important. reactions.

Q1 Now, in there things vrong.... what do you think in wroes vith architecture today? or the stodeots of vboever...

A] I think that wat is acervhat wrang in today"s architecture in encessive inventiveness. Invention, in the Greek sense of the vord, neaat the costant improvenent of a procesa or a technique, but in the architecture of our tises, Inventice is fuat that; inventice. The arehitest feels constantly pressured to create woething new, soeshias differeat, and 
that usinterrapted series of changes detracts froe the quality ad the importance of the vork. I think the fault 1fes, not with the architect. but with the agitation of the bodern vorld that is always asking for sonethirg different, denanding change; and the architect sirply natisfies that exagserated insistence. It $\operatorname{san}^{\prime} t$ up to the architect to change things. As long an the varld is in soch a state of enrest and needs constant invention, the architect has to oblige.

Q: What about... one of the things that they alvays say about South American architects...I soticed that in Brasilia.... is the probles of mintenance. the quality of the vork, of the constructioe. Is this a difficulty for an architect working in South Anerica?

A: Yes, it is * * It's very difficult.

Qi But wy...is it traditional in Mediterrasean architectere evea is Burope that there's not a loc of boney set aside for maintensnce?

At Yes, and I'11 go back to speaking Portugeese. Maintenance in a probles here in Brazil doe to a nubber of sdverse factors, and particularly because there is a lack of production to be naintained. He creake noesething and then we Arop it and to it over rather than preserve the older efforts. South Anericass In Goneral-asd Brazilians in particular-don't like antiques, fon't care for tradition. They'd rather let noething fall sport and then bulld another one. And naybe that's the right appronch, dan't you thisk?

Q: Yes, that's the ansver. Do you have a favorite bullaing naterial? Do you bave a faverite? Or do you-mileb do you use nost, because it's available? Coscrete of sunething like that?

Ai of courne. Here in Branil we use concrete, becasese it's ensier. But that

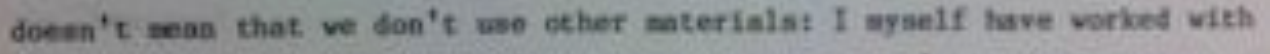
vood, atose, steel-there $t_{\text {nn' }} \mathrm{t} t$ any material that $\operatorname{can}^{\prime} \mathrm{t}$ be used.

Qr Does the sacerial that gon have arailable, Itke concrete, influence the way yos do desigat If you had steel vould you do it differentiy?

At Nì, I don't think so. In a way, res, Onty the appearance vould change. because the rest to a queation of.... We vork with wood, of we work with stnee, and wat ve tern out is not very different fron what ve to with

- Dederscered worte were mid in Knalinh 
concrete or steel. The spirit of the vork retains the saso. So I don't thite the choice of naterial plays an inportast part.

Q: What technical developaent proaises to ake the greatest change in the way buildings are bullt and designed? I sean, is atr conditicaing an inportant factor, or the autceobile....the plana.... is this a different kind of plan than the plan that vould have been aade thirty, fifty years ago? Is there sone new influesce?

A: No. I don't think technical factors are as iaportant as the spirit of the tises. I believe that is precisely the asos isportast the spirit prevailing over the particular point in time. I'm one of those whe believe in, aed like to refer to, the sedieval period. In the middle ages, the architecture of pointed archen and fiying battresses predated the era wen the advantages of eupolas, ogdves and all that sort of thing became spparent. The Gothic arch and the flying butcress vere needed to express the spirit of the tines, so they were created. Sovalays the aane is true. If we med a certais type of material of technology to express ourselves, we create theal. Hut it doesa't wark the other vsy roubd: no. techical innoratios of inveation is going to elange the spirit of the architecture or the urban developecit of the tises. On the contrary, I believe that the epirit of the tien, reyairiag a particular type of architecture or of city planeling to express itself, calls for the discovery or developeent of certain techniques of inventions. That's vhat I think.

Q1 Is there any social developant-the fact that ve have aore people, the explodifo population, or political organization or economic changes -does thia influence your natter of people, yos relaticoship with poople that is changing?

A: Withoot a doubt, and I believe that it is precisely that number of Feople, this deaperate iscrease in the birth rste, that vill coapel the we of wach oore intelligeat procedures than those sand at present. Right now we cosid ane-the vhole world could uetma serien of laventions ind processen that are very well known and could result is atghly intefestiag creationa. Enfertunate1y, certain tockors-backardneus, the calt of maneness, and the tike-keep those solutions from belng uned. I think that the very thite that is happening now wili becose increaninaly 
widespread, that is, the spiraling popelation and rising aubber of businesses will congel the use of those procedures. Hence vhat as appear to be bad at first blush-aight be beneficial for architects, because it will give us a series of opportunities that ve cannot attain at present, for ve're always faced vith that conservative attitude that rejects innorations, that insista on following the aase old vays. The emberant process now taking place is going to force a change in thase acthods. And that can be simply fabolous for ull architects if ve nanage to be in the vanguard of the movesent.

Q: Wonderful, vondertul, very good. Now this last one, this 11 eit any be kind of a tricky questios, and so feel free to not to pick three, you know ve talked sbout this yesterday but vorks that you like, fost nose works that you $11 \mathrm{ke}$.

A: I can't pick three. I could nane 30, of 40; but I cas't narrov it down to three.

Qt Are there any traditional works that have isfleseced your work? Are there asy great vorka of the past that have influenced your thinking about eity planning of about how butldings ahould be built?

A: Of course there are. A wole series of works fron the pant until now influtece owr vork, both in city plannisg and in architecture, and it is quite posaible that great worka of the past can iapreas us and tench us sore than do those of cur own tines.

Q: Is there any vonderful early Erazilian influence? Is your vark related to eariy Brasilian....?

At In a vay, yes, In the serenity of Arazilian molutions and then apecifically in the careful way they protected Brazilians frce the heat. as vell as the ean in Braxil, which ill no joke. (Claintelligible...,it cowld be soeething like "Phia nase approach")) any be seen once again in the sost recest varks of Braziliain archstecture.

Q: What is the future of modern architecture? What should be 717 What ahould we think of for tha future? Are you an optimist about it, do jou think ve should work eloser tegerher, or how-what's the futare...t?

A: I believe that arehitecture, at an organization, an a disciplise, and at the anse time as an escape, a frean and an art, vill becose increasingly vilespread and that ankind vil have an increasing need of thin 
organized and splendid thing. Then, too, there wil be ever increaning opportunities for arcbiecture as it is neen in a greater nusber of things and a greater number of places. That is what I think.

Q. Would you do me a favor? Give se that tast answer in Knglish also, Just try it in English. The.... if you like.... the future of architecture...

A; It is not cany to say it in Engliab-mich nore conplitcated, but 1 wil do my best; I wil try. I think that architecture, as organization, as discipline, as trainieg, and an art in everjutere. I think that toborrov people will seed such things more than they do today. Tonorrow's architecture will be wuch nore in evidence everybere than it is today and I belleve that tomorrow's architects wil have a great deal nore to do than they have today. Becasse toeorros architecture vill not be confined to houses and teaples, buildings and cieles. Everything vill be architecture, everything wil be beautiful and organized. That's all.

Qi It will be the spaces as vell as the building*. Do you think that if you were to give your?? a?? boy nom advice, what would he concentrate on, What would he stody? City planning, naybe? ((uninte11igible))

At. I don't believe in eity plathing AXD architecturet I never separate thea. I think it is architecturet city planning il simpler. Aut I think that it is the sase thing, they are completely (??) the sare thing. 


\section{PORTUGUÊS}

Pergunta: What is your nane, birthplace and beckground?

Resposta; Eu prefizo responder en portuguds, porqua me expresurel welhor na vinhe proprla lingus. Ru me chaso Marcele Roberto. sou o prineiro de wa faailita de arquifetos. Meus dofa tratos asts aoces tanbla sao arquitetos - eu nascl an 1908, aes trato Milton oa 1914, - Kauriefo, o mals soço, an 1921. Sasel na eldede do Rio de Janeiro, excesaente de onde estou lhe falando, spenas wa

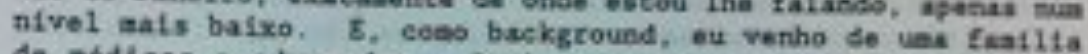
de abdicos e adrogados. Crelo que estou satistefto porqua o - senber perguntou.

Pergunca: Was your grandtather, or tather, or anybody as arelaftect?

Resposta: No, Meu paf ora mbdice, beu avo era mbdteo e mas thos, quase todos, tanto do lado materno quanto do lado paterno, eran ou ebdicos ou sdvogados; nentru arquitoto. I an the first in the farily.

Pergunta: What abeat school?

Resposta: Tanco eu comb seus frelos cursasos a Bscola de Arquitcetura aqui da cldade do 3.10 de Jameiro. Todo o mosas eurso foraal fol telto aquil no. Rlo de Janelro. Ao vlagens que eu $\mathrm{tiz}$, depols, ja tiz eeano arquilteeo a manca ese intencto de tazer novo curso, ans sia apreveitar a procurar melhorar eonheclaestos, vesde. eatuilahdo o que os outros flewran, as jasals eurros forasis.

Pergunta: You afghe Ealk a IItele about working with your brothers, and that you all.....

Resposta: Eu cosocol a trabalhse, quando cheguel da guropa, sa 1930, depola de ter passado dots anos as França, auls viafando e mals conhacendo do que srabathando formalaence coa algum arquiteto de noeasca (rr?) e seu-1mado, Mitton, o seu traso segundo, velo

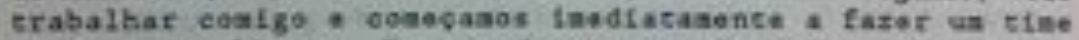
aut to, autto 11 gado. E, anes depols, seu Irato Maurtelo o o di. two dos arquitcecos, Roberto, tanbia valo para o sosso escrites-

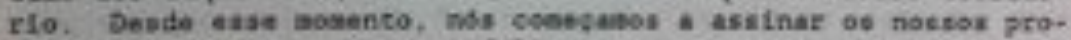

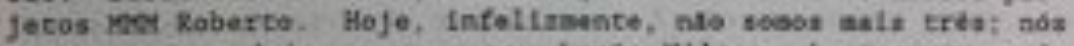
somos apenas dola, porque aeu traso Rilicen, fustamence o do

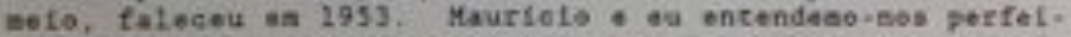

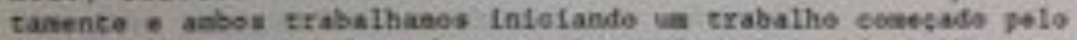
outro e egeaegulas lewd- lo cono se nito houvesse solucto st con-

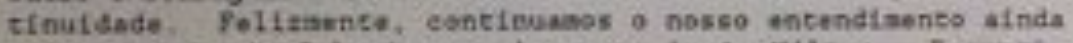
eator sepols do falecteenco do nosso Irato xiltod E coets- 
muanos a levar o nosso trabalho para a frente, e eada vez aata untdos.

Rergunta: How..... naybe we will get to that later... But later $\mathrm{I}$ want to ask you about bov you feel about group practices tor Individual work.... When ve talk about plillosophy....

Reposta: De wa certa foraa, sin, de una certa forma nalo. 0 aeu caso,

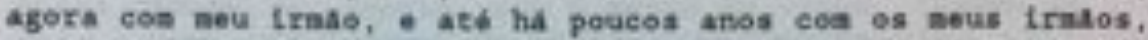
era ua caso codo especial. Noa tinhazos un entendinento sodo particular. Eu nio acredito que noralaente os crabalhos as conjunto possas sor efiados trabalhos de grande Importaneia.

- Podersa ser desecvolvidos ea eonjuneo, ass eu orelo que o trabathe propelo de eriaçso depende, principalnente, do un Individuo. Agora, cono atb hoje, no nosso eserfedrlo, tanto o nou Iraso eoeo eu nós começanos un trabsitho, depols o outro contimua coeo se nase fosse a mesal pessoa, por causs desze entendiaento todo particular que nos teaes a que tol adquirldo através de aultos anos de un corvivio total *, ainda por cina, atravis de 11 gaçeles todas espectals. Mas, normalaente, eu ado acredito an obras priase erfadas por eonjunto.

Pergunca: I can follow 14ttle.... ...... that is your definition of an architect...

Resposta: Eu erolo que o arquiteto, primefro que tudo, of uartista, ua grande artista. Sngundo, que 6 usa pessoa que sabe asnipular técnicas 6 meterfafs e, por ultim, ua fndividuo que cea pela buanidade intelra, por codos os hosens ea geral, un grande anot. Este que para als ${ }^{\circ}$ argut teto.

Pergunta: How did you happen to becoas an architect? Why arehitect, inatead of englneerting. ......

Resposta: No sau caso, i un caso Interessante, Desde multo jovsa, dasde zufto pequeno, eu gostava do desenhar a alnha ade tinha uaa colecto de usa reviata Ieglesa, "The studio", e, cono fovea, coso erlança, eu gostava de folhear a Fevista. E wa dea ainhas distracoea era copfar aquelea "cotrages" Ingleses do coeego do seculo, " cea aquilio rodo mundo disla: "Marcelo, quando erescer, val ser un bonea de fazer casas". Depots ou soube que quen fatia casas chasava-se arquiteto. E, deade asito jovea, ou querta aer o Moeen qua desenta casas. E essa a explicacto.

Pergunea: Who gavn you the best architet..... advise? ..... And chis could be your father, or anocher architect, or .....

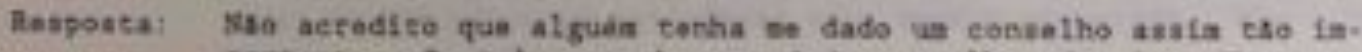
portante. Ou talvez teehaa me dado conselhos desais. Mas, on- 
tretanto, eu nto conafgo gardar nenhe censelho assin timportan* te.

Pergunta: What is the aost important influence in your vork? .....

Regposta: Eu aeredito que a alor fafludnela que teve na afnha obra fol o sol beasileiro. A inportanefa do sol, o calor erlado pelo nol. porque que nos devanos defender o sol aqui sa nosat terra, na nossa eldade. E, depola, sob o ponto de vista, quanda eu era ali joven, oa livros de Corvousier/Courvolsier ( 77$\}-$ ato entendo): nas as obras, as os Lvros de Corvousler (79). Estas 6 que ou acredito que foras as Influbncias anis Importantes que - eu tenha sentido.

Pergunta: Any other book that Influenced you, besides......?

Besposta: Na ainha primefra fuventude, es ereio que so Corvouster (77) que

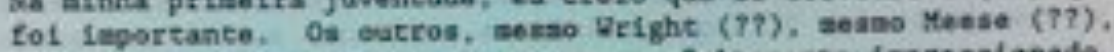
fol mala tarde. Depola, eu estava perfoltanente Impressionado, oono digo, nao organizapbea de Corvouster, ats es "slogans", as frases, aquele iepato eseríto nod 11 vros de Corvousier.

Rergunta: What is your arehitectural philosophy? What is your ehleiking about ....?

Resposta: Eu nao chanarla de filosofta, was eu acreditco que a nosaa als: sae, a nissas do arqutteto d preelsamence organlear espaco para - desenrolar de acoetectanotos huasnos. Qoer dizer, qualquer acontecfuento, mas coscando que seja forte, vivo a impottaste. Kao creio que a arquitetura seja apenas ua jogo foral. Nao ae parece: a arquitecura é príneipalmente fsso, a preparacto, a de: finiça * a ifnitaço do espaço para esse jogo do coaportamenteo bumapo atravis das suan rescoles, as mats inportantes.

Pergunta: Bow, aro theze things wrong with the .....t whet do you chink is wrong with ........?

Resposta: Ru abredito que o que ssed us pouco errado con a arquilcecura de boje seja o axcesso de Inveoça. A Invenglo, no sentido grego da palarra, era a belhorla doestante dua processo ou de in aods,

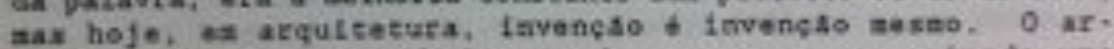
quiteto se sente na obrigapao de eacar seapre criando ua novidade, quer dizer, aAEd seapro tazendo ua colsa diforente, essa variacá Inieterrupta prefudiea a qualldade, a Imporedecia da obra. Eu creio que o culpado nao to arquitceco; t a agitacas do aundo soderso. จue peda seapre una colas diforante, quer

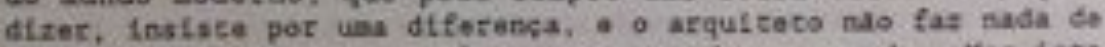
mals do que procurar antstazer esse anselo axagerado. Mas late 
noo dependeri do arquiteco aodiflear, quer dizar, anquanto o aundo for agttado, enquanto o aundo necasaltar de trvenços constantes, sla tas que formecer sasa fevengso.

Pergunta: What about... oce of the thinge that they always ay about south Naerfean architects, I notioed that in Bessilia.....

Responta: Yes, it fr. E multo difiell.

Pergunta: Is this traditional in anditerranesn architecture that there is not a lot of money sot aside for malntenence?

Besposta; Yes, eu falarta novanente en portugues. $\$$ aulto dificfl a parte de conservaço aqul ha nossa terra, porgue nda cenos ua porçto de fatores, fatorea adversos, s afnda por ofma, fuatuate isso. nós tebos una talta de producto de conservar. Nós defxabos, nos Eazesoa as eolsas a preterieos abandonat aquela colsa o fazaraos outra vez do que conservar-a cofsa antiga. O sul-aaerfoano ea geral, - o brasiletre en particular, aho gosta de cofsas antigas, sao gosta de tradiço, gle prefere delxar aquela colsa acabaz e fazer autra ver, no que talves ele estaja certo. nso it?

Pergunta: That is the answer, yes, Do you have a favored bullding atert. a1. do you have a favor? .......

Respoata: Claro, Bds aqui, no Brasil, usamos concrato, porque o eonereto i asia fAefl. Kas nAo quer dizer que procuraboa usar, porque eu eosao ja tenho trabalbado cos aadafra, jA techo trabalhado coa pedra, 14 tasho trabalhado con aco e nao tea nachua material que seja...., qualquer aacerial podo ner usado.

Pergunts: Tha aatertal that you have avallable, like concrete, Influence the vay you do deafgot.....t.

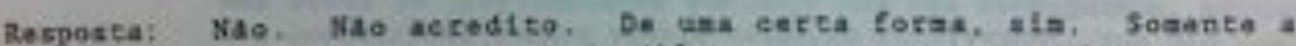

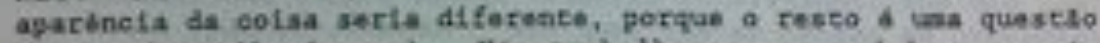
da .... (nlo diz de que). Nos erabalthasos noe endetra, ou bos trabalhanos con padra. O que nos taraaos nao te multe diferonte,

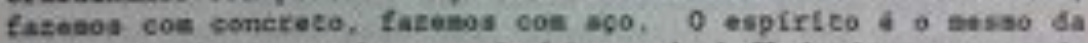
obra. Por taso au acho que slo ha grande Influbnela tha parte do macarial.

Pergunta: what technicat development proalssa to aske the grost.... t

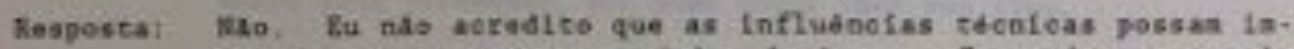
portar tanto quaneo o espirico da ipeea, Eu crelo que o ants isportante + Jubeamenee fsco. \$ o esplefte que praside a epoca 
Bo momento. Eu pertenco aqueles que scredicaa, aqueles que oles gostan de ef car seapro, na queatao medieval. quer dizer, na Idede Nédla a arquitetura das ogfvas, as arquiteturas des arcos botantes começaran antes deles conheceren as vantagena das clipulas, das ogivas, dessa colsa toda. O espirito do mosento exige, para se expressar, ogivas, arcos butantes, etc. Poz Laso, eles criaraa esses tipos. Agora, no mosento moderno, serA a mesaa colaA, Se nos, para nos exprosasrmoa, necessiterroos ta deterninado tipo de aaterial ou tecnologico, nos crlaremos essas colsas. Nao sord o contrario, ndo serd uma erlagso técntea, una Invencle que val aodiflear o eapirite da arquiteteura e do ur. banisao do momento. Pelo contrírio, eu acbo que justamente o - espititeo da época, becessitendo para se expressar ua tipo de ar. quitetura e un tipo de elty planning ( 777 -pouco elafo) val exi. gif a descoberta ou desenvolviaento de certas técnicas o de cercas fervençdes. I lsso o que eu penso.

Pergunta: Is there any ___ (TP) developaent, the fact that wo have aore people, exploding population, of politefeal ........

Resposta: Isso sez duvida Benhuaa, e ou acredite que fustasente essa quanefdade de gente, essa gente que nasce deseperadaskece val forẹaf que sejas eapregabos processos multo als inteligentes do que os que sao empregados atualnente. Nó poderiasos hofe, no mando inceiro, ucilizaraos una sirte de invencoses, ual abrie de processos que sto perfeitanente conbecidos a que poderlan resultcar ea erlaçlea profundaseste Interessances. Mas, Infelizaente, a .......... (nato ae entesdo), o atraso, a gesalce, todas ostas colass impeden que essas soluçea sejan eapregadas. Eu croto que Justamente con essa coisa que esta acontecendo, val acontecer dada vez and, quer $d i z e r$, nafor nüavro de pessoas zando $(7 t 7)$. necessitcando vao forçaz a utilizacso dessea processos. Por fsso, o que parece asl a prisefra vista, para nos arquiteros talvez seja curioso, porgue les vio sos dar una serte da oportunidades que hoje nob nato eonatguimos, porque nos encoscraaos seapre aquela colsa do eanservador, quo nas quer .......... (nato so entende). Ble quer que as colsas ate processea cono le esta acostuasdo. Rrsa colaa exuberante que esta se processando yai forear que esses processos sefas aodificados. Aeroditeo que laso para ads, arquitecos, se nos conseguitras estar na frente do novisento ad podera ser fabuloso.

Perguntaz Wonderful, vonderful, wery good. ......... aay be a kind of a … question, and so teal free to not to plek chree. We talked about this yesterday, but soae vorks that you like.

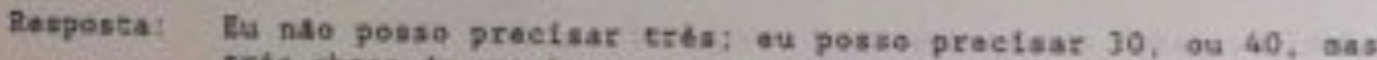
crba obraa de arguitecurs nto posso prectsar. 
Pergunta: Ara there any traditlonal work that have influebed your vork,....

Mesposta: Clars. Toda uan abrie de obras do passado ate hoje influenoin a mossa obra. tanco na parte de city planning eono na parte de arquitaturs o talwez as grasdes obras \&o passado nos fapressionea - noa peratical as liçoea aufto abtores do que as obras de prosente.

Pergunta: In there any wonderful early Brazilian fafleenee? Is your vork retated to arly Brazilian....?

Resposta: De certa form, sla. Kaquela erangotildade das solugdes saele.

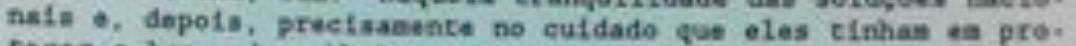
cegor o hoene brasilefro do calor a do sol brasileiro cabber. que nao 6 de beincadelra. ....... (Nto se eneende)... val apare * cer movamente he nows ditlak afquitetura do Bresil.

Pergunta: What is the future of moders arquitecture? that should be ….

Resposta: Eu acredit to que a arepilenturs, osoo organizaço, eoeo diselplitas

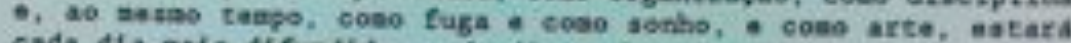
eada dia mais difundids, eada dia os howas sentirio mati nocen. aldade deasa colas organizada e bela. Logo, cada vez havera alor oportunidade para a arquitetura. eada vaz a arpuitesura estark en safor miacro de cofmas a maior nübero de lugarea. Inso \& o que va penss.

Forgunta: Would you do as a favors give ae that last anaver In Bngliah alao, just ery te in Bnglish.

Resposta: It is not easy to say it in Ëgllah, I say it wuch, wach soa. plicated, but I witi do ay besc, I witi try. I chink that as. chitecture, as organization, as disofpline, as drafn (7r?), as art, It everywhere. I think chat toeortor peopla vill need auch aore chose chiegs than today. Arehleccture toacros wi11 be wuch are in tvary place thas it is exday, and I think shat the arebitects of edoorrow will have auch sore ehinga to do that they have coday, but becasuse cosortow afehitecture with not be only bouse and tonplas, and bulldings, and eletes, Architee. eure, everyching will be areattecturs, everyehing vili be beastiful, wili be organtzed, will be archiececure. That is
all.

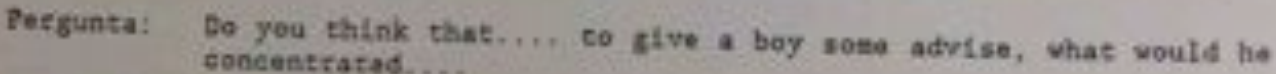


Iespoeta: I think thet eity plennieg. A I satd, I don't belleve in sity plannites and architecture. I naver separse thea. I think that it to architecture, we asy efey plenning. It is atapler. But 1 It ia architecture, we asy eicy planning. It ls alaples. bus ching.

$P$ 
PRECEDÊNCIAS E REFERÊNCIAS USA

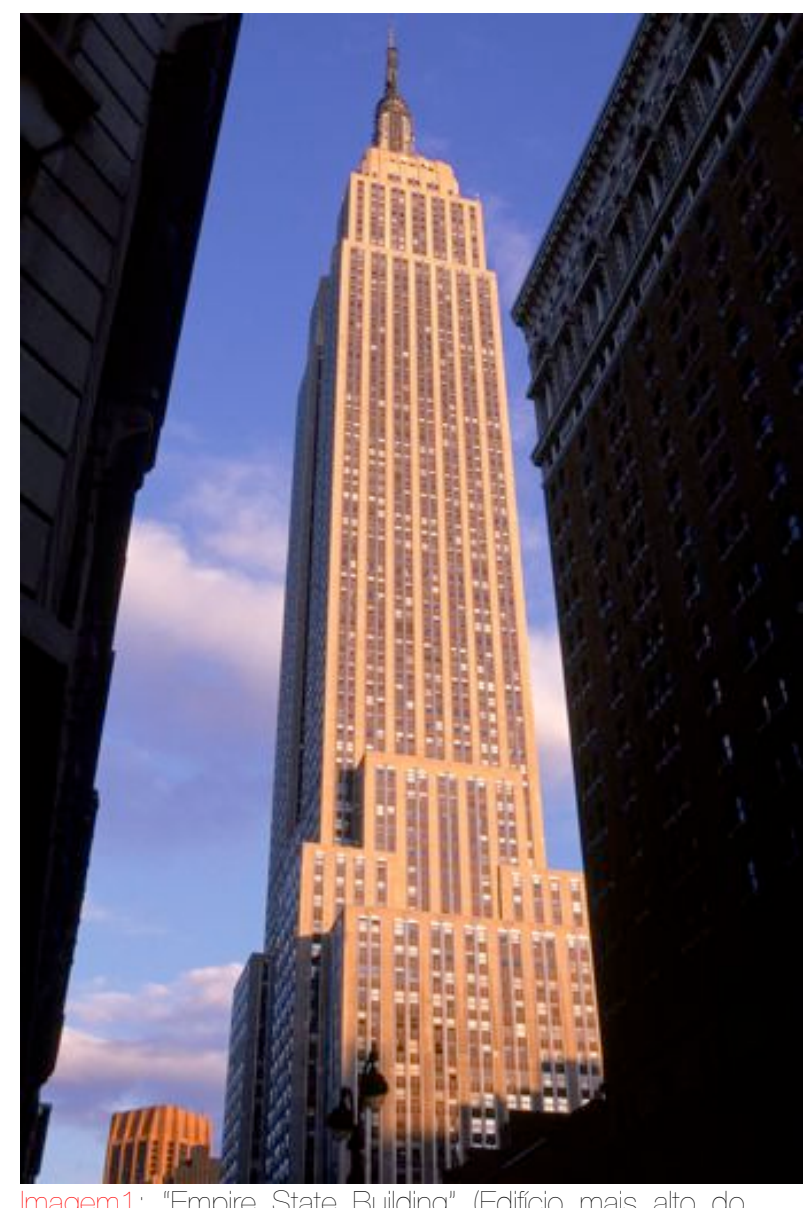

Imagem 1: "Emprre State Bullaing" (Edificio mais ato do
mundo até 1971). 1929-1931. New York, New York, USA. Arquitetura: William F. Lamb da firma de arquitetura Shreve, Lam e Harmon. Foto: Débora Lima.
QUADRO
COMPARATIVO

(100 IMAGENS)

\section{Antes...}

TROCAS, TRANSFERÊNCIAS E FATOS (100 IMAGENS)

1914: Rudolf Schindler emigra para os EUA e passa a colaborar com Frank Lloyd Wright.

1922: Semana de Arte Moderna em São Paulo.
OBRAS BRASILEIRAS

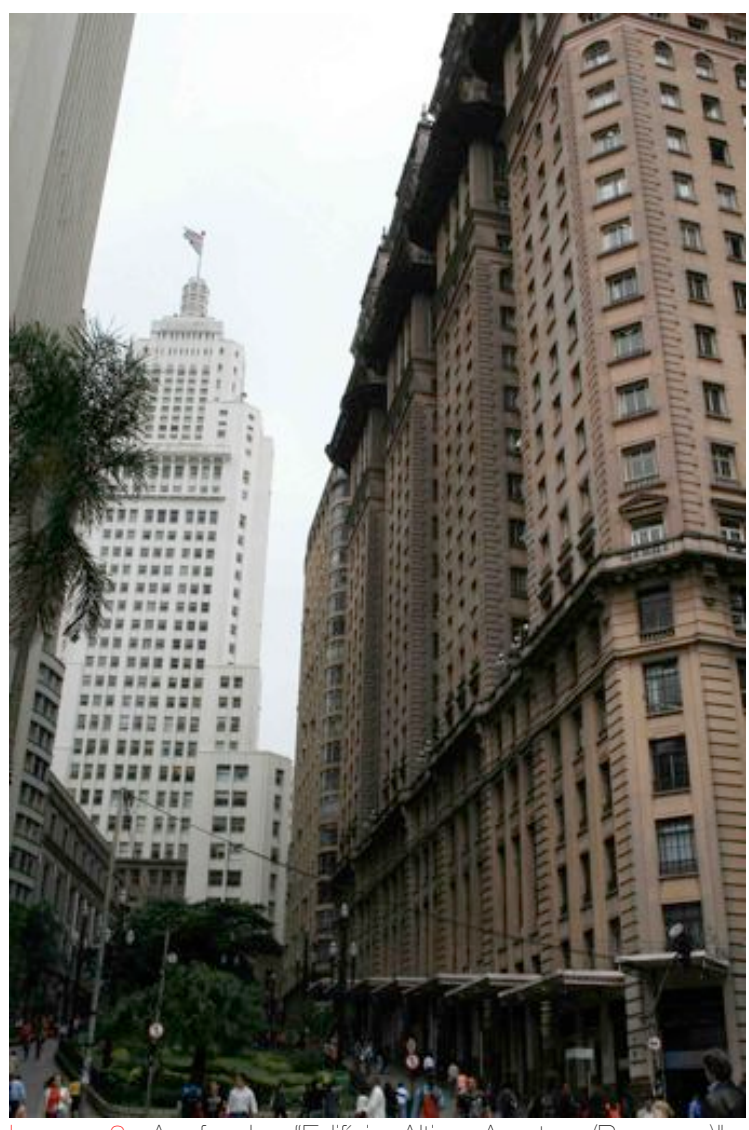

1939- 1947. Arquitetura: Plínio Botelho do Amaral. A direita: "Edifício Martinelli" (Primeiro arranha-céu de São Paulo). 1922-1929. Arquitetura: William Fillinger. São Paulo, São Paulo, Brasil. Foto: Débora Lima. 
PRECEDÊNCIA E REFERÊNCIAS USA

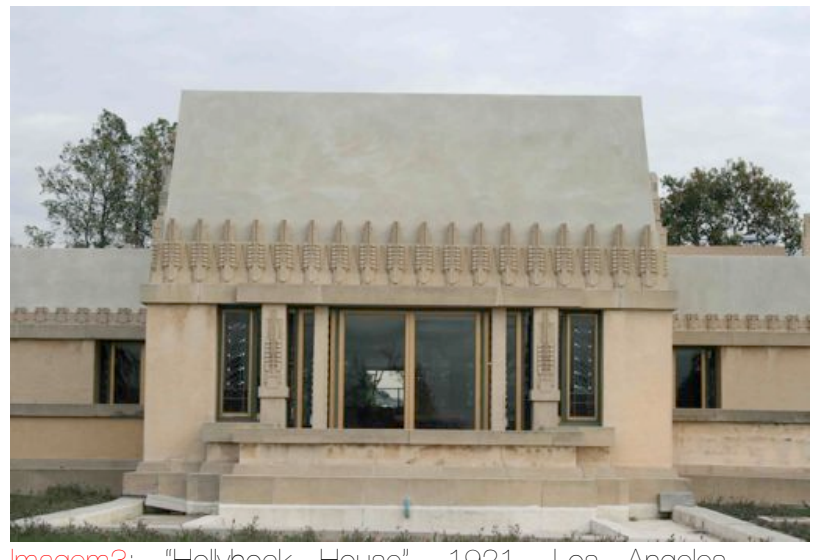

magem3: "Hollyhock House". 1921. Los Angeles, Calf́́rnia, USA.

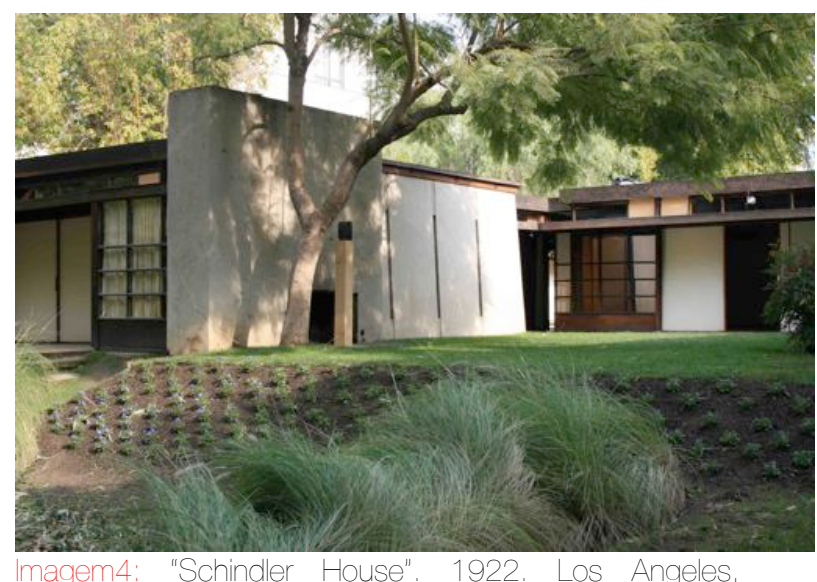

Califórnia, USA. Arquitetura: Rudolf Schindler. Foto: Débora Lima.

\section{2-1928}

TROCAS, TRANSFERÊNCIAS E FATOS

1923: Richard Neutra emigra para os EUA

1923: Gregori Warchavchik emigra para o Brasil ad findar seus estudos na Italia.

1923: Flavio de Carvalho retorna a Brasil após concluir seu curso de engenharia na Durhan University em New Castle, England

1926: Rino Levi retorna ao Brasil após estudar na Academia de Brera e Milão e na Escola Superior de Arquiteturea em Roma, e abre seu escritorio em São Paulo, em 1928

1928: Fundação do CAM, em La Sarraz Switzerland
OBRAS BRASILEIRAS

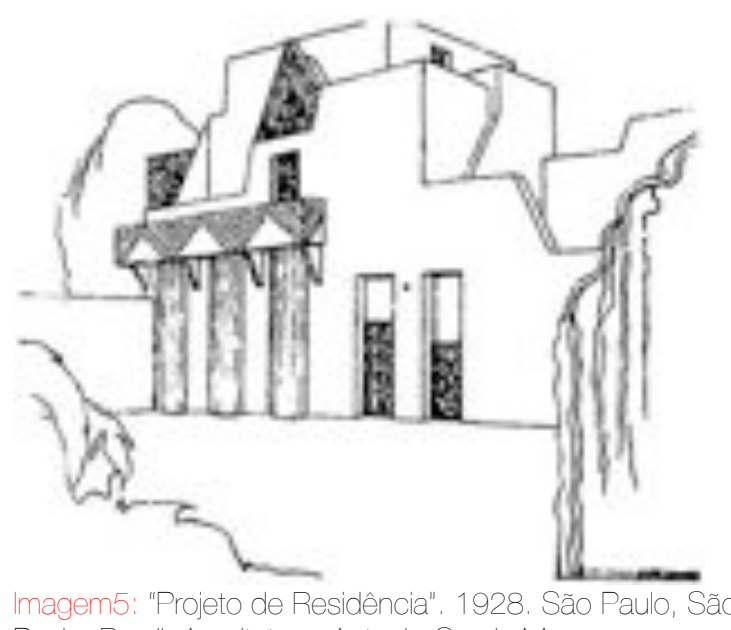
Paulo, Brasil. Arquitetura: Antonio Garcia Moya.
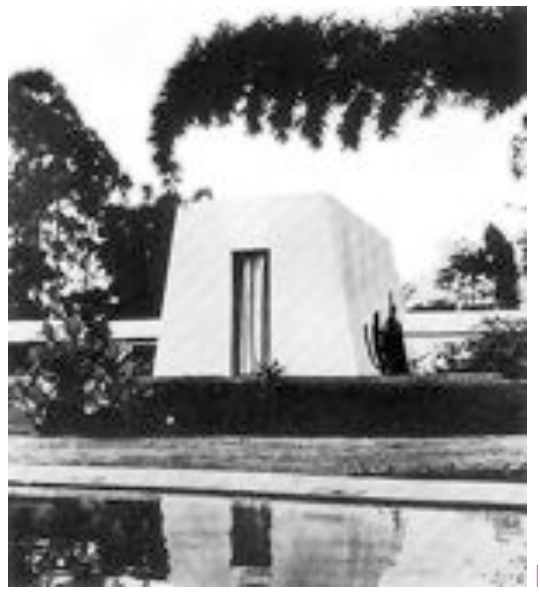

"Casa da Fazenda Capuava". 1929-1938 São Paulo, São Paulo, Brasil. Arquitetura: Flavio de Carvalho. 
PRECEDÊNCIAS E REFERÊNCIAS USA

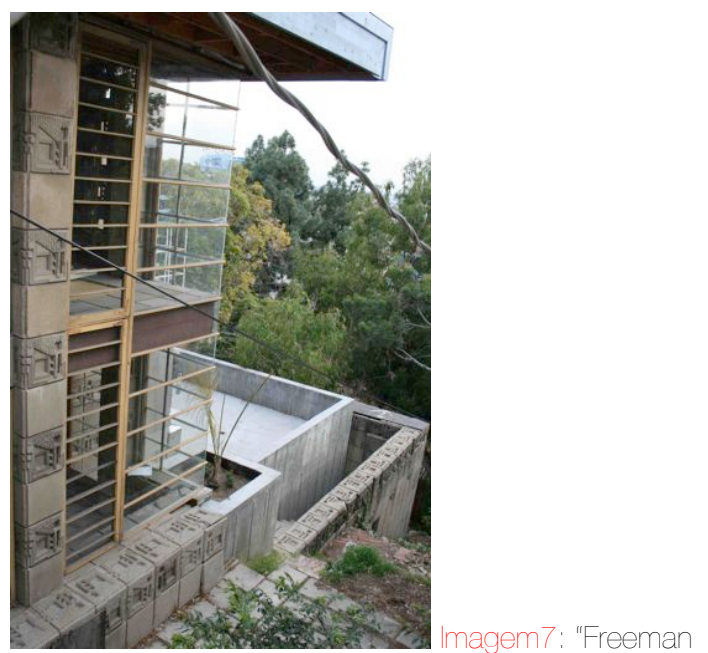

House" 1923. LS Angeles, Calíórnia USA Arquitetura: Frank Lloyd Wright. Foto: Débora Lima.

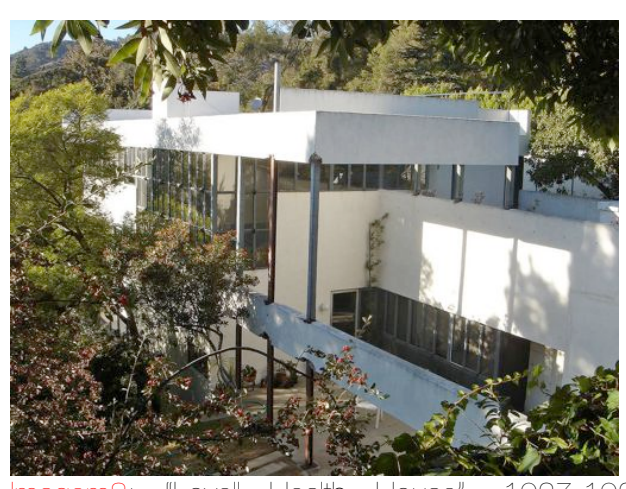
ura: Richard Neutra Foto: Débora Lima

\section{8-1930}

TROCAS, TRANSFERÊNCIAS E FATOS

1929: Le Corbusier visita o Brasil pela primeira vez

1930: N Congresso Pan-Americano de Arquitetos no Rio de Janeirc

1930: Inauguração da "Casa Modernista" em São Paulo

1930: Gregori Warchavchik é designado por Sigfried Giedion representante da América Latina no $2^{\circ} \mathrm{CIAM}$, que acontece em Bruxelas.

1930: Getulio Vargas assume a presidência do Brasil.
OBRAS BRASILEIRAS
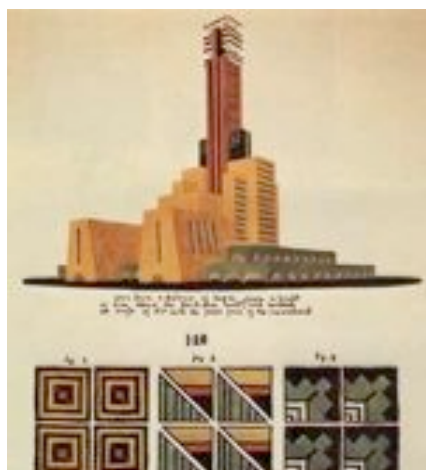

匀

. para o Farol do Colombo". 1929. São Paulo, São Paulo Brasil. Arquitetura: Flavio de Carvalho.

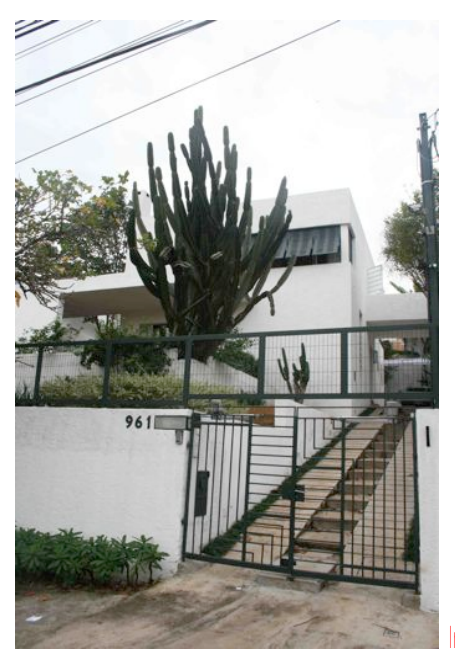

Modernista" 1930. São Paulo, São Paulo, Bract. Arquitetura: Gregory Warchavchik. Foto: Débora Lima. 
PRECEDÊNCIAS E REFERÊNCIAS USA

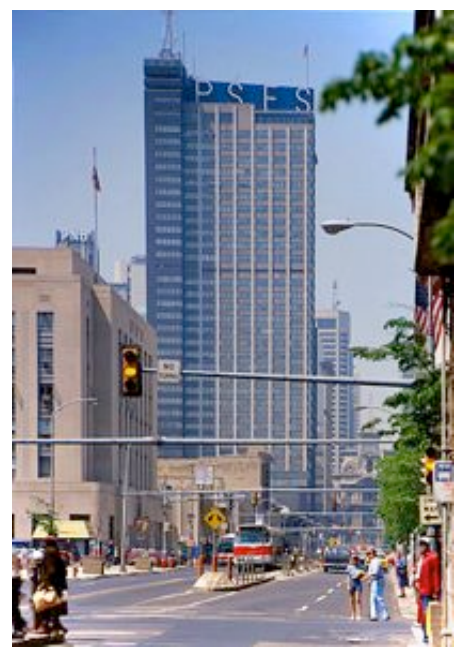

"Philadelohia Savings Fund Society (PSFS) Building". 1932 Philadelohia, Pennsyvania. Arcuitetura: William Edmond Lescaze. Considerado o primeiro "International Modemist Skyscraper"

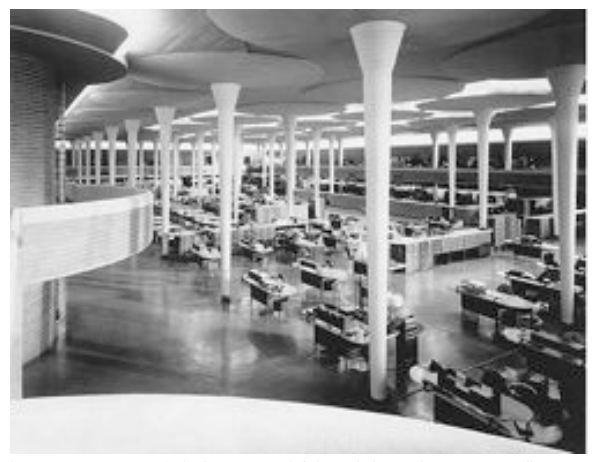

Imacem12. "Johnson Wax Headquarters" 1936 Racine Wisconsin, USA. Arquitetura: Frank Lloyd Wright.

\section{1-1935}

TROCAS, TRANSFERÊNCIAS E FATOS

1931: Salão Nacional de Belas Artes ou Salão de 1931, cuja seção moderna (inoficial) é coordenada por Lucio Costa.

1931: Frank Lloyd Wright visita o Brasil para participar do Júri do Concurso Internacional para o Farol do Colombo

1932: Exposição no MoMA de New York: Modern Architecture: International Exhibition e catalogo: The International Style: Architecture since 1922.

1933: Franklin D. Roosevelt presidente dos EUA

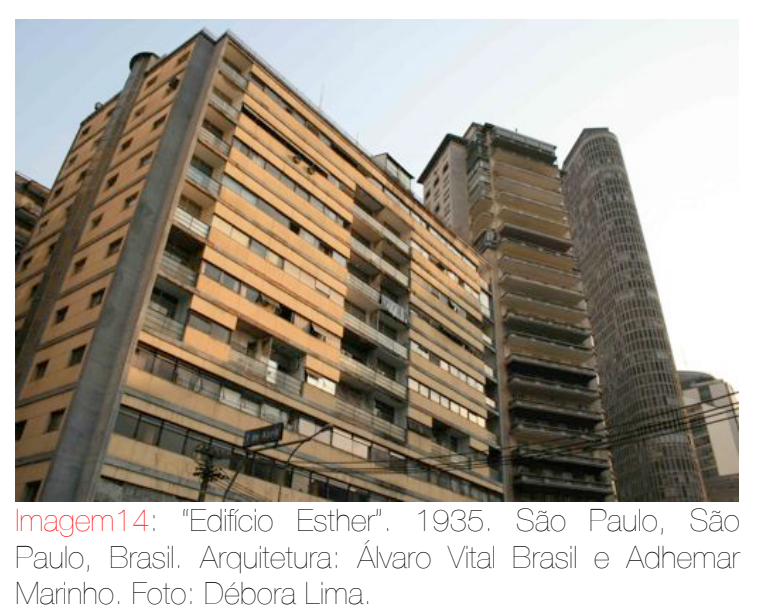

OBRAS BRASILEIRAS

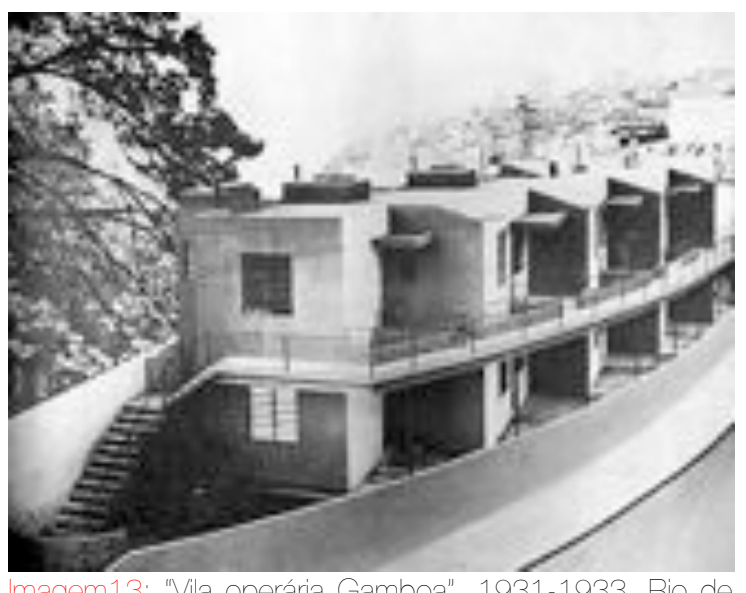

Janeiro, Rio de Janeiro, Brasil. Arquitetura: Lucio Costa e Gregori Warchavchik Marinho. Foto: Débora Lima. 
PRECEDÊNCIAS E REFERÊNCIAS USA

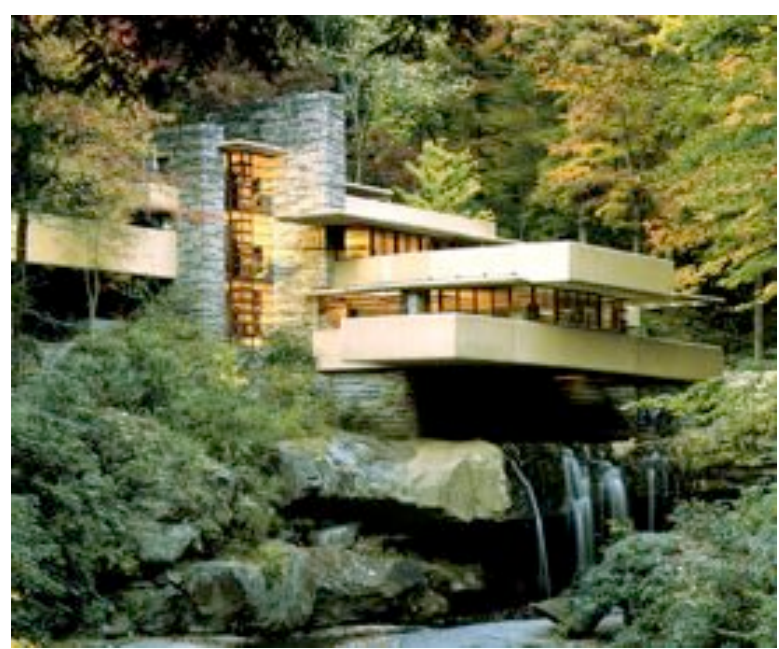

Imagem15: "Fallingwater / Kaufmann's House". 1936. Wright

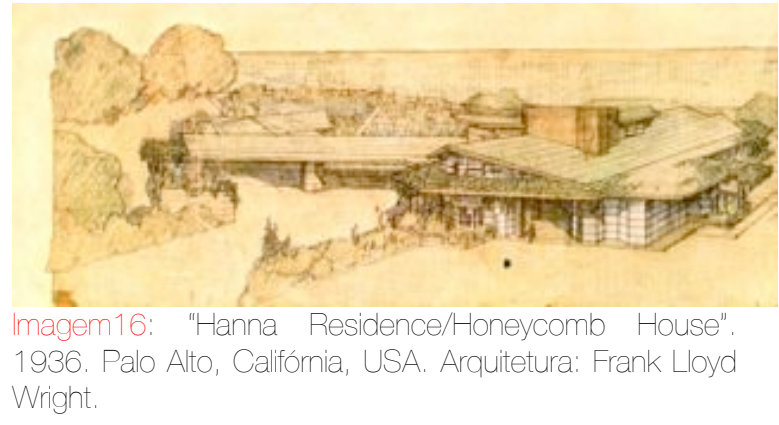

1936

TROCAS, TRANSFERÊNCIAS E FATOS

1936: Le Corbusier visita o Brasil pela segunda vez.

1936: Projeto para o Ministério da Educação e Saúde e a Universidade do Brasi.

1936: Primeira visita de um presidente americano ao Brasil: Franklin D. Roosevelt (parada no Rio de Janeiro a caminho de Buenos Aires)
OBRAS BRASILEIRAS

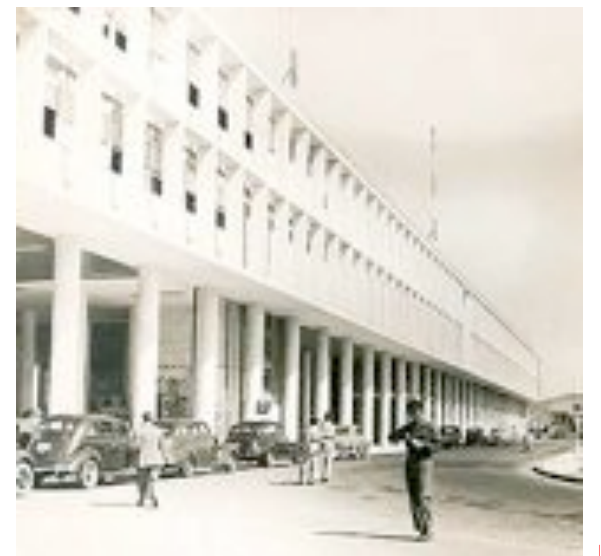

"Aeroporto Santos Dumont", 1937. Rio de Janeiro, Rio de Janeiro, Brasil. Arquitetura: Irmãos Roberto.

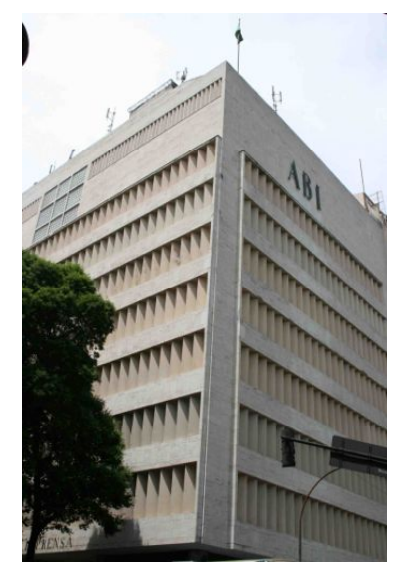
1936 1938. Rio de Janeiro, Rio de Janeiro, Brasi (M) Marcelo Roberto

(MMRoberto). Foto: Débora Lima. 
PRECEDÊNCIAS E REFERÊNCIAS USA

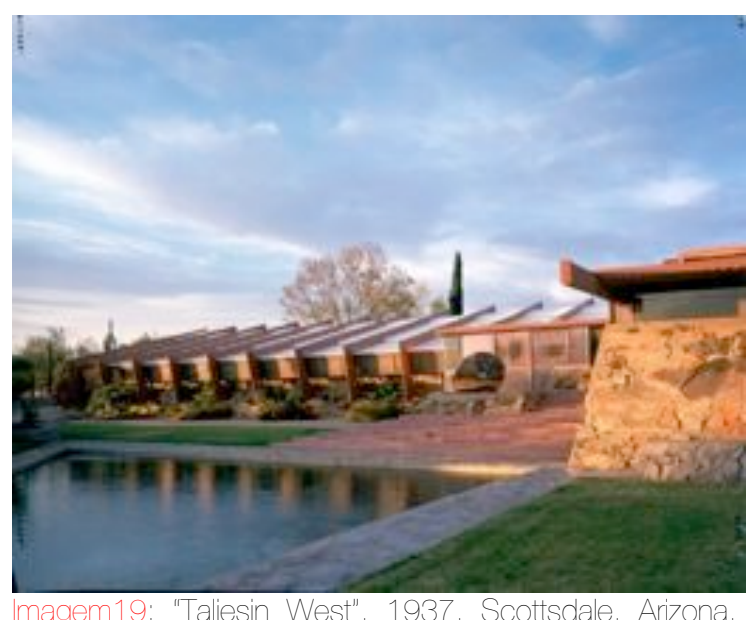

USA. Arquitetura: Frank Lloyd Wright.

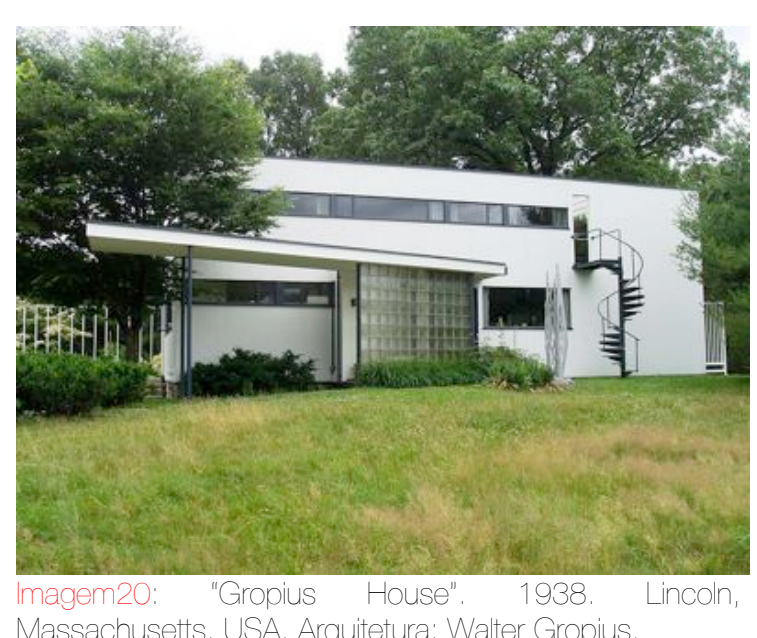

Massachusetts, USA. Arquitetura: Walter Gropius.

\section{7}

TROCAS, TRANSFERÊNCIAS E FATOS

1937: Estado Novo

1937: Emigram para os EUA Ludwig Mies van der Rohe, Walter Gropius e Marcel Breuer.
OBRAS BRASILEIRAS
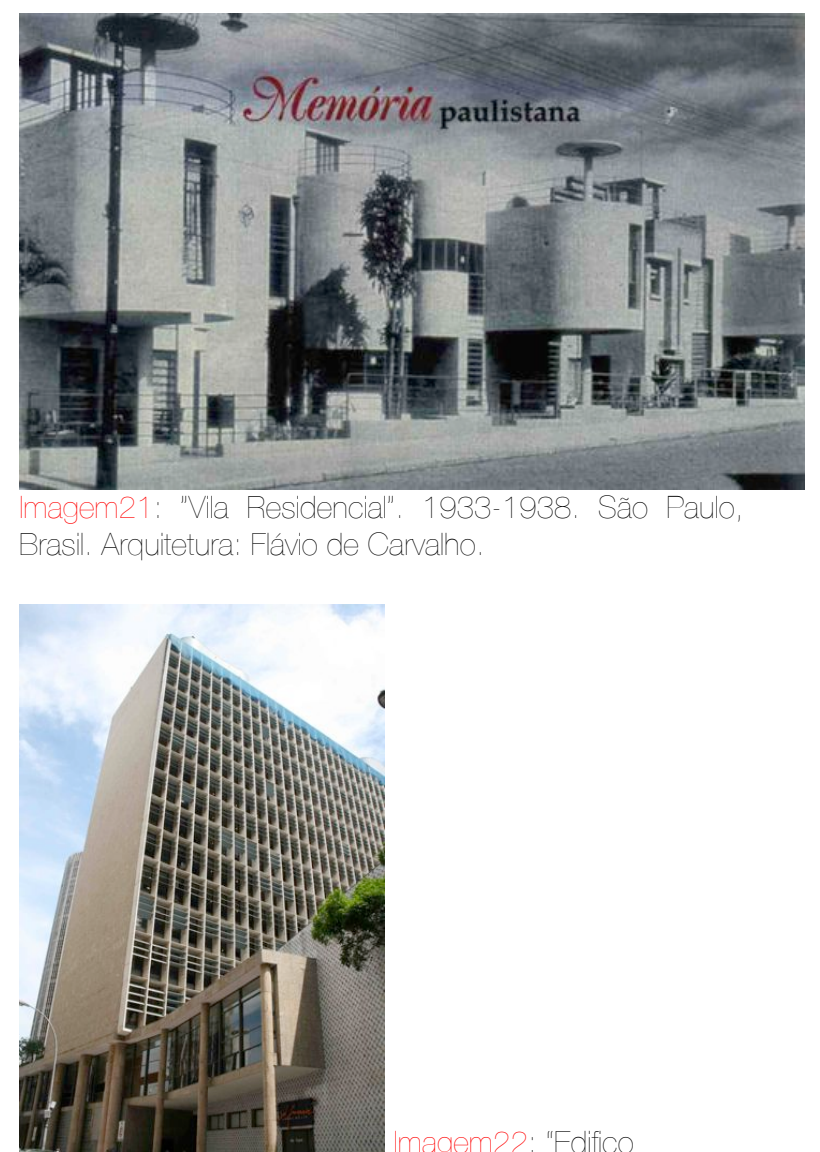

Gustavo Capanema - MEC". 1936-1945, Rio de Janeiro

Rio de Janeiro, Brasil. Arouitetura:Lucio Costa. Affonso

Eduardo Reidy, Carlos Leão, Jorge Moreira, Emani

Vasconcellos, Oscar Niemeyer. Consultoria: Le Corbusier Foto: Débora Lima 
PRECEDÊNCIAS E REFERÊNCIAS USA

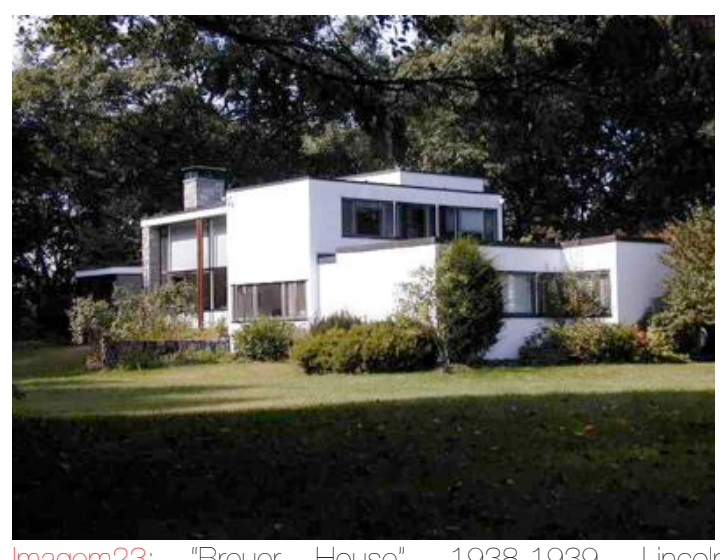

Massachusetts, USA, Arquitetura: Marcel Breuer e Walter Gropius

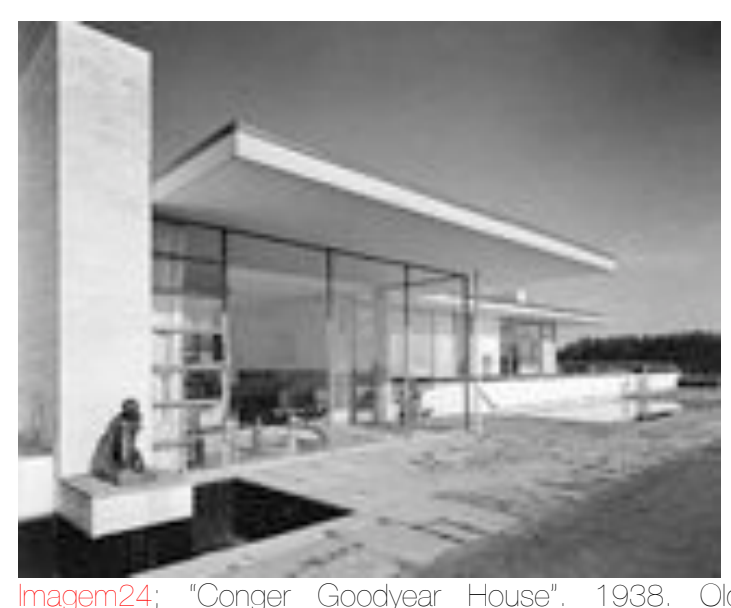

Westbury, Long Island, USA. Arquitetura: Edward Durel Stone.

\section{8-1939}

TROCAS, TRANSFERÊNCIAS E FATOS

1939: Inicia a Segunda Guerra Mundial.

1939: Projeto do Pavilhão do Brasil na New York World's Fair. Lucio Costa e Oscar Niemeyer permanecem oito meses na cidade e projetam Pavilhão com os arquitetos americanos Paul Lester Wiener e Thomas Price (paisagista).
OBRAS BRASILEIRAS

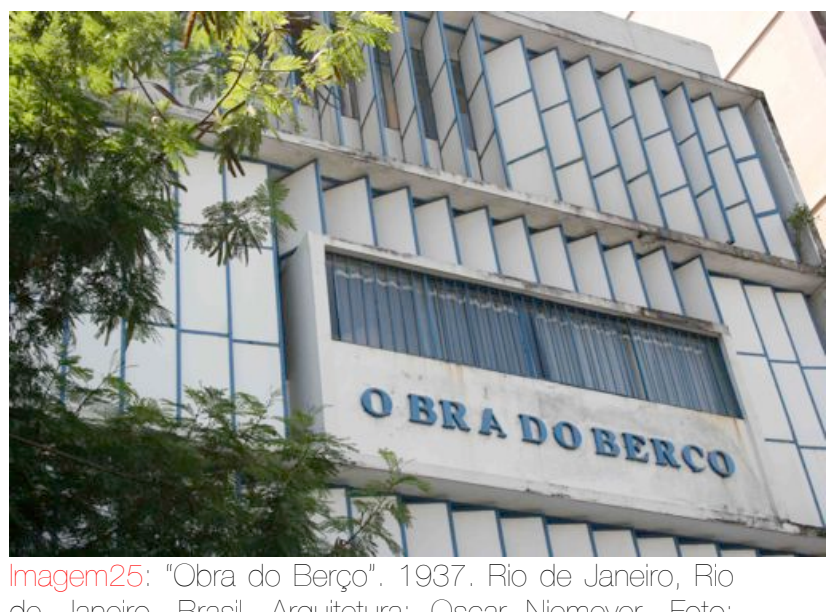

de Janeiro, Brasil. Arquitetura: Oscar Niemever. Foto: Débora Lima

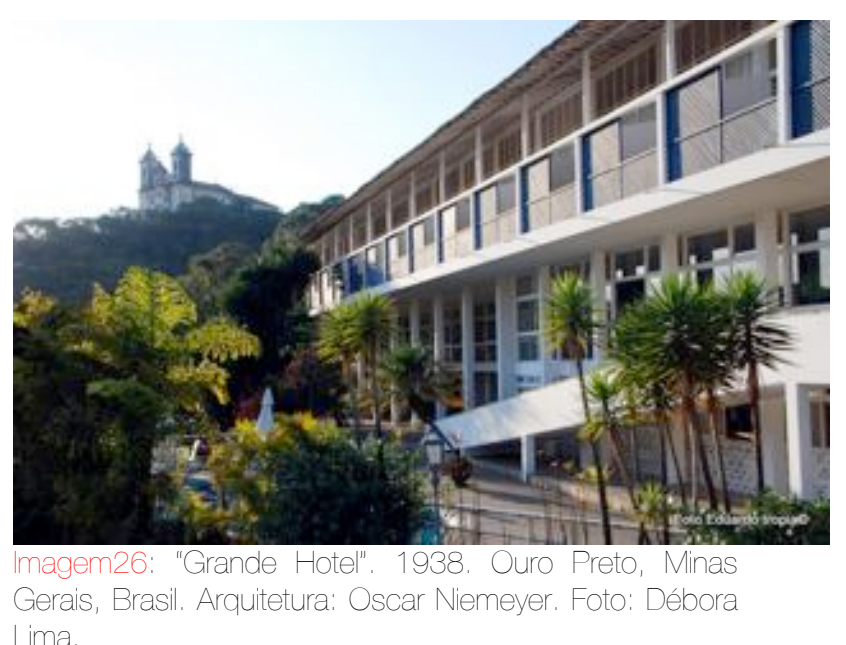


PRECEDÊNCIAS E REFERÊNCIAS USA

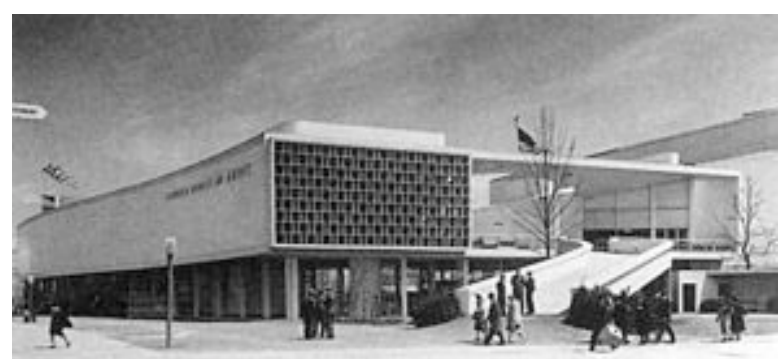

Imagem27: "Pavilhão do Brasil na New York World's Fair 1939-1940. New York, New York, USA. Arquitetura Oscar Niemeyer, Lucio Costa, Paul Lester Wiener $\theta$ Thomas Price. DEMOLDO

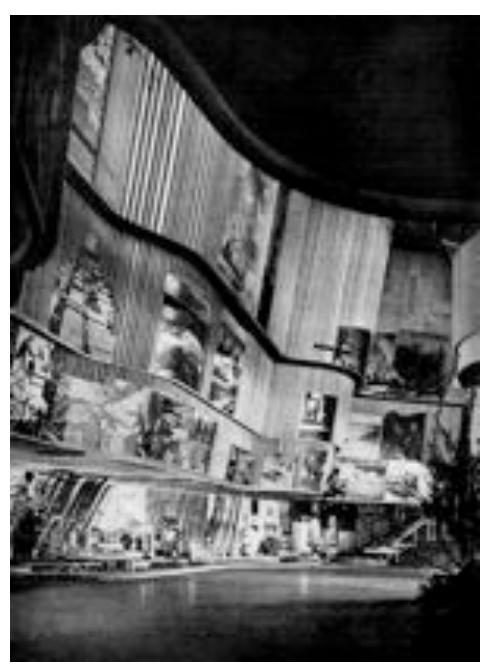

"Pavilhão da Finlândia na Now York World's Fair" 1930 1940. New York, New Your, USA. Arquitetura: Avar Aalte

\section{0-1941}

TROCAS, TRANSFEREANCIAS E FATOS

1940: Criação do Office of the Coordinator of InterAmerican Affairs (OCIAA) chefado pelo então presidente do MoMA Nelson Rockefeller.

1941: Criação do Departamento Cultural de OCIAA, chefiado por Wallace Harrison.
OBRAS BRASILEIRAS

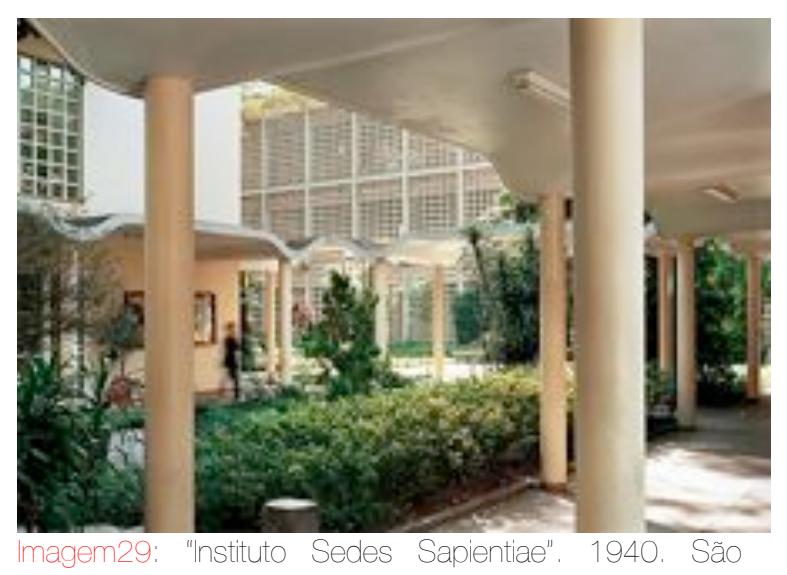

Paulo, São Paulo, Brasil. Arouitetura' Rino Levi. Foto Nelson Kon

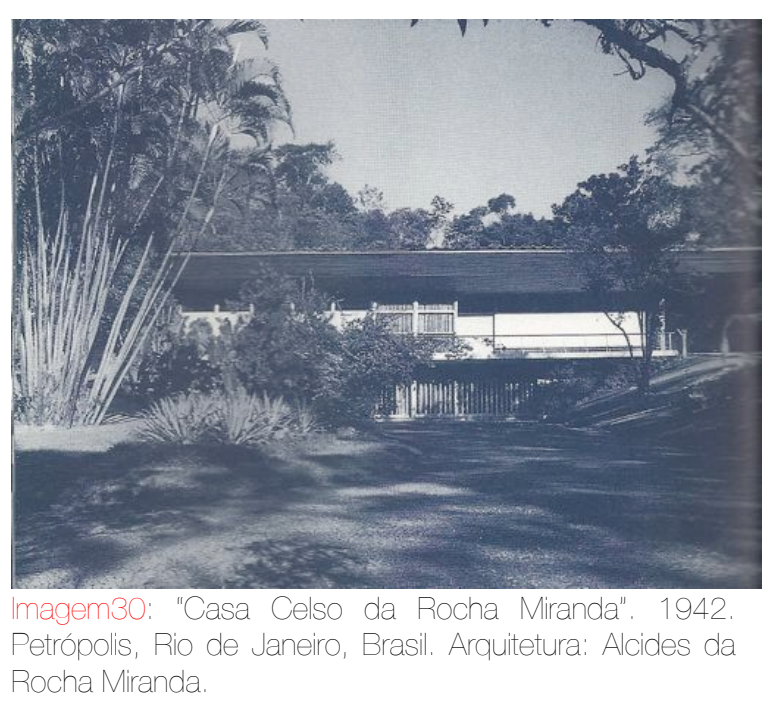


PRECEDÊNCIAS E REFERÊNCIAS

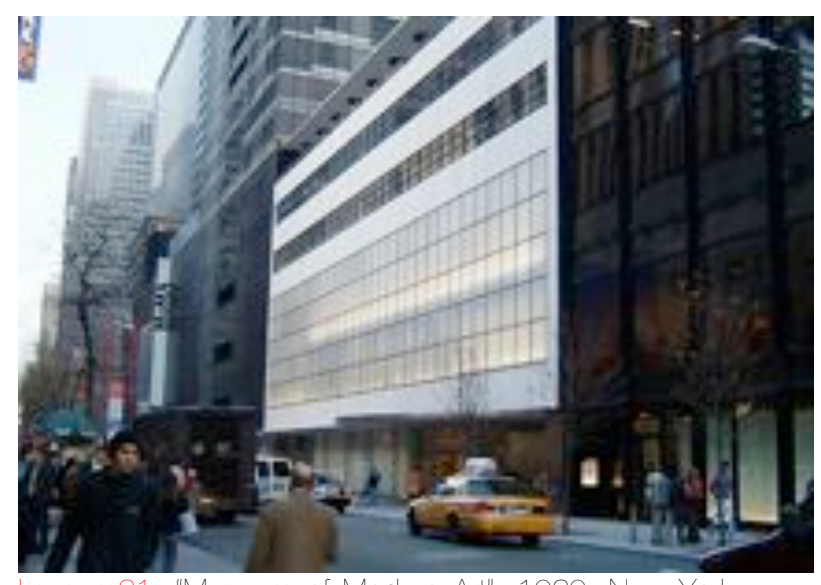

New York, USA. Arquitetura: Philip Goodwin e Edward Durell Stone. Foto: Débora Lima.

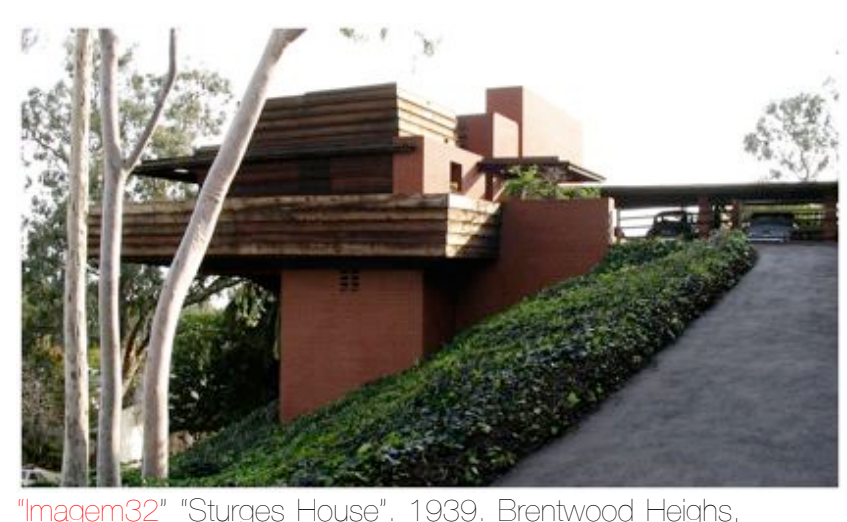

"Imagem32" "Sturges House". 1939. Brentwood Heighs, Débora Lima.
1942-1943

TROCAS, TRANSFERÊNCIAS E FATOS

1942: Philip Goodwin e George E. Kidder-Smith passam 6 meses no Brasil. visitando edificios e entrevistando a nova geração de arquitetos brasileiros

1943: Franklin Delano Roosevelt visita o Brasi (Belém e Natal)

1943: Inauguração da Exposição Itinerante e do livro Brazil Builds: New and Old 1652-1942 no Museum of Modern Art, em New York. A Exposição é descrita como de Arquitetura Colonial e Moderna porque a possibilidade de analogia com o conteto americano se tornava assim mais direta.

Finda a mostra no MoMA, a mostra circula pelos Estados Unidos, México e Canadá

1945: Projeto para a Cidade dos Motores em Volta Redonda no Rio de Janeiro, por José Luis Sert e Paul Lester Wiener
OBRAS BRASILEIRAS

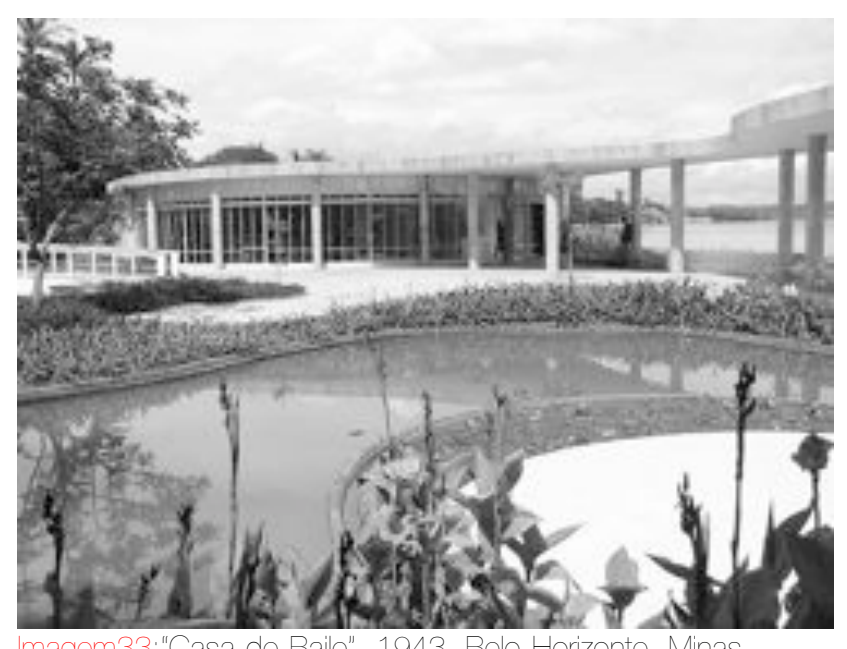

Gerais, Brasil. Arquitetura: Oscar Niemeyer

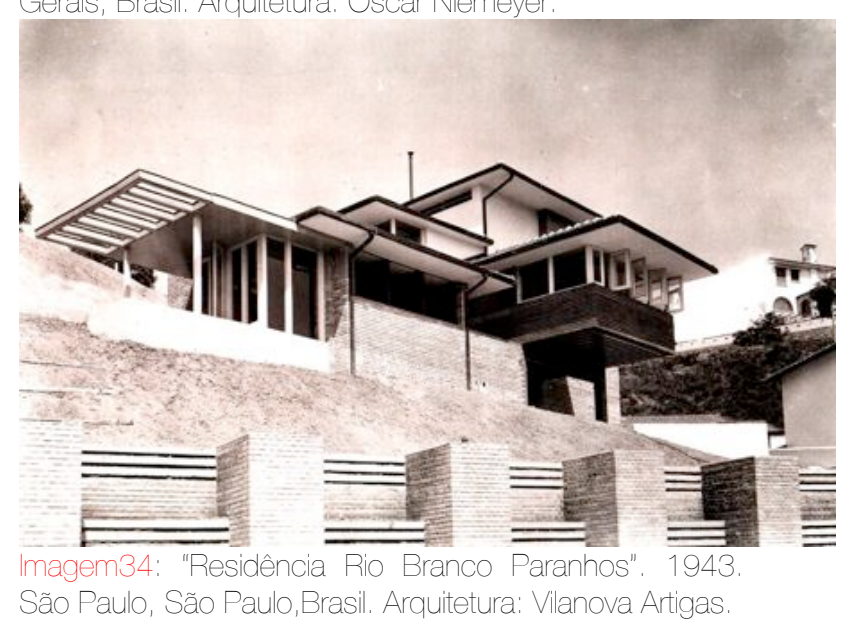


PRECEDÊNCIAS E REFERÊNCIAS USA

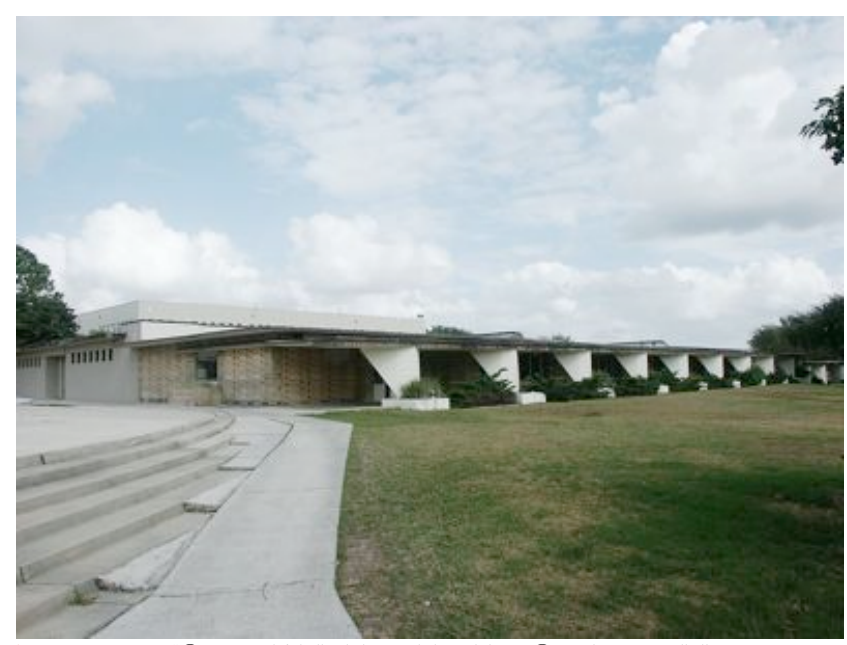

Imagem35: "Carter, Walbridge, Hawkins Seminar Building - Florida Southern College", 1941. Lakeland, Florida

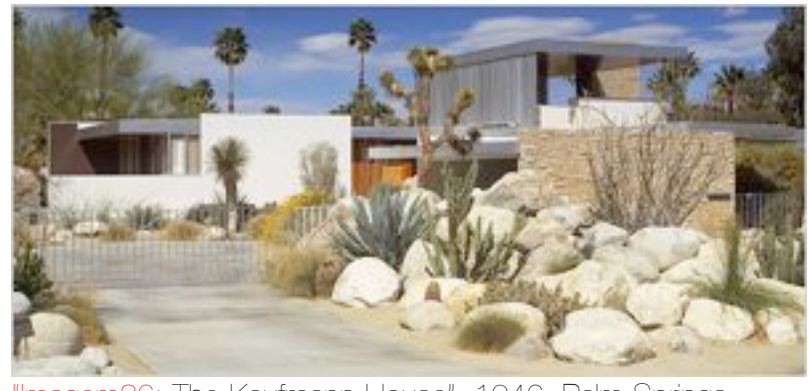

"Imagem36: The Kaufmann House". 1946. Palm Springs,

Califómia, USA. Arquitetura: Richard Neutra. Foto: Débora

Lima.

\section{4-1945}

药

TROCAS, TRANSFERÊNCIAS E FATOS

1944: Exposição no MoMA de New York: Built in JSA- since 1932

1945: Inicio na California, EUA, do projeto Case Study Houses, dirigido por Johm Entenza da Arts \&

Architecture Magazine. Se estende até o ano de 1966

1945: Viagem de Richard Neutra pela América do Sul. Na época ainda era o presidente da seção norte-americana no CIAM. No Brasil visita São Paulo, Rio de Janeiro, Belo Horizonte e Ouro Preto Em São Paulo encontra-se com Warchavchilk Henrique Midlin, Rino Levi, Lucyan Korngold $\theta$ Vilanova Artigas, entre outros. No Rio de Janeiro com Oscar Niemeyer, Jorge Moreira, Lucio Costa

os irmãos Roberto, Burle Marx, Affonso Reidy entre outros

1945-1950: Boom da Arquitetura moderna americana em Palm Springs, California, EUA
OBRAS BRASILEIRAS

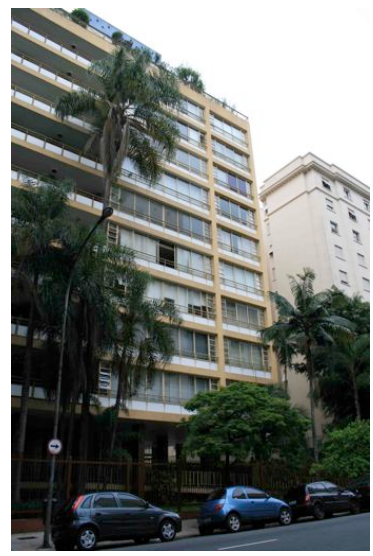

Prudência", 1944. São Paulo São Paulo. Braś Arouitetura: Rino Levi. Foto: Débora Lima.

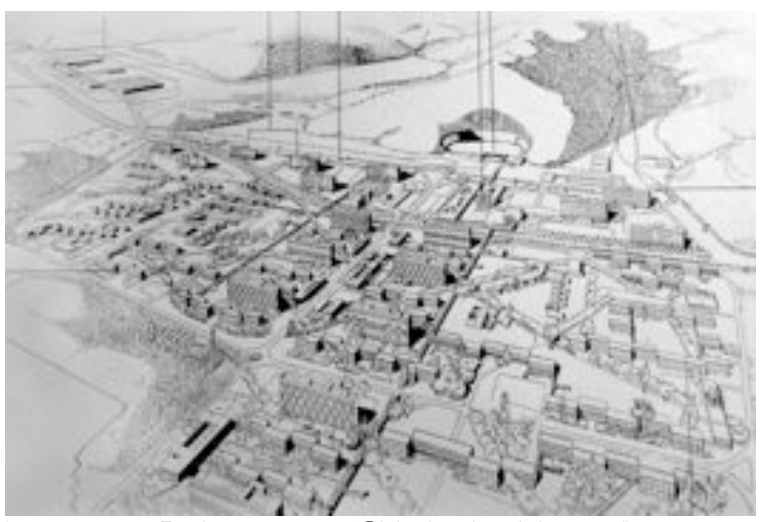

macem 38: Projeto para a "Cidade dos Motores" 1945 46. Xerém, Rio de Janeiro, Brasil. Arquitetura: TPA Town Planning Associates, de propriedade de Paul Lester Weiner, Josep Lluis Sert e Paul Schulz. 
PRECEDÊNCIAS E REFERÊNCIAS USA

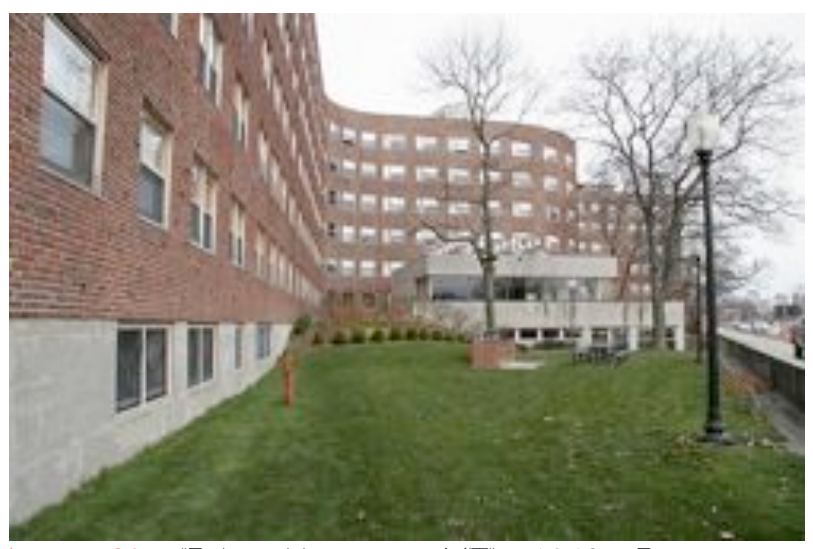

Imagem39: "Baker House at MIT". 1946. Boston, Massachusetts,
Débora Lima.

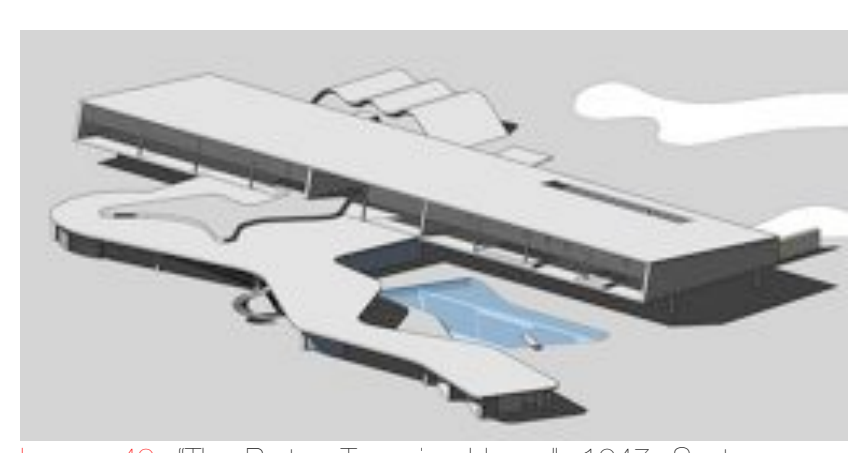

Imagem40: "The Burton Tremaine House". 1947. Santa Barbara, Califórnia, USA. Arquitetura: Oscar Niemeyer e Burle Marx. Não construída.

\section{6-1947}

TROCAS, TRANSFERÊNCIAS E FATOS

1946-1947: Permanência de João Batista Vilanova Artigas nos Estados Unidos, com bolsa da Fundação Guggenheim. Conhece Alvar Aalto Walter Gropius, Carl Kock, Ralph Rapson, Gyorgy Kepes e Joseph Hudnut.

1947: Viagem de estudos com duração de $\theta$ meses de Miguel Forte e Jacob Ruchti aos EUA.

1947: Inauguração do Museu de Arte de São Paulo (MASP), em São Paulo, ligado à Nelsor Rockefeller

1947: Participação proeminente de Oscar Viemeyer no grupo de trabalho internacional para a construção do Edíício-sede da Organização das Nações Unidas, em New Yrok. Permanência do arquiteto na cidade por alguns meses.

1947: Visita de Harry Truman ao Brasill para participar da Conferencia de Petrópolis que resultou na criação do Tratado Interamericano de Assistência Reciproca (TIAR).

1947: Projeto de Oscar Niemeyer para a residência Burton-Tremaine em Santa Bárbara, Califórnia.
OBRAS BRASILEIRAS

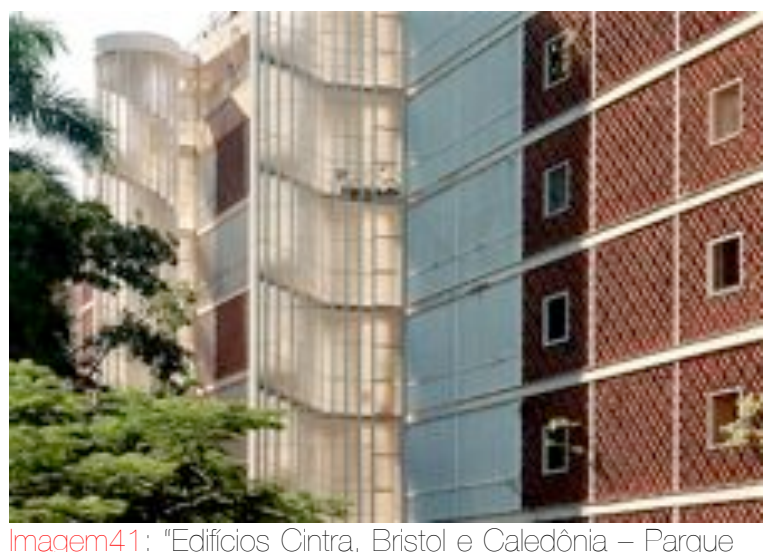

Guinle". 1948-1950-1954. Rio de Janeiro. Rio de

Janeiro, Brasill. Arquitetura: Lucio Costa. Foto: Débora Lima.

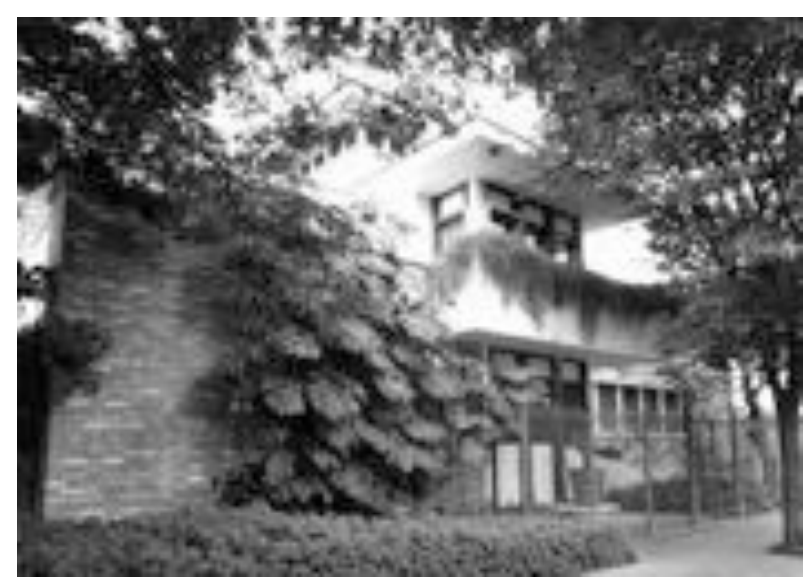

São Paulo, Brasil. Arquitetura: Miguel Forte. 
PRECEDÊNCIAS E REFERÊNCIAS USA

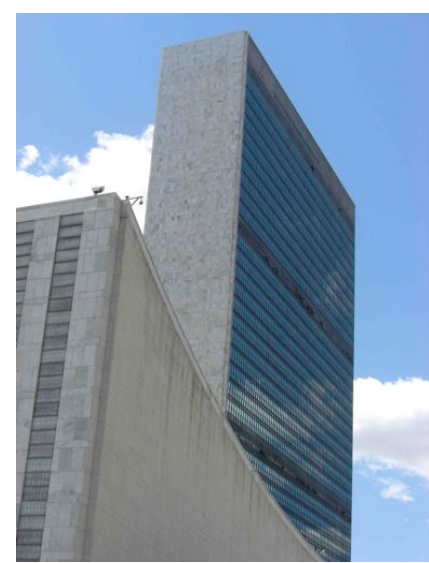

USA. Arquitetura: Oscar Niemeyer, Le Corbusier, Wallace Harrison. Foto: Débora Lima

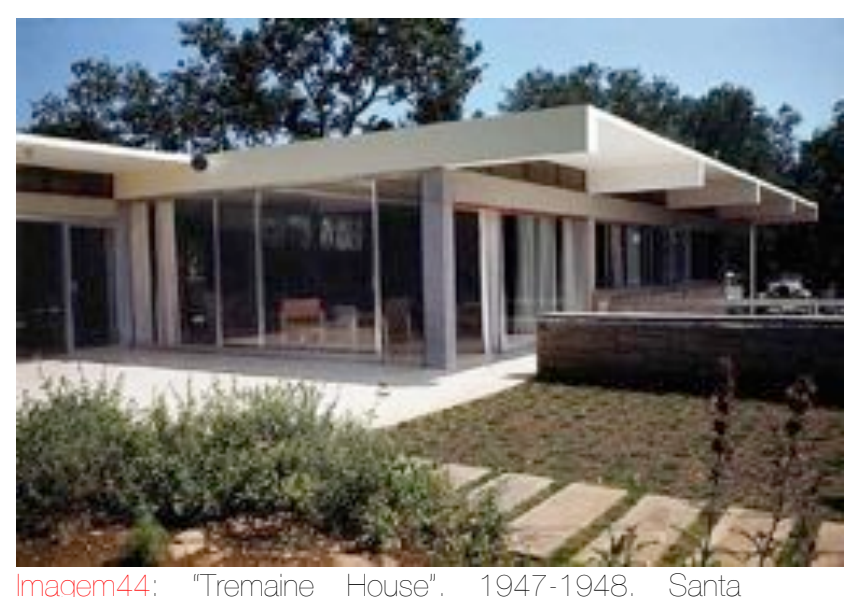
Barbara, Califórnia, USA. Arquitetura: Richard Neutra

\section{8}

TROCAS, TRANSFERÊNCIAS E FATOS

1948: Publicação do livro de Richard Neutra "Architecture of Social Concern", no Brasil intitulado "Arquitetura social em paises de clima quente" acerca das suas impressões da viagem a Porto Rico empreendida em 1945 com prefácio de Gregori Warchavchik.
OBRAS BRASILEIRAS

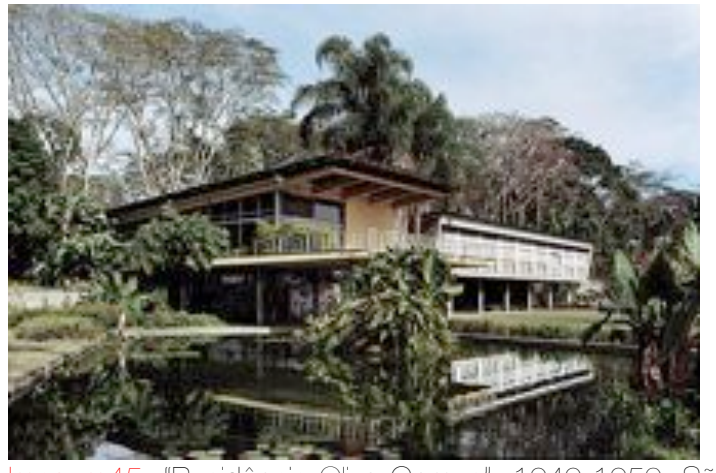

Jasé dos Campos, São Paul, Brasil. Arquitetura:Rino Levi. Foto: Nelson Kon

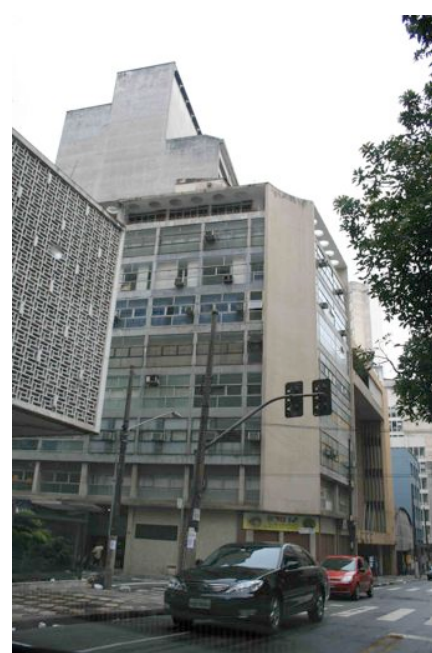

ABC" 1949. São Paulo, São Paulo, Br Oswaldo Arthur Bratke. Foto: Débora Lima. 
PRECEDÊNCIAS E REFERÊNCIAS USA

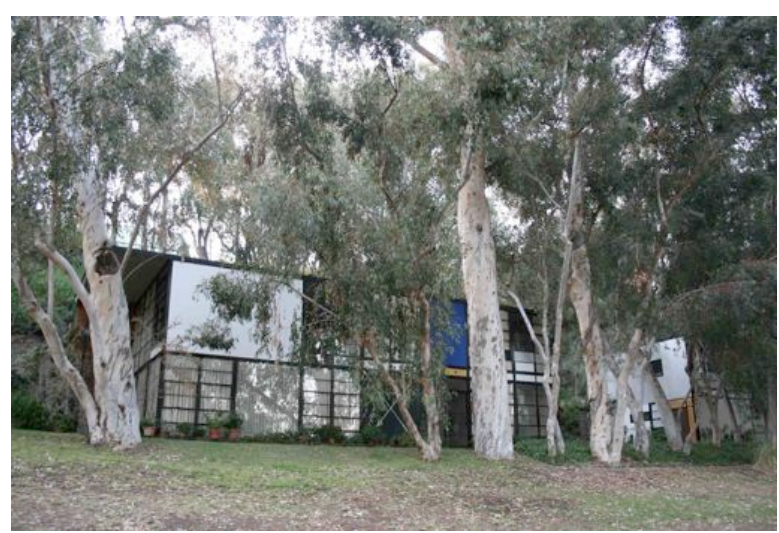

Imagem47: Case Study House \#8, "Eames House".

Charles e Ray Eames. Foto: Débora Lima.

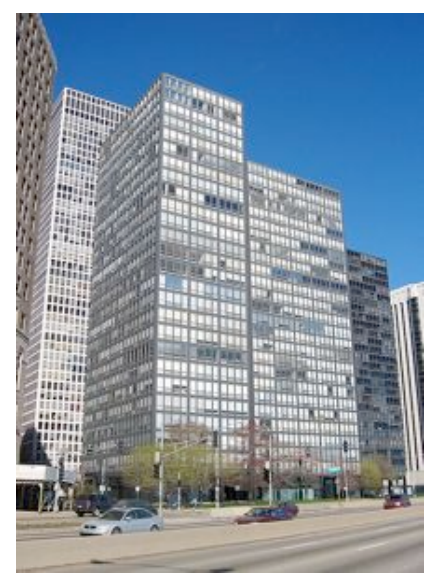

Ludwig Mies van der Rohe. Foto: Débora Lima

\section{9-1950}

TROCAS, TRANSFERÊNCIAS E FATOS

1949: Inauguração do MASP (ligado à Nelsor Rockefeller) em São Paullo, cujo modelo museográfico era o do MoMA de New York

1950: O arquiteto grego radicado nos EUA, Stamo Papadaki publica "The Work of Oscar Niemeyer"
OBRAS BRASILEIRAS

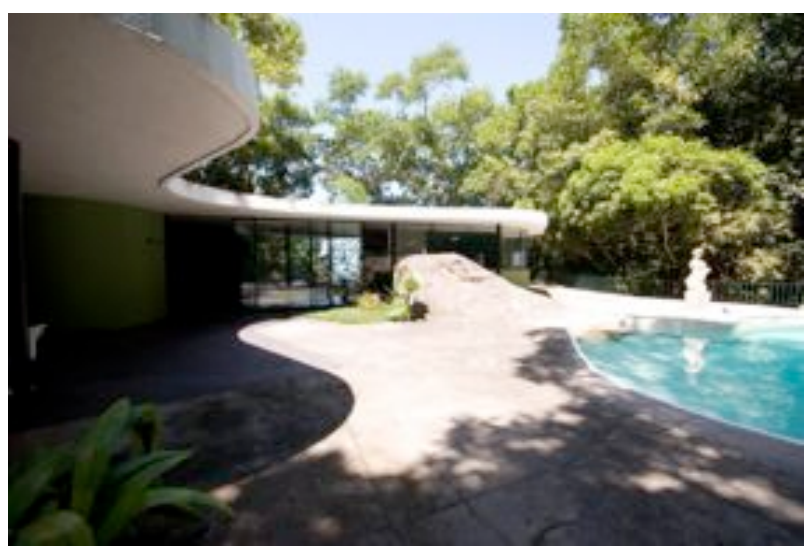

magem49: "Casa das Canoas", 1951. Rio de Janeiro,

Rio de Janeiro, Brasil. Arquitetura: Oscar Niemeyer. Foto Débora Lima.

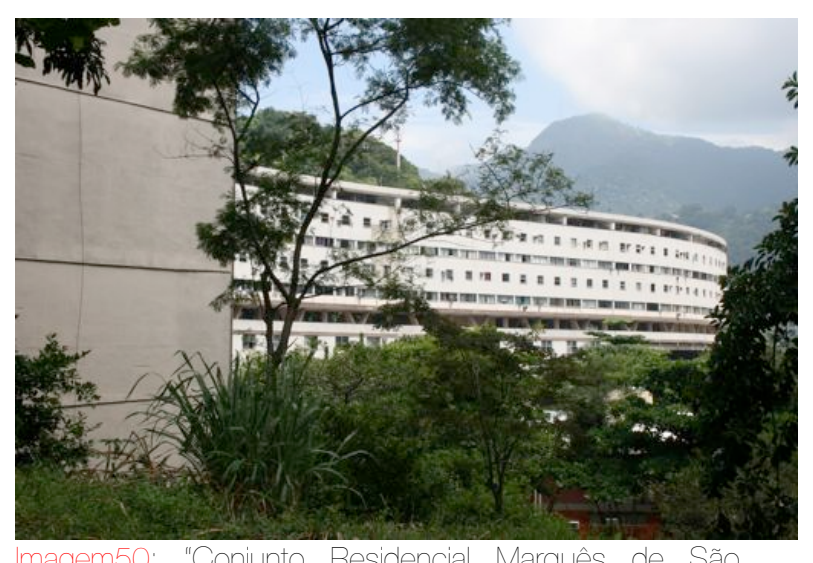

Vicente". 1952. Rio de Janeiro, Rio de Janeiro, Brasil. Arquitetura: Affonso Eduardo Reidy. Foto: Débora Lima. 
PRECEDÊNCIAS E REFERÊNCIAS USA

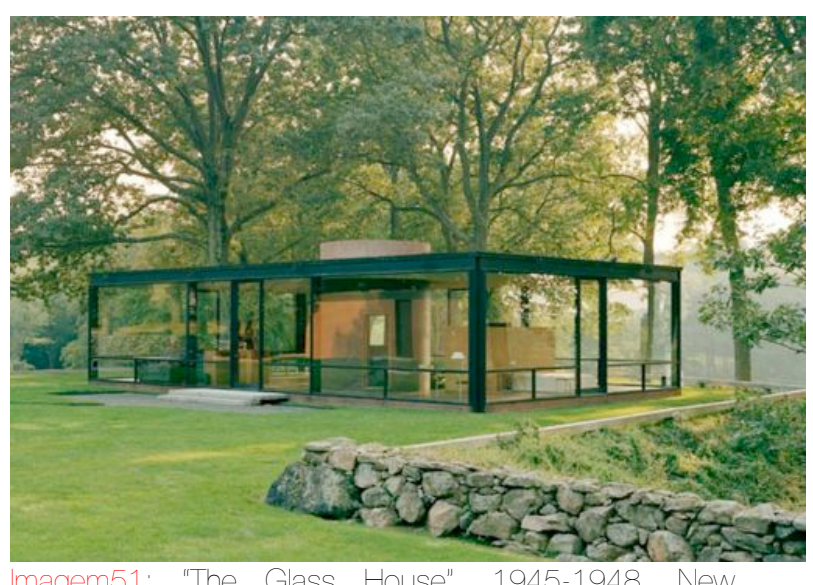

Canaan, Connecticut, USA. Arquitetura: Philip Johson

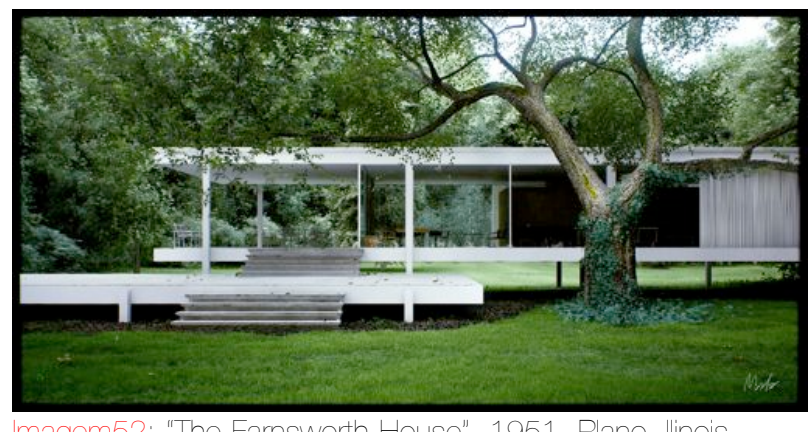

USA. Arquitetura: Ludwig Mies van der Rohe.

\section{1}

TROCAS, TRANSFERÊNCIAS E FATOS

1951: Primeira Bienal Internacional de Arte $e$ Primeira Exposição Internacional de Arquitetura de São Paulo.

1951: Inauguração do Museu de Arte Moderna (ligado ao MoMA de New Nork) de São Paulo Siegfried Giedion, entre outros, visitam o pais
OBRAS BRASILEIRAS

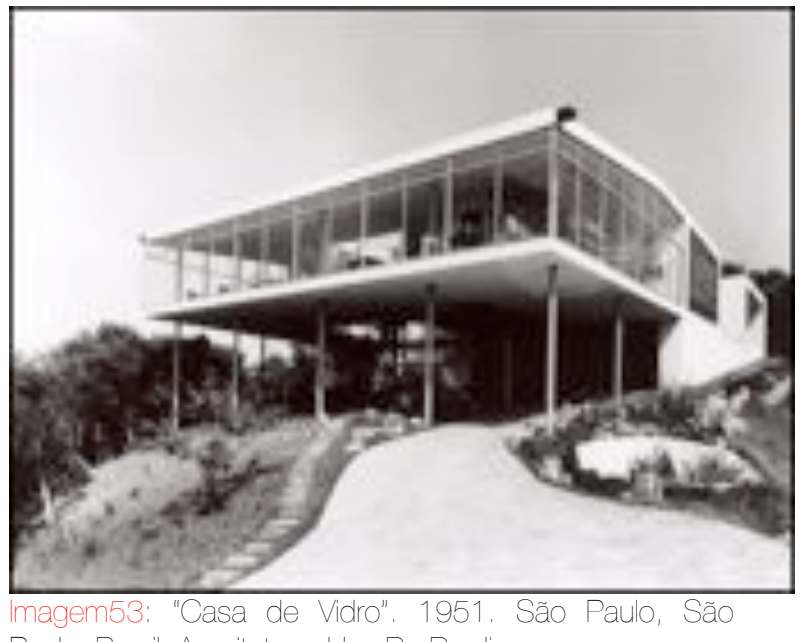

Paulo, Brasil. Arquitetura: LIna Bo Bardi.

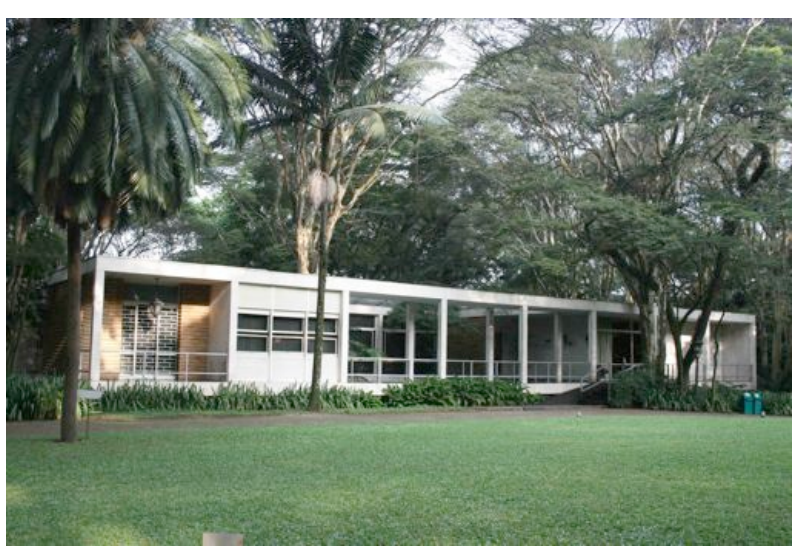
1950. São Paulo, São Paulo, Brasil. Arquitetura: Oswaldo Arthur Bratke. Foto: Débora Lima 
PRECEDÊNCIAS E REFERÊNCIAS USA

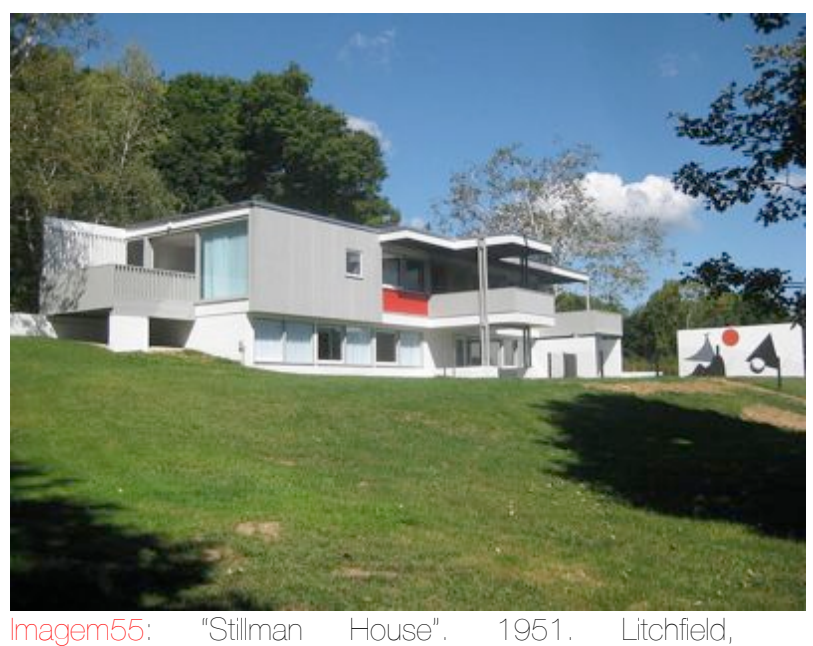

Connecticut., USA. Arquitetura: Marcel Breuer

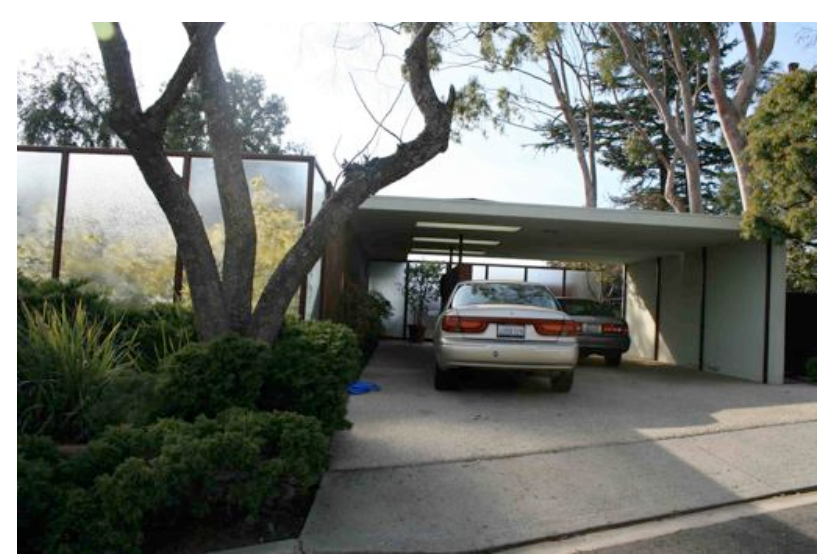

Imagem56: Case Study House \#16. 1951-1952. Bel Air

Califómia, USA. Arquitetura: Craig Ellwood. Foto: Débora Lima.
1952

TROCAS, TRANSFERÊNCIAS E FATOS
OBRAS BRASILEIRAS
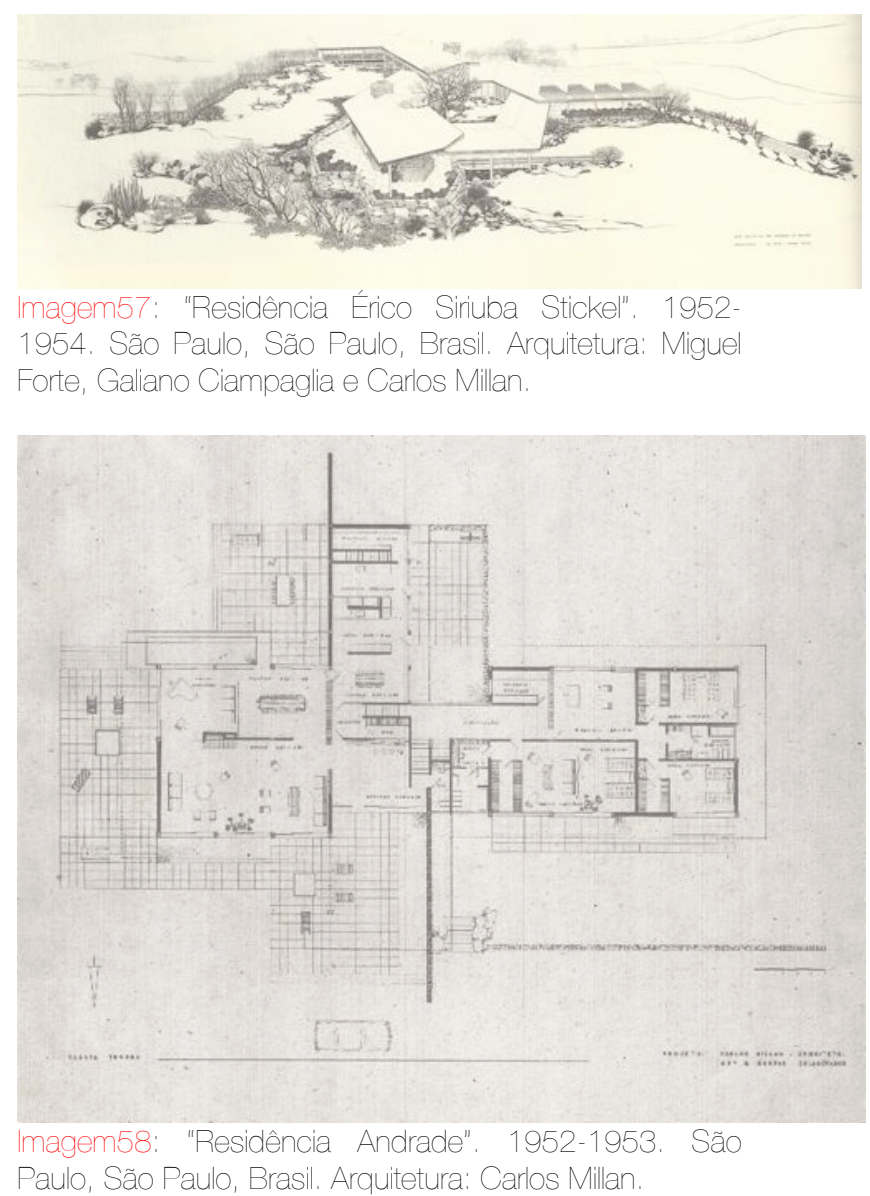
PRECEDÊNCIAS E REFERÊNCIAS USA
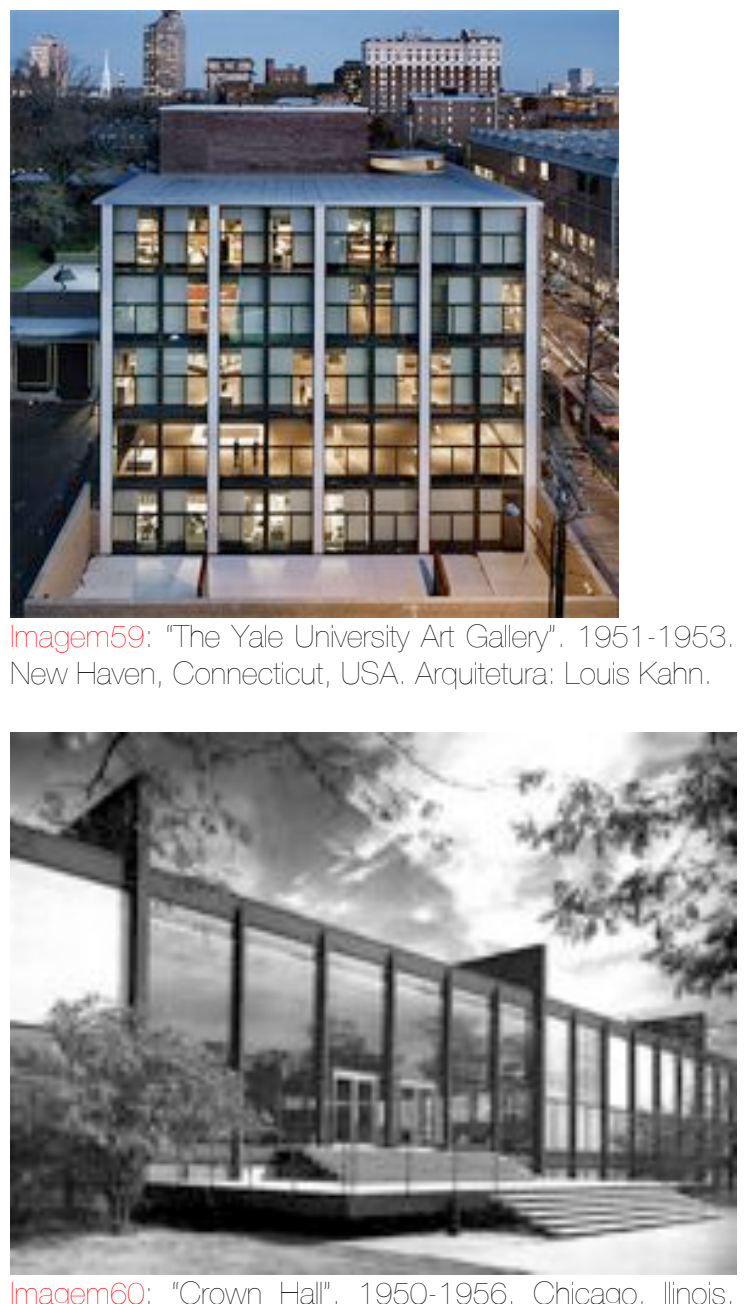

USA. Arquitetura: Ludwig Mies van der Rohe.

\section{2}

TROCAS, TRANSFERÊNCIAS E FATOS
OBRAS BRASILEIRAS
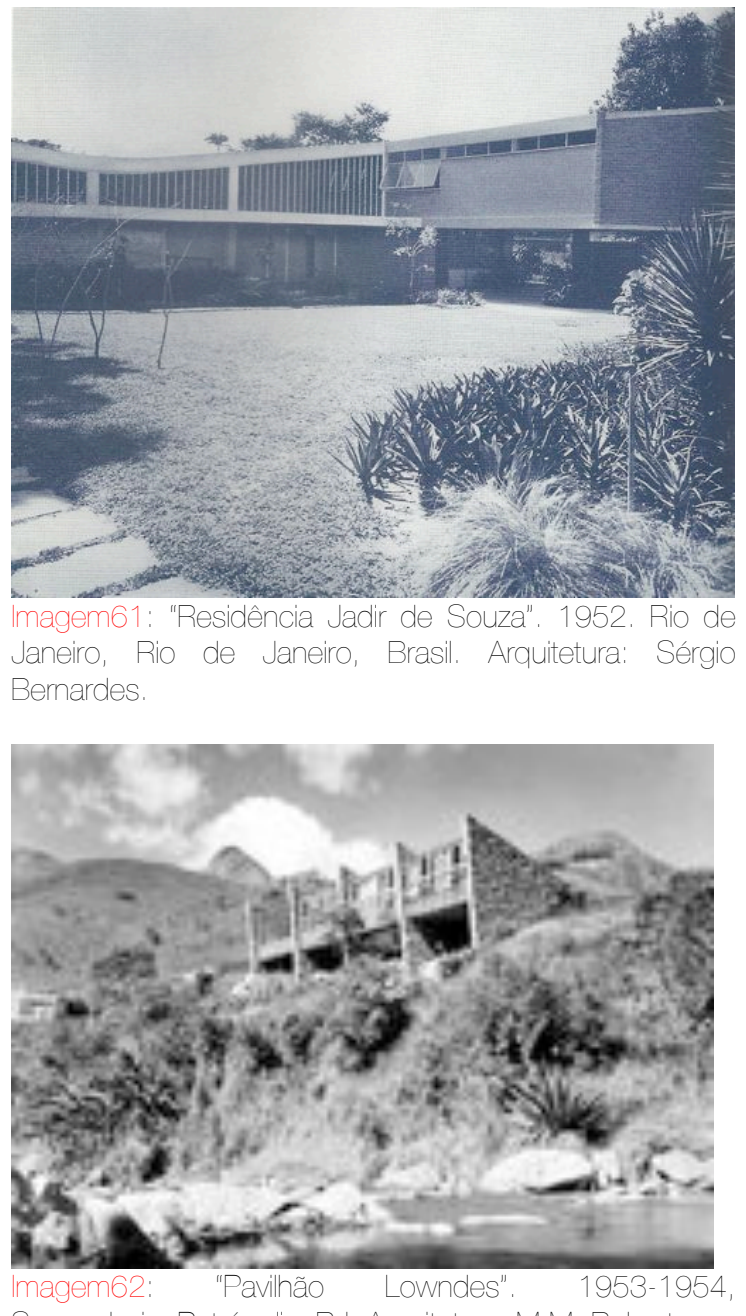
PRECEDÊNCIAS E REFERÊNCIAS USA

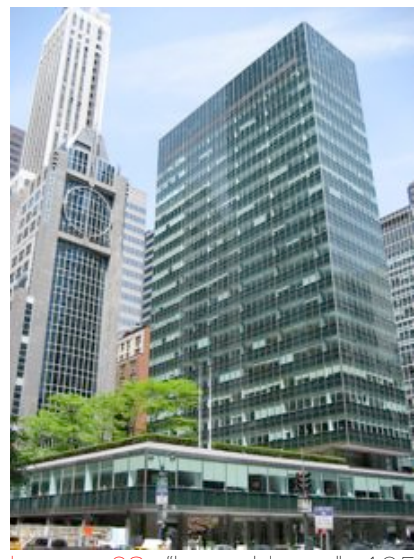

magem63: "Lever House". 1951-1952. New York, New York, USA. Arquitetura: Gordon Bunshaft da Skidmore Owings and Merrill. Foto: Débora Lima

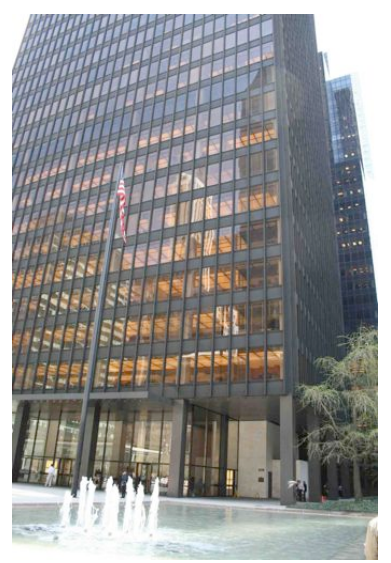

Imagem64: "Seagram Building". 1954-1958. New York, New York, USA. Arquitetura: Ludwig Mies van der Rohe. Foto:Débora Lima

\section{3}

TROCAS, TRANSFERÊNCIAS E FATOS

1953: || Exposição Internacional de Arquitetura Visitam o Brasi para o evento: Walter Gropius, Alvar Aalto, Ernesto Rogers, entre outros. Homenageados os arquitetos americanos Philip Jonhson, Arne Jacobsen, Paul Rudolph.

\section{OBRAS BRASILEIRAS}

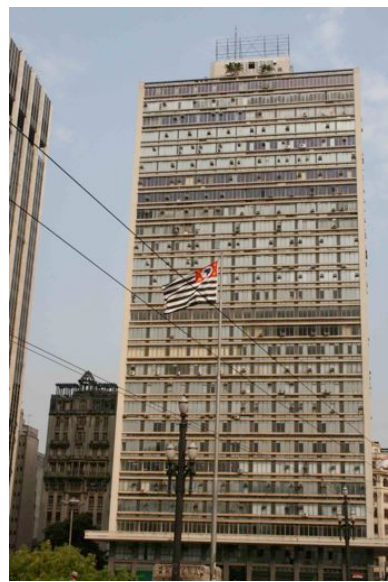

magem65: "Edificio conde de Prates". 1952. São Paulo, São Paulo, Brasil. Arquitetura: Giancarlo Palanti. o:Débora Lima

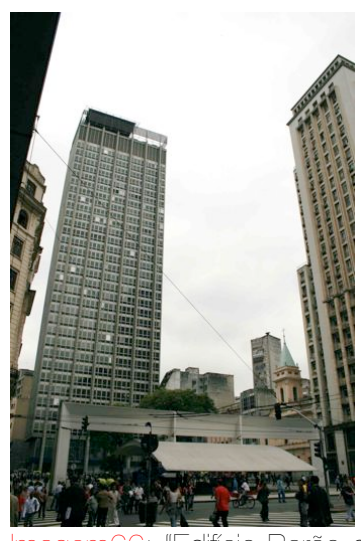

de lquape". 1956. Sä Paulo, São Paulo, Brasi. Arqutetura. Jacques Pion e Giancaro Gasperini. Foto: Débora Lima. 
PRECEDÊNCIAS E REFERÊNCIAS USA

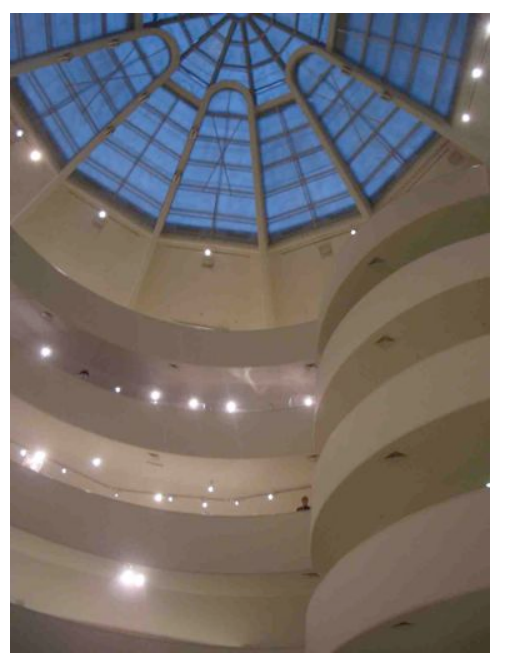

magem67: "Guggenheim Museum". 1956-1959. New York, New York, USA. Arquitetura: Frank Lloyd Wright. Foto: Débora Lima.

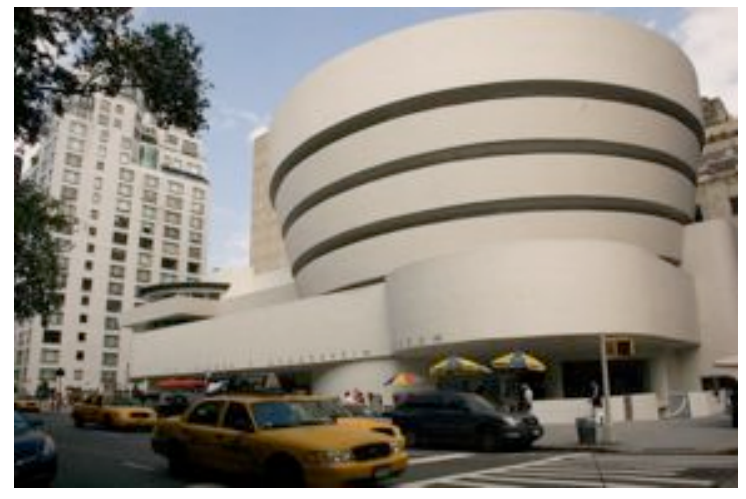

\section{4}

TROCAS, TRANSFERÊNCIAS E FATOS

1954: Inauguração do Complexo do Parque do birapuera, de Oscar Niemeyer e Burle Mar

1954: John Peter (editor das revistas Look e Life repórter de rádio e televisão da CBS americana) entrevista para a pesquisa de seus livros "Masters of Modern Architecture", de 1958, e posteriormente "The Oral History of Modern Architecture", publicado em 1994: Affonso Eduardo Reidy, Marcelo Roberto, Oscar Niemeyer e Oswaldo Bratke.
OBRAS BRASILEIRAS

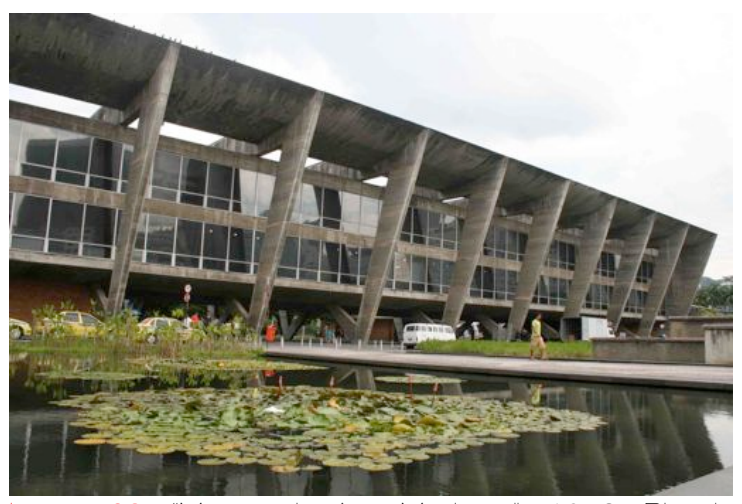

"magen 08, Museu de Arte Moderna", 1953. Rio Eduardo Reidy Foto:Débora

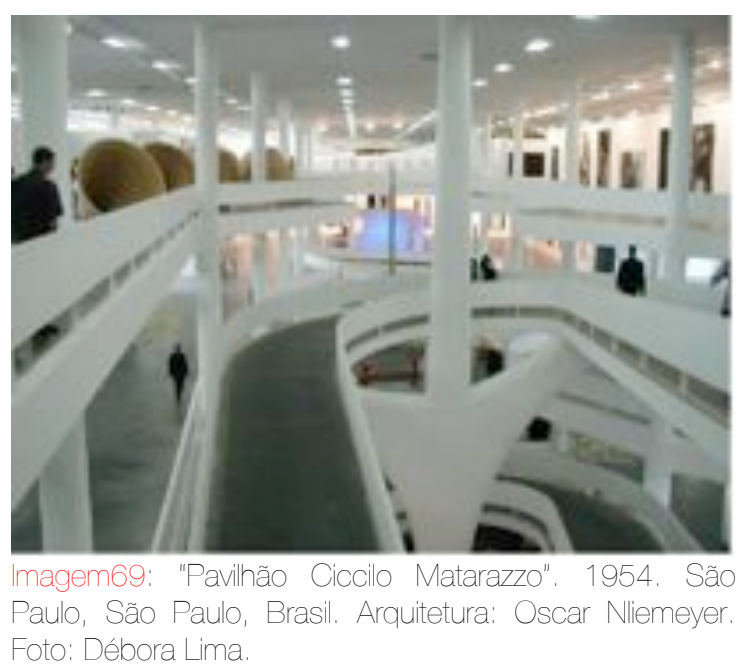


PRECEDÊNCIAS E REFERÊNCIAS USA

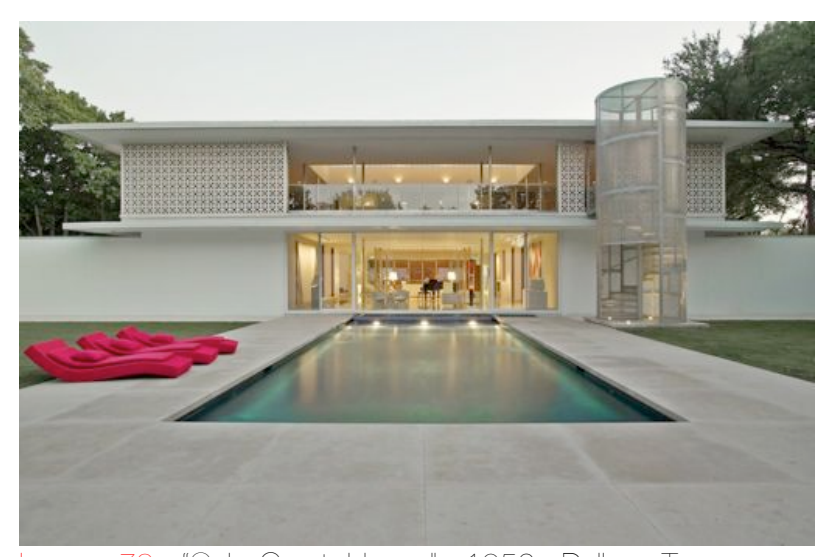

Imagem70: "Oak Court House", 1956. Dallas, Texas,

USA. Arquitetura: Edward Durell Stone.

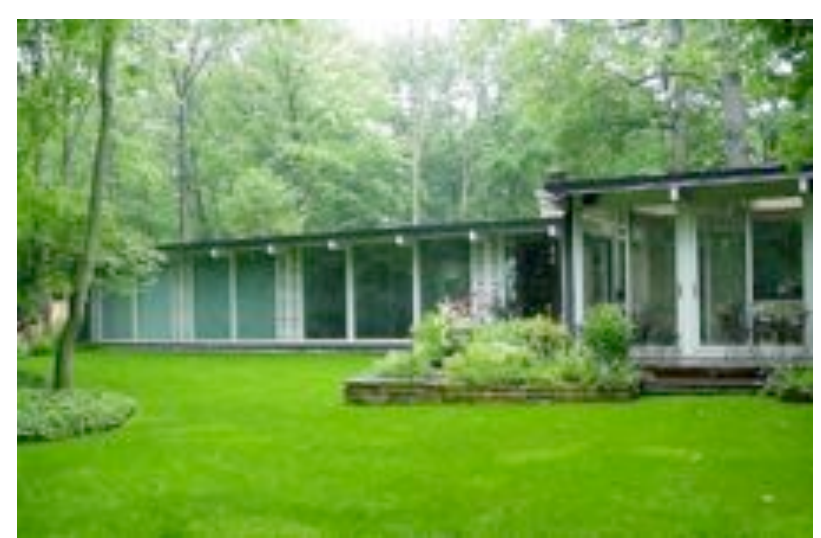

Imagem71: "Chicago solar Home". 1955. Chicago, llinois,

USA. Arquitetura: Geoge Frederick Keck.

\section{5}

TROCAS, TRANSFERENNCIAS E FATOS

1955: I| Bienal

1955: Visita de Mies van der Rohe ao Brasil.

1955: Esposição no MoMA de New York: "Modern Architecture in Latin America since 1945", com organização de Henry-Russel Hitchcock.
OBRAS BRASILEIRAS

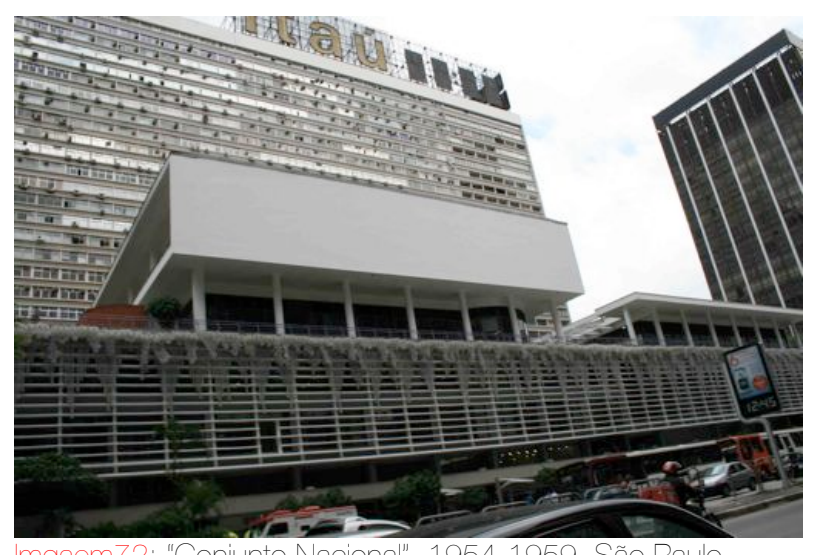

"Coniunto Nacional". 1954-1959 São Paulo,

São Paulo, Brasil. Arquitetura: David Libeskind. Foło: Débora Lima

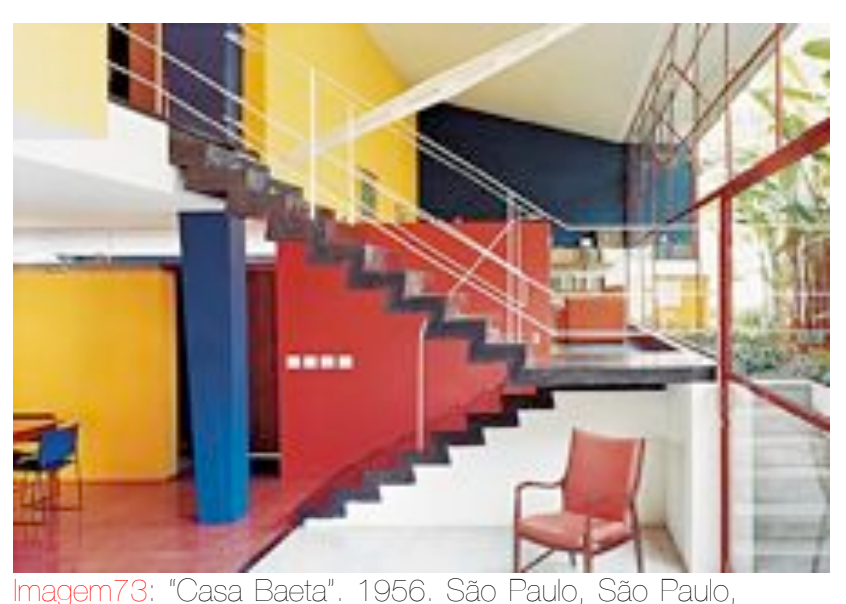

Brasil. Arquitetura: João Batista Vlanova Artigas. Foto Nelson Kon 
PRECEDÊNCIAS E REFERÊNCIAS USA

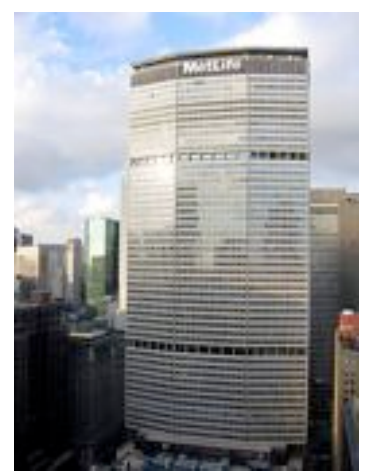

magem74: "Pam Am Building" 1958-1963. New York New York, USA. Arouitetura: Water Gropius com Pietro Belluschi e Emery Roth \& Sons.

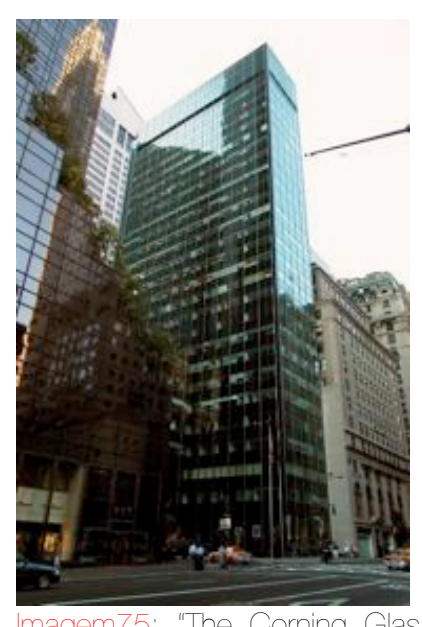

Imagem75: "The Corning Glass Building". 1956-1959. New York, New York, USA. Arquitetura: Harrison, Abramovitz \& Abbe

\section{6-1957}

TROCAS, TRANSFERÊNCIAS E FATOS

1956: Juscelino Kubitschek presidente do Brasil

1956: Publicação do livo de Henrique Mindlir "Modern Architecture in Brazil", com a primeira edição é lançada em inglês, antes mesmo na versão em português

1957: V Bienal. Presença no Brasil de Mies Var der Rohe, Marcel Breuer e Philii Johnson.

1957: Lucio Costa vence o concurso para o Plano Piloto de Brasilia

1957-1962: Desenvolvimento do Projeto do Consulado dos Estados Unidos no Brasil por Mies van der Rohe.
OBRAS BRASILEIRAS

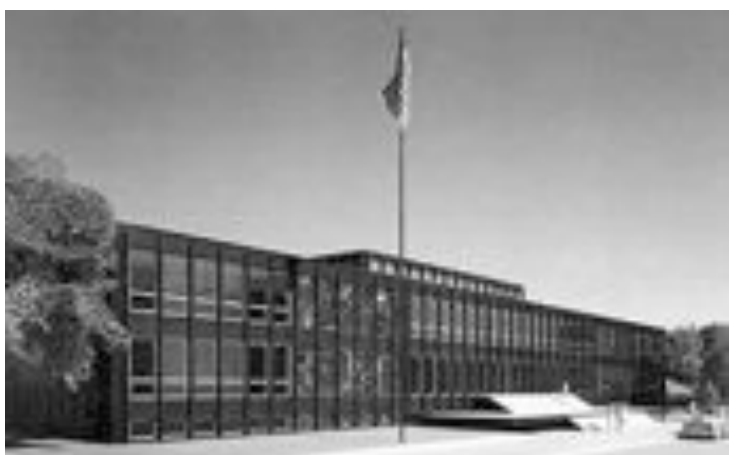

magem76: "Projeto para o Consulado dos Estados Unidos". 1957-1962. São Paulo, São Paulo, Brasil Arquitetura: Mies van der Rohe. Maquete - Projeto não construido

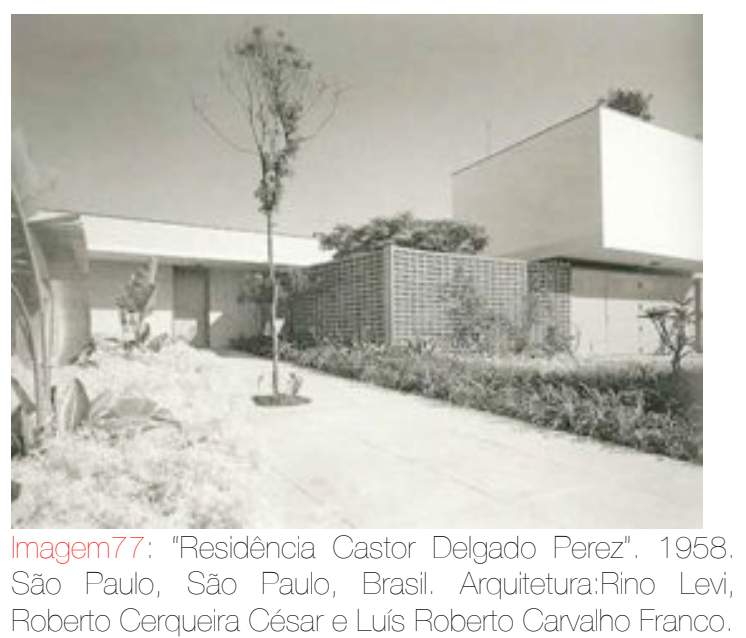


PRECEDÊNCIAS E REFERÊNCIAS USA

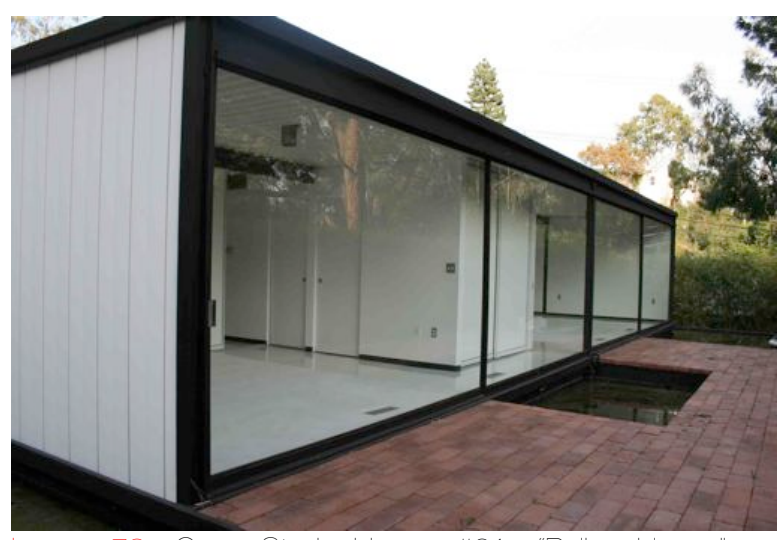

1958. West Hollwood. Caliórnia, USA. Arquitetura:

Pierre Koenig. Foto: Débora Lima.

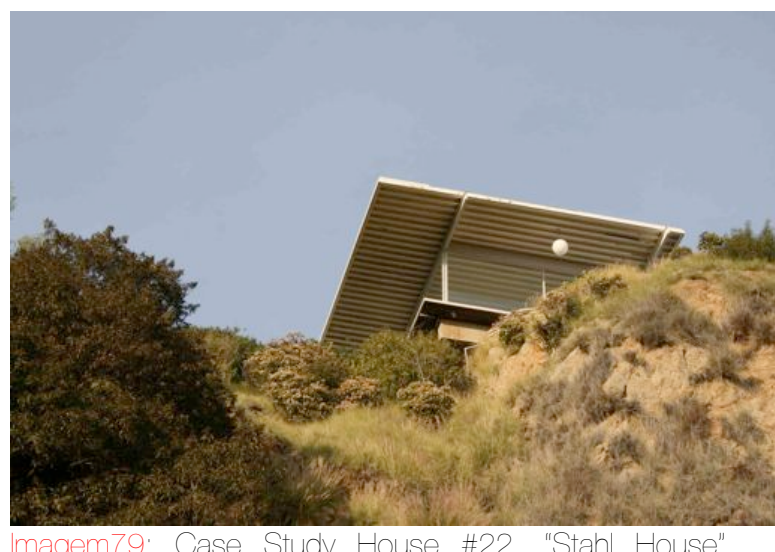

1960 West Holluwoed Calíómia USA Arquitetura Pierre Koenig Foto: Débora Lima.
1958

TROCAS, TRANSFERÊNCIAS E FATOS
OBRAS BRASILEIRAS

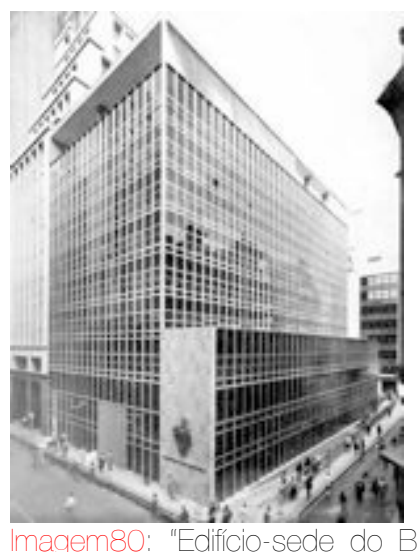
Amenca lda "Barão de louape" 1950 São Paulo São Paulo, Brasil. Arquitetura'Henrique Mindilin e Giancaro Palant

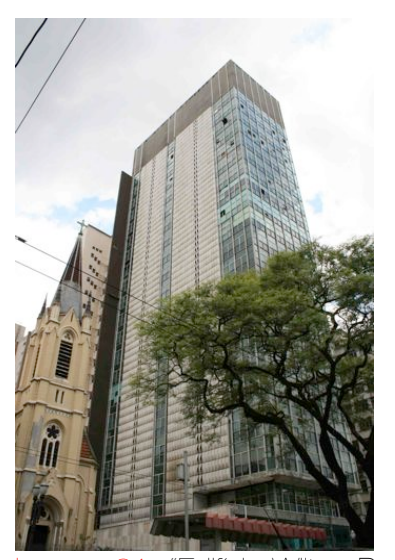
Paulo, São Paulo, Brasil. Arquitetura: Roger Zmekohl. Foto: Débora Lima. 
PRECEDÊNCIAS E REFERÊNCIAS USA

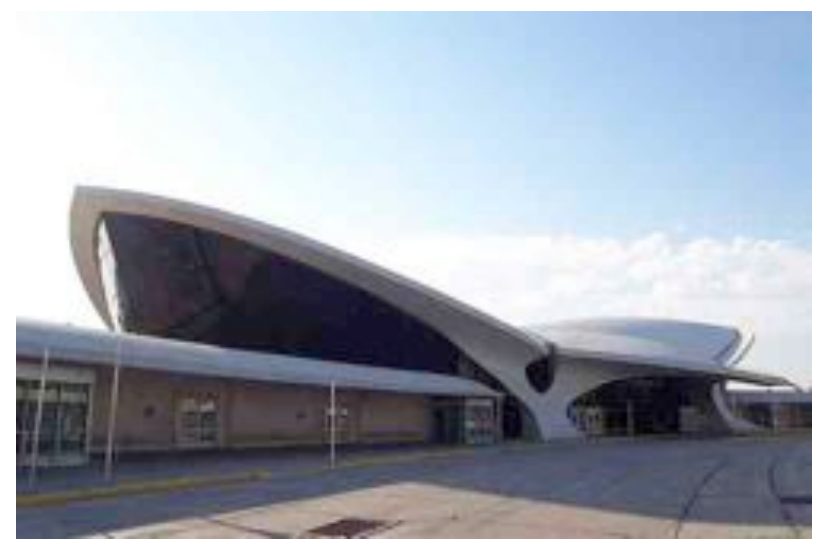

Imagem82: "TWA Terminal - interior at JFK Airport"

1956-1962. New York, New York, USA. Arquitetura: Eero Saarinen

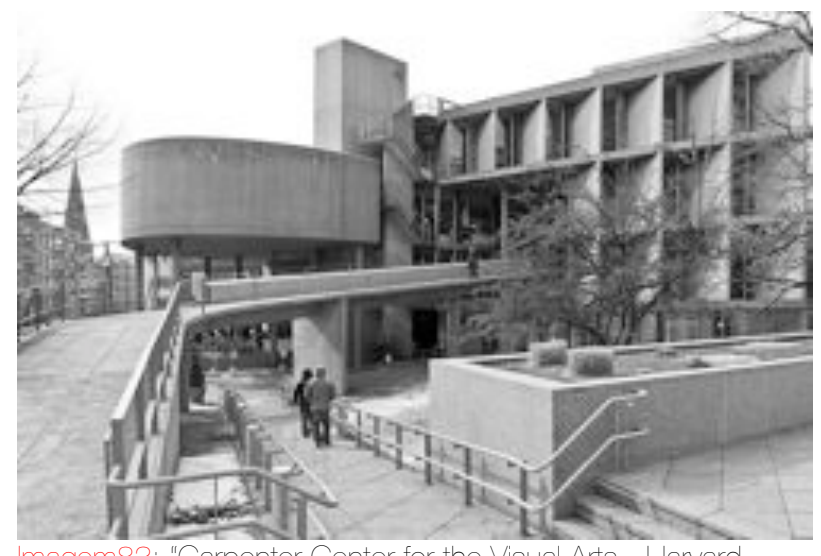

Imagem83: "Carpenter Center for the Visual Arts - Harvard

University". 1960-1963. Cambridge. Massachusetts,

USA. Arquitetura: Le Corbusier. "Único prédio do arquiteto construído nos EUA"

\section{9}

TROCAS, TRANSFERÊNCIAS E FATOS

1959: V Bienal Internacional de Arte de São Paulo Brasi

1959: Congresso Internacional Extraordinário de Críticos de Arte, que ocorre em São Paulo, Rio de Janeiro e Brasilia

\section{OBRAS BRASILEIRAS}
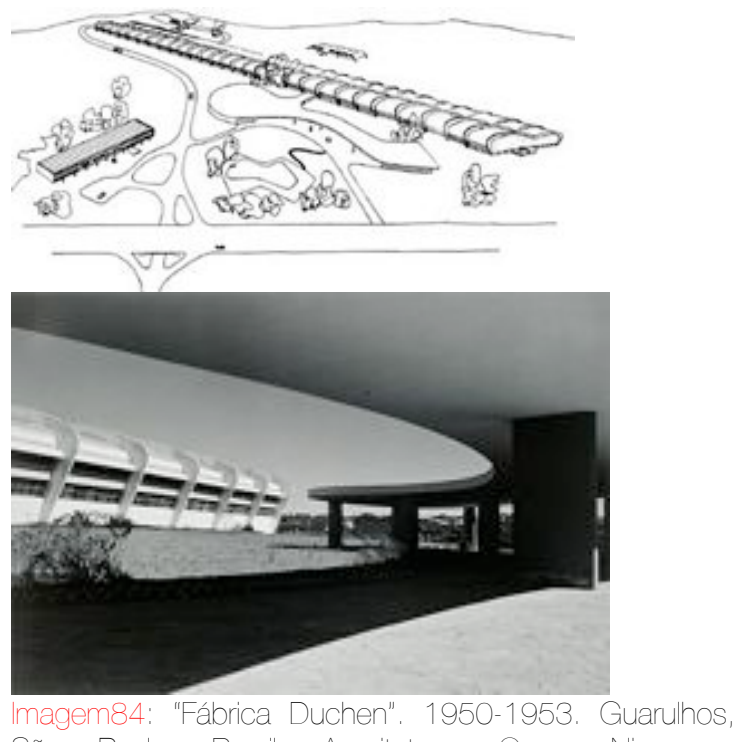

São Paulo Brasil Arquitetura: Oscar Niemeyer.

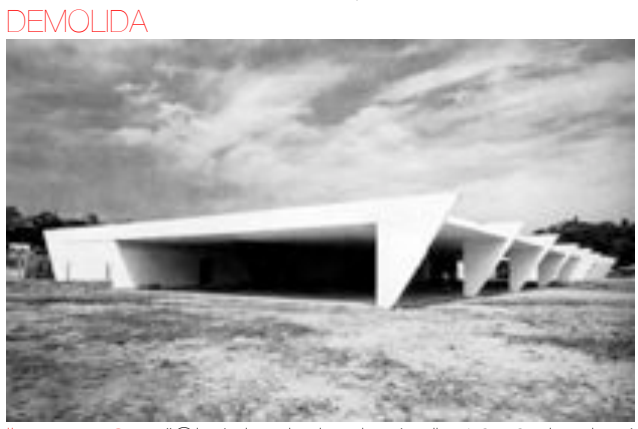

Imagem85; "Ginásio de Itanhaém" 1959. Itanhaém São

Paulo, Brasil. Arquitetura: João Batista Vilanova Artigas e Carlos Cascaldi. 
PRECEDÊNCIAS E REFERÊNCIAS USA

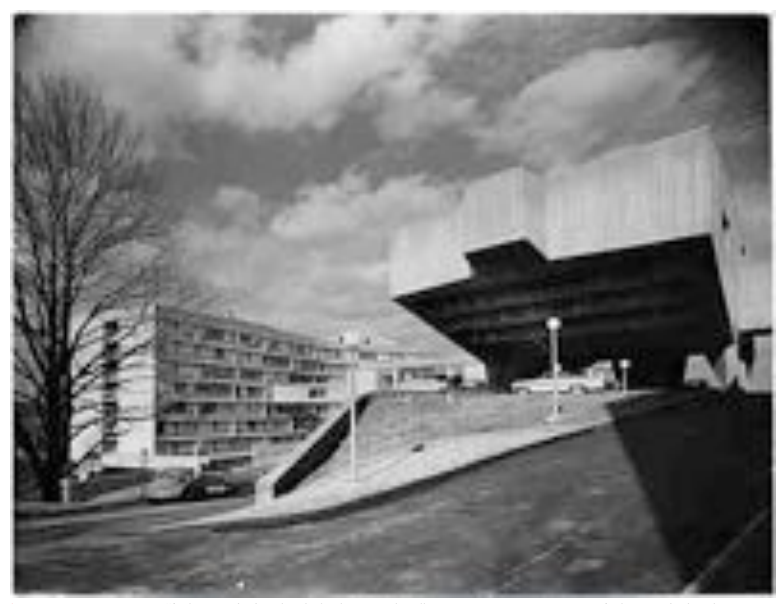

New York, USA. Arquitetura: Marcel Breuer. Foto: Débora

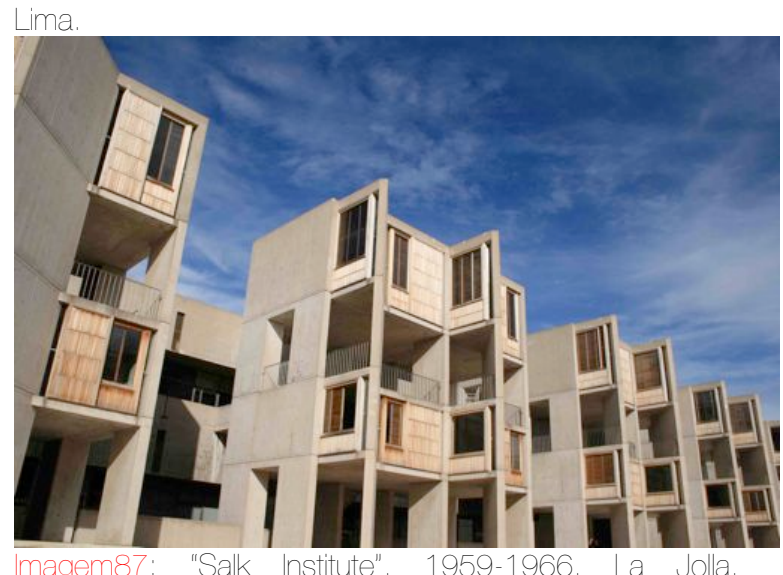

Calformia USA. Arquitetura: Louis Kahn. Foto: Débora Lima.

\section{0}

TROCAS, TRANSFERÊNCIAS E FATOS

1960: Inauguração de Braslia

1960: Dwight Eisenhower visita o Brasil, ficando

em Brasilia São Paulo e Rio de Janeiro, em um tour

que incluiu também Argentina, Uruguai e Chile.
OBRAS BRASILEIRAS

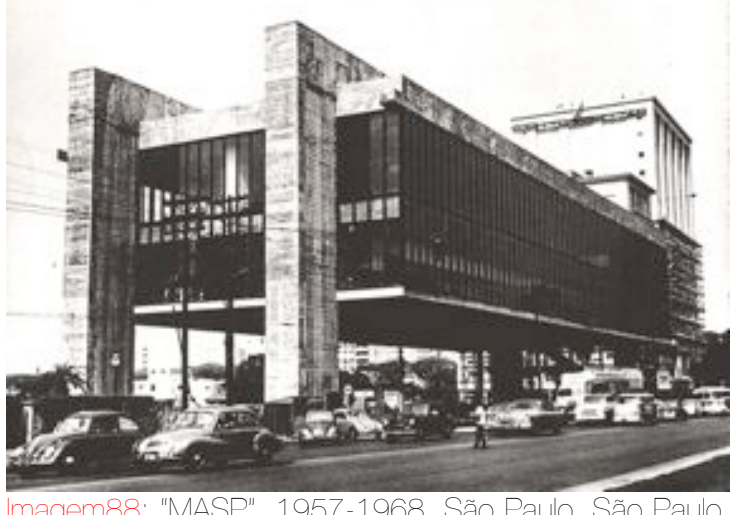

Brasil. Arquitetura: Lna Bo Bardi

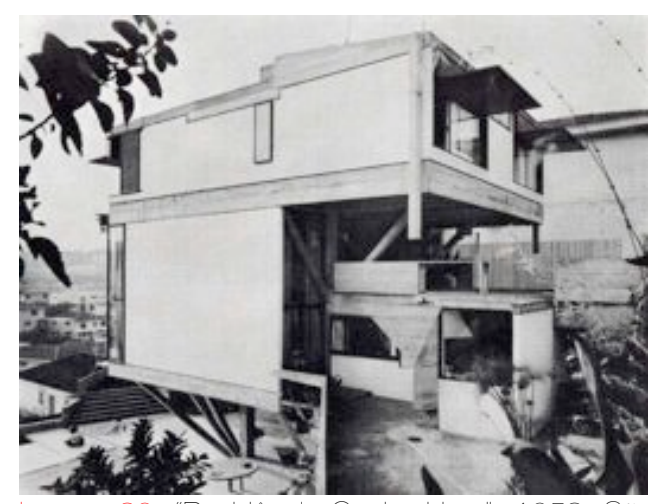

São Paulo, Brasil. Arquitetura: Joaquim Guedes 
PRECEDÊNCIAS E REFERÊNCIAS USA

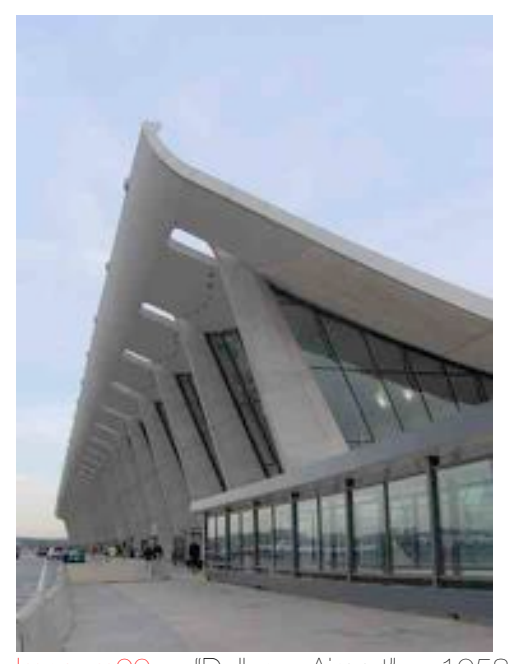

magem90: "Dulles Airpor" 1958-1962 Chantilly Virginia, USA. Arquitetura: Eero Saarinen. Foto: Débora Lima.

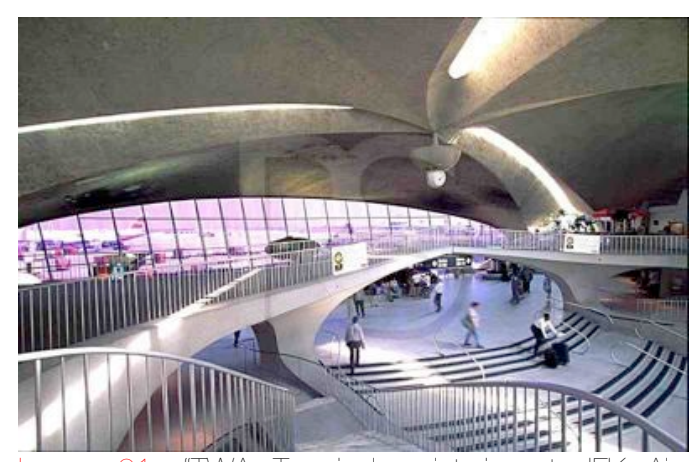

NA Terminal - interior at JFK Airoont.

1956-1 962. New York, New York, USA. Arquitetura: Eero Saarinen.

\section{Brasilia}

TROCAS, TRANSFERÊNCIAS E FATOS
OBRAS BRASILEIRAS
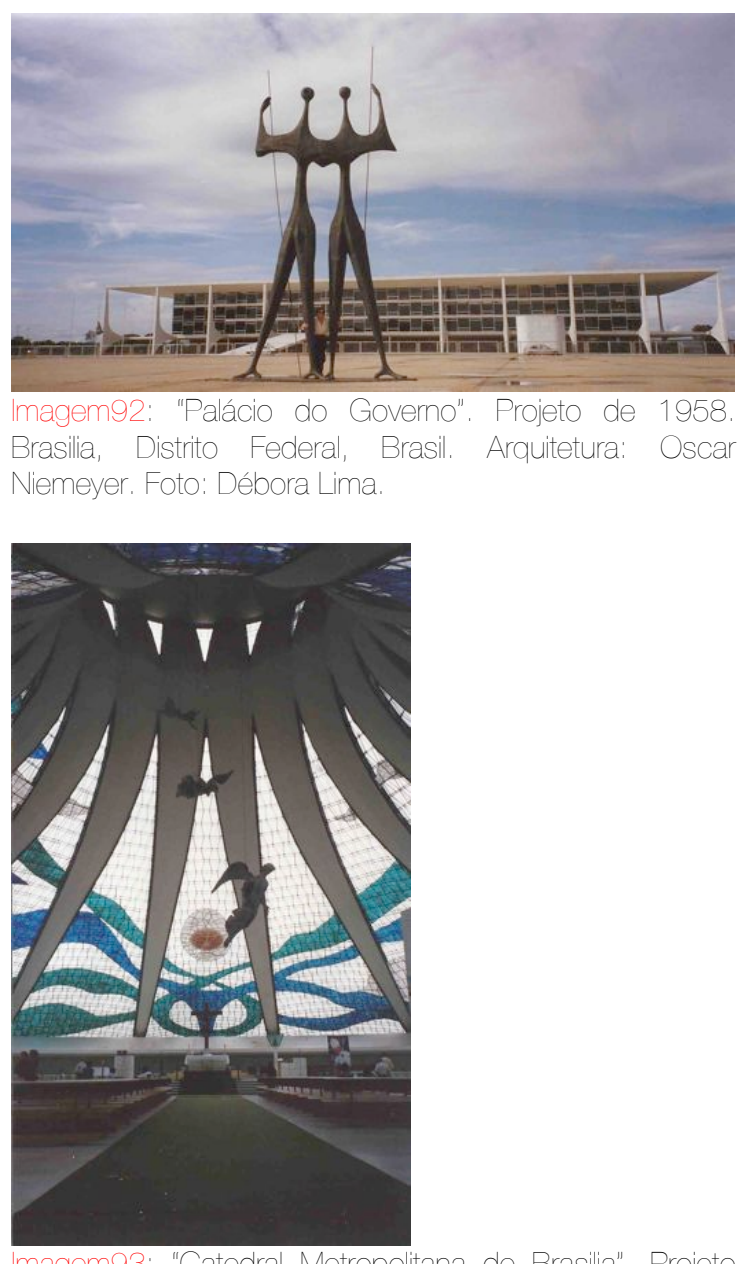

a de Brasilla". Proleto

de 1958. Brasilia, Distrito Federal, Brasil. Arquitetura: Oscar Niemeyer. Foto: Débora Lima. 
PRECEDÊNCIAS E REFERÊNCIAS USA

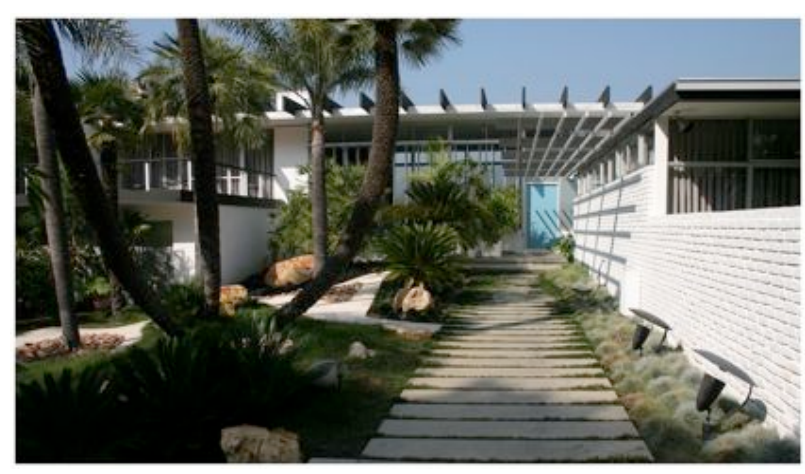

Imagem94: "Strick House". 1964. Santa Monica, Débora LIma

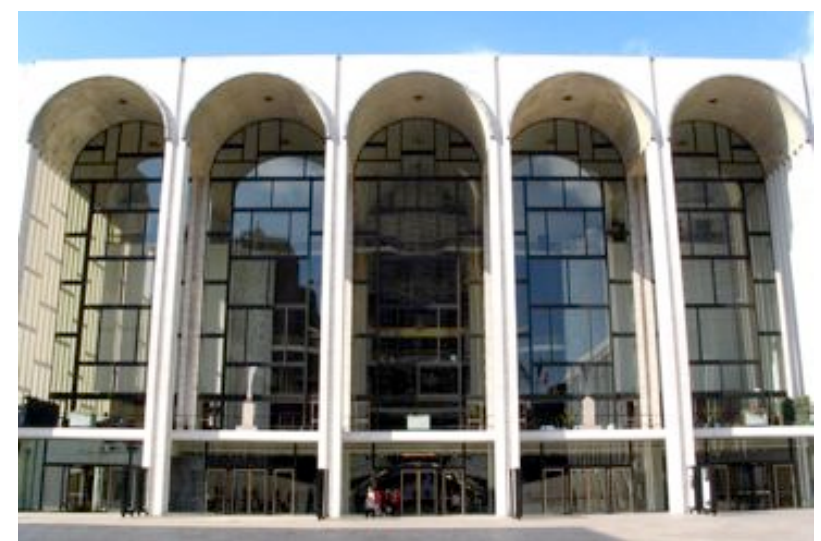

Imagem95; "Metropolitan Opera House - Lincoln Center". 1966. New York, New York, USA. Arquitetura: Wallace Harrison. Foto: Débora Lima

\section{1-1963}

TROCAS, TRANSFERENNCIAS E FATOS

1964: Oscar Niemeyer projeta a Casa Strick em Santa Mônica, Califórnia, EUA
OBRAS BRASILEIRAS

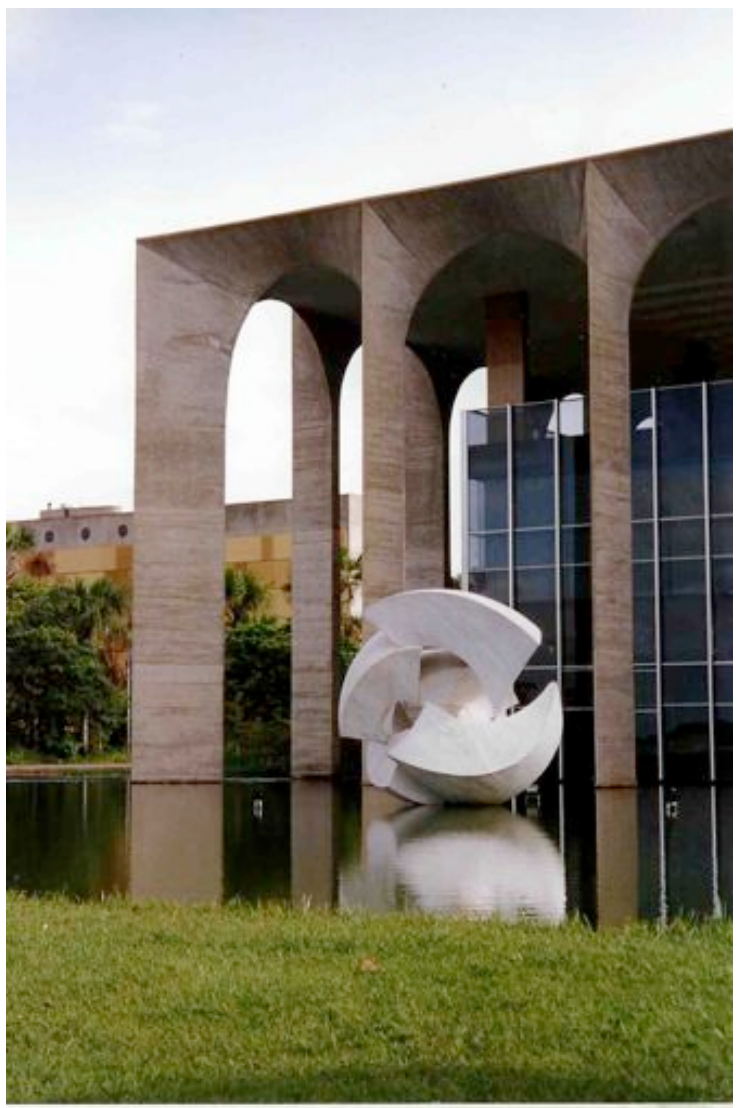

Imagem96: "Palácio do Itamaraty". 1960. Brasilia, Distrito Federal, Brasil. Arquitetura: Oscar Niemeyer. Foto: Débora Lima. 
PRECEDÊNCIAS E REFERÊNCIAS USA

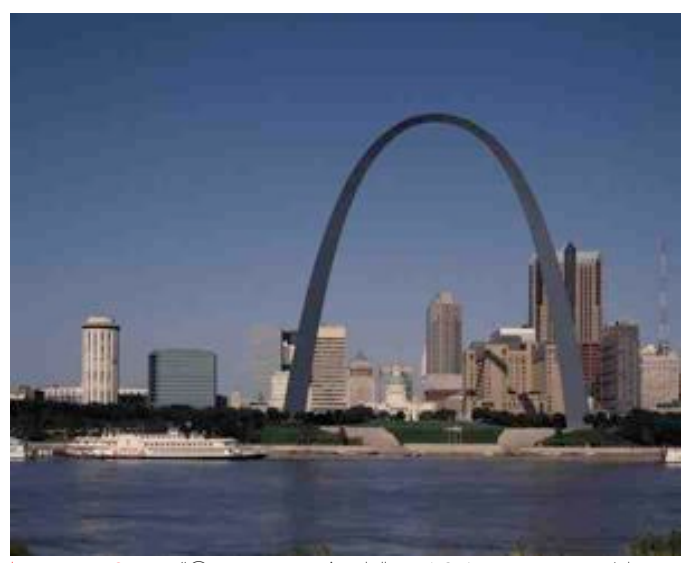

Imagem97; "Gateway Arch". 1947 construído entre
1961-1966. Saint Loius, Missouri, USA. Arquitetura: Fero Saarinen.

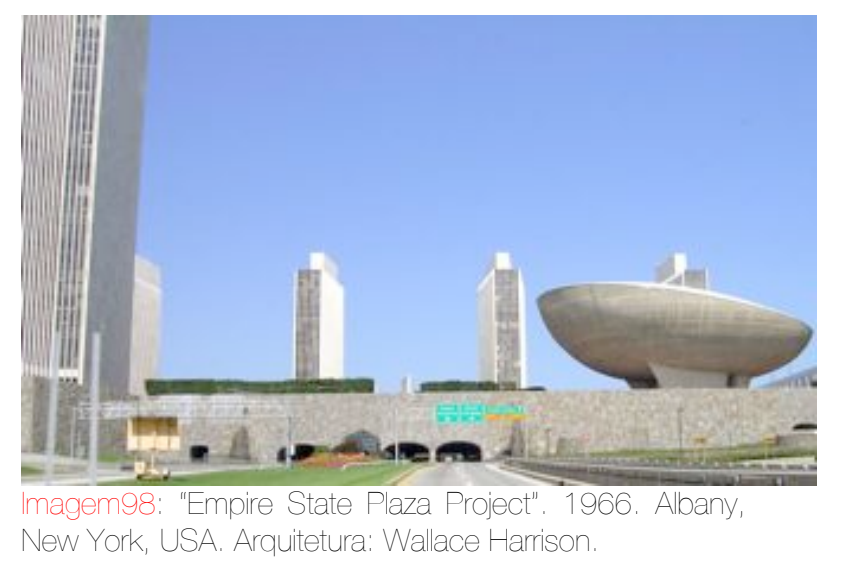

\section{Depois...}

TROCAS, TRANSFERÊNCIAS E FATOS
OBRAS BRASILEIRAS

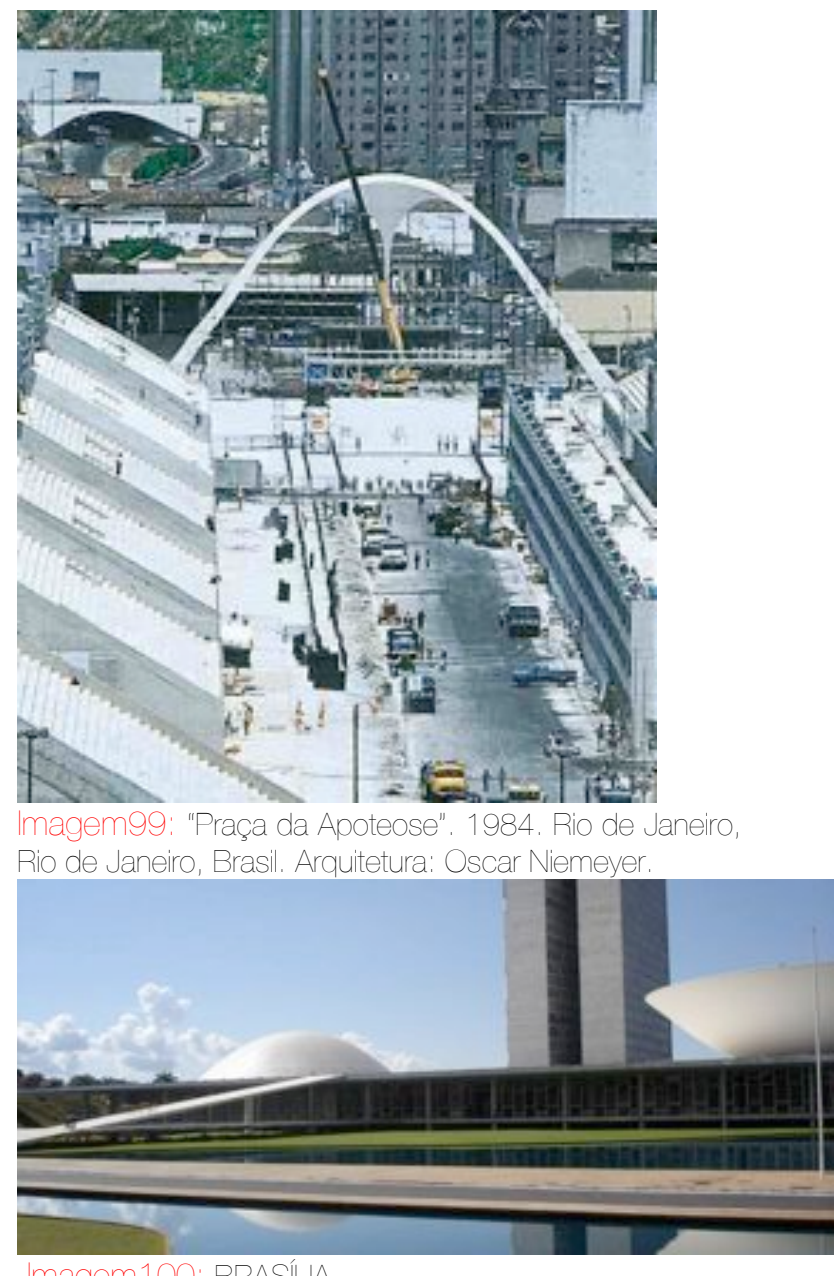




\section{Arquitetos americanos e/ou emigrados para os EUA}

Alvar Aalto

Charles Eames

Craig Ellwood

Edward Durell Stone

Eero Saarinen

Emery Roth \& Sons

Frank Lloyd Wright

Geoge Frederick Keck

Gordon Bunshaft

Harrison, Abramovitz \& Abbe

Le Corbusier

Louis Kahn

Ludwig Mies van der Rohe

Marcel Breuer

Paul Lester Wiener

Paul Schulz

Philip Goodwin

Philip Johson

Pierre Koenig

Pietro Belluschi

Ray Eames

Richard Neutra

Rudolf Schindler

Josep Lluis Sert

Shreve, Lam and Harmon

Skidmore, Owings and Merrill

Thomas Price

Wallace Harrison

Walter Gropius

William Edmond Lescaze
Arquitetos com obras presentes no

\section{QUADRO COMPARATIVO}

Arquitetos brasileiros e/ou emigrados para o Brasil

Adhemar Marinho

Afonso Eduardo Reidy

Alcides da Rocha Miranda

Alvaro Vital Brasil

Antonio Garcia Moya

Burle Marx

Carlos Cascaldi

Carlos Leão

Carlos Millan

David Libeskind

Ernani Vasconcellos

Flávio de Carvalho

Galiano Ciampaglia

Giancarlo Gasperin

Giancarlo Palanti

Gregori Warchavchik

Henrique Mindlin

Jacques Pilon

João Batista Vilanova Artigas

Joaquim Guedes

Jorge Moreira

Lina Bo Bardi

Lucio Costa

Luís Roberto Carvalho Franco

Marcelo Roberto

Miguel Forte

Milton Roberto

M.M. Roberto

Oscar Niemeyer

Oswaldo Arthur Bratke

Plínio Botelho do Amaral

Rino Levi

Roberto Cerqueira César

Roger Zmekohl

Sérgio Bernardes

William Fillinge 